\title{
СОЦИОЛОГИЧЕСКОЕ ОБОЗРЕНИЕ
}

2018* Toм $17 *$ № 3

\section{RUSSIAN SOCIOLOGICAL REVIEW \\ $2018 *$ Volume $17 *$ Issue 3}




\title{
СОЦИОЛОГИЧЕСКОЕ ОБОЗРЕНИЕ
}

\author{
* \\ 2018 \\ Toм 17. № 3
}

ISSN 1728-1938

\section{Редакционная коллегия}

Главный редактор

Александр Фридрихович Филиппов

Зам. главного редактора

Марина Геннадиевна Пугачева

Члены редколлегии

Светлана Петровна Баньковская

Андрей Михайлович Корбут

Наиль Галимханович Фархатдинов

Редактор веб-сайта

Наиль Галимханович Фархатдинов

Литературнье редакторь

Каринэ Акоповна Щадилова

Перри Франц

Корректор

Инна Евгеньевна Кроль

Верстальщик

Андрей Михайлович Корбут

\section{Международный редакционный совет}

Николя Айо (Университет Фрибура, Швейцария)

Джеффри Александер (Йельский университет, США)

Яан Вальсинер (Университет Ольборга, Дания)

Виктор Семенович Вахштайн (РАНХиГС, Россия)

Гэри Дэвид (Университет Бентли, США)

Дмитрий Юрьевич Куракин (Ниу вшэ, Россия)

Александр Владимирович Марей (Ниу вшЭ, Россия)

Питер Мэннинг (Северо-восточный университет, США)

Альбер Ожьен (Высшая школа социальных наук, Франция)

Энн Уорфилд Роулз (Университет Бентли, США)

Ирина Максимовна Савельева (НИу вшЭ, Россия)

Никита Алексеевич Харламов (Университет Ольборга, Дания)

\section{Учредители}

- Национальный исследовательский университет

«Высшая школа экономики»

- Александр Фридрихович Филиппов 


\section{О журнале}

«Социологическое обозрение» - академический рецензируемый журнал теоретических, эмпирических и исторических исследований в социальных науках. Журнал выходит четыре раза в год. В каждом выпуске публикуются оригинальные исследовательские статьи, обзоры и рефераты, переводы современных и классических работ в социологии, политической теории и социальной философии.

\section{Цели}

- Поддерживать дискуссии по фундаментальным проблемам социальных наук.

- Способствовать развитию и обогащению теоретического словаря и языка социальных наук через междисциплинарный диалог.

- Формировать корпус образовательных материалов для развития преподавания социальных наук.

\section{Область исследований}

Журнал «Социологическое обозрение» приглашает социальных исследователей присылать статьи, в которых рассматриваются фундаментальные проблемы социальных наук с различных концептуальных и методологических перспектив. Нас интересуют статьи, затрагивающие такие проблемы как социальное действие, социальный порядок, время и пространство, мобильности, власть, нарративы, события и т.д.

В частности, журнал «Социологическое обозрение» публикует статьи по следующим темам:

- Современные и классические социальные теории

- Теории социального порядка и социального действия

- Методология социального исследования

- История социологии

- Русская социальная мысль

- Социология пространства

- Социология мобильности

- Социальное взаимодействие

- Фрейм-анализ

- Этнометодология и конверсационный анализ

- Культурсоциология

- Политическая социология, философия и теория

- Нарративная теория и анализ

- Гуманитарная география и урбанистика

\section{Наша аудитория}

Журнал ориентирован на академическую и неакадемическую аудитории, заинтересованные в обсуждении фундаментальных проблем современного общества и социальных наук. Кроме того, публикуемые материалы (в частности, обзоры, рефераты и переводы) будут интересны студентам, преподавателям курсов по социальным наукам и другим ученым, участвующим в образовательном процессе.

\section{Подписка}

Журнал является электронным и распространяется бесплатно. Все статьи публикуются в открытом доступе на сайте: http://sociologica.hse.ru/. Чтобы получать сообщения о свежих выпусках, подпишитесь на рассылку журнала по адресу: farkhatdinov@gmail.com. 


\section{RUSSIAN SOCIOLOGICAL} REVIEW

*

\section{8 \\ Volume 17. Issue 3}

ISSN 1728-1938

Email:puma7@yandex.ru

Web-site: sociologica.hse.ru/en

\section{Editorial Board}

Editor-in-Chief

Alexander F. Filippov

Deputy Editor

Marina Pugacheva

Editorial Board Members

Svetlana Bankovskaya

Nail Farkhatdinov

Andrei Korbut

Internet-Editor

Nail Farkhatdinov

Copy Editors

Karine Schadilova

Perry Franz

Russian Proofreader

Inna Krol

Layout Designer

Andrei Korbut

\section{International Advisory Board}

Jeffrey C. Alexander (Yale University, USA)

Gary David (Bentley University, USA)

Nicolas Hayoz (University of Fribourg, Switzerland)

Nikita Kharlamov (Aalborg University, Denmark)

Dmitry Kurakin (HSE, Russian Federation)

Alexander Marey (HSE, Russian Federation)

Peter Manning (Northeastern University, USA)

Albert Ogien (EHESS, France)

Anne W. Rawls (Bentley University, USA)

Irina Saveliyeva (HSE, Russian Federation)

Victor Vakhshtayn (RANEPA, Russian Federation)

Jaan Valsiner (Aalborg University, Denmark)

\section{Establishers}

- National Research University Higher School of

Economics

- Alexander F. Filippov 


\section{About the Journal}

The Russian Sociological Review is an academic peer-reviewed journal of theoretical, empirical and historical research in social sciences.

The Russian Sociological Review publishes four issues per year. Each issue includes original research papers, review articles and translations of contemporary and classical works in sociology, political theory and social philosophy.

\section{Aims}

- To provide a forum for fundamental issues of social sciences.

- To foster developments in social sciences by enriching theoretical language and vocabulary of social science and encourage a cross-disciplinary dialogue.

- To provide educational materials for the university-based scholars in order to advance teaching in social sciences.

\section{Scope and Topics}

The Russian Sociological Review invites scholars from all the social scientific disciplines to submit papers which address the fundamental issues of social sciences from various conceptual and methodological perspectives. Understood broadly the fundamental issues include but not limited to: social action and agency, social order, narrative, space and time, mobilities, power, etc.

The Russian Sociological Review covers the following domains of scholarship:

- Contemporary and classical social theory

- Theories of social order and social action

- Social methodology

- History of sociology

- Russian social theory

- Sociology of space

- Sociology of mobilities

- Social interaction

- Frame analysis

- Ethnomethodology and conversation analysis

- Cultural sociology

- Political sociology, philosophy and theory

- Narrative theory and analysis

- Human geography and urban studies

\section{Our Audience}

The Russian Sociological Review aims at both academic and non-academic audiences interested in the fundamental issues of social sciences. Its readership includes both junior and established scholars.

\section{Subscription}

The Russian Sociological Review is an open access electronic journal and is available online for free via http://sociologica.hse.ru/en. 


\section{Содержание}

СОЦИОЛОГИЧЕСКАЯ ТЕОРИЯ И МЕТОДОЛОГИЯ ИССЛЕДОВАНИЙ

Структурная позиция священника в системах дарообмена . . . . . . . . . . . . 9 Николай Емельянов, Григорий Юдин

\section{ПОЛИТИЧЕСКАЯ ФИЛОСОФИЯ}

Политическая теология и секуляризация: о настойчивости одного понятия . . 30 Максим Фетисов

Политическая теология в «Левиафане» Томаса Гоббса . . . . . . . . . . . . . . . 56 Тимофей Дмитриев

Спасутся не все: границы политического сообщества как социальноонтологическая предпосылка . . . . . . . . . . . . . . . . . . . . 90

Олег Кильдюшов

\section{WEBER-PERSPEKTIVE}

Религия и экономика: можем ли мы все еще опираться на Макса Вебера?. . . . 107 Иван Забаев

\section{СТАТЬИ И ЭССЕ}

Параллаксы лисы: к определению предмета и границ социальной философии . . . . . . . . . . . . . . . . . . . . . . . . . . 149 Александр Павлов

Креативные индустрии - модели развития . . . . . . . . . . . . . . . . 173 Рустан Хестанов

Идеология в обществе позднего модерна: исчезновение или трансформация? . . . . . . . . . . . . . . . . . . . . . . . . . . . . . . . . . . 197 Дмитрий Руденкин, Алексей Логинов

Репрезентативная культура современного российского студенчества . . . . . . 221 Виктор Филоненко, Людмила Штомпель, Олег Штомпель

\section{РУССКАЯ АТЛАНТИДА}

«Единственные картины в воспоминании славной войны»: героика, ориентализм и проблемы живописной репрезентации Русско-турецкой войны $1877-1878$ гг. . . . . . . . . . . . . . . . . . . . . . . . . . 240 Андрей Тесля 
Грезы Русской революции в утопиях Александра Чаянова и Андрея

Платонова . . . . . . . . . . . . . . . . . . . . . . . . . 256 Александр Никулин

ОБзоры

Гипотеза модернизации и неолиберализм . . . . . . . . . . . . . . . . . . . . . . . 291 Светлана Щербак

Глобальная (им)мобильность в зеркале постмодернистских трансформаций: политический аспект . . . . . . . . . . . . . . . . . . . . . . 329 Вера Тормошева

\section{РАЗМЫШЛЕНИЯ НАД КНИГОЙ}

Русская культура в философской перспективе . . . . . . . . . . . . . . . . . . . . 346 Дмитрий Носов

Изучение эмоций как область междисциплинарной интеграции: история и социология в поисках объяснения «эмоционального поворота» . . . . . . . . 356 Ольга Симонова

\section{РЕЦЕНЗИИ}

Социальная мобильность: успех или неудача? . . . . . . . . . . . . . . . . . . . . 379 Александрина Ваньке

Рецензия: Олег Аронсон. Силы ложного: опыты неполитической

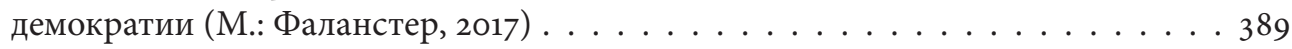
Александра Володина

Рецензия: Ева Берар. Империя и город: Николай II, «Мир искусства» и городская дума в Санкт-Петербурге. 1894-1914 (М.: Новое литературное обозрение, 2016). . . . . . . . . . . . . . . . . . . . . 400 Борис Степанов 


\section{Contents}

SOCIOLOGICAL THEORY AND RESEARCH METHODOLOGY

Structural Position of the Priest in Gift-Exchange Systems . . . . . . . . . . . . . 9 Nikolay Emelyanov, Greg Yudin

\section{POLITICAL PHILOSOPHY}

Political Theology and Secularization: On the Inexorability of a Concept . . . . . . . 30 Maxim Fetisov

The Political Theology of Thomas Hobbes' Leviathan . . . . . . . . . . . . . . . 56 Timofey A. Dmitriev

Not All Will Be Saved: The Boundaries of the Political Community as a Socioontological Premise . . . . . . . . . . . . . . . . . 90 Oleg Kildyushov

\section{WEBER-PERSPEKTIVE}

Religion and Economics: Can We Still Rely on Max Weber? . . . . . . . . . . . . . . 107 Ivan Zabaev

\section{ARTICLES AND ESSAYS}

The Parallaxes of the Fox: Towards Definition of the Subject and Status of Social Philosophy . . . . . . . . . . . . . . . . . . . . . . . . 149 Alexander Pavlov

Creative Industries - Models of Development . . . . . . . . . . . . . . . . 173 Rouslan Khestanov

Ideology in Late Modern Society: Disappearance or Transformation? . . . . . . . . . 197 Dmitry V. Rudenkin, Aleksei V. Loginov

The Representative Culture of Modern Russian Students . . . . . . . . . . . . . 221 Victor Filonenko, Liudmila Shtompel, Oleg Shtompel

\section{RUSSIAN ATLANTIS}

“The Only Pictures in Memory of the Great War": The Heroic Spirit, Orientalism, and the Problems of Representational Depictions of the Russo-Turkish War

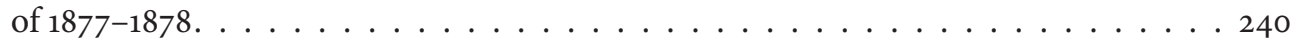
Andrei Teslya 
Dreams of the Russian Revolution in the Utopias of Alexander Chayanov and Andrei Platonov . . . . . . . . . . . . . . . . . . . 256 Alexander Nikulin

оБзоры

Modernization Hypothesis and Neoliberalism . . . . . . . . . . . . . . . 391 Svitlana Shcherbak

Global (Im)mobility in the Mirror of Postmodern Transformations:

The Political Aspect . . . . . . . . . . . . . . . . . . . 329 Vera S. Tormosheva

\section{РАЗМЫШЛЕНИЯ НАД КНИГОЙ}

Russian Culture in the Philosophical Perspective . . . . . . . . . . . . . . . 346 Dmitry Nosov

The Study of Emotions as an Area of Interdisciplinary Cooperation: The History and Sociology of Emotions in the Search for the Explanation of "Emotional Turn". . 356 Olga Simonova

\section{РЕЦЕНЗИИ}

Social Mobility: Success or Failure? . . . . . . . . . . . . . . . . . . . . . . . . 379 Alexandrina Vanke

Book Review: Oleg Aronson, Sily lozhnogo: opyty nepoliticheskoy demokratii [Powers of Falseness: Essays on Non-political Democracy] (Moscow: Falanster, 2017) (in Russian) . . . . . . . . . . . . . . . . . . . . . . . 389 Alexandra Volodina

Book Review: Eva Berar, Imperija i gorod: Nikolay II, "Mir iskusstva” i gorodskaja duma v Sankt-Peterburge. 1894-1914 [Empire and City: Nikolay II, "Mir iskusstva" and City Duma in Saint Petersburg, 1894-1914] (Moscow: New Literary Observer, 2016) (in Russian) . . . . . . . . . . . . . . . . . . . . . 400 Boris Stepanov 


\title{
Структурная позиция священника в системах дарообмена*
}

\author{
Николай Емельянов \\ Кандидат философских наук, протоиерей, научный сотрудник научной лаборатории \\ «Социология религии» Православного Свято-Тихоновского гуманитарного университета \\ Адрес: Лихов пер., д. 6, стр. 1, Москва, Российская Федерация 127051 \\ E-mail:pr_nikolay@mail.ru

\section{Григорий Юдин} \\ Кандидат философских наук, старший научный сотрудник \\ лаборатории экономико-социологических исследований \\ Национального исследовательского университета «Высшая школы экономики» \\ Научный сотрудник научной лаборатории «Социология религии» \\ Православного Свято-Тихоновского гуманитарного университета \\ Адрес: ул. Мясницкая, д. 20, г. Москва, Российская Федерация 101000 \\ E-mail: gregloko@yandex.ru
}

\begin{abstract}
В данной статье мы показываем, что благодаря своей специфической структурной позиции священник обладает исключительными возможностями для стимулирования и воспроизводства отношений дарообмена. Дарообмен представляет собой важную форму экономической интеграции, препятствующую как разрушительной конкуренции, так и иждивенческой зависимости от центральной власти. Опираясь на теорию дарообмена, мы показываем, почему развитие дарообменных отношений сегодня сдерживается: главным барьером выступает отказ от второго императива дара по М. Моссу - от обязанности принимать дар. С помощью аргументов М. Салинза и К. Грегори мы демонстрируем, что разблокировать отношения дарообмена позволяет появление «исключенного участника», который входит в отношения дарообмена, но в то же время гарантированно не имеет в них собственного интереса. Присутствие такого участника позволяет принимать от него дары, не опасаясь впасть в личную зависимость. Анализ нормативных представлений о функции священника в христианской теологии показывает, что позиция священника структурно предполагает «исключенное участие»: он одновременно является репрезентацией Христа (то есть действует не для себя и не от себя), и в то же время принадлежит к общине, выступая ее главой. Ключевая задача священника может быть определена как генерация дарообмена: историческая литература показывает, что именно на этом принципе традиционно строились христианские общины.
\end{abstract}

Ключевые слова: дарообмен, священник, Марсель Мосс, теология, христианство, хозяйственная этика

(С) Емельянов Н. Н., 2018

( ) Юдин Г. Б., 2018

() Центр фундаментальной социологии, 2018

DOI: $10.17323 / 1728-192 X-2018-3-9-29$

* Статья подготовлена в рамках проекта «Жизнь в долг: социальное значение долговых практик в жизни сообществ в России», осуществленного по Программе научных исследований Фонда развития ПСТГУ в 2014 г. Текст написан по итогам работы регулярного семинара «Теория дарообмена» в Лаборатории «Социология религии» ПСТГУ в 2015 г. Мы выражаем благодарность всем участникам семинара за участие в обсуждениях. Мы также признательны П. Джилджеру, К. Харту и И. Забаеву за комментарии к предыдущим версиям текста. 
Человеческие общества обнаруживают множество способов организации хозяйства. Жизнеспособность и потенциал развития общества зависят от его способности поддерживать одновременно разные модели организации. Эта идея была впервые высказана Карлом Поланьи в связи с его знаменитой триадой форм интеграции: обмен, перераспределение, реципрокность (Поланьи, 2002). В частности, эффективность рыночной модели («обмен» в терминах Поланьи), опирающейся на индивидуализм и конкуренцию, особенно зависит от параллельного функционирования модели дарообмена («реципрокности»), скрепляющей общество, предупреждающей взаимную вражду и усиление неравенства. Логика дарообмена не дает подчинить всю жизнь экономическим принципам, превратить в товар основы человеческой социальности, и тем самым поддерживает в обществе продуктивный баланс (Polanyi, 1957).

Модель дарообмена имеет глубокие корни в организации российского общества - она всегда выступала компенсаторным механизмом, за счет которого обеспечивалось выживание как в условиях давления централизованного государства, так и в ситуации дикого рынка. Сети реципрокности обеспечили выживание множества российских семей в момент перехода от одной из этих систем к другой (Барсукова, 2004, 2005). Однако в современном российском обществе возникновение и функционирование систем дарообмена блокируется. Дело в том, что становление отношений дарообмена требует доверия, готовности принять дар и признать свою зависимость от другого человека. Иными словами, дарообмен невозможен без готовности вступить в непосредственное социальное отношение с другим человеком, со всеми рисками, которые это отношение влечет за собой (Luhmann, 200о). Как советский мир манипулируемых сверху «коллективов», так и пришедшая ему на смену неолиберальная мораль индивидуального успеха и агрессивной конкуренции препятствуют становлению и развитию дарообменных отношений.

Экономическая антропология со времен Бронислава Малиновского (2004) показывает, что дарообмен может возникать там, где существуют или строятся сообщества, объединяющие людей и основанные на мотивации, не сводящейся к преследованию личного интереса. Церковь - одна из основных институций, апеллирующих к надындивидуальному в человеке. Церковь регулярно сталкивается с задачей организации хозяйственных отношений на нерыночной основе - при построении церковного прихода, при привлечении пожертвований, при оказании помощи нуждающимся, а также в социальной работе. В церковной жизни дарообмен становится естественной работающей альтернативой рыночному обмену.

Несмотря на то что религиозные основания экономики дарообмена были ясны уже первым исследователям реципрокности ${ }^{1}$, идея о том, что церковная община выстроена на принципах дарообмена, напрямую не высказывалась. Из-за этого

1. Мосс называл дарообмен «тотальным социальным фактом», то есть таким, в котором «одновременно находят выражение разного рода институты: религиозные, юридические и моральные - и вместе с тем политические и семейные; экономические, предполагающие особые формы производства 
остается необъясненной, почти мистической способность церковных общин строить и продвигать альтернативные хозяйственные отношения в условиях современного капитализма. Отсутствие ясного понимания функционирования дарообмена как интегрирующей основы для сообщества верующих не дает возможности сознательно выстраивать такие сообщества. И, напротив, из-за этого непонимания примеры построения успешно функционирующих на основании дарообмена церковных сообществ часто вызывают в обществе недоверие и попытки найти скрытый корыстный мотив.

В частности, одной из загадок в формировании таких сообществ по-прежнему остается священник. Нет сомнений, что священник играет ключевую роль в становлении и поддержании отношений дарообмена. Разумеется, способность организовать крепкую общину в значительной степени зависит от преданности священника своему призванию. Однако существуют и структурные причины, которые делают фигуру священника центральной. Понимание этих причин позволяет ответить на ряд практических вопросов: с какими трудностями сталкивается священник и какими ресурсами он обладает для организации дарообмена? В данной работе мы с опорой на антропологическую теорию дарообмена покажем, каким образом специфическая позиция священника позволяет ему снимать или ослаблять барьеры для функционирования систем дарообмена.

\section{Второй принцип Мосса и блокировка дарообмена}

Каким образом возникает дарообмен и в чем может состоять препятствие для его реализации? Внутренняя структура дарообмена была раскрыта Марселем Моссом. Мосс показал, что дарообмен может существовать только при функционировании нормативной структуры, состоящей из трех императивов: дарить, принимать, отдаривать (Мосс, 2011: 152). Развивая теорию солидарности Эмиля Дюркгейма, Мосс выдвинул утверждение, что именно на этих трех императивах во все времена держалась целостность общества. Именно благодаря им отношения купли-продажи не подчинили себе все социальное взаимодействие.

При этом, однако, современный капитализм, с точки зрения Мосса, вверг дарообменные основы общества в забвение (хотя и не смог полностью от них избавиться). В этом состоит наиболее серьезная опасность для существования общества: если принципы дарообмена будут забыты, то богатые перестанут обращать внимание на потребности бедных, списывая несчастья последних на их безответственность и отсталость. Моральный пафос теории дарообмена Мосса состоит в том, что необходимо уберечь логику дарообмена от полного уничтожения современными торговыми отношениями. Рынок может приводить к процветанию общества, только если последнее держится на фундаменте дарообмена.

и потребления или, точнее, поставок и распределения; не говоря уже о феноменах эстетических, венчающих эти факты, и морфологических, выражающихся в названных институтах» (Mocc, 2011: 137). 
Ставя современному обществу диагноз, Мосс исходит из того, что из трех нормативных компонентов дарообмена под угрозой оказываются первый и третий обязательства отдавать и отвечать даром. Именно поэтому он полагает, что необходимо «вернуться к архаическому, к исходным началам», чтобы обнаружить «мотивы жизни и действия, до сих пор известные многочисленным обществам и классам: радость отдавать публично; удовольствие тратить художественно и великодушно; удовольствие принимать гостей и участвовать в личном и общественном празднике» (Мосс, 2011: 267). Вернуть людям готовность отдавать, а не только присваивать и накапливать - в этом Мосс видит основной вызов для современной политики. Дарообмен приходит в упадок из-за преобладания своекорыстных мотивов над мотивами взаимности: в результате третий императив перестает работать, люди предпочитают не возвращать полученный дар, а преумножать собственное состояние.

Образ субъекта современного капитализма, который рисует Мосс, выглядит несколько гротескным. Мольеровский скупой вряд ли может служить хорошей моделью базовой мотивации современного хозяйства. Теория Мосса неудачна не тем, что она преувеличивает жадность и корысть человека, действующего в мире капитализма, а тем, что она упускает ключевой элемент мотивации экономического субъекта, на которой основывается современная неолиберальная хозяйственная система. Для этого субъекта главным мотивом является не просто максимизация богатства, но сохранение собственной независимости, и уже в этих условиях - самостоятельная максимизация полезности. Иными словами, Мосс, рассуждая в дюркгеймианском стиле, главной опасностью видит утерю обществом морали и триумф аморального своекорыстия, и по этой причине упускает моральные основания преследования личной выгоды. Чтобы возникло общество, где главной добродетелью выступает преследование личной полезности, требуется не разрушение морали, а, напротив, основательная моральная работа, производящая соответствующего морального субъекта (см.: Fourcade, Healy, 2007).

Моральным основанием неолиберального капитализма является императив сохранения личной независимости. Максимизация полезности получает позитивную оценку только в том случае, если она осуществлена самостоятельно, без обращения в зависимость от кого-либо другого. Именно императив «добейся сам» управляет неолиберальным субъектом и подталкивает его к тому, чтобы рассматривать себя как собственный ресурс, который подлежит максимизации. Сегодняшний homo economicus - это не бессовестный оппортунист, присваивающий себе чужое, но индивид с твердой моральной ориентацией, требующей оберегать собственную независимость, достигать успеха самостоятельно и вкладываться в собственное развитие; М. Фуко называет неолиберального субъекта «самопредпринимателем» (Foucault, 2004: 232).

Эти наблюдения подсказывают, что в нормативной триаде Мосса основная дисфункция, вызываемая современным неолиберализмом, связана не с первым и третьим компонентами, но со вторым - со способностью принимать дар. Забота об 
охране собственной независимости не позволяет поставить себя в положение принимающего и, соответственно, обязанного. В действительности, совершать благодеяния для современного субъекта гораздо проще в силу того, что одаривание создает моральное преимущество, тогда как принятие дара или помощи, напротив, предполагает уязвимость. Основной вопрос восстановления дарообмена поэтому состоит не в том, как побудить человека возмещать полученный дар, а в том, как побудить его принимать дар и тем самым оказывать доверие дарующему.

Одна из наиболее влиятельных интерпретаций теории Мосса была предложена Маршаллом Салинзом, который предложил понимать дарообмен как решение проблемы «войны всех против всех», как Моссову версию теории общественного договора (Sahlins, 1972: 169). При этом Салинз указал на то, что обязательность принятия дара и последующего принесения ответного дара обусловлена не духом дарителя, который (т. е. дух) угрожает гибелью тому, кто прервет цепь дарообмена (как полагал Мосс), а тем, что можно назвать «императивом неприсвоения избытка» - то есть требованием увеличивать (символическую) ценность каждого последующего дара по отношению к предыдущему. Важно, что этот императив, предписывая участникам не извлекать прямую материальную выгоду из полученного дара, тем самым устанавливает связь между принятием дара/возвратным дарением, с одной стороны, и преумножением богатства - с другой. Благодаря действию этого императива каждый участник дарообменной цепи увеличивает ценность приносимого/возвращаемого дара, за счет чего возрастает общее богатство.

Важно, что при этом в схеме Салинза принципиальную роль играет исходный даритель. Исходной инстанцией дарения не может выступать обычный участник дарообмена, нацеленный на максимизацию собственного статуса, - в этом случае цепь дарообмена не запустится. Исходной инстанцией должен быть кто-то, действующий «от лица» принципа изобилия: в знаменитом примере с духом хау у маори, который разбирает Мосс, Салинз указывает, что исходной инстанцией является дух изобилия, который жрецы помещают в лесу. По этой причине богатство, которое в дальнейшем возникает благодаря духу изобилия, должно быть компенсировано жрецам в виде ответного дара (Sahlins, 1972: 158). Иначе говоря, чтобы цепь дарообмена была запущена, запускающий должен обладать некоторым символическим преимуществом, представлять некоторую безличную силу, которая заведомо выключена из отношений конкуренции между членами сообщества. Только в этом случае его интенция может быть прочитана как работа не на собственный статус, а на преумножение блага сообщества. Иными словами, запускающему цепь дарообмена для порождения доверия необходим некоторый «аванс», который он получает путем связи с безличным источником богатства. Именно поэтому отказ принимать дар от этой инстанции или отказ возвращать ей дар вызывает моральное осуждение.

Крис Грегори (Gregory, 1980), рассматривая функционирование систем дарообмена, приходит к сходному выводу. С его точки зрения, системы, в которых дары 
приносятся не человеку, а богу르, обладают некоторыми особыми свойствами. Когда инстанция, играющая роль представителя Бога (в примере Грегори это церковь), организует систему даров, то она способна, во-первых, сформировать у участников системы мотивацию к максимизации исходящих потоков, а во-вторых, получать из системы в виде даров ресурс, который может направляться на различные цели. «Отказ от имущества предполагает передачу владения (то есть отчуждение) чем-либо от естественной личности к сверхъестественной [non-natural] личности („богу“). Дар может получить от лица Бога другая личность, однако этот посредник не включается в отношение дара-долга, поскольку дар отчуждается от исходного владельца. Поскольку дар - это вещь неотчуждаемая, ясно, что дар богу осуществляет отчуждение неотчуждаемого» (Gregory, 1980: 645).

Несмотря на то что церковь, с точки зрения Грегори, не является необходимым элементом дарообмена (система «даров людям», в противовес «дарам богам», не предполагает существования церкви), появление в схеме церкви производит два важных изменения. Церковь выполняет роль «неучаствующего участника», то есть она одновременно и находится в отношениях дарообмена, и выключена из них. Эта позиция включенного исключения позволяет устранить препятствия для дарообмена, поскольку находящийся в ней участвует в дарообмене не от своего лица, он дарит не от себя и принимает дары не для себя. Благодаря этому в примере Грегори в Папуа - Новой Гвинее удалось запустить систему «даров богам» в тот момент, когда предыдущая система «даров людям» была ликвидирована под давлением привнесенного колонизаторами рынка (Gregory, 1980: 635).

В дополнение к этому, неучаствующий участник благодаря своему незаинтересованному положению изымает из системы ресурс, который может направлять на социально одобряемые цели. Как отмечает Грегори, аналогичная система, в которой функцию изъятия богатств выполняет потлач, приводит к тому, что богатство просто уничтожается. «Исключенный участник» гарантирует, что богатства не вернутся к исходным донорам прибылью (то есть удостоверяет, что это не коммерческая инвестиция), и тем самым символически ликвидирует эти богатства. Однако поскольку физически богатства сохраняют свое существование, он при этом способен использовать их для иных нужд (например, в описанном Грегори случае, для помощи пострадавшим от стихийного бедствия) (Gregory, 1980: 630).

Таким образом, позиция «исключенного участника», обнаруженная Грегори, описывает роль исходной инстанции дарения, которую фиксирует модель Салинза. Однако в модели Грегори есть два ограничения. Во-первых, изъятые из системы исключенным участником средства должны быть направлены вне самой системы (например, на благотворительную помощь нуждающимся, не принадлежащим к общине), иначе их использование десакрализует исходные дары. Хотя Грегори отмечает, что многие жители недовольны таким расходованием ресурсов, остает-

2. При этом следует иметь в виду, что «дары богу» в примере Грегори - это просто система для оформления отношения между людьми. Грегори не рассматривает теологическую сторону этого процесса. 
ся непонятным, насколько принципиально расходовать собранные средства именно вовне, чтобы уберечь их от деградации в статус коммерческой инвестиции.

Во-вторых, неясно, какое значение имеет тот факт, что позицию исключенного участника в примере Грегори занимает церковь. Может ли на этом месте оказаться кто-либо другой? Какими свойствами должен обладать занимающий эту позицию? Более того, в анализе Грегори «церковь» фигурирует как обобщенный макроактор, который появился после христианизации Папуа - Новой Гвинеи. Однако в цепь дарообмена не может войти агрегированный агент, ибо каждый новый участник немедленно определяется с точки зрения его места в системе межличностных отношений, отношений между конкретными людьми. Если церковь выступает от лица бога, то кто выступает от лица церкви? В чем состоит функция священника? Это возвращает нас к исходному вопросу данной статьи и подталкивает к тому, чтобы рассмотреть причины, по которым священник предрасположен к тому, чтобы занимать роль исключенного участника в системах дарообмена.

\section{Позиция священника в элементарных социальных отношениях}

Чтобы показать, какие возможности для инициирования и поддержания отношений дарообмена возникают у священника, мы предложим модель, раскрывающую специфику роли священника (и, в частности, православного священника) в элементарных социальных отношениях. Отвечая на вопрос о возможности общества, Георг Зиммель отмечает, что в социальном взаимодействии другой, во-первых, всегда дан нам только как тип, а во-вторых, индивидуальность его личности всегда выходит за пределы типа (Зиммель, 1996: 518). Рассуждая о католическом священнике, Зиммель указывает, что он представляет собой предельный случай, в котором «церковная функция полностью скрывает и поглощает индивидуальное для-себя-бытие» (Там же). Иными словами, католический священник всегда как бы полностью вовлечен в отношения с другим, у него нет никакого «помимо того», которое могло бы оставлять элемент личностного отношения.

Однако для понимания специфики роли священника (в равной мере православного или католического) в элементарных социальных отношениях принципиальное значение имеет ее религиозная составляющая. Церковная функция священника, рассматриваемая Зиммелем в целом как тип, противостоящий «индивидуальному для-себя-бытию», имеет сложную внутреннюю структуру. Для понимания роли священника в отношениях дарообмена важно выделить две неразрывно связанные между собой составляющие церковной функции священника. Они маркируются в богословском дискурсе как «репрезентация Христа» и «руководство общиной». Первая составляющая объективируется в совершении Таинств, вторая - в душепопечении. При этом два компонента мыслятся таким образом, что руководство общиной возможно только через ее единение вокруг совершения Таинств, а совершение Таинств возможно только в общине и для общины. Иными словами, с нормативной точки зрения священник никогда не является 
только жрецом, функционирующим исключительно в сакральном пространстве, но и никогда не является только простым участником элементарных социальных отношений, функционирующим только в профанном пространстве бытия.

В нормативном для Русской Православной Церкви документе - Катехизисе, составленном митрополитом Филаретом (Дроздовым), священство определяется как «Таинство, в котором Дух Святой правильно избранного через рукоположение святительское (епископское) поставляет совершать Таинства и пасти стадо Христово» (Святитель Филарет, 2006: 100).

Сходное понимание предлагает католическое богословие священства. Так, в папском наставлении для приходских священников Иоанн Павел II обращает внимание на то, что функция священника имеет два измерения: «он обязан развивать и поддерживать единство между членами и Главой, а также между самими членами» (Pope John Paul II, 2003: 157). Священник in persona Christi обеспечивает присутствие Христа, Главы Церкви - то есть репрезентирует его, будучи полностью поглощенным Христом. В то же время, чтобы связать Христа с членами Церкви, священнику необходимо «желать быть источником единства и братского пожертвования собой для всех, в особенности для наиболее нуждающихся» (Ibid.).

На онтологическом уровне схема медиации, которая здесь работает, состоит в том, что священник скрепляет религиозную общность воедино силой Главы Церкви, то есть единение осуществляется именно посредством репрезентации Христа (и наоборот, обеспечение присутствия Христа происходит через укрепление общины). Чтобы выполнить эту задачу, священник должен быть одновременно членом сообщества, его руководителем и слугой всех его членов.

Священство, таким образом, обладает иерархическим и пастырским измерениями, то есть соотносится с руководством сообществом таким образом, что власть руководителя происходит не из самого сообщества, но является «даром», идущим от самого Христа (Булгаков, 1883: 59-60).

Папа Иоанн Павел II отмечает, что эта двойственность требует определенного баланса и неизбежно ставит перед священником проблему избегания двух крайностей (Pope John Paul II, 2003: 156). С одной стороны, существует риск утери статуса одного из членов Церкви и отдаления от сообщества, в результате чего сообщество лишается источника священства изнутри себя.

Это, среди прочего, означает порочность иерархической организации общины, при которой священник занимается патримониальным перераспределением ресурсов между остальными членами (они автоматически становятся иждивенцами). Дарообмен не следует путать с иерархией. Поланьи подчеркивает различие между перераспределением и дарообменом (реципрокностью) как формами организации хозяйства: иерархия и централизация власти и ресурсов соответствует перераспределению, в то время как реципрокность основана на взаимодействии между «симметричными группами». Эти группы одаривают друг друга, но не по принципу do ut des, а имея в виду, что принесенный дар может впоследствии вер- 
нуться от третьей стороны, поскольку реальным «дарителем» и «возместителем даров» является само сообщество (Поланьи, 2002: 70).

Противопоставление формально понимаемого иерархического и пастырского начала в Церкви становится важной темой в богословии XX века (Ермилов, 2018). Внутренние церковные проблемы эпохи гонений на Русскую Православную Церковь в XX веке трактуются в богословии новомучеников как следствия неверного понимания принципа иерархичности. Епископ Дамаскин (Цедрик) утверждает, что именно стремление «во что бы то ни стало сохранить видимую структуру Церкви, ее управления» привело к искажению «внутренней Правды Христовой Церкви» (Косик, 2009: 301). Этому порочному принципу, по мнению богословановомученика, необходимо противопоставить «установление прочных духовноблагодатных связей между пастырями и пасомыми» (Там же: 318). На благополучном Западе, не пережившем эпоху форсированной секуляризации, высказывались почти в точности такие же идеи. Так, кардинал Й. Ратцингер (будущий папа Бенедикт) считал, что не внешняя иерархическая структура Церкви, а «регулярное душепастырство» должно стать основанием церковной жизни (Ratzinger, 1970: 122-125).

Противоположная опасность состоит в том, что может происходить «секуляризация» священника и исчезновение той специфической роли, которую он играет в церковном сообществе ${ }^{3}$. В обоих случаях онтологическая структура сообщества не будет функционировать так, как это подразумевается и православной, и католической экклезиологией: приход перестает представлять собой единство, потому что священник покидает свою уникальную структурную позицию.

Если на экклезиологическом уровне проблема выглядит решенной, то эмпирически священнику трудно удержаться в равновесном положении, что приводит к существенным искажениям пастырского служения. Так, Патриарх Кирилл указывает, что так называемый эффект «выгорания» является следствием потери связи между «сакральным служением» и «властью, административной и общественной деятельностью» священника (Святейший Патриарх Кирилл, 2017б). Исследование католических священников, проведенное в Германии П. Цуленером, показывает, что поиски баланса приводят к тому, что священники тяготеют к одному из четырех основных типов, которые можно разделить по двум основаниям (Zulehner, 2001: 22). Во-первых, священник может быть ориентирован скорее на функцию репрезентации Христа или на общинную жизнь; во-вторых, он может быть более или менее восприимчив к историческим изменениям позиции священника (функция священника может восприниматься как инвариантная относительно культурных условий или как отвечающая потребностям общества в каждый исторический момент). Крайними типами в этом двухмерном пространстве являются «клирик вне времени» и «современный руководитель общины»: все

3. «На примере такого священника люди могут в конечном итоге перестать видеть сакральный характер Церкви, поставив ее в один ряд с общественными организациями» (Святейший Патриарх Кирилл, 2017а: 5). 
существо первого охвачено задачей представления Христа, в то время как второй почти полностью посвящает себя делам общины. Между ними находятся «актуальный церковник», ориентированный скорее на современную церковь, чем на общину; а также «открытый времени священнослужитель» - наиболее умеренный и равновесный тип. Эти результаты свидетельствуют о том, что священники могут по-разному решать практическую (и экзистенциальную) проблему поиска равновесия между двумя измерениями священнического призвания.

Еще более существенно, что в зависимости от того, как священник сочетает в себе функции репрезентации и руководства общиной, сообщество будет обладать разными структурными свойствами. Позиция «исключенного участника», необходимая для интеграции сообщества посредством дарообмена, требует от священника совмещения двух измерений его миссии, приближения к позиции «открытого времени священнослужителя», если пользоваться термином Цуленера. Тот, кто полностью погружен в общину и является для ее членов только «одним из них» и ничем более, не может получить значительного преимущества, происходящего от функции репрезентации Христа. Он не может добиться единения сообщества: на теологическом языке это эквивалентно отсутствию скрепляющей сообщество благодати, а на социологическом, как мы покажем далее, это означает, что он не способен запустить процесс дарообмена. Эмпирически это будет означать, что священник становится слишком «мирским», чтобы его статус мог снять барьеры для преодоления страха перед зависимостью. Напротив, тот, кто сфокусирован на функции представления Христа и осмысляет ее как свою эксклюзивность, неизбежно отдаляется от сообщества и не входит во взаимодействия внутри него.

\section{Пастырская модель дарообмена}

Теперь, когда мы описали специфику позиции священника, мы можем перейти к рассмотрению возможностей, которые эта позиция открывает при организации дарообмена. Мы преследуем здесь двоякую цель: с одной стороны, мы укажем, каким образом центральная роль священника позволяет запускать процесс дарообмена, и тем самым сформулируем модель дарообмена, которую назовем «пастырской». При наличии более 17 ооо священников РПЦ только на территории РФ (Emelyanov, 2016: 191) можно предположить, что эта модель потенциально способна стать важным фактором регулирования экономической жизни России в целом. При этом мы не утверждаем, что это единственная модель, позволяющая инициировать и поддерживать дарообмен; сравнение позиции священника с альтернативными социальными позициями, обладающими потенциалом для развития дарообмена, также не входит в наши задачи ${ }^{4}$. С другой стороны, мы покажем, каким

4. Кажется, что такое сравнение помогло бы лучше понять легитимацию и оценить эффективность различных форм благотворительности, а также по-новому взглянуть на проблемы локальных сообществ. 
образом взгляд на священника как генератора дарообменных взаимодействий позволяет дополнить существующие представления о функциях священника.

Как было показано выше, ключевая особенность священника состоит в том, что во взаимодействии с ним не может возникнуть личной зависимости: эта возможность целиком поглощается его церковной функцией. Любой дар, принимаемый священником, становится даром не ему лично, а Богу. Поэтому приносящий дар священнику отдает его Богу и вместе с тем переносит на священника предельную ответственность за использование этого дара. Это создает потенциал для деблокировки второго принципа дарообмена по Моссу: поскольку ключевым препятствием для развития отношений дарообмена является страх личной зависимости, священник в силу своей социальной позиции обладает способностью устранять этот страх.

Священник оказывается в идеальной позиции для того, чтобы стать исключенным участником: с одной стороны, он обеспечивает устойчивое воспроизводство системы дарообмена как инстанция, сообщающая перемещению даров символический смысл. С другой стороны, он исключен из дарообмена как обычный участник, нацеленный на соперничество и максимизацию своего статуса. В свою очередь, принимающий дар от священника принимает его не как личное одолжение, а как дар Божий. Таким образом, снимается и проблема асимметрии между приносящим и принимающим дар.

Позиция исключенного участника ценна еще и тем, что позволяет изымать ресурс из системы, аккумулировать его и направлять на нужды, которые оставались бы неудовлетворенными вне системы дарообмена. Здесь, однако, возникает некоторая трудность с возможными направлениями использования такого ресурса. Принимаемый священником дар становится даром Богу, что затрудняет его дальнейшее использование, поскольку переносит его в сферу сакрального. Любое практическое использование такого дара влечет его неизбежную профанацию. Как упоминалось выше, наиболее безопасным с точки зрения сохранения сакрального статуса дара является его использование вне системы - например, на помощь нуждающимся.

В то же время церковная функция священника такова, что, принимая дар как «представитель Христа», он всегда остается также «руководителем общины» и принимает этот дар от лица общины и для общины. Церковная община сама по себе является сакральной, поэтому профанные практические нужды общины и ее конкретных членов получают символическое значение и предельную ценность, как нужды, необходимые для самого существования общины. Этот факт является обоснованием возможности для священника распределить эти дары на нужды общины и конкретных людей в общине. Одновременно это исключительное положение в системе дарообмена и специфика его церковной функции позволяют священнику активизировать и третий императив дарообмена - отдаривание. Он получает возможность просить дар на нужды общины, поскольку, с одной стороны, эти нужды получают предельный ценностный смысл, с другой стороны, его 
церковная функция «руководства общиной» прямо предполагает и требует этого от него.

Децентрализованные системы дарообмена предполагают появление локальных лидеров, наиболее успешных в деле перемещения даров. Малиновский (2004: 113) говорит о том, что некоторые участники таких систем первенствуют в реализации принципа щедрости: «всегда существует жестокая конкуренция за право считаться самым щедрым». Однако несложно увидеть, что для того, чтобы быть самым щедрым, то есть отдавать больше всех, необходимо и получать больше всех. Поэтому более существенно, что такое лидерство связано с объемом ресурсов, проходящих через человека. В терминах сетевой теории такие лидеры являются «сетевыми брокерами» - узлами, соединяющими отрезанные друг от друга участки сетей; их превосходство обеспечивается не тем, что им удается накопить больше всего ресурсов, но тем, что они включены в наибольшее количество наиболее ресурсоемких взаимодействий.

При этом лидерство, приобретаемое за счет центральности в дарообменных отношениях, создает символическую власть особого рода. Как подчеркивает Салинз, такая власть не предполагает наличия властной должности, которую можно было бы занимать, - лидер остается первым среди равных. В антропологической литературе закрепился термин «бигмен», обозначающий это условное превосходство. Власть бигменов в корне отличается от власти «вождей», которые занимают пост, принципиально отделимый от личности его обладателя (Sahlins, 1963: 288)5. Эти два типа власти соотносятся так же, как система симметричных отношений отличается от распределения в рамках централизованной иерархии.

Хотя священник не входит в отношения конкуренции и безразличен к максимизации ресурсов («когда творишь милостыню, пусть левая рука твоя не знает, что делает правая» ${ }^{6}$ ), в его позиции все же можно найти нечто общее с символической властью бигмена. Статусом репрезентации Христа священник наделен изначально, и с этой точки зрения в сообществе заведомо присутствует элемент иерархии, но его возможность активировать переток ресурсов в сообществе и обеспечить интеграцию зависит от того, в какой степени он способен стать лидером дарообмена. Подобно власти бигмена, символическая власть священника базируется на том, что он инициирует передачу ресурсов, не стесняется ни дарить, ни принимать дары, и в конечном итоге увеличивает объем ресурсов, доступный всему сообществу, - то есть в конечном случае заботится в том числе и о материальном благополучии сообщества посредством дарообменных практик. Хотя «бигмен» - это просто неформальное обозначение относительного влияния вну-

5. Салинз ошибочно сравнивает бигменов с мелкими буржуа и столь же ошибочно видит аналогию вождям в феодалах. Буржуа требуют защиты со стороны централизованных политических структур, и точно так же идея отделимости места власти от ее носителя, которая лежит в основании современного государства, возникает как раз в ходе преодоления феодализма.

6. Этот императив становится важной составляющей церковной традиции. Ему стараются следовать иногда буквально. См., например, соответствующее свидетельство об о. Иоанне Кронштадтском в последнем разделе настоящей статьи. 
три сообщества, а «священник» - формальный статус, получаемый при хиротонии, священник становится лидером дарообмена (так же как бигмен становится бигменом) только тогда, когда ему удается привести в действие базовые принципы дарообмена и стать центральным посредником в дарообменных сетях, стимулирующим дарить и принимать. Статус «исключенного участника» (совмещение двух базовых измерений священнической идентичности) дает священнику априорное преимущество для активизации дарообмена, однако это преимущество не является гарантией развития коммуникации между членами общины, ее интеграции и материального благополучия.

\section{Генерация дарообмена в структуре пастырской деятельности}

Как способность священника генерировать процессы дарообмена меняет концепцию священнической деятельности? В пастырском богословии (как в православии, так и в католицизме) существует устойчивое представление о структуре функций священника. Начиная с отцов-каппадокийцев в качестве основных функций священника выделяются наставничество, священнослужение и управление общиной. Эта триада вписана в нормативные источники, определяющие сегодня пастырскую практику. Так, в «Православно-догматическом богословии» митрополита Макария (Булгакова) с опорой на три вида служения Христа (пророческое, первосвященническое и царское) определяются три обязанности священника: «учить своих пасомых; совершать для них священнодействия; духовно управлять словесным стадом» (Булгаков, 1883: 215). Аналогичные указания можно найти и в практических наставлениях пастырям вплоть до учебников пастырского богословия (иеромонах Иоанн, 2010: 6; Милов, 2002: 6). В католичестве современный Кодекс канонического права, основанный на решениях Второго Ватиканского собора, включает в себя mutatis mutandis аналогичную формулировку: «Епископы, по установлению Божию преемствующие Апостолам через данного им Святого Духа, поставлены в Церкви пастырями, дабы они тоже были наставниками в вероучении, священниками священного культа Бога и служителями управления» (Кодекс канонического права, 2007: 175).

Деятельность священника по установлению и развитию дарообменной коммуникации внутри общины практически не освещается в нормативной литературе При этом можно найти достаточно теологических обоснований и исторических свидетельств того, что священник обязан выступать и традиционно выступал в роли того, кто запускает дарообмен в церковной общине и за ее формальными границами.

7. Ни упомянутые выше Катехизис (Святитель Филарет, 2006) и авторитетный компендиум православной догматики митрополита Макария (Булгаков, 1883), ни множество различных учебников пастырского богословия XIX-XX вв. не упоминают о дарообмене в контексте рассуждений об обязанностях и функциях священника. 
Современный библеист Джон Доминик Кроссан, один из наиболее авторитетных участников «Поиска исторического Иисуса», фокусирует внимание на бинарной оппозиции богатый/нищий. В Римской империи эта оппозиция выражалась формой патрон/клиент. Клиенты богатых хозяев могли сами становиться патронами для еще более бедных людей, превращаясь в своего рода посредников, брокеров. Римскую империю Кроссан называет «brokered empire», т. е. основанной на «посредничестве» (brokerage), причем рассматривает этот принцип как ключевой для экономической, социальной, политической и религиозной жизни (Андреев, 2016: 15-18).

Согласно Кроссану, совместная трапеза, устраиваемая Иисусом, была своего рода противопоставлением трапезам патронов с клиентами. Она разрушала границы общества: исчезали всевозможные иерархические связи и зависимости. «Его стратегией (эксплицитно для Него и имплицитно для Его последователей) была комбинация свободного исцеления и свободной трапезы, религиозный и экономический эгалитаризм, равно отрицавший иерархические и патронажные нормы как еврейской религии, так и римской власти» (Crossan, 1991: 422). В этой перспективе христианское священство, всегда осознававшееся, как продолжение служения Христа, получает значение постоянного корректива существующей системы социально-экономических отношений.

Не ограниваясь собственным примером, Христос дает прямое повеление апостолам в момент послания их на проповедь: «даром получили, даром отдавайте» (Мф 10: 8). Этот принцип, в первую очередь связанный с дарами благодати, получил дальнейшее распространение в апостольской общине и в позднейшей канонической традиции христианской Церкви. Книга Деяний содержит свидетельство о Симоне Волхве (Деян. 8: 9-24), который пытался купить у апостолов благодатный дар священства, за что был строго обличен и отвергнут апостолом Петром. Позднее принципиальная «непродаваемость» божественной благодати утверждается рядом церковных канонов ${ }^{8}$. Древний толкователь Зонара объясняет значение этого канона именно тем, что в церковную жизнь, основанную на даре Христа, не должно привноситься само понятие «торговли», как в корне ей противоречащее (Московское Общество, 1876: 64). Более того, этому дается богословское обоснование, связанное с разрушением принципа дара: неотчуждаемый дар Божий отчуждается и присваивается покупателем. «Продающий же что-нибудь продает как господин продаваемого, а покупающий, желая быть господином покупаемого, ценой серебра приобретает его» (Там же).

Другим важным теологическим обоснованием дарообмена как функции священника является пример Иерусалимской общины, описанный в книге Деяний и посланиях апостола Павла. «Общение имуществ», практиковавшееся в Иеруса-

8. Второе правило IV Вселенского собора гласит: «Аще который епископ за деньги рукоположение учинит, и непродаваемую благодать обратит в продажу... таковый, быв обличен, яко на сие покусился, да будет подвержен лишению собственной степени» (Книга правил, 1893: 53-54). См. также VI Вселенский собор, правила 22, 23; VII Вселенский собор, правила 4, 5, 19 и др. (Там же). 
лимской общине, обычно является предметом анализа в контексте его исключительности и экономической неэффективности (Dunn, 2oo9: 180-184). Однако для древнейшей христианской традиция этот пример важен в первую очередь с точки зрения осуществления «братского» способа жизни и церковного единства (Экземплярский, 1910: 24-25). Важно отметить, что осуществляли сбор и распределение средств сами апостолы, а потом специально поставленные для этого диаконы (Деян. 6: 1-6).

В этом смысле сбор средств для Иерусалимской общины, организованный апостолом Павлом (1Кор. 16: 1-4), является нормативным теологическим обоснованием для осуществления дарообменной коммуникации священником. В Павловых посланиях ясно указана цель этого сбора - не экономическое обеспечение жизни общины, а дарообмен: «ныне, вот избыток в восполнении их недостатка, а после их избыток в восполнение вашего недостатка» (2Кор. 8: 14). Причем апостол остается в позиции исключенного третьего и специально это подчеркивает. Он сам зарабатывает на свое содержание и не пользуется пожертвованиями, хотя и признает за собой это право (2Фес. 3: 7-9).

Агиографическая литература дает многочисленные примеры того, как священники и епископы не просто сами подавали милостыню, но одновременно способствовали тому, чтобы это делали другие. Житие Иоанна Милостивого, патриарха Александрийского (Жития: 282-304) прямо указывает, что он «умел привлечь к подаянию милостыни и скупых, и сребролюбцев» (Там же: 293), и изобилует соответствующими примерами. В ряде случаев милостыня служила тому, что получивший использовал ее для осуществления того или иного успешного экономического предприятия и тем самым или возвращал себе потерянное имущество, или избавлялся от каких-то тяжелых экономических обстоятельств. Такие примеры дают не только житие Иоанна Милостивого, но и другие жития и патериковые истории (см., например: Русский Пантелеимонов монастырь, 1897: 77). Учитывая особенности жанра, предполагающего определенную степень обобщения и следования богословскому канону (Grégoire, 1962), подобные примеры тем более свидетельствуют о нормативности такого понимания функции священника.

Обращение к более поздним периодам церковной истории дает свидетельства о деятельности священников, осуществлявших дарообменную коммуникацию, более достоверные с исторической точки зрения. Самым известным примером, хотя далеко не единственным, является деятельность отца Иоанна Кронштадтского. Его служение дает как примеры осуществления многочисленных благотворительных проектов, с привлечением большого объема пожертвований от множества людей ${ }^{9}$, так и достаточно хорошо документированные истории частных лиц,

9. Например, только один Дом трудолюбия, основанный о. Иоанном в 1882 году, фактически изменил сам подход к организации подобных заведений, запустив процесс быстрого роста их количества в России. К началу ХХ века проект оценивался в 1 млн рублей (подробнее см.: Ильяшенко, 2011). 
практически повторяющие классические образцы агиографической литературы ${ }^{10}$. Пример отца Иоанна замечателен еще и тем, что при всей громадной социальной и пастырской деятельности он ежедневно совершал литургию (Иеромонах Михаил, 1904: 32) и настаивал на этом как на принципиальном основании служения священника, преобладающем над остальными его обязанностями и задающем уникальность позиции священника в Церкви.

\section{Заключение}

Значение систем дарообмена для организации экономики сложно переоценить: они способны балансировать рыночный обмен, создавать стабильность и ограничивать враждебность, возникающую на почве рыночной конкуренции. Однако антропология обычно предполагает, что дарообмен возникает естественным образом, и противопоставляет его рыночному обмену как искусственному явлению; из-за этого вопрос о том, как формируются такие системы, остается в литературе без ясного ответа. В данной статье мы показали, каким образом социальная позиция священника создает ресурсы для преодоления главного препятствия, встающего сегодня на пути дарообменных отношений, - страха личной зависимости. Преимущество священника состоит в том, что изначально он находится в положении представителя Бога, и потому как получение, так и передача дара священнику не создает личных обязательств. Излишне говорить, что священник может распорядиться этим преимуществом по-разному, и исходный «аванс», который он имеет для отношений дарообмена, может быть упущен, так что священник будет восприниматься как обладатель личного корыстного интереса. В этом случае возможность инициировать отношения дарообмена будет утеряна.

В заключение заметим, что в силу того, что предложенная здесь модель основывается на некоторых элементарных свойствах социальной позиции священника в современном обществе, круг включаемых в дарообмен необязательно должен быть ограничен сообществом верующих. В самом деле, пограничная позиция священника, сочетающая в себе личный и безличный компоненты, не зависит от того, верит ли в Бога его партнер по взаимодействию. Священник обретает элемент безличности не потому, что мы присоединяемся к нему в его вере, но потому, что такова его социальная роль, которая считывается и неверующими. Именно по этой причине инициируемые священником системы дарообмена нередко включают в себя и нерелигиозных членов, а также определяют поведение вне сакральной

10. «Многократно случалось, что о. Иоанн, находясь в толпе, буквально одной рукой принимал от кого-то конверт с деньгами и, не вскрывая, другой рукой передавал его кому-нибудь из просящих, хотя в таких конвертах лежали тысячи, иногда десятки тысяч рублей - деньги очень большие в то время. И кронштадтский пастырь так же запросто, как получил, так и отдавал какому-нибудь просителю, даже не взглянув, сколько их там. Однако свидетели таких сцен утверждают, что прозорливость никогда не изменяла о. Иоанну, и деньги он всегда отдавал тому, кто в них остро нуждался» (СеменовТян-Шанский, 1990: 43-44). 
сферы ${ }^{11}$. Механизм дарообмена, запускаемый священником, способен производить солидарность как в сакральных, так и в профанных ситуациях: воздействие учреждаемых священником отношений может простираться далеко за пределы приходского хозяйства. Как социология религии, так и экономическая социология до сих пор избегали вопроса о роли священника в организации современной хозяйственной жизни - однако без исследования этого вопроса как описание роли пастыря, так и современного хозяйства неизбежно будет оставаться неполным.

\section{Литература}

Андреев А. В. (2016). Кем был Иисус из Назарета: реконструкция образа исторического Иисуса конца XX - начала XXI века // Вестник ПСТГУ. Серия I. Богословие. Философия. Религиоведение. Вып. 6. С. 9-25.

Барсукова С. (2004). Реципрокные взаимодействия: сущность, функции, специфика // Социологические исследования. № 9. С. 20-29.

Барсукова С. (2005). Сетевые обмены российских домохозяйств: опыт эмпирического исследования // Социологические исследования. № 8. С. 34-45.

Булгаков М. (митрополит) (1883). Православно-догматическое богословие. Т. II. СПб.: Р. Голике.

Ермилов П. В. (2018). Образ Церкви в творениях священномученика Дамаскина Цедрика // Вестник ПСТГУ. Серия I: Богословие. Философия. Религиоведение. Вып. 75. С. 28-47.

Зиммель Г. (1996). Как возможно общество? / Пер. с нем. А. Ф. Филиппова // Зиммель Г. Избранное. Т. 2. М.: Юристъ. С. 509-526.

Иеромонах Иоанн (Ведерников Н.) (протоиерей). (2010). Быть священником вчера и сегодня. М.: Изд-во Московской Патриархии.

Иеромонах Михаил (Семенов). (1904). Отец Иоанн Кронштадтский: полная биография. СПб.: Слово.

Ильяшенко Ф. (священник). (2011). Жизнь и служение отца Иоанна Кронштадтского // Святой праведньй Иоанн Кронштадтский. Избранные сочинения, проповеди, материалы. М.: ПСТГУ. С. 7-97.

Книга правил Святых Апостолов, Святых Соборов Вселенских и Поместных и Святых Отцов. М.: Синодальная типография, 1893.

Кодекс канонического права / Пер. с лат. А. Н. Коваля. М.: Институт философии, теологии и истории св. Фомы, 2007.

Косик О. В. (2009). Истинный воин Христов: книга о священномученике епископе Дамаскине (Цедрике). М.: ПСТГУ.

Малиновский Б. (2004). Аргонавты Западной части Тихого океана / Пер. с англ. В. Н. Поруса. М.: РОССПЭН. 
Милов В. (епископ) (2002). Пастырское богословие с аскетикой. М.: Московское подворье Свято-Троицкой Сергиевой лавры.

Московское Общество любителей духовного просвещения. (1876). Правила Святых Апостолов, Святых Соборов Вселенских и Поместных и святых отцов с толкованиями. М.: Современные известия.

Mосс M. (2011). Опыт о даре // Мосс М. Общества. Обмен. Личность: труды по социальной антропологии / Пер. с франц. А. Б. Гофмана. М.: КДУ. С. 134-285.

Поланьи К. (2002). Экономика как институционально оформленный процесс / Пер. с англ. М. С. Добряковоий // Экономическая социология. Т. 3. № 2. С. 62-73.

Святитель Филарет (Дроздов). (сост.). (2006). Пространный христианский катехизис Православной Кафолической Восточной Церкви. М.: Издательский совет Русской Православной Церкви.

Русский Пантелеимонов монастырь на Афоне. (1897). Афонский патерик, или Жизнеописания святых, на Святой Афонской Горе просиявших. Ч. 1. М.: И. Ефимов.

Святейший Патриарх Кирилл. (2017а). Доклад Святейшего Патриарха Кирилла на Архиерейском Соборе Русской Православной Церкви (29 ноября - 2 декабря 2017 года). URL: http://p2.patriarchia.ru/2017/11/29/1239116292/doklad\%20AS2017. docx (дата доступа: 17.01.2018).

Святейший Патриарх Кирилл. (2017б). Доклад Святейшего Патриарха Кирилла на Епархиальном собрании г. Москвы (21 декабря 2017 г.). URL: http://www. patriarchia.ru/db/text/5085962.html (дата обращения: 17.01.2018).

Семенов-Тян-Шанский А. (епископ). (1990). Отец Иоанн Кронштадтский. Париж: YMCA-Press.

Экземплярский В. И. (1910). Учение древней Церкви о собственности и милостыне. Киев: И. Н. Кушнерев и Ко.

Юдин Г. Б., Орешина Д. А. (2016). Дарообмен и регуляция потребительского кредитования в сообществах: случай православных приходских общин // Социологический журнал. Т. 22. № 2. С. 110-134.

Crossan J. D. (1991). The Historical Jesus: The Life of a Mediterranean Jewish Peasant. San Francisco: Harper.

Dunn J. D. G. (2009). Beginning from Jerusalem: Christianity in the Making. Vol. 2: Grand Rapids. Cambridge: Eerdmans.

Emelyanov N. (2016). The Temporal Structure of the Activities of Priests, and the Substantive Effects of Religious Life in Contemporary Russia // Russian Sociological Review. Vol. 15. № 4. P. 176-201.

Foucault M. (2004). Naissance de la biopolitique. Paris: Seuil, Gallimard.

Fourcade M., Healy K. (2007). Moral Views of Market Society // Annual Review of Sociology. Vol. 33. P. 285-311.

Grégoire R. (1962). Manuale di agiologia: introduzione alla letteratura agiografica. Fabriano: Monastero San Silvestro Abate.

Gregory C. (1980). Gifts to Men and Gifts to God: Gift Exchange and Capital Accumulation in Contemporary Papua // Man. New Series. Vol. 15. № 4. P. 626-652. 
Luhmann N. (200o). Familiarity, Confidence, Trust: Problems and Alternatives // Gambetta D. (ed.). Trust: Making and Breaking Cooperative Relations. Oxford: Oxford University Press. P. 94-107.

Polanyi K. (1957). The Great Transformation: The Political and Economic Origins of Our Time. Boston: Beacon Press.

Pope John Paul II. (2003). The Role of the Priest in Parish Community // The Pope Speaks. Vol. 48. Huntington: Our Sunday Visitor.

Ratzinger J. (1970). Glaube und Zukunft. München: Kösel-Verlag.

Sahlins M. (1962). Poor Man, Rich Man, Big-Man, Chief: Political Types in Melanesia and

Polynesia // Comparative Studies in Society and History. Vol. 5. № 3. P. 285-303.

Sahlins M. (1972). Stone Age Economics. Chicago, N.Y.: Aldine, Atherton.

Zulehner P. M. (2001). Priester im Modernisierungsstress. Ostfilden: Schwabenverlag.

\title{
Structural Position of the Priest in Gift-Exchange Systems
}

\author{
Nikolay Emelyanov \\ Candidate of Philosophy, Archpriest, Research Fellow, Research Laboratory of the Sociology of Religion, \\ St. Tikhon's Orthodox University \\ Address: Lihov per., 6, str. 1, Moscow, Russian Federation 127051 \\ E-mail:pr_nikolay@mail.ru
}

\section{Greg Yudin}

Candidate of Philosophy, Senior Research Fellow, Laboratory for Studies in Economic Sociology, National Research University Higher School of Economics

Research Fellow, Research Laboratory of the Sociology of Religion, St. Tikhon's Orthodox University

Address: Myasnitskaya str., 20, Moscow, Russian Federation 101000

E-mail: gregloko@yandex.ru

In this paper, we argue that the priest has a unique structural position to initiate and promote gift exchange. Gift exchange is an important mode of economic integration, one that prevents both cutthroat competition and a parasitic dependence on a centralized hierarchy. In dwelling on gift exchange theory, we demonstrate why the promotion of gifts is largely suppressed nowadays: Marcel Mauss' second imperative of the gift, that is, the obligation to receive gifts, becomes inoperative under neoliberal capitalism. We rely on Marshall Sahlins' and Chris Gregory's analyses to argue that gift giving can be de-blocked by introducing the position of the 'excluded participant' who takes part in the gift exchange system but is known to have no self-interest. His presence enables other participants to accept gifts without being afraid of falling into personal bondage. We analyze the Christian theological ideas of the function of the priest in reaching the conclusion that priests are predisposed to take the position of the 'excluded participant'. On one hand, the priest in persona Christi acts neither on his own behalf nor for his own self-interest, while on the other hand, he remains a member and governor of the community. Historical sources confirm that generating the gift exchange has always been the key activity of priests in Christian communities.

Keywords: gift exchange, priest, Marcel Mauss, theology, Christianity, economic ethics 


\section{References}

Andreev A. (2016) Kem byl lisus iz Nazareta: rekonstrukcija obraza istoricheskogo lisusa konca XX — nachala XXI veka [Who Was Jesus from Nazareth: Reconstruction of the Image of Historical Jesus in the Late 2oth - Early 21st Centuries]. Vestnik PSTGU. Series I: Theology. Philosophy. Religious Studies, no 6, pp. 9-25.

Barsukova S. (2004) Reciproknye vzaimodejstvija: Sushhnost', funkcii, specifika [Reciprocal Interactions: Essence, Functions, and Peculiarities]. Sociological Studies, no 9, pp. 20-29.

Barsukova S. (2005) Setevye obmeny rossijskih domohozjajstv: opyt jempiricheskogo issledovanija [Network Exchanges between Russian Households: Account of Empirical Research]. Sociological Studies, no 8, pp. 34-45.

Bulgakov M. (Metropolitan) (1883) Pravoslavno-dogmaticheskoe bogoslovie. T. 2 [OrthodoxDogmatic Theology, Vol. 2], Saint Petersburg: R. Golike.

Crossan J. D. (1991) The Historical Jesus: The Life of a Mediterranean Jewish Peasant, San Francisco: Harper.

Dunn J. D. G. (2009) Beginning from Jerusalem: Christianity in the Making, Vol. 2: Grand Rapids, Cambridge: Eerdmans.

Ekzemplyarsky V. (1910) Uchenie drevnej Cerkvi o sobstvennosti i milostyne [Doctrine of the Ancient Church on Oroperty and Charity], Kiev: Kushenerev \& Co.

Emelyanov N. (2016) The Temporal Structure of the Activities of Priests, and the Sub-stantive Effects of Religious Life in Contemporary Russia. Russian Sociological Review, vol. 15, no 4, pp. 176-201.

Ermilov P. (2018) Obraz Cerkvi v tvorenijah svjashhennomuchenika Damaskina Cedrika [Image of the Church in the Work of Hieromartyr Damascene (Cedric)]. Vestnik PSTGU. Series I: Theology. Philosophy. Religious Studies, no 75, pp. 28-47.

Foucault M. (2004) Naissance de la biopolitique, Paris: Seuil, Gallimard.

Fourcade M., Healy K. (2007) Moral Views of Market Society. Annual Review of Sociology, vol. 33, pp. 285-311.

Grégoire R. (1962) Manuale di agiologia: Introduzione alla letteratura agiografica, Fabriano: Monastero San Silvestro Abate.

Gregory C. (1980) Gifts to Men and Gifts to God: Gift Exchange and Capital Accumulation in Contemporary Papua. Man: New Series, vol. 15, no 4, pp. 626-652.

Ilyahenko F. (Priest) (2011) Zhizn'i sluzhenie otca loanna Kronshtadtskogo [Life and Service of Father John of Kronstadt]. Saint Pious John of Kronstadt, Selected Writings, Sermons, Materials, Moscow: PSTGU, pp. 7-97.

Kniga pravil svjatyh Apostolov, svjatyh soborov, vselenskih i pomestnyh i svjatyh otsov [Book of Canons of Saint Apostles, Ecumenical and Local Saint Councils and Saint Fathers], Moscow: Synod Press, 1893.

Kodeks kanonicheskogo prava [Code of Canon Law]. Moscow: St. Thomas Institute of Philosophy, Theology, and History, 2017.

Kosik O. (2009) Istinnyj voin Hristov: kniga o svjashhenomuchenike episkope Damaskine (Cedrike) [True Warrior of Christ: A book on hieromartyr and archbishop Damascene (Cedric)]. Moscow: PSTGU.

Luhmann N. (2000) Familiarity, Confidence, Trust: Problems and Alternatives. Trust: Making and Breaking Cooperative Relations (ed. D. Gambetta), Oxford: Oxford University Press, pp. 94-107.

Malinowski B. (2004) Argonavty Zapadnoj chasti Tihogo okeana [Argonauts of the Western Pacific], Moscow: ROSSPEN.

Mauss M. (2011). Opyt o dare [Essay on the Gift]. Societies. Exchange. Personality: Writings in Social Anthropology, Moscow: KDU, pp. 134-285.

Mikhail (Semenov) (Hieromonk) (1904) Otec loann Kronshtadtskij: polnaja biografija [Father John of Kronstadt: Complete Biography], Saint-Petersburg: Slovo.

Milov V. (Archbishop) (2002) Pastyrskoe bogoslovie s asketikoj [Pastoral Theology and Ascetics], Moscow: The Trinity Lavra of St. Sergius.

Moscow Association of the Lovers of Spiritual Enlightenment (1876) Pravila svjatyh Apostol, svjatyh soborov, vselenskih i pomestnyh i svjatyh otec s tolkovanijami [Canons of Saint Apostles, 
Ecumenical and Local Saint Councils and Saint Fathers with Commentary], Moscow: Sovremennye izvestia.

Patriarch Kirill of Moscow (2017) Doklad Svjatejshego Patriarha Kirilla na Arhierejskom Sobore Russkoj Pravo-slavnoj Cerkvi (29 oktiabrya - 2 dekabrya 2017 goda) [Address by His Holiness Patriarch Kirill at the Bishops' Council of the Russian Orthodox Church (October 29 - December 2, 2017)]. Available at: http://www.patriarchia.ru/db/text/5072994.html (accessed 17 January 2018).

Patriarch Kirill of Moscow (2017) Doklad Svjatejshego Patriarha Kirilla na Eparhial'nom sobranii g. Moskvy (21 dekabrya 2017 goda) [Address by His Holiness Patriarch Kirill at the Moscow Diocesan Assembly (December 21, 2017)]. Available at: http://www.patriarchia.ru/db/text/5085962.html (accessed 17 January 2018).

Polanyi K. (1957) The Great Transformation: The Political and Economic Origins of Our Time, Boston: Beacon Press.

Polanyi K. (2002) Jekonomika kak institucional'no oformlennyj process [Economy as Instituted Process]. Economic Sociology, vol. 3, no 2, pp. 62-73.

Pope John Paul II (2003) The Role of the Priest in Parish Community. The Pope Speaks, Vol. 48, Huntington: Our Sunday Visitor.

Ratzinger J. (1970) Glaube und Zukunft, München: Kösel-Verlag.

Russian Saint-Panteleimon Monastery on Afon (1897) Afonskij paterik ili zhizneopisanija svjatyh, na Svjatoj Afonskoj Gore prosijavshih. Ch. 1 [Patericon of Afon; or, Hagiography of Those Shined on the Saint Mount of Afon, Part 1], Moscow: I. Efimov.

Sahlins M. (1962) Poor Man, Rich Man, Big-Man, Chief: Political Types in Melanesia and Polynesia. Comparative Studies in Society and History, vol. 5, no 3, pp. 285-303.

Sahlins M. (1972) Stone Age Economics, Chicago, New York: Aldine, Atherton.

Semyonov-Tyan-Shansky A. (Archibishop) (1990) Otec loann Kronshtadtskij [Father John of Kronstadt], Paris: YMCA-Press.

Simmel G. (1996) Kak vozmozhno obshhestvo? [How Society is Possible?]. Izbrannoe. T. 2 [Selected Works, Vol. 2], Moscow: Yurist, pp. 509-526.

St. Filaret (Drozdov) (ed.) (2006) Prostrannyj hristianskij katihizis Pravoslavnoj Kafolicheskoj Vostochnoj Cerkvi [Extensive Christian Catechism of Russian Orthodox Oecumenical Eastern Church], Moscow: Publishing Council of the Russian Orthodox Church.

Vedernikov N. (Hieromonk loann, Archpriest) (2010) Byt'svjashhennikom vchera i segodnja [To Be a Priest Yesterday and Today], Moscow: Moscow Patriarchate.

Yudin G., Oreshina D. (2016) Daroobmen i reguljacija potrebitel'skogo kreditovanija v soobshhestvah: sluchaj pravoslavnyh prihodskih obshhin [Gift Exchange and Control of Consumer Credit in Russian Ortodox Communities]. Sociological Journal, vol. 22, no 2, pp. 110-134.

Zulehner P. M. (2001) Priester im Modernisierungsstress. Ostfilden: Schwabenverlag. 


\title{
Политическая теология и секуляризация О настойчивости одного понятия ${ }^{*}$
}

\author{
Максим Фетисов \\ Кандидат философских наук, координатор \\ Центра социальной теории и политической антропологии им. Н. Н. Козловой \\ философского факультета Российского государственного гуманитарного университета \\ Адрес: Миусская площадь, д. 6, ГСП-3, Москва, Российская Федерация 125993 \\ E-mail: msfetisov@gmail.com
}

Последние десятилетия после краха СССР отмечены возвращением интереса к религии. Это возвращение оказалось столь внушительным, что дало повод говорить о «конце секуляризации», а современные общества характеризовать как «постсекулярные». Одним из наиболее ярких симптомов этого процесса стало возрождение интереса к политической теологии. Статья предлагает рассматривать политическую теологию не в узком смысле, а как потенциальную возможность, постоянно присутствующую в рамках мыслительных моделей, которые могли бы показаться исключительно секулярными. Такой подход иллюстрируется на примере трех случаев, обнаруживающих проявление политической силы религии. В качестве первого примера рассматривается объяснение иранской революции 1978 года, предложенное Мишелем Фуко. Введенное Фуко понятие «политической духовности» указывает на проблематику политической теологии не как на предмет наследия истории мысли, а как на живую политическую реальность, наполненную враждой и конфликтами. Второй случай посвящен разбору анализа взаимоотношений религий и постсекулярных обществ, предпринятого немецким философом Юргеном Хабермасом в первое десятилетие XXI века. Утверждается, что отстаиваемое Хабермасом «постметафизическое мышление» не может решить проблемы мирного сосуществования различных религиозных и политических мировоззрений в рамках публичной сферы современных западных обществ. Темой третьего случая является «проблема зла». Эту тему политической теологии, играющую роль важнейшей демаркационной линии в любых политико-философских построениях, теоретики радикальной демократии считают важной частью своей теории «не-суверенных» политических институтов, которые должны будут возникнуть в результате кризиса современной политической рациональности. Вывод статьи состоит в том, что политическая теология выступает не столько радикальной противоположностью светского политического разума или политической философии, сколько дополнительным ресурсом, открывающим новые возможности понимания в ситуациях кризиса, когда перестают работать знакомые нормативные объяснения.

Ключевые слова: Фуко, Хабермас, политическая теология, зло, человеческая природа, постметафизическая философия, секуляризация, публичная сфера

() Фетисов М. С., 2018

(ㄷ Центр фундаментальной социологии, 2018

DOI: 10.17323/1728-192X-2018-3-30-55

* Этот текст написан по итогам сообщения, сделанного на секции ЦФС НИУ ВШЭ «„Смертный бог“ в эпоху позднего модерна: государство и его конкуренты на (пост)глобальном рынке коллективного спасения» в рамках XXV Международного симпозиума «Пути России: границы политики» (3о31 марта 2018 г.)». Автор выражает благодарность организаторам и модераторам секции О. В. Кильдюшову и А. А. Тесле за возможность выступить, а также предложить дальнейшее развитие тезисов выступления в форме предлагаемой статьи. 


\section{«Теолого-политическая проблема» (вместо введения)}

Способность развести вопросы веры и вопросы управления «человеческими вещами» всегда была предметом особой гордости для Современности. В своей знаменитой речи «Модерн - незавершенный проект» Юрген Хабермас, вторя во многом Максу Веберу, говорит о распаде «субстанциального разума, выражающегося в религиозных и метафизических картинах мира», на обособленные «ценностные сферы науки, морали и искусства», которые переходят в ведение специалистов, представляющих соответствующие экспертные культуры (Хабермас, 2005: 17). Это обособление и в настоящее время составляет основу институциональных рамок действия в современных обществах, формируя его нормативный фон, который воспринимается как сам собой разумеющийся.

Необходимой и очень важной составной частью этого процесса (сам Хабермас называет его Просвещением) стала «секуляризация политики». Выражаясь словами Чарльза Тэйлора, «в наших «светских» обществах вы можете быть полностью вовлечены в политику, не встречаясь никогда с Богом... несколько моментов рудиментарного ритуала или молитвы едва ли представляют собой сегодня такую встречу, тогда как в более раннем христианском мире это было бы неизбежно» (Taylor, 2007: 1). Это «великое разделение» (Lilla, 2007: 58), понимаемое как вытеснение вопросов веры и богословия за «внешний контур» любых действий, связанных с вопросами государства, права и материального конституирования политических сообществ, достигло своей наивысшей точки в XX веке. Его великие революции, войны, национально-освободительные и социальные движения, как правило, легитимировались «посюсторонними», светскими интересами, даже если язык, на котором они себя выражали, зачастую имел вполне очевидное милленаристское и эсхатологическое строение. Принято было считать, что секуляризация, понимаемая как игра с нулевой суммой между Современностью и мировыми религиями, неизменно будет идти в комплекте с остальными конвенциональными составляющими модерна. Примерно так выглядит общепринятый нарратив об отночениях разума (включая его политическую ипостась) и религии, служащий, в свою очередь, частью другого, еще более обширного повествования о Современности как эпохе модернизаиии ${ }^{1}$.

Оказалось, однако, что так будет не всегда. Религия возвращается в политику. Происходит это иногда в карикатурном, но чаще всего в довольно фанатичном и варварском виде. О причинах этого возвращения было сказано уже очень много (глобализация рынков и средств коммуникации, крах идеологий эмансипации и светских национализмов, кризис национальных государств, аффирмативная политика идентичности и т. д.); бесспорно одно: этот процесс еще далек от своего завершения. Так или иначе, доминирующий «нарратив секуляризации» столкнулся с серьезными вызовами, вынудив ведущих теоретиков Современности описывать свои общества как «постсекулярные» (Taylor, 2007: 534; Хабермас, 2002). Понятно,

1. Общий обзор сюжета см., например: Узланер, 2012. 
что это «религиозное возрождение» не осталось не замеченным политическими философами и теоретиками, вынудив их обратиться к проблемам добродетели, устройства человеческой природы, богословским вопросам происхождения современного государства и даже к вопросу о природе зла, одним словом, к вопросам, всегда находившимся на спорной территории между сферами разума и религии. Совсем неудивительно, что этот возврат религии в объяснительные модели совпал с возвращением взрывного интереса к понятию, недолгий расцвет которого связывают с неустойчивой эпохой Interbellum и проигранного дела Веймарской республики. Речь идет о «политической теологии» 2 . Одно из основных затруднений, связанных с употреблением этого словосочетания, состоит в том, что у него нет одного разделяемого общепринятого значения. Знаменитая «теорема секуляризации» (Meier, 2011: 197), предложенная Карлом Шмиттом в начале третьей главы «Политической теологии» и так замечательно приспособленная для написания истории идей ${ }^{3}$, была введена им в качестве полемического оружия в непростом Веймарском контексте. Это оружие успело ярко блеснуть в его работах межвоенного периода, чтобы, будучи затем вытесненным на периферию, оставаться на протяжении почти всего XX века уделом отдельных «опасных умов». Один из них, Лео Штраус, для которого теолого-политическая проблема, по его собственному признанию, еще с 1920-х годов стала основной темой (Meier, 2006: 4), в своих лекциях 1954-1955 гг., стремясь отделить политическую теологию от политической философии, предложил следующую краткую формулировку: «Под политической теологией мы понимаем политические учения, основанные на божественном откровении. Политическая же философия ограничивается тем, что доступно человеческому уму, причем без посторонней помощи» (Штраус, 2оооб: 12). Несмотря на всю свою лапидарность и, казалось бы, предельно формальный характер, формула Штрауса дает достаточно исчерпывающее описание проблемы. Эта формула довольно недвусмысленным образом исходит из того, что inter auctoritatem et philosophiam nihil est medium, указывая на далеко не безоблачные отношения между двумя регионами опыта ${ }^{4}$. Эти непростые отношения и составляют «теолого-политическую проблему», в самом основании которой заложен конфликт. Штраус ограничивает область авторитета религиями откровения, хотя с определенным упрощением можно сказать, что кризис сопровождает философию практически с момента ее появления: первым проявлением теолого-политической проблемы стал конфликт Сократа с Афинами.

Предлагаемый текст не ставит своей целью упражнение в политической теологии. Ни в узком смысле, в каком обычно говорят о политической теологии, упоминая о Карле Шмитте, Лео Штраусе или Вальтере Беньямине, ни в более широком, когда хотят поведать о старинной традиции политического мышления, вытеснен-

2. Подробный анализ теоретической траектории понятия см.: Филиппов, 2016: 479-50о.

3. К примеру, основные тексты Дж. Агамбена можно рассматривать как продолжение и развитие этого тезиса.

4. По поводу формулы см. послесловие А. Михайловского в: Майер, 2012. 
ной на обочину современным секулярным политико-философским разумом, который теперь не знает, что ему с этой победой делать (Lilla, 2007: 3-13). Не ставит он перед собой и задачи в очередной раз порассуждать о перипетиях «секуляризации в постсекулярных обществах» - литература на эту тему поистине необъятна. Цель данной работы - на примере нескольких, внешне на первый взгляд мало связанных между собой сюжетов из истории мысли, показывающих внезапную политическую силу религии, очертить смысловые рамки возвращения теологополитической проблематики там, где это казалось уже невозможным, где секуляризация уже казалась необратимой. Поэтому в том смысле, в каком Карл Шмитт рассматривал свою работу как форму критики, как способ «разыскать «политические теологии» даже там, где всякая теология недвусмысленно отвергается, политическое отрицается, а всякая политическая теология объявляется «исчерпанной» (Майер, 2012: 95), этот текст хотел бы быть таким упражнением.

\section{В поисках «политической духовности»: Фуко едет в Иран}

Обычно возвращение религии к активной политической роли философы датируют разными зрелищными событиями вроде 11 сентября (Хабермас, 2002: 117), что верно, принимая во внимание последовавшие за ними глобальные изменения, но верно лишь отчасти. В этой связи полезно вспомнить об одной революции, чей очередной юбилей можно начинать праздновать уже сейчас. 1 октября 1978 года газета «Corriere della sera» публикует репортаж под заголовком «Шах устарел на 100 лет». Однако этот заголовок был версией редакции газеты. Изначальное авторское название текста звучало по-другому и теперь выглядит намного более уместным: «Мертвое бремя Модерна». Автор статьи, Мишель Фуко, по заданию итальянской газеты поехал в Иран, чтобы, по его словам, «присутствовать там, где рождаются идеи» (Afary, Anderson, 2005: 3). Фуко совершает два недельных вояжа в сентябре и ноябре 1978 года и пишет (довольно простым газетным языком) о том, что видит: о шахском режиме, нефти, массовых беспорядках и репрессиях спецслужб. В своем втором репортаже он высказывает довольно смелую по тем временам мысль, что не иранская революция является возвращением архаики в современность, а именно западный модерн, чей крах мы наблюдаем в Иране, отныне является архаикой и отсталостью:

...я понял, что недавние события означают не отступление перед лицом модернизации, вызванное давлением крайне ретроградных элементов, но отторжение целой культурой и целым народом модернизации, которая сама по себе есть архаизм.

Неудача шаха заключается в поддержке этого архаизма. Его преступление - в поддержке при помощи коррумпированной и деспотической системы той части прошлого в настоящем, которое ее больше не желает.

Итак, модернизация как политический проект и как принцип социальной трансформации есть теперь для Ирана достояние прошлого. (Там же: 195-196) 
Возникает впечатление, что Фуко, говоря о «модернизации, которая сама по себе есть архаизм», вводит в свой анализ перевернутую темпоральность: он отказывается рассматривать его в рамках конвенционального модернизационного нарратива о противостоянии современности и традиций. Иранские события это не разворот течения времени вспять и не «борьба современности и традиций»: речь идет о решительном коллективном политическом отказе от того, что обычно принято считать Современностью или Модерном. Этот отказ завораживает Фуко, и он стремится выявить его причины. Разумеется, он замечает необычайно важную роль религии в развитии восстания. Благодаря широкому распространению кассетных магнитофонов, одному из материальных артефактов той самой «отторгнутой модернизации», подрывные проповеди шиитских богословов распространяются по стране с невиданной скоростью:

Говорят, что Де Голль устоял во время алжирского путча благодаря транзистору. Если шах близок к падению, то произойдет это благодаря магнитофонной кассете. Это инструмент контринформации par excellence. B прошлое воскресенье я отправился на тегеранское кладбище - единственное место, где разрешены собрания в условиях военного положения. Люди стояли под лозунгами и лавровыми венками, проклиная шаха. Потом все уселись на землю. Трое мужчин, в том числе и религиозный лидер, по очереди вставали и начинали говорить с невероятной силой, почти что с яростью в голосе. Но когда они собрались расходиться, по меньшей мере две сотни солдат заблокировали ворота при помощи пулеметов, броневиков и двух танков. Арестованы были те, кто брал слово, а также все, у кого были магнитофоны.

Однако кассеты с речами самых известных ораторов вы можете найти за порогом большинства провинциальных мечетей по очень низкой цене. Вам встретятся дети, идущие по самым людным улицам с магнитофонами в руках. Голоса, записанные в Куме, Мешхеде и Исфахане, звучат с такой громкостью, что перекрывают шум автомобилей. (Там же: 219)

Невиданная ранее политическая сила религии становится для него все более очевидной:

Днем в мечетях муллы яростно выступали против шаха, американцев и Запада с его материализмом. Они призывали народ к борьбе с режимом во имя Корана и ислама. Когда мечети перестали вмещать толпы слушателей, на улицы выставили громкоговорители. Эти голоса, видимо, столь же грозные, как голос Савонароль во Флорениии, голоса анабаптистов из Мюнстера и пресвитериан времен Кромвеля, разносились по всему району, по всей округе. Многие из этих проповедей были записаны на кассеты, распространившиеся по всему Ирану. (Там же: 200-201)

Переход Фуко к языку прямых исторических аналогий в этом отрывке из газетной статьи под названием «Тегеран: вера против шаха» весьма показателен и красноречив: он полагает, что в Иране его ждет аналог тех великих религиозных, бого- 
словско-политических конфликтов, что стояли у истоков современного Запада ${ }^{5}$. Фуко не откажешь в проницательности. Дата публикации этой статьи в «Corriere della sera» - 8 октября 1978 года, и исход разворачивающихся в Иране событий еще совсем не ясен в том числе и многим его непосредственным участникам, но Фуко, как кажется, уже видит ту силу, что в итоге возьмет верх в этом противостоянии.

В своем следующем тексте, «О чем мечтают иранцы», опубликованном во французском еженедельнике «Le Nouvel Observateur» в номере за 16-22 октября 1978 года, Фуко весьма недвусмысленно вычерчивает контуры давно забытого теолого-политического конфликта, который теперь разворачивался на глазах всего современного мира. Светский просвещенный монарх против религиозного проповедника, разговаривающего с окружающим миром на языке абсолютной вражды: «Ситуацию в Иране можно понять как великий поединок под традиционными эмблемами: как поединок короля и святого; вооруженного правителя и обездоленного изгнанника; деспота, лицом к лицу столкнувшегося с человеком, идущим против него с голыми руками под восторженные приветствия своего народа. Этот образ обладает своей собственной мощью, но он говорит от лица действительности, под которой только что подписались тысячи мертвых» (Там же: 204).

Фуко не разделяет оптимизма светских иранских оппозиционеров, считающих «ислам» и «Хомейни» просто удобными пропагандистскими инструментами эффективного «расшатывания режима». Возникающая реальность совершенно новой «политической воли» для него очевидна: «„Чего вы хотите?“ На протяжении всего моего пребывания в Иране я ни разу не услышал в ответ слова „революция“, но в четырех случаях из пяти мне отвечали: „Исламского правительства“» (Там же: 205). Очевидный для непосредственных участников мессианский горизонт разворачивающихся событий только укрепляет это его убеждение: «Часто говорят, что для шиитов плоха всякая власть, что не от Имама. Дело, как мы видим, обстоит гораздо сложнее. Вот что сказал мне в первые минуты нашей встречи аятолла Шариатмадари: „Мы ждем возвращения Имама, однако это не значит, что мы отбрасываем саму возможность создать хорошее правительство. Вы, христиане, стремитесь к тому же, хоть и ждете Судного дня“» (Там же: 205).

В знаменитом окончании статьи, до сих пор вызывающем споры и разногласия, Фуко суммирует смысл открывшейся ему новой «политической воли» и раскрывает свои собственные резоны, лежащие в основании его интереса к Ирану: «Для людей, издавна живущих на этой земле, смысл их поисков состоит в том, чтобы найти, пусть даже ценой своей жизни, то, о чем мы позабыли со времен Возрождения и великих кризисов христианства, - политическую духовность. Я уже слышу, как смеются французы. Но я знаю: они не правы» (Там же: 209). Смех не заставил себя долго ждать. «Духовность» вызвала бурю критики. Иранская эмиграция

5. Заголовок, предложенный самим Фуко, «В ожидании Имама» (Afary, Anderson, 2005: 295), имел несомненный мессианский подтекст. Цитаты из статей Фуко даются по: Afary, Anderson, 2005. Порусски достаточно подробное описание сюжета см.: Эрибон, 2008. 
и французские востоковеды указывают на опасность игр с политическим исламом, предупреждая о том, что Хомейни будет тем лекарством, которое может оказаться хуже болезни. Дальнейшее развитие событий скорее подтвердило, чем опровергло их предостережения. В то же время едва ли стоит представлять Фуко наивным «ориенталистом», отправившимся на восток в поисках «духовности», которую, по его мнению, давно утратил современный Запад. Он достаточно трезво и в более долгой перспективе мог представить себе последствия, которыми отзовется революция в Иране. В своей итоговой статье «Пороховая бочка под названием ислам», вышедшей уже в феврале 1979 года, он дает вполне недвусмысленный прогноз будущих событий:

\begin{abstract}
Это ненасильственное восстание целого народа, опрокинувшее всесильный режим - невероятно редкий для двадцатого века результат, - сталкивается с решающим выбором. Вероятно, историческое значение этого события будет состоять не в его соответствии признанной «революционной» модели, но в его способности перевернуть существующую на Ближнем Востоке политическую ситуацию, а значит, и общемировое стратегическое равновесие. Уникальность этого конфликта, до сих пор придававшая ему силу, теперь по той же причине грозит привести к его дальнейшему разрастанию. Следовательно, в качестве «исламского» движения он способен охватить своим пламенем весь регион, ниспровергнуть самые нестабильные режимы и поколебать самые устойчивые. Ислам, который есть не просто религия, но и образ жизни, наследие истории и цивилизации, имеет все шансы стать гигантской пороховой бочкой для сотен миллионов человек. Начиная со вчерашнего дня в любом мусульманском государстве можно ждать внутреннего переворота, основанного на освященных временем традициях. (Там же: 241)
\end{abstract}

«Политическая духовность», вызвавшая бурю критики, это не ориенталистский конструкт, придуманный пресыщенным западным интеллектуалом, а взрывоопасный, наполненный реальным мессианизмом богословско-политический синтез, непосредственная связь слов и действий, отчаянно ищущая свою политическую форму, и в этом своем, зачастую насильственном, поиске способная опрокидывать режимы и менять границы государств. Таким было западное христианство на заре Нового времени (и соответствующие отсылки, к которым обращается Фуко, здесь не случайны). Эта «непосредственность», давно утраченная Западом, плотно опутанным сложной сетью дисциплин, дискурсов и институтов, притягивает и завораживает Фуко. Он, к тому моменту погруженный в изучение истории изобретения западного субъекта, пытается дать адекватное определение этой непосредственной связи. Едва ли словосочетание «политическая духовность» может служить удачным примером такого определения. Однако он прав в одном (а в тот момент это мало кто понимает, в том числе, видимо, и сам Фуко; можно сказать, что через него просто говорят события): тот конвенциональный образ, который имелся у Запада в отношении самого себя, натолкнулся на непредвиденное препятствие. Модерн (по крайней мере, в том виде, в каком его обобщённо представ- 
ляет западная социальная теория) перестает быть всеобщей историей. Отныне ему предстоит доказывать и отстаивать свою собственную состоятельность перед лицом иных сил, также стремящихся утвердить собственную значимость и открыто провозглашающих свою враждебность, основанную на вере.

\title{
«Осознание недостающего»: Хабермас идет на похороны
}

\begin{abstract}
9 апреля 1991 года в церкви монастыря Св. Петра в Цюрихе прошла церемония прощания с Максом Фришем. Вначале его спутница Карин Пиллиод зачитала короткую волю покойного. В числе прочего, там провозглашалось: «Пусть говорят близкие; произносить „аминь“ не нужно. Я благодарен служителям церкви Св. Петра в Цюрихе... за разрешение поместить гроб в церкви для нашей церемонии прощания. Прах будет где-нибудь развеян». Говорили двое друзей. Ни священника, ни благословения. Скорбящие были интеллектуалами, и у большинства из них не находилось времени для церкви и религии. Меню последующей поминальной трапезы было составлено самим Фришем. В тот момент эта церемония не показалась мне необычной. Тем не менее форма, место и ход ее были необычными. Вне всякого сомнения, Макс Фриш, агностик, отвергавший исповедание какой-либо веры, чувствовал нелепость процедуры нерелигиозных похорон и своим выбором места церемонии публично провозгласил, что просвещенному современному веку так и не удалось найти подходящей замены религиозному способу организовать финальный rite de passage, завершающий жизненный путь. (Habermas, 2010: 15 )
\end{abstract}

Этим воспоминанием начинается небольшое эссе, название которого можно перевести как "Осознание недостающего» ${ }^{6}$, написанное Юргеном Хабермасом в 2007 году. Очень необычное начало для текста, созданного философом, сделавшим за последние полвека для обоснования светской и рациональной культуры, политики рациональной аргументации всё и даже немного больше. Этот небольшой текст подводит итог изучению Хабермасом вопросов веры и религии, к которым он обратился в начале $2000-\mathrm{X}$ гг. $^{7}$

Фактически Хабермас предлагает признать, что доминирующие формы современной секулярной рациональности оказываются бессильны во многих предельных, чрезвычайных ситуациях. Как и в случае Фуко, который приезжает в Иран, оперируя конвенциональными представлениями о Современности, и, столкнувшись с непонятной ему практикой коллективного политического действия, базирующегося на слове, вынужден отступить в поисках определения того, что увидел; так и в описанном Хабермасом случае смерти друга, в ситуации, требующей перехода к действию, могущественный современный разум в поисках опоры

6. Эссе было текстом выступления Хабермаса на дискуссии с профессорами Высшей иезуитской школы в Мюнхене. Впервые оно было опубликовано в «Neue Zuercher Zeitung» 10 февраля 2007 года, и позже вошло в книгу, посвященную этому диспуту (Habermas, 2010).

7. См.: Хабермас, 2002, 2006, 2011. 
вдруг осознаёт нехватку собственных ресурсов. У него, безусловно, есть в распоряжении обладающие невероятной мощью институты и традиции современной науки, однако последняя, переведя описание чрезвычайной ситуации на свой натуралистический язык, в лучшем случае может указать на то, чего, по мнению франкфуртского философа, как раз-таки «не достает» современной секулярной рациональности. Эта «нехватка» есть слово, описывающее общее положение современных светских обществ. Продолжающаяся секуляризация, или, как сказал бы сам Хабермас, «постепенное замещение авторитета божественного авторитетом достигнутого консенсуса» (Adams, 2006: 79), не смогла полностью заменить прежнюю этическую субстанцию, исторически лежавшую в основаниях модерна. Современный разум, секулярный и космополитический, даже в его «демократической», коммуникативной форме, во-первых, не знает, что делать с пограничными ситуациями, такими, например, как смерть; во-вторых, не имеет самостоятельного представления о том, что такое добродетельная жизнь. Хабермас вынужден констатировать господство «пораженческого отношения к разуму», с которым «мы сегодня сталкиваемся как в постмодернистской радикализации „диалектики Просвещения“, так и в натурализме, основанном на наивной вере в науку» (Habermas, 2010: 18). Это «пораженчество современного разума» находит свое выражение в прогрессирующем мотивационном дефиците светского модерного государства. Лежащая в его основе процедурная рациональность, построенная на «извлечении легитимности из легальности» (Хабермас, 20о6а: 49) не может вдохновить граждан на добродетельные поступки (в отличие от действий, основанных на собственном интересе). Хабермас переформулирует здесь то, что ранее во введении к дискуссии с кардиналом Ратцингером назвал «теоремой Бёкенфёрде»: «Могут ли объединенные в государство народы жить одним лишь предоставлением свободы отдельной личности, не имея объединяющих уз, которые предшествовали бы этой свободе (Там же: 53)?» Бёкенфёрде задается вопросом о том самом утраченном, об «этической субстанции», составляющей «дополитические основы демократического правового государства». Данный здесь же Хабермасом ответ на этот вопрос еще предполагает отсылку к коммуникации и демократической процедуре к знаменитому «конституционному патриотизму», предмету его особой гордости: «Те „объединяющие узы“, которых не находит Бёкенфёрде, есть сам демократический процесс - коммуникативная практика, которая может осуществляться лишь совместно и в которой на повестке дня стоит в конечном счете правильное понимание конституции» (Там же). Позже, однако, он признает, что современным государством утрачены «контроль над образами морального целого, сохраняемыми религией», и способность формулировать «коллективно обязывающие идеалы» (Habermas, 2010: 19). За «недостающим» современный разум вынужден обратиться к традициям и жизненным формам давно, казалось бы, изгнанным на периферию Современности, среди которых не последнее место принадлежит религии: 
В жизни религиозных сообществ, если только они избегают догматизма и принуждения, может сохраниться нетронутым нечто такое, что утрачено в других областях и что нельзя восстановить с помощью одного только профессионального знания экспертов, - я имею в виду достаточно дифференцированные возможности выражения и способности чувствовать жизненные заблуждения, общественные болезни, неудачу индивидуальных проектов жизни и деформированность искаженных жизненных условий. На асимметрии эпистемических притязаний основывается готовность философии учиться у религии (Хабермас, 20о6а: 66-67).

Таким образом, динамика секуляризации может быть описана как обоюдный Lernprozess - процесс взаимного обучения и перевода понятий, в ходе которого религия учится рациональной аргументации и изложению своих принципов на доступном для публичной сферы языке, а философия учится использовать этикополитический потенциал священных текстов:

Это взаимопроникновение одновременно способствовало и усвоению философией исконно христианских постулатов. Работа по усвоению этих постулатов нашла свое выражение в таких многозначных нормативных кластеpax понятий, как ответственность, автономия и оправдание, как история и воспоминание, новое начало, инновация и возвращение, как эмансипация и исполнение, как освобождение, осознание и воплощение, как индивидуальность и общность. Эта работа трансформировала первоначально религиозный смысл, но не устранила, не выхолостила его из этих понятий... Содержание библейских понятий выводится за пределы религиозного сообщества и становится достоянием инаковерующих и неверующих. (Там же)

Так, библейское представление о человеке, созданном по «образу и подобию Божьему», нашло свое мирское выражение в принципе одинаковой ценности всех человеческих существ, грех стал виной, а нарушение заповедей преступлением закона. Однако этот процесс перевода небезобиден: при переформатировании истин писания происходит частичная утрата их содержания. Утраченное - это мессианская перспектива искупления, поддерживающая представления о цельной и добродетельной жизни, которые есть у религии, но которых нет у современных секулярных обществ. Поэтому разум и вера, по мнению Хабермаса, должны заключить пакт о взаимном признании:

Религиозная сторона должна признать авторитет «естественного» разума, выраженный в фаллибилистских результатах институционализированных наук, а также в базовых принципах универсалистского эгалитаризма в праве и морали. В свою очередь, секулярный разум не должен считать себя вправе судить об истинах веры, даже если в итоге он может принять как обоснованное только то, что может перевести в свои собственные, по существу, универсально доступные рассуждения. (Habermas, 2010: 16) 
Хабермас выступает за безусловное ограничение притязаний разума:

\begin{abstract}
Этот современный разум научится понимать себя только тогда, когда прояснит свое отношение к современному, ставшему рефлексивным религиозному сознанию, уловив общность происхождения двух взаимодополняющих форм духа в результате сдвига, произошедшего в эпоху «осевого времени». Говоря о взаимодополняющих формах духа, я отвергаю две позиции: с одной стороны, позицию узколобого Просвещения, которое, будучи непросвещённым относительно себя самого, отказывает религии в каком-либо разумном содержании, а с другой - точку зрения Гегеля, для которого религия является достойной упоминания формой духа, но только в виде подчиненного философии «представляющего мышления». (Habermas, 2010: 18)
\end{abstract}

Таким образом, разум и религиозная вера оказываются в сложных отношениях взаимной неустранимости: «То, каким образом вера остается непроницаемой для разума, невозможно ни отвергнуть, ни просто принять» (Ibid.). Хабермас предлагает решение, своего рода посредника в коммуникации между современным секулярным разумом, запутавшимся в апориях постмодернизма и натурализма, и претендующими на признание религиозными традициями: «постметафизическое мышление» (Ibid.). Оно принципиально отличается как от религиозных мировоззрений, так и от традиционной, идущей еще из античности метафизики, также претендующей на право быть «всеобъемлющей доктриной» и путем спасения: «Каждая из великих мировых религий прокладывает свой привилегированный и выдвигающий особые требования путь к индивидуальному спасению - например, путь к спасению странствующего буддийского монаха или христианского отшельника. Философия рекомендует в качестве своего пути спасения жизнь, посвященную созерцанию, - bios theoretikos» (Habermas, 1992: 32 ).

Постметафизическое же мышление отвергает подобные претензии и отдает себе отчет в собственной ограниченности: оно погружено в толщу социальных интеракций, таких, например как труд, или, что еще важнее, язык. Человек - это трудящееся и лингвистическое животное: «Философии с ее возможностями остается интерпретирующее посредничество между экспертными знаниями и повседневной практикой, нуждающейся в ориентации. Ей остается освещать развитие самопонимания процессов жизненного мира, процессов, связанных с тотальностью, поскольку необходимо защищать жизненный мир от предельного отчуждения в руках объективирующих, морализаторских $и$ эстетических вмешательств экспертных культур» (Ibid.: 17-18). Отсюда стоящая перед постметафизическим мышлением принципиальная задача: выявить заложенные в различных формах духа и повседневной практики прагматические предпосылки, сделав тем самым возможной их нацеленную на достижение консенсуса коммуникацию в едином публичном пространстве.

Попытка Хабермаса предложить нравственно-политическое обоснование функционирования современных обществ, вдруг оказавшихся в новой для себя 
постсекулярной ситуации, остается одним из самых амбициозных политико-философских предприятий последних пятнадцати лет. Тем не менее если мы пойдем по пути самого Хабермаса и попробуем эксплицировать лежащие в основе этого предприятия когнитивные предпосылки, то увидим, что оно также не свободно от определенных изъянов. Оно строит модель коммуникации теологии и западной политической рациональности на основе своей «родной», конститутивной для этой рациональности христианской традиции, тогда как различие между христианством и другими религиями откровения принципиально и для исторической генеалогии современного Запада, и для реального функционирования нынешних модерных плюралистических обществ (Манан, 2004: 47).

Каким образом в этих плюралистических современных обществах будут функционировать предлагаемые Хабермасом «рынки мировоззрений», на которых современное государство собирается пополнять свои ресурсы солидарности? Для построения модели можно привлечь любимое Хабермасом понятие публичной сферы, однако исторически на Западе она имеет отчетливую христианскую и, если принять во внимание количество религиозных конфликтов между различными деноминациями, очень проблематичную историческую генеалогию. Как в ней будут ощущать себя представители иных конфессий и традиций, а также атеисты и агностики, отказывающиеся признавать сам факт какого-либо религиозного наследия? Даже если допустить, что произошла полная секуляризация публичной сферы, она полностью нейтральна и готова допустить все мировоззрения на «рынок идей», то как будет происходить ее политическое функционирование? В конце концов, даже придуманная Локком толерантность опиралась на очень серьезные, субстанциальные и по своей сути политико-теологические исключения (Локк, 1988: 81-82, 124-125) $)^{8}$. Можно, конечно, опираясь на логику самого Хабермаса, сослаться на то, что современные либеральные государства в ходе своего исторического существования неуклонно расширяли пространство возможного участия, а исключение - это всего лишь исключение, давно ставшее достоянием истории. Но тогда сначала придется найти серьезные возражения знаменитым словам одного не самого любимого Хабермасом автора: «Исключение интереснее нормального случая. Нормальное не доказывает ничего, исключение доказывает все; оно не только подтверждает правило, само правило существует благодаря исключению» (Шмитт, 200о: 29).

Хабермас предлагает положить в основание своей мировоззренчески нейтральной и не признающей исключений публичной сферы (Хабермас, 2011: 123) различение между этикой и моралью: этика, или нравственность - это нечто, относящееся к жизни сообществ (религиозных, этнических и т.п.) с их субстанциалистскими представлениями о правильной жизни, а мораль - это интерсубъективно разделяемые универсальные нормы о правильном и должном, под прикрытием которых должно сосуществовать (почему-то мирно, по мысли Хабермаса) этическое

8. В своих текстах и выступлениях, посвященных этой проблеме, Хабермас предпочитает обойти этот вопрос (см.: Хабермас, 2006б, 20116). 
разнообразие культур, традиций, религий и образов жизни. Однако это различение предполагает, что между этикой (ценностями культур и традиций) и моралью (универсальными нормами и процедурами, которым должны подчиняться эти ценности и традиции) нужно установить жесткую непроницаемую границу, а для этого нужно представить, что нормы и ценности могут существовать независимо, никак друг на друга не влияя. Кто выступит оператором этой границы? Современное либеральное государство? Но каковы его мотивы для постоянного поддержания подобной границы в функционирующем состоянии и какие ресурсы в прямом и переносном смысле слова для этого понадобятся?

Итак, на роль посредника, связывающего в едином коммуникативном пространстве различные верования, традиции и современный разум в различных его ипостасях, Хабермас предлагает «постметафизическое» мышление. В отличие от религий и предшествующей ему «традиционной» метафизики, оно осведомлено о собственных границах и реальных возможностях и поэтому предполагает, что с высоты птичьего полета может обозреть публичное пространство, идентифицировать проблемные, конфликтные места и «расшить» их с опорой на доступные ему семантические ресурсы. Однако представленная Хабермасом в качестве обоснования историческая генеалогия этого мышления довольно проблематична. Объединяя мировые религии и метафизику в рамках одной категории (и та и другая - путь к спасению, придуманный в «осевое время»), Хабермас предлагает руководствоваться их возможными сходствами, но ничего не говорит о существующих между ними различиях, которые как минимум так же важны (Штраус, 2ооо: 294-298). Не стоит забывать и о том, что теолого-политическая проблема как история взаимоотношений между разумом, притязающим на самостоятельную роль в рамках политического сообщества, и верой (в форме гражданской религии либо религии откровения), притязающей на то же самое, началась с конфликта, с кризиса. Едва ли стоит предполагать, что Хабермасу неизвестны эти обстоятельства, однако своим вниманием он их не удостаивает.

Не переоценивает ли франкфуртский философ роль коммуникации и языка в умиротворении конфликтов и обеспечении бесперебойного функционирования либеральной публичной сферы? Как следует поступить современному либеральному государству, опирающемуся на нормы и уважающему все ценности, в том случае если какая-то часть его собственного плюралистического разнообразия, обладающая всеми формальными правами на участие, начинает разговаривать (как в описанном выше случае Фуко в Иране) с окружающим миром на языке войны и «чистой», «абсолютной вражды» (Derrida, 2005: 112-133)? То есть, ссылаясь на собственные ценности, она отказывается признавать в качестве равноправных партнеров по коммуникации это самое государство с его нормами и конституцией, другие культуры, религии и традиции с их ценностями, а заодно и либеральную публичную сферу с постметафизическим мышлением в качестве ее оператора, по той причине, что считает их, к примеру, порождением «неверия», безусловным, подлежащим уничтожению злом. Ответ, который здесь напрашивается, носит 
позитивно-правовой характер: есть нормы, есть принципы и процедуры, они автономны и притязают на рациональную приемлемость для всех граждан (Хабермас, 20о6а: 49). Более того, суверен (правовое государство) может даже попытаться определить в позитивно-правовом смысле степень и глубину опасности не только враждебных действий, но мнений и высказываний, попытавшись перейти к их прямому полицейскому администрированию 9 . Однако диагностированный Хабермасом дефицит солидарности и ценностной мотивации рано или поздно заставит это государство обратиться за помощью к существующим традициям с имеющимися в их распоряжении семантическими ресурсами. Какой выбор сможет сделать суверен, если на имеющемся перед ним рынке мировоззрений сосуществуют все традиции, но он при этом отгорожен от них непроницаемым забором «автономных» норм? Какими ценностями должны руководствоваться те, кто будет отвечать за поддержание этих универсальных норм в действии? Ведь серьезность создавшейся ситуации вынуждает суверена к принятию решения о создании исключения, тогда как неэксклюзивный и антиэссенциалистский характер сконструированной им же самим публичной сферы делает такое решение невозможным.

Хабермас недооценивает амбивалентность языка и речи - вторая сигнальная система может выступать не только заслоном на пути внутривидовой агрессивности и средством установления солидарных связей, но и катализатором агрессии и вражды. Не отсылает ли, таким образом, «постметафизическая философия» к старому «метафизическому» вопросу о существе человеческой природы: является ли она доброй или же она изначально греховна и погрязла во зле? Лежащая в основе этого вопроса фундаментальная антропологическая дихотомия между «по природе добрым» и «по природе злым» человеком, которая также прочерчивает демаркационную линию между политической теологией и политической философией, не имеет никакого однозначного решения средствами теории. Ответ на вопрос о том, на что следует делать ставку - на разум или на первородный грех, может быть предметом только решения. Понятны ставки самого Хабермаса. Но готово ли тогда постметафизическое мышление иметь дело с «проблемой зла»? Если смысл отношений между философией и богословием заключен во взаимном публичном переводе, то поддается ли эта проблема переводу на осторожный и «осмотрительный» язык постметафизики, или же современному секулярному государству остается в этом случае довольствоваться языком позитивно-правовых «автономных», «универсальных» норм? ${ }^{10}$ Вал рассуждающей о «зле» медий-

9. На высокие издержки и риски подобной политики указывал еще Спиноза. В конечном итоге такая политика достаточно быстро приведет к тем же самым «эрозии гражданской солидарности» и «дефициту мотивации». См.: Спиноза, 1957: 258-268.

10. Невиданный взрыв интереса к политико-теологической проблематике все же заставил Хабермаса отреагировать публикацией текста под характерным заголовком «Политическое». В нем он признает сложное положение, в котором оказались современные государства под давлением «новых глобальных вызовов», размывающих их привычную секулярную демократическую легитимацию, а также необходимость реагировать на притязания религиозных сообществ. «Политическое» же он рассматривает как опасный анахронизм, сохранившийся с тех времен, когда власть была «монополией 
но-публицистической риторики служит весьма красноречивым симптомом очень важного отсутствия (Bernstein, 2005: 10-11).

\section{«После суверенитета»: политическая теология и теории радикальной демократии}

К проблеме «зла» философы всегда относились с изрядной долей подозрения. Оно всегда требовало «теодицеи». Природное «зло» перестало считаться проблемой уже достаточно давно, а зло моральное всегда проистекало из несовершенства человеческой природы, то есть, так или иначе, должно было в конечном итоге привести к естественным причинам (Neiman, 2002: 1-12). Современное решение предложил Кант, разделив два порядка аргументации: моральный и теологический (Кант, 1980). Таким образом, моральным философам остались рассуждения о справедливости, равенстве, свободе и даже добродетели, а проблему зла было решено передать теологам. Однако политическая повестка двадцатого века, вернувшаяся к философам с проблемой «радикального зла», не дала завершить этот обмен (Bernstein, 2002: 4). Все пришлось начинать практически заново. Краткое резюме таково: зло для философа представляет собой некую абсолютную метафизическую границу, кладущую предел человеческому пониманию и действию (Neiman, 2002: 7).

То, что зло может корениться в самой «природе человека», не было новостью, начиная как минимум с Макиавелли. Он же предложил возможность инструментализации этого понятия в политических целях. Раннемодерные теоретики естественного права довели до совершенства мысль о том, что не одни лишь благие намерения могут лежать в основе социального порядка (Шмитт, 2016: 335-336). Наконец, Кант окончательно сформулировал определение «изначального (radikales), прирожденного зла... в человеческой природе», только лишь для того, чтобы потом перейти к полностью секулярному языку обоснования морали (Кант, 1980: 103). Когда философская антропология XX века предложила, опираясь на достижения естественных наук и психологии, рассматривать человека как динамически «открытое», опасное, а потому скорее склонное ко злу существо, для этого уже имелись мощные предпосылки в истории европейской метафизики (Шмитт, 2016: 337).

на решение» и потому нуждалась в теологической легитимации. Сегодня она, по мнению Хабермаca, в таковой больше не нуждается, а ренессанс политической теологии является результатом непростого состояния современных западных обществ и носит по преимуществу компенсаторный характер, иллюзорно обещая вернуть политике утраченную ею субстанцию. «Клерикально-фашистским» концепциям политического Хабермас предлагает противопоставить свою идею публичной сферы как пространства взаимного перевода светских и религиозных содержаний (Habermas, 2011). Опять мы видим, как Хабермас, предлагая весьма утонченную и нюансированную историко-генетическую критику политического, не решается тем не менее заходить на собственную территорию политической теологии и полемизировать с тем, что составляет именно ее, политической теологии, differentia specifica, обходя тем самым возможные неудобные вопросы (Ibid.). 
Именно в этом виде зло как проблема попадает в фокус современных теорий радикальной демократии. В отличие от Хабермаса, их сторонники не пытаются обойти проблему зла молчанием, а берутся за нее непосредственно, в том числе и в ее теолого-политических предпосылках. Паоло Вирно напрямую обращается к фрагментам «Понятия политического», содержащим знаменитые политико-антропологические дистинкции (Virno, 2008: 14-15; Шмитт, 2016: 335-337). Действительно, невозможна никакая теория институтов, никакая теория социального порядка, которая не отдавала бы себе отчета в своем базовом отношении к существу человеческой природы, причем выбор этого отношения может быть исключительно вопросом «решения». Ведь если человек «по природе зол», то для обуздания «внутривидовой агрессивности» ему необходимы институты «суверенитета», которые смогут поставить под контроль применение насилия. Если же человек «по природе добр», то нет никакой необходимости в дополнительных авторитарных ограничителях (Critchley, 2012: 108). Присущие человеку от природы способности к труду и коммуникации сами решат вопрос порядка: все монопольные инстанции будут упразднены, «отомрут» (в анархических и коммунистических версиях решения), либо, в ходе своего исторического существования, как это предлагает, например, Хабермас, будут максимально лишены признаков, указывающих на наличие у них некогда «монополии на политическое решение» (в либеральных и социал-демократических версиях). Это концептуальный тупик, причем с отчетливым теолого-политическим подтекстом. Рациональный выбор между двумя альтернативами невозможен. Конечно, есть массивы эмпирических данных, дающих нам массу свидетельств в пользу второй из них, однако относительно первой их тоже как минимум не меньше. Вирно предлагает «реалистический» выход из этого тупика. Действительно, любой претендующей на связность теории порядка необходимо признать существование «зла» в человеческой природе, однако такое признание совершенно необязательно влечет за собой признание неизбежности возникновения суверенного господства:

Наполненная риском нестабильность человеческого животного - так называемое зло - никоим образом не подразумевает формирования и поддержания той «верховной власти», которая выступает в роли суверенитета Государства. Наоборот, «враждебный по отношению к Государству» и капиталистическим средствам производства радикализм, отнюдь не предполагающий, что наш вид обладает смирным нравом, может создать подлинную основу для полного признания «проблематичности» человеческого животного, т. е. его неопределённого и потенциального (а значит, опасного) характера. Критика «монополии на политическое решение», как и вообще институтов, чьи правила функционируют в виде навязчивого принуждения, должна опираться именно на признание того, что человек «по природе зол». (Virno, 2008: 16$)^{11}$

11. Частичный русский перевод А. Скидана и А. Пензина под заголовком «Антропология и теория политических установлений» опубликован по адресу: http://eipcp.net/transversal/o407/virno/ru. 
В течение долгого времени государство было удобной концептуальной рамкой размышлений о политике. Такой же точки зрения придерживался и сам Шмитт, но он никогда не говорил о том, что государство будет вечной и неизменной формой порядка (Шмитт, 2016: 281). Данные истории и социальной антропологии скорее подтверждают этот взгляд: государство совсем не обязательно, а кризис его современной разновидности вынуждает искать новые политические формы совместной жизни ${ }^{12}$. Для описания этого кризиса Вирно пользуется библейским понятием «исхода». Именно в этой логике находятся предлагаемые Вирно «постгосударственные» или «не-суверенные» институты. Существенным отличием, однако, здесь является попытка отказаться от стандартного анархо-коммунистического взгляда на природу общественных и политических институтов, согласно которому последние лишь искажают изначально благой характер человеческой природы и только мешают проявлению ее подлинной сути. Именно признание особенного, сингулярного характера человеческого животного как опасного и нестабильного Вирно предлагает сделать воротами для исхода в новую эпоху без государства, в которой он предлагает сделать особый упор на два института, имеющих парадоксальный характер в силу своей укорененности одновременно в природной и социальной реальностях. Речь идет о языке и ритуале. Их двойная укорененность не дает провести четкую границу между естественным и гражданским состоянием. Они одновременно находятся как бы внутри и вовне человеческой реальности. Аналогии с известными интерпретациями «чрезвычайного положения» несомненны (Шмитт, 20оо; Агамбен, 2011). В соответствии со своей «естественноисторической» критикой идеи зла Вирно рассматривает язык как амбивалентное образование: это не только средство коммуникации и установления консенсуса, но также инструмент агрессии и вражды. Он может как отрицать и дегуманизировать, так и устанавливать отношения взаимности. Важно здесь то, что Вирно предлагает понимать базовое действие языка как исключение, например, исключение врага при объявлении войны или, наоборот, исключение исключения, когда происходит взаимное признание.

Чтобы пояснить смысл второго института, ритуала, Вирно использует прямые теологические аналогии. Он цитирует знаменитый фрагмент из второй главы Второго послания апостола Павла Фессалоникийцам: «Ибо тайна беззакония уже в действии, только не совершится до тех пор, пока не будет взят от среды удерживающий теперь». Предметом анализа здесь выступает образ «удерживающего», для которого Павел использует греческое слово katechon. Здесь Вирно пытается вступить в полемику со Шмиттом, который интерпретировал katechon как фигуру суверенного господства, удерживающего хрупкий социальный порядок от обрушения в апокалиптический хаос (Шмитт, 2008: 33-39). Полемизируя со Шмиттом, Вирно фактически лишает katechon эсхатологической перспективы и предлагает понимать его как дополитический «ритуал», задающий необходимую для функ-

12. Целая традиция антропологических и социологических исследований от Пьера Кластра до Джеймса Скотта посвящена исследованию «жизни без государства». 
ционирования множества границу между порядком и хаосом, но совсем не обязательно требующий связи с какими-либо централизованными, суверенными формами отправления власти. Его задачей является защита множества от присущих ему же темных сторон, от того, что Х. Плесснер определяет как «потенциально неограниченную внутривидовую агрессию», а сам Вирно - как «перманентное чрезвычайное положение» (Virno, 20o8: 56-67).

Несомненная продуктивность предпринятой Вирно попытки рассмотреть «проблему зла», совместив языки эволюционной биологии, структурной лингвистики, антропологии и политической теологии, не освобождает ее от вопросов. В чем смысл теолого-политических аналогий и заимствований? Ведь фактическое устранение из них эсхатологии, предпринимаемое Вирно, не оставляет этим заимствованиям и аналогиям никакого другого смысла, помимо полемического. Получаемое в сухом остатке «историко-натуралистическое» истолкование «зла» означает фактическую натурализацию проблемы, и в этом нет ничего плохого, но чем тогда эта философская антропология «опасного животного» принципиально отличается от идей консервативных антилиберальных философов вроде Джона Грея? Они тоже исходят из очень близких посылок, но приходят к совсем иным, куда более пессимистическим выводам о расе приматов-убийц, ведущей планету к катастрофе (Critchley, 2012: 109-110). Как установить это различие в случае фактического отказа от обещающей мессианской логики? При этом фактически предлагаемое Вирно решение «проблемы зла» в соответствии с хайдеггеровской интерпретацией строки из Гёльдерлина «Wo aber Gefahr ist, waechst / das Rettende auch» ${ }^{13}$ имеет настолько очевидные теолого-политические и мессианские основания, что их стоило бы эксплицировать перед тем, как переходить к непосредственному применению данного принципа. Прибегая же к исключающей, «чрезвычайной» логике в описании функционирования институтов множества (языка и ритуала), Вирно скорее следует Шмитту, чем полемизирует с ним.

Если подход Вирно к проблеме «зла» мы описывали как «реалистический», то попытка исследовать «зло», предпринятая его коллегами и единомышленниками Майклом Хардтом и Антонио Негри, манифестирует несколько иную точку зрения. Вышедшая в 2009 году, их книга с трудно переводимым на русский язык названием «Commonwealth» содержит примечательное интермеццо под названием «Сила противостоять злу». В нем авторы также обращаются к известному фрагменту Второго послания Павла Фессалоникийцам, которое, по их мысли, служит прекрасным теологическим обоснованием любой пессимистической политической антропологии, занимающей почетное место в истории западной политической рациональности. Для них, однако, анализы того же самого текста, уже предпринятые Вирно и Агамбеном, служат скорее отправной точкой для конструирования собственной политической теории «зла» ${ }^{14}$.

13. „Но там, где опасность, растёт и спасающее».

14. Агамбен интерпретирует «удерживающего» не просто как «меньшее, но необходимое зло». В этом случае его интерпретация мало бы отличалась от той, что уже была предложена Шмиттом. 
Отдавая должное трезвому взгляду этих авторов на природу человека, Хардт и Негри тем не менее полагают, что те переоценивают проблему: вполне справедливо отказываясь от «доброго по природе» человека, они гипостазируют зло, превращая его в фундаментальный и неизменный элемент человеческой природы. Ведь если оно присутствует в ней очевидным образом, то katechon как способ удержания его в границах, становится таким же злом, только неизбежным, а значит, «меньшим» (Hardt, Negri, 2009: 198). Но идея «меньшего зла» самой проблемы зла никак не решает. Вирно, по их мнению, все еще находится в плену модерной идеи границы (между внутренним и внешним, злом и благом, приватным и публичным, природой и человеком и т.п.), в само понятие которой заложена идея ее удержания. Однако все эти великие различения, как и сама идея границы, уже не имеют прежнего значения в эпоху постсовременного имперского суверенитета, с ее постоянно меняющимися гибридными идентичностями. Что касается Агамбена, то его воображение чрезмерно захвачено образом закона, выступающего необходимым регулятивным принципом метафизики «радикального зла». Авторы иллюстрируют этот тезис теологическим аргументом, цитируя фрагмент из седьмой главы послания Павла к Римлянам: «Но я не иначе узнал грех, как посредством закона» (Ibid.: 190).

Подлинная же проблема, с их точки зрения, заключена в том, что любое представление о фундаментально доброй, либо о фундаментально злой природе человека упускает изначально реляционные отношения этих двух понятий, поэтому сама проблема должна быть переформулирована: «Неправильно задаваться вопросом, является ли человеческая природа доброй или злой, прежде всего потому, что добро и зло - это зависящие от обстоятельств оценочные категории, а не инварианты. Это суждения, возникающие как результат действий воли. Спиноза, например, а вслед за ним и Ницше, объясняет, что люди стремятся к чему-либо не потому, что считают это что-либо добром, но, наоборот, считают его добром потому, что стремятся к нему» (Ibid.: 191).

«Проблему зла», по мысли Хардта и Негри, должна решить предлагаемая ими трансформативная спинозистская онтология: «Вопрос не в том, какой именно инвариант определяет человеческую природу, а в том, чем человеческая природа может cmamb. Самый важный факт относительно человеческой природы (если мы все еще собираемся ее так называть) заключается в том, что она может быть пре-

\footnotetext{
Агамбен фактически предлагает отождествить «удерживающего» с «сыном погибели». Таким образом, суверенный закон, удерживая, скрывает свою подлинную сущность, заключенную в голом насилии, которое «Господь Иисус убьет духом уст своих и истребит явлением пришествия своего» (Agamben, 2005: 108-112). Основываясь на этой интерпретации, в тексте «Бегемот и Левиафан» Агамбен предлагает свою версию разгадки таинственного названия знаменитого трактата Гоббса. Левиафан принципиально двойственен: государство - это не только то, что ограждает от хаоса, но также и потенциально невероятно опасное устройство, всегда чреватое избыточным насилием и гражданской войной; это не только katechon, но и «эсхатологический зверь», подлежащий упразднению Вторым пришествием (Agamben, 2015: 66-67). Для Агамбена, в отличие от Шмитта и Вирно, определяющей является именно мессианская и эсхатологическая перспектива писем Павла.
} 
образована и постоянно преобразуется. Именно на этой метаморфозе и должна сосредоточиться реалистическая политическая антропология» (Ibid.: 191).

В основание социального порядка авторы кладут спинозистскую геометрию conatus - cupiditas - amor: эта позитивная, кумулятивная последовательность выступает в качестве силы онтологического конституирования общности, в процессе которого человеческая природа претерпевает трансформации (Ibid.: 192). Тем не менее отрицать существование зла глупо, необходимо знать о его истоках, чтобы успешнее ему противостоять. Спиноза был, как известно, суровым политическим реалистом, отдающим себе отчет в том, что люди вполне могут сражаться «за свое порабощение, как за свое спасение». Зло в такой оптике не может пониматься традиционным для философии образом, как нехватка блага или бытия, возникающая из незнания, страха или суеверия. Зло - это препятствие, возникающее на пути этого накопления позитивных аффектов. Это аффекты, повернувшие «не туда», аффекты, либо разрушающие связь между мыслью и действием, либо обратившие учредительную силу спинозистской amor против нее самой (Ibid.: 193). Хардт и Негри обращаются к яркому историческому примеру - к русской революции 1917 года, когда изначальный мощный учредительный импульс движения масс вошел в противоречие с жесткими компромиссами и ограничениями, которые привели к установлению суверенной большевистской диктатуры:

...мы должны подумать об одном ужасающем историческом опыте отноше-
ния между любовью и силой в социалистической и большевистской концеп-
циях партии. Исходная посылка разумна и понятна: пока мы разрозненны,
мы не можем ничего; лишь единение дает результат и умножает величину
единичного негодования и индивидуального бунта. Поэтому революционе-
ры действуют рука об руку и создают компактную группу, вооруженную зна-
нием и страстным стремлением. Она должна была стать искрой, которая вы-
зовет преобразование общества. Вывод, однако, ложен: медленно, но верно
неуклонное следование партией нормам и установкам, а также принимаемые
ею решения (даже право жизни и смерти) отделяются от опыта социальных
движений и поглощаются логикой капиталистического отчуждения, превра-
щаясь в тиранию и бюрократию. То, что должно было придать силу множе-
ственности, становится насилием тождества. Единство предстает в качестве
трансцендентной ценности, и лозунг революции начинает служить разложе-
нию общего. Нет, партия не победит зло. Сегодня память об этом разложе-
нии лишь подталкивает нас к тому, чтобы найти силу противостояния злу.
(Іьіd.: 198-199)

Приведенный исторический пример говорит в первую очередь о том, что вопрос об организационных формах чаемой авторами трансформации человеческой природы остается, мягко говоря, открытым, а поиск незавершенным, и одного отождествления «зла» с «тождеством» и «единством» здесь явно будет недостаточно. Ведь вопрос в этом конкретном случае должен ставиться таким образом: как вышло, что исторически данная констелляция уступок и тактических ком- 
промиссов обернулась злом? Одних лишь теолого-политических аналогий здесь будет недостаточно, хотя политическая теология может, наверное, принести немалую пользу в разборе решений, чрезвычайных мер и серьезных ситуаций той революции.

\section{Вместо заключения}

В 1948 году в своих заметках к лекции «Разум и откровение» Лео Штраус в очередной раз попытается сформулировать для себя «теолого-политическую проблему»: «Философия утверждает философствование как единственно нужную вещь. Этому утверждению противоречит учение откровения. Следовательно, философ должен опровергнуть учение откровения. Более того, он должен доказать невозможность откровения. Ведь если оно возможно, то в этом случае все философское предприятие оказывается фундаментально неверным» (Meier, 2006: 179). В 1962 году, в новом предисловии к своей книге о Спинозе он придаст этой дихотомии разума и веры еще большую определенность: «Принять возможность откровения означает принять тот факт, что философское объяснение и философский образ жизни не являются с необходимостью и очевидностью подлинным объяснением и подлинным образом жизни: философия как поиск очевидного и необходимого покоится на неочевидном решении, акте воли, таком же как вера» (Ibid.). Философия и религия не только принципиально не сводимы друг к другу посредством отнесения их, например, к общему происхождению, но зачастую находятся в отношениях нескрываемой взаимной вражды. Именно об этом хочет сказать Штраус. Однако другое, еще более важное следствие его рассуждений заключено в том, что ответ на вопрос об их взаимоотношениях не может быть чисто теоретическим. Он всегда будет носить практический, политический характер, и современному разуму с политической философией в качестве его интегральной части придется это учитывать, если они хотят заново, может быть, впервые с XVII века, урегулировать отношения с религией и той силой, которую она представляет.

Описывая отношения политической теологии с современным разумом, американский исследователь Марк Лилла предложил образ двух берегов. Река, разделяющая их, неширокая, но значительной глубины. Обитатели «берега разума» со смесью недоумения и высокомерия наблюдает за происходящим на берегу, на котором располагаются тысячелетние религиозные и богословские традиции, совершенно не опознавая себя в них и забыв о том, что они когда-то тоже жили на этом противоположном берегу. Берег разума не понимает, не может припомнить, что с исторической точки зрения аномалией является он сам и что в качестве таковой существует по историческим меркам совсем недолго (Lilla, 2007: 4-5). «Современная политика, - пишет другой консерватор, Джон Грей, - это глава в истории религии» (Gray, 2008: 1).

Если развивать это движение мысли дальше, то можно было бы добавить, что обитатели «берега разума» запамятовали, что мостки, которые пусть уже не очень 
надежно, но еще все же могут иногда соединить оба берега, а также дамбы, предохраняющие их от затопления на тот случай, если река вдруг выйдет из берегов, были возведены на заре Нового времени очень опытными и грамотными инженерами. Сделать это их вынудили трудные, а зачастую и просто опасные, чрезвычайные исторические обстоятельства, поэтому нынешний относительный комфорт светского разума есть во многом результат набора случайностей.

Этот вдохновленный современными консерваторами образный ряд можно было бы продолжать еще долго, однако есть основания сомневаться в том, что вышедшая из берегов река сможет вернуть утраченное и восстановить «Великое разделение». Поэтому нелишним будет вспомнить другой знаменитый образ отношений между разумом и теологией, образ, также введенный в оборот одним веймарским мыслителем, но, быть может, более подходящий нашей эпохе бесчисленных чрезвычайных положений по той причине, что он был рожден в похожее время: это образ куклы из шахматного автомата и спрятанного в нем карлика.

\section{Литература}

Агамбен Д. (2011). Homo sacer: чрезвычайное положение / Пер. с ит. М. Велижева, И. Левиной, О. Дубицкой, П. Соколова. М.: Европа.

Кант И. (1980). Религия в пределах только разума / Пер. с нем. Н. М. Соколова // Кант. И. Трактаты и письма. М.: Наука. С. 78-278.

Локк Дж. (1988). Опыт о веротерпимости / Пер. с англ. А. Э. Яврумяна // Локк Дж. Сочинения. Т. 3. М.: Мысль. С. 66-9о.

Майер X. (2012). Карл Шмитт, Лео Штраус и «Понятие политического»: о диалоге отсутствующих / Пер. с нем. Ю. Коринца. М.: Скименъ.

Манан П. (2004). Общедоступный курс политической философии / Пер. с франц. В. И. Божовича. М.: Московская школа политических исследований.

Михайловский A. В. (2012). Политическая философия vs политическая теология // Майер X. Карл Шмитт, Лео Штраус и «Понятие политического»: о диалоге отсутствующих / Пер. с нем. Ю. Коринца. М.: Скименъ. С. 167-191.

Спиноза Б. (1957). Богословско-политический трактат // Спиноза Б. Избранные произведения. Т. 2. / Пер. с лат. М. Лопаткина. М.: Госполитиздат. С. 5-284.

Узланер Д. (2012). От секулярной современности к «множественным»: социальная теория о соотношении религии и современности // Государство, религия, церковь в России и за рубежом. № 1. С. 8-32.

Филиппов А. Ф. (2016). К истории понятия политического: прошлое одного проекта // Шмитm К. Понятие политического. СПб.: Наука. С. 433-551.

Хабермас Ю. (2002). Вера и знание // Хабермас Ю. Будущее человеческой природы / Пер. с нем. М. Хорькова. М.: Весь мир. С. 117-137.

Хабермас Ю. (2005). Модерн - незавершенный проект // Хабермас Ю. Политические работы / Пер. с нем. Б. Скуратова. М.: Праксис. С. 7-31. 
Хабермас Ю. (2006а). Дополитические основы демократического правового государства? // Хабермас Ю., Ратиингер Й. (Бенедикт XVI). Диалектика секуляризации: о разуме и религии / Пер. с нем. В. Витковского. М.: Библейско-богословский институт св. апостола Андрея. С. 39-75.

Хабермас Ю. (20066). Когда мы должны быть толерантными? О конкуренции видений мира, ценностей и теорий / Пер. с нем. А. А. Зотова // Социологические исследования. № 1. С. 45-53.

Хабермас Ю. (2011). Между натурализмом и религией / Пер. с нем. Б. Скуратова. М.: Весь мир.

Хабермас Ю. (20116). Религиозная толерантность как пионер прав культурной жизни // Хабермас Ю. Между натурализмом и религией / Пер. с нем. Б. Скуратова. М.: Весь мир. С. 235-253.

Шмитт К. (200о). Политическая теология: четыре главы к учению о суверенитете // Шмитт К. Политическая теология / Пер. с нем. Ю. Ю. Коринца, А. Ф. Филиппова. М.: КАНОН-Пресс-Ц. С. 11-98.

Шмитт К. (2008). Номос Земли в праве народов jus publicum europaeum / Пер. с нем. К. В. Лощевского, Ю. Ю. Коринца. СПб.: Владимир Даль.

Шмитт К. (2016). Понятие политического / Пер. с нем. А. Ф. Филиппова // Шмитт К. Понятие политического. СПб.: Наука. С. 280-408.

Штраус Л. (200оа). Взаимное влияние философии и теологии // Штраус Л. Введение в политическую философию / Пер. с англ. М. Фетисова. М.: Логос, Праксис. C. 294-309.

Штраус Л. (20о0б). Что такое политическая философия? // Штраус Л. Введение в политическую философию / Пер. с англ. М. Фетисова. М.: Логос, Праксис. C. 9-50.

Эрибон Д. (2008). Мишель Фуко / Пер. с франц. Е. Бабаевой. М.: Молодая гвардия. Adams N. (2006). Habermas and Theology. Cambridge: Cambridge University Press.

Afary J., Anderson K. (2005). Foucault and the Iranian Revolution. Chicago: University of Chicago Press.

Agamben G. (2005). The Time That Remains. Stanford: Stanford University Press.

Agamben G. (2015). Stasis: Civil War as a Political Paradigm. Stanford: Stanford University Press.

Bernstein R. (2002). Radical Evil. Cambridge: Polity.

Bernstein R. (2005). The Abuse of Evil: The Corruption of Politics and Religion since 9/11. Cambridge: Polity.

Critchley S. (2012). The Faith of the Faithless. Experiments in Political Theology. L.: Verso. Derrida J. (2005). The Politics of Friendship. L.: Verso.

Gray J. (2008). The Black Mass: Apocalyptic Religion and the Death of Utopia. N.Y.: Farrar, Straus \& Giroux.

Habermas J. (1992). Postmetaphysical Thinking. Cambridge: MIT Press. 
Habermas J. (2010). An Awareness of What is Missing // Habermas J. et al. An Awareness of What is Missing. Faith and Reason in a Post-secular Age. Cambridge: Polity. P. 15-23.

Habermas J. (2011). «The Political»: The Rational Meaning of a Questionable Inheritance of Political Theology // Butler J., Habermas J., Taylor C., West C. The Power of Religion in the Public Sphere. N.Y.: Columbia University Press. P. 15-33.

Hardt M., Negri A. (2009). Commonwealth. Cambridge: Belknap Press.

Lilla M. (2007). The Stillborn God: Religion, Politics, and the Modern West. N.Y.: Vintage Books.

Meier H. (2006). Leo Strauss and the Theologico-Political Problem. Cambridge: Cambridge University Press.

Meier H. (2011). The Lesson of Carl Schmitt. Four Chapters on the Distinction between Political Theology and Political Philosophy. Chicago: University of Chicago Press.

Neiman S. (2002). Evil in Modern Thought: An Alternative History of Philosophy. Princeton: Princeton University Press.

Taylor C. (2007). A Secular Age. Cambridge: Belknap Press.

Virno P. (2008). Multitude: Between Innovation and Negation. N.Y.: Semiotext(e).

\title{
Political Theology and Secularization: On the Inexorability of a Concept
}

\author{
Maxim Fetisov \\ PhD in Philosophy, Kozlova Center for Social Theory and Political Anthropology, Department of Philosophy, \\ Russian State University for the Humanities \\ Address: Miusskaya Sq., 6, GSP-3, Moscow, Russian Federation 125993 \\ E-mail:msfetisov@gmail.com
}

The collapse of the Soviet bloc and the demise of grand secular emancipatory ideologies led to a growth of interest in the topics concerning religion and secularization. One of the vivid manifestations of this interest is a significant resurgence of research interest in political theology during the last three decades. The paper is intended to deal not so much with political theology in the narrow sense of the term, usually associated with the names of Carl Schmitt, Leo Strauss or Walter Benjamin as to explore some cases in the history of thought revealing the political power of religion. The first case deals with Michel Foucault's experience of Iranian Revolution. It argues that his exploration of the so-called "political spirituality", a vague and widely criticized notion, discloses the problematics of political theology not as a historical inheritance or a marginal intellectual activity but as a living constituent reality pointing towards the limits of Western political mind. The second case is devoted to a widely known study of religion within post-secular societies done by a renowned German philosopher Jürgen Habermas. It claims that his idea of "postmetaphysical thinking" boasting to have done away with the "old prejudices" of classical metaphysics and theology does not suffice to ensure the peaceful coexistence of various religious as well as secular worldviews within the Western public sphere. Postmetaphysical treatment of politico-theological problems as irrelevant leads to their reappearance under the new guises: this is what happened 
to the "problem of evil" that plays a crucial role in the drawing up of the most part of modern political distinctions. "Evil" is dealt with in the third case, as a subject of political theories of radical democracy. Some proponents of radical democracy such as Paolo Virno, Antonio Negri and Michael Hardt consider that part of political theology to be very important for their own projects of "non-sovereign" political institutions that will arise when the current crisis of modern political rationality is over. The paper comes to a conclusion with the idea that political theology should be considered not only as a radical opposite to a political philosophy or secular reason in general but also as an ever-present possibility that comes to reactivation in the moments of crisis.

Keywords: M. Foucault, J. Habermas, evil, human nature, the public sphere, secularization, political theology

\section{References}

Adams N. (2006) Habermas and Theology, Cambridge: Cambridge University Press.

Afary J., Anderson K. (2005) Foucault and the Iranian Revolution, Chicago: University of Chicago Press.

Agamben G. (2005) The Time That Remains, Stanford: Stanford University Press.

Agamben G. (2011) Homo sacer: chrezvychajnoe polozhenie [Homo Sacer: The State of Exception], Moscow: Evropa.

Agamben G. (2015) Stasis: Civil War as a Political Paradigm, Stanford: Stanford University Press.

Bernstein R. (2002) Radical Evil, Cambridge: Polity.

Bernstein R. (2005) The Abuse of Evil: The Corruption of Politics and Religion since 9/11, Cambridge: Polity.

Critchley S. (2012) The Faith of the Faithless. Experiments in Political Theology, London: Verso.

Derrida J. (2005) The Politics of Friendship, London: Verso.

Eribon D. (2008) Mishel' Fuko [Michel Foucault], Moscow: Molodaya gvardiya.

Filippov A. (2016) K istorii ponyatiya politicheskogo: proshloe odnogo proekta [On the History of the Concept of the Political]. Schmitt C., Ponyatie politicheskogo [The Concept of the Political], Saint Petersburg: Nauka, pp. 433-551.

Gray J. (2008) The Black Mass: Apocalyptic Religion and the Death of Utopia, New York: Farrar, Straus and Giroux.

Habermas J. (1992) Postmetaphysical Thinking, Cambridge: MIT Press.

Habermas J. (2002) Vera i znanie [Faith and Knowledge]. Budushchee chelovecheskoj prirody [The Future of Human Nature], Moscow: Ves mir, pp. 117-137.

Habermas J. (2005) Modern — nezavershennyj proekt [Modernity: An Incomplete Project]. Politicheskie raboty [Political Writings], Moscow: Praksis, pp. 7-31.

Habermas J. (2006) Dopoliticheskie osnovy demokraticheskogo pravovogo gosudarstva? [Prepolitical Foundations of the Democratic Constitutional State?]. Habermas J., Ratzinger J. (Benedikt XVI), Dialektika sekulyarizacii: o razume i religii [The Dialectics of Secularisation: On Reason and Religion], Moscow: St. Andrew's Biblico-Theological Institute, pp. 39-75.

Habermas J. (2006) Kogda my dolzhny byt' tolerantnymi? O konkurencii videnij mira, cennostej i teorij [When Must We be Tolerant? On Competing Worldviews, Values and Theories]. Sociological Studies, no 1, pp. 45-53.

Habermas J. (2010) An Awareness of What is Missing. Habermas J. et al., An Awareness of What is Missing: Faith and Reason in a Post-secular Age, Cambridge: Polity, pp. 15-23.

Habermas J. (2011) Mezhdu naturalizmom i religiej [Between Naturalism and Religion], Moscow: Ves mir.

Habermas J. (2011) Religioznaya tolerantnost' kak pioner prav kul'turnoj zhizni [Religious Tolerance as Pacemaker of Cultural Rights]. Mezhdu naturalizmom i religiej [Between Naturalism and Religion], Moscow: Ves mir, pp. 235-253.

Habermas J. (2011) "The Political": The Rational Meaning of a Questionable Inheritance of Political Theology. Butler J., Habermas J., Taylor C., West C., The Power of Religion in the Public Sphere, New York: Columbia University Press, pp. 15-33.

Hardt M., Negri A. (2009) Commonwealth, Cambridge: Belknap Press. 
Kant I. (1980) Religiya v predelah tol'ko razuma [Religion within the Boundaries of Mere Reason]. Traktaty i pis'ma [Treatises and Letters], Moscow: Nauka, pp. 78-278.

Lilla M. (2007) The Stillborn God: Religion, Politics, and the Modern West, New York: Vintage Books.

Locke J. (1988) Opyt o veroterpimosti [An Essay Concerning Toleration]. Sochineniya. T. 3 [Works, Vol. 3], Moscow: Mysl, pp. 66-90.

Manent P. (2004) Obshchedostupnyj kurs politicheskoj filosofii [A Familiar Course of Political Philosophy], Moscow: Moscow School of Political Research.

Meier H. (2006) Leo Strauss and the Theologico-Political Problem, Cambridge: Cambridge University Press.

Meier H. (2011) The Lesson of Carl Schmitt. Four Chapters on the Distinction between Political Theology and Political Philosophy, Chicago: University of Chicago Press.

Meier H. (2012) Carl Shmitt, Leo Strauss i "Ponyatie politicheskogo": o dialoge otsutstvuyushchih [Carl Schmitt and Leo Strauss: The Hidden Dialogue], Moscow: Skimen.

Mikhailovsky A. (2012) Politicheskaya filosofiya vs politicheskaya teologiya [Political Philosophy vs Political Theology]. Meier H., Carl Shmitt, Leo Strauss i "Ponyatie politicheskogo": o dialoge otsutstvuyushchih [Carl Schmitt and Leo Strauss: The Hidden Dialogue], Moscow: Skimen, pp. 167-191.

Neiman S. (2002) Evil in Modern Thought: An Alternative History of Philosophy, Princeton: Princeton University Press.

Schmitt C. (2000) Politicheskaya teologiya: chetyre glavy k ucheniyu o suverenitete [Political Theology: Four Chapters on the Concept of Sovereignty]. Politicheskaya teologiya [Political Theology], Moscow: KANON-Press-C, pp. 11-98.

Schmitt C. (2008) Nomos Zemli v prave narodov jus publicum europaeum [The Nomos of the Earth in the International Law of Jus Publicum Europaeum], Saint Petersburg: Vladimir Dal.

Schmitt C. (2016) Ponyatie politicheskogo [The Concept of the Political]. Ponyatie politicheskogo [The Concept of the Political], Saint Petersburg: Nauka, pp. 280-408.

Spinoza B. (1957) Bogoslovsko-politicheskij traktat [Tractatus Theologico-Politicus]. Izbrannye proizvedeniya. T. 2 [Selected Works, Vol. 2], Moscow: Gospolitizdat, pp. 5-284.

Strauss L. (2000) Vzaimnoe vliyanie filosofii i teologii [The Mutual Influence of Theology and Philosophy]. Vvedenie v politicheskuyu filosofiyu [An Introduction to Political Philosophy], Moscow: Logos, Praksis, pp. 294-309.

Strauss L. (2000) Chto takoe politicheskaya filosofiya? [What is Political Philosophy]. Vvedenie v politicheskuyu filosofiyu [An Introduction to Political Philosophy], Moscow: Logos, Praksis, pp. 9-50.

Taylor C. (2007) A Secular Age, Cambridge: Belknap Press.

Uzlaner D. (2012) Ot sekulyarnoj sovremennosti k "mnozhestvennym": social'naya teoriya o sootnoshenii religii i sovremennosti [From Secular Modernity to "Multiple Modernities": Social Theory on the Relations Between Religion and Modernity]. State, Religion, Church in Russia and Worldwide, no 1, pp. 8-32.

Virno P. (2008) Multitude: Between Innovation and Negation, New York: Semiotext(e). 


\title{
Политическая теология в «Левиафане» Томаса Гоббса
}

\author{
Тимофей Дмитриев \\ Кандидат философских наук, доцент школы культурологии факультета гуманитарных наук \\ Национального исследовательского университета «Высшая школа экономики» \\ Адрес: ул. Мясницкая, дом 20, г. Москва, Российская Федерация 101000 \\ E-mail: tdmitriev@hse.ru
}

\begin{abstract}
Эволюция политической мысли Томаса Гоббса в 1630-1640-е гг. отмечена заметным интересом к отношениям между политикой и религией, государством и церковью. Этот интерес нашел свое выражение в созданной английским мыслителем оригинальной версии политической теологии, наиболее полное изложение которой можно найти в его трактате «Левиафан». Свою концепцию политической теологии Гоббс считал эффективным способом решения теолого-политической проблемы Нового времени. В основу своей политической теологии Гоббс кладет новое истолкование ряда доктринальных положений христианского вероучения, призванное согласовать его с абсолютной властью светского суверена. Особое внимание в статье уделено рассмотрению тех прагматических стратегий, которые были предложены Гоббсом для обезвреживания взрывоопасного для гражданского мира и безопасности государства потенциала христианской религии. Показано также, что полное подчинение церкви государству в политической теологии Гоббса послужило отправной точкой для важнейшего этапа секуляризации западного мира, который привел к отделению политики от религии и государства от церкви.

Ключевые слова: новая политическая наука, политическая теология, религиозные и гражданские войны, политика и религия, государство и церковь, политический либерализм, мир модерна
\end{abstract}

Историк политической философии, обращающийся к трудам Томаса Гоббса, в которых изложены основы его политической философии - «Элементам закона» (1640), «О гражданине» (1642) и «Левиафану» (1651), - практически сразу замечает, что от одного произведения к другому заметно растет значение, которое Гоббс придает критике религии ради связного и убедительного изложения своей политической теории. Если в «Элементах закона» религиозные вопросы затрагиваются лишь походя, а именно прежде всего в главах VI и VII второй части этого трактата, где Гоббс разбирает вопрос о значении частных суждений в религиозных спорах, а также о верховенстве светского суверена в вопросах религиозной веры, то в трактате «О гражданине» им уже посвящена одна из трех частей этого произведения, которая так и называется - «Религия». Своей кульминации эта тенденция достигает в «Левиафане», из четырех книг которого две - «О христианском государстве» и «О царстве тьмы» - обсуждают вопросы религии. «Трем главам в „Elements“ соответствует четыре главы в „De Cive“ и семнадцать - в „Левиафа-

() Дмитриев Т. А., 2018

(с) Центр фундаментальной социологии, 2018

DOI: $10.17323 / 1728-192 \mathrm{X}-2018-3-56-89$ 
не“. Это количественное расширение сопровождается углублением критики. Отклонение Гоббса от теологической традиции становится все более заметным при переходе от одной книги к другой» (Strauss, 1963 [1936]: 71-72). Таким образом, интерес Гоббса к выяснению той роли, которую играет религия в жизни общества, лишь возрастал по мере того как он писал свои политические произведения.

Однако одно дело - зафиксировать некий факт, и совсем другое - дать ему внятное толкование. Изучение политических произведений Гоббса, а также его переписки показывает, что с конца 1630-х годов отношения политики и религии, государства и церкви становятся одним из тех важнейших проблемных узлов, к которым было приковано внимание английского мыслителя. В особенности его занимало христианство как религия, от учета доктринальных и институциональных аспектов которой в огромной степени зависело нахождение правильного баланса между светской и духовной властями. Центральное место, которое в политической теологии Гоббса занимает христианство и его духовная история, было обусловлено как той ролью, которую оно играло в повседневной жизни народов Европы, так и тем, что, по твердому убеждению философа, от правильного истолкования основных догматов христианства зависела судьба гражданского мира не только в Англии, но и на европейском континенте. Крайне примечательно то, что не далее как летом 1641 года в своей переписке с Уильямом Кавендишем, графом Девонширским, этим замечательным учеником, другом и покровителем Гоббса, последний львиную долю вины за гражданские и конфессионально-религиозные войны, терзавшие в то время Англию и другие страны Европы, возлагает на конфликт светских и религиозных властей по поводу их полномочий. Гоббс писал своему адресату:

Я придерживаюсь того мнения, что священнослужитель должен скорее священствовать, чем управлять, и что всякое церковное правление должно зависеть от светского государства и власти его, иначе не может быть никакого единства в церкви. Вы можете думать, что это мнение есть только плод философской фантазии; но я полагаю, что опыт достаточно научил нас тому, что спор между духовной и светской властью был всегда более, чем что-либо другое, причиной гражданских войн во всех христианских странах. (Hobbes, 1994: 120)

Что это за «опыт», о котором говорит Гоббс в своем письме? Из рассуждений философа явствует, что речь идет о политико-религиозных войнах, характерных для эпохи перехода Запада от «христианского мира» к цивилизации «классической Европы» ${ }^{1}$. Как верно замечает Отфрид Хёффе, опыт гражданской войны это всегда опыт радикального кризиса политического сообщества и потрясения самих основ государственно-правового порядка. «Высшая точка потрясения го-

1. По поводу цивилизации «классической Европы», ее хронологических рамок и содержательных характеристик см. довольно давнее (1965), но добротное и не потерявшее своей ценности исследование Пьера Шоню: Шоню, 2005: 8-17. 
сударства - политико-религиозные войны, т.е. как раз те условия, при которых возникла политическая теория Гоббса и которые, хотя и в весьма смягченной форме, продолжают существовать и в сегодняшних плюралистических демократиях, заявляя о себе в борьбе интересов различных групп и союзов» (Нӧffe, 1987: 22). Именно в ходе гражданских войн люди получают наглядный урок того, зачем им в их совместной жизни необходимо государство и право, без опоры на которые невозможны гражданский мир и выживание людей ${ }^{2}$. Тем самым опыт гражданской войны дает политическому философу уникальный шанс поставить вопрос об основах политического и правового порядка не только в практико-политической, но и в теоретической плоскости. В свою очередь, соблюдение условий гражданского мира было невозможно без правильного разрешения вопроса о полномочиях духовных и светских властей, о чем Гоббс прекрасно отдавал себе отчет ${ }^{3}$.

\section{Зачем Гоббсу политическая теология?}

Хорошо известно, что основы политического порядка, которые Гоббс очерчивает в первых двух книгах «Левиафана», строятся на индивидуальных правах человека и договорной теории создания общей власти. Как утверждает Лео Штраус, Гоббс был первым политическим философом модерна, который перенес акцент с обязательств индивида перед высшими (космическими или божественными) силами на его индивидуальные права, и прежде всего - на его право на самосохранение 4 . По этой причине Штраус считает Гоббса основателем либерализма Нового времени. «Если мы называем политическим либерализмом такую политическую доктрину, - пишет Штраус, - которая считает фундаментальным политическим фактом права, а не обязанности человека, и которая отождествляет функцию государства с защитой этих прав, то мы можем сказать, что основателем либерализма был Гоббс» (Strauss, 1965: 13).

2. «Эта гражданская война, - писал Гоббс об опыте гражданской войны в Англии в „Левиафане“ в связи со спором о правах суверена, - послужила людям таким уроком в отношении верховных прав, что теперь (в Англии) найдутся немногие, которые не видят, что эти права неделимы и будут признаваться до тех пор, пока не забудутся пережитые бедствия, но не дольше, разве что простонародье станет более просвещенным, чем оно было до сих пор» (Leviathan. Part II, ch. 18; Гоббс, 1991: 141). Отметим, что в этой концептуализации уроков гражданской войны в Англии, предложенной Гоббсом, in писе уже содержится его программа политического просвещения подданных.

3. Формулируя проблему взаимоотношения светской и духовной властей в «Левиафане», Гоббс пишет, что «слова мирская и духовная власть являются лишь словами, внесенными в мир, дабы у людей двоилось в глазах и дабы люди не понимали, кто их законныцй суверен» (Leviathan. Part III, ch. 39; Гоббс, 1991: 359).

4. «Каждый стремится к тому, - пишет Гоббс в трактате „О гражданине“, - что является для него благом, и избежать того, что является злом, прежде всего величайшего из зол - смерти; и все это происходит с той же природной необходимостью, с какой камень падает вниз. Поэтому ничуть не бессмысленно, ничуть не позорно, ничуть не противоречит истинному разуму прилагать все силы к тому, чтобы уберечь и спасти от смерти и страданий собственное тело и его части. А то, что не противоречит истинному разуму, то признается всеми и справедливым и совершенным по праву... Таким образом, первое основание естественного права состоит в том, чтобы каждый в силу своих возможностей оберегал собственную жизнь и тело» (De Cive. Cap. 1, art. 7; Гоббс, 1989a: 289). 
Однако эта конструкция, которая складывается из четырех основных составляющих: 1) естественных прав индивида; 2) его инструментальной рациональности, ориентированной на поиск средств для самосохранения; 3) общественного договора как механизма создания общей власти и 4) абсолютной власти суверена, учрежденной этим договором, - не является самодостаточной. Более того, как отмечает немецкий политический философ Херфрид Мюнклер, изучение эволюции теоретико-политических воззрений Гоббса подводит к выводу, что чем дальше он разрабатывал свою теорию общественного договора и связанную с ней идею неограниченной власти суверена, тем сильнее чувствовал необходимость подведения под эту инструментальную конструкцию государства теологического и морального фундамента. Соответственно, увеличение объема разделов его произведений, посвященных религиозным вопросам, объясняется в первую очередь растущим пониманием философом того, что государство, основанное на одном только стремлении индивида к самосохранению с опорой на инструментальную рациональность ${ }^{5}$, д долгосрочном плане, даже несмотря на концентрацию всей полноты власти в руках светского суверена, рискует оказаться чрезвычайно хрупким и недолговечным (Münkler, 2014: 17). Для того чтобы люди «могли образовать совместно прочное и долговечное здание, состоящее из них самих» (Гоббс, 1991: 250) ${ }^{6}$, необходимы некие дополнительные узы, помимо абсолютной власти суверена и тех страстей, что делают их склонными к миру, к числу которых Гоббс причисляет «страх смерти, желание вещей, необходимых для хорошей жизни, и надежду приобрести их своим трудолюбием» (Гоббс, 1991: 98) ${ }^{7}$.

Решить эту проблему и было призвано обращение к политической теологии. Разъясняя вопрос о том, зачем Гоббсу понадобилась политическая теология, Х. Мюнклер говорит о двух проблемных, или «узких» местах в его политической философии, которые не позволили английскому философу построить свою теорию государства и основанного на нем социального порядка на сугубо индивидуальноправовых и договорных основаниях. С одной стороны, даже обладая абсолютной и неограниченной властью, суверен не может править, опираясь на одну только силу. Какой бы неограниченной ни была его власть, одних только законов и силовых средств принуждения, имеющихся в распоряжении суверена, недостаточно для того, чтобы сделать его власть прочной. Используя политический язык Макиавелли, можно было бы сказать, что для того, чтобы быть хорошим государем, мало быть только львом; надо уметь быть еще и лисой. При этом, однако, «необходимо уметь хорошо скрыть в себе это лисье существо и быть великим притворщиком

5. «Мысли, - пишет Гоббс в „Левиафане“, - играют по отношению к желаниям роль разведчиков и лазутчиков, ищущих путей к желаемым вещам, и всякое твердое направление движений ума и их живость проистекают из желаний» (Leviathan. Part I, ch. 8; Гоббс, 1991: 56). По поводу истолкования Гоббсом термина «истинный разум» (recta ratio), одного из центральных понятий его политической теории, см. его разъяснение понятия «естественного закона» в трактате «О гражданине» (De Cive. Cap. 2, art. 1; Гоб6с, 1989a: 293-294).

6. Leviathan. Part II, ch. 29. Перевод исправлен мной по изданию: Hobbes, 1996: 212.

7. Leviathan. Part I, ch. 13. 
и лицемером» ${ }^{8}$. Судя по всему, Гоббс вполне отдавал себе отчет в серьезности этой проблемы, поставленной Макиавелли, но, в отличие от последнего, предпочитал формулировать ее в морально нейтральных терминах. В то время как у Макиавелли идет речь о пользе лжи и обмана в мире политического, Гоббс говорит о том, что суверен обязан внушать своим подданным правильные представления о добре и зле, справедливом и несправедливом, а также о необходимости повиновения верховной власти. Такие представления образуют содержание особой гражданской религии, без которой невозможно длительное сохранение государства.

В хорошо устроенном государстве подданные должны быть уверены, что повиновение приказам и распоряжениям суверена является их священной обязанностью и не может быть поставлено под вопрос какими-либо иными - будь то естественными или сверхъестественными - источниками авторитета. Отсюда перед Гоббсом встает необходимость дать такую интерпретацию благам религиозного спасения, чтобы их ценность в глазах подданных не могла перевесить блага законопослушности и повиновения суверену в земной жизни. Интерпретация христианского учения о спасении и грядущем Царствии Божием с точки зрения того, способствует оно или нет воцарению гражданского мира и упрочению власти суверена, представляет собой основу политической теологии Гоббса.

С другой стороны, для поддержания гражданского мира и социального порядка суверену было бы крайне опрометчиво рассчитывать на одну лишь инструментальную рациональность своих подданных. Если бы люди в своем поведении руководствовались исключительно голым расчетом и сравнением потерь и приобретений, которые причитались бы им за исполнение или же неисполнение приказаний суверена, то у них не возникло бы особого повода для неповиновения. Однако вопрос существенно осложняется тем, что в партитуре человеческих поступков первую партию очень часто исполняет не разум, а страсти людей, которые побуждают их нарушать законы и не слушать повелений суверена. Сила воздействия этих страстей, первую скрипку среди которых играют честолюбие и корыстолюбие, бывает такова, что даже самая сильная человеческая страсть страх насильственной смерти, которая у Гоббса служит эквивалентом разума оказывается не в силах остановить людей от разрушения политического порядка (Strauss, 1963 [1936]: 158-160). Поэтому возникает потребность в специальной программе политического образования для «лучших людей» из привилегированных классов и гражданского наставления подданных из числа простого народа, дабы они могли знать, каковы их обязанности перед сувереном. Эта программа политического образования и просвещения составляет прикладную часть гражданской религии Гоббса.

8. «Ma è necessario qusta natura saperla bene colorire e essere gran simulatore e dissimilatore» (Machiavelli, 2014: 125). Как поясняет эту идею Макиавелли Мартин Джей, «его откровенное допущение иллюзии и видимости в политике, говоря более широко - необходимость акцентирования символической природы политической власти, - получило признание в силу очевидной невозможности включения политического в естественный или божественный порядок, претендующий на абсолютную истину» (Джей, 2015: 34). 
Таким образом, необходимость гражданской религии для поддержания мира и спокойствия в государстве обусловлена тем, что, по Гоббсу, поведение человека в обществе определяется не только его страстями, главную роль среди которых играют страх смерти, честолюбие и корыстолюбие, но и общепринятыми мнениями о добре и зле, которыми люди руководствуются в своих поступках. Страх смерти подталкивает человека к тому, чтобы согласиться с созданием общей власти и принять над собой неограниченную власть суверена, а «разум подсказывает подходящие условия мира» (Гоббс, 1991: 98) ${ }^{9}$, однако другие страсти вкупе с ложными представлениями о добре и зле, добродетели и пороке уводят его с этого единственно верного пути, ведущего к гражданскому миру и согласию. Поэтому именно «честолюбие и корыстолюбие, чье могущество опирается на ложные представления толпы о праве и справедливости» (Гоббс, 1989a: 272-273) ${ }^{10}$, Гоббс выбирает на роль главного противника своей новой политической науки. По его словам,

для всякого мало-мальски здравомыслящего человека очевидно, что человеческие действия управляются теми мнениями, которые люди имеют о благе и зле, могущих проистекать для них из этих деяний, и что если люди, у которых раз сложилось мнение, что их повиновение суверенной власти будет более вредно, чем неповиновение, не будут повиноваться законам, этим они опрокинут государство и внесут хаос и гражданскую войну, для избежания которой и установлено всякое гражданское правление. (Гоббс, 1991: 414)

Поэтому светские суверены должны контролировать также и мнения о добре и зле, которым учат подданных, и позволять давать такие наставления лишь специально на то уполномоченным ими лицам, как гражданским, так и духовным. «Вот почему, - заключает Гоббс, - во всех государствах язычников суверены носили имя пастырей народа, так как ни один подданный в этих государствах не мог учить чему-либо народ без их разрешения и полномочий» (Там же $)^{11}$.

Правда, Гоббс, в отличие от другого крупнейшего теоретика гражданской религии общества модерна Жана-Жака Руссо, не питал особых иллюзий по поводу миротворческого потенциала древних гражданских религий. Основой таких религий является идололатрия, т.е. боязнь невидимых духов и необходимость постоянно искать их расположения с помощью регулярного приношения даров и использования других магических ритуальных средств, что в глазах Гоббса является воплощением крайнего суеверия ${ }^{12}$. Более того, с таким политеистическим строем гражданских религий язычников совершенно несовместим строгий монотеизм христианского типа, который, как справедливо замечает Гоббс, в конечном счете ведет верующего человека к признанию существования единого и находящегося вне мира Создателя. К признанию такого Бога, по Гоббсу, людей ведет не страх

\footnotetext{
9. Leviathan. Part I, ch. 13.

10. De Cive. Ep. ded.

11. Leviathan. Part III, ch. 42.

12. Leviathan. Part I, ch. 12.
} 
перед могуществом неведомых вещей, но желание людей познать причины естественных тел и их действий ${ }^{13}$. Таким образом, в отличие от Руссо, для Гоббса гражданские религии греков и римлян - это воплощения крайнего суеверия, и в этом своем качестве они совершенно небезопасны для гражданского мира.

\section{Теолого-политическая проблема модерна}

Главная же проблема, вокруг которой затягивается узел политической теологии Гоббса, состояла в том, что та политическая форма, на которую было направлено острие его критики в «Левиафане», была совершенно неизвестна Древней Греции и Риму с их гражданскими религиями. Она появляется уже после крушения античного мира и достигает своего расцвета в Средние века. В эту историческую эпоху Европа знала несколько политических форм. Главными из них были Священная Римская империя и средневековый город-коммуна, который своим историческим предшественником имел античный полис ${ }^{14}$. К ним надо добавить еще одну важную политическую форму, а именно средневековую христианскую монархию. Однако в Средние века на политической сцене Европы появляется новое действующее лицо - христианская Церковь. Конечно, в отличие от города-коммуны, империи и средневековой европейской монархии, Церковь не была сугубо политической формой; она не занималась напрямую организацией общественной и политической жизни людей. Однако ее религиозная миссия представляла собой колоссальную политическую проблему. Политическое развитие Европы может быть понято только как история ответов на проблемы, поставленные христианской Церковью, которая была человеческой общностью нового типа. Всякий институциональный ответ, в свою очередь, создавал новые проблемы и требовал поиска новых ответов. Поэтому ключом к европейской истории в Новое время можно считать теолого-политическую проблему (Manent, 1987: 19-20) ${ }^{15}$.

В Европе как в Средние века, так и в раннее Новое время

Церковь рассматривала себя не как одну из ассоциаций среди всех прочих, что существуют во всеобъемлющем пространстве общества и «плюрализм» которых Государство гарантирует и охраняет, но как полноценное общество, которое заключает свой принцип в себе самом и чья цель является неизмеримо более важной, чем все остальные цели общества; иными словами, она рассматривала себя как respublica perfecta, независимость которой является

13. «К мысли о едином Боге, таким образом, люди приходят помимо всякой мысли об их судьбе, забота о которой делает их склонными к страху и отвращает их от исследования причин других вещей и этим способствует измышлению стольких богов, сколько есть людей, измышляющих их» (Leviathan. Part I, ch. 12; Гоббс, 1991: 83).

14. О преемстве и различии античного полиса и средневекового города-коммуны см.: Вебер, 2017 [1921]: 93-248.

15. В своем изложении политико-теологической проблемы Нового времени я опираюсь прежде всего на работы французского политического философа Пьера Манана: Манан, 2004: 39-54; 1987: 1730; 2007: 142-179; 2014: 213-327. 
не просто функциональной, но онтологической, и которая по этой самой причине не может быть подчинена какой-либо другой власти или институту, включая секулярное Государство. (Manent, 2014: 221)

Такое самопонимание христианской Церкви как совершенной общности ищущих спасения было особенно характерно для Средних веков с их спорами между империей и папством за верховенство не только в духовных, но и в мирских делах, более того, оно продолжало давать знать о себе и в раннее Новое время.

Как показывает Пьер Манан, определение, которое давала себе христианская Церковь, заключало в себе противоречие. Благо, которое Церковь обещала своим верным последователям - спасение на небесах, - не было благом посюстороннего мира. «Посюсторонний мир», «мир Кесаря», не интересовал ее. В отличие от языческих религий, греческой и римской, которые были религиями города, христианство как религия Откровения и христианская Церковь как религиозное сообщество спасения не образуют собой единое целое с соответствующей политической общностью. С другой стороны, Бог и Его Сын - Иисус Христос возложили на себя миссию водительства людей к спасению, и Церковь благодаря Божественной благодати являлась уникальным оператором этого спасения. Тем самым Церковь получала право надзирать над всем, что могло помешать спасению. Однако поскольку практически все человеческие действия сталкиваются с выбором между добром и злом, Церковь тем самым притязала на право надзора над всеми человеческими действиями. «При этом среди всех человеческих действий наиболее важными и чреватыми последствиями были те, которые совершали правители. Поэтому Церковь, в силу самого смысла своего существования, была призвана бдительно следить за тем, чтобы правители не отдавали подданным приказов, которые могли бы помешать их спасению, а также за тем, чтобы они не давали подданным „возможности“ совершать поступки, идущие вразрез с ним» (Manent, 1987: 20-21). Иными словами, Церковь в Средние века притязала на полноту не только духовной, но и светской власти - plenitudo potestas, причем это притязание достигает своей кульминации в период реформ папы Григория VII и его борьбы за инвеституру с императором Священной Римской империи Генрихом IV в конце XI века ${ }^{16}$.

Специфическая политическая проблема, связанная с христианской религией, была обусловлена этой принципиальной двойственностью Церкви. С одной стороны, благодаря формуле Иисуса — «отдайте кесарево Кесарю, а Божие Богу» (Матф. 22: 21) $)^{17}$ - она высвобождает мирское и профанное пространство политическо-

16. На значение борьбы за инвеституру (1057-1122) как одного из важнейших этапов в завязывании узла теолого-политической проблемы в истории средневекового Запада особое внимание обращает Эрнст-Вольфганг Бёкенфёрде, который видит в этой борьбе первый шаг в развертывании многовекового процесса секуляризации западного мира (Böckenförde, 2013: 93-99).

17. «Эта фраза, - пишет Филипп Бенетон, - постулирует принцип, чуждый как греко-римскому, так и иудейскому миру: религия и политика занимают различные области. Новый закон противостоит всякому политико-религиозному порядку, он разбивает традиционное единство власти. В другом 
го и дает политическим обществам свободу устраиваться по своему усмотрению; в отличие от иудаизма и ислама, христианская Церковь не является носителем политического закона. В то же время она обесценивает политические общности посюстороннего мира сего и, что самое главное, характерный для них принцип авторитета. «Итак, - пишет Августин в „О граде Божием“, - два Града созданы двумя родами любви: земной - любовью к себе, дошедшею до презрения к Богу, небесный - любовью к Богу, дошедшей до презрения к себе. Первый полагает славу свою в самом себе, второй - в Господе» (De Civitate Dei. XIV, 28; Блаженный Августин, 1998: 48) ${ }^{18}$. Критикуя главный принцип, на котором построен земной град (любовь к самому себе вплоть до презрения к Богу), во имя своего принципа (любви к Богу вплоть до презрения к самому себе), Церковь тем самым подтачивала легитимность земного Града в глазах его подданных (Манан, 2004: 48).

Гоббс был одним из первых политических философов модерна, кто попытался разрешить эту проблему при помощи своей новой политической науки. В заключительной главе своего трактата «Об общественном договоре», посвященном изложению идеи гражданской религии, Жан-Жак Руссо писал о его усилиях:

Из всех христианских философов Гоббс - единственный, кто хорошо видел и зло, и средства его устранения, кто осмелился предложить соединить обе главы орла и привести все к политическому единству, без которого ни Государство, ни Правление никогда не будут иметь хорошего устройства. Но он должен был видеть, что властолюбивый дух христианства несовместим с его системой и что интересы священника будут всегда сильнее, чем интересы Государства. Не столько то, что есть ужасного и ложного в политических воззрениях Гоббса, как то, что в них есть справедливого и истинного, и сделало их ненавистными. (Руссо, 1969: 250)

Эта оценка, которую Руссо дает политико-теологическим идеям Гоббса, совершенно четко и недвусмысленно фиксирует то обстоятельство, что взгляды Гоббса на религию и ее отношение к политике были тем самым элементом его философии, который вызвал наибольшее негодование у его современников и послужил поводом для затянувшихся на целое столетие обвинений философа в «атеизме»

смысле „Кесарю - кесарево“ не означает разрыва, поскольку признает законную роль политики: Кесарю следует отдать то, что ему причитается» (Бенетон, 2002: 47).

18. Правда, здесь стоит оговориться, что у Августина в его трактате «О Граде Божием» мы не встречаем прямого отождествления Града Небесного - с видимой Церковью, а Града Земного - с политическим сообществом, будь оно языческим или христианским. По мнению Майкла Суини, историка средневековой политической философии Запада, «политическая философия Августина понималась неправильно в тех случаях, когда Небесный Град - Град Божий - отождествлялся с Церковью. Причина этой ошибки - в упрощенном понимании Церкви как зримого проявления Града Божия, то есть как образа Града Божия. Так же упрощенно понимается и государство. Однако для Августина граница между Церковью и Градом Божиим ясна. Переплетение Града Божьего и Града человеческого означает, что отождествление первого с Церковью, а второго с государством невозможно... Можно быть гражданином государства и принадлежать Граду Божию одновременно. В конечном счете решающим будет не гражданство в государстве или членство в Церкви, а что́ является предметом любви» (Суини, 2006: 43-44). 
и «безверии». По сути дела, именно третья и четвертая части «Левиафана» создали Гоббсу репутацию атеиста, человека, стремящегося к разрушению религиозных основ общества. Надо признать, что для такого неудовольствия как у благонамеренной, так и у религиозно экзальтированной английской публики были определенные основания. Как доказывает Ричард Так, в «Левиафане» Гоббс излагает новаторскую мысль, к которой он пришел в конце 1640-х годов, о том, что возможна такая интерпретация христианства, которая, не имея ничего общего с религией язычников, была бы в то же время полностью совместима с абсолютной властью суверена, правда, при условии, что будут отвергнуты традиционные христианские учения о бессмертии души и об аде (Tuck, 1993: 130). От последних, по мнению Гоббса, следовало отказаться потому, что учение о бессмертии души и вечных муках только добавляет новые страхи к тем, которые люди имеют обыкновение испытывать в силу самой своей природы. Утверждение такой религии абсолютной властью суверена должно было стать, согласно Гоббсу, важнейшей гарантией гражданского мира в сотрясаемом пароксизмами общественно-политических и религиозных междоусобиц английском обществе. В свою очередь, решение этих задач потребовало от Гоббса дать новое, соответствующее базовым принципам его политической теории истолкование некоторых основных доктринальных положений христианского вероучения. Тем самым Гоббс, как впоследствии и Б. Спиноза в «Богословско-политическом трактате» (1670), будучи политическим философом, становится интерпретатором Библии и одним из основателей исторической и философской критики авторитета Священного Писания.

\section{Неортодоксальная интерпретация христианского учения о спасении как основа политической теологии Гоббса}

Наблюдая гражданскую войну в Англии и анализируя ее причины, Гоббс пришел к выводу, что люди обладают несовместимыми концепциями блага, как земного, так и небесного, и потому постоянно борются друг с другом, пытаясь утвердить свою истину в политике, притом что они сходятся друг с другом лишь в том, что является для них наибольшим злом: смерть. Поэтому Гоббс счел необходимым устранить борьбу мнений из политики и заменить ее механикой страстей. Объединяющим людей началом не может служить ни природа, ни благодать, но лишь такой политический порядок, в основе которого лежит страх людей перед насильственной смертью. Если прежде, в классической политической традиции Запада основой политических деяний была идея положительного блага, будь то естественного или сверхъестественного, то у Гоббса основой как политического действия, так и политической науки становится изначальное, высшее и величайшее зло (summum malum) - страх человека перед насильственной смертью от руки других людей. В отличие от таких положительных благ, как счастье у древних греков или спасение на небесах у христиан, страх смерти, будучи благом негативным, 
не затрагивается конфликтом мнений. Именно поэтому Гоббс выбирает его на роль истинного первоначала своей новой политической науки.

Однако одним созданием новой политической науки теолого- политическая проблема модерна не решается. Все дело в том, что для Гоббса страх является основой не только политического порядка, но и религии. Страх перед физическим насилием со стороны других людей заставляет человека соглашаться с учреждением общей власти, берущей на себя заботу о его личной безопасности. Страх перед неизвестными силами природы заставляет его искать в естественном порядке природы и космоса высший божественный порядок ${ }^{19}$. Как показывает Ричард Шерлок, у Гоббса «по существу своему как религиозная вера, так и политический авторитет производны от страха, который человек испытывает перед миром. Однако то, что они дают разные ответы на самые элементарные страхи человека, приводит к тому, что они вступают в противоречие друг с другом, и это противоречие должно быть разрешено» (Sherlock 1982: 48), поскольку в противном случае гражданскому суверену не удастся обеспечить повиновение подданных своей воле ${ }^{20}$.

Сохранение гражданского мира в решающей степени зависит от власти суверена над жизнью и смертью его подданных. Если люди верят в то, что существуют какие-то иные силы, помимо власти суверена, которые способны наделить их бо́льшим благом, нежели жизнь, и причинить им большее зло, нежели смерть, они будут бояться этих сил пуще суверена, что неизбежно нанесет ущерб его авторитету. «Вечная жизнь» и «вечные муки», о которых устами своих священнослужителей толкует христианская церковь, представляют собой сверхъестественные блага, которые превосходят такие естественные блага, как жизнь и смерть. Согласно Гоббсу, от нахождения правильного баланса между стремлением подданных к земным и небесным благам (благам спасения) и их страхом перед земными и небесными карами (смертью естественной и вечной) прямо зависит прочность политического порядка и незыблемость власти светского суверена.

В главе XXXVIII «Левиафана» Гоббс формулирует эту дилемму совершенно недвусмысленно:

Так как сохранение гражданского общества зависит от правосудия, а правосудие - от власти над жизнью и смертью и другими меньшими наградами

19. Согласно Гоббсу, «страх перед невидимыми вещами есть естественное семя того, что каждый называет религией» (Leviathan. Part I, ch. 11; Гоббс, 1991: 81). Отталкиваясь от подобного понимания религии как страха человека перед невидимыми силами, Гоббс в «Левиафане» следующим образом определяет то, что такое религия, суеверие и истинная религия: «Страх перед невидимой силой, придуманной умом или воображаемой на основе выдумок, допущенных государством, называется религией, не допущенных - суеверием. А если воображаемая сила в самом деле такова, как мы ее представляем, то это истинная религия» (Leviathan. Part I, ch. 6; Гоббс, 1991: 43).

2о. По словам Гоббса, при создании прочного политического порядка «страсть, на которую можно положиться, - это страх, причем этот страх имеет два наиболее общих объекта. Первый объект это сила невидимых духов, второй - сила тех людей, которым нарушение обещания принесет ущерб. И хотя сила первых превосходит силу вторых, однако страх перед силой последних обычно сильнее страха перед силой первых» (Leviathan. Part I, ch. 14; Гоббс, 1991: 108). 
и наказаниями власти, присвоенной тем, кто имеет верховную власть в государстве, то не может сохраниться государство, в котором кто-либо иной, кроме суверена, имел бы власть выдавать бо́льшие награды, чем жизнь, или налагать наказания более жестокие, чем смерть. И вот ввиду того что вечная жизнь есть бо́льшая награда, чем земная жизнь, а вечное мучение - бо́льшее наказание, чем естественная смерть, то всем людям, желающим повиновением власти избежать бедствий смуты и гражданской войны, стоит хорошенько подумать над тем, что подразумевается в Священном Писании под вечной жизнью и вечным мучением, за какие и против кого совершенные преступления люди должны быть осуждены на вечные муки и за какие деяния они должны получить вечную жизнь. (Гоббс, 1991: 343$)^{21}$

Для того чтобы решить теолого-политическую проблему модерна, Гоббс прибегает к целому ряду стратегий. Прежде всего он считает необходимым дать такую трактовку основных понятий и положений библейской теологии, которая сделала бы их совместимыми с основными положениями и интенциями его новой политической науки. С этой целью Гоббс в третьей книге «Левиафана» подробно разъясняет значение таких библейских понятий, как «дух» (spirit), «ангел» (angel), «вдохновение» (inspiration), «Царствие Божие» (Kingdom of God), «святой» (holy), «посвященный» (sacred), «таинство» (sacrament), «Слово Божие» (Word of God), «чудо» (miracle), «вечная жизнь» (eternal life), «ад» (hell), «спасение» (salvation), «грядущий мир» (world to come), «муки ада» (torments of hell), «искупление» (redemption) и «Церковь» (Church) ${ }^{22}$.

Среди доктринальных положений христианского вероучения Гоббс особо отмечает те два, которые, по его мнению, заслуживают самого пристального внимания серьезной политической мысли. Это - догма о будущей загробной жизни и широко распространенное в его время среди верующих мнение о доступности сверхъестественной Божественной воли для знания и понимания отдельного человека. Это - те самые пункты, которые являются наиболее уязвимыми с точки зрения неограниченной власти светского суверена. Вера в даруемую Богом загробную жизнь уменьшает страх смерти, испытываемый людьми перед властью земного суверена и подрывает способность политической власти вызывать повиновение. С другой стороны, вера в то, что воля Божья может стать известна человеку напрямую и сделаться прямым руководителем его действий, ведет к конфликту лояльностей подданных, вынужденных делать непростой выбор между подчинением воле Бога и подчинением приказам светского суверена. В подобных ситуациях бескомпромиссное следование требованию подчиняться скорее Богу, нежели людям, также ведет к умалению авторитета светского суверена ${ }^{23}$.

21. Leviathan. Part III, ch. 38 .

22. Leviathan. Part III, ch. 34-39.

23. В главе XLIII «Левиафана» Гоббс писал, что «наиболее частым предлогом для мятежа и гражданской войны служила в течение долгого времени во всех христианских государствах недостаточно разрешенная и поныне трудность повиноваться одновременно Богу и человеку в тех случаях, когда повеления того и другого противоречат друг другу. Вполне очевидно, что, когда человек получает два 
Отсюда для Гоббса вытекает необходимость дать такое толкование учению о загробной жизни и загробном воздаянии, чтобы оно не вступало в противоречие со страхом людей перед наказаниями, налагаемыми светскими властями за нарушение законов государства. Кроме того, чтобы ниспровергнуть притязания последователей радикальных христианских сект на то, что им может быть так или иначе прямо известна сверхъестественная воля Бога, Гоббс подвергает тщательному рассмотрению вопрос о том, как Бог открывает Себя и свои деяния верующим: 1) в пророчествах, 2) при посредстве Священного Писания и, наконец, 3) при посредстве дела и личности Христа. По этой причине содержание третьей части «Левиафана» связано прежде всего с теми новыми истолкованиями, которые Гоббс дает этим двум аспектам христианского вероучения.

По первому вопросу - о загробной жизни, загробном воздаянии и грядущем Царствии Божием - Гоббс прямо говорит, что он обладает таким громадным значением для поддержания гражданского мира и порядка в обществе, что определять его содержание имеет право только светская власть в лице суверена и уполномоченных им на то должностных лиц. Однако при этом Гоббс, принимая во внимание печальный опыт гражданской войны в Англии, считает необходимым изложить в «Левиафане» свои собственные взгляды на этот счет, правда делает он это крайне осмотрительно и осторожно. Тем самым Гоббс предлагает новую версию некоторых религиозных учений христианства, и в особенности его эсхатологии ${ }^{24}$. Ядром этой новой теологии является глава XXXVIII «Левиафана», посвященная истолкованию идей «вечной жизни», «ада», «спасения», «грядущего мира» и «искупления». В ней же Гоббс развивает свою идею о том, что «Царствие Божие есть гражданское государство, в котором сам Бог является сувереном в силу прежде всего Ветхого, а затем и Нового завета и в котором он царствует через своего заместителя, или наместника» (Там же: $347-348)^{25}$.

Стратегия истолкования учения о Царствии Божием, принятая Гоббсом в «Левиафане», направлена на ниспровержение притязаний Церкви как на светскую власть, так и на власть над потусторонним миром. Согласно Гоббсу, идея нематериальности человеческой души, а также учение о ее бессмертии неизбежно ведут к страху перед духами и к боязни невидимых сил в земной жизни. Учение же Церкви об аде и о «вечных муках» заставляет людей бояться еще более страшных невидимых сил. В свою очередь, политическая теология, излагаемая Гоббсом в XXXVIII главе «Левиафана», призвана избавить людей от этих страхов.

Если в трактате «О гражданине» Гоббс еще продолжал придерживаться конвенциональной точки зрения, согласно которой Царствие Божие - не от мира

\footnotetext{
противоречивых приказания и знает, что одно из них исходит от Бога, он обязан повиноваться этому приказанию, а не другому, хотя бы и отданному ему его законным сувереном (монархом или сувереном собрания) или собственным отцом» (Leviathan. Part III, ch. 43; Гоббс, 1991: 448).

24. Эсхатология Гоббса в «Левиафане» является предметом подробного анализа и оценки в статье Джона Покока: Pocock, 1989: 148-201.

25. Leviathan. Part III, ch. 38.
} 
сего, и располагается оно не на земле, а на небе ${ }^{26}$, то в «Левиафане» он совершает довольно крутой поворот и последовательно настаивает на том, что согласно как Ветхому, так и Новому завету грядущее Царствие Божие, в котором праведники будут наслаждаться вечной жизнью, а главой которого будет Христос, наступит не на небе, а на земле после всеобщего воскрешения ${ }^{27}$. По словам Гоббса, «когда наш Спаситель снова придет во всем своем величии и славе, чтобы царствовать фактически и вовеки, Царствие Божие должно быть на земле» (Там же: 348$)^{28}$. Таким образом, Гоббс утверждает, что вечная жизнь, утраченная Адамом вследствие грехопадения и возрожденная Христом, будет вечной жизнью праведников на земле, причем в телесном обличье, а Христос, вместо того чтобы забрать праведников себе на небеса, спустится за землю и будет править ими вечно.

Тем самым в отличие от более ранних политических произведений, центр тяжести аргументации Гоббса в «Левиафане» приходится на идею о том, что высший смысл миссии Христа заключается в возрождении политического Царствия Божия на земле, которое уже существовало у евреев от Моисея до Самуила. Поскольку евреи отвергли предложение Христа восстановить это царство, то теперь это Царствие Божие будет осуществляться Им над новым избранным народом: избранными праведниками из числа христиан. Рассуждая о миссии Христа как спасителя, Гоббс пишет, что «Его Царство должно было наступить лишь после воскресения. Но тогда Он будет царем не только как Бог, в каковом смысле он уже является и всегда был царем над всей землей в силу своего всемогущества, но также в особенности царем своих избранных в силу завета, заключенного с ними при крещении» (Там же: 374$)^{29}$. Тем самым будет положен конец старому миру, и дано начало новому. «После второго пришествия, - писал Гоббс о грядущем пришествии Христа, - начнется его славное царствование над своими избранными, которое будет продолжаться вечно» (Там же: 370$)^{30}$. Характер правления также будет отличаться: если прежде Бог правил избранным народом при помощи Моисея и пророков, то во втором Царстве он будет править в лице Христа в его человеческом обличье и человеческой природе. При этом, как отмечает Джон Покок, в «Левиафане» Гоббс проводит далеко идущее сближение Моисея и Христа в качестве правителей Царствия Божьего (Pocock, 1989: 173) ${ }^{31}$. Следствием этой стратегии истолкования Гоббсом учения о Царствии Божием, в сочетании с его тезисом о преемственности грядущего земного правления Христа правлению Моисея, является то, что Царствие Небесное становится продолжением земного царства. Правда, с точки зрения Гоббса, Царство Христово не предшествует концу мира, а следует за ним, и по этой причине Гоббса нельзя считать милленаристом (Там же: 174). В любом случае, однако, следствием предложенной Гоббсом трактовки является

26. De Cive. Cap. 17, art. 13.

27. Leviathan. Part III, ch. 35.

28. Leviathan. Part III, ch. 38 .

29. Leviathan. Part III, ch. 41.

30. Leviathan. Part III, ch. 41.

31. Leviathan. Part III, ch. 41. 
то, что, не отвергая формально христианское учение о воскрешении из мертвых, он отбрасывает учение о потустороннем мире, где праведники будут вести блаженное существование в раю.

Гоббс также отрицает учение о бессмертии души и ее существовании, отдельном от тела. Вместо этого он доказывает, что те праведники, которые были предназначены к вечной жизни при воскресении, «были бессмертны не в силу особенности, вытекающей из сущности или природы человеческого рода, а по воле Бога, которому было угодно по одной своей милости пожаловать вечную жизнь праведникам» (Гоббс, 1991: 347) ${ }^{32}$. Напротив, христианская догма, что «человеческая душа бессмертна по своей природе и является живым существом, независимым от тела, или что какой-нибудь человек (за исключением Еноха или Ильи) бессмертен иначе, чем при воскресении в день Страшного суда, есть учение, недоказуемое на основе Писания» (Там же $)^{33}$. Воскресшие праведники не будут подвержены ни рождению, ни смерти; они будут обладать не бессмертной душой, но особыми духовными телами, вместо тех естественных тел, которые они имели при жизни (Там же: 444$)^{34}$.

Противоположностью Царствия Небесного является ад с его «вечными муками» и страданиями грешников за свои грехи. Гоббс дает такое символическое и психологическое прочтение христианского учения об аде и адских муках, которое призвано сделать их менее страшными в глазах людей. Он добивается этого психологического эффекта, доказывая, что ад и адские муки христианам следует понимать метафорически. Согласно Гоббсу, ад также будет находиться на земле, поскольку дьявол является земным, а не небесным врагом Церкви и Христа. Гоббс утверждает, что коль скоро под словами «враг», «обвинитель» и "разрушитель» в Священном Писании подразумевается враг тех, кто будет находиться в Царствии Божием, а после воскресения Царствие Божие должно установиться на земле, то и враг его, и его царство также должны быть на земле. По словам Гоббса, «как Царство Божие и вечная жизнь, так и враги Бога с их муками после Судного дня, насколько видно из Писания, должны иметь свое место на земле» (Там же: 348$)^{35}$.

По поводу «вечных мук», на которые, согласно Священному Писанию, будут обречены грешники в аду, Гоббс говорит, что все места в Священном Писании, где об этом идет речь, «метафорически изображают горечь и досаду нечестивцев от лицезрения вечного блаженства других, которое они потеряли из-за своего неверия и непослушания. А так как такое блаженство познается лишь сравнением с собственными реальными бедствиями, то отсюда следует, что нечестивцы должны претерпеть такие страдания и бедствия, которые бывают уделом людей, не только живущих под властью злых и жестоких правителей, но и имеющих также своим врагом вечного Царя праведников - всемогущего Бога. К этим физическим

32. Leviathan. Part III, ch. 38 . 33. Leviathan. Part III, ch. 38 . 34. Leviathan. Part III, ch. 42. 35. Leviathan. Part III, ch. 38 . 
страданиям также следует отнести вторую смерть каждого из этих нечестивцев» (Там же: 351-352) ${ }^{36}$. На основании своего истолкования Священного Писания Гоббс делает вывод, что «должна быть вторая смерть для каждого осужденного в день Суда, после чего он уже больше не будет умирать» (Там же: 352$)^{37}$. Иными словами, грешники также будут испытывать телесные муки и в конце концов умрут второй смертью. По словам Гоббса, «для отверженных остается после воскресения вторая, и вечная, смерть, а промежуток между воскресением и их второй, и вечной, смертью есть для них лишь время наказания и мучений, время, которое будет продолжаться благодаря последовательной смене поколений грешников до тех пор, пока человеческий род будет продолжать размножаться, т. е. вечно» (Там же: 481$)^{38}$.

Согласно Гоббсу, фундаментальной проблемой, связанной с христианским учением о жизни после смерти, было то, что догма о муках ада, превосходящих саму физическую смерть, подрывала готовность подданных подчиняться светской власти, поскольку самое большее, чем эта последняя могла им грозить, была насильственная смерть от карающей длани суверена. Своим учением об аде Гоббс пытается устранить это затруднение. Для нечестивцев, т. е. тех, кто в наибольшей степени склонен к политическому неповиновению, не будет ни вечных мук, ни вечной жизни после смерти. В обоих случаях значимость учения об аде как источнике раздора оказывается серьезно нивелированной. С одной стороны, «муки ада» не обязательно должны быть страшнее, чем страх насильственной смерти, которым грозит нам светский суверен в случае отказа повиноваться его приказам. С другой стороны, поскольку «для отверженных остается после воскресения вторая, и вечная, смерть», то их адские муки не будут длиться вечно (Sherlock, 1982: 56-57).

Гоббс прекрасно отдавал себе отчет в том, что его новая теология может показаться совершенно неортодоксальной его соотечественникам; он прямо пишет об этом в XXXVIII главе «Левиафана», где повторяет, что единственным законным правом на истолкование Слова Божьего, выраженного в Священном Писании, обладает светский суверен. Гоббс пишет о своей политической теологии:

Так как это учение, хотя и доказанное многочисленными и ясными по смыслу местами Писания, покажется большинству людей новшеством [will appear to most men a novelty], то я лишь предлагаю его, но не настаиваю на том или другом мнении в области религии, поскольку это мнение расходится с общепринятыми на этот счет взглядами, и слежу за исходом еще не решенного между моими соотечественниками спора мечом о власти. От этой власти будет зависеть, какие учения должны быть приняты и какие отвергнуты, а еe постановлениям, как устным, так и письменным, должны повиноваться все люди, желающие получить защиту ее законов, каковы бы ни были мнения от-

36. Leviathan. Part III, ch. 38 . 37. Leviathan. Part III, ch. 38 . 38. Leviathan. Part III, ch. 44. 
дельных людей. Ибо пункты учения, касающиеся Царствия Божиего, имеют столь огромное влияние на царство людей, что они должны быть установлены лишь теми, кто под владычеством Бога имеет верховную власть. (Гоббс, 1991: 348$)^{39}$

Эту же позицию по отношению к истолкованию Священного Писания Гоббс принимает и сам, когда в той же главе «Левиафана» он специально оговаривается, что во всех вопросах, «решение которых зависит от Писания», он подчиняется «толкованию Библии, авторизованному государством, подданным которого я являюсь» (Там же: 344$)^{40}$.

Вторая проблема, на которую Гоббс обращает особое внимание в «Левиафане», связана с вопросом о том, кому следует повиноваться в первую очередь: Богу или человеку? Она тесно связана с первой проблемой, о Царствии Божием, поскольку, согласно Гоббсу, на вопрос о том, кому следует повиноваться, Богу или людям, нельзя дать удовлетворительного ответа, не зная, что необходимо делать в земной жизни для того, чтобы заслужить вечное спасение. «Поэтому все люди, - доказывает Гоббс, - желающие избежать тех наказаний, которым они могут быть подвергнуты в этом мире за неповиновение своему земному суверену, так и тех, которым они могут подвергнуться в грядущем за неповиновение Богу, необходимо должны научиться хорошо различать между необходимым и не необходимым для вечного спасения» (Там же: 449) ${ }^{41}$.

Отвечая на вопрос о том, следует ли прежде всего подчиняться Богу, а не людям, Гоббс задается сперва другим вопросом: откуда верующим известна сверхъестественная воля Бога? Кому мы должны верить и чьим повелениям должны следовать, спрашивает Гоббс, коль скоро мы придерживаемся христианской веры? Для ответа необходимо подвергнуть обстоятельному рассмотрению «основы христианской веры» (the causes of Christian faith), поскольку «основания, в силу которых люди верят какому-нибудь христианскому учению, бывают разные» (Там же: 451 ${ }^{42}$. По словам Гоббса, «вера христиан после эпохи нашего Спасителя имела своим основанием, во-первых, репутацию их пастырей, а затем авторитет тех, кто сделал Ветхий и Новый завет правилом веры, а это могли сделать одни лишь христианские суверены. Поэтому эти суверены являются верховными пастырями и единственными лицами, которые говорят нынешним христианам от имени Бога, за исключением таких лиц, с которыми в наши дни Бог говорит непосредственно, сверхъестественным образом» (Там же: 451$)^{43}$.

Как, однако, быть с теми христианами, которые объявляют себя пророками и заявляют, что с ними «Бог говорит непосредственно, сверхъестественным образом»? В отношении этих последних необходимо следовать особого рода такти-

39. Leviathan. Part III, ch. 38. 40. Leviathan. Part III, ch. 38 . 41. Leviathan. Part III, ch. 43. 42. Leviathan. Part III, ch. 43. 43. Leviathan. Part III, ch. 43. 
ке. Прежде всего, как показывает Гоббс в XXXII главе «Левиафана», необходимо знать, по каким признакам можно отличить истинных пророков от ложных. Само по себе пророчество, по Гоббсу, не несет с собой никаких явных знаков, которые заставили бы тех, к кому оно обращено, безоговорочно признать его авторитет. Поэтому Гоббс, опираясь на Священное Писание, стремится выяснить, «с помощью каких признаков можно узнать пророка» (by what marks prophets are known) (Там же: 290 ${ }^{44}$. В Священном Писании он находит два таких указания, одно из которых - скорее позитивного, а второе - скорее негативного свойства. Как подчеркивает Гоббс, эти два указания необходимо брать вместе, т. е. в сочетании друг с другом, поскольку по отдельности «ни одно из них не является достаточным» $(\text { Там же })^{45}$. Пророк, чье пророчество стоит доверия тех, к кому обращено, должен, во-первых, творить чудеса, и, во-вторых, он не должен вводить новую религию, идущую вразрез с уже установленной (that which is already established) ${ }^{46}$. Примечательно, что этому второму, негативному указанию Гоббс придает бо́льшую силу и вес по сравнению с первым, поскольку предположение, что основой веры является сверхъестественное откровение воли Бога, данное отдельным людям, подрывает самые основы политического и религиозного порядка. «Как бы ни были велики чудеса, - подчеркивает Гоббс, - однако если они имеют целью побудить к восстанию против короля или против того, кто управляет его именем, то совершающий такие чудеса должен считаться посланным для испытания верности подданных» (Там же: 291 ${ }^{47}$. В любом случае решающим по вопросу о том, каких пророков считать истинными, а каких ложными, должно быть авторитетное суждение светской власти. Как подчеркивает Гоббс, «так как испытание учений есть дело верховного пастыря, то лицом, которому все, кто не имеет специального откровения, обязаны верить, является во всех государствах верховный пастырь, т. е. гражданский суверен» (Там же: 451$)^{48}$.

Правда, в «Левиафане» Гоббс настаивает на том, что время пророков в прежнем, библейском смысле этого слова прошло. О непосредственном откровении сверхъестественной воли Бога человеку он прямо заявляет, что в современную ему эпоху Бог больше не говорит с человеком при посредстве пророков. По словам Гоббса, «в эпоху Нового завета - не было верховного пророка, кроме нашего Спасителя, который был одновременно Богом, который говорил, и пророком, с которым Бог говорил» (Там же: 331$)^{49}$. На основе этого тезиса Гоббс делает два вывода, которые имеют решающее значение для его оценки религиозных пророчеств и их роли в общественно-политической жизни. Первый вывод гласит, что с политической точки зрения христианское учение о пророчестве несет с собой угрозу граж-

44. Leviathan. Part III, ch. 32.

45. Leviathan. Part III, ch. 32.

46. «Первый - это творение чудес, второй - не учить другой религии, кроме уже установленной» (Leviathan. Part III, ch. 32; Гоб6c, 1991: 290).

47. Leviathan. Part III, ch. 32.

48. Leviathan. Part III, ch. 43.

49. Leviathan. Part III, ch. 36. 
данскому миру, и по этой причине надо крайне осмотрительно подходить к оценке претензий отдельных христиан на то, что они являются истинными пророками. Согласно второму выводу, который идет вразрез с экзальтированным настроением многих его соотечественников в период гражданской войны в Англии, пророчествам нет места в современном мире. «Чудеса прекратились, пророков больше нет, - пишет Гоббс, - и их место заняло Священное писание» (Там же: 292) которое в современном мире остается единственным источником религиозной истины в качестве Слова Божия. По этой причине, как доказывает Гоббс,

мы не обязаны прислушиваться к какому-либо учению, выходящему за рамки Священного писания, которое со времени нашего Спасителя заменяет пророчество и является достаточным восполнением отсутствия всяких других пророчеств и из которого при мудром и научном толковании и при внимательном умозаключении [by wise and learned interpretation, and careful ratiocination] могут быть выведены без всякого вдохновения и сверхъестественного внушения [without enthusiasm, or supernatural inspiration] все правила и предписания, указывающие наши обязанности по отношению как к Богу, так и к человеку. (Там же: 292) ${ }^{51}$

В этом пункте мы напрямую сталкиваемся с необычайно важным для политической теологии Гоббса вопросом о том, какая инстанция в государстве обладает законным правом на нормативно значимое толкование содержания Священного Писания. На этот счет Гоббс в «Левиафане» высказывается совершенно недвусмысленно. Согласно его точке зрения, лишь светский суверен имеет полное и исключительное право давать нормативное истолкование содержания Священного Писания, как и всех остальных учений, способных повлиять на вопросы гражданского мира. В главе XXXIII «Левиафана» Гоббс пишет:

вопрос об авторитете Писания сводится к следующему: являются ли христианские короли и верховные собрания христианских государств абсолютными суверенами в пределах своих собственных территорий непосредственно ответственными перед Богом, или же они подвластны какому-то наместнику Христа, поставленному над универсальной церковью, так что они могут быть судимы, осуждены, низложены и подвергнуты смертной казни, если только этот наместник Христа сочтет это иеелесообразным или необходимымм в иелях общего блага? (Там же: 302-303) 52

В данном случае Гоббс выступает против религиозного универсализма и против притязаний римско-католической Церкви на толкование Священного Писания, доказывая, что в современном мире существует много христианских церквей, законным главой которых являются их светские суверены. Было бы большой ошиб-

50. Leviathan. Part III, ch. 32.

51. Leviathan. Part III, ch. 32.

52. Leviathan. Part III, ch. 33. Курсив Гоббса. 
кой полагать, доказывает Гоббс, «будто все христианские короли, папы, духовенство и весь остальной христианский люд составляют единое государство. Ибо очевидно, что Франция - это одно государство, Испания - другое, Венеция третье и т.д. Эти государства состоят из христиан, поэтому они являются также различными группами христиан, т. е. различными церквами, и они представлены различным суверенам» (Там же: 442$)^{53}$.

Поэтому проблема права на истолкование Священного Писания в глазах Гоббса сводится к тому, обладает ли тот, кто может канонизировать определенный текст в качестве священного текста, еще и силой, чтобы утвердить то или иное его толкование в качестве нормативного или же, напротив, запретить его. Гоббс подчеркивает, что согласно Ветхому завету, светская и духовная власть должна быть объединена в одних руках, на что указывает то обстоятельство, что древние цари были не только суверенами-законодателями, но и толкователями Слова Божьего ${ }^{54}$. Такое же положение, согласно Гоббсу, должно установиться и в современных христианских государствах. После того как в мире появились христианские суверены, первым из которых был император Константин Великий, вся полнота светской и духовной власти сосредоточилась в их руках. Теперь только светский суверен или же те инстанции, которым он дал такое право, вправе назначать священнослужителей и давать интерпретацию Священному Писанию. По словам Гоббса, «никто, кроме суверена, в христианском государстве не может знать, что́ есть и что́ не есть слово Божие» (Там же: 360$)^{55}$. Иными словами, Гоббс убежден в том, что в мире существует много христианских церквей, главами которых являются разные гражданские суверены, которые и обладают правом толковать Священное Писание, либо самостоятельно, либо при посредстве специально для этого назначенных людей. Соответственно, «только суверену принадлежит право назначать судей и толкователей канонических писаний, ибо только он один придает им силу законов» (Там же: 420$)^{56}$.

Благодаря тому, что светский суверен в «Левиафане» наделяется Гоббсом неограниченной властью не только судить религиозные учения с точки зрения того, способствуют ли они гражданскому миру, но и интерпретировать с этой целью Священное Писание, в его политической теологии происходит

\begin{abstract}
диалектический поворот от реформаторской трактовки идеи двух царств (духовного и светского) и их разделения к доктрине государственной церкви, не признававшей за Священным Писанием никакого собственного нормативного содержания... Поскольку религия обретает у Гоббса свою значимость лишь благодаря воле суверена, религиозное теряет свое качественное своеобразие. Если истины Священного Писания являются производными от воли правителя и только воля, но не убеждение становятся конститутивным
\end{abstract}

53. Leviathan. Part III, ch. 42. 54. Leviathan. Part III, ch. 40. 55. Leviathan. Part III, ch. 40. 56. Leviathan. Part III, ch. 42. 
элементом в выборе государственной религии, то поворот к секуляризации государства можно считать почти свершившимся. (Козловски, 1998: 143)

\section{Прагматические стратегии политической теологии Гоббса}

Стратегии, используемые Гоббсом в «Левиафане» для парирования угрозы, исходящей от христианской религии для гражданского мира в государстве, не исчерпываются новаторским истолкованием доктринальных положений христианского вероучения, призванном согласовать их с абсолютной властью светского суверена. Взрывоопасный потенциал христианских религий, высвобожденный протестантской Реформацией и спровоцированной ею эпохой межконфессиональных и религиозных войн, Гоббс стремится разрядить также и иными средствами. Особое значение имеют две стратегии, тесно связанные между собой. С одной стороны, Гоббс добивается устранения доктринальной сложности христианского вероучения, с тем чтобы можно было избежать потенциальных конфликтов на его почве. С другой стороны, он предлагает лишить Церковь полномочий давать свою собственную интерпретацию христианской доктрины, целиком поставив эту сторону ее пастырской деятельности под контроль светских властей.

Таким образом, те средства, которые Гоббс применяет в «Левиафане» для обезвреживания конфликтного потенциала, связанного с отношениями религии и политики, характеризуются двумя базисными требованиями: 1) необходимостью сокращения диапазона возможных содержательных интерпретаций христианского вероучения и 2) необходимостью определения инстанции, получающей право на монопольное истолкование содержания религиозных учений с точки зрения того, способствуют они или нет установлению гражданского мира в государстве. Право давать религиозному учению нормативно значимую интерпретацию, а также выносить обязывающие суждения по его поводу Гоббс безоговорочно отдает мирской инстанции в лице светского суверена, который один (либо непосредственно, либо при посредстве специально на то им уполномоченных лиц и институтов) имеет право судить, какая интерпретация религиозной доктрины является единственно верной, причем делает он это, исходя не из соображений религиозного спасения, а из соображений сохранения гражданского мира (Grossheim, 20o8: 241). Тем самым во главу угла в религиозных делах в мире раннего модерна у Гоббса ставится политика, и притом особого рода, а именно политика гражданского мира.

Для преодоления религиозно-политических конфликтов Гоббс стремится свести основы христианского учения к минимуму доктринальных положений, оставив только те из них, которые не вызывают принципиальных разногласий у представителей различных христианских конфессий ${ }^{57}$. Таким бесспорным положением христианской доктрины, вера в которое безусловно необходима для спасения, Гоббс считает догмат «Иисус есть Христос». Эта мысль красной нитью проходит

57. «Его истолкование основных начал христианской веры, - пишет о Гоббсе Р. Так, - отмечено явно выраженной тенденцией к минимализму» (Tuck, 2002: 96). 
через все три его главных политических произведения - «Элементы закона», «О гражданине» и «Левиафан» ${ }^{58}$. Своим оппонентам, настаивавшим на необходимости обнародования других доктринальных положений, Гоббс возражал, что все прочие базовые религиозные истины христианства могут без особого труда быть выведены из этого исходного доктринального положения.

В защиту своего тезиса Гоббс приводит несколько аргументов, наиболее интересными из которых являются два: 1) необходимая для спасения вера легка, как тому учит Священное Писание, и 2) указанный догмат является основой всех остальных. Что касается первого аргумента, то Гоббс доказывает, что «если необходимым условием спасения было бы внутреннее признание всех учений относительно христианской веры, которым теперь учат, то не было бы на свете ничего более трудного, чем быть христианином» (Гоббс, 1991: 454) ${ }^{59}$. Однако главным доводом Гоббса в пользу его минималистского символа христианской веры является тезис о том, что этот догмат есть основа веры, а тот, кто исповедует основу веры, будет спасен. Что же касается всех остальных догматов, необходимых для спасения, то все они, по мнению Гоббса, могут быть с большими или меньшими затруднениями выведены из этого исходного основного догмата. «Одним словом, - заключает Гоббс, - тот, кто исповедует основу, а именно что Иисус есть Христос, исповедует этим сознательно все те следствия, которые он выводит из нее, и бессознательно всё, что вытекает из этой основы, хотя бы сам верующий не обладал достаточным искусством, чтобы вывести эти следствия» (Там же: 458) ${ }^{60}$.

Соответственно, те христиане, которые разделяют это положение, но имеют неортодоксальные взгляды по другим доктринальным вопросам, не могут быть отлучены от Церкви. По словам Гоббса, «для отлучения от церкви человека, признающего основной догмат, а именно что Иисус был Христом, за инакомыслие в других пунктах, не затрагивающих этого основного догмата, Писание не дает никакого основания, и мы не находим у апостолов подобного примера» (Там же: $390)^{61}$. Тем самым Гоббс добивается двойного эффекта: он не только расширяет границы религиозной терпимости, но и урезает возможности Церкви и ее священнослужителей налагать кары и отлучения на отступников. Ведь именно в этом пункте Церковь обычно вступает в конкуренцию с государством, суля своим приверженцами в случае неповиновения наказания более страшные, нежели те, которыми может грозить им как подданным светская власть.

Почитание верующими мучеников и страданий, которые они претерпели ради веры, всегда служило Церкви прекрасным поводом для укрепления ее позиций в борьбе со светской властью. Для того чтобы не допустить появления мучеников в христианском государстве, Гоббс добавляет в формулировку христианского символа веры дополнительный светский компонент, а именно требование, чтобы

58. Elements of Law. Part II, ch. 6, $\$$ 6; De Cive. Cap. 18, art. 5; Leviathan. Part III, ch. 43.

59. Leviathan. Part III, ch. 43.

6o. Leviathan. Part III, ch. 43.

61. Leviathan. Part III, ch. 42. 
верующие подчинялись законам государства. Его цель в данном случае состоит в том, чтобы примирить повиновение Богу с повиновением гражданскому суверену. По словам Гоббса, «все, что необходимо для спасения, содержится в двух добродетелях: в вере в Христа и в повиновении законам» (Там же: 449) ${ }^{62}$.

Правда, сводя воедино христианскую веру и повиновение закону государства, Гоббс отдает явное предпочтение последнему, в том числе и в тех вопросах, что затрагивают регламентацию религиозного поведения подданных. Неудивительно поэтому, что во всех трех изложениях своей политической философии Гоббс доказывает, что безусловное повиновение светской власти является священной обязанностью всякого христианина постольку, поскольку эта власть не запрещает веру в Иисуса как Христа ${ }^{63}$. Однако решающий вопрос - обязан ли христианин повиноваться светской власти, если та запрещает ему исповедовать свою веру? - получает разные ответы в ранних и поздних изложениях его политической философии. В ранних изложениях утверждается, что правом и обязанностью христианина в таких случаях является исключительно пассивное сопротивление и мученичество ${ }^{64}$, тогда как в «Левиафане» за простыми верующими-христианами вообще отрицается не только обязанность, но и право мученичества, которое сохраняется только за теми, чьим особым призванием является проповедь Благой вести (Strauss, 1963 [1936]: 72).

Согласно разъяснениям, которые Гоббс дает по этому вопросу в «Левиафане», мучениками за веру Христову могут считаться только те христиане, которые были свидетелями воскрешения Иисуса Христа из мертвых и которые в силу этого чудесного события были призваны открыто проповедовать и исповедовать Царство Христа. По словам Гоббса, «есть лишь один догмат, приняв смерть за который заслуживают почетное имя мученика, и этот догмат гласит, что Иисус есть Христос, т.е. тот, который искупил нас и придет снова, чтобы дать нам спасение и вечную жизнь в своем Царстве Славы» (Гоббс, 1991: 384) ${ }^{65}$. Что же касается всех остальных христиан, которые не были свидетелями чудесного воскрешения Иисуса Христа и не были посланы Богом проповедовать эту благую весть, то им следует держаться политики внешнего конформизма, веруя на словах в те религиозные догмы, которые предписывает им светский суверен, и исполняя с помощью своих внешних действий ритуалы, установленные государством для публичного исповедания религии.

Но как быть в том случае, спрашивает Гоббс, если какой-нибудь царь, сенат или какой-либо другой суверен запретит нам верить в Христа? По мнению Гоббса, такое запрещение останется безрезультатным, ибо вера и безверие никогда не следуют человеческим указаниям. «Вера есть дар Божий, которого никто не может дать, ни отнять обещанием награды и угрозой пыток» (Там же: 382$)^{66}$. А как следу-

62. Leviathan. Part III, ch. 43. Cp.: Elements of Law. Part II, ch. 6, art. 10; De Cive. Cap. 18, art. 2.

63. Elements. Part II, ch. 6, $\$$ 6; De Cive. Cap. 17, art. 13 и сар. 18, art. 13; Leviathan. Part III, ch. 42 и ch. 43. 64. Elements. Part II, ch. 6, $\$ 14$; De Cive. Cap. 18, art. 13.

65. Leviathan. Part III, ch. 42. Перевод исправлен мной по изданию: Hobbes, 1998: 334.

66. Leviathan. Part III, ch. 42. 
ет поступать христианину тогда, когда его законный суверен прикажет ему сказать вслух, что он не верит в Христа, - обязан ли он и в этом случае повиноваться его приказанию? На это Гоббс отвечает, что публичное отречение от Христа на словах есть лишь внешний жест и имеет не большее значение, чем любой внешний жест, которым мы выражаем свою покорность суверену. Соответственно, все, что подданный должен делать из повиновения своему суверену, и все, что он делает не по собственному побуждению, «а повинуясь законам своей страны, - всякое такое деяние является деянием не подданного, а его суверенов, и не подданный отрицает в данном случае Христа перед людьми, а правитель и закон его страны» (Там же: 382-383) ${ }^{67}$. Таким образом, заключает Гоббс, если в нехристианском государстве суверен предпишет христианам выражать языком или внешними знаками исповедания, противные христианству, то они должны повиноваться законам государства, сохраняя при этом в сердце веру в Христа. Грех при этом ляжет не на них, а на суверена, издавшего такое предписание в форме государственного закона 68 .

Защита Гоббсом такой откровенно компромиссной, если не сказать - двулично-лицемерной линии поведения верующих христиан - становится возможной потому, что он, помимо всего прочего, проводит в «Левиафане» далеко идущее противопоставление между личной невидимой верой (faith) и публичным официальным исповеданием религии (confession). Это последнее должен санкционировать христианский суверен как доказательство лояльности по отношению к нему со стороны подданных, тогда как все спорные вопросы христианского вероучения необходимо отнести к области личной веры. При этом все, что касается личной веры, является внутренним и невидимым. Поэтому внешне необходимо демонстрировать почтение и послушание светскому суверену, причем даже тогда, когда суверен из признания доктринального положения Иисус есть Христос делает ложные выводы или вообще является неверующим.

Те, кому Бог путем сверхъестественного Откровения не приказывает противного, обязаны во всяком государстве повиноваться законам своих суверенов в отношении своих внешних действий и в отношении исповедания религии. Что же касается сокровенных мыслей и веры людей, которых человеческие правители не могут знать (ибо один Бог знает сердце человеческое), то они непроизвольны и обусловлены не законами, а сокровенной волей и могуществом Бога и, следовательно, не подпадают под обязательство. (Там же: $370-371)^{69}$

Помещая спорные догматы христианского вероучения в область личной невидимой веры, Гоббс тем самым рассчитывал сделать предметом официального

67. Leviathan. Part III, ch. 42.

68. В подобных ситуациях христиане, согласно Гоббсу, должны поступать подобно сирийскому военачальнику Нееману, который, уверовав в Бога Израиля в душе своей, был вынужден в то же самое время поклоняться идолу Риммону, и такое поведение, как подчеркивает Гоббс, было одобрено пророком Елисеем (4 Цар. 5, 17, 18) (Leviathan. Part III, ch. 42).

69. Leviathan. Part III, ch. 40. 
вероисповедания лишь те положения, которые могли бы вызвать согласие у всех христианских конфессий. Вывод, к которому приходит Гоббс, заключается в следующем: «Государство должно хранить нейтралитет в вопросах веры, коль скоро оно устанавливает официальный минимум вероисповедания и все остальное предоставляет на свободный суд личной веры» (Münkler 2014: 140). Тем самым Гоббс хотел защитить единство государства, обеспеченное публичным почитанием Бога, и свести к минимуму религиозные распри, порождаемые спорами о Его природе ${ }^{70}$.

На основании противопоставления личной невидимой веры и официального исповедания установленной светским сувереном религии Гоббс проводит еще одно важное для его политической теологии различение, а именно - между государственным и частным исповеданием религии (public and private worship). Публичное исповедание - это официальная религия государства, установленная его сувереном. Каждый гражданин обязан демонстрировать внешнее согласие как с учениями официальной религии, так и с ее ритуалами. Что же касается сокровенных мыслей и веры людей, то они составляют частное исповедание религии, которое не должно иметь внешних проявлений и обязано происходить втайне $\mathrm{e}^{71}$.

Государственное поклонение является предметом выбора в том смысле, что государство само, в лице своего суверена, вправе выбирать официальную религию и ее содержание. Напротив, отдельные граждане лишены права выбирать официальную религию, ее догматы и ритуалы. Они обязаны демонстрировать внешнее почитание официальной религии государства своими внешними действиями. Отсюда Гоббс выводит также необходимость держаться единообразия в государственном культе. В вопросах институциональной организации Церкви нельзя терпеть плюрализма, поскольку это может поставить под угрозу единство государства. Поэтому религиозное многообразие недопустимо, а гражданский суверен должен быть одновременно и главой Церкви. По словам Гоббса,

ввиду того, что государство есть единое лицо, оно должно иметь единую форму культа, и это имеет место тогда, когда государство постановляет, что культ должен совершаться частными лицами публично, а это и есть государственный культ, существенным свойством которого является единообразие. Ибо действия, совершаемые разными людьми различным образом, не могут называться государственным культом. Поэтому там, где допускаются различные виды культа, вытекающие из различных религий частных лиц, не существует государственного культа и государство как таковое не имеет религии вообще. (Гоббс, 1991: 284-285) 72

70. «Когда люди, исходя из принципов естественного разума, - пишет Гоббс, - спорят о божественных атрибутах, они лишь хулят Бога. Ведь атрибутам, которые мы приписываем Богу, мы не должны придавать значение философских истин, в них следует видеть лишь выражение нашего благочестивого намерения воздать Богу величайшую честь, какую мы только способны воздать» (Leviathan. Part II, ch. 31: Гоб6c, 1991: 284).

71. Leviathan. Part II, ch. 31.

72. Leviathan. Part II, ch. 31. 
Таким образом, Гоббс прекрасно отдавал себе отчет в том, что в принципиальных вопросах религии нельзя ни в коем случае допускать двусмысленности. Здесь последнее слово всегда должно оставаться за светским сувереном. Лишь в «Обозрении и заключении» к «Левиафану» Гоббс допускает возможность распространения нового учения, созданного им самим, которое при определенных обстоятельствах может войти в противоречие с уже утвержденными государством формулировками. Защищая свое политическое учение и отстаивая необходимость его преподавания в университетах, Гоббс оперирует доводами двоякого рода: он подчеркивает, что его учение является истинным и что оно направлено на обеспечение гражданского мира и повиновения подданных светскому суверену. «В той части, которая трактует о христианском государстве, - пишет он, - имеются некоторые новые идеи, которые в государстве, где окончательно установились противоположные взгляды, может быть, были бы преступлением, как узурпация места учителя со стороны подданного, не имеющего разрешения на провозглашение новых идей. Однако в наше время, когда люди ищут не только мира, но и истины, предлагать вниманию тех, кто еще раздумывает, такие учения, которые я считаю истинными и которые явно способствуют водворению мира и лояльности, - значит лишь предлагать новое вино, которое должно быть влито в новые бочки, дабы и то и другое могло сохраниться. И я предполагаю, что когда новое учение не порождает никакой смуты и никакого беспорядка в государстве, люди не настолько склонны благоговеть перед древностью, чтобы предпочитать старые ошибки новой и вполне доказанной истине» (Там же: 542-543) ${ }^{73}$. Правда, в этом пункте мы уже имеем дело с переходом от политической теологии Гоббса к его программе политического просвещения, которую он рассчитывал предложить властям новой, республиканской Англии и на основе которой он считал необходимым реформировать гражданское образование в английских университетах.

\section{Вместо заключения: от подчинения Церкви государству — к нейтральному и светскому государству модерна}

Поставив в центр своей версии политической теологии резкое противопоставление официального исповедания религии и личной веры, Гоббс этим положил начало характерному для современной эпохи и далеко идущему процессу нейтрализации и деполитизации тех жизненных содержаний, определение которых не должно отдаваться на откуп светскому суверену, но является исключительно личным делом его подданных. Такая стратегия исключает обсуждение основных доктринальных вопросов веры из публичного пространства, равно как и выводит их из области обязывающих для подданных суждений суверена по вопросам веры, помещая их в своего рода «серую зону». В конечном счете эта логика приводит к тому, что государство-суверен отказывается от принудительной регламентации

73. Leviathan. Review and Conclusion. 
множества вопросов, включая религиозные, за которые еще в XVI-XVII веках между европейцами, по словам самого Гоббса, шла ожесточенная «борьба перьев и мечей» ${ }^{74}$.

Карл Шмитт в своем сочинении «Левиафан в учении о государстве Томаса Гоббса» (1938) в общем и целом оценивает этот процесс негативно, полагая, что тем самым Гоббс открыл ящик Пандоры и в конечном счете это привело к крушению его теории абсолютного и неограниченного суверенитета светской власти. Суверенное представительное лицо, доказывает Шмитт, гибнет от разрыва между внешним и внутренним в делах веры, спровоцированным учением Гоббса о политической теологии. В тот самый момент, когда «в XVIII столетии в государстве абсолютного монарха Левиафан... получил во внешнем мире свое наивысшее воплощение... судьба его в этот промежуток времени завершилась тем, что сформировалась разница между внутренним и внешним. Вопрос о вере и чуде здесь стал для него роковым» (Шмитт, 2006 [1938]: 183). По словам Шмитта, «в этом месте, на вершине суверенной власти, соединяющей религию и политику, в этом во всех других отношениях столь завершенном, неоспоримом единстве обнаруживается изъян» (Там же: 189). Речь у Шмитта в данном случае как раз и идет о проведенном Гоббсом противопоставлении внутренней невидимой веры и внешнего официального исповедания веры, которое должно находить свое выражение исключительно в поступках верующих и исполнении им официальных религиозных обрядов и ритуалов.

Дело в том, что в этом месте в политическую систему «Левиафана» вводится различие между внутренней верой и внешним исповеданием веры. Гоббс объявляет вопрос о чудесах и волшебстве делом «публичного», а не «частного» разума; однако в силу всеобщей свободы мышления — quia cogitatio omnis libera est - он оставляет единичному человеку свободу верить или не верить внутренне, наедине с собой, в согласии со своим частным разумом и сохранять собственное суждение (judicium) в своем сердце, intra pectus suum. Конечно, как только речь заходит о внешнем исповедании веры, частные суждения замолкают, а что истинно и что не истинно - определяет суверен. (Там же: 189-190)

Тем самым, по Шмитту, в «Левиафане» «в политическую систему вводится оговорка относительно внутренней, частной свободы совести и мысли. Она-то и стала зерном смерти, изнутри разъявшей грозного Левиафана и погубившей смертного Бога» (Там же: 191$)^{75}$.

74. Подобная постановка вопроса применительно к политическому процессу современности находит свое первое отчетливое выражение в статье Карла Шмитта «Эпоха деполитизаций и нейтрализаций» (Шмитт, 2016 [1929]: 357-372). Обобщенную характеристику процесса возникновения нейтрального и светского государства модерна Шмитт дает в статье «Государство как конкретное понятие, связанное с определенной исторической эпохой» (Шмитт, 2012 [1941]: 205-215).

75. Критическую оценку этого тезиса К. Шмитта см. в статьях: Филиппов, 2006: 5-100, особ. 66-84; Fischer, 2011: 141-158; Slomp, 2011: 99-112. 
Сегодня, однако, ничто не мешает нам посмотреть на этот характерный для мира модерна процесс нейтрализации религиозных, мировоззренческих и жизненных содержаний под иным углом зрения. По оценке Германа Люббе, характерная для Гоббса

\begin{abstract}
уверенность в том, что авторитарное установление общественных религиозных обязанностей (если оно не затрагивает наиважнейшее и одновременно бесспорное для каждого содержание веры) может устанавливать и гарантировать мир, служит убеждением, подготавливающим либерализм. Ведь именно потому, что суверен, вместо того чтобы ссылаться на истину, легитимирует свое авторитарное установление общественных религиозных обязанностей прагматически, с целью установления мира, он оставляет открытым вопрос об истинности того, к чему он формально обязывает. Тем самым он открывает свободное пространство для субъективных очевидностей, которые никому не дозволено возвещать и тем более пропагандировать публично и, однако, никому не воспрещается исповедовать их приватно, равно как и подпитывать их непосредственным обращением к библейским источникам истины. В результате того, что для легитимации общественно значимых религиозных обязанностей отсылают не к истине, а лишь к авторитету монополиста политических решений, выступающего гарантом мира, внутренняя религиозная убежденность инакомыслящих остается незатронутой. (Люббе, 2012: $147-148)$
\end{abstract}

Однако на этом либеральная эволюция еще не заканчивается. В конце концов она кладет конец и притязаниям суверена на легитимацию общественно значимых религиозных обязанностей. Суть этой либеральной эволюции в направлении нейтрализации мировоззренческих и религиозных вопросов для мира политики в современную эпоху заключается в том, что

современное общество вынуждено либо структурироваться тоталитарно, либо резко сократить то множество религиозных, мировоззренческих, идеологических и моральных содержаний, которые оно может вменить каждому в качестве обязательных. Либо возрастающая нейтральность наших религиозных, конфессиональных, мировоззренческих, идеологических и культурных идентификаций, либо политическая тотальность - такова альтернатива, аналитически ясно выраженная Карлом Шмиттом, а равно Максом Вебером. (Люббе, 2012: 148-149)

Нетрудно предположить, что такая либеральная эволюция взглядов на общественное значение базисных мировоззренческих вопросов для общества и культуры модерна была обусловлена не в последнюю очередь трагическим опытом религиозных и гражданских войн XVI-XVII веков, в том числе опытом гражданской войны в Англии, наглядно показавших опасность усилий той или иной противоборствующей партии реализовать свою истину в политике при помощи силы. Учет этого опыта потребовал эмансипации политической власти мира модерна от 
религиозных предпочтений и деполитизации того круга вопросов, которые влекли за собой возможность столкновения между подданными одного государя по поводу религиозных и мировоззренческих проблем. Тем самым оказывался запущенным важнейший этап процесса секуляризации, в ходе которого появляется как светское и нейтральное государство модерна, так и его противоположность гражданское общество модерна, состоящее из частных индивидов ${ }^{76}$.

Выдвигая требование полного подчинения Церкви государству, а религии политике, Гоббс тем самым, доказывает М. Гроссхейм, добивался вовсе не «завершения Реформации», как полагал Карл Шмитт (Шмитт, 2006 [1965]: 248-296), но отстаивал абсолютный примат и верховенство политики в мире раннего модерна, в том числе и в вопросах религии и общественной морали. Иными словами, в политической теологии Гоббса речь идет не о Реформации, но о такой трансформации христианства, конечным результатом которой должно стать обезвреживание этого религиозного явления в качестве источника вредных для гражданского мира политических воздействий. Близость же воззрений Гоббса к протестантизму была в конечном счете обусловлена тем, что в его время протестантизм представлял собой единственную возможность оправдать религиозный партикуляризм, основанный на принципе cuius regio, eius religio (Grossheim, 2008: 247). Тем самым в политической философии и политической теологии Гоббса преломляется не процесс завершения Реформации, а процесс секуляризации, ведущий к появлению нейтрального в религиозном и мировоззренческом отношении государства модерна ${ }^{77}$.

По мере того как современность будет вступать в свои права, все больше и больше будет крепнуть решимость одним махом разрубить гордиев узел отношений между политикой и религией, государством модерна и Церковью. По мнению Пьера Манана, такое радикальное решение теолого-политической проблемы модерна было предложено либерализмом, который стремится по возможности полно и бескомпромиссно отделить власть от мнения и прежде всего от религиозного мнения, с тем чтобы лишить такое опасное для гражданского мира начало, как духовная власть, самой ее основы. В случае успеха этой стратегии Церковь как духовный институт больше не должна была иметь иной, кроме как «мягкой власти» наставлять тех, кто того пожелает, в основах христианской веры, а светская власть не должна была больше иметь своего мнения и, что в данном случае немаловажно, мнения религиозного. Власть, лишенная своего собственного мнения, против мнений, лишенных власти, - вот формула либерального решения теолого-политической проблемы в ее зрелой форме. Однако власть, в принципе лишенная собственного мнения, - это и есть то, что в современную эпоху принято на-

76. Понятие «секуляризация» используется здесь в значении, данном ему Германом Люббе, согласно которому секуляризация - это «изъятие или высвобождение какого-либо дела, территории или института из-под церковно-религиозного наблюдения и господства» (Lübbe, 1965: 23).

77. Сбалансированная историческая и философско-правовая характеристика процесса отделения политики от религии, государства от церкви в мире модерна дается в статье Эрнста-Вольфганга Бёкенфёрде: Bökenförde, 2013: 92-114. 
зывать нейтральным или светским государством модерна, призванным служить прежде всего самосохранению индивидов и защищать их права. «Государство по мере того, как оно будет отказываться от всякого религиозного мнения, будет все более ясно осознавать, что цель его существования - защита, осуществление и гарантия Прав человека» (Манан, 2004: 49). Правда, при жизни Гоббса время такого радикального решения теолого-политической проблемы модерна еще не пришло. Тем не менее предложенное Гоббсом решение теолого-политической проблемы модерна было важной вехой на этом пути, а самому философу довелось сыграть на нем непростую роль первопроходца. Как точно замечает Йен Шапиро, «урок религиозных войн XVII века учит нас тому, что неделимые блага лучше убрать с политического стола. Если Церковь отделена от государства, то вероятность религиозных битв за командные высоты в нем снижается» (Shapiro, 2016: 52) ${ }^{78}$. С высоты сегодняшнего дня очевидно, что полное подчинение Церкви светскому суверену, в том числе и в доктринальных вопросах, провозглашенное Гоббсом, в исторической перспективе стало отправной точкой для запуска того важнейшего этапа секуляризации западного мира, который в итоге привел к отделению Церкви от государства. Религия как неделимое благо была убрана с политического стола мира модерна, правда, как выясняется сегодня, отнюдь не навсегда и не безвозвратно.

\section{Литература}

Бенетон Ф. (2002). Введение в политическую науку / Пер. с франц. М. М. Федоровой. М.: Весь Мир.

Блаженный Августин. (1998). О Граде Божием. Книги XIV-XXII. СПб.: Алетейя. Вебер М. (2017 [1921]). Город / Пер. с нем. М. И. Левиной. М.: Strelka Press.

Гоббс Т. (1989a). О гражданине / Пер. с лат. Н. А. Федорова // Гоббс Т. Сочинения. Т. 1. М.: Мысль. С. 270-506.

Гоббс Т. (1989б). Человеческая природа / Пер. с англ. А. Гутермана // Гоббс Т. Сочинения. Т. 1. М.: Мысль. С. 507-573.

Гоббс Т. (1991). Левиафан, или Материя, форма и власть государства церковного и гражданского / Пер. с англ. А. Гутермана // Гоббс Т. Сочинения. Т. 2. М.: Мысль. С. 3-545.

Джей М. (2015). Добродетели лицемерия: о лжи в политике / Пер. с англ. М. Кукарцевой. М.: Канон+.

78. В отличие от делимых благ, таких как доход и благосостояние, которые могут быть распределены между согражданами самыми разными способами, «неделимые блага», согласно современной политической философии укорененные прежде всего в этнической идентичности, расе и религии, не поддаются такому многообразному распределению среди членов политической общности. «Это не означает, - подчеркивает Й. Шапиро, - что неделимые блага, обычно укорененные в религии, расе и этнической идентичности, должны быть изгнаны из политики конституционным указом. Ничто нельзя изгнать конституционным указом. Но тем не менее это означает, что лучше всего избегать овеществления неделимых благ, ориентируясь на них в политике, это так же благоразумно, как стремиться избегать ярко выраженных предпочтений» (Shapiro, 2016: 48). 
Козловски П. (1998). Общество и государство: неизбежный дуализм / Пер. с нем. Е. Л. Петренко. М.: Республика.

Люббе Г. (2012). Карл Шмитт в восприятии либералов / Пер. с нем. О. В. Кильдюшова // Логос. № 5 (89). С. 143-157.

Манан П. (2004). Общедоступный курс политической философии / Пер. с франц. В. И. Божовича. Москва: Московская школа политических исследований.

Руссо Ж.-Ж. (1969). Об Общественном договоре, или Принципы политического права / Пер. с франц. А. Д. Хаютина, В. С. Алексеева-Попова // Руссо Ж.-Ж. Трактаты. М.: Наука. С. 151-256.

Суини М. (2006). Лекции по средневековой философии. Вып. 2: Средневековая политическая философия Запада. М.: Институт философии, теологии и истории Святого Фомы.

Филиппов А. Ф. (2006). Критика Левиафана // Шмитm К. Левиафан в учении о государстве Томаса Гоббса: смысл и фиаско одного политического символа / Пер. с нем. Д. В. Кузницына. СПб.: Владимир Даль. С. 5-10о.

Шмитm К. (2006 [1938]). Левиафан в учении о государстве Томаса Гоббса: смысл и фиаско одного политического символа / Пер. с нем. Д. В. Кузницына. СПб.: Владимир Даль.

Шмитm К. (2006 [1965]). Завершенная Реформация // Шмитm К. Левиафан в учении о государстве Томаса Гоббса: смысл и фиаско одного политического символа / Пер. с нем. Д. В. Кузницына. СПб.: Владимир Даль. С. 248-297.

Шмитm К. (2012 [1941]). Государство как конкретное понятие, связанное с определенной исторической эпохой / Пер. с нем. А. Ф. Филиппова // Логос. № 5 . С. 205-215.

Шмитm К. (2016 [1929]). Эпоха нейтрализаций и деполитизаций / Пер. с нем. А. Ф. Филиппова // Шмитт К. Понятие политического. СПб.: Наука. С. 357-372. Шоню П. (2005). Цивилизация классической Европы / Пер. с франц. В. Бабинцева. Екатеринбург: У-Фактория.

Böckenförde E.-W. (2013). Die Entstehung des Staates als Vorgang der Säkularisation // Böckenförde E. $W$. Recht, Staat, Freiheit. Studien zur Rechtsphilosophie, Staatstheorie und Verfassungsgeschichte. Frankfurt am Main: Suhrkamp. S. 92-114.

Fischer K. (2011). Hobbes, Schmitt and the Paradox of Religious Liberality // Tralau J. (ed.). Thomas Hobbes and Carl Schmitt: The Politics of Order and Myth. L.: Routledge. P. 141-158.

Grossheim M. (2008). Religion und Politik: Die Teile III und IV des Leviathan // Kersting W. (Hg.) Thomas Hobbes, Leviathan. Berlin: Akademie Verlag. S. 234-259.

Hobbes T. (1994). The Correspondence, 1622-1659. Oxford: Oxford University Press.

Hobbes T. (1996). Leviathan. Oxford: Oxford University Press.

Höffe O. (1987). Politische Gerechtigkeit: Grundlegung einer kritischen Philosophie von Recht und Staat. Erweiterte Ausgabe. Frankfurt am Main: Suhrkamp.

Lübbe H. (1965). Säkularisierung: Geschichte eines ideenpolitischen Begriffs. Freiburg, München: Karl Alber. 
Macchiavelli N. (2014). Il Principe. Torino: Einaudi.

Manent P. (1987). Histoire intellectuelle du liberalism: dix leçons. Paris: Calmann-Lévy.

Manent P. (2007). Naissances de la politique moderne: Machiavelli - Hobbes - Rousseau. Paris: Gallimard.

Manent P. (2013). Metamorphoses of the City: On the Western Dynamics. Cambridge: Harvard University Press.

Münkler H. (2014). Thomas Hobbes: Eine Einführung. Frankfurt am Main: Campus.

Pocock J. G. A. (1989 [1972]). Time, History and Eschatology in the Thought of Tomas Hobbes // Pocock J. G. A. Politics, Language and Time. Essays on Political Thought and History. Chicago: University of Chicago Press. P. 148-201.

Shapiro I. (2016). Politics against Domination. Cambridge: Harvard University Press.

Sherlock R. (1982). The Theology of Leviathan: Hobbes on Religion // Interpretation. Vol. 10. № 1. P. 43-60.

Slomp G. (2011). The Liberal Slip of Thomas Hobbes' Authoritarian Pen // Tralau J. (ed.). Thomas Hobbes and Carl Schmitt: The Politics of Order and Myth. L.: Routledge. P. 99-111.

Strauss L. (1963 [1936]). The Political Philosophy of Hobbes: Its Basis and Its Genesis. Chicago: Chicago University Press.

Strauss L. (1965). On the Spirit of Hobbes' Political Philosophy // Brown C. K. (ed.). Hobbes Studies. Oxford: Basil Blackwell. P. 1-30.

Tuck R. (1993). The Civil Religion of Thomas Hobbes // Phillipson N., Skinner Q. (eds.). Political Discourse in Early Modern Britain. Oxford: Oxford University Press. P. $120-138$.

\title{
The Political Theology of Thomas Hobbes' Leviathan
}

\author{
Timofey A. Dmitriev \\ Associate Professor, Faculty of Humanities, National Research University High School of Economics \\ Address: Myasnitskaya str., 20, Moscow, Russian Federation 101000 \\ E-mail: tdmitriev@hse.ru
}

The evolution of Thomas Hobbes' political thought in the 1630s-1640s was marked by a considerable increase in an interest in the problems of the relations between politics and religion, and the state and the Church. This interest was expressed in his creation of the original conception of political theology, of which the most complete exposition is contained in his treatise Leviathan. In his concept of political theology, Hobbes saw an effective way to solve the theologico-political problem of modernity. At the heart of his political theology lays a new interpretation given by Hobbes to a number of doctrinal propositions of the Christian faith, which was designed to harmonize it with the absolute power of the temporal sovereign. Particular attention is paid to the consideration of those pragmatic strategies where Hobbes proposed to neutralize the explosive potential of the Christian religion for civil peace and the security of the state. It is also shown that the complete subordination of the Church to the State in the political theology of Hobbes served 
as a starting point for the impotent stage of the process of secularization of the Western world, which led to the separation of politics from religion, and the state from the Church.

Keywords: modern political science, political theology, religious and civil wars, politics and religion, state and Church, political liberalism, modernity

\section{References}

Bénéton F. (2002) Vvedenie v politicheskuyu nauku [Introduction to Political Science], Moscow: Ves mir.

Böckenförde E.-W. (2013) Die Enstehung des Staates als Vorgang der Säkularisation. Recht, Staat, Freiheit. Studien zur Rechtsphilosophie, Staatstheorie und Verfassungsgeschichte, Frankfurt am Main: Suhrkamp, pp. 92-114.

Chaunu P. (2005) Civilizaciya klassicheskoj Evropy [The Civilization of Classical Europe], Ekaterinburg: U-Faktoriya.

Filippov A. (2006) Kritika Leviafana [Critique of Leviathan]. Schmitt C., Leviafan v uchenii o gosudarstve Tomasa Gobbsa: smysl i fiasko odnogo politicheskogo simvola [The Leviathan in the State Theory of Thomas Hobbes: Meaning and Failure of a Political Symbol], Saint Petersburg: Vladimir Dal, pp. 5-100.

Fischer K. (2011) Hobbes, Schmitt and the Paradox of Religious Liberality. Thomas Hobbes and Carl Schmitt. The Politics of Order and Myth (ed. J. Tralau), London: Routledge, pp. 141-158.

Grossheim M. (2008) Religion und Politik: Die Teile III und IV des Leviathan. Thomas Hobbes, Leviathan (ed. W. Kerting), Berlin: Akademie Verlag, pp. 234-259.

Hobbes Th. (1989) O grazhdanine [On Citizen]. Sochineniya. T. 1 [Works, Vol. 1], Moscow: Mysl, pp. 270-506.

Hobbes Th. (1989) Chelovecheskaya priroda [Human Nature]. Sochineniya. T. 1 [Works, Vol. 1], Moscow: Mysl, pp. 507-573.

Hobbes Th. (1991) Leviafan [Leviathan]. Sochineniya. T. 2 [Works, Vol. 2], Moscow: Mysl, pp. 3-545.

Hobbes Th. (1994) The Correspondence, 1622-1659 (ed. N. Malcolm), Oxford: Oxford University Press. Hobbes Th. (1996) Leviathan, Oxford: Oxford University Press.

Höffe O. (1987) Politische Gerechtigkeit: Grundlegung einer kritischen Philosophie von Recht und Staat, Frankfurt am Main: Suhrkamp.

Jay M. (2015) Dobrodeteli licemeriya: o Izhi v politike [The Virtues of Mendacity: On Lying in Politics], Moscow: Kanon+.

Kozlovski P. (1998) Obshchestvo i gosudarstvo: neizbezhnyj dualizm [Society and State: Inevitable Dualism], Moscow: Respublika.

Lübbe H. (1965) Säkularisierung. Geschichte eines ideenpolitischen Begriffs, Freiburg: Karl Alber.

Lübbe H. (2012) Karl Schmitt v vospriyatii liberalov [Karl Schmitt as Liberals Perceive Him]. Logos, no 5, pp. 143-157.

Macchiavelli N. (2014) II Principe, Torino: Einaudi.

Manent P. (1987) Histoire intellectuelle du liberalism: dix leçons, Paris: Calmann-Lévy.

Manent P. (2004) Obshchedostupnyj kurs politicheskoj filosofii [Political Philosophy Made Simple], Moskva: MSPS.

Manent P. (2007) Naissances de la politique moderne: Machiavelli — Hobbes — Rousseau, Paris: Gallimard.

Manent P. (2013) Metamorphoses of the City: On the Western Dynamics, Cambridge: Harvard University Press.

Münkler H. (2014) Thomas Hobbes: Eine Einführung, Frankfurt am Main: Campus.

Pocock J. G. A. (1989 [1972]) Time, History and Eschatology in the Thought of Tomas Hobbes. Politics, Language and Time: Essays on Political Thought and History, Chicago: University of Chicago Press, pp. 148-201.

Rousseau J.-J. (1969) Ob Obshchestvennom dogovore, ili Principy politicheskogo prava [On the Social Contract; or, Principles of Political Rights]. Traktaty [Treatises], Moscow: Nauka, pp. 151-256. 
Schmitt C. (2006 [1938]) Leviafan v uchenii o gosudarstve Tomasa Gobbsa: Smysl i fiasko odnogo politicheskogo simvola [The Leviathan in the State Theory of Thomas Hobbes: Meaning and Failure of a Political Symbol], Saint Petersburg: Vladimir Dal.

Schmitt C. (2006 [1965]) Zavershennaya Reformaciya [The Completed Reformation]. Leviafan v uchenii o gosudarstve Tomasa Gobbsa: Smysl i fiasko odnogo politicheskogo simvola [The Leviathan in the State Theory of Thomas Hobbes: Meaning and Failure of a Political Symbol], Saint Petersburg: Vladimir Dal, pp. 248-297.

Schmitt C. (2012 [1941]) Gosudarstvo kak konkretnoe ponyatie, svyazannoe s opredelennoj istoricheskoj ehpohoj [State as a Concrete Concept Related to the Particular Historical Era]. Logos, no 5, pp. 205-215.

Schmitt C. (2016 [1929]) Epoha nejtralizacij i depolitizacij [The Era of Neutralization and Depolitization]. Ponyatie politicheskogo [The Concept of Political], Saint Petersburg: Nauka, pp. 357-372.

Shapiro I. (2016) Politics against Domination, Cambridge: Harvard University Press.

Sherlock R. (1982) The Theology of Leviathan: Hobbes on Religion. Interpretation, vol. 10, no 1, pp. $43-60$.

Slomp G. (2011) The Liberal Slip of Thomas Hobbes' Authoritarian Pen. Thomas Hobbes and Carl Schmitt. The Politics of Order and Myth (ed. J. Tralau), London: Routledge, pp. 99-111.

St. Augustine (1998) O Grade Bozhiem. Knigi XIV—XXII [City of God, Books XIV—XXII], Saint Peterburg: Aleteya.

Strauss L. (1963 [1936]) The Political Philosophy of Hobbes: Its Basis and its Genesis, Chicago: Chicago University Press.

Strauss L. (1965) On the Spirit of Hobbes' Political Philosophy. Hobbes Studies (ed. C. K. Brown), Oxford: Basil Blackwell, pp. 1-30.

Sweeney M. (2006) Lekcii po srednevekovoj filosofii. Vyp. 2: Srednevekovaya politicheskaya filosofiya Zapada [Lectures on Medieval Philosophy, Issue 2: The Medieval Western Political Philosophy], Moscow: St. Thomas Institute.

Tuck R. (1993) The Civil Religion of Thomas Hobbes. Political Discourse in Early Modern Britain (eds. N. Phillipson, Q. Skinner), Oxford: Oxford University Press, pp. 120-138.

Weber M. (2017 [1921]) Gorod [The City], Moscow: Strelka Press. 


\title{
Спасутся не все: границы политического сообщества как социально-онтологическая предпосылка
}

\author{
Олег Кильдюшов \\ Научный сотрудник Центра фундаментальной социологии \\ Национального исследовательского университета «Высшая школа экономики» \\ Адрес: ул. Мясницкая, д. 20, г. Москва, Российская Федерация 101000 \\ E-mail: kildyushov@mail.ru
}

\begin{abstract}
В статье проблематизируется круг вопросов, уже обсуждавшихся на ряде мероприятий ЦФС НИУ ВШЭ в течение 2017-2018 годов. В целом они связаны с рамочной темой возвращения сакрального, казалось бы, в давно секуляризированный мир позднего модерна. Конкретно речь идет о роли государства в этом процессе политической реабилитации трансцендентного. В качестве постановки проблемы фиксируются значительные структурные изменения в глобальном дискурсивном ландшафте, включающие в себя утрату глобалистским нарративом доминирующей роли, еще недавно выглядевшей незыблемой в ценностно-символической сфере. Ставится вопрос о возвращении государства как оператора посюстороннего спасения, обеспечивающего через свои институты включенность социального в мир трансцендентного, а также вопрос о круге спасаемых. Далее делается краткий историко-философский экскурс, призванный продемонстрировать укорененность проблемы границы объединенных трансцендентными ценностями солидарных сообществ в традиции социально-научного знания, начиная с античности. В следующей части через обращение к аристотелевскому пониманию политического формулируется партиципаторная модель взаимного признания членов определенной «мы-группы», структурно отделенной от других исторически контингентных сообществ судьбы. Приводятся примеры попыток концептуального преодоления неизбежной дискретности социальной онтологии со стороны универсалистского дискурса посредством возвращения на рынок идей космополитических утопий в виде проектов глобального гражданства, постнациональной инклюзивной политики и т.д. Затем реконструируется восходящая к Аристотелю и Руссо альтернативная линия аргументации, эксплицитно разработанная Карлом Шмиттом, в которой гомогенность постулируется в качестве условия возможности любого солидарного сообщества. В заключение делаются предварительные выводы относительно релевантности данной топики для теории социального порядка.
\end{abstract}

Ключевые слова: рынки спасения, сакральное, постсекулярное, «мы-группы», космополитизм, гомогенность, границы политических сообществ, Аристотель, Карл Шмитт

(c) Кильдюшов О. В., 2018

(c) Центр фундаментальной социологии, 2018

DOI: $10.17323 / 1728-192 \mathrm{X}-2018-3-90-106$

* В основу статьи положен одноименный доклад на секции “„Смертный бог“ в эпоху позднего модерна: государство и его конкуренты на (пост)глобальном рынке коллективного спасения», организованной Центром фундаментальной социологии НИУ ВШЭ в рамках XXV Международного симпозиума «Пути России: границы политики» (30-31 марта 2018 года).

Публикация подготовлена в рамках проекта «Реакция, справедливость и прогресс: социальный порядок в перспективе фронетических социальных наук», выполняемого в рамках Программы фундаментальных исследований НИУ ВШЭ в 2018 году. 
Все люди одинаково достойны любви. Заботиться обо всех, однако, невозможно, и поэтому следует уделять заботу прежде всего тем, с кем - местностью ли, временем ли, иными ли обстоятельствами - то есть, по сути, судьбой связаны теснее.

Августин. «De doctrina Christiana I»

\section{К постановке проблемы}

В веберовской эвристике социального аналитически различаются понятия «политический союз» (в основном понимаемый в эпоху модерна как светское государство) и «иерократический союз» (распределяющий религиозные блага спасения) ${ }^{1}$. В политической практике между ними лежат не столько четкие институциональные границы, сколько смешанные или переходные формы. Как показывают многие конкретно-исторические исследования, а также политические и религиозносоциологические работы самого Вебера, практически все устойчивые структуры господства даже в Новое время опирались на мощные ресурсы спасения, обеспечивавшие сообществам связь с миром сакрального (ср.: Вебер, 20о6, 2017). В этом смысле не только в Средневековье, но и в раннем модерне политическое невозможно представить без легитимации через трансцендентное - сначала в виде собственно религиозных, а затем и других дискурсов (естественно-правовых, гуманистически-эмансипаторных, просвещенчески-прогрессистских и т.д.) ${ }^{2}$. Не случайно Томас Гоббс в своем «Левиафане» назвал государство «смертным богом» (Гоббс, 2001: 119), а Жан-Жак Руссо в одноименной главе своего «Общественного договора» ввел довольно странное на первый взгляд понятие «гражданская религия», имевшее тем не менее далеко идущие последствия для политической теории и практики модерна ${ }^{3}$. Тот же Макс Вебер в работах о Русской революции описывает левых радикалов как носителей секуляризованной доктрины спасения (Вебер, 2007: 21-22), а Карл Шмитт назовет попытки полемически использовать язык сакрального в целях политической мобилизации «политической теологией» (Шмитт, 2000: $57-58)^{4}$.

1. См. $\$ 17$ «Политический союз, иерократический союз» в веберовских «Основных социологических понятиях» (Вебер, 2016: 110-112).

2. См., например, раздел III («Понимание политики в Новое время») статьи «Политика» в русской версии знаменитого словаря Р. Козеллека (Зеллин, 2014).

3. Его аргумент звучит следующим образом: «...для государства весьма важно, чтобы каждый гражданин имел религию, которая заставляла бы его любить свои обязанности; но догматы этой религии интересуют государство и его членов лишь постольку, поскольку эти догматы относятся к морали и обязанностям, которые тот, кто ее исповедует, обязан исполнять по отношению к другим... Существует, следовательно, исповедание веры чисто гражданское, статьи которого надлежит устанавливать суверену; и не в качестве догматов религии, но, как правило, общежития, без которых невозможно быть ни добрым гражданином, ни верным подданным» (Руссо, 1969: 254).

4. Известный исследователь творчества Шмитта Райнхард Меринг указывает на инструментальность политической теологии как средства выхода за пределы нейтрального описания в направлении 
В (пост)секулярной ситуации позднего модерна (национальное) государство, с одной стороны, по-прежнему претендует на роль основного оператора коллективного спасения, символически репрезентируя единство верхов и низов в рамках одного политического космоса. Функционально это обеспечивает ему эффективные средства мобилизации масс, опознающих в нем не только социальные, но и сакральные компетенции. С другой стороны, на протяжении последних десятилетий положение государства-нации характеризуется значительной степенью неопределенности. Это нашло отражение в многочисленных гипотезах о более или менее быстром «уходе» государства или по меньшей степени резком сокращении его функционала. Подобные предсказания и надежды, связанные с появлением глобального, сетевого, деиерархизированного пространства с универсальным, политически-нейтральным языком описания, принципиально угрожали положению государства как оператора посюстороннего спасения.

Однако в начале XXI века наметился совершенно иной тренд: обозначилась ускоренная фрагментация самой глобальной институциональной среды, причем происходит это в основном усилиями самих недавних агентов глобализации. Едва возникший рынок глобальных ресурсов сакрального вновь локализуется и регионализируется на наших глазах - здесь достаточно вспомнить актуальные общественно-политические дебаты, связанные с такими феноменами, как новый протекционизм (включая трампизм), Brexit, подъем политических национализмов в ЕС, сепаратизмы в Каталонии и Шотландии и т.д.

В этой связи неизбежно встает вопрос о переформатировании рынков спасения в глобальном постглобалистском мире. Вместе с тем для постсекулярной фазы общественного развития характерно не только появление новых, но и возвращение старых политических субъектов, использующих мобилизационный ресурс спасения. Одним словом, новые реалии, связанные с повсеместно наблюдаемым «поворотом к государству», одновременно ставят вопрос о том, возможно ли возрождение государства в смысле института коллективного спасения и в каких форMax.

Стоит ли говорить, что вся эта старая-новая проблематика носит не просто актуально-политический характер, но чрезвычайно релевантна и для фундаментальной социальной теории - прежде всего в аспектах, связанных со структурой политического в эпоху (позднего) модерна: кто является его «субъектом», насколько осмысленно полностью отождествлять его с институциональной формой существующих наций-государств, есть ли пределы их суверенитета и т.д.

Не меньшую остроту сохраняет и вопрос, имеющий длительную традицию в истории социально-научной мысли: каковы пределы солидарной группы, получающей благодаря политико-правовому дизайну государства шанс на реализацию совместно разделяемых представлений о справедливости и общем благе? В полемически-обостренной форме эту проблему можно сформулировать как вопрос

конфессионального участия, отказа от научной теории в пользу политической практики (Mehring, 2017: 36). 
о динамической границе между теми, кто признается в качестве участника национального и/или глобального рынка посюстороннего спасения, и теми, кто по тем или иным причинам остается не охвачен сотериологическими компетенциями политического в эпоху современности. Таким образом, даже в условиях перманентно модернизирующихся обществ модерна ${ }^{5}$ проблематика посюстороннего спасения сохраняет свою актуальность: речь может идти лишь о расширении/сокращении круга «спасаемых» в результате эволюции институтов, связанных с производством коллективных ценностей в течение XIX-XXI веков, тогда как сама граница политического сообщества по-прежнему является конститутивной в социально-онтологическом смысле - как conditio sine qua non для любого человеческого общежития.

\section{Проблематизация границ солидарных групп в античности: Аристотель vs. стоики}

Великие мыслители прошлого очень рано осознали трансцендентный функционал политического, который позволяет объединяющимся в государства людям достигать целей, выходящих за рамки индивидуально достижимого. Так, Аристотель в самом начале 1-й книги своей «Политики» говорит о наивысшем благе, достигаемом посредством того общения (коเvwvía), «которое является наиболее важным из всех и обнимает собой все остальные общения. Это общение и называется государством (то́ $ı \varsigma)$ или общением политическим» (Аристотель, 1984: 1252a). Его институционально-правовая рамка позволяет практически реализовать понятие справедливости: «Понятие справедливости связано с представлением о государстве, так как право, служащее мерилом справедливости, является регулирующей нормой политического общения» (Аристотель, 1984: 1253a). Более того, по Аристотелю, люди никогда не объединяются в такого рода субъекты коллективного действия или солидарные мы-сообщества исключительно по прагматическим соображениям, например, ради обеспечения безопасности и взаимных практических интересов, но ими всегда движет цель посюстороннего спасения в форме максимально возможной благой жизни: «Государство создается не ради того только, чтобы жить, но преимущественно для того, чтобы жить счастливо» (Аристотель, 1984: 1280а). На эти и схожие представления опирается вся классическая социально-теоретическая традиция теодицеи государства, в том или ином виде вменяющая, казалось бы, формальной политико-правовой сфере жизни явные ценностно-нормативные и тем самым сотериологические компетенции.

Однако одновременно с обнаружением морального и сакрального функционала политических сообществ античная мысль столкнулась с проблемой определения их границ по ту сторону узко понимаемой прагматики совместной жизни. Тот же Аристотель в 3-й книге «Политики» ставит ее в эксплицитной форме: «Равным

5. Рамочной темой XXV Германского социологического конгресса (1990) была «Модернизация модерных обществ» (Glatzer, 1991). Также см.: Beck, Bonß, 2001. 
образом государство не возникает ради заключения союза в целях предотвращения возможности обид с чьей-то стороны, также не ради взаимного торгового обмена и услуг; иначе этруски и карфагеняне и вообще все народы, объединенные заключенными между ними торговыми договорами, должны были бы считаться гражданами одного государства» (Там же). По этой же причине из него им исключаются те, кто не разделяет совместные ценности членов данного сообщества и их стремления к общему благу, хотя живет рядом с ними (например, рабы, животные и т.д.), поскольку «государственное общение - так нужно думать - существует ради прекрасной деятельности, а не просто ради совместного жительства» (Аристотель, 1984: 1281a).

При этом здесь же Старигит указывает на возможность политико-контекстуального определения полноправного члена сообщества. «Ясно, что сначала следует определить, что такое гражданин (polités), ведь государство есть совокупность граждан. Итак, до́лжно рассмотреть, кого следует называть гражданином и что такое гражданин. Ведь часто мы встречаем разногласие в определении понятия гражданина: не все считают гражданина одного и того же; кто в демократии гражданин, в олигархии часто уже не гражданин» (Там же: 1275а) и т. д.

Если бегло пройтись по сложившейся за прошедшие почти две с половиной тысячи лет социально-научной традиции, то применительно к проблеме границы политического сообщества в истории мысли можно обнаружить две противоположных линии аргументации. Первая, восходящая в том числе к Аристотелю, политико-реалистическая или прагматическая линия, фиксирует практически неизбежные ограничения круга участников любой солидарной мы-группы. Вторая, с которой я и начну, - условно универсалистская - напротив, стремится максимально расширить объем понятия «член политического сообщества» или «гражданин государства» вплоть до включения в него всех людей, живущих в том или ином географическом локусе, а в пределе - вообще все человечество. Причем первые попытки такого радикально расширительного толкования гражданства также начались уже в античности - достаточно вспомнить космополитизм стоиков, которые рассматривали всех людей в качестве граждан глобального политического сообщества - космополиса, населенного, соответственно, «космополитами» ${ }^{6}$ Уже в «Политии» основателя стоической школы Зенона Китийского выдвигается идея подобного охватывающего весь мир суперполиса, что представляло собой радикальный разрыв с традицией греческого политического мышления, в котором именно полис, т. е. небольшой город-государство, мыслился в качестве единственно возможной формы объединения свободных людей ${ }^{7}$. Правда, живущие в этом

6. Сам термин заимствован у киников, в частности его изобретение приписывается знаменитому Диогену Синопскому. Ср.: «На вопрос, откуда он, Диоген сказал: «Я - гражданин мира» (Диоген Лаэртский, 1986: 254 [VI, 63]).

7. Ср.: «...вызывающая общее удивление государственная система основателя стоической школы Зенона сводится к единственному положению - чтобы мы жили не особыми городами и общинами, управляемыми различными уставами, а считали бы всех людей своими земляками и согражданами, так чтобы у нас была общая жизнь и единый распорядок, как у стада, пасущегося на общем пастбище. 
едином космополисе стоиков космополиты были вовсе не «безродными» - просто границы между политическими сообществами стирались за счет того, что граждане каждого отдельного полиса одновременно являлись гражданами и всех остальных. Тем самым постулировался принцип всеобего равенства и братства всех людей как членов глобального государства ${ }^{8}$. Этот принцип сохранился и у представителей поздней Стои. Например, Эпиктет в «Беседах» предлагал брать пример с Сократа и на вопрос о происхождении отвечать не «афинянин» или «коринфянин», а «гражданин мира» (Эпиктет, 1997: 55) 9. А в «Размышлениях» императора Марка Аврелия идея космополитизма логически выводится из единства человеческого разума. Общая нравственность и рациональность делают необходимым общий для всех закон, который является основой общего гражданства: «Раз так, мы граждане; раз так, причастны некоей государственности; раз так, мир есть как бы город. Ибо какой иной общей государственности причастен весь человеческий род?» (Марк Аврелий, 1985: 11).

Понятно, что для ранних стоиков, начиная с Зенона, историческим референтом такого рода построений стала держава Александра Македонского, объединившая в единое государство - хоть и на короткий срок - почти весь известный грекам цивилизованный мир. Тогда как для поздних стоиков идея такого государства, обнимающего все человечество, была возможна уже в рамках Pax Romana - когда с замирением медитерранной ойкумены небольшой город на Тибре расширился до размеров мировой империи. Интересно, что Макс Вебер в своих работах по социологии религии неоднократно сравнивал государственно-идеологический потенциал стоицизма с конфуцианством, ставшим официальной доктриной в Китае в эпоху Хань. Так, ссылаясь на Тацита, он говорит, что вплоть до эпохи Антонинов стоическая школа была скорее учением сенатской оппозиции, и лишь с ее уходом с исторической сцены императоры стали воспринимать и даже разделять учение стоиков, как в случае с упомянутым Марком Аврелием (Вебер, 2017: 306-307, 353).

Целью данных размышлений не является полноценный экскурс в историю космополитизма с Античности и вплоть до популярных еще недавно концепций глобального гражданства (Held, 1995), поэтому далее я укажу лишь на пару социально-теоретически значимых примеров последних десятилетий.

Зенон представил это в своих писаниях как мечту, как образ философского благозакония и государственного устройства...» (Плутарх, 1998: 405).

8. О политических представлениях стоиков см. раздел «Рождение стоической философии» во введении к работам Эпиктета: (Маринович, Кошеленко, 1997: 12).

9. По мнению В. С. Нерсесянца, попытавшегося реконструировать политические взгляды исторического Сократа, тот скорее оставался «в традиционном горизонте полисного патриотизма, критически относился к различным современным ему космополитическим веяниям и настаивал на обязанностях гражданина по отношению к государству» (Нерсесянц, 1977: 55). 


\section{Критика инклюзивных утопий эпохи глобализации от Аристотеля до К. Шмитта}

Прежде всего следует вспомнить про концепцию «мирового общества» Никласа Лумана, в которой фиксируется включение всей территории Земли в сеть регулярных коммуникативных отношений: «Начиная со второй половины XIX века возникает и единое мировое время. Это означало, что в любом месте Земли, независимо от локального течения времени, стало возможно зафиксировать одновременность со всеми иными местами и осуществлять коммуникации без потери времени во всемирном масштабе... если в каком-то месте нечто происходит раньше или позже, то и в другом месте оно происходит, соответственно, раньше или позже... Благодаря этому исчезает возможность определять единство системы общества территориальными границами или же различением его членов и нечленов» (Луман, 2011: 157).

Второй релевантный пример - знаменитая формула «постнациональной констелляции» Юргена Хабермаса, разработанная им в одноименной работе 1998 года (Habermas, 1998). В ней он указывает на возможность радикально инклюзивной политики, противоположной традиционному исключающему, эксклюзивному характеру национального законодательства: инклюзивные политико-правовые практики ориентированы на всех людей в равной степени. Такого рода инклюзия подразумевает, что государственная система является принципиально открытой для лиц любого происхождения, не требуя от них включения в национально-культурную гомогенность данного политического сообщества. Хабермас делает в этой связи важное уточнение: хотя исторически культурный консенсус и сыграл роль катализатора демократизации, отныне подобная культурная лояльность становится излишней, по мере того как дискурсивно структурированные практики формирования общественного мнения и публичного волеизъявления делают возможным разумное политическое взаимопонимание в том числе и между чужими: «демократический процесс гарантирует легитимность уже в силу своих процессуальных свойств, при необходимости он может залатать дыры в социальной интеграции и - учитывая изменения в культурном составе населения - произвести общую для него политическую культуру» (Хабермас, 2003: 119).

Понятно, что историческим референтом такого рода идентитарных утопий была ускоренная неолиберальная глобализация рынков информации, финансов и обслуживающего их персонала на рубеже II и III тысячелетий. Именно в этой связи Хабермас всерьез обсуждает шансы на успех этого процесса отрыва политической культуры от культуры большинства, когда солидарность граждан перестраивается на абстрактной основе «конституционного патриотизма» (Там же: 149), ставшего своеобразным мемом эпохи наивно-глобалистского оптимизма времен второго президентского срока Билла Клинтона.

Примечательно, что в качестве источника концептуальных возражений против такого рода формально-нормативной лояльности, как основы нового солидарно- 
го сообщества, от которых невозможно просто отмахнуться, Хабермас довольно точно идентифицирует восходящую к Аристотелю традицию понимания политического. Поэтому имеет смысл вернуться к тому месту в 3-й книге «Политики», где формулируется прагматическое определение границ политического сообщества. Как известно, Стагирит исключает из него рабов, иностранцев-метеков, женщин, несовершеннолетних, старцев, изгнанников и некоторые другие категории эллинского населения, не говоря уже о варварах, per definitionem не относившихся к греческому культурному миру. Видимо, он ориентировался на реальную ситуацию в Аттике V-IV вв. до н. э.: по некоторым оценкам, лишь около 20\% жителей являлись полноправными гражданами Афин (Welwei, 1999; Funke, 2003). При этом в качестве институционального ценза Аристотель называет квалифицирующие человека в качестве гражданина практики, конститутивные для жизни полиса: участие в суде и занятие должностей ${ }^{10}$. Лишь тот, кто способен быть полноправным участником в политико-правовой сфере государства, может считаться его гражданином в строгом смысле. Одного совместного проживания на общей территории вовсе не достаточно для признания в качестве члена политического сообщества, поскольку им функционально является только тот, кто, как говорит Аристотель далее, находится «в известном отношении к государственной жизни» (Аристотель, 1984: $1278 \mathrm{~b})$, т. е. кто фактически - единолично или вместе с другими - несет на себе бремя заботы о государственных делах. Таким образом, лишь фактическое соучастие в обеспечении общего блага квалифицирует граждан политически и создает структурные основания для их взаимного признания в качестве полноправных членов солидарной мы-группы. Подобное - условно практически-партиципаторное - понимание границы политических сообществ сохраняет свою эвристическую значимость и для всех нынешних попыток решения проблемы социальной онтологии. Его можно представить в качестве объяснительной формулы: сначала - участие, затем - признание.

В этой связи также можно вспомнить социологическое определение сословных границ у Макса Вебера: в качестве типичных признаков функционального равенства социальных акторов классик называет сочетание commercium, т. е. правоспособности заключать между собой сделки (вступать в деловые отношения), и connubium, т. е. правоспособности вступать между собой в брак. Лишь наличие двух этих правовых компетенций служит для него индикатором социальной равнозначности; отсутствие даже одной из них свидетельствует о качественном различии статусов (Вебер, 2017: 67).

Карл Шмитт в посвященном демократии $\$ 17$ своего «Учения о конституции» цитирует знаменитое место из 7-й книги «Политики» Аристотеля (

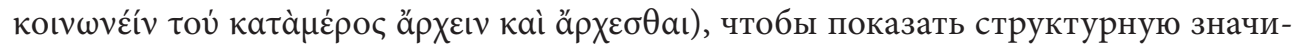
мость функционального равенства участников идеального политического сообще-

10. Ср.: «Что такое гражданин, отсюда ясно. О том, кто имеет участие в законосовещательной или судебной власти, мы можем утверждать, что он и является гражданином данного государства» (Аристотель, 1984: 1275b). 
ства (Шмитт, 2010: 74-75), в котором «всем до́лжно в равной степени поочередно властвовать и подчиняться» (Аристотель, 1984: 1332b). Как справедливо отмечает Шмитт, данная конструкция взаимного правления граждан над самими собой возможна лишь при условии их взаимного признания в качестве принципиально равных, что требует значительной культурной и социальной гомогенности (Шмитт, 2010: 74). Сама форма такого рода политии, отчасти напоминающей современную партиципаторную демократию, - на структурном уровне предполагает четкое институциональное разграничение членов данного солидарного сообщества. Ведь посредством границ обеспечивается его фактическая однородность, когда «равенство для равных состоит в одинаковом положении: все обитатели государственной территории, стремящиеся к введению новых порядков, оказываются заодно с подчиненными» (Аристотель, 1984: 1332b ) и т.д.

\section{Гомогенность и границы модерных солидарных сообществ}

Поскольку любая полития как форма организации совместной жизни граждан прямо предполагает их большую или меньшую однородность в качестве условия возможности, социально-онтологически необходимым является различение между членами политического сообщества и не-членами. В этой связи Шмитт подчеркивает, «что подобное государство, в котором все как господствуют, так и подчиняются, не является политией всего человечества» (Шмитт, 2010: 74). Он подтверждает этот тезис еще одной ссылкой на Аристотеля, для которого политически квалифицирующими являются не только принадлежность к эллинскому культурному ареалу, но и фактически правовой статус (равенство по рождению и равенство перед законом): «...справедливость, как кажется, есть равенство, и так оно и есть, но только не для всех, а для равных; и неравенство также представляется справедливым, и так оно есть на самом деле, но опять-таки не для всех, а лишь для неравных» (Аристотель, 1984: 1280а). При этом Шмитт считает далеко не случайным, что именно стоики, первыми попытавшиеся преодолеть различия эллинов и варваров, рабов и свободных и объединить всех в качестве граждан мира в мировом государстве, управляемом общим для всех разумом, отбросили идею демократии, сделав выбор в пользу монархии (Шмитт, 2010: 75).

Переходя к модерным представлениям о политических сообществах, основанных на договорных отношениях, Шмитт на примере идеи общей воли у Руссо показывает, что и здесь конститутивным является качество их членов: «Все желают одного и того же, поэтому в действительности никто не остается в меньшинстве при голосовании, а если кто-то и остается, то он заблуждался относительно своей истинной и наилучшей воли». Таким образом, демократия как принцип невозможна без поддержания определенного уровня гомогенности: «Желание подчиняться большинству происходит не от того что это большинство, а потому что субстанциальная однородность народа настолько велика, что все желают одного 
и того же. Это наиболее сильное и последовательное выражение демократической мысли» (Шмитт, 2010: 76).

Интересно, что практически одновременно с Карлом Шмиттом проблематику гомогенности как фактора демократии в условиях Веймарской Германии разрабатывал его идеологический антипод Герман Геллер, написавший отдельную работу на эту тему (Heller, 1928). Правда, социал-демократически настроенного Геллера интересовала в первую очередь социальная гомогенность как основа государственного единства. Тем не менее, как показывают сравнительные исследования их подходов, в преставлениях этих политических оппонентов о гомогенности встречаются некоторые параллели. Основные различия в позициях связаны с определением основ самой гомогенности: если Шмитт подчеркивает сознательную самоидентификацию индивида с политическим единством, то Геллера больше интересовали рамочные предпосылки (Pasquino, 1985).

Говоря языком современной политической философии, гомогенность можно операционализировать как то минимальное общее, что необходимо для конституирования и сохранения политического сообщества. Исторически набор гомогенизирующих факторов может довольно сильно отличаться в различные эпохи и в различных политических условиях. Однако в любом случае должен наличествовать некий фундаментальный минимум, без которого нет самой солидарной группы. Этот базовый набор может меняться, например, расширяться или интенсифицироваться. Но он структурно необходим - от него невозможно отказаться полностью, не ставя при этом под угрозу стабильность самого человеческого общежития (Изензее, 2005: 420).

Обращаясь к идентитарной практике модерна, Шмитт приводит пример Французской революции, которая, несмотря на свои идеи о человечестве и всеобщем братстве народов, одновременно конституировала французскую нацию принципиально равных компатриотов. Предпосылкой этого рода демократии опять-таки является гомогенность, на сей раз - национальная: «Если нация понимается как субстанция демократического равенства, то отсюда вытекают практические последствия особого рода. Демократическое государство, находящее предпосылки своей демократии в национальной однородности своих граждан, соответствует так называемому признаку национальности, согласно которому одна нация образует одно государство, а одно государство охватывает одну нацию. В таком случае национально гомогенное государство выступает в качестве чего-то нормального» (Шмитт, 2010: 79).

В качестве интересного кейса Шмитт рассматривает Советскую Россию, в которой большевики попытались заменить национальную гомогенность на гомогенность классовую - пролетарскую. Он приводит ст. 20 Конституции РСФСР от 10 июля 1918 года, в которой говорилось следующее: «Исходя из солидарности трудящихся всех наций, Российская Социалистическая Федеративная Советская Республика предоставляет все политические права российских граждан иностранцам, проживающим на территории Российской Республики для трудовых занятий 
и принадлежащим к рабочему классу или к непользующемуся чужим трудом крестьянству, и признает за местными Советами право предоставлять таким иностранцам, без всяких затруднительных формальностей, права российского гражданства». Для Шмитта подобная попытка постулировать равенство политических прав трудящихся всех наций вовсе не снимает структурную для демократии проблему границы солидарного сообщества, а просто переносит ее из сферы национальной идентичности в сферу классовой борьбы, где пролетарии противостоят буржуа. Тем самым место национальных противоречий занимает противостояние пролетарских и капиталистических государств, и группирование «друг - враг» тем самым получает новую интенсивность (Шмитт, 2010: 83).

Как убедительно показал Шмитт, если сущность демократического равенства заключается в субстанциальной однородности политического народа, то центральное понятие демократии - народ, а не человечество. Ведь любая реализованная демократия вообще может существовать только как демократия определенного народа, а не как демократия всего человечества, поскольку лишь в границах конкретной солидарной группы возможно реализовать тождество господствующего и подданного, правящего и подчиненного, приказывающего и повинующегося. Именно поэтому понятие «класс» для него не может заменить понятие «народ»: если класс перестает быть чисто экономической категорией, а становится политической величиной, позволяющей проводить новые групповые различия по линии разграничения «друг - враг» (Шмитт, 2010: 79-83) и т. д.

Известный левый теоретик Шанталь Муфф, реагируя на тезис Карла Шмитта о тождестве как принципе демократии, признает, что демократическая политика - это всегда борьба за определение того, что есть народ:

Такое понимание либерально-демократической политики означает признание идеи Шмитта о различии между «нами» и «ними», потому что эта борьба за установление «народа» всегда ведется в конфликтной области и предполагает существование соперничающих сил. В действительности нет никакой гегемонистской артикуляции без установления границы определения «их». Но в случае либерально-демократической политики такая граница является внутренней, а «они» не вечные чужаки. (Муфф, 2004: 153)

В любом случае дифференцированные посредством национальных границ дискретные солидарные группы по-прежнему являются практическим условием реализации принципов свободы, равенства и братства - несмотря на все попытки универсалистского дискурса дискредитировать территориально локализованные, исторически контингентные сообщества судьбы как несоответствующие высоким идеалам глобального гуманизма. Государство модерна по-прежнему остается единственной рационально организованной структурой, обладающей демократической легитимностью. При этом оно вынуждено все время отбиваться от морально доминирующего пафоса универсализации, столь же суггестивного, как и безответственного в своей нереалистичности (Депенхоер, 2005). 


\section{0 предварительных выводов для теории социального порядка}

1. В мире людей живут не я-индивиды, а $\mathcal{M b l - г р у п п ы . ~ Э т и ~ м ы - г р у п п ы ~ в с е г д а ~ и м е - ~}$ ют свои границы. Попытка их сознательной отмены приводит лишь к сдвигу этой границы внутрь самой мы-группы.

2. Всякого рода попытки неограниченного расширения круга участников политического сообщества обречены на провал, поскольку конкретные формы социального взаимодействия фактически зависят от культурной традиции и тем самым всегда обусловлены предшествующей практикой конкретной мыгруппы $^{11}$.

3. Взаимное фактическое, а не нормативно декларируемое или политически октроированное признание участников носит конститутивный характер для любого сообщества действия. Оно невозможно без основанного на реальном позитивном опыте доверия участников мы-группы друг к другу.

4. Это доверие обеспечивается совместным культурным капиталом участников, делающим возможным стабильное воспроизводство правил и норм поведения в духе дюркгеймовского «морального сообщества» или парсоновского нормативного решения проблемы социального порядка (Кильдюшов, 2016) 12 .

5. Существование границ между исторически конкретными и политически дискретными сообществами коллективного действия - это не политическая фикция, а социально-онтологическое условие возможности конституирования социального порядка.

6. Вопрос о границе мы-группы одновременно является вопросом о том, к какому солидарному сообществу мы хотели бы принадлежать, что, в свою очередь, связано с тем, какими людьми мы хотели бы быть. Таким образом, здесь мы возвращаемся к вполне аристотелевскому по своей интенции вопросу о трансцендентных мотивах совместной жизни той или иной группы людей.

7. Попытки отделения демократических политико-правовых практик от породивших их исторически-конкретных солидарных сообществ, настойчиво продвигаемые глобалистским мейнстримом, ставят под вопрос сохранение демократией конститутивного для нее тождества, т.е. тождества правящих и подчиняющихся, о которых говорил еще Аристотель.

8. Посюстороннее спасение через политическое посредничество государства было и остается дефицитным благом, которое уже в силу ограниченности материальных и символических ресурсов не может распространяться на тех, кто не принадлежит к соответствующей солидарной группе.

11. Именно так можно понимать указание Макса Вебера в «Основных социологических понятиях», где он говорит о постоянной соотнесенности социального действия с поведением других членов референтной мы-группы. Ср.: «Социальное действие (включая отказ от действия или претерпевание) может быть ориентировано на прошедшее, настоящее или ожидаемое в будущем поведение других людей... «Другими» могут быть отдельные и знакомые люди или неопределенные многие и совершенно незнакомые... (Вебер, 2016: 82).

12. Особенно см. раздел «Парсоновский „нормативный“вариант решения проблемы социального порядка: интеграция посредством совместно разделяемых норм и ценностей» (с. 135-138). 
9. Универсалистское отчуждение государства от собственных контингентных (этнокультурных) оснований угрожает его функциональности в качестве оператора посюстороннего спасения, если из-за нереалистичности взятых сотериологических обязательств оно окажется не в состоянии «спасти» даже тех, для спасения которых и было создано.

10. Солидарность не делится поровну на всех: дифференциация людей на ближних и дальних не только этически допустима, но и структурно необходима для сохранения культуры, основанной на такого рода системе различений. При этом фактической альтернативой ей является не утопическое братство граждан глобального космополиса, а абсолютное равенство в условиях status naturalis, малопривлекательные симптомы которого описал еще Гоббс в своем «Левиафане».

\section{Литература}

Аристотель. (1984). Политика / Пер. с древнегреч. С. А. Жебелева // Аристотель. Сочинения. Т. 4. М.: Мысль. С. 375-644.

Вебер М. (2006). Протестантская этика и дух капитализма / Пер. с нем. М. И. Левиной // Вебер М. Избранное. М.: РОССПЭН. С. 19-186.

Вебер M. (2007). К положению буржуазной демократии в России // Вебер M. О России / Пер. с нем. А. Кустарева. М.: РОССПЭН. С. 14-55.

Вебер М. (2016). Хозяйство и общество: очерки понимающей социологии. Т. 1: Социология / Пер. с нем. В. А. Брут-Цехового, Л. Г. Ионина, И. А. Судариковой, А. Н. Беляева, Д. Б. Цыганкова под ред. Л. Г. Ионина. М.: ВШЭ.

Вебер М. (2017). Хозяйственная этика мировых религий: опыты сравнительной социологии религии. Конфуцианство и даосизм / Пер. с нем. О. В. Кильдюшова. СПб.: Владимир Даль.

Гоббс Т. (2001). Левиафан, или Материя, форма и власть государства церковного и гражданского / Пер. с англ. А. Гутермана. М.: Мысль.

Депенхоер О. (2005). Не все люди будут братьями: дифференциация как практическое условие солидарности. Философско-правовое размышление с практическими целями // Хефбфе О., Изензее Й. (ред.). Политическая философия в Германии / Пер. с нем. Д. Мироновой, С. Погорельской. М.: Современные тетради. C. 429-441.

Диоген Лаэртский. (1986). О жизни, учениях и изречениях знаменитых философов / Пер. с дренегреч. М. Л. Гаспарова под общ. ред. А. Ф. Лосева. М.: Мысль.

Зеллин Ф. (2014). Политика // Зарецкий Ю., Левинсон К., Ширле И. (сост.). Словарь основных исторических понятий. Т. 1 / Пер. с нем. К. Левинсона. М.: Новое литературное обозрения. С. 414-519.

Изензее Й. (2005). Европа - политическая идея географической части света // Хеффе О., Изензее Й. (ред.). Политическая философия в Германии / Пер. с нем. Д. Мироновой, С. Погорельской. М.: Современные тетради. С. 410-428. 
Кильдюшов О. В. (2016). Проблема социального порядка (Гоббсова проблема): к эвристике и прагматике конститутивного вопроса современной теории общества // Социологическое обозрение. Т. 15. № 3. С. 122-149.

Луман Н. (2011). Общество общества. М.: Логос.

Маринович Л. П., Кочеленко Г. А. (1997). Эпиктет // Эпиктет. Беседы Эпиктета / Пер. с древнегреч. Г. А. Тароняна. М.: Ладомир. С. 5-36.

Марк Аврелий. (1985). Размышления / Пер. с древнегреч. А. К. Гаврилова. Л.: Наука. Мyфб Ш. (2004). Карл Шмитт и парадокс либеральной демократии / Пер. с англ. А. А. Смирнова // Логос. № 6. С. 140-153.

Нерсесяни В. С. (1977). Сократ. М.: Наука.

Плутарх. (1998). О судьбе и доблести Александра. Речь первая / Пер. с древнегреч. Я. М. Боровского // Плутарх. Сравнительные жизнеописания. Трактаты. Диалоги. М.: Рипол Классик. С. 400-409.

Руссо Ж.-Ж. (1969). Об Общественном договоре, или Принципы политического права / Пер. с франц. А. Д. Хаютина и В. С. Алексеева-Попова // Руссо Ж.-Ж. Трактаты. М.: Наука. С. 151-256.

Хабермас Ю. (2003). Постнациональная констелляция и будущее демократии / Пер. с нем. Б. В. Скуратова // Логос. № 4/5. С. 105-152.

Шмитт К. (200о). Политическая теология: четыре главы к учению о суверенитете // Шмитт К. Политическая теология / Пер. с нем. Ю. Ю. Коринца, А. Ф. Филиппова. М.: КАНОН-Пресс-Ц. С. 11-98.

Шмитт К. (2010). Учение о конституции (фрагмент) // Шмитт К. Государство и политическая форма / Пер. с нем. О. В. Кильдюшова. М.: ВШЭ. С. 33-236.

Эпиктет. (1997). Беседы Эпиктета / Пер. с древнегреч. Г. А. Тароняна. М.: Ладомир.

Beck U., Bon $\beta$ W. (Hg.). (2001). Die Modernisierung der Moderne. Frankfurt am Main: Suhrkamp.

Funke P. (2003). Athen in klassischer Zeit. München: C. H. Beck.

Habermas J. (1998). Die Postnationale Konstellation und die Zukunft der Demokratie // Habermas J. Die Postnationale Konstellation: Politische Essays. Frankfurt am Main: Suhrkamp. S. 91-163.

Glatzer W. (Hg.). (1991). Die Modernisierung moderner Gesellschaften: 25. Deutscher Soziologentag in Frankfurt vom 9.-12.10.199o. Sektionen - Arbeits- und Ad Hoc-Gruppen - Ausschuss für Lehre. Opladen: Westdeutscher Verlag.

Held D. (1995). Democracy and the Global Order: From the Modern State to Cosmopolitan Governance. Cambridge: Polity.

Heller H. (1971 [1928]). Politische Demokratie und soziale Homogenität // Heller H. Gesammelte Schriften. Bd. 2: Recht, Staat, Macht. Leiden: Sijthoff.

Mehring R. (2017). Carl Schmitt: Denker im Widerstreit. Werk - Wirkung - Aktualität. Freiburg: Karl Alber. S. 421-433. 
Pasquino P. (1985). Politische Einheit, Demokratie und Pluralismus: Bemerkungen zu Carl Schmitt, Hermann Heller und Ernst Fraenkel // Müller Ch. (Hg.). Staatslehre in der Weimarer Republik. Frankfurt am Main: Suhrkamp. S. 114-127.

Welwei K.-W. (1999). Das klassische Athen: Demokratie und Machtpolitik im 5. und 4. Jahrhundert. Darmstadt: Wissenschaftliche Buchgesellschaft.

\title{
Not All Will Be Saved:The Boundaries of the Political Community as a Socio-ontological Premise
}

\author{
Oleg Kildyushov \\ Research Fellow, National Research University Higher School of Economics \\ Address: Myasnitskaya Str., 20, Moscow, Russian Federation 101000 \\ E-mail: kildyushov@mail.ru
}

The article offers an exposition of the range of topics discussed at the events of the Centre for Fundamental Sociology at the National Research University Higher School of Economics in 2017-2018. These topics were generally connected with the basic theme of the return of the sacred to the world of late modernity which seemed to be completely secularized long ago. Special emphasis is given to the role the state plays in this process of the political rehabilitation of the transcendent. The statement of the problem starts with the analysis of significant structural changes within the global discursive landscape, including the demise of the leading role of triumphalist globalization narratives which, until recently, dominated the sphere of values and symbolic meanings. Then it raises the question of the return of the state as an operator of worldly, secular salvation, which, through its institutions, ensures the inclusion of the social world into the transcendent one, thereby defining the circle of those to be rescued. A short historical-philosophical excursus then demonstrates the rooted-ness of the problem of borders of communities in solidarity united by certain transcendent values in the tradition of social science since the times of antiquity. The next section, appealing to the Aristotelian understanding of the political, proposes a participatory model of the mutual recognition for the members of a certain "We"-group structurally separated from other historically-contingent communities of fate. By conceptual means, the article offers an analysis of the attempts to overcome the inevitably discrete character of social ontology undertaken by universalist discourse through the return to cosmopolitan utopias such as projects of global citizenship, post-national inclusive politics, etc. Finally, the text proposes a reconstruction of the alternative line of argumentation usually associated with the names of Aristotle and Rousseau, but explicitly developed by Carl Schmitt. In this line of reasoning, homogeneity is postulated as a condition of the possibility for any community of solidarity. The article offers preliminary conclusions on the relevance of this topic to the theory of social order.

Keywords: salvation markets, sacred, post-secular, "We"-groups, cosmopolitanism, homogeneity, border of political community, Aristotle, Carl Schmitt

\section{References}

Aristotle (1984) Politika [Politics]. Sochinenija. T. 4 [Works, Vol. 4], Moscow: Mysl, pp. 375-644. Beck U., Bonß W. (eds.) (2001) Die Modernisierung der Moderne, Frankfurt am Main: Suhrkamp. Depenhoer O. (2005) Ne vse ljudi budut brat'jami: differenciacija kak prakticheskoe uslovie solidarnosti. Filosofsko-pravovoe razmyshlenie s prakticheskimi celjami [Not All People Will Be 
Brothers: Differentiation as a Practical Condition of Solidarity. Philosophical and Legal reflection with Practical Goals]. Politicheskaja filosofija v Germanii [Political Philosophy in Germany] (eds. O. Heff, J. Isensee), Moscow: Sovremennye tetradi, pp. 429-441.

Diogenes Laërtius (1986) O zhizni, uchenijah i izrechenijah znamenityh filosofov [Lives and Opinions of Eminent Philosophers], Moscow: Mysl.

Funke P. (2003) Athen in klassischer Zeit, München: C. H. Beck.

Glatzer W. (ed.). (1991) Die Modernisierung moderner Gesellschaften: 25. Deutscher Soziologentag in Frankfurt vom 9.-12.10.1990. Sektionen - Arbeits- und Ad Hoc-Gruppen - Ausschuss für Lehre, Opladen: Westdeutscher Verlag.

Habermas J. (1998) Die Postnationale Konstellation und die Zukunft der Demokratie. Die Postnationale Konstellation: Politische Essays, Frankfurt am Main: Suhrkamp, pp. 91-163.

Habermas J. (2003) Postnacional'naja konstelljacija i budushhee demokratii [Post-national Constellation and the Future of Democracy]. Logos, no 4-5, pp. 105-152.

Held D. (1995) Democracy and the Global Order: From the Modern State to Cosmopolitan Governance, Cambridge: Polity.

Heller H. (1971) Politische Demokratie und soziale Homogenität. Gesammelte Schriften, Vol. 2: Recht, Staat, Macht, Leiden: Sijthoff.

Hobbes Th. (2001) Leviafan, ili Materija, forma i vlast' gosudarstva cerkovnogo i grazhdanskogo [Leviathan; or, The Matter, Forme and Power of a Common Wealth Ecclesiasticall and Civil], Moscow: Mysl.

Isensee J. (2005) Evropa — politicheskaja ideja geograficheskoj chasti sveta [Europe — a Political Idea of the Geographical Part of the World]. Politicheskaja filosofija v Germanii [Political Philosophy in Germany] (eds. O. Heff, J. Isensee), Moscow: Sovremennye tetradi, pp. 410-423.

Kildyushov O. (2016) Problema social'nogo porjadka (Gobbsova problema): k jevristike i pragmatike konstitutivnogo voprosa sovremennoj teorii obshhestva [The Problem of Social Order (Hobbes Problem): Towards Heuristics and Pragmatics of the Constitutional Question of the Modern Theory of Society]. Russian Sociological Review, vol. 15, no 3, pp. 122-149.

Luhmann N. (2011) Obshhestvo obshhestva [Society of Society], Moscow: Logos.

Marinovich L., Koshelenko G. (1997) Jepiktet [Epictetus]. Besedy Jepikteta [The Discourses of Epictetus] (ed. G. Taronyan), Moscow: Ladomir, pp. 5-36.

Marcus Aurelius (1985) Razmyshlenija [Meditations], Leningrad: Nauka.

Mouffe Ch. (2004) Karl Shmitt i paradoks liberal'noj demokratii [Carl Schmitt and the Paradox of Liberal Democracy]. Logos, no 6, pp. 140-153.

Nersesyants V. (1977) Sokrat [Socrates], Moscow: Nauka.

Plutarch (1998) O sud'be i doblesti Aleksandra. Rech' pervaja [Life of Alexander. Part 1]. Sravnitel'nye zhizneopisanija. Traktaty. Dialogi [The Parallel Lives. Treatises. Dialogues], Moscow: Ripol Classic, pp. 400-409.

Rousseau J.-J. (1969) Ob obshhestvennom dogovore, ili Principy politicheskogo prava [The Social Contract; or, Principles of Political Rights]. Traktaty [Treatises], Moscow: Nauka, pp. 151-256.

Mehring R. (2017) Carl Schmitt: Denker im Widerstreit. Werk - Wirkung - Aktualität, Freiburg: Karl Alber, pp. 421-433.

Pasquino P. (1985) Politische Einheit, Demokratie und Pluralismus: Bemerkungen zu Carl Schmitt, Hermann Heller und Ernst Fraenkel. Staatslehre in der Weimarer Republik (ed. Ch. Müller), Frankfurt am Main: Suhrkamp, pp. 114-127.

Schmitt C. (2000) Politicheskaya teologiya: chetyre glavy k ucheniyu o suverenitete [Political Theology: Four Chapters on the Concept of Sovereignty]. Politicheskaya teologiya [Political Theology], Moscow: KANON-Press-C, pp. 11-98.

Schmitt C. (2010) Uchenie o konstitucii (fragment) [The Doctrine of the Constitution (Fragment)]. Gosudarstvo i politicheskaja forma [State and Political Form], Moscow: HSE, pp. 33-236.

Sellin F. (2014) Politika. Slovar' osnovnyh istoricheskih ponjatij T. 1 [Dictionary of Basic Historical Concepts, Vol. 1], Moscow: New Literary Observer, pp. 414-519.

Weber M. (2006) Protestantskaja jetika i duh kapitalizma [Protestant Ethics and the Spirit of Capitalism]. Izbrannoe [Selected Works], Moscow: ROSSPEN, pp. 19-186. 
Weber M. (2007) K polozheniju burzhuaznoj demokratii v Rossii [On the Situation of Bourgeois Democracy in Russia]. O Rossii [About Russia], Moscow: ROSSPEN, pp. 14-55.

Weber M. (2016) Hozyajstvo i obshchestvo: ocherki ponimayushchej sociologii. T. 1: Sociologiya [Economy and Society: An Outline of Interpretive Sociology, Vol. 1: Sociology], Moscow: HSE. Weber M. (2017) Hozjajstvennaja jetika mirovyh religij: opyty sravnitel'noj sociologii religii. Konfucianstvo i daosizm [Economic Ethics of World Religions: Essays in Comparative Sociology of Religion. Confucianism and Taoism], Saint Peterburg: Vladimir Dal.

Welwei K.-W. (1999) Das klassische Athen: Demokratie und Machtpolitik im 5. und 4. Jahrhundert, Darmstadt: Wissenschaftliche Buchgesellschaft. 


\title{
Религия и экономика: можем ли мы все еще опираться на Макса Вебера?
}

\author{
Иван Забаев \\ Кандидат социологических наук, доцент кафедры философии религии \\ и религиозных аспектов культуры богословского факультета \\ Православного Свято-Тихоновского гуманитарного университета \\ Адрес: Лихов пер., д. 6, стр. 1, Москва, Российская Федерация 127051 \\ E-mail: zabaev-iv@yandex.ru
}

\begin{abstract}
В статье, в рамках логики, предложенной М. Вебером в «Протестантской этике и духе капитализма», делается попытка выделить ключевую для русского православия этическую категорию; категорию, которая могла бы выполнять ту же роль, что и Beruf (профессия/призвание) для анализа протестантизма и его потенциального влияния на формирование экономики. Делается попытка выделить данную категорию, опираясь на работы Вебера, посвященные анализу хозяйственной этики мировых религий. В частности, делается попытка интерпретации веберовской категоризации русского православия как «специфического мистицизма». Для расшифровки веберовского тезиса используются тексты Ф. Ницше и М. Шелера, в рамках заочной полемики которых и появляется веберовский тезис. Анализ текстов Вебера, Ницше и Шелера приводит к предположению, что подобной категорией может являться «смирение». В работах по социологии религии «смирение» используется Вебером для характеристики «мистицизма» в том же ключе, что и призвание для «аскетизма». Вместе с тем для построения типологии хозяйственных этик мировых религий Вебер переинтерпретирует учение Ницше о ресентименте. Для Ницше смирение часто оказывается синонимом ресентимента. В веберовской интерпретации тезис о ресентименте получил форму «теодицей страдания», в типологии которых смирение оказалось связанным с созерцанием, уходом от мира и т. д. - всем тем, что присуще мистицизму, как его понимал М. Вебер. Рецепция и критика тезиса о ресентименте была также осуществлена М. Шелером, который в своих работах смог противопоставить ресентимент и основную христианскую добродетель - смирение. Анализ заочной дискуссии Ф. Ницше, М. Вебера и М. Шелера о ресентименте и этике христианства позволил предложить типологию этик, как кажется, пригодную для построения гипотез о (потенциальном) влиянии православия на экономическую жизнь страны.
\end{abstract}

Ключевые слова: мистицизм, Вебер, Ницше, Шелер, смирение, призвание, хозяйственная этика, ресентимент, православие

\section{В России начиная с постперестроечных времен активно дискутируется вопрос о модернизации страны, ускорении экономического роста, преобразовании в духе}

\footnotetext{
(с) Забаев И. В., 2018

(с) Центр фундаментальной социологии, 2018

DOI: $10.17323 / 1728-192 \mathrm{X}-2018-3-107-148$

* Статья подготовлена в рамках проекта «Экономика как проблема: теории границ экономического в политической и теологической мысли» при поддержке Фонда Развития ПСТГУ.
} 
вестернизации ее политической и общественной жизни (Ясин, 2001; Ясин, Яковлев, 2004; Щербакова, 2010; Счастная, 2011; Шмырова, 2010). Наряду с другими факторами анализируется и роль религии в развитии страны (Buss, 2003; Элбакян, Медведко, 2001; Ефремова, 2010; Ефремова, 2014; Сусоколов, Четырчинская, 2008; Савельев, Сусоколов, 2011; Сусоколов, 20о9; Габдрахманова, 2010). Одним из важнейших является в этой связи вопрос о значении религии для социального и экономического развития. Поскольку экономика находилась в фокусе научного и общественного интереса, а марксистский, историко-материалистический подход перестал считаться единственно правильным, влияние базисных, производственных отношений на религию совершенно ушло из поля зрения исследователей модернизации, тогда как воздействие религии на общество вызывало значительный интерес. Как в России, так и в мире связи религии с экономикой обсуждаются в социальных науках с трех точек зрения. Во-первых, анализируется прямое влияние Церквей и религиозных организаций на экономику страны: сюда относятся, например, церковные доктрины по экономическим вопросам, нравственные правила и кодексы поведения в экономике (Novak, 1993; Hoffman, 2013); предоставление Церковью общественно значимых услуг (Merchel, 20o8; Павлюткина, 2012; Орешина, 2016). Исследуется роль Церкви на рынке труда: например, католическая Caritas и лютеранская Diakonie являются крупными работодателями Германии (Schroeder, 2017). Церкви/религиозные организации могут выступать агентами экономического поля, формирующими спрос или предложение, пользующимися теми или иными налоговыми льготами и т.д. и, соответственно, вносящими определенный вклад в экономику общества (Митрохин, Эдельштейн, 20oo; Owen, Taira, 2015; Hoge, 1996; Cadge, Wuthnow, 2003; Allahyari, 2000).

Во-вторых, изучается непрямое влияние религии на экономику различных стран. Здесь рассматриваются соииальные институть, явные и неявные правила, которые возникают в тех или иных религиях и потом приживаются в более широкой социальной среде: например, создание трастовых фондов (Kuran, 20o1; Salarzehi, Armesh, Nikbin, 2010), выдача беспроцентных кредитов для членов общин (Юдин, Орешина, 2016), развитие сетей дарообмена среди прихожан (Врублевская, 2016), вклад религиозных организаций в социальный капитал своих последователей (Putnam, 2000; Knack, Keefer, 1997; Greeley, 1997; Забаев, Орешина, Пруцкова, 2014), оценка деловой репутации членов религиозных организаций (Вебер, 199об; Расков, 2012), формирование навыков, необходимых в тех или иных экономиках, борьба религиозных организаций с пороками, которые прямо влияют на уменьшение благосостояния семей и целых территорий (Martin, 1998; Martin, 1995), участие в религиозных общинах для сохранения семей и приумножения капитала (Gooren, 2001). Сюда же можно отнести и анализ деятельности религиозных организаций по формированию доверия людей друг к другу, к тем или иным институтам (Porta et al., 1996; Sosis, 2005; Welch et al., 2004) и т.д.

В-третьих, в рамках анализа непрямого влияния исследователи также разбирают воздействие религии на общество посредством формирования у последовате- 
лей той или иной религии этики, ценностей, трудовой или хозяйственной мотивации. Классической работой этого третьего направления, повлиявшей вместе с тем и на развитие других направлений осмысления связи «религия - экономика», является исследование Макса Вебера «Протестантская этика и дух капитализма» ${ }^{1}$.

Значение «Протестантской этики» трудно переоценить. За прошедшие сто лет по поводу «Протестантской этики» было написано очень много текстов по следующим основным направлениям:

- Исторические опровержения. Вебера много критиковали специалисты по истории религии и экономической истории (Fischer, 1978; Rachfahl, 1978). В таких работах проводится межстрановой анализ или разбираются отдельные «критические» случаи. Часто приводят в пример ситуацию в Шотландии, где кальвинизм был, а развитой капитализм не сложился (Samuelsson, 1961; Robertson, 1933; Fanfani, 1935; Delacroix, Nielsen, 2001; Mackinnon, 1988a; Mackinnon, 1988b; Marshal, 1979; Marshal, 198ob; Marshall, 1980a; Mutch, 2009; Mutch, 2012).

- Прояснение, защита, комментирование тезиса Вебера (Schluchter, 1988a; Schluchter, 1988b; Schluchter, 1995; Schluchter, 2009; Swatos, Boulder, 2005; Schluchter, Graf, 2005; Lehmann, Roth, 1995; Trevor-Roper, 1967; Tawney, 1926; Zafirovski, 2016; Zafirovski, 2013; Eisenstadt, 1968). Указанные выше авторы пытаются защитить методологию, использованную в «Протестантской этике», отделить теоретическую часть аргумента от исторической либо восстановить исторический и идейный контекст, в котором писалась работа.

- Приложение веберовской логики (с большей, но чаще с меньшей точностью) к разным странам. Авторы пытаются найти ответ на вопрос, какие религии порождали тот или иной экономический «дух» и способствовал ли он, в свою очередь, возникновению определенной экономической или общественнополитической практики (Collins, 1997; Hyma, 1938; Stokes, 1975; Tamari, 1987;

1. Под «Протестантской этикой и духом капитализма» могут пониматься разные публикации. Основу известного сегодня текста составили статьи 1904-1905 годов. Несколько позже - в 1907-1910 годах - М. Вебер выпустил несколько текстов, отвечающих на критические замечания Ф. Рахфаля и К. Фишера. Позже, переработав исходные статьи 1904-1905 годов и ответы на критические замечания 1907-1910-х («антикритику»), в первом томе «Собрания сочинений по социологии религии» (1920) Вебер выпустил следующий вариант «Протестантской этики и духа капитализма». В этот же том вошли еще два текста: «Предварительные замечания» (относящиеся ко всему трехтомнику) и написанные в 1906 году «Протестантские секты и дух капитализма». Иногда под «Протестантской этикой и духом капитализма» понимают собственно текст двух первых статей, иногда имеют в виду текст 1920 года вместе с «Предварительными замечаниями» и «Протестантскими сектами». Есть еще одна трактовка, весьма распространенная в наши дни: рассматривать вместе «Протестантскую этику и дух капитализма» 1920 года и «Предварительные замечания» к трехтомнику 1920-го. Именно эти тексты были объединены под одной обложкой в 1930 году в первом англоязычном издании «Протестантской этики», хотя, строго говоря, сам Вебер не компоновал текст подобным образом. 
Bellah, 1963; Забаев, 2012; Martin, 1995). В более широкой перспективе сюда же можно отнести исследования, посвященные влиянию идей на формирование тех или иных социальных практик (Campbell, 1987; Bellah, 1957; Overman, 2011; Quinn, Crocker, 1999; Paretskaya, 2010; Parsons, 2014; Zafirovski, 2007; Gorski, 1993).

Веберовский текст содержит в себе две неравные по объему части: одна посвящена капитализму и его духу, другая - протестантской этике. Гораздо больше внимания исследователи, особенно желающие опровергнуть "веберовский тезис», уделяли первой части, существенно меньше - второй, этической (см.: Капелюшников, 2018; Samuelson, 1961). Остановимся подробно на второй части.

По мнению Вебера, протестантская этика и дух западного капитализма имеют общий элемент - идею призвания (Beruf) человека как жизненную задачу, поставленную ему Богом. Немецкий ученый писал, что в своем переводе Библии Лютер ввел новое этическое понятие «призвания/профессии», в то время как в романских языках, находящихся под преимущественным влиянием католической традиции, не было эквивалента протестантским Beruf, beroep, calling и т. д. Вебер полагал, что именно разработка протестантами разных деноминаций специфической доктрины призвания содействовала выработке некоторых важных компонентов духа современного капитализма: «Один из конституционных компонентов современного капиталистического духа... рациональное ведение жизни [Lebensführung] на основе идеи профессионального призвания - возник из духа христианской аскезы» (Вебер, 1990а: 205; перевод исправлен).

Поствеберианский анализ категории Beruf в социальных науках, как правило, строился вокруг вопроса о том, была ли эта этика присуща той или иной конфессии (Trevor-Rouper, 1967; Robertson, 1933; Brodrick, 1934), где она зародилась, была ли она связана с проблемой неопределенности (Mackinnon, 1988a; Mackinnon, 1988b; Zaret, 1992; Zaret, 1993), описывала ли беспокойство типичного протестанта, каковы ее аналоги в других конфессиях (Bellah, 1957) и т. д. Существует значительное количество и богословских работ, анализирующих проблематику Beruf (обзор см., например, в: Lanczkowski, Schrey, Wingren, 1980).

Одновременно этическая часть «Протестантской этики» породила относительно самостоятельную линию исследований, а именно поиск ответов на вопросы, каким образом та или иная религиозная организация влияет на своих последователей, даже если в явном виде не указывает им голосовать на выборах, платить налоги в таком-то размере, не заниматься микрокредитованием и т. д. Помимо явного - через доктрины и институты - существует другое, невидимое, непреднамеренное, но в ряде случаев гораздо более значимое влияние Церквей на жизнь человека. Оно осуществляется через формирование определенного этоса, который связан с теми или иными способами действия человека ради достижения спасения.

Как писал П. Бурдье: «Наибольшая заслуга Макса Вебера заключалась в том, что он показал, что урбанизация (и сопутствующие ей преобразования) способ- 
ствует „рационализации“ и „морализации“ религии лишь постольку, поскольку она благоприятствует развитию корпуса специалистов, распоряжающихся ценностями спасения [курсив мой. - И. 3.]» (Бурдье, 2005: 15). Анализируя тексты классиков социологии религии, он замечает: «...религия способствует (скрытому) утверждению тех или иных принципов структурирования, восприятия и понимания мира - в частности, социального, навязывая систему практик и представлений, чья структура, объективно основанная на принципе политического разделения, предстает как естественная-сверхъестественная структура космоса» (Там же: 13). Таким образом, интерпретируя Вебера, Бурдье подчеркивает, что религиозные специалисты, обслуживая ценности спасения, способствуют утверждению у последователей религии принципов видения мира и связанных с ним практик и представлений. Ядром этих ценностей спасения в каждой конфессии, по мнению Вебера, являются те, которые отвечают на вопрос «что верующему нужно сделать в миру, чтобы спастись» (в случае протестантизма - это этос призвания). Соответственно, поняв, как устроена этическая категория, лежащая в основе проповеди той или иной Церкви, исследователь может сформулировать гипотезу о характере фундаментального влияния этой Церкви на ее последователей.

Иными словами, анализ влияния той или иной религии на модернизацию страны будет неполным, а то и вовсе неадекватным, если принимать во внимание только экономические доктрины Церквей, их участие в хозяйственной деятельности или разработанные ими те или иные институциональные правила. Дело в том, что религия, помимо всего вышеперечисленного, создает определенный этос, определенный характер, определенный тип человека, утверждая ценности спасения. И человек будет действовать в экономике так, как религия его сформировала, часто не оглядываясь на доктрины и институты. Вся эта асинхронность доктрин, институтов и этоса не будет способствовать ни ускорению модернизации, ни ее безболезненному протеканию.

III

Вернемся к проблеме модернизации России и роли религии в этом процессе. В работах по этой теме на Вебера ссылаются довольно часто (Зарубина, 1997; Савченко, 2006; Шкаратан, Карачаровский, 2002; Кулинченко, Кулинченко, 2003; Малкина, 2011; Чимирис, Донцев, 2010; Федотова, Кросс, 2006; Федотова, 2007). Однако влияние религии на хозяйственную жизнь социологами и даже экономистами нередко понимается как частный случай влияния культуры на экономику, что, строго говоря, не совсем правильно. Хотя в современном мире ситуация зачастую выглядит именно так, однако следует признать, что русская культура, в значительной степени определяющая современную хозяйственную и политическую жизнь страны, укоренена в православии и, более того, продолжает испытывать влияние не некоего абстрактного православия, но вполне конкретной Русской православной церкви с ее патриархом, епископами, священниками и т. д. За этой очевидностью кро- 
ется проблема. С одной стороны, часто утверждают, что православие стало чуть ли не единственным символом позитивной самоидентификации людей в стране, но с другой - остается неясным, каким образом оно может способствовать модернизации страны. Некоторые авторы (Харрисон, Ясин, 2001) считают, что православие, скорее, тормозит развитие. Отсюда вопрос: реформировать ли в таком случае, и если да, то как реформировать (заменять, убирать) Церковь и православную культуру, с которой ассоциируют себя более 80\% населения страны? Что в них менять? Это болезненный вопрос, в особенности если ставить его в такой жесткой форме: либо модернизация и эффективность экономики, либо сохранение православия в его целостности.

В разрешении этого вопроса может помочь веберовский анализ, представленный в «Протестантской этике». Вебер предположил, что если посмотреть на протестантизм (западную религиозность) через призму Beruf (профессии/призвания), можно обнаружить новый тип человека, эффективный в капиталистической экономике ${ }^{2}$. Вебер использовал этот идеальный тип как средство агрегирования и выделения определенных сторон религиозной жизни: фактически он указал на то, что для построения определенных гипотез можно пренебречь всем многообразием протестантской и католической догматики, а сосредоточиться на ключевой ценности в христианстве - на средствах к достижению спасения. Чтобы понять, как конфессия выстраивает свое отношение к миру, как она «окормляет» мирян, нужно выяснить, каким образом священнослужители направляют мирян к спасению.

В то же время предложенный Вебером подход вызывает определенные сложности применительно к русскому православию, которое в целом индифферентно по отношению к Beruf (призванию/профессии). Как же, оставаясь в рамках веберовского подхода, выявить подобный Beruf (призванию/профессии) этос русского православия? Можно предложить два пути. Первый - провести эмпирические исследования того, как ценности спасения обслуживаются в современном православии. Но тут возникает следующая проблема: возможно, в современном мире, который организован в рамке immanent frame (Тэйлор, 2017) или ухода больших трансценденций (Лукман, 2014), ценности спасения уже не так важны даже для религиозных людей, хотя этосы, закрепленные в культурах и Церквях сохраняются. Иными словами, Beruf (призвание/профессия) остается в активном словаре представителей конфессий, а спасение - нет. То же и с современным православием. Другой путь: отталкиваясь от «Протестантской этики», выяснить, чему Вебер противопоставлял Beruf и с какими еще этосами сопоставлял; как он сам харак-

2. Это не означает, что протестантизм может быть редуцирован к доктрине призвания, а показывает, что можно провести различение между «призванием» и «чем-то еще» (позже аналогичную функцию будет выполнять различение «аскетизма» и «мистицизма»). При таком различении можно обнаружить, что в протестантизме проявлялся этос призвания, который (вкупе с другими факторами) мог приводить к таким-то и таким-то последствиям. 
теризовал русскую религиозность и как эта характеристика соотносится с призванием/профессиец̆.

\section{Логика аргументации «Протестантской этики»}

В нескольких текстах Вебер анализирует, как складывался современный хозяйственный космос, какие факторы повлияли на возникновение современного капитализма. В «Истории хозяйства», «Протестантских сектах», даже в «Предварительных замечаниях» К «Хозяйственной этике мировых религий» Вебер описывает эти факторы, практически не касаясь роли этики в современном обществе. Однако «Протестантская этика» - это работа о том, как этическая составляющая могла бы повлиять на становление современного Веберу общества. Собственно, вся книга - это повествование о том, как появилось и развивалось такое понимание профессии, при котором речь идет не просто о выполнении определенной работы, а об отклике на зов Божий. Немецкое слово Beruf содержит в себе оба класса коннотаций - и профессии, и призвания. Наиболее часто воспроизводимая в учебниках и критической литературе часть веберовской аргументации связана именно с тем, как идея призвания возникла в лютеранско-кальвинистских кругах и как это понятие оказалось связанным с деятельностью в миру. Нет нужды подробно цитировать Вебера здесь, обозначим лишь основной ход его мысли и подчеркнем ряд мест, на которые часто не обращают внимания.

Анализируя общий ход рассуждений о Beruf в веберовском тексте, обозначим символами А1-A9 основную линию аргументации, символами Б1, В1 - развилки и дополнительные линии. (A1) Вебер приводит документ, в котором схвачен дух капитализма, - отрывок из автобиографии Франклина. Модальность отношения к жизни в этом документе, по мнению Вебера, лучше всего может быть описана как призвание (Вебер, 1990а: 71-74). Далее (A2) он ставит вопрос: «Каким же образом эта деятельность, которую в лучшем случае признавали этически допустимой, могла превратиться в призвание» - в понимании Бенджамина Франклина? (Там же: 93)3․ (А3) Вебер указывает, что идея призвания, похожая на то, что можно увидеть в автобиографии Франклина, окончательно оформилась у Лютера (в лютеранских кругах) (Там же: 97). Здесь появляется важное ответвление от «веберовского тезиса», сформулированного поколениями толкователей и критиков. (Б1) Вебер говорит, что идея призвания у Лютера созвучна идеям такого мистика, как И. Таулер. Приведем здесь развернутую цитату:

Почва для лютеровской концепции профессионального призвания была (как мы увидим из последующего анализа средневековой религиозной этики) уже в значительной степени подготовлена немецкими мистиками, в част-

3. Там же есть важное дополнение: модальность отношения к жизни не присутствовала в центрах тогдашнего капитализма, что, помимо прочего, подвергает сомнению все попытки критики веберовского текста через анализ связи протестантизма с экономическим ростом, ростом ВВП и т. д. (Вебер, 1990a: 93). 
ности Таулером с его отношением к духовным и мирским профессиям, как к равноценным, и сравнительно невысокой оценкой традиционных форм аскетического усердия, поскольку для мистиков единственно существенным являются созерцание и экстатический порыв, сопровождающий слияние души с Богом. Более того, лютеранство в некотором отношении даже делает шаг назад по сравнению с мистиками, поскольку у Лютера - а еще больше в лютеранской церкви - психологические основы профессиональной рациональной этики становятся более шаткими, чем у мистиков (чьи воззрения в этой области во многом близки отчасти пиетистской, отчасти квакерской религиозной психологии) ${ }^{4}$. (Там же: 101-102)

Мы видим, что здесь Вебер вводит дихотомию «аскетизм-мистицизм» и на данном этапе Beruf не оказывается в жесткой связке именно с аскетизмом.

После этого (A4) описывается понимание идеи Beruf в кальвинизме и у пуритан. Анализируется доктрина предопределения: Вебер говорит, что вопрос о том, к чему предызбран каждый человек - к жизни или к смерти, должен быть самой важной проблемой для верующих данных деноминаций. Он описывает способы решения верующим этой проблемы:

Речь может идти о двух взаимосвязанных типах душеспасительных назиданий. В одном случае верующему вменяется в прямую обязанность считать себя избранником Божьим и прогонять сомнения как дьявольское искушение, ибо недостаточная уверенность в своем избранничестве свидетельствует о неполноте веры и, следовательно, о неполноте благодати. Увещевания апостола об «упрочении» своего призвания здесь толкуются, следовательно, как обязанность завоевать в повседневной борьбе субъективную уверенность в своем избранничестве и в своем оправдании. На смену смиренным грешникам, которым Лютер сулил Божью милость, если они, преисполненные веры и раскаяния, вверят себя Богу, теперь в лице непреклонных купцов героической эпохи капитализма приходят выпестованные пуританизмом «святые»; отдельные представители их сохранились вплоть до наших дней. Второй способ состоит в том, что в качестве наилучшего средства для обретения внутренней уверенности в спасении рассматривается неутомимая деятельность в рамках своей профессии. Она, и только она, прогоняет сомнения религиозного характера и дает уверенность в своем избранничестве. (Там же: 148-149).

Этот элемент «веберовского тезиса» (проблема экзистенциальной обеспокоенности и неуверенности) подвергался критике (см., напр.: MacKinon, 1988a, 1988b; Капелюшников, 2018), которая, однако, не затрагивает общего хода аргумента о Beruf и не ставит значимость самой идеи под сомнение. Кроме того, существует «критика критики», защищающая веберовский аргумент (см.: Zaret, 1992)5. Наконец, влияние изменения богословской доктрины на человека признавали разные

4. См. также: Вебер 1990: 130, 133, 148-149.

5. Б. Нельсон в «Идее ростовщичества» анализирует следствия некоторых других изменений в богословии, кратко упомянутых Вебером. Он посвятил свою книгу толкованию одного абзаца из 
авторы. Так, К. Маркс определил это влияние следующим образом: «Лютер... превратил попов в мирян, превратив мирян в попов... Речь... шла уже не о борьбе мирянина с попом вне мирянина, а о борьбе со своим собственным внутренним попом» ${ }^{6}$ (Маркс, 1955: 422-423). Протестантский богослов и историк церкви К. Холль в начале XX века в статье «История слова Beruf» писал об этом так: «Таким образом, история слова показывает полный переворот его значения. Сначала говорилось: только у монашества есть призвание/профессия; Лютер, напротив, считает: как раз у монашества и нет призвания/профессии; истинное призвание Божье реализуется в мире и в мирской работе» (Holl, 1965: 219).

Здесь уже неявно присутствует еще одна (третья) линия аргументации, которая будет развита в известной метафоре «железной клетки» или «стального панциря» (stahlhartes Gehäuse) ${ }^{7}$. Истолковывая кальвинистское учение о предопределении (B1), Вебер пишет: «Всякая тварь отделена от Бога непреодолимой пропастью и обречена им на вечную смерть, разве только он решит иначе во славу величия своего. Нам известно лишь одно: часть людей предопределена к блаженству, остальные же прокляты навек» (Вебер, 1990а: 142); «обоснование кальвинистской этики учением о предопределении привело к тому, что духовную аристократию монахов вне мира и над ним вытеснила духовная аристократия святых в миру, от века предопределенная Богом к спасению, аристократия, которая по своему character indelebilis была отделена от остальных, от века предопределенных к погибели людей» (Там же: 157).

веберовской «Истории хозяйства», касающегося развития капиталистического мировоззрения и связанного, в свою очередь, с аргументом в «Протестантской этике» (Вебер, 2001: 321; Nelson, 1969: XVI).

6. Полностью цитата из «Введения к гегелевской философии права» Маркса звучит вполне в духе «Протестантской этики»: «Лютер победил рабство по набожности только тем, что поставил на его место рабство по убеждению. Он разбил веру в авторитет, восстановив авторитет веры. Он превратил попов в мирян, превратив мирян в попов. Он освободил человека от внешней религиозности, сделав религиозность внутренним миром человека. Он эмансипировал плоть от оков, наложив оковы на сердце человека. Но если протестантизм не дал правильного решения задачи, то всё же он правильно поставил её. Речь теперь шла уже не о борьбе мирянина с попом вне мирянина, а о борьбе со своим собственным внутренним попом, со своей поповской натурой» (Маркс, 1955: 422-423).

7. Эта метафора сама по себе вызвала довольно значительную полемику. Т. Парсонс перевел веберовский «stahlhartes Gehäuse» («стальной панцирь») как «Iron Cage» («железная клетка»), затем последовали другие толкования с опорой, с одной стороны, на этические идеи Дж. Бэньяна, а с другой - на Ф. Ницше и В. Гёте (см.: Kent, 1983; Tiryakian, 1981; Baehr, 2001; Turner, 1982). Исходное употребление этой метафоры в веберовском тексте все же имело некоторые внутренние ограничения: именно Beruf создавал «стальной панцирь», и этому этосу человек «добровольно» следовал. В парсоновской же традиции акцент сместился на некоторые внешние структуры: бюрократию, организации, весь космос капитализма или общества модерна в целом и т. д. См. напр., получившую признание работу У. Пауэлла и П. Димаджио «Новый взгляд на железную клетку». Интерпретируя Вебера, они, в частности, пишут: «В условиях капитализма рационалистический порядок превратился в „железную клетку“... как организационное проявление рационального духа бюрократия представляет собой столь эффективное и сильное средство контроля над людьми, что, единожды восторжествовав, бюрократизация становится необратимой» (Димаджио, Пауэлл, 2010: 35). Это достойная исследовательская традиция, но мы бы хотели подчеркнуть, что исходный веберовский текст акцентировал иной смысл. В силу того что Вебер активно пользовался идеей «избирательного сродства» между духом и формой капитализма, удержать эти различения становится довольно сложно. 
Иными словами, работа в профессии/призвании, которая будет описываться Вебером дальше, строго говоря, не является средством спасения. От самой работы ничего не зависит - она есть средство избавиться от неопределенности. Веберовское толкование звучит примерно следующим образом: подавляющее большинство людей (те, кто не входит в духовную аристократию святых) прокляты Богом. И чтобы как-то забыть про это проклятие, люди начинают усердно трудиться или наживаться (что не одно и то же). Как будет видно в конце «Протестантской этики», проклятие все равно настигает их - уже в этой жизни. Попросту говоря, призвание - это обратная сторона проклятия ${ }^{8}$.

Здесь же продолжает развиваться вторая линия, а именно сопоставление аскетизма и мистицизма. Вебер (Б2) в явном виде вводит эту дихотомию, различая таким образом лютеранство и кальвинизм:

\begin{abstract}
Специфическая реформатская религиозность с самого начала отвергала как квиетизм Паскаля с его бегством от мира, так и лютеранскую религиозность с ее чисто духовной настроенностью. Реальное проникновение Бога в человеческую душу полностью исключалось его абсолютной трансцендентностью по отношению ко всему тварному: «initum non est capax infiniti». Общение Бога с его избранниками может осуществляться и осознаваться лишь посредством того, что Бог действует в них («ореratur»), что они это осознают и что их деятельность проистекает тем самым из веры, данной им милостью Божьей, а эта вера, в свою очередь, свидетельствует о своем божественном происхождении посредством той деятельности, в которой она находит свое выражение. В этом обнаруживаются столь глубокие различия в ощущении своей избранности, что они вообще могут лечь в основу классификации практической религиозности как таковой: виртуоз религиозной веры может удостовериться в своем избранничестве, ощущая себя либо сосудом божественной власти, либо ее орудием. В первом случае его религиозная жизнь тяготеет к мистическо-эмоциональной культуре, во втором - к аскетической деятельности. Первому типу близок Лютер, ко второму принадлежит кальвинизм. (Там же: 150)
\end{abstract}

Здесь же Вебер со ссылкой на уже упоминавшегося Таулера говорит, что «мистическое созерцание и рациональная концепция призвания сами по себе не исключают друг друга» (Там же: 221, ссылка 50). Помимо этого (Б3), отличая религиозность Лютера и Цинцендорфа от аскетизма кальвинистов и пуритан, Вебер для характеристики первой часто использует категорию «смирения» (см., напр.: Там же: 141, 149, 150, 228, 238).

8. Последователи Парсонса видели в призвании «Протестантской этики» преимущественно положительную и вдохновляющую составляющую. Например, в известном проекте «Привычки сердца» Р. Белла с коллегами вводили различение «работа - карьера - призвание», которое описывало отношение человека к работе. В этой трихотомии «призвание» обозначало наиболее позитивное восприятие работы, способствующее ее наилучшему выполнению (Bellah et all., 1985). С другой стороны, марксист 3. Бауман подчеркивал, что «хозяйственная этика» была создана для того, чтобы «втащить» людей в машину капитализма (Bauman, 2004: 5-22). Примерно этот же аспект акцентируют Л. Болтански и Э. Кьяпелло (Болтански, Кьяпелло, 2011). 
Наконец, (A5) Вебер ставит вопрос о влиянии данной идеи (Beruf) на предпринимательскую деятельность (Там же: 183). Чуть позже (А6) он описывает критерии соответствия профессии призванию (по материалам пасторской литературы пуритан): «И еще одно, и это самое важное: полезность профессии и, следовательно, ее угодность Богу в первую очередь определяются с нравственной точки зрения, затем степенью важности, которую производимые в ее рамках блага имеют для „всего общества“; однако в качестве третьего и практически безусловно наиболее важного критерия выступает ее „доходность“» (Там же: 190).

В заключение Вебер (A7) говорит о том, что отношение к труду и наживе как к призванию в сочетании со строгой аскезой в потреблении должны были увеличить производительность труда «в капиталистическом значении этого понятия» (Там же: 202-203). И (A8) подводя итог всей работе, он указывает на то, что ему удалось объяснить:

Один из конституционных компонентов современного капиталистического духа [выделение мое. - И. 3.], и не только его, но и всей современной культуры, - рациональное ведение жизни [Lebensführung] на основе идеи профессионального призвания - возникло (и настоящая работа посвящена доказательству этого) из духа христианской аскезы. Достаточно вспомнить приведенный в начале нашего исследования трактат Франклина, чтобы обнаружить, насколько существенные элементы того образа мыслей, который мы определили как «дух капитализма», соответствуют тому, что (мы показали это выше) составляет содержание пуританской профессиональной аскезы, только без ее религиозного обоснования - ко времени Франклина оно уже отмерло. (Там же: 205; перевод исправлен)

Иными словами, речь идет не обо всех капитализмах, не о современном капитализме, не о цивилизованном капитализме, не о наиболее эффективном капитализме, не о росте ВВП или его аналогах, даже не о капиталистическом духе в целом. Речь идет только об одном компоненте капиталистического духа. И (B1) это вовсе не позитивная оценка капитализма. «Протестантская этика» и ее часть, связанная с экспликацией понятия Beruf, заканчивается пессимистическим диагнозом относительно людей профессии (Berufsmensch):

Пуританин хотел быть профессионалом, мы должны быть таковыми [Puritaner wollte Berufsmensch sein, - wir müssen es sein]... По Бакстеру, забота о мирских благах должна обременять его святых не более чем «тонкий плащ, который можно ежеминутно сбросить». Однако плащ этот волею судеб превратился в стальной панцирь... В настоящее время стремление к наживе, лишенное своего религиозно-этического содержания, принимает там, где оно достигает своей наивысшей свободы, а именно в США, характер безудержной страсти, подчас близкой к спортивной... не наступит ли век механического окостенения, преисполненный судорожных попыток людей поверить в свою значимость... применительно к «последним людям» этой культурной эволюции обретут истину следующие слова: «Бездушные профессионалы 
[Fachmenschen ohne Geist], бессердечные сластолюбцы - и эти ничтожества полагают, что они достигли ни для кого ранее не доступной ступени человеческого развития». (Там же: 206-207)

На немецком языке в финале «Протестантской этики» появляются такие образы: «люди, запертые в профессиях»; «практически обслуживающие космос машинной экономики, люди ввергаются в этот космос с рождения»; «современные люди свободно отказываются от полноты человеческого существования». Именно в этом смысл отсылок к Гёте (Там же: 206-207; см. также: Kent, 1983). Напомним, в чем Вебер видел специфику современного капитализма: «Однако наряду с этим типом капитализма Западу Нового времени известен и другой, нигде более не существовавший, - рациональная капиталистическая организация свободного (формально) труда» (Вебер, 1990а: 51). Современные люди свободно выбирают собственную несвободу, чтобы выжить.

Что для нас означает этот промежуточный итог? Что, возможно, Веберу было интересно возникновение некоторого нового типа человека. На стадии своего зарождения этот новый тип людей (пионеры капитализма), возможно, и вызывал у Вебера восхищение, но не в сформировавшемся виде (Berufsmensch). Berufsmensch является антиподом того типа характера, который сформировался под воздействием этоса Beruf и который Вебер описывает категориями «мистицизм» и «смирение». Оппонентом Berufsmensch выступает и «гармоничный, прекрасный человек» Гёте. Хотя некоторые толкователи Вебера (см., напр.: Kent, 1983) отмечают схожесть в этом отношении Гёте и пионеров капитализма. Кроме того, две «альтернативные» линии аргументации «Протестантской этики» восходят к идеям Ницше: Вебер заканчивает «Протестантскую этику» цитатой про «последних людей».

\section{Русское православие как «мистицизм»}

В «Протестантской этике» Вебер вводит противопоставление «аскетизм - мистицизм». И православие он описывает как мистицизм:

В православной церкви присутствует специфический мистицизм, основанный на неизбывной вере Востока в то, что братская любовь и милосердие эти специфические человеческие отношения, которые великие религии спасения преобразили (и которые настолько слабы у нас), - что эти отношения определяют не только некоторые социальные последствия, которые являются абсолютно незначительными, но и путь к познанию смысла мира, к мистическому отношению с Богом. (Toennies et al., 1973: 144-145) ${ }^{9}$

9. Эту позицию на протяжении XX века разделяли многие авторы (см., напр.: Müller-Armack, 1945; Buss, 1989). 
Прежде чем идти дальше, восстановим логику использования Вебером понятия «мистицизм». То, что было начато Вебером в «Протестантской этике», получило свое относительное завершение в «Хозяйственной этике мировых религий» и «Социологии религии». Ко времени Вебера уже был накоплен достаточно большой корпус исследований мистицизма. Как понятие «мистицимз» входит в арсенал зарождающихся психологии религии (у У. Джеймса) и феноменологии религии (у Р. Отто). В свою очередь, Вебер выделяет ряд, по его мнению, сущностно важных критериев, по которым можно анализировать пару «мистицизм - аскетизм» ${ }^{10}$.

Мистицизм и аскетизм у Вебера как рациональные методики спасения противостоят многочисленным, относительно менее рационализированным, религиозным техникам, связанным с оргиями, магией или ритуалами ${ }^{11}$ :

С рационализацией религиозной методики спасения дурманящие оргии все более вытесняются постоянным и прежде всего осознанным типом поведения. Развитие это обусловлено также характером концепции «божественного»... Там, где людям противостоит всемогущий надмирный Бог, целью методики спасения уже не может быть самообожествление в таком смысле, ею становится обретение требуемых Богом религиозных качеств. Тем самым методика спасения становится потусторонне и этически ориентированной; она стремится не к тому, чтобы «обладать» Богом - это невозможно, а к тому, чтобы быть либо его «орудием», либо его сосудом. (Вебер, 1994а: 197)

Итак, по Веберу, мистицизм - это методика спасения, метафорически обозначенная как «сосуд» в противовес «орудию». Как раскрывается эта метафора? Соответствующие фрагменты из «Хозяйства и общества» и «Хозяйственной этики мировых религий» ${ }^{12}$ позволяют нам составить следующую сравнительную таблицу:

10. Друг и коллега Вебера Э. Трёльч выстраивает другое противопоставление: «церковь-сектамистицизм» (Troeltsch, 1992). У Трёльча мистицизм обозначает полюс асоциальной религии. Мистики у него - это в большей или меньшей степени одиночки, люди, в основном не затронутые процессами Vergesellschaftung и Vergemeinschftung. Несмотря на то что Вебер не использует трёльчевский вариант, для нас это может оказаться небесполезным указанием: возможно, стоит проверить гипотезу о том, что русское православие сознательно не педалирует идеи коллективных ценностей (см. об этом подробнее: Забаев, 2011). Очень возможно, что то, что хотели бы считать «соборностью», «общинностью», «коллективным характером русской религиозности», на самом деле может быть атрибутировано коммунизму крестьянской общины, а не православной религиозности.

11. См., напр.: Krech, 2001: 254; Adair-Toteff, 2002.

12. Вот одна из ключевых в этом отношении цитат: «Особая покорная „сломленность“характеризует мирскую деятельность мистика - он все время стремится уйти (и уходит) в тишь и уединение, где ощущает свою близость Богу. Аскет (если он полностью соответствует этому типу) уверен в том, что служит орудием Бога. Поэтому подлинность „смирения“, налагаемого на него должным сознанием своей твердости, вызывает сомнение. Ведь успех в его деятельности - это успех Бога, Бог этому способствовал - или уж во всяком случае знак божьего благословения его и его действий. Для подлинного мистика успех его мирской деятельности не может иметь значения в деле его спасения, напротив, подлинное смирение является единственной гарантией того, что его душа не предалась искушению мира. Чем больше он связан с миром, тем „более сломленным“ становится его отношение к нему, в отличие от гордого сознания своей избранности к спасению, которое дает ему внемирское созерцание. Для аскета уверенность в спасении всегда подтверждается рациональной по своему 
Таблица 1. Методики спасения: аскетизм и мистицизм

\begin{tabular}{lll} 
& Мистицизм & Аскетизм \\
\hline $\begin{array}{l}\text { Ключевая метафора: верую- } \\
\text { щий — это... }\end{array}$ & Сосуд Бога & Орудие Бога \\
Модус бытия (1-й вариант) & Созерцание & Действие \\
Модус бытия (2-й вариант) & Состояние & Действие \\
Деятельность & Как искушение & Как задача; как средство удо- \\
& стовериться в спасении
\end{tabular}

В качестве промежуточного вывода укажем, что в веберовских сочинениях можно обнаружить антагониста «призвания», а именно «смирение», которое описывает то, что должен делать мистик, или, вернее, что имеет большое значение в деле спасения. При описании подобного мистицизма Вебер часто приводит в пример Таулера и Лао-цзы (напр.: Вебер, 2017: 204-205). Кроме того, категория "смирения» относится к ядру христианской догматики в целом и православия в частности, что может оказаться важным для нас. Хотя, безусловно, смирение Лао-цзы и смирение православных XX века - не одно и то же.

Характерно, что Вебер сохранил/предусмотрел в своем исследовании возможность для построения более сложных схем. Речь идет о предложенных им разных типах аскетизма и мистицизма. Так, Вебер использовал следующие различения: 1) внутримирской/внемирской (innerweltliche/außerweltliche) и 2) отвергающий мир/бегущий от мира (weltablehnende/weltflüchtige) ${ }^{13}$. Самому Веберу был в первую очередь интересен тип отрицающей мир внутримирской аскезы, наиболее резким антагонистом которой был бегущий от мира мистицизм.

$\mathrm{B}$ «Хозяйственной этике мировых религий» мистицизм и аскетизм обозначают разные пути к спасению, связанные с теодицеей страдания: аскетизм - активный, мистицизм - пассивный. По большому счету идея теодицеи страдания у Вебе-

смыслу, средствам и цели деятельностью, осуществляемой в соответствии с однозначными принципами и правилами» (Вебер, 1994а: 207-208).

13. Известный исследователь творчества Вебера В. Шлюхтер еще более усложняет схему (см., напр.: Schluchter, 1987: 110, 112). Однако, на наш взгляд, эти усложнения не помогают в решении нашей задачи. 
ра - это специфическая разработка идеи Ницше о ресентименте, но вместе с тем и критический ответ на аргументы Ницше ${ }^{14}$. Вебер пишет:

Общую, в известном смысле абстрактную, классовую обусловленность религиозной этики можно было бы как будто после появления блестящего эссе Ф. Ницше вывести из его теории затаенной обиды [Ressentiment], подхваченной и серьезными психологами... Однако сколь ни удачно и ни плодотворно само по себе открытие психологического значения затаенной обиды, оценивать ее социальный смысл следует с большой осторожностью... что касается оценки страдания в религиозной этике, то она, без сомнения, претерпела характерное изменение, которое, будучи правильно интерпретировано, до известной степени подтверждает теорию, впервые предложенную Ницше. (Вебер, 19946: 46)

Итак, разбирая веберовскую пару «аскетизм - мистицизм», мы снова приходим к «смирению» и к Ницше. В «Протестантской этике» смирением обозначалась религиозность Лютера в противовес религиозности Кальвина и пуритан, во введении к «Хозяйственной этике мировых религий» со смирением связаны некоторые другие виды мистицизма - уже упоминавшиеся Таулер и Лао-цзы. Если «Протестантская этика» заканчивалась отсылкой к «последним людям» из Заратустры, то «Введение», содержащее пару «аскетизм - мистицизм», содержит отсылку к ресентименту. Оба этих повтора, по-видимому, не случайны.

\section{Ницшеанский след в построениях Вебера и «смирение»}

В «Протестантской этике» мы обнаруживаем как минимум две линии аргументации.

Во-первых, так называемый «веберовский тезис» о том, что протестантизм мог каким-то образом содействовать возникновению капитализма. В американской социологии и социальных науках, инспирированных ею (или же в социальных науках, инспирированных развитием практической программы действий по модернизации $\left.{ }^{15}\right)$, эта линия аргументации была воспринята как основная или единственная. И сегодня критики продолжают поддерживать эту гипотезу или похожие на нее.

Вторая линия аргументации связана с категориальной парой «проклятие-призвание». В отличие от первой, давшей основания считать капитализм чем-то хорошим, ассоциируемым с демократией, рынком, ростом ВВП и т. д., вторая линия аргументации представляет капитализм в менее радужном свете. Но, на наш взгляд, она является не менее важной и куда больше соответствует исходной вебериан-

14. Идеи Ницше стали одним из источников «Хозяйственной этики мировых религий» (Strong, 1992). О влиянии Ницше на Вебера см. подробнее в: Hennis, 1988; Kent, 1983; Stauth, 1992; Turner, 2011. Задача поиска категории из христианского словаря, противоположной «призванию», в этих текстах не ставится.

15. О программе модернизации в администрации Г. Трумана см.: Йоас, Кнёбль, 2011: 445. 
ской посылке, что находит подтверждение как в логике изложения «Протестантской этики», так и в общественных настроениях немецких интеллектуалов того времени (Рингер, 2008).

Макс Вебер видел много проблем в общественно-политическом устройстве предвоенной Германии, он считал, что высшая бюрократия уже не может решать насущные задачи на должном уровне. Кроме того, на формировании замысла «Протестантской этики» отразилась и тяжелая личная ситуация, в которой оказался ученый, посвятивший себя науке как Beruf и вдруг, в один момент, ставший практически недееспособным на этом поприще. Это один из первых больших текстов Вебера после серьезной нервной болезни, продолжавшейся несколько лет. В это время Вебер не мог встречаться с людьми, не мог писать, не мог читать. «Протестантская этика» созревала вовсе не как гимн новому миру. В 1920 году, готовя к выпуску ее расширенное издание, Вебер напишет горькие слова о том, что наука больше не ведет к великим целям, мечты эпохи Просвещения развеялись, ни на какой большой и важный для человека вопрос наука ответить уже не может. Наука вообще занимается вовсе не самыми важными делами: помочь действующему оценить последствия собственного действия, да и то с трудом. Чтобы что-то сделать, приходится становиться специалистом-профессионалом, посвящать всего себя изучению какой-то ничтожной детали. Ничего великого в науке не остается. Она не может помочь сохранить полноту человеческого (именно в этом смысл ссылок на Гёте в конце «Протестантской этики»). И тем не менее настоящий ученый (тот, кто призван) не может бросить ею заниматься. Многие помнят эту цитату: «Без странного упоения, вызывающего улыбку у всякого постороннего человека, без страсти и убежденности в том, что „должны были пройти тысячелетия, прежде чем появился ты, и другие тысячелетия молчаливо ждут“, удастся ли тебе твоя догадка, - без этого человек не имеет призвания к науке, и пусть он занимается чем-нибудь другим» (Вебер, 1990в: 708) ${ }^{16}$. Она может восприниматься в духе горделивого превосходства, на самом деле в ней зафиксирован тяжелый диагноз - ученый занимается чем-то неважным, но не заниматься этим он не может. Он призван. Это то же самое, что «он проклят» ${ }^{17}$.

16. Веберовская идея науки имела значительное влияние. Ближе всего к проблематике данной статьи находится шелеровская критика этой идеи. Подробнее об этом см.: Давыдов, 1998: 105-211.

17. Подобная интерпретация текстов Вебера не является совсем уж надуманной. Вот пример из другого дискурса. В 2017 году у Хари Холле - героя бестселлеров Ю. Несбё - случится такой диалог с врачом Стеффенсом:

«- Мм... Можно задать вам личный вопрос, Стеффенс?.. В результате вы остаетесь в плюсе?

- Простите?

- Радость от спасения жизни минус отчаяние от потери тех, кого ты мог спасти.

- Нет.

- Но вы продолжаете этим заниматься?

- Это призвание.

- Да, я видел распятие у вас в кабинете. Вы верите в призвание.

- Думаю, вы тоже, Харри. Я видел вас. Может быть, не Бог призвал вас, но призвание вы ощущаете.

- Означает ли это, что вы не любите свою работу? 
Кажется, что это и есть лейтмотивное настроение «Протестантской этики». И скорее всего, именно оно инспирировано ницшеанским взглядом на мир. В чем состоит этот ницшеанский след? О чем эта пара «последние люди-ресентимент»? Можно предположить, что Вебер имеет в виду примерно следующее: над современным человеком висит какое-то проклятие, оно начало действовать когда-то раньше и в недалеком будущем сделает из человека «последнего человека». «Последние люди» - это ницшеанский приговор современному человечеству. «Последние люди» - это антоним сверхчеловека. Вот как презентует Ницше этого «последнего человека»: «Я говорю вам: нужно носить в себе еще хаос, чтобы быть в состоянии родить танцующую звезду. Я говорю вам: в вас есть еще хаос. Горе! Приближается время, когда человек не родит больше звезды. Горе! Приближается время самого презренного человека, который уже не может презирать самого себя. Смотрите! Я показываю вам последнего человека» (Ницше, 1996б: 11). Финал «Протестантской этики» практически повторяет это описание, указывая еще и на некоторые моменты эволюции в истории современного мира: «Пуританин хотел быть профессионалом, мы должны быть таковыми» (Вебер, 1990а: 206).

В немецком тексте у Вебера стоит Berufsmensch, что, возможно, следует переводить как «человек профессии». Здесь, безусловно, идет речь о профессиональном совершенстве, но не только (и не столько) о нем. Важно не потерять противопоставление хотел/должен в начале «Протестантской этики», где ставится вопрос о свободной организации труда. Свобода свободной организации труда очень условна. Нельзя сказать, что ее нет: люди свободно выбирают эту несвободу. Люди могут существовать, только соблюдая границы профессий. Человек может быть профессионалом только в рамках профессии. Если он начнет выходить за ее рамки («распыляться»), то не сможет сделать ничего на уровне достижений своего времени ${ }^{18}$.

Но что такое «общество профессионалов»? Это общество, упорядоченное по профессиям ${ }^{19}$. И жить в нем только людям профессий. Это, вероятно, стоит вос-

- Я ненавижу свою работу, - улыбнулся главный врач. - Если бы я мог выбирать, я бы стал концертирующим пианистом.

- Мм... А вы хороший пианист?

- В этом и заключается проклятие - когда человек недостаточно хорош для того, чем он любит заниматься, и хорош для того, чем он заниматься ненавидит, не так ли?

Харри кивнул:

- Это проклятие. Мы делаем то, для чего нас можно использовать.

- А ложь заключается в том, что того, кто следует своему призванию, ждет награда.

- Возможно, иногда работа является достаточной наградой» (Несбё, 2017: 271).

18. В финале «Протестантской этики» Вебер в сноске ссылается на главу 18 классической работы Т. Бельшовского о Гете. Вот что пишет Бельшовский: «Две большие основные мысли проходят через «Годы странствования»: труд и отречение... Человек должен ограничить свои стремления и на этой одной ограниченной области сосредоточить все свои силы...» (Бельшовский, 1908: 462).

19. Профессиям в «Хозяйстве и обществе» посвящена отдельная глава. В ней есть такое определение: «Профессией следует называть ту спецификацию, специализацию и комбинацию трудовых усилий индивида, которая является для него основой возможности непрерывного жизнеобеспечения 
принимать, оглядываясь на Ницше - хаоса больше нет. Заратустра, пытаясь вызвать отвращение у слушателей, говорит:

Смотрите! Я показываю вам последнего человека. «Что такое любовь? Что такое творение? Устремление? Что такое звезда?» - так вопрошает последний человек и моргает. Земля стала маленькой, и по ней прыгает последний человек, делающий все маленьким... «Счастье найдено нами», - говорят последние люди и моргают. Они покинули страны, где было холодно жить: ибо им необходимо тепло. Также любят они соседа и жмутся к нему: ибо им необходимо тепло. Захворать или быть недоверчивым считается у них грехом: ибо ходят они осмотрительно. Одни безумцы еще спотыкаются о камни или о людей! От времени до времени немного яду: это вызывает приятные сны. А в конце побольше яду, чтобы приятно умереть. Они еще трудятся, ибо труд - развлечение. Но они заботятся, чтобы развлечение не утомляло их... Каждый желает равенства, все равны: кто чувствует иначе, тот добровольно идет в сумасшедший дом. «Прежде весь мир был сумасшедший», говорят самые умные из них и моргают. Все умны и знают все, что было; так что можно смеяться без конца. Они еще ссорятся, но скоро мирятся - иначе это расстраивало бы желудок. У них есть свое удовольствьице для дня и свое удовольствьице для ночи; но здоровье - выше всего. "Счастье найдено нами», — говорят последние люди и моргают. (Ницше, 1996б: 11-12)

Но они отвечают: «Дай нам этого последнего человека, о Заратустра, - так восклицали они, - сделай нас похожими на этих последних людей! И мы подарим тебе сверхчеловека!» (Там же: 12). Люди сами выбирают отказ от хаоса, они не могут не выбирать его. Они не могут отказаться от тепла и комфорта, но, возможно, Заратустра говорит, что это погубит их? То, что начинается как описание последних людей в «Заратустре», уточняется в «К генеалогии морали»как ресентимент. Исследователи творчества Ницше, скорее, согласны с тем, что психологические и этические механизмы, описываемые Ницше в «К генеалогии морали» и в «Так говорил Заратустра», идентичны (см., напр.: Bittner, 1994: 127-128). Возможно, peсентимент - это вторая важная характеристика того проклятья, которое висит над «современным человеком, рожденным европейской культурой».

Вот как Ницше описывает его:

Восстание рабов в морали начинается с того, что ressentiment сам становится творческим и порождает ценности: ressentiment таких существ, которые не способны к действительной реакции, реакции, выразившейся бы в поступке, и которые вознаграждают себя воображаемой местью. В то время как всякая преимущественная мораль произрастает из торжествующего самоутверждения, мораль рабов с самого начала говорит Нет «внешнему», «иному», «несобственному»: это Нет и оказывается ее творческим деянием. Этот поворот оценивающего взгляда - это необходимое обращение вовне вместо обращения к самому себе - как раз и принадлежит к ressentiment: мораль рабов

или получения дохода» (Вебер, 2016: 187). Иными словами, человек обеспечивает свою жизнь в рамках профессий. Он зависит от профессии. Он может существовать практически только в ней. 
всегда нуждается для своего возникновения прежде всего в противостоящем и внешнем мире, нуждается, говоря физиологическим языком, во внешних раздражениях, чтобы вообще действовать, - ее акция в корне является реакцией... Человек ressentiment не откровенен, не наивен, и не честен, и не прям сам с собою. Душа его косит; ум его любит закоулки, тайные дороги и задние двери, все скрытое нравится ему как его мир, его безопасность... он умеет молчать, не забывать, ждать, предварительно унижаться и смиряться. (Ницше, 1996а: 424-425)

Таким образом, ресентимент - это затаенная жажда мести; такая модальность существования человека, в которой он скорее терпит и ждет, нежели активно чему-то сопротивляется. Можно предположить, что именно благодаря этой пассивности, умению терпеть и ждать появляются «последние люди» (как в конце «Протестантской этики» Вебер называет носителей духа рационалистического капитализма). Сам Ницше связывал появление ресентимента с возникновением иудео-христианской религии. Вебер считал, что ресентимент - это частный случай теодицеи страдания и тоже каким-то образом связан с религией. Особенно если социальная ситуация этому благоприятствует. Например, ситуация народапарии, в которой важно «социальное недовольство негативно привилегированных слоев», не способных к успешному политическому действию (Вебер, 2017: 159-161, 165). Чем сложнее становится социальная и политическая ситуация народа-парии, тем сильнее становится его религиозность, говорит Вебер.

Вместе с тем можно предположить, что Вебер не ограничил бы возможность появления ресентимента только религиозной сферой. Современники Вебера выражались более определенно. В. Зомбарт, подход которого иногда противопоставляют подходу Вебера (Давыдов, 1998: 89-111), в данном случае оказывается скорее сторонником Вебера, нежели оппонентом. Зомбарт напрямую связывал «дух капитализма», или «мещанский дух», с ресентиментом:

Ресентимент является отличительной особенностью семейных хроник Альберти. Ранее я уже цитировал места из них, где комичная ребяческая ненависть к «сеньорам», к их кругу, недоступному для него, прямо-таки бросается в глаза; примеры легко умножить. Характерно и то, что каждую тираду против сеньоров, их основного развлечения, охоты, против нравов его клиентов-господ и т.д. он заканчивает фарисейской хвалой собственной добропорядочной «буржуазности». Конечно, и торговые интересы, и плоды философских чтений, и утешительные слова духовника - все влияло на то, что восприятие жизни постепенно обуржуазивалось. Но безмерная бранчливость, в которую Альберти впадает всякий раз, когда заходит речь о «сеньорах», и которая свидетельствует о том, что у него, наверное, был чертовски неудачный опыт общения с ними, - все-таки говорит о другом: главной движущей силой, приведшей его к благоразумному буржуазному мировоззрению, был именно ресентимент. (Цит. по: Шелер, 1999: 149) 
Зомбартовское описание относится к более раннему периоду, нежели тот, в который возник пуританизм, однако это не играет существенной роли в контексте нашего исследования (сам Зомбарт также не считает тезис Вебера лишенным оснований (Зомбарт, 2005: 317) и, по крайней мере, частично соглашается с ним). Важнее то, что и Зомбарт и Вебер воспринимают современный им капитализм сходным образом. С этой же оценкой солидаризируется и Макс Шелер в книге «Ресентимент в структуре моралей». Шелер полностью поддерживает сказанное Зомбартом о ресентименте в связи с Альберти и духом мещанства (Шелер, 1999: 149-150), однако замечает:

В своих работах о происхождении современного капитализма из кальвинизма Макс Вебер и Эрнст Трёльч блестяще показали, что специфически современная тяга к труду... вовсе не является результатом мироутверждающего и жизнеутверждающего способа мыслить и чувствовать (что было, например, в итальянском Возрождении) - она выросла на почве мрачного, враждебного наслаждению кальвинизма, поставившего труду трансцендентную, а потому недостижимую цель («труженик во славу Божию») и одновременно через труд одурманивавшего верующих неопределенностью и сомнением относительно того, будут ли они «призваны» и «избраны». (Там же: 173, 158)

Подобная характеристика практически полностью совпадает с нашей интерпретацией связки «призвания-проклятия» в веберовской «Протестантской этике». Но Шелер вводит еще одну пару — «подло» оценивающих типов: «сопряженный с силой - карьерист»/«сопряженный со слабостью - ресентиментный тип» (Там же: 30). Разница между подлым человеком и благородным (в сравнении с которым Шелер выстраивает два негативных подтипа) в том, что подлый переживает ценности, соотнося собственные ценности с ценностями другого, благородному же ценности даны до сравнения (Там же: 29). Этот подход дает дополнительные коннотации веберовской характеристике человека призвания. Можно предположить, что человек призвания следует ему, для него важна сама суть той деятельности, к которой Бог его призвал. Человек профессии (Berufsmensch) вынужден исполнять ее, делать что-то по сути малозначимое, что-то, для чего очень важна форма. Эти суть и форма между собой сильно связаны, иногда их различает лишь смещение акцента. Для ученого важны публикации, но как только он будет обращать основное внимание не на суть дела, а на количество публикаций и прочие формальные показатели, его профессия-призвание рискует стать проклятьем. Кажется, что веберовский Berufsmensch и шелеровский «карьерист» - это описание одного и того же типа. Если в образе Гёте можно еще видеть прекрасного человека призвания, то в образе Франклина уже присутствует двойственность: соскальзывание из призвания в профессию, из «быть» в «казаться». Это подмечал тот же Зомбарт, описывая на примере Франклина мещанский дух: 
...в деловых интересах - достаточно, если считаешься благопристойным. Быть им, во всяком случае, недостаточно, нужно также считаться им. Вследствие того Бенджамин Франклин и пришел к этому решению: «Чтобы усилить мой кредит и мое положение как делового человека, я заботился о том, чтобы не только быть в действительности трудолюбивым и трезвым, но избегать также всякой видимости противного. Я одевался поэтому просто; я не показывался никогда в таких местах, где устраивались пустые развлечения; я не ходил никогда ловить рыбу, охотиться и т. д.». (Зомбарт, 2005: 169)

Вебер в «Протестантсткой этике» на примере Франклина изображает позитивный тип активного человека (этоса $=$ типа характера = отношения к миру), но, говоря о человеке профессии (Berufsmensch), он уже определенно описывает негативный тип. Пафос Вебера в «Протестантской этике» состоит именно во введении понятия «этос/этика», он пытается показать, как притязание на нравственный идеал оборачивается трагедией. Зомбарт отказывает капиталисту в нравственном идеале. Шелер проводит четкую границу между двумя типами.

Очевидно, что немецкие авторы того времени, работавшие на стыке философии и социальных наук, связывают дух капитализма с чем-то негативным. Возвращаясь к теме о связи религии и ресентимента, нужно отметить, что Шелер, несмотря на замечательную защиту христианства от интерпретации его Ницше как исключительно ресентиментного мировоззрения, все же вынужден был признать, что в целом ряде мест это настроение было характерно для христианства (Шелер, 1999: 46-47, 94). Шелер также связывает ресентимент с особенностями социальной ситуации того или иного типа действия:

Среди известных истории типов человеческой деятельности опасность ресентимента меньше всего угрожает солдату, больше всего - священнику. Об этом справедливо писал Ф. Ницше, не преминув, правда, сделать совершенно недопустимые выпады против религиозной морали. Причины этого достаточно очевидны. «Священник» - тип, который опирается (по крайней мере декларативно) не на земные средства власти; он говорит об их слабости, и в то же время в отличие от homo religiosus служит вполне реальному институту и участвует в мирских партийных противоборствах. К тому же он больше, чем другие, обязан держать в узде, по крайней мере внешне, свои чувства (мстительные порывы, гнев, ненависть), всюду являя и представляя собой образ и принцип внутреннего «смирения». (Там же: 44-45)

По большому счету Шелер здесь описывает то же самое, что и Вебер, говоря о мистицизме: та же «пассивная» религиозность, религиозность принятия, верующий как сосуд, но не как орудие. Однако и Вебер и Шелер выделяют несколько подтипов мистицизма или религиозности принятия. Это позволяет им не сводить все христианство к ресентименту. Вебер будет критиковать использование Ницше категории «ресентимент» по отношению к индуизму и буддизму (Вебер, 2017: 161), которые постулируют, что «страдание заслужено самим индивидом». В ресенти- 
ментной религии считается, что в страдании человека виноват кто-то иной. В целом Шелер полагает, что христианство не могло быть источником тех этических перемен, которые приписывает ему Ницше. Он пишет:

\begin{abstract}
Греческой аксиоме, согласно которой любовь есть стремление низшего к высшему, здесь нанесен смелый удар. Любовь, наоборот, должна проявляться в том, чтобы благородный снизошел, низвел себя до неблагородного, здоровый до больного, богатый до бедного, красивый до безобразного, добрый и святой до злого и подлого, мессия до мытарей и грешников - и все это не только без античного страха потерять себя и самому стать неблагородным, но и в благочестивой вере приобрести в совершении этого акта «снисхождения», «склонения», в этой «самоутрате» нечто более высокое, стать подобным Бory. Трансформация идеи Бога и его отношения к миру и человеку не причина, а следствие этого поворота в движении любви. Теперь Бог не есть, подобно звезде, вечная, покоящаяся цель; он больше не движет миром, как «любимый движет любящим», но сама его сущность становится любовью и служением, а следовательно - и творением, волением, деянием. (Шелер, 1999: 73-74)
\end{abstract}

Итак, с точки зрения Ницше, угнетенные слои общества создали такую картину мира, в которой признавали не важным все, чего они не могли сделать. Важным же они считали только маленькое, ничтожное, убогое, легко достижимое. С точки зрения Шелера, идея христианства состояла в другом: важно не высокое, дорогое, сильное само по себе, важна любовь. Тот, у кого она была, достигал полноты жизни, вне зависимости от того, на какие объекты эта любовь направлена. «Нас влечет жертвовать - до того, как мы узнаем, кому, почему и зачем! - пишет Шелер. - Образ природы и жизни у Иисуса, который можно воссоздать по разрозненным крупицам и намекам из его речей и метафор, позволяет утверждать, что для него это был очевидный факт» (Там же: 80). Таким образом, Шелер, защищая христианство от критики Ницше, 1) признает, что христианству не до конца удалось избавиться от ресентимента, но 2) предъявляет позитивный вариант христианской духовности, совершенно не похожий на призвание.

Защита христианства в целом, представленная Шелером в «Ресентименте», уточняется в статье «О реабилитации добродетели», соседствующей с «Ресентиментом» в сборнике «О перевороте в ценностях». Основной частью этой статьи является экскурс о смирении. То, как Шелер пишет о смирении, повторяет его защиту христианского идеала, представленного в «Ресентименте». Создается впечатление, что именно смирение и есть вторая часть этической дихотомии, где первая - призвание. Двумя ключевыми составляющими смирения, по Шелеру, являются 1) отказ от эго (потеря эго, отпускание его), то есть от достоинства, заслуг, прав, собственной ценности, уважения людей, самоуважения, и 2) восприятие мира как дара (Scheler, 2005: 24).

Шелер пытается описать «смирение» с помощью ряда различений, например, «intensification of the spirit» против «relaxation of the spirit and will». Ссылаясь на 
У. Джеймса, он говорит о двух типах обращения: «основанном на воле» («based in the will») и «основанном на самоотречении» («based in self-abandonment»). Описывая второй тип, Шелер приводит цитату из Джеймса, характеризующую соответствующий опыт, в которой повествование строится на фрагменте из автобиографической повести Фрэнка Баллена (Frank Bullen) «С Христом в море: религиозная автобиография». Баллен во время мощной бури пытается закрепить паруса, но его выбрасывает за борт; каким-то образом его нога оказывается обмотанной веревкой, и только поэтому он не падает в море и какое-то время висит над водой. Но одновременно в этот момент он чувствует «только высокое ликование моей уверенности в вечной жизни». Баллен говорит:

Я висел там вряд ли более пяти секунд, но в это время я прожил целую вечность наслаждения» - и далее так подытоживает прожитое в этой ситуации: «Это внутреннее чудо вечно обновляемого возрождения и получения из бесконечного резервуара энергии силы для того, чтобы «закрепить паруса» посредством полного отречения от «собственных сил» и даже от малейшего чувства собственного достоинства, это и есть та цель, к которой бессознательно направлены все формы смирения. (Цит. по: Scheler, 2005: 30)

Кажется, что шелеровская дихотомия человеческих типов, связанных с силой, может быть соотнесена с веберовской парой «аскет ${ }^{20}-$ человек профессии (Berufsmensch)». В ряде мест своей книги Шелер фактически озвучивает дихотомию «смирение - призвание», апеллируя к веберовским работам в одних текстах сборника и к идеям смирения - в других; хотя полного совпадения между позициями двух авторов здесь нет.

\section{Вместо заключения}

Возвращаясь к вопросу о том, чем «Протестантская этика» может быть полезна сегодня при исследовании современного русского православия и его влияния на экономику страны, можно резюмировать: выделив ключевые этические категории, содержащиеся в проповеди той или иной Церкви, можно определить направление, в котором должно идти образование гипотез о характере фундаментального влияния этой Церкви на ее последователей. Веберовская рецепция ницшеанского пессимистического взгляда на современного человека и идей о ре-

2о. Возможно, правильнее будет говорить о трех типах человека у Вебера, который в неявном виде предлагает следующую классификацию: 1) человек, живущий полной и разнообразной жизнью; 2) человек призвания; 3) человек профессии. Примером первого типа человека мог бы служить Гёте; примером человека призвания - Франклин, который, с одной стороны, воплощает в себе некоторые черты предыдущего типа (человека, живущего многообразной жизнью), а с другой - постепенно редуцирует эту полноту посредством ориентации на призвание. Человек профессии живет и действует в рамках своей профессии. У Шелера дихотомия человеческих типов, связанных с силой, скорее соотносится с первым и третьим типами веберовской типологии. Но для нашего разбора мы можем пренебречь веберовским первым типом и несколько упростить конструкцию. 
сентименте или «последних людях» предлагает исследователю иную перспективу, помимо прямолинейной оценки «продуктивности - непродуктивности» религии с точки зрения роста ВВП. Вебер обращается к Гёте ${ }^{21}$ и Франклину не только и не столько в связи с идеями экономической продуктивности, но исходя из проблемы полноты человеческого (Kent, 1983), понимания того, как должно или может быть устроено общество, чтобы позволить человеку избежать проклятья Berufsmensch и ресентимента. В этом отношении веберовская постановка вопроса ближе к позициям таких современных исследователей, как А. Сен и М. Нуссбаум (Nussbaum, Sen, 1993), критикующих рассмотрение ВВП как основного измерителя качества человеческого общежития. Веберовская демонстрация следствий доминирования призвания в этической сфере, с одной стороны, выступает важным предостережением, с другой - все же указывает на внутримирской аскетизм как на возможный вариант решения проблемы.

Ряд авторов (Тюрель, 1999; Mitzman, 2005) считают, что Вебер с большим интересом относился к мистицизму, выросшему на почве русского православия и отраженному в романах Толстого и Достоевского (Тюрель, 1999). Однако, как нам кажется, сам Вебер скорее разделял пессимизм Толстого, нежели видел в его рецептах какое-то решение 22 .

Мы попытались рассмотреть этическую часть «Протестантской этики» Вебера с целью обнаружить ее некоторые до сих пор не использованные ресурсы для анализа современного русского православия и его потенциального влияния на своих последователей. Опираясь на другие работы Вебера, мы попытались определить ту категорию, которая могла бы быть аналогом Beruf в православии. На наш взгляд, это категория «смирение». Вебер использует ее при описании мистицизма (в том числе применительно к русскому православию); в рассуждениях о ресентименте и «последних людях» Ницше, отражая атаки Ницше на христианство, обращаясь

21. «Что ограничение человеческой деятельности рамками профессии вместе с отказом от фаустовской многосторонности (который, естественно, вытекает из этого ограничения) является в современном мире обязательной предпосылкой плодотворного труда, что, следовательно, «дело» и «отречение» в настоящее время взаимосвязаны - этот основной аскетический мотив буржуазного стиля жизни (при условии, что речь идет именно о стиле, а не об отсутствии его) хотел довести до нашего сознания уже Гёте на вершине своей жизненной мудрости» (Вебер, 1990а: 205-206).

22. В веберовском тексте есть одно важное рассуждение касательно данной проблемы: «В настоящее время дух аскезы - кто знает, навсегда ли? - ушел из этой мирской оболочки. Во всяком случае, победивший капитализм не нуждается более в подобной опоре с тех пор, как он покоится на механической основе» (Вебер, 1990а: 206). Но что это значит из богословско-этической перспективы? Что значит, что дух аскезы ушел? Что капитализм оторвался от религиозных корней? Ведь этика призвания никуда не делась по большому счету. Что изменилось? Можно предположить, что причиной является следующая этическая перемена. Призвание (да и смирение) уже не рассматривается как средство для спасения. Оно стало важно само по себе. Постепенно перед верующим перестала стоять проблема спасения. Проблемой остался поиск призвания (или достижения смирения). См. разработку идеи реификации в связи с работами Вебера, в первую очередь - с «Протестантской этикой» (Mitzman, 2005: 4, 172). 
к идеям Шелера. Таким образом, данная категория играет важную роль в наследии Вебера ${ }^{23}$.

Что же нового дает нам категория «смирения» для исследования современного русского православия и его способа формирования характера православного человека? Во-первых, веберовская (и зомбартовско-шелеровская) разработка ницшеанского тезиса о ресентименте позволяет построить типологию этосов религии, того этического отношения, которое характерно для разных религиозных организаций (см. табл. 2).

Таблица 2. Типология этосов

\begin{tabular}{|c|c|c|c|}
\hline & \multicolumn{2}{|c|}{ «Шелер» } \\
\hline & & $\begin{array}{c}\text { «Благородные» } \\
\text { типы }\end{array}$ & $\begin{array}{c}\text { «Подло» оцени- } \\
\text { вающие типы }\end{array}$ \\
\hline \multirow{2}{*}{ «Вебер» } & $\begin{array}{l}\text { Активная религиоз- } \\
\text { ность } \approx \text { «Аскетизм» }\end{array}$ & «Призвание» & «Карьеризм» \\
\hline & $\begin{array}{l}\text { Пассивная религиоз- } \\
\text { ность } \approx \text { «истицизм» }\end{array}$ & «Смирение» & «Ресентимент» \\
\hline
\end{tabular}

Эта типология отношений религиозных организаций к миру позволяет оценивать, какие именно этические предписания транслирует та или иная церковь своим последователям. Если предположить, что для русского православия характерен «мистицизм» и его основной этос - смирение, то ключевой задачей для представителей Церкви будет избегание отношений по типу ресентимента. Именно эта опасность подстерегает «пассивный», «воспринимающий» тип религиозности. Более важным для священников может стать противопоставление не смирения и призвания, а смирения и ресентимента. Если перед ними будет поставлена задача реформировать РПЦ, то, на наш взгляд, стоит в первую очередь попытаться максимально избавиться от ресентимента.

Сказанное Ницше и Вебером о смирении позволяет понять, что это слово может обозначать различные практики и этические установки. Веберовский мистик находится один на один с Богом. Его смирение гораздо ближе к тому, что Шелер обозначил как принятие мира как дара. Человек смирения и ресентимента у Ницше - это человек пресмыкающийся, терпящий, завидующий, желающий отомстить и молящийся об отмщении. Все это подразумевает отношения не только

23. Подобный вывод совпадает с некоторыми результатами эмпирических исследований, проведенных в последние годы (Забаев, 2012; Русселе, 2011; Кнорре, 2011; Дубовка, 2015). Кроме того, именно эти категории описываются в начале XX века С. Булгаковым как те, которые составляют ядро православного отношения к жизни. Булгаков видел большой потенциал в человеке, движимом подобной мотивацией (Булгаков, 1997б: 288-294). Вместе с тем он отмечал, что именно такое отношение к миру раздражало русскую интеллигенцию того времени. Раздражение было, по-видимому, не случайным. Категории смирения и послушания описывали некоторые важные черты того мира, от которого человек Просвещения, человек модернизации и русская интеллигенция как их воплощение хотели избавиться. Это раздражение можно было видеть в цитированных нами фрагментах Ницше. 
с Богом, но и с другим человеком, который может занимать совершенно разные позиции: быть врагом, начальником, ближним, наконец, священником, то есть посредником между человеком и Богом. А это, в свою очередь, предполагает целую палитру возможных отношений. Анализ православного дискурса может помочь выяснить, что доминирует в нем: смирение как кротость или смирение как подчинение; смирение только перед Богом (как у средневековых рыцарей или воинов ислама) или смирение перед другим человеком, который, возможно, лучше тебя. Это смирение может оказаться отказом от действия, иждивенчеством, непротивлением злу или смирением, которое позволяет примириться со своими недостатками, не думать о них и шаг за шагом выполнять послушание. Может проповедоваться смирение, позволяющее не выпячивать свое «Я», слушать других людей, за счет этого обогащаться новыми идеями, претворять их в жизнь, капитализировать эти результаты и становиться, таким образом, экономически продуктивным. Для анализа всего этого, а также для анализа потенциальных последствий тех или иных сторон данного этоса требуется развернутая исследовательская программа. Возможно, подобные исследования, находясь в избирательном сродстве с этикой и догматикой Церкви, могут оказаться средством ее внутреннего развития и изменения; причем в гораздо большей степени, нежели критические замечания в отношении тех или иных ее доктрин и практик. По крайней мере, если верить Веберу, центральное звено во всей этой схеме именно этика.

\section{Литература}

Бельшовский А. (1908). Гёте: его жизнь и произведения. СПб.: Л. Ф. Пантелеев.

Болтански Л., Кьяпелло Э. (2011). Новый дух капитализма / Пер. с франц. О. Волчек, Н. Калягиной, С. Рындина и др. М.: Новое литературное обозрение.

Булгаков С. (1997а). Народное хозяйство и религиозная личность // Булгаков С. Два града: исследования о природе общественных идеалов. СПб.: Изд-во РХГИ. C. 111-125.

Булгаков С. (1997б). Героизм и подвижничество // Булгаков С. Два града: исследования о природе общественных идеалов.СПб.: Изд-во РХГИ. С. 275-299.

Бурдье П. (2005). Генезис и структура поля религии / Пер. с франц. О. И. Кирчик // Бурдве П. Социальное пространство: поля и практики. СПб.: Алетейя. С. 7-75.

Вебер М. (1990а). Протестантская этика и дух капитализма / Пер. с нем. М. И. Левиной // Вебер М. Избранные произведения. М.: Прогресс. С. 61-272.

Вебер М. (1990б). Протестантские секты и дух капитализма / Пер. с нем. М. И. Левиной // Вебер М. Избранные произведения. М.: Прогресс. С. 273-306.

Вебер М. (199ов). Наука как призвание и профессия / Пер. с нем. П. П. Гайденко // Вебер М. Избранные произведения. М.: Прогресс. С. 707-736.

Вебер М. (1994а). Социология религии (типы религиозных сообществ) / Пер. с нем. М. И. Левиной // Вебер М. Избранное. Образ общества. М.: Юрист. С. 78-3о8. 
Вебер М. (19946). Хозяйственная этика мировых религий. Попытка сравнительного исследования в области социологии религии. Введение / Пер. с нем. М. И. Левиной // Вебер М. Избранное. Образ общества. М.: Юрист. С. 43-73.

Вебер М. (2016). Хозяйство и общество: очерки понимающей социологии. Т. 1: Социология / Пер. с нем. В. А. Брут-Цехового, Л. Г. Ионина, И. А. Судариковой, А. Н. Беляева, Д. Б. Цыганкова под ред. Л. Г. Ионина. М.: ВШЭ.

Вебер М. (2017). Хозяйство и общество: очерки понимающей социологии. Т. 2: Общности / Пер. с нем. И. А. Судариковой, А. В. Михайловского, М. И. Левиной, В. А. Брут-Цехового, Д. Б. Цыганкова под ред. Л. Г. Ионина. М.: ВШЭ.

Врублевская П. В. (2016). Круговорот детских вещей в приходской церкви: к вопросу о значении дарообмена // Религиоведческие исследования. № 1. С. 103-127.

Габдрахманова Г. Ф. (2010). Особенности социально-экономических взглядов православных и мусульман и перспективы изучения (по материалам исследований в Республике Татарстан) // Вопросы культурологии. № 11. С. 49-54.

Гориков М. К., Тихонова Н. Е. (2010). Готово ли российское общество к модернизации? // Общество и экономика. № 5. С. 105-172.

Давыдов Ю. Н. (1998). Макс Вебер и современная теоретическая социология: актуальные проблемы веберовского социологического учения. М.: Мартис.

Димаджио П., Пауэлл У. (2010). Новый взгляд на «железную клетку»: институциональный изоморфизм и коллективная рациональность в организационных полях / Пер. с англ. Г. Б. Юдина // Экономическая социология. Т. 11. № 1. С. 35-56.

Дубовка Д. (2015). Забытое время, или Практики самотрансформации в современном православном монастыре // Государство, религия, церковь в России и за рубежом. № 3. С. 322-344.

Ефремова М. В. (2010). Влияние религиозной идентичности на экономические установки и представления россиян // Альманах современной науки и образования. № 10. С. 90-95.

Ефремова М. В. (2014). Роль религиозной идентичности в моделях экономического поведения: межконфессиональный анализ // Актуальные проблемы психологического знания. № 1. С. 20-30.

Забаев И. В. (2012). Основные категории хозяйственной этики современного русского православия: социологический анализ. М.: Изд-во ПСТГУ.

Забаев И., Орешина Д., Пруцкова Е. (2014). Социальный капитал русского православия в начале XXI в.: исследование с помощью методов социально-сетевого анализа // Государство, религия, церковь в России и за рубежом. № 1. С. 40-66.

Зарубина Н. Н. (1997). Модернизация и хозяйственная культура (концепция М. Вебера и современные теории развития) // Социологические исследования. № 4. C. 46-54.

Зомбарт В. (2005). Буржуа: к истории духовного развития современного экономического человека. СПб.: Владимир Даль.

Йоас Х., Кнёбль В. (2011). Социальная теория: двадцать вводных лекций / Пер. с нем. К. Г. Тимофеевой. СПб.: Алетейя. 
Капелюшников Р. И. (2018). Гипноз Вебера (заметки о «Протестантской этике и духе капитализма»). Препринт $\mathrm{WP}_{3} / 2018 / 01$. М.: ВШЭ.

Кнорре Б. (2011). Категории вины и смирения в системе ценностей церковно-приходской субкультуры // Агаджанян А., Русселе К. (ред.). Приход и община в современном православии: корневая система российской религиозности. М.: Весь мир. С. 317-340.

Кулинченко В. А., Кулинченко А. В. (2003). О духовно-культурных основаниях модернизации России // Полис. № 2. С. 150-156.

Лапин Н. И. (2011). Социокультурные факторы российской стагнации и модернизации // Социологические исследования. № 9. С. 317.

Лукман Т. (2014). Дополнение к третьему немецкому изданию «Невидимой религии» / Пер. с нем. Е. Костровой, И. Забаева // Социологическое обозрение. Т. 13. № 1. С. $139-153$.

Малинкин А. Н. (1997). Учение Макса Шелера о ресентименте и его значение для социологии // Социологический журнал. № 4. С. 116-150.

Малкина М. Ю. (2011). Институциональные ловушки инновационного развития российской экономики // Журнал институциональных исследований. Т. 3. № 1 . C. $50-60$.

Маркс К. (1955). К критике гегелевской философии права. Введение // Маркс К., Энгельс Ф. Полное собрание сочинений. Т. 1. М.: Госполитиздат. С. 414-429.

Митрохин Н. А., Эдельштейн М. Ю. (20о0). Экономическая деятельность Русской Православной Церкви и ее теневая составляющая. М.: РГГУ.

Несбё Ю. (2017). Жажда. СПб.: Азбука.

Ницие Ф. (1996а). К генеалогии морали / Пер. с нем. К. А. Свасьяна // Ницие Ф. Сочинения. Т. 2. М.: Мысль. С. 407-524.

Ницие Ф. (19966). Так говорил Заратустра. Книга для всех и никого / Пер. с нем. Ю. М. Антоновского // Нищие Ф. Сочинения. Т. 2. М.: Мысль. С. 6-237.

Орешина Д. А. (2016). Партнёрский приход: сотрудничество священнослужителей и мирян как фактор развития социальной деятельности в современных приходах Русской Православной Церкви // Вестник Православного Свято-Тихоновского гуманитарного университета. Серия 1: Богословие. Философия. Религиоведение. Вып. 5. С. 99-120.

Павлюткина Е. Л. (2012). «Скрепление» и ответственность: специфика некоммерческих организаций в работе с бездомными (на примере религиозных организаций) // Журнал исследований социальной политики. Т. 1о. № 4. С. 539-554.

Расков Д. Е. (2012). Экономические институты старообрядчества. СПб.: СПбГУ.

Рингер $\Phi$. (20о8). Закат немецких мандаринов: академическое сообщество в Германии, 1890-1933 / Пер. с англ. Е. Канищевой и П. Гольдина. М.:. Новое литературное обозрение.

Русселе К. (2011). Об отношениях между священниками и мирянами: послушание и благословение // Агаджанян А., Русселе К. (ред.). Приход и община в совре- 
менном православии: корневая система российской религиозности. М.: Весь Мир. С. 298-316.

Савельев Д. А., Сусоколов А. А. (2011). Иудаизм и этика предпринимательства // Лебедева Н. М., Татарко А. Н. (ред.). Культура и экономическое поведение. М.: МАКС-Пресс. С. 261-303.

Савченко В. В. (2006). Экономическая культура как фактор развития общества // Наука. Инновации. Технологии. № 1. С. 88-97.

Стиглии, Д., Сен А., Фитусси Ж.-П. (2016). Неверно оценивая нашу жизнь: почему ВВП не имеет смысла. Доклад Комиссии по измерению эффективности экономического и социального прогресса. М.: Изд-во Института Гайдара.

Сусоколов А. А. (2009). Ислам и предпринимательство в России // Журнал социологии и социальной антропологии. Т. 12. № 1. С. 32-51.

Сусоколов А., Четьцчинская О. (2008). Влияние религиозной принадлежности на установки в сфере предпринимательства (на примере современной России) // Вопросы культурологии. № 6. С. 32-36.

Счастная T. В. (2011). Стратегия развития банковского сектора и модернизация российской экономики // Вестник Томского государственного университета. Экономика. Т. 3. № 15. С. 120-125.

Тейлор Ч. (2017). Секулярный век / Пер. с англ. А. Васильева, Л. Колкера, А. Лукьянова под ред. А. Бодрова. М.: ББИ.

Тюрель X. (1999). Интеллектуальная религиозность, семантика «смысла», этика братства: Макс Вебер и его отношение к Толстому и Достоевскому / Пер. с нем. Р. П. Шпаковой // Журнал социологии и социальной антропологии. Т. 2. № 4. C. 23-32.

Федотова В. Г. (2007). Человеческий капитал, персональная модернизация и проблема развития человека (окончание) // Знание. Понимание. Умение. № 2. C. 21-27.

Федотова В. Г., Кросс Ш. (2006). Православие, Вебер и новый русский капитализм // Общественные науки и современность. № 2. С. 41-51.

Франииск, папа римский. (2014). Апостольское обращение Evangelii Gaudium. M.: Изд-во Францисканцев.

Чимирис Е. С., Донцев С. П. (2010). Церковь и модернизация в России: в поиске новых ценностных основ // Полис. № 6. С. 68-75.

Шелер М. (1999). Ресентимент в структуре моралей / Пер. с нем. А. Н. Малинкина. М.: Наука.

Шкаратан О. И., Карачаровский В. В. (2002). Русская трудовая и управленческая культура: опыт исследования в контексте перспектив экономического развития // Мир России. Т. 11. № 1. С. 3-56.

Шмырова Н. В. (2010). Модернизация российской экономики и основные пути ее осуществления в современный период // Вестник Нижегородского университета им. Н. И. Лобачевского. № 3. С. 639-643. 
Щербакова Л. А. (2010). Модернизация российской экономики: многофакторная задача со многими неизвестными // ЭКО. № 9. С. 73-93.

Элбакян Е. С., Медведко С. В. (2001). Влияние религиозных ценностей на экономические предпочтения верующих россиян // Социологические исследования. № 8. С. 103-111.

Юдин Г. Б., Орешина Д. А. (2016). Дарообмен и регуляция потребительского кредитования в сообществах: случай православных приходских общин // Социологический журнал. Т. 22. № 2. С. 110-134.

Ясин Е. Г. (2001). Модернизация российской экономики: что в повестке дня // Экономический журнал Высшей школы экономики. Т. 5. № 2. С. 158-178.

Ясин Е., Яковлев А. (2004). Конкурентоспособность и модернизация российской экономики // Вопросы экономики. № 7. С. 4-34.

Adair-ToteffC. (2002). Max Weber's Mysticism // European Journal of Sociology. Vol. 43. № 3. P. 339-353.

Allahyari Rebecca A. (2000). Visions of Charity: Volunteer Workers and Moral Community. Berkeley: University of California Press.

Baehr P. (2001). The «Iron Cage» and the «Shell as Hard as Steel»: Parsons, Weber, and the Stahlhartes Gehäuse Metaphor in the Protestant Ethic and the Spirit of Capitalism. History and Theory. Vol. 40. № 2. P. 153-169.

Barro R. J., McCleary R. (2003). Religion and Economic Growth. NBER Working Paper № 9682. Cambridge: National Bureau of Economic Research.

Bauman Z. (2004). Work, Consumerism and the New Poor. Maidenhead: McGraw-Hill.

Becker S. O., Woessmann L. (2009). Was Weber Wrong? A Human Capital Theory of Protestant Economic History // Quarterly Journal of Economics. Vol. 124. № 2. P. 531-596.

Bellah R. N. (1957). Tokugawa Religion: The Values of Pre-industrial Japan. Glencoe: Free Press.

Bellah R. N. (1963). Reflections on the Protestant Ethic Analogy in Asia // Journal of Social Issues. Vol. 19. № 1. P. 52-60.

Bellah R. N., Madsen R., Sullivan W. M., Swidler A., Tipton S. M. (1985). Habits of the Heart: Individualism and Commitment in American Life. N.Y.: Harper \& Row.

Bittner R. (1994). Ressentiment // Schacht R. (ed.) Nietzsche, Genealogy, Morality: Essays on Nietzsche's On the Genealogy of Morals. Berkeley: University of California Press. P. $127-138$.

Blum U., Dudley L. (2001). Religion and Economic Growth: Was Weber Right? // Journal of Evolutionary Economics. Vol. 11. № 2. P. 207-230.

Brodrick J. (1934). The Economic Morals of the Jesuits: An Answer to Dr. H. M. Robertson. Oxford: Oxford University Press.

Buss A. (1989). The Economic Ethics of Russian-Orthodox Christianity, Part I // International Sociology. Vol. 4. № 3. P. 235-258.

Buss A. E. (2003). The Russian-Orthodox Tradition and Modernity. Leiden: Brill. 
Cadge W., Wuthnow R. (2003). Religion and the Nonprofit Sector // Steinberg R., Powell W. (eds.). The Nonprofit Sector: A Research Handbook. New Haven: Yale University Press. P. 444-466.

Campante F., Yanagizawa-Drott D. (2015). Does Religion Affect Economic Growth and Happiness? Evidence from Ramadan // Quarterly Journal of Economics. Vol. 130. № 2. P. 615-658.

Campbell C. (1987). The Romantic Ethic and the Spirit of Modern Consumerism. Oxford: Basil Blackwell.

Collins R. (1997). An Asian Route to Capitalism: Religious Economy and the Origins of Self-Transforming Growth in Japan // American Journal of Sociology. Vol. 62. № 6. P. 843-865.

Delacroix J., Nielsen F. (2001). The Beloved Myth: Protestantism and the Rise of Industrial Capitalism in Nineteenth-Century Europe // Social Forces. Vol. 80. № 2. P. 509-553.

Durlauf S. N., Kourtellos A., Tan C. M. (2012). Is God in the Details? A Reexamination of the Role of Religion in Economic Growth // Journal of Applied Econometrics. Vol. 27. № 7. P. 1059-1075.

Eisenstadt S. N. (1968). The Protestant Ethic and Modernization. N.Y.: Basic Books.

Fanfani A. (1935). Catholicism, Protestantism and Capitalism. L.: Sheed \& Ward.

Fischer H. K. (1978). Kritische Beiträge zu Professor Max Webers Abhandlung «Die Protestantische Ethik und der Geist des Kapitalismus» // Weber M. Die Protestantische Ethik II: Kritiken und Antikritiken. Gütersloh: Mohn. S. 11-26.

Gabriel I., Kirchschläger P. G., Sturn R. (Hg.). (2017). Eine Wirtschaft, die Leben fördert: Wirtschafts- und unternehmensethische Reflexionen im Anschluss an Papst Franziskus. Ostfildern: Grünewald.

Gooren H. P. P. (2001). Rich among the Poor: Church, Firm, and Household among SmallScale Entrepreneurs in Guatemala City. West Lafayette: Purdue University Press

Gorski P. S. (1993). The Protestant Ethic Revisited: Disciplinary Revolution and State Formation in Holland and Prussia // American Journal of Sociology. Vol. 99. № 2. P. $265-316$.

Greeley A. (1997). Coleman Revisited: Religious Structures as a Source of Social Capital // American Behavioral Scientist. Vol. 40. № 5. P. 587-594.

Grier R. (1997). The Effect of Religion on Economic Development: A Cross National Study of 63 Former Colonies // Kyklos. Vol. 50. № 1. P. 47-62.

Guiso L., Sapienza P., Zingales L. (2003). People's Opium? Religion and Economic Attitudes // Journal of Monetary Economics. Vol. 50. № 1. P. 225-282.

Guiso L., Sapienza P., Zingales L. (2006). Does Culture Affect Economic Outcomes? // Journal of Economic Perspectives. Vol. 20. № 2. P. 23-48.

Hennis W. (1998). Max Weber: Essays in Reconstruction / Transl. K. Tribe. L.: Allen \& Unwin.

Hoffman M. (2013). Usury in Christendom: The Mortal Sin That was and Now is Not. Idaho: Independent History and Research.

Hoge Dean R. (1996). Money Matters: Personal Giving in American Churches. Louisville: Westminster John Knox. 
Holl K. (1965). Gesammelte Aufsätze zur Kirchengeschichte. Bd. 3: Der Westen. Darmstadt: Wissenschaftliche Buchgesellschaft.

Hyma A. (1938). Calvinism and Capitalism in the Netherlands // Journal of Modern History. Vol. 10. № 3. P. 321-343.

Kent S. A. (1983). Weber, Goethe, and the Nietzschean Allusion: Capturing the Source of the «Iron Cage» Metaphor // Sociological Analysis. Vol. 44. № 4. P. 297-319.

Knack S., Keefer P. (1997). Does Social Capital Have an Economic Payoff? A Cross-country Investigation // Quarterly Journal of Economics. Vol. 112. № 4. P. 1251-1288.

Krech V. (2001). Mystik // Kippenberg H. G., Riesebrodt M. (Hg.). Max Webers «Religionssystematik». Tübingen: J. C. B. Mohr. S. 241-262.

Kuran T. (2001). The Provision of Public Goods under Islamic Law: Origins, Impact, and Limitations of the Waqf System // Law and Society Review. Vol. 34. № 4. P. 841-898.

Lanczkowski G., Schrey H.-H., Wingren G. (1980). Beruf // Müller G. (Hg.). Theologische Realenzyklopädie. Bd. 5. Berlin: De Gruyter. S. 654-676.

Lehmann H., Roth G. (eds.). (1995). Weber's Protestant Ethic: Origins, Evidence. Cambridge: Cambridge University Press.

Luckmann T. (1990). Shrinking Transcendence, Expanding Religion? // Sociological Analysis. Vol. 51. № 2. P. 127-138.

Mackinnon M. (1988a). Calvinism and the Infallible Assurance of Grace // British Journal of Sociology. Vol. 39. № 2. P. 143-177.

Mackinnon M. (1988b). Weber's Exploration of Calvinism // British Journal of Sociology. Vol. 39. № 2. P. 178-210.

Makridis V. N. (2010). Orthodox Christianity and Economic Development: The Case of Greece // Teme. Vol. 34. № 1. P. 225-238.

Marshal G. (1979). The Weber Thesis and the Development of Capitalism in Scotland // Scottish Journal of Sociology. № 3. P. 173-211.

Marshal G. (1980a). Presbyteries and Profits: Calvinism and the Development of Capitalism in Scotland, 1560-1707. Oxford: Clarendon Press.

Marshal G. (1980b). The Dark Side of Weber Thesis: The Case of Scotland // British Journal of Sociology. Vol. 31. № 3. P. 419-440.

Martin B. (1995) New Mutations of the Protestant Ethic among Latin American Pentecostals // Religion. Vol. 25. № 2. P. 101-117.

Martin B. (1998) From Pre- to Post-Modernity in Latin America: The Case of Pentecostalism // Heelas P., Martin D., Morris P. (eds.). Religion, Modernity and Postmodernity. Oxford: Blackwell. P. 102-146.

Merchel J. (2008). Trägerstrukturen in der Sozialen Arbeit: Eine Einführung. Weinheim: Beltz Juventa.

Mitzman A. (2005). The Iron Cage: An Historical Interpretation of Max Weber. New Brunswick: Transaction.

Müller-Armack A. (1945). Zur Religionssoziologie des europäischen Ostens // Weltwirtschaftliches Archiv. Jg. 61. № 2. P. 163-192. 
Mutch A. (2009). Weber and Church Governance: Religious Practice and Economic Activity // Sociological Review. Vol. 57. № 4. P. 586-607.

Mutch A. (2012). Theology, Accountability and Management: Exploring the Contributions of Scottish Presbyterianism // Organization. Vol. 19. № 3. P. 363-379.

Nelson B. (1969). The Idea of Usury: From Tribal Brotherhood to Universal Otherhood. Chicago: University of Chicago Press.

Novak M. (1993). The Catholic Ethic and the Spirit of Capitalism. N.Y.: Free Press

Nussbaum M., Sen A. (eds.). (1993). The Quality of Life. Oxford: Oxford University Press.

Overman S. J. (2011). The Protestant Ethic and the Spirit of Sport: How Calvinism and Capitalism Shaped America's Games. Macon: Mercer University Press.

Owen S., Taira T. (2015). The Category of «Religion» in Public Classification: Charity Registration of the Druid Network in England and Wales // Stack T., Goldenberg N. R., Fitzgerald T. (eds.). Religion as a Category of Governance and Sovereignty. Leiden: Brill. P. 90-114.

Paretskaya A. (2010). The Soviet Communist Party and the Other Spirit of Capitalism // Sociological Theory. Vol. 28. № 4. P. 377-401.

Parsons J. (2014). Vocation in Seventeenth-Century France: The Catholic Ethic and the Spirit of étatisme // French History. Vol. 28. № 3. P. 322-342.

Porta R. L., Lopez-De-Silane F., Shleifer A., Vishny R. W. (1996). Trust in Large Organizations. NBER Working Paper № 5864. Cambridge: National Bureau of Economic Research.

Putnam R. D. (200o). Bowling Alone: America’s Declining Social Capital // Crothers L., Lockhart Ch. (eds.). Culture and Politics: A Reader. Basingstoke: Palgrave Macmillan. P. 223-234.

Quinn D. M., Crocker J. (1999). When Ideology Hurts: Effects of Belief in the Protestant Ethic and Feeling Overweight on the Psychological Well-Being of Women // Journal of Personality and Social Psychology. Vol. 77. № 2. P. 402-414.

Rachfahl F. (1978). Kalvinismus und Kapitalismus // Weber M. Die Protestantische Ethik II: Kritiken und Antikritiken. Gütersloh: Mohn. S. 57-148.

Robertson H. M. (1933). Aspects of the Rise of Economic Individualism: A Criticism of Max Weber and His School. Cambridge: University Press.

Salarzehi H., Armesh H., Nikbin D. (2010). Waqf as a Social Entrepreneurship Model in Islam // International Journal of Business and Management. Vol. 5. № 7. P. 179-186.

Samuelsson K. (1961). Religion and Economic Action: The Protestant Ethic, the Rise of Capitalism, and the Abuse of Scholarship. N.Y.: Harper \& Row.

Scheler M. (2005). On the Rehabilitation of Virtue // American Catholic Philosophical Quarterly. Vol. 79. № 1. P. 21-37.

Schluchter W. (1987) Weber's Sociology of Rationalism and Typology of Religious Rejections of the World // Whimster S., Lash S. (eds.). Max Weber, Rationality and Modernity. L.: Routledge. P. 92-118.

Schluchter W. (1988a). Max Webers Sicht des okzidentalen Christentums: Interpretation und Kritik. Frankfurt am Main: Suhrkamp. 
Schluchter W. (1988b). Religion und Lebensführung. Frankfurt am Main: Suhrkamp.

Schluchter W. (1995). Ethik und Kapitalismus: Zwei Thesen Max Webers // Berliner Journal für Soziologie. № 3. S. 335-347.

Schluchter W. (2009). Die Entzauberung der Welt: Sechs Studien zu Max Weber. Tübingen: Mohr Siebeck.

Schluchter W., GrafF. W. (2005). Asketischer Protestantismus und «Geist» des modernen Kapitalismus: Max Weber und Ernst Troeltsch. Tübingen: Mohr Siebeck.

Schroeder W. (2017). Die Fallstudien: Caritas und Diakonie im Transformationsprozess // Schroeder W. Konfessionelle Wohlfahrtsverbände im Umbruch: Fortführung des deutschen Sonderwegs durch vorsorgende Sozialpolitik. Berlin: Springer. S. 51-103.

Sexton J. (1978) Protestantism and Modernization in Two Guatemalan Towns // American Ethnologist. Vol. 5. № 2. P. 280-302.

Sosis R. (2005). Does Religion Promote Trust? The Role of Signaling, Reputation, and Punishment // Interdisciplinary Journal of Research on Religion. Vol. 1. Article 7. URL: http://www.religjournal.com/articles/article_view.php?id=7 (дата доступа: 28.02.2018).

Stauth G. (1992). Nietzsche, Weber, and the Affirmative Sociology of Culture // European Journal of Sociology. Vol. 33. № 2. P. 219-247.

Stokes R. G. (1975). Afrikaner Calvinism and Economic Action: The Weberian Thesis in South Africa // American Journal of Sociology. Vol. 81. № 1. P. 62-81.

Swatos W., Boulder L. K. L. (eds.). (2005). The Protestant Ethic Turns 100: Essays on the Centenary of the Weber Thesis. Boulder: Paradigm.

Tamari M. (1987). «With All Your Possessions»: Jewish Ethics and Economic Life. N.Y.: Free Press.

Tawney R. H. (1926). Religion and the Rise of Capitalism. New Brunswick: Transaction.

Trevor-Roper H. R. (1967). Religion, Reformation and Social Change // Trevor-Roper H. R. Religion, Reformation and Social Change. L.: Macmillan. P. 1-45.

Toennies F., Simmel G., Troeltsch E., Weber M. (1973). Max Weber on Church, Sect, and Mysticism // Sociological Analysis. Vol. 34. № 2. P. 140-149.

Troeltsch E. (1992). The Social Teaching of the Christian Churches. Westminster: John Knox Press.

Turner B. S. (2011). Max Weber and the Spirit of Resentment: The Nietzsche Legacy // Journal of Classical Sociology. Vol. 11. № 1. P. 75-92.

Turner S. P. (1982). Bunyan's Cage and Weber's Casing // Sociological Inquiry. Vol. 52. № 1. P. 84-87.

Van Kessel J. H. (2012). Bulgakov's Sophiology: Towards an Orthodox Economic Theological Engagement with the Modern World // Studies in East European Thought. Vol. 64. № 3/4. P. 251-267.

Welch M. R., Sikkink D., Sartain E., Bond C. (2004). Trust in God and Trust in Man: The Ambivalent Role of Religion in Shaping Dimensions of Social Trust // Journal for the Scientific Study of Religion. Vol. 43. № 3. P. 317-343. 
Zafirovski M. (2007). The Protestant Ethic and the Spirit of Authoritarianism: Puritanism, Democracy, and Society. Berlin: Springer.

Zafirovski M. (2013). The Sociological Core vs. the Historical Component of the Weber Thesis: Some Deviant Cases Revisited // Dahms H. F. (ed.). Social Theories of History and Histories of Social Theory. Bingley: Emerald. P. 75-128.

Zafirovski M. (2016). The Weber Thesis of Calvinism and Capitalism: Its Various Versions and Their «Fate» in Social Science // Journal of the History of the Behavioral Sciences. Vol. 52. № 1. P. 41-58.

Zaret D. (1992). Calvin, Covenant Theology and the Weber Thesis // British Journal of Sociology. Vol. 43. № 3. P. 369-391.

Zaret D. (1993). The Use and Abuse of Textual Data // Lehmann H., Roth G. (eds.). Weber's Protestant Ethic: Origins, Evidence, Context. Cambridge: Cambridge University Press. P. 145-272.

\section{Religion and Economics: Can We Still Rely on Max Weber?}

\section{Ivan Zabaev}

Candidate of Sociological Sciences, Associated Professor, Theological Faculty, St.Tikhon's Orthodox University Address: 6 Likhov lane, 1, Moscow, Russian 127051

E-mail: zabaev-iv@yandex.ru

The article, within the framework of the logic proposed by M. Weber in The Protestant Ethic and the Spirit of Capitalism, attempts to identify the core ethical category of the Russian Orthodox Church that could function in the same way as Beruf (profession/vocation) does for the analysis of Protestantism and its potential impact on the formation of the economy. The attempt to apprehend this category relies on Weber's works that analyze the economic ethics of world religions. In particular, an effort is made to interpret the Weberian categorization of Russian Orthodoxy as a "specific mysticism". The texts of F. Nietzsche and M. Scheler are used to decipher Weber's thesis. The analysis of the texts of Weber, Nietzsche, and Scheler leads to the assumption that "humility" could be the category in question. In his works on the sociology of religion, Weber used "humility" to describe "mysticism" in the same vein as is "vocation" for "asceticism". At the same time, Weber reinterprets Nietzsche's doctrine of ressentiment to construct the typology of economic ethics of world religions. For Nietzsche, humility is often synonymous to ressentiment. In the Weberian interpretation, the thesis on ressentiment becomes a "theodicy of suffering". In the typology of suffering, humility was associated with contemplation, or the withdrawal from the world, that is, with everything specific for mysticism as it was understood by Weber. M. Scheler also took notice of this and criticized the thesis on ressentiment, contrasting it with humility as the basic Christian virtue. An analysis of the texts of F. Nietzsche, M. Weber and M. Scheler on the ressentiment and ethics of Christianity made it possible to propose a typology of ethics that seems to be suitable for constructing hypotheses about the (potential) influence of Orthodoxy on Russian economic life.

Keywords: mysticism, Weber, Nietzsche, Scheler, humility, vocation, economic ethics, ressentiment, Orthodox Christianity 


\section{References}

Adair-Toteff C. (2002) Max Weber's Mysticism. European Journal of Sociology, vol. 43, no 3, pp. 339353.

Allahyari Rebecca A. (2000) Visions of Charity: Volunteer Workers and Moral Community, Berkeley: University of California Press.

Baehr P. (2001) The "Iron Cage" and the "Shell as Hard as Steel": Parsons, Weber, and the Stahlhartes Gehäuse Metaphor in the Protestant Ethic and the Spirit of Capitalism. History and Theory, vol. 40, no 2, pp. 153-169.

Barro R. J., McCleary R. (2003) Religion and Economic Growth (NBER Working Paper No 9682), Cambridge: National Bureau of Economic Research.

Bauman Z. (2004) Work, Consumerism and the New Poor, Maidenhead: McGraw-Hill.

Becker S. O., Woessmann L. (2009) Was Weber Wrong? A Human Capital Theory of Protestant Economic History. Quarterly Journal of Economics, vol. 124, no 2, pp. 531-596.

Bellah R. N. (1957) Tokugawa Religion: The Values of Pre-industrial Japan, Glencoe: Free Press.

Bellah R. N. (1963) Reflections on the Protestant Ethic Analogy in Asia. Journal of Social Issues, vol. 19, № 1, pp. 52-60.

Bellah R. N., Madsen R., Sullivan W. M., Swidler A., Tipton S. M. (1985) Habits of the Heart: Individualism and Commitment in American Life, New York: Harper \& Row.

Bielschowsky A. (1908) Goethe: ego zhizn'i proizvedeniya [Goethe's Life and Works], Saint Petersburg: L. Panteleev.

Bittner R. (1994) Ressentiment. Nietzsche, Genealogy, Morality: Essays on Nietzsche's On the Genealogy of Morals (ed. R. Schacht), Berkeley: University of California Press, pp. 127-138.

Blum U., Dudley L. (2001) Religion and Economic Growth: Was Weber Right?. Journal of Evolutionary Economics, vol. 11, no 2, pp. 207-230.

Boltanski L., Chiapello E. (2011) Novyj duh kapitalizma [New Spirit of Capitalism], Moscow: New Literary Observer.

Bourdieu P. (2005) Genezis i struktura polya religii [Genesis and Structure of the Field of Religion]. Social'noe prostranstvo: polya i praktiki [Social Space: Fields and Practices], Moscow: Aleteya, pp. 7-75.

Brodrick J. (1934) The Economic Morals of the Jesuits: An Answer to Dr. H. M. Robertson, Oxford: Oxford University Press.

Bulgakov S. (1997) Narodnoe hozyajstvo i religioznaya lichnost' [National Economy and Religious Personality]. Dva grada: issledovaniya o prirode obshchestvennyh idealov [Two Cities: Studies on the Nature of Public Ideals], Saint Petersburg: RGHI, pp. 111-125.

Bulgakov S. (1997) Geroizm i podvizhnichestvo [Heroism and Asceticism]. Dva grada: issledovaniya o prirode obshchestvennyh idealov [Two Cities: Studies on the Nature of Public Ideals], Saint Petersburg: RGHI, pp. 275-299.

Buss A. E. (1989) The Economic Ethics of Russian-Orthodox Christianity, Part I. International Sociology, vol. 4, no 3, pp. 235-258.

Buss A. E. (2003) The Russian-Orthodox Tradition and Modernity, Leiden: Brill.

Cadge W., Wuthnow R. (2003) Religion and the Nonprofit Sector. The Nonprofit Sector: A Research Handbook (eds. R. Steinberg, W. Powell), New Haven: Yale University Press, pp. 444-466.

Campante F., Yanagizawa-Drott D. (2015) Does Religion Affect Economic Growth and Happiness? Evidence from Ramadan. Quarterly Journal of Economics, vol. 130, no 2, pp. 615-658.

Campbell C. (1987) The Romantic Ethic and the Spirit of Modern Consumerism, Oxford: Basil Blackwell.

Chepenko V., Andreev V. (2011) Modernizaciya rossijskoj ehkonomiki i vozrozhdenie otechestvennogo mashinostroeniya [Modernization of the Russian Economy and the Revival of Domestic Engineering]. Voprosy ehkonomiki, no 5, pp. 125-129.

Chimiris E., Dontsev S. (2010) Cerkov'i modernizaciya v Rossii: v poiske novyh cennostnyh osnov [Church and Modernization in Russia: In Search of Value Bases]. Polis: Political Studies, no 6, pp. 68-75.

Collins R. (1997) An Asian Route to Capitalism: Religious Economy and the Origins of SelfTransforming Growth in Japan. American Journal of Sociology, vol. 62, no 6, pp. 843-865. 
Davydov Y. (1998) Max Weber i sovremennaya teoreticheskaya sociologiya: aktual'nye problemy veberovskogo sociologicheskogo ucheniya [Max Weber and Modern Theoretical Sociology: Current Problems of the Weberian Sociological Doctrine], Moscow: Martis.

Delacroix J., Nielsen F. (2001) The Beloved Myth: Protestantism and the Rise of Industrial Capitalism in Nineteenth-Century Europe. Social Forces, vol. 80, no 2, pp. 509-553.

DiMaggio P. J., Powell W. W (2010) Novyj vzglyad na "zheleznuyu kletku": institucional'nyj izomorfizm i kollektivnaya racional'nost' $v$ organizacionnyh polyah [The Iron Cage Revisited: Institutional Isomorphism and Collective Rationality in Organizational Fields]. Economic Sociology, vol. 11, no 1, pp. 35-56.

Dubovka D. (2015) Zabytoe vremya, ili Praktiki samotransformacii v sovremennom pravoslavnom monastyre [The Forgotten Time; or, Self-Transformation Practices in a Modern Orthodox Monastery]. State, Religion and Church in Russia and Worldwide, no 3, pp. 322-344.

Durlauf S. N., Kourtellos A., Tan, C. M. (2012) Is God in the Details? A Reexamination of the Role of Religion in Economic Growth. Journal of Applied Econometrics, vol. 27, no 7, pp. 1059-1075.

Eisenstadt S. N. (1968) The Protestant Ethic and Modernization, New York: Basic Books.

Efremova M. (2010). Vliyanie religioznoj identichnosti na ehkonomicheskie ustanovki i predstavleniya rossiyan [The Influence of Religious Identity on Economic Attitudes and Ideas of Russians]. Almanac of Contemporary Science and Education, no 10, pp. 90-95.

Efremova M. (2014) Rol' religioznoj identichnosti v modelyah ehkonomicheskogo povedeniya: mezhkonfessional'nyj analiz [The Role of Religious Identity in Models of Economic Behavior: Interconfessional Analysis]. Current Issues in Psychological Knowledge, no 1, pp. 20-30.

Elbakyan E.., Medvedko S. (2001) Vliyanie religioznyh cennostej na ehkonomicheskie predpochteniya veruyushchih rossiyan [The Influence of Religious Values on the Economic Preferences of Russian Believers]. Sociological Studies, no 8, pp. 103-111.

Fanfani A. (1935) Catholicism, Protestantism and Capitalism, London: Sheed \& Ward.

Fedotova V. (2007) Chelovecheskij kapital, personal'naya modernizaciya i problema razvitiya cheloveka (okonchanie) [The Human Capital, the Personal Modernization and the Problem of Human Development (the Ending)]. Znanie. Ponimanie. Umenie, no 2, pp. 21-27.

Fedotova V., Kross S. (2006) Pravoslavie, Weber i novyj russkij kapitalizm [The Orthodoxy, Weber and New Russian Capitalism]. Social Sciences and Contemporary World, no 2, pp. 41-51.

Fischer H. K. (1978) Kritische Beiträge zu Professor Max Webers Abhandlung "Die Protestantische Ethik und der Geist des Kapitalismus". Die Protestantische Ethik II: Kritiken und Antikritiken, Gütersloh: Mohn, pp. 11-26.

Francis, the pope (2014) Apostol'skoe obrashchenie Evangelii Gaudium [The Apostolic Letter Evangelii Gaudium]. Available at: http://cathmos.ru/files/docs/papal_documents/Evangelii_ gaudium.pdf (accessed 28 February 2018).

Gabdrakhmanova G. (2010) Osobennosti social'no-ehkonomicheskih vzglyadov pravoslavnyh i musul'man i perspektivy izucheniya (po materialam issledovanij v Respublike Tatarstan) [Features of Socio-economic Views of Orthodox and Muslims and the Prospects for Studying (Based on Research in the Republic of Tatarstan)]. Voprosy culturologii, no 11, pp. 49-54.

Gabriel I., Kirchschläger P. G., Sturn R. (eds.) (2017) Eine Wirtschaft, die Leben fördert: Wirtschafts- und unternehmensethische Reflexionen im Anschluss an Papst Franziskus, Ostfildern: Grünewald.

Gooren H, pp. P. (2001) Rich among the Poor: Church, Firm, and Household among Small-Scale Entrepreneurs in Guatemala City, West Lafayette: Purdue University Press

Gorski P. S. (1993) The Protestant Ethic Revisited: Disciplinary Revolution and State Formation in Holland and Prussia. American Journal of Sociology, vol. 99, no 2, pp. 265-316.

Gorshkov M., Tikhonova N. (2010) Gotovo li rossijskoe obshchestvo k modernizacii? [ls Russian Society Ready for Modernization?]. Society and Economy, no 5, pp. 105-172.

Greeley A. (1997) Coleman Revisited: Religious Structures as a Source of Social Capital. American Behavioral Scientist, vol. 40, no 5, pp. 587-594.

Grier R. (1997) The Effect of Religion on Economic Development: A Cross National Study of 63 Former Colonies. Kyklos, vol. 50, no 1, pp. 47-62.

Guiso L., Sapienza P., Zingales L. (2003) People's Opium? Religion and Economic Attitudes. Journal of Monetary Economics, vol. 50, no 1, pp. 225-282. 
Guiso L., Sapienza P., Zingales L. (2006) Does Culture Affect Economic Outcomes?. Journal of Economic Perspectives, vol. 20, no 2, pp. 23-48.

Hennis W. (1998) Max Weber: Essays in Reconstruction, London: Allen \& Unwin.

Hoffman M. (2013) Usury in Christendom: The Mortal Sin That was and Now is Not, Idaho: Independent History and Research.

Hoge Dean R. (1996) Money Matters: Personal Giving in American Churches, Louisville: Westminster John Knox.

Holl K. (1965) Gesammelte Aufsätze zur Kirchengeschichte, Vol. 3: Der Westen, Darmstadt: Wissenschaftliche Buchgesellschaft.

Hyma A. (1938) Calvinism and Capitalism in the Netherlands. Journal of Modern History, vol. 10, no 3, pp. 321-343.

Joas H., Knöbl W. (2011) Social'naya teoriya: dvadcat'vvodnyh lekcij [Social Theory: Twenty Introductory Lectures], Saint Petersburg: Aleteya.

Kapelyushnikov R. (2018) Gipnoz Webera (zametki o "Protestanskoj ehtike i duhe kapitalizma") [Hypnosis of Weber: Notes about The Protestant Ethic and the Spirit of Capitalism] (HSE Preprint WP3/2018/01), Moskow: HSE.

Kent S. A. (1983) Weber, Goethe, and the Nietzschean Allusion: Capturing the Source of the "Iron Cage" Metaphor. Sociological Analysis, vol. 44, no 4, pp. 297-319.

Knack S., Keefer P. (1997) Does Social Capital Have an Economic Payoff? A Cross-country Investigation. Quarterly Journal of Economics, vol. 112, no 4, pp. 1251-1288.

Knorre B. (2011) Kategorii viny i smireniya v sisteme cennostej cerkovno-prihodskoj subkul'tury [Categories of Guilt and Humility in the System of Values of the Church-Parish Subculture]. Prihod i obshchina v sovremennom pravoslavii: kornevaya sistema rossijskoj religioznosti [Parish and Community in the Modern Orthodoxy: The Root System of Russian Religiosity] (eds.

A. Agadzhanyan, K. Russele), Moscow: Ves Mir, pp. 317-340.

Krech V. (2001) Mystik. Max Webers "Religionssystematik" (eds. H. G. Kippenberg, M. Riesebrodt), Tübingen: J. C. B. Mohr, pp. 241-262.

Kulinchenko V., Kulinchenko A. (2003) O duhovno-kul'turnyh osnovaniyah modernizacii Rossii [About the Spiritual and Cultural Grounds of the Modernization of Russia]. Polis: Political Studies, no 2 , pp. 150-156.

Kuran T. (2001) The Provision of Public Goods under Islamic Law: Origins, Impact, and Limitations of the Waqf System. Law and Society Review, vol. 34, no 4, pp. 841-898.

Lanczkowski G., Schrey H.-H., Wingren G. (1980) Beruf. Theologische Realenzyklopädie, Vol. 5 (ed. G. Müller), Berlin: De Gruyter, pp. 654-676.

Lapin N. (2011) Sociokul'turnye faktory rossijskoj stagnacii i modernizacii [Socio-cultural Factors of Stagnation and Modernization]. Sociological Studies, no 9, pp. 3-17.

Lehmann H., Roth G. (eds.) (1995) Weber's Protestant Ethic: Origins, Evidence, Contexts, New York: Cambridge University Press.

Luckmann Th. (1990) Shrinking Transcendence, Expanding Religion?. Sociological Analysis, vol. 51, no 2, pp. 127-138.

Luckmann Th. (2014) Dopolnenie k tret'emu nemeckomu izdaniyu "Nevidimoj religii” [Addition to the Third German Edition of Invisible Religion]. Russian Sociological Review, vol. 13, no 1, pp. 139153.

Mackinnon M. (1988) Calvinism and the Infallible Assurance of Grace. British Journal of Sociology, vol. 39, no 2, pp. 143-177.

Mackinnon M. (1988) Weber's Exploration of Calvinism. British Journal of Sociology, vol. 39, no 2, pp. 178-210.

Makridis V. N. (2010) Orthodox Christianity and Economic Development: The Case of Greece. Teme, vol. 34, no 1, pp. 225-238.

Malinkin A. (1997) Uchenie Maksa Shelera o resentimente i ego znachenie dlya sociologii [The Doctrine of Max Scheler on the Resentment and Its Significance for Sociology]. Sociological Journal, no 4, pp. 116-150. 
Malkina M. (2011) Institucional'nye lovushki innovacionnogo razvitiya rossijskoj ehkonomiki [Institutional Traps of Innovative Development of the Russian Economy]. Journal of Institutional Studies, vol. 3, no 1, pp. 50-60.

Marshal G. (1979) The Weber Thesis and the Development of Capitalism in Scotland. Scottish Journal of Sociology, no 3, pp. 173-211.

Marshal G. (1980) Presbyteries and Profits: Calvinism and the Development of Capitalism in Scotland, 1560-1707, Oxford: Clarendon Press.

Marshal G. (1980) The Dark Side of Weber Thesis: The Case of Scotland. British Journal of Sociology, vol. 31, no 3, pp. 419-440.

Martin B. (1995) New Mutations of the Protestant Ethic among Latin American Pentecostals. Religion, vol. 25, no 2, pp. 101-117.

Martin B. (1998) From Pre- to Post-Modernity in Latin America: The Case of Pentecostalism. Religion, Modernity and Postmodernity (eds. P. Heelas, D. Martin, P. Morris), Oxford: Blackwell, pp. 102-146.

Marx K. (1955) K kritike gegelevskoj filosofii prava. Vvedenie [To the Critics of Hegel's Philosophy of Law. The Introduction]. Polnoe sobranie sochineniy. T. 1 [Complete Works, Vol. 1], Moscow: Gospolitizdat, pp. 414-429.

Merchel J. (2008) Trägerstrukturen in der Sozialen Arbeit: Eine Einführung, Weinheim: Beltz Juventa.

Mitrokhin N., Edelshtein M. (2000) Ekonomicheskaya deyatel'nost'Russkoj Pravoslavnoj Cerkvi i ee tenevaya sostavlyayushchaya [Economic Activity of the Russian Orthodox Church and Its Shadow Component], Moscow: RGGU.

Mitzman, A. (2005) The Iron Cage: An Historical Interpretation of Max Weber, New Brunswick: Transaction.

Müller-Armack A. (1945) Zur Religionssoziologie des europäischen Ostens. Weltwirtschaftliches Archiv, vol. 61, no 2, pp. 163-192.

Mutch A. (2009) Weber and Church Governance: Religious Practice and Economic Activity. Sociological Review, vol. 57, no 4, pp. 586-607.

Mutch A. (2012) Theology, Accountability and Management: Exploring the Contributions of Scottish Presbyterianism. Organization, vol. 19, no 3, pp. 363-379.

Nelson B. (1969) The Idea of Usury: From Tribal Brotherhood to Universal Otherhood, Chicago: University of Chicago Press.

Nesbo J. (2017) Zhazhda [The Thirst], Saint Petersburg: Azbuka.

Nietzsche F. (1996) K genealogii morali [On the Genealogy of Morality]. Sochineniya. T. 2 [Works, Vol. 2], Moscow: Mysl, pp. 407-524.

Nietzsche F. (1996b.) Tak govoril Zaratustra. Kniga dlya vsekh i nikogo [Thus Spoke Zarathustra. The Book for Everybody and No One]. Sochineniya. T. 2 [Works, Vol. 2], Moscow: Mysl, pp. 6-237.

Novak M. (1993) The Catholic Ethic and the Spirit of Capitalism, New York: Free Press

Nussbaum, M., Sen, A. (eds.) (1993) The Quality of Life, Oxford: Oxford University Press.

Oreshina D. (2016) Partnyorskij prihod: sotrudnichestvo svyashchennosluzhitelej i miryan kak faktor razvitiya social'noj deyatel'nosti v sovremennyh prihodah Russkoj pravoslavnoj Cerkvi [Partner Parish: Cooperation of Clergy and Laity as a Factor in the Development of Social Activities in the Modern Parishes of the Russian Orthodox Church]. St. Tikhon's University Review. Series I: Theology. Philosophy. Religious Studies, no 5, pp. 99-120.

Overman S. J. (2011) The Protestant Ethic and the Spirit of Sport: How Calvinism and Capitalism Shaped America's Games, Macon: Mercer University Press.

Owen S., Taira T. (2015) The Category of "Religion" in Public Classification: Charity Registration of the Druid Network in England and Wales. Religion as a Category of Governance and Sovereignty (eds. T. Stack, N. R. Goldenberg, T. Fitzgerald), Leiden: Brill, pp. 90-114.

Paretskaya A. (2010) The Soviet Communist Party and the Other Spirit of Capitalism. Sociological Theory, vol. 28, no 4, pp. 377-401.

Parsons J. (2014) Vocation in Seventeenth-Century France: The Catholic Ethic and the Spirit of étatisme. French History, vol. 28, no 3, pp. 322-342.

Pavlyutkina E. (2012) "Skreplenie" i otvetstvennost': specifika nekommercheskih organizacij v rabote s bezdomnymi (na primere religioznyh organizacij) ["Bounding" and Responsibility: The 
Specificity of Non-profit Organizations in Working with the Homeless (the Example of Religious Organizations)]. Journal of Social Policy Studies, vol. 10, no 4, pp. 539-554.

Porta R. L., Lopez-De-Silane F., Shleifer A., Vishny R. W. (1996) Trust in Large Organizations (NBER Working Paper No 5864), Cambridge: National Bureau of Economic Research.

Putnam R. D. (2000) Bowling Alone: America's Declining Social Capital. Culture and Politics: A Reader (eds. L. Crothers, Ch. Lockhart), Basingstoke: Palgrave Macmillan, pp. 223-234.

Quinn D. M., Crocker J. (1999) When Ideology Hurts: Effects of Belief in the Protestant Ethic and Feeling Overweight on the Psychological Well-Being of Women. Journal of Personality and Social Psychology, vol. 77, no 2, pp. 402-414.

Rachfahl F. (1978) Kalvinismus und Kapitalismus. Die Protestantische Ethik Il: Kritiken und Antikritiken, Gütersloh: Mohn, pp. 57-148.

Raskov D. (2012) Ekonomicheskie instituty staroobryadchestva [The Economic Institutions of Old Believers], Saint Petersburg: SPSU.

Ringer F. (2008) Zakat nemeckih mandarinov: akademicheskoe soobshchestvo v Germanii, 1890-1933 [The Sunset of German mandarins. The Academic Community in Germany, 1890-1933], Moscow: New Literary Observer.

Robertson H. M. (1933) Aspects of the Rise of Economic Individualism: A Criticism of Max Weber and His School, Cambridge: University Press.

Russele K. (2011) Ob otnosheniyah mezhdu svyashchennikami i miryanami: poslushanie i blagoslovenie [About Relationships between Priests and Laity: Obedience and Blassing]. Prihod i obshchina v sovremennom pravoslavii: kornevaya sistema rossijskoj religioznosti [Parish and Community in the Modern Orthodoxy: The Root System of Russian Religiosity] (eds. A. Agadzhanyan, K. Russele), Moscow: Ves Mir, pp. 298-316.

Salarzehi H., Armesh H., Nikbin D. (2010) Waqf as a Social Entrepreneurship Model in Islam. International Journal of Business and Management, vol. 5, no 7, pp. 179-186.

Samuelsson K. (1961) Religion and Economic Action: The Protestant Ethic, the Rise of Capitalism, and the Abuse of Scholarship, New York: Harper \& Row.

Savchenko V. (2006) Ekonomicheskaya kul'tura kak faktor razvitiya obshchestva [Economic Culture as the Factor of the Community Development]. Science. Innovations. Technologies, no 1, pp. 8897.

Saveliev D., Susokolov A. (2011) ludaizm i ehtika predprinimatel'stva [Judaism and Ethics of Entrepreneurship]. Kul'tura i ehkonomicheskoe povedenie [Culture and Economic Behavior] (eds. N. Lebedeva, A. Tatarko), Moscow: MAKS-Press, pp. 261-303.

Schastnaya T. (2011) Strategiya razvitiya bankovskogo sektora i modernizaciya rossijskoj ehkonomiki [Strategy of Development of the Banking Sector and Modernization of the Russian Economy]. Tomsk State University Journal of Economics, vol. 3, no 15, pp. 120-125.

Scheler M. (2005) On the Rehabilitation of Virtue. American Catholic Philosophical Quarterly, vol. 79, no 1, pp. 21-37.

Shcherbakova L. (2010) Modernizaciya rossijskoj ehkonomiki: mnogofaktornaya zadacha so mnogimi neizvestnymi [Modernization of Russian Economy: Multifactor Task with Many Unknown]. EHO, no 9, pp. 73-93.

Schluchter W. (1987) Weber's Sociology of Rationalism and Typology of Religious Rejections of the World. Max Weber, Rationality and Modernity (eds. S. Whimster, S. Lash), London: Routledge, pp. 92-118.

Schluchter W. (1988) Max Webers Sicht des okzidentalen Christentums: Interpretation und Kritik, Frankfurt am Main: Suhrkamp.

Schluchter W. (1988) Religion und Lebensführung, Frankfurt am Main: Suhrkamp.

Schluchter W. (1995) Ethik und Kapitalismus: Zwei Thesen Max Webers. Berliner Journal für Soziologie, no 3, pp. 335-347.

Schluchter W. (2009) Die Entzauberung der Welt: Sechs Studien zu Max Weber, Tübingen: Mohr Siebeck.

Schluchter W., Graf F. W. (2005) Asketischer Protestantismus und "Geist" des modernen Kapitalismus: Max Weber und Ernst Troeltsch, Tübingen: Mohr Siebeck. 
Schroeder W. (2017) Die Fallstudien: Caritas und Diakonie im Transformationsprozess. Konfessionelle Wohlfahrtsverbände im Umbruch: Fortführung des deutschen Sonderwegs durch vorsorgende Sozialpolitik, Berlin: Springer, pp. 51-103.

Sexton J. (1978) Protestantism and Modernization in Two Guatemalan Towns. American Ethnologist, vol. 5, no 2, pp. 280-302.

Shkaratan O., Karacharovsky V. (2002) Russkaya trudovaya i upravlencheskaya kul'tura: opyt issledovaniya v kontekste perspektiv ehkonomicheskogo razvitiya [Russian Labor and Management Culture: Experience of Research in the Context of Economic Development Prospects]. Universe of Russia, vol. 11, no 1, pp. 3-56.

Shmyrova N. (2010) Modernizaciya rossijskoj ehkonomiki i osnovnye puti ee osushchestvleniya v sovremennyj period [Modernization of the Russian Economy and the Main Ways of Its Achievement in Out Times]. Vestnik of Lobachevsky University of Nizhni Novgorod, no 3, pp. 639643.

Sombart W. (2005) Burzhua: $k$ istorii duhovnogo razvitiya sovremennogo ehkonomicheskogo cheloveka [Bourgeois: Toward the History of the Spiritual Development of Modern Economic Man], Saint Petersburg: Vladimir Dal.

Sosis R. (2005) Does Religion Promote Trust? The Role of Signaling, Reputation, and Punishment. Interdisciplinary Journal of Research on Religion, vol. 1, article 7. Available at: http://www. religjournal.com/articles/article_view.php?id=7 (accessed 28 February 2018).

Stauth G. (1992) Nietzsche, Weber, and the Affirmative Sociology of Culture. European Journal of Sociology, vol. 33, no 2, pp. 219-247.

Stiglitz D., Sen A., Fitoussi J.-P. (2016) Neverno ocenivaya nashu zhizn': pochemu VVP ne imeet smysla [Mismeasuring Our Lives: Why GDP Doesn't Add Up], Moscow: Gaidar Institute Press.

Stokes R. G. (1975) Afrikaner Calvinism and Economic Action: The Weberian Thesis in South Africa. American Journal of Sociology, vol. 81, no 1, pp. 62-81.

Susokolov A. (2009) Islam i predprinimatel'stvo v Rossii [Islam and Entrepreneurship in Russia]. Journal of Sociology and Social Anthropology, vol. 12, no 1, pp. 32-51.

Susokolov A., Chetyrchinskaya O. (2008) Vlijanie religioznoj prinadlezhnosti na ustanovki v sfere predprinimatelstva (na primere sovremennoj rossii) [The Influence of Religious Identity on the Attitudes in the Area of Entrepreneurship (the Example of Modern Russia)]. Voprosy culturologii, no 6, pp. 32-36.

Swatos W., Boulder L. K. L. (eds.) (2005) The Protestant Ethic Turns 100: Essays on the Centenary of the Weber Thesis, Boulder: Paradigm.

Tamari M. (1987) "With All Your Possessions": Jewish Ethics and Economic Life, New York: Free Press.

Taylor Ch. (2017) Sekulyarnyj vek [The Secular Age], Moscow: BBI.

Tawney R. H. (1926) Religion and the Rise of Capitalism, New Brunswick: Transaction.

Trevor-Roper H. R. (1967) Religion, Reformation and Social Change. Religion, Reformation and Social Change, London: Macmillan, pp. 1-45.

Toennies F., Simmel G., Troeltsch E, Weber M. (1973) Max Weber on Church, Sect, and Mysticism. Sociological Analysis, vol. 34, no 2, pp. 140-149.

Troeltsch E. (1992) The Social Teaching of the Christian Churches, Westminster: John Knox Press.

Turner S. P. (1982) Bunyan's Cage and Weber's Casing. Sociological Inquiry, vol. 52, no 1, pp. 84-87.

Turner B. S. (2011) Max Weber and the Spirit of Resentment: The Nietzsche Legacy. Journal of Classical Sociology, vol. 11, no 1, pp. 75-92.

Tyrell H. (1999) Intellektual'naya religioznost', "semantika smysla”, ehtika bratstva: Max Weber i ego otnoshenie k Tolstomu i Dostoevskomu [Intellectual Religiosity, the "Semantics of Meaning", the Ethics of Brotherhood: Max Weber and His Attitude to Tolstoy and Dostoevsky]. Journal of Sociology and Social Anthropology, vol. 2, no 4, pp. 23-32.

Van Kessel J. H. (2012) Bulgakov's Sophiology: Towards an Orthodox Economic Theological Engagement with the Modern World. Studies in East European Thought, vol. 64, no 3-4, pp. 251-267.

Vrublevskaya P. (2016) Krugovorot detskij veshchej v prihodskoj cerkvi: k voprosu o znachenii daroobmena [The Cycle of Children's Things in the Parish Church: The Question of the Meaning of Gift Exchange]. Researches in Religious Studies, no 1, pp. 103-127. 
Weber M. (1990) Protestantskaya ehtika i duh kapitalizma [The Protestant Ethic and the Spirit of Capitalism]. Izbrannye proizvedeniya [Selected Works], Moscow: Progress, pp. 61-272.

Weber M. (1990) Protestantskie sekty i duh kapitalizma [Protestant Sects and the Spirit of Capitalism]. Izbrannye proizvedeniya [Selected Works], Moscow: Progress, pp. 61-107.

Weber M. (1990) Nauka kak prizvanie i professiya [Science as a Vocation]. Izbrannye proizvedeniya [Selected Works], Moscow: Progress, pp. 707-736.

Weber M. (1994) Sociologiya religii (tipy religioznyh soobshchestv) [Sociology of Religion (The Typology of Religious Communities)]. Izbrannoe: Obraz obshchestva [Selected Works: The Image of Society], Moscow: Yurist, pp. 78-308.

Weber M. (2016) Hozyajstvo i obshchestvo: ocherki ponimayushchej sociologii. T. 1: Sociologiya [Economy and Society: An Outline of Interpretive Sociology, Vol. 1: Sociology], Moscow: HSE.

Weber M. (2017) Hozyajstvo i obshchestvo: ocherki ponimayushchej sociologii. T. 2: Obshchnosti [Economy and Society: An Outline of Interpretive Sociology, Vol. 2: Communities], Moscow: HSE.

Welch M. R., Sikkink D., Sartain E., Bond C. (2004) Trust in God and Trust in Man: The Ambivalent Role of Religion in Shaping Dimensions of Social Trust. Journal for the Scientific Study of Religion, vol. 43, no 3, pp. 317-343.

Yasin E. (2001) Modernizaciya rossijskoj ehkonomiki: chto v povestke dnya [Modernization of the Russian Economy: What is on the Agenda]. HSE Economic Journal, vol. 5, no 2, pp. 158-178.

Yasin E., Yakovlev A. (2004) Konkurentosposobnost'i modernizaciya rossijskoj ehkonomiki [Competitiveness and Modernization of the Russian Economy]. Voprosy ekonomiki, no 7, pp. 4-34.

Yudin G., Oreshina D. (2016) Daroobmen i regulyaciya potrebitel'skogo kreditovaniya v soobshchestvah: sluchaj pravoslavnyh prihodskih obshchin [Gift Exchange and Regulation of Consumer Lending in Communities: The case of Orthodox Parish Communities]. Sociological Journal, vol. 22, no 2, pp. 110-134.

Zabaev I. (2012) Osnovnye kategorii hozyajstvennoj ehtiki sovremennogo russkogo pravoslaviya: sociologicheskij analiz [Main Categories of the Economic Ethics of Modern Russian Orthodoxy: Sociological Analysis], Moscow: PSTGU.

Zabaev I., Oreshina D., Prutskova E. (2014) Social'nyj kapital russkogo pravoslaviya v nachale XXI v.: issledovanie s pomoshch'yu metodov social'no-setevogo analiza [Social Capital of Russian Orthodoxy at the Beginning of the 21st Century: Research Using Social and Network Analysis Techniques]. State, Religion and Church in Russia and Worldwide, no. 1, pp. 40-66.

Zafirovski M. (2007) The Protestant Ethic and the Spirit of Authoritarianism: Puritanism, Democracy, and Society, Berlin: Springer.

Zafirovski M. (2013) The Sociological Core vs. the Historical Component of the Weber Thesis: Some Deviant Cases Revisited. Social Theories of History and Histories of Social Theory (ed. H. F. Dahms), Bingley: Emerald, pp. 75-128.

Zafirovski M. (2016) The Weber Thesis of Calvinism and Capitalism: Its Various Versions and Their "Fate" in Social Science. Journal of the History of the Behavioral Sciences, vol. 52, no 1, pp. 41-58.

Zaret D. (1992) Calvin, Covenant Theology and the Weber Thesis. British Journal of Sociology, vol. 43, no 3, pp. 369-391.

Zaret D. (1993) The Use and Abuse of Textual Data. Weber's Protestant Ethic: Origins, Evidence, Context (eds. H. Lehmann, G. Roth), New York: Cambridge University Press, pp. 145-272.

Zarubina N. (1997) Modernizaciya i hozyajstvennaya kul'tura (koncepciya M. Webera i sovremennye teorii razvitiya) [Modernization and Economic Culture (M. Weber's Theory and Modern Development Theories)]. Sociological Studies, no 4, pp. 46-54. 


\title{
Параллаксы лисы: к определению предмета и границ социальной философии
}

\author{
Александр Павлов \\ Кандидат юридических наук, доцент Школы философии, факультет гуманитарных наук, \\ Национальный исследовательский университет «Высшая школа экономики» \\ Ведущий научный сотрудник Института философии РАН \\ Адрес: ул. Мясницкая, дом 2о, г. Москва, Российская Федерация 101000 \\ E-mail: apavlov@hse.ru
}

\begin{abstract}
Автор статьи пытается (пере)осмыслить проблемное поле социально-философского знания. В тексте говорится, чем социальная философия принципиально отличается от теоретической социологии, исторической социологии и политической философии, на основании чего обосновывается утверждение, что социальная философия - самостоятельная и целостная дисциплина. Далее формулируются несколько возможных подходов к изучению общества, которые можно было бы охарактеризовать как «слабые программы» социальной философии. Утверждается, что на их базе может быть сформулирована «сильная программа» социальной философии. Такая программа должна органически сочетать в себе следующие установки - методологию неомарксизма, включая ориентацию на традиционные для этого течения объекты анализа; аккуратные и тщательные исследования, а также фундированность и концептуальность, т. е. обязательный выход за пределы отработанного эмпирического материала. Далее формулируется один из главных вызовов, с которым сталкивается и/или должна столкнуться социальная философия в ближайшем будущем. Перед социальной философией стоит сложная задача - сказать что-то осмысленное о времени, в котором мы живем, определить изменения в культуре и экономике, попытаться ответить на вопрос, что пришло на смену постмодерну, если он вообще существовал. На основании сказанного предлагается рабочая дефиниция социальной философии: многочисленные (не всегда) философские концептуализации социальных проблем, феноменов, сложных понятий, а также теоретические попытки интерпретации нашего и/или иного времени, во-первых, предполагающие нормативное измерение и, во-вторых, основанные на богатом эмпирическом материале. Обозначенный подход также можно объяснить через понятие «параллаксы лисы», предполагающее, что социальная философия занимается многими вещами, но старается путем тщательного и многофакторного исследования этих вещей взглянуть на изучаемую проблему по-новому или обнаружить ее эвристический потенциал.
\end{abstract}

Ключевые слова: социальная философия, неомарксизм, постмодерн, постпостмодерн, культурсоциология, политическая философия, социальная теория, историческая социология

(с) Павлов А. В., 2018

(c) Центр фундаментальной социологии, 2018

DOI: $10.17323 / 1728-192 \mathrm{X}-2018-3-149-172$ 
Надеюсь, читателя не пугает и не смущает название этой статьи. Оба слова, вынесенных в заглавие, не только имеют концептуальное значение для всего того, что будет сказано в последующем, но также относятся к богатой традиции социальнофилософского знания. Во-первых, слово «лиса». Эту фигуру использовали в своих текстах многие мыслители, начиная от Антилоха и Никколо Макиавелли и заканчивая Ханной Арендт и Исайей Берлином. Я обращаюсь к этой фигуре в контексте рассуждений Берлина, увидевшего в изречении Антилоха «Много знает лиса, а ёж знает одно - но важное» большой эвристический потенциал для истории идей. В свое время, обсуждая взгляды Льва Толстого на историю, Берлин предположил, что всех известных нам мыслителей и философов, так или иначе, можно разделить на два типа - «ежей» и «лис». Первые были монистами и старались на протяжении жизни осваивать одну тему, вторые - будучи плюралистами, обращались к самым разным вещам. Это отнюдь не означает, что «лис» следует считать поверхностными, а «ежей» - глубокими, и что вообще «лиса» в чем-то уступает «ежу». Отнюдь. Это различение относится скорее к типу философствования как таковому и помогает лучше понять структуру философского знания. Например, «ежи» чаще встречаются среди тех, кто занимается теорией познания и, как правило, настаивает на объективности и единичности истины. В самом деле разве могут, скажем, христианские религиозные мыслители типа Августина допустить, что нечто не находится в компетенции Бога или Божественного предопределения? Даже те, кто соглашался с различением истин разума и истин откровения, по большей части считали, что откровение превосходит разум, часто полагая, что они не противоречат друг другу, но скорее взаимоподчинены. Это же мы могли бы сказать и про тех, кто занимается онтологией. Но в том, что обыкновенно считается практической философией, дела обстоят скорее наоборот. Такие авторы, большей частью современные, могли обращаться к самым разным вещам, как та же Ханна Арендт, предложившая глубокие суждения относительно природы тоталитаризма, сущности революции, феномена насилия и многих других вещей, имевших отношение к человеку и обществу. И хотя среди социально-политических философов как таковых было не так уж и мало «ежей» (например, Эрик Фёгелин, Лео Штраус), в целом социальная философия не может, но должна знать много, однако, как в случае «ежа», - это все равно важное знание. Социальная философия изучает не только «социальное» как таковое, что мы покажем в дальнейшем, но также и различные феномены социальной и политической жизни - капитализм, революции, неравенство, власть, культуру в целом, секс, труд, досуг и т. д. Иными словами, существует слишком много тем, которые социальная философия не может упустить из внимания, а следовательно, подход «ежа» в данном случае невозможен.

Проблема возникает тогда, когда мы начинаем задаваться вопросом: а не занимаются ли всеми этими темами другие сферы гуманитарного и социального знания? Действительно, разве культурой не должна заниматься культурология, властью - политическая философия, капитализмом - историческая социология, революцией - социальная теория, а неравенством - экономисты? И хотя очевид- 
но, что все эти предметные разграничения более чем условны (капитализм, например, в том числе и предмет экономики), все же получается, что у социальной философии как бы нет своего предмета. Заявить, что социальная философия изучает все это на свой лад - сказать мало, если вообще что-то сказать. Каким особенным образом она все это изучает? Разве у нее есть своя уникальная методология? Если да, то, например, какая именно? До сих пор при изучении власти мы обращаемся к классическому определению Макса Вебера, либо рассматриваем ее в совершенно новом понимании, предложенном Мишелем Фуко или Стивеном Льюксом (Льюкс, 2010). Социальная философия вправе ссылаться и на того, и на другого, и на третьего, но точно так же на этих мыслителей ссылаются социологи и политологи. Именно здесь к нам приходит на помощь понятие параллакса. Этот термин, между прочим, ввел в широкий обиход социально-гуманитарного знания вовсе не социальный философ Славой Жижек в своей книге «Параллаксное видение» - еще раньше про то же самое говорил социальный теоретик Ноэль Паркер, предложивший изучать революцию в соответствии с параллаксами (Паркер, 2008).

Параллакс предполагает следующее. При наблюдении за предметом/феноменом/вещью с разных точек зрения, под разным углом, на разном расстоянии и в разных обстоятельствах изучаемый объект представляется нам в новом свете и открывает такие свои качества и свойства, которые бы в других обстоятельствах мы просто не заметили. Таким образом, становится понятным словосочетание «параллаксы лисы». «Лиса» смотрит на самые разные феномены общественной жизни, но при этом должна делать это с совершенно разных позиций, предлагая не то чтобы комплексный подход к объекту изучения, но скорее всякий раз пытаясь найти что-то новое. Иными словами, понимание капитализма Максом Вебером, Вернером Зобмартом или Фредриком Джеймисоном может дать нам какое-то знание, но окажется ли оно полным для проникновения в суть явления, особенно если учитывать, что капитализм постоянно меняется? Вместо этого мы можем использовать идеи Джеймисона, чтобы проверить, работает ли его концептуальная схема до сих пор, или же мы нуждаемся в принципиально новом анализе капитализма. Но такой подход работает и в сторону прошлого, а не только будущего. Так, Альберт Хиршман (признанный авторитет во многих дисциплинах - экономике, политической науке, истории и т.д.) в свое время обнаружил, что капитализм был подготовлен даже не протестантской этикой, но социально-политическими аргументами в его пользу «до его возникновения», т. е. идея капитализма фактически созрела в социально-философских дискуссиях еще в XV столетии (Хиршман, 2012). И потому, чем больше мы изучаем предмет с разных сторон и в разных условиях, тем больше мы приближаемся к его постижению, можно сказать, даже к «схватыванию».

Следовательно, при таком подходе мы получаем дополнительные знания о предмете, а не только размышляем о нем в экономическом, политологическом или социологическом контексте. Это, впрочем, чревато некоторой размытостью социально-философского знания. И правда, если это до определенной степени 
«междисциплинарный подход», пусть и уникальный, разве можно вести речь о самостоятельности социальной философии? На этот вопрос у меня есть ответ. Чтобы аргументировать свою позицию, я сделаю следующее. Во-первых, пунктирно покажу, чем социальная философия принципиально и по своей сути отличается от теоретической социологии, исторической социологии и политической философии, т. е. постараюсь доказать, что социальная философия - самостоятельная дисциплина. Во-вторых, сформулирую несколько возможных подходов к изучению общества, которые можно было бы охарактеризовать как социально-философские, и приведу соответствующие аргументы. В-третьих, я, коснувшись проблем понимания предмета дисциплины, озвучу главный вызов, с которым сталкивается и/или должна столкнуться социальная философия в ближайшем будущем. Итак, в первой части исследования речь идет о сущности социальной философии и ее дисциплинарных границах, во второй - о методологии, которую она может использовать, а в третьей - о предметной области социально-философского знания, точнее, об одной из ее областей, особенно важной для нас сегодня. После чего читатель, надеюсь, получит некоторую ясность, что же такое социальная философия.

\section{Различения}

Социальная философия - не просто раздел философского знания. Социальная философия, как и некоторые другие отрасли философии и иные гуманитарные науки, выделилась из философии и, что принципиально важно (этого вопроса я еще коснусь), отдалилась от нее. До определенного времени философам было достаточно рассуждать о политических вещах - формах правления, лучших и худших режимах, природе власти, возникновении политической жизни и т. д. Лишь с развитием новых институтов и возникновением новых феноменов общественной жизни, для которых было недостаточно политико-философского знания, появляется то, что можно было бы назвать социальной философией. Последняя понадобилась для того, чтобы дать интерпретацию или концептуализировать такие феномены общественной жизни, как революция, идеология, нация и национализм, капитализм, буржуазия/третье сословие. Даже философия истории, которую обычно относят к сфере компетенций социально-философского знания, возникает, как утверждает большинство авторов, в последней трети XVIII столетия вместе с революцией, нацией, идеологией и третьем сословием. Иными словами, как единый (линейный или циклический) поэтапный процесс историю начинают мыслить сравнительно недавно. Следовательно, наряду с этими явлениями возникают и новые типы философствования, которые пытаются обособиться в отдельную дисциплину - социологию. Неслучайно социологи XX столетия post factum относили к отцам дисциплины не только Макса Вебера и Эмиля Дюркгейма, Вернера Зомбарта и Вильфредо Парето, но также Карла Маркса и Алексиса де Токвиля (и конечно, Огюста Конта). Некоторые авторы даже предпринимали попытку найти корни социологической мысли еще глубже. В частности, Раймон Арон опи- 
сывал политического философа Монтескье как первого социолога, обнаруживая в концепции последнего куда больше теоретической строгости, чем ее было на самом деле (Арон, 1992: 36-85). Таким образом, западная теоретическая социология присвоила все то, чем, по идее, должна была заниматься социальная философия. Как итог, сегодня на Западе (и почти во все время существования) практически не используют понятие социальной философии, традиционно разделяя сферу ее деятельности на социальную теорию/теоретическую социологию, историческую социологию и политическую философию/теорию. В тех редких случаях, когда некоторые ученые все же используют понятие «социальная философия», то, как правило, она идет в упряжке с «политической философией», а содержательное наполнение книг с названием «Социальная и политическая философия» сводится к легитимным темам политической теории/философии (справедливость, равенство, демократия, феминизм, свобода, рациональность и т. д.) (Sterba, 2001; Simon, 2002) $)^{1}$.

Таким образом, нет ничего удивительного в том, что социальная философия в России часто «заходит» на территорию социологии, некоторые авторы даже утверждают, что социальная философия ничем не отличается от теоретической социологии. Проблема, однако, заключается в том, что если так обстоят дела на самом деле, зачем социальная философия вообще нужна? Ее можно переименовать или вообще упразднить. Но социальная философия радикально отличается от социологии в следующих отношениях. Социология, как и все другие области знания, - не простая дисциплина, у нее есть своя история, на протяжении которой далеко не все ученые соглашались друг с другом, чем она должна заниматься (впрочем, это касается многих дисциплин, активно развивавшихся в последние сто пятьдесят лет, - как, скажем, политическая теория/политическая наука). Длительное время в социологии доминировал сциентизм, а вместе с ним универсализм и объективизм. Многие авторы пытались предложить общую теорию (general theory) или эпическую теорию (grand theory) - то есть макротеорию, которая бы объясняла общество как таковое, а вместе с ним и все его сферы - политическую, экономическую, культурную и т.д. Например, культура, если ее вообще касались, мыслилась только как социология культуры и тем самым имела строго подчиненный общей/эпической теории характер. Примерами таких общих социологических теорий могут считаться подходы Толкотта Парсонса и Никласа Лумана. Структурно-функциональный анализ, в рамках которого общество понималось как система, предполагающая, что каждый ее элемент имеет и выполняет свою функцию, долгое время доминировал в американской академии. Однако уже в середине 1950-х «теорию» стали осторожно критиковать на тех основаниях, что она не учитывала или не могла объяснить некоторое количество явлений или факторов, которые просто-напросто сознательно исключались из «системы» или объявлялись дисфункциональными. Лишь в середине 1960-х социальный теоре-

1. Можно отметить относительное тематическое единство таких книг. 
тик Ральф Дарендорф начал открытое наступление на структурный функционализм, замечая, что данная «теория», претендующая на научность и всеохватность, часто плохо скрывает свои ценностные компоненты и даже оценочные суждения. Самый серьезный упрек структурному функционализму со стороны Дарендорфа состоял в том, что последний был статичным и не учитывал динамические изменения системы (Дарендорф, 2002). Тем самым внутри самой социологии вычленялся новый подход, который ставил в центр анализа конфликт и его позитивное значение для развития общества. И хотя Дарендорф уже предлагал новую социальную теорию, которая допускала некоторую вольность рассуждений, этого было недостаточно. Более решительная атака на «социологическую теорию» началась в середине 1980-х годов.

Многие социологи увидели возможность освободиться от сциентизма и универсализма в очень популярном на тот момент постмодернизме, что бы под ним ни понималось. Тяготившиеся «научностью» ученые обнаружили в идее постмодерна целую программу исследований, позволявших заниматься вещами, до тех пор несвойственными социологии. Одним из таких пропонентов постмодерна стал Зигмунт Бауман, объявивший о завершении модерна, логически приведшего к Холокосту, и вхождении общества в новый этап своего развития - постсовременность. Новое состояние общества также предполагало и то, что прежние теории, объяснявшие предшествующую эпоху, неадекватны нынешней, а потому именно социологии предстоит создать новый понятийно-категориальный аппарат и предложить свежие концепции социальных трансформаций. Бауман начал атаку на философию, считая, что времена законодателей (мыслителей типа Канта или Гуссерля, претендующих на объективизм и универсальность их теорий) безвозвратно прошли, на арену выходят интерпретаторы (типа Гадамера), предлагающие лишь всевозможные толкования, но не теорию, в соответствии с которой должны были бы действовать все науки. Бауман предложил пересмотреть традиционные отношения философии и (постмодернистской) социологии. Последняя, по его мнению, перестала выполнять функцию «служанки философии» и становилась самостоятельной, а порой даже превосходящей все другие дисциплины (Bauman, 1989; Бауман, 1993). Один из главных пунктов программы Баумана - создание совершенно новой социологической теории взамен прежней - был предельно важным и отражал установки многих авторов, желавших расширить предметное поле социологии. Однако после того как Бауман, казалось, одержал победу и получил возможность предлагать собственные концепции современности, не обращая внимания на требования сциентизма, он отказался от постмодерна и стал писать о «текучей современности» (Bauman, 1997; Бауман, 20о8).

Примерно в том же ключе рассуждал «социолог» Стивен Сейдман. Он объявил «конец социологической теории», которая в конце 1980-х в лучшем случае, с его точки зрения, была интересна лишь сама себе. Программа Сейдмана была позитивной в том смысле, что он предложил заменить социологическую теорию на антисциентистскую «социальную теорию с нравственными интенциями» (Seidman, 
1994). С помощью постмодерна, не претендовавшего на универсальность и всеохватность теоретического знания, Сейдман совершал революцию в социологии, которая в итоге, можно сказать, увенчалась успехом. Получив возможность заниматься «социальной теорией», Сейдман приступил к исследованиям тех тем, которые его интересовали, но изучать которые традиционная социология до этого ни за что бы не позволила, - сексуальность, постколониальный национализм и т. д. Если посмотреть на то, чем Сейдман занимается сегодня, видно, насколько сильно расширились предметные рамки теоретической социологии/социальной теории ${ }^{2}$. Принципиально важной в этом отношении является текст «Оспариваемое знание», в котором Сейдман пытается доказать, что универсалистская социологическая теория (от Маркса и до Хабермаса) закончилась и на ее место пришли адекватные своему времени подходы и концепции - квир-теория, расовая теория, постколониальная теория, феминизм и т. д. ${ }^{3}$ Каким бы спорным этот тезис ни был, обилие подходов и тем в сегодняшней социальной теории демонстрирует, насколько сильно расширились возможности дисциплины. К слову, Энтони Гидденс, теорию которого Сейдман списывает в утиль, двигался в одном с ним направлении, уделяя внимание не только классическим темам, но и таким вопросам, как интимность, глобализация и т. д. ${ }^{4}$ В книге «Основные понятия социологии» Гидденс и его соавтор Филип Саттон наряду с традиционными для социологии понятиями («класс», «господство», «капитализм» и проч.) используют в качестве основных и такие как «сексуальность», «сеть», «моральная паника», «патриархат» и т. д. (Гидденс, Саттон, 2018).

Теперь мы можем провести ключевое различение «теоретической социологии» и социальной философии. Последняя является аналогом и синонимом социаль-

2. Например, в последнее время Сейдман занимается sexuality studies (Seidman, Fischer, Meeks, 2011).

3. Так видит новейшие тенденции в социальной теории Сейдман. Его книгу можно было бы сравнить с более конвенциональными и в то же время более традиционными (и отчасти уже устаревшими) авторскими историями социологической мысли, например, Л. Козера (впервые вышла в 1971 году) или Р. Коллинза (впервые вышла в 1994 году) (Козер, 2006; Коллинз, 20о9). Но если ранее социологи говорили именно о «социологической мысли», то Сейдман настаивает на том, что речь идет о «социальной теории». Таким образом, понятие «социальная теория» оказывается шире «социологической теории». Впрочем, в книге социолога Джорджа Ритцера «Современные социологические теории» (Ритцер, 2002) мы находим упоминания многих авторов, традиционно не считающихся социологами в классическом значении этого слова. Наконец, немецкие исследователи Х. Йоас и В. Кнебль, несмотря на то что они стараются быть осторожными в выборе авторов и следовать скорее классике социологии, все равно включают в свои лекции о социальной теории политических и моральных философов (типа Джона Ролза или Аласдера Макинтайра) или феминистскую критику (Йоас, Кнёбль, 2013). У Сейдмана совершенно иной, взвешенный, продуманный и обоснованный подход к теме (Seidman, 2012). Между прочим, многие «...studies» чаще всего основаны именно на социальной теории, особенно это касается cultural studies. Если заглянуть в один из самых популярных учебников по cultural studies, то можно обнаружить, что главные авторы для дисциплины - Антонио Грамши, Стюарт Холл, Рэймонд Уильямс, Мишель Фуко, Жан Бодрийяр, Фредрик Джеймисон и т. д. (Barker, 2012) (четвертое издание, первое вышло в 2002 году).

4. Например, одну из своих последних книг Энтони Гидденс посвятил переосмыслению европейского континента (Гидденс, 2015). 
ной теории в понимании Стивена Сейдмана, т. е. предполагает ценностное измерение и возможность выносить оценочные суждения. Иными словами, социальная (а не социологическая) теория/философия валюативна. Это, по моему глубокому убеждению, ключевой признак социальной философии. Впрочем, отмечу, что при этом валюативность ни в коем случае не должна становиться морализаторством, поскольку социальная философия, в отличие, скажем, от публицистики, предполагает аргументированность выводов и тщательную работу с эмпирическим материалом. На таких основаниях тот же Зигмунт Бауман, рассуждающий о «постмодернистской этике» (Bauman, 1993), или Жиль Липовецкий, размышляющий о «гипермодерне» (Lipovetsky, 2015), могут быть названы социальными теоретиками в западном смысле слова, и социальными философами - в отечественном значении.

В рамках социологии есть еще одна дисциплина, которая, если так можно выразиться, составляет конкуренцию социальной философии. Это историческая социология. В работе социолога Ричарда Лахмана «Что такое историческая социология?» предметные поля обеих дисциплин едва ли не идентичны. Темы, которые изучает историческая социология, с его точки зрения, это: истоки капитализма, революции и социальные движения, империи, государства, неравенство, гендер и семья, культура, предсказание будущего (Лахман, 2016). Если нам кажется, что мы обнаруживаем здесь традиционный набор социально-философских тем, то так оно и есть на самом деле. Если социальная философия в самом деле ориентируется на эмпирический материал (а как еще обсуждать революцию, если не обращаться к историческим примерам?), то предметные поля дисциплин сильно пересекаются. Но есть и существенные отличия. В рамках исторической социологии возможны какие угодно подходы. Очень часто, особенно в эпоху всеобщей увлеченности сциентизмом, историческая социология пыталась ориентироваться на принципы работы естественных наук, предлагая модели того или иного явления. Так действовали в отношении исследований революции Крейн Бринтон, Баррингтон Мурмладший, Теда Скочпол, за что часто подвергались острой критике со стороны других ученых (Малиа, 2015: 352-368) и т.д. Однако в стремлении построить единую модель революции, которая бы объясняла все революции в истории, исторические социологи, занимаясь исключительно классовым анализом, упускали из внимания роль государства (девизом Скочпол в ее знаменитом труде «Государство и социальные революции» было возвращение государства в изучение революции) и уж тем более идеологии. В итоге новые исследователи (например, Эрик Селбин) постарались исправить ситуацию, но сделали крен в другую сторону (Селбин, 2008). Даже на этом примере видно, что историческая социология развивалась в том же направлении, что и теоретическая - к культуре. В сравнении с исторической социологией подход Ханны Арендт к революции был куда более социальнофилософским, предполагавшим нравственные интенции автора. Арендт выделила две «модели» революции, но фокусировалась скорее на мотивах и основаниях революций, показывая, что революционеры во Франции преследовали прежде всего социальные интересы, в то время как американские революционеры желали до- 
стичь свободы (Арендт, 2011). Нетрудно заметить, что Арендт стремилась доказать «добродетельность» отцов-основателей Соединенных Штатов и осудить «неправильные» европейские революции. Этот пример хорошо показывает, в чем именно и как расходятся историческая социология и социальная философия.

Наконец, политическая философия. Проблема с этой дисциплиной заключается в том, что и внутри нее возможны совершенно различные программы. Например, некоторые авторы ориентировались на анализ «великих текстов», другие изучали историю политических идей от Платона до нынешнего дня, третьи строили самостоятельные теории, основанные на в высшей степени абстрактных рассуждениях (как, например, делал Джон Ролз и те, кто включился в его дискурсивную программу, - Роберт Нозик, Рональд Дворкин и т. д.). Были и такие, кто усматривал истоки революций, войн, тоталитаризма, Холокоста и т.д. в различных философских течениях прошлого - в гностицизме (Эрик Фегелин), рационализме (Майкл Оукшот), релятивизме (Лео Штраус) и т.д. Когда на Западе используют термин «социальная философия», то очень часто делают это именно в паре с понятием «политическая философия». Рассуждения идут на языке, сформулированном Ролзом, а это уже радикально иной проект «социальной философии», почти не пересекающийся с тем, чем занимается отечественная социальная философия, и мало пересекающийся с тем, что на Западе понимается под социальной теорией. Так, Эрик Фегелин, предлагавший свой проект философии истории, вполне может считаться социальным философом в нашем понимании. При этом в последнее время предпринимаются (весьма удачные) попытки увязать традиционную/классическую социальную теорию с политической теорией. Дэниел Чернило пытается показать, что в основании современной (в значении modern, a не contemporary) coциальной теории лежит теория естественного права - классическая тема политической философии 5 . Политическая философия и социальная философия не только пересекаются, но даже совпадают, а точнее - у обеих дисциплин один и тот же объект (общество), и предмет политической философии включен в предмет социальной. Социальная философия изучает и власть, и режимы, и государство, часто прибегая при этом к широкой перспективе, пытаясь взглянуть на эти вещи параллаксным взглядом, а не сосредотачиваясь на едином подходе, будь это даже такая влиятельная эпическая теория, как теория справедливости Ролза.

Теперь, когда мы выяснили степень автономности социальной философии и определили ее свободу, посмотрим, какие возможности существуют у социальной философии - «лисы» - в рамках параллаксного видения.

\section{Вариации}

В России у социальной философии были конкретные истоки: эта дисциплина непосредственно формируется из того, что ранее называлось историческим материа-

5. Помимо прочего, Чернило подробно разбирает идеи Л. Штрауса и Э. Фегелина (Chernilo, 2013). 
лизмом со всеми вытекающими отсюда последствиями, причем не только негативными, но во многом и позитивными. Наследие марксизма, вне всякого сомнения, предоставляет богатый инструментально-методологический аппарат, предметное поле для социально-философских исследований и теоретических обобщений среднего и высшего уровня. «Капитализм», «идеология», «революция», «исторический процесс», «отчуждение», «классовая борьба», «товарный фетишизм» и т. д. лишь немногое из того, что мы получили в наследие от Маркса и советского марксизма. Если учитывать то обстоятельство, что огромное количество социальных философов/мыслителей ориентированы (нео)марксистки (А. Грамши, Д. Лукач, Э. Блох, Г. Маркузе, Л. Альтюссер, М. Мерло-Понти, Ж.П. Сартр, А. Негри, И. Валлерстайн, Ф. Джеймисон, С. Жижек и др.), т. е. исходят из определенных ценностных предпосылок и даже идеологических позиций (что не смущает и не должно, как мы сказали выше, смущать социальную философию), то этого достаточно, чтобы оправдать существование нашей дисциплины сегодня. Социальной философии можно не конкурировать с иными дисциплинами типа социологии или политической философии, потому что мало кто из названных выше оригинальных мыслителей считается «социологом» в строгом смысле слова, в лучшем случае «социальным теоретиком», но в широком, как было указано выше, смысле. Точно так же их редко рассматривают в дискурсе политической философии по причине того, что в рамках этой области знания на Западе доминируют наследники эпической теории Ролза. Авторы, работающие в рамках политической философии, скорее рассуждают о теориях демократии, политическом измерении феминизма, экологии и т. д. Таким образом, социальная философия ни в коем случае не должна отказываться от марксистского наследия, но пытаться сохранить и приумножить его. Однако такой подход можно было бы охарактеризовать как один из вариантов «слабой программы» социальной философии, ведь у этой дисциплины куда больший эвристический потенциал. Что имеется в виду?

Может показаться неожиданным, но социальная философия не обязана быть «философией». Это спорное умозаключение, поэтому предлагаю некоторые аргументы в пользу данного тезиса. Обратимся к идеям американского ученого (довольно затруднительно подобрать более точное определение, разве что: психиатра) Томаса Саса, чей подход к анализу социальных проблем является безусловно социально-философским. Между тем у него нет собственной «теории» или уникальной методологии, в соответствии с которыми он работал над своими проектами. Однако у него была своя (нефилософская) концепция и, если угодно, гражданская позиция. Сас писал свои книги с целью изменить сложившуюся в Соединенных Штатах ситуацию, но все же эти книги написаны в академическом ключе. Он сформулировал концепцию «терапевтического государства» и фактически встал у истоков антипсихиатрического движения в США, вдохновив очень многих на борьбу. С точки зрения Саса, государство (и именно государство), преследуя «ненормальных» (в это понятие раньше включались наркоманы, гомосек- 
суалы, алкоголики и еще много других категорий граждан), занималось тем же, чем в XV веке инквизиция - «охотой на ведьм» (Сac, 2008).

Сас утверждал, что обществу некомфортно с теми, кто якобы отклоняется от нормы, и потому люди стремятся дистанцироваться от «иных» и обвинить во всех социальных проблемах «сумасшедших». Сас отмечает, что кто угодно мог использовать этот прием в политических целях: достаточно было указать на человека как на сумасшедшего, и тот попадал под пристальный контроль психиатров. Самое ужасное, по мнению автора, в том, что деятельность психиатров оплачивало государство, тем самым умножая свое могущество. Сас предлагал альтернативу - «договорную психиатрию», в рамках которой пациент сам бы обращался к специалисту, сам оплачивал сеансы, и обе стороны могли бы прервать контракт в любое время. Мы видим, что Сас не использует какую-либо методологию и не прикрывается авторитетными именами, но при этом осуществляет колоссальную по объемам исследовательскую работу, предлагая анализ богатого эмпирического материала - от подборок статей в СМИ за несколько десятилетий до редких исторических источников. Иными словами, социально-философскую концепцию, предполагающую в том числе гражданскую позицию, можно построить и без философии или специальных методов, лишь бы она при этом была фундирована. Стоит ли говорить, что такой подход остается все еще «слабой программой» социальной философии? Заметим, что именно идеями Томаса Саса в свое время вдохновился Фуко при создании своих социально-философских концепций о «рождении клиники». Мы не раз можем встретить ссылку на Саса на страницах «Истории безумия» - очередное подтверждение тому, какое существенное влияние «нефилософская социальная философия» может оказать на философскую социальную философию.

Еще одним примером этого варианта социальной философии могут быть не концептуализированные (не предлагающие языков описания эпохи) в строгом смысле слова тексты, но анализирующие богатый эмпирический материал. Яркий образец такого подхода - книга английского урбаниста Адама Гринфилда «Радикальные технологии: устройство повседневной жизни» (Гринфилд, 2018) 6 . Автор не просто описывает новейшие феномены современного общества (смартфон, блокчейн, криптовалюта, искусственный интеллект и автоматизация труда), но активно ссылается на Карла Маркса, Рэймонда Уильямса, Мишеля де Серто, Джеймса Скотта. Его анализ, хотя об этом не заявляется прямо, имеет ярко выраженный «левый» характер - Гринфилд постоянно обращается к теме неравенства, злоупотреблений элит и т.д.

Другой показательный пример нефилософской социальной философии - paботы британского историка Перри Андерсона, которого обычно называют «выдающимся интеллектуалом XX столетия» ${ }^{7}$. И хотя Андерсон - наиболее знамени-

6. Классический пример такого подхода «Демократия в Америке» Алексиса де Токвиля (Токвиль, 1992).

7. Так Андерсона называет английский консерватор Роджер Скрутон (Scruton, 2015). 
тый из ныне живущих неомарксистов, приверженность к левой идее и марксизму грамшианского толка для него - скорее политическая и гражданская позиция, нежели теория и методология. Он начинал свою карьеру как историк, однако в рамках этой дисциплины его талантам явно было тесно. Его вклад в развитие социально-философской мысли трудно переоценить. Во-первых, он обобщил историю «западного марксизма», придав этому интеллектуальному направлению метанарративный характер, одновременно с завидной регулярностью публикуя европейских марксистов на английском языке в журнале «New Left Review». Boвторых, он систематизировал огромное количество высказываний на тему постмодерна, обратившись к самым истокам употребления термина, указал на то, как каждый из авторов в течение долгого времени работал с понятием в собственном ключе. Андерсон проследил, как термин из эстетики перебрался в критику, искусство и литературоведение, и только затем - в философию (Андерсон, 2011). При этом Андерсон не претендует на теоретические обобщения и весьма скромен в собственном анализе эпохи постмодерна. Это исследование, а не теоретические построения, но оно дает куда больше, чем многие попытки мыслить о постмодерне философски. В-третьих, примерно такой же прием Андерсон использовал в отношении концепта «гегемония», показав, что разные авторы слишком вольно распоряжаются этим понятием, порою противореча сами себе (Андерсон, 2016, 2018; Anderson, 2017). Знакомство с этой исследовательской книгой скажет о гегемонии - традиционном понятии для социальной философии - куда больше, чем мы узнаем, прочитав тексты Грамши или некоторых других авторов. При этом Андерсон позволяет себе часто слишком острые, но обоснованные оценки, не выходя за пределы выбранной им исследовательской парадигмы. Этот подход мы могли бы назвать третьим вариантом «слабой программы» социальной философии. «Слабой» - потому что это все еще ограниченная сфера деятельности (кропотливая исследовательская работа с тем, что можно было бы назвать «сложными понятиями», такими как «гегемония» или «постмодерн») для ученого. Обратим также внимание, что позиция Андерсона отличается от позиции Саса: последний работает с материалом, чтобы фундировать свою концепцию, нежели ставит перед собой задачу прийти в своих изысканиях к ясному пониманию феномена или термина.

Данная «слабая программа» социальной философии предполагает, что ее авторы часто выходят за ее пределы. Скажем, социальный теоретик левой ориентации Йоран Терборн, с одной стороны, может размышлять о том, как устроен современный мир, с другой - анализировать нынешнее состояние марксистской теории (Терборн, 2015; Therborn, 20о8) ${ }^{8}$. Иными словами, на основаниях первой

8. Впрочем, есть прекрасные примеры, когда авторы основывают свой анализ эмпирического материала на социально-философских концепциях марксизма, в частности, это касается классического исследования города Дэвидом Харви (Харви, 2018). Харви пытается перевести понятие «справедливость» из ролзовских абстракций в сферу эмпирики, осуществляя тем самым переход (добавляя к перераспределению производство), как заявляет сам автор, от либеральной справедливости - к социалистической. 
«слабой программы» социальной философии часто работает третья «слабая программа».

Наконец, еще одним вариантом социальной теории, который мы могли бы охарактеризовать как четвертая «слабая программа» социальной философии, является концепция культурсоциологии Джеффри Александера. Александер, как и упомянутые выше социологи, долгое время тяготился засильем общих теорий в социологической науке. На протяжении десятилетий разрабатывая свой подход, он лишь сравнительно поздно (в 2003 году) смог наконец сформулировать принципы своей работы. Александер настаивает, что культура - не просто сфера общества, как предполагает социология культуры, она обладает собственной автономией. В культуре определяются смыслы социальной жизни, которые не позволяет вскрыть традиционная социология. Александер посвящает свои исследования самым неожиданным темам - как работает зло (и почему это не недостаток добра, а нечто большее), как функционируют скандалы и моральные паники, как социально конструируются нравственные универсалии, в частности Холокост, и каким образом работает дискурс гражданского общества (конкретного американского гражданского общества) (Александер, 2013; Alexander, 2012). Если бы отечественная социальная философия занималась тем, что Александер называет культурсоциологией, мы смогли бы многое понять о российском обществе, его гражданском дискурсе, конструировании ценностей, многочисленных скандалах и т. д. Более того, то, что сформулировал в качестве методологии культурсоциологии Джеффри Александер, подходит и для отечественной социальной философии: «Мои очерки курсируют между теоретизированием и исследованием, интерпретацией и объяснением, культурной логикой и культурной прагматикой», а также: «Мои очерки, даже когда в них предлагаются модели и присутствуют претензии на обобщение... все равно укоренены в прагматических, нормативных, в широком понимании этого термина, интересах» (Александер, 2013: 49). При этом Александер, в отличие от таких авторов, как Сейдман, сохраняет почтительное отношение к классической социологической теории (Alexander, 2013). Но стоит ли говорить, что и этого недостаточно для «сильной программы»? Что же в таком случае мы можем считать «сильной программой» социальной философии?

Представляется, что сложное - параллаксное - сочетание упомянутых четырех вариантов «слабых программ» ((нео)марксизм как методология анализа социальных феноменов и проблем в сочетании с политической позицией, концептуальная «нефилософская социальная философия», исследования социально-философских вызовов и терминов без теоретизации, культурсоциология) для начала будет достаточным, чтобы задать тон новой исследовательской парадигме социальной философии. Все упомянутые подходы имеют отчетливо нормативный - в широком смысле слова - характер, что, как мы уже обсуждали, и составляет ключевой принцип социальной философии/социальной теории. 


\section{Проблематизации}

Рассмотрим, как работает «сильная программа» социальной философии, состоящая из четырех «слабых программ». Однако прежде необходимо проговорить одну важную вещь. До сих пор мы обращались к тем проектам социальной философии, которые имеют скорее нефилософский характер, в том смысле что они довольно далеки от того, что зовется метафизикой. В самом начале я упомянул, что социальная философия, как и некоторые другие дисциплины, вышла из философии, все больше отдаляясь от нее. Вместе с тем сегодня мы можем наблюдать продуктивные попытки, с одной стороны, социальных теоретиков, а с другой классических философов, построить социальную теорию на базе метафизики. Некоторые авторы предполагают, что «философская социальная философия» тоже существует, поскольку ключевые проблемы, принадлежащие философии (прежде всего онтологии), могут быть разрешены и/или прояснены посредством обращения к эмпирическим исследованиям.

Так, социальный теоретик и антрополог Бруно Латур сопровождает одно из своих исследований «метафизическим трактатом» (Латур, 2015). Развивая собственный проект - акторно-сетевую теорию, он использует термины «практическая метафизика» и «эмпирическая метафизика» (Латур, 2014: 74-76) ${ }^{9}$. Последний термин для обозначения своего исследования употребляет и антрополог медицины Аннмари Мол: она решает онтологические проблемы, изучая множественность заболеваний и тел в медицинских практиках в конкретном госпитале ${ }^{10}$. Со стороны философов «новую философию общества» предлагает Мануэль Деланда (Деланда, 2017). Наконец, философ Грэм Харман, дружественно полемизируя с Латуром (Latour, Harman, Erdélyi, 2011), строит объектно-ориентированную онтологию и применяет ее к исследованию «социальной материи», называя свою теорию «имматериализмом» (Харман, 2018). Такой - метафизический - подход к социальным вопросам находит отклик у отечественных социологов: так, Виктор Вахштайн и его коллеги активно обсуждают возможность и развитие объектно-ориентированной социологии (Вахштайн, 2017) ${ }^{11}$. Все эти авторы, предлагая разные подходы, движутся в одном направлении - разрабатывают философский язык, который позволит описывать вещи и процессы в реалистическом ключе в рамках социальной теории. Чтобы указать на единый вектор подобных усилий, Харман предпринимает неоднократные попытки доказать, что и он сам, и Латур и его последователи, а также Деланда действуют в общем - философском - поле социальной теории (Харман, 2017; DeLanda, Harman, 2017). Таким образом, «философская социальная философия» может быть также рассмотрена в качестве одной из «слабых программ» социальной философии, однако ее трудно совместить с пере-

9. Пояснение точки зрения Латура: Астахов, Гавриленко, Писарев, 2017: 23.

10. Свое исследование она называет «упражнением в эмпирической философии» (Мол, 2017: 33).

11. Сам термин появляется у Латура в «Пересборке социального» (Латур, 2014: 103): «объектноориентированная социология для объектно-ориентированных людей». 
численными выше программами, и потому она может быть лишь одним из подходов (языков описания) в рамках социальной философии/теории как таковой. Но обратимся к «социальному».

Как это ни странно, но в своем ключевом принципе социальная философия не исходит и не может исходить исключительно из понятия «социального». Это невозможно по той простой причине, что «социальное» в истории философского знания относительно новое «изобретение» (если мы полагаем, что оно конструируется какими-то внешними факторами) и новое «явление» (если мы утверждаем, что оно возникает стихийно и самостоятельно) ${ }^{12}$. Несмотря на то что и до Нового времени многие философы писали о политических вещах или же касались некоторых «традиционно социальных» вопросов (семья, право на восстание, естественное право), «социального» как такового в этих рассуждениях не было. Используя традиционную пару понятий социальной философии, мы можем назвать социальные организации до возникновения социального «общностью», в то время как с возникновением социального - «обществом». «Социальное» как таковое может быть связано с понятием «гражданское общество» (или с нацией, или с другими формами общества), со стремлением людей осознавать себя в качестве некоторого «коллективного субъекта социального действия», или же того, что называется «публичной сферой» или общественностью. (Заметим, что, например, термин «public relations» - еще одно недавнее изобретение - означает не только «связи с общественностью», как у нас принято переводить, но также отношения тех или иных субъектов на публике, то есть в публичном пространстве, а не в частном.) Социальная философия должна учитывать эти нюансы и потому, хотя и является «социальной», ни в коем случае не может ограничиваться изучением лишь «социального». Мы видим, что ее сфера компетенций куда шире.

Все эти рассуждения о «социальном» относятся не только к истории, но и важны в свете сегодняшних проблем. Так, многие авторы на протяжении последней трети XX века объявляли о «конце социального». Некоторые из них, например, французский социолог Ален Турен, увязывают «социальное» с «Современностью» (Модерном), в том смысле что с возникновением «социального», т. е. знакомого нам общества, мир вступает в принципиально иную эпоху. Проблемой, однако, является то, что сегодня, по мнению Турена, «Современность» вытесняет «общество» (Touraine, 2007: 77-78). Примерно так же думают многие другие социальные теоретики и философы, озабоченные процессами «индивидуализации», благодаря которым «социальное» исчезает, умирает или заканчивается. Кроме Турена об этом пишут Зигмунт Бауман и Жиль Липовецкий. Фиксируя тектонические изменения в социальном, они предлагают различные концепции современности «текучую современность» (Бауман, 2008), «гиперсовременность» (Lipovetsky, 2015), «радикализированную современность» (Гидденс, 2011) и т. д. Иными словами, если

12. Особенный - авторский — и весьма любопытный подход к определению «социального» предложил Александр Филиппов, но разбор его концепции уведет нас в совсем другом направлении (Филиппов, 2015). 
даже социальное, каким мы его знаем, исчезнет, это вовсе не означает, что для социальной философии не останется предмета для размышления. Наоборот, именно тогда социальная философия вступает в свою активную фазу, принимая вызов и пытаясь описать и объяснить новые черты становящегося мира.

В последние пятнадцать-двадцать лет перед социальной философией стоит важнейшая задача. Если мы солидарны с заявлениями многих авторов ${ }^{13}$ о том, что постмодерна как долгой исторической эпохи больше не существует, то как описать мир, который пришел ему на смену? Хотя некоторые мыслители все еще пытаются рассуждать о том или ином виде современности, но вместе с тем уже появилось несколько в разной степени влиятельных концепций, предлагающих иной диагноз эпохи - ремодернизм (художники Билли Чайлдиш и Чарльз Томсон), реньювализм (Джош Тот), альтермодернизм (куратор Николя Буррио), упоминаемый выше гипермодернизм (Жиль Липовецкий), автомодернизм (Роберт Самуэльс), диджимодернизм (Алан Кирби), перформатизм (Рафаэль Эшельман), метамодернизм (Тимотеус Вермюлен и Робин ван ден Аккер) ${ }^{14}$, а также космодернизм (Кристиан Морару) (Moraru, 2011). Ни одна из этих концепций не является доминирующей в социально-философском дискурсе. Вместе с тем собранные вместе они дают синергийный эффект: создается ощущение, что мы и в самом деле живем в эпоху безвременья, отчаянно нуждающуюся в интерпретации. Некоторые из этих теорий не находят поддержки, другие, напротив, «набирают обороты». Так, к проекту метамодернизма подключились Рафаэль Эшельман (перформатизм) и Джош Тот (реньювализм), опубликовав в новейшем сборнике, посвященном метамодерну, свои тексты (Van den Akker, Gibbons, Vermeulen, 2017). На наш взгляд, лучшим вариантом было бы назвать все эти концепции «постпостмодернизмом», то есть всем тем, что пришло на смену постмодерна, но все равно покоится на его основах.

Впрочем, это затруднительно сделать по следующим причинам. Сами сторонники альтернативы «ушедшей эпохи» намеренно избегают семантической связки с постмодерном именно потому, что они таким образом как бы вписываются в проект постмодерна, развивая его. Как точно заметили «метамодернисты»: синтаксически такая приставка верна, но семантически - нет. Кроме того, существует концепция «постпостмодернизма», ее автор Джеффри Нилон как раз соглашается с тем, от чего другие сторонники новых идей отказываются: он не отрицает, что его взгляды имеют генетическое родство с предшествующей теорией, однако поскольку мир изменился, то требуется инвентаризация постмодерна (Nealon, 2012). Нилон напрямую наследует идеям Фредрика Джеймисона, ведущего аналитика постмодерна, и тем самым развивает его «теорию» постмодернизма как культурной логики позднего капитализма. «Новый» капитализм для Нилона является актуальным (just-in-time), а его культурной логикой в таком случае оказывается

13. Ключевые аналитики постмодерна - Ихаб Хассан, Фредрик Джеймисон, Зигмунт Бауман, Линда Хатчеон - в той или иной форме объявили о его конце (Bauman, Tester, 20о7; Hassan, 20о3; Hutcheon, 2002; Jameson, 2007).

14. См. антологию, в которую вошли почти все эти концепции: Rudrum, Stavris, 2015. 
«постпостмодернизм». Таким образом, только на этом основании было бы не совсем верно обозначать другие «модернизмы» как постпостмодернизм, хотя все они представляют собой именно постпостмодернизм. Если использовать последнее понятие в самом широком смысле, то новые модернизмы окажутся если не семантически, то дискурсивно постпостмодернизмами. Почему это так?

Во-первых, все возникшие альтернативные варианты постмодернизма появляются буквально после него, если не «стоят на его плечах», то пытаются что-то возделывать на, видимо, все еще плодоносной почве. Во-вторых, почти все авторы альтернативных проектов используют слово «-модернизм», тем самым сохраняя связку «модернизм - постмодернизм - то, что после». В-третьих, почти все они уделяют в своих текстах место размышлениям о постмодерне, предлагая аргументы, почему он умер или почему его следует преодолеть, и только после этого переходят к позитивным частям своих программ. В-четвертых, и это самое главное, почти все авторы используют уже наработанные постмодернистские дискурсивные стратегии. Речь идет не о том, что они нечто «деконструируют», объявляют смерть субъекта или заявляют о том, что реальности не существует. Это - как раз не стратегии постмодерна, но скорее оригинальные философские позиции с вытекающими из них следствиями. Почти все те, кто возвещает о новых «-модернизмах», обращаются к культуре - к архитектуре, кинематографу, литературе и т. д. Разумеется, в каждом конкретном случае есть свои нюансы, как, например, в «диджимодернизме», но по большому счету это единая линия аргументации показать изменения в культуре, а не в обществе. Некоторые авторы по этой причине совершают следующий ход и начинают говорить о «новой эпохе», в пользу чего свидетельствует якобы чрезвычайно изменившаяся культура. Тем самым альтернативы используют уже существующие паттерны - паттерны, созданные «постмодернизмом». Все эти мыслители двигаются по проторенной колее, кажется, даже не замечая, что в своих глубинных основаниях их концепции имманентны проекту постмодерна.

Вот почему, прежде чем предлагать версию современной эпохи, «сильной программе» социальной философии следует описать все существующие версии «-модернизмов» и объяснить, почему они «не работают» или почему не получили широкого распространения. Какое место в новом мире займет «социальное», если оно останется? Как будет развиваться культура? Какие прогнозы мы можем дать? На все эти вопросы, обращаясь к эмпирическому материалу и иным концепциям, должна ответить отечественная социальная философия.

\section{Заключение}

Итак, мы описали свой вариант предметного поля социальной философии и возможных методов работы с этим полем, предложив синтез четырех «слабых программ» социальной философии, которые вместе могли бы составить ее «сильную программу». Эта программа должна органически сочетать в себе следующие уста- 
новки - методологию неомарксизма, включая ориентацию на традиционные для этого течения объекты анализа (капитализм, идеология, отчуждение); аккуратные и тщательные исследования; почтительное отношение к культуре (и ее приоритет в анализе), а также фундированность и концептуальность, т. е. обязательный выход за пределы обработанного эмпирического материала. Таким образом, социальная философия не может быть только эмпирической (как историческая социология в традиционном понимании) или только теоретической (как теоретическая социология), но должна предлагать аргументированные варианты моральных ориентиров для общества, в том числе для российского.

Исходя из вышеизложенного, мы можем дать рабочее определение социальной философии, которое, возможно, в дальнейших исследованиях будет скорректировано или дополнено. Социальная философия представляет собой многочисленные (не всегда) философские кониептуализации социальных проблем, феноменов, сложных понятий, а также теоретические попьтки интерпретации нашего и/или иного времени, во-первых, предполагающие нормативное измерение и, во-вторых, основанные на богатом эмпирическом материале. Несмотря на то, что это довольно широкая дефиниция, в целом она позволяет понять содержание дисциплины. На наш взгляд, она проясняет смысл обозначенного подхода и словосочетание «параллаксы лисы», предполагающее, что социальная философия занимается многими вещами, но старается путем тщательного и многофакторного исследования этих вещей взглянуть на изучаемую проблему по-новому или обнаружить ее эвристический потенциал.

Перед социальной философией стоит сложная задача - сказать что-то осмысленное о времени, в котором мы живем, определить изменения в культуре и экономике, а далее концептуализировать их, ответив на вопрос, что пришло на смену постмодерну, если он в принципе существовал. Более того, если мы согласимся, что постмодерн был - хотя бы на уровне дискурса (в том числе академического, где он точно существовал и даже процветал на протяжении как минимум двадцати лет), встает вопрос, настолько ли мы уверены, что сегодняшнее социальное состояние не может быть описано в категориях постмодерна? Возможно, он просто изменился, мутировал, заснул или перебрался в другие сферы знания. Как бы то ни было, эту проблему необходимо решить, но это задача уже для совсем другого исследовательского проекта.

\section{Литература}

Александер Дж. (2013). Смыслы социальной жизни: культурсоциология / Пер. с англ. Г. К. Ольховикова под ред. Д. Ю. Куракина. М.: Праксис.

Андерсон П. (2011). Истоки постмодерна / Пер. с англ. А. Аполлонова под ред. М. Маяцкого. М.: Территория будущего.

Андерсон П. (2016). Размышления о западном марксизме. На путях исторического материализма. M.: Common Place. 
Андерсон П. (2018). Перипетии гегемонии / Пер. с англ. Д. Кралечкина. М.: Изд-во Ин-та Гайдара.

Арендт Х. (2011). О революции / Пер. с англ. И. Косича. М.: Европа.

Арон Р. (1992). Этапы развития социологической мысли / Пер. с франц. А. И. Рычагова, В. А. Скиба. М.: Прогресс.

Астахов С., Гавриленко С., Писарев А. (2017). Акторно-сетевая теория: незавершенная сборка // Логос. № 1. С. 1-40.

Бауман 3. (1993). Философия и постмодернистская социология // Вопросы философии. № 3. С. 46-61.

Бауман 3. (2008). Текучая современность / Пер. с англ. С. А. Комарова под ред. Ю. В. Асочакова. СПб.: Питер.

Вахштайн В. (2017). Революция и реакция: об истоках объектно-ориентированной социологии // Логос. № 1. С. 41-84.

Гидденс Э. (2011). Последствия современности / Пер. с англ. Г. К. Ольховикова, Д. А. Кибальчича. М.: Праксис.

Гидденс Э. (2015). Неспокойный и могущественный континент: что ждет Европу в будущем? / Пер. с англ. А. Матвеенко, М. Бендет. М.: Дело.

Гидденс Э., Саттон Ф. (2018). Основные понятия в социологии / Пер. с англ. Е. Рождественской, С. Гавриленко под науч. ред. С. Гавриленко. М.: ВШЭ.

Гринфилд А. (2018). Радикальные технологии: устройство повседневной жизни / Пер. с англ. И. Кушнаревой. М.: Дело.

Дарендорф Р. (2002). Тропы из утопии: работы по теории и истории социологии / Пер. с нем. Б. Скуратова, В. Близнекова. М.: Праксис.

Деланда М. (2017). Новая философия общества: теория ассамбляжей и социальная сложность / Пер. с англ. К. Майоровой. Пермь: Гиле Пресс.

Йоас Х., Кнёбль В. (2013). Социальная теория: двадцать вводных лекций / Пер. с нем. К. Г. Тимофеевой. СПб.: Алетейя.

Козер Л. А. (2006). Мастера социологической мысли: идеи в историческом и социальном контексте / Пер. с англ. Т. И. Шумилиной под ред. И. Б. Орловой. М.: Норма.

Коллинз Р. (2009). Четыре социологических традиции / Пер. с англ. В. Россмана. М.: Территория будущего.

Латур Б. (2014). Пересборка социального: введение в акторно-сетевую теорию/ Пер. с англ. И. Полонской под ред. С. Гавриленко. М.: ВШЭ.

Латур Б. (2015). Пастер: война и мир микробов. С приложением «Несводимого» / Пер. с франц. А. Дьякова. СПб.: ЕУСПб.

Лахман Р. (2016). Что такое историческая социология? / Пер. с англ. М. В. Дондуковского под ред. А. А. Смирнова М.: Дело.

Льюкс С. (2010). Власть: радикальный взгляд / Пер. с англ. А. Кырлежева. М.: ВШЭ.

Малиа М. (2015). Локомотивы истории: революции и становление современного мира / Пер. с англ. Е. Володиной. М.: РОССПЭН. 
Мол А. (2017). Множественное тело: онтология в медицинской практике / Пер. с англ. В. Гусейновой, Д. Кожемяченко, Г. Коновалова, К. Майоровой, В. Легейдо, М. Меньшиковой, А. Павловой, А. Салина, А. Титова под науч. ред. А. Писарева, С. Гавриленко. Пермь: Гиле Пресс.

Павлов А. В. (2018). Образы современности в XXI веке: диджимодернизм: рецензия на книгу Алана Кирби // Философия. Журнал Высшей школы экономики. 2018. T. II. № 2. C. 197-212.

Паркер Н. (2008). Параллаксы: революция и «революции» в глобальном представлении // Бляхер Л. Е., Межуев Б. В., Павлов А. В. (ред.). Концепт «революция» в современном политическом дискурсе. СПб.: Алетейя. С. 163-184.

Ритцер Дж. (2002). Современные социологические теории / Пер. с англ. А. Бойкова, А. Лисицыной. СПб.: Питер.

Cac T. (2008). Фабрика безумия: сравнительное исследование инквизиции и движения за душевное здоровье / Пер. с англ. А. Ишкильдина. Екатеринбург: Ультра.Культура.

Селбин Э. (2008). Деятельность и культура в революциях // Бляхер Л. Е., Межуев Б. В., Павлов А. В. (ред.). Концепт «революция» в современном политическом дискурсе. СПб.: Алетейя. С. 184-195.

Терборн Й. (2015). Мир: руководство для начинающих / Пер. с англ. Е. М. Горбуновой, Л. Г. Титаренко под науч. ред. С. М. Гавриленко. М.: ВШЭ.

Токвиль А. (1992). Демократия в Америке / Пер. с франц. В. Т. Олейника, Е. П. Орловой, И. А. Малаховой, И. Э. Иванян, Б. Н. Ворожцова. М.: Прогресс.

Филиппов А. Ф. (2015). К определению социального // Филиппов A. Ф. Sociologia: наблюдение, опыты, перспективы. Т. 2. СПб.: Владимир Даль. С. 98-118.

Харви Д. (2018). Социальная справедливость и город / Пер. с англ. Е. Герасимовой. М.: Новое литературное обозрение.

Харман Г. (2017). Сети и ассамбляжи: возрождение вещей у Латура и Деланда / Пер. с англ. А. Писарева // Логос. № 3. С. 1-34.

Харман Г. (2018). Имматериализм: объекты и социальная теория / Пер. с англ. А. Писарева. М.: Изд-во Ин-та Гайдара.

Хиршман А. (2012). Страсти и интересы: политические аргументы в пользу капитализма до его триумфа / Пер. с англ. Д. Узланера. М.: Изд-во Ин-та Гайдара.

Alexander J. (2012). Trauma: A Social Theory. Cambridge: Polity.

Alexander J. (2013). The Dark Side of Modernity. Cambridge: Polity.

Anderson P. (2017). The H-Word: The Peripeteia of Hegemony. L.: Verso.

Barker C. (2012). Cultural Studies: Theory and Practice. L.: SAGE.

Bauman Z. (1989). Legislators and Interpreters: On Modernity, Post-Modernity and Intellectuals. Cambridge: Polity.

Bauman Z. (1993). Postmodern Ethics. Oxford: Wiley-Blackwell.

Bauman Z. (1997). Postmodernity and Its Discontents. Cambridge: Polity.

Bauman Z., Tester K. (2007). On the Postmodern Debate // Goulimari P. (ed.) Postmodernism: What Moment? Manchester: Manchester University Press. P. 22-31. 
Chernilo D. (2013). The Natural Law Foundations of Modern Social Theory: A Quest for Universalism. Cambridge: Cambridge University Press.

DeLanda M., Harman G. (2017). The Rise of Realism. Cambridge: Polity.

Hassan I. (2003). Beyond Postmodernism: Toward an Aesthetic of Trust // Stierstorfer K. (ed.) Beyond Postmodernism: Reassessments in Literature, Theory, and Culture. Berlin: Walter de Gruyter. P. 199-212.

Hutcheon L. (2002). The Politics of Postmodernism. L.: Routledge.

Jameson F. (2007). Postscript // Goulimari P. (ed.) Postmodernism: What Moment? Manchester: Manchester University Press. P. 213-216.

Latour B., Harman G., Erdélyi P. (2011). The Prince and the Wolf: Latour and Harman at the LSE. Winchester: Zero Books.

Lipovetsky G. (2015). Time Against Time, or The Hypermodern Society // Rudrum D., Stavris N. (eds.). Supplanting the Postmodern: An Anthology of Writings on the Arts and Culture of the Early 21st Century. L.: Bloomsbury Academic. P. 191-208.

Moraru C. (2011). Cosmodernism: American Narrative, Late Globalization, and the New Cultural Imaginary. Ann Arbor: University of Michigan Press.

Nealon J. T. (2012). Post-postmodernism; or, The Logic of Just-in-Time Capitalism. Stanford: Stanford University Press.

Rudrum D., Stavris N. (eds.). (2015). Supplanting the Postmodern: An Anthology of Writings on the Arts and Culture of the Early 21st Century. L.: Bloomsbury Academic.

Scruton R. (2015). Fools, Frauds and Firebrands: Thinkers of the New Left. L.: Bloomsbury.

Seidman S. (1994). The End of Sociological Theory // Seidman S. (ed.). The Postmodern Turn: New Perspectives on Social Theory. Cambridge: Cambridge University Press. P. 119-139.

Seidman S., Fischer N., Meeks Ch. (2011). Introducing the New Sexuality Studies. L.: Routledge.

Seidman S. (2012). Contested Knowledge: Social Theory Today. Oxford: Wiley-Blackwell. Simon R. L. (ed.). (2002). The Blackwell Guide to Social and Political Philosophy. Oxford: Blackwell Publishers.

Sterba J. P. (ed.). (2001). Social and Political Philosophy: Contemporary Perspectives. L.: Routledge.

Therborn G. (2008). From Marxism to Post-marxism. L.: Verso.

Touraine A. (2007). A New Paradigm for Understanding Today's World. Cambridge: Polity.

Van den Akker R., Gibbons A., Vermeulen T. (eds.). (2017). Metamodernism: Historicity, Affect, and Depth after Postmodernism. Lanham: Rowman \& Littlefield. 


\title{
The Parallaxes of the Fox: Towards Definition of the Subject and Status of Social Philosophy
}

\author{
Alexander Pavlov \\ Associate Professor, School of Philosophy, National Research University Higher School of Economics (HSE) \\ Leading Reserach Fellow, Head of Department of Social Philosophy, RAS Institute of Philosophy \\ Address: Myasnitskaya str., 20, Moscow, Russian Federation 101000 \\ E-mail: apavlov@hse.ru
}

The author of this article tries to reconsider the subject field of social-philosophical knowledge. He considers the principal difference of social philosophy from theoretical sociology, historical sociology, and political philosophy. On the basis of this differentiation, it is stated that social philosophy is a separate and coherent discipline. The author then considers several possible approaches to the study of society that could be characterized as "weak programs" of social philosophy. On such a basis, it is claimed that a "strong program" of social philosophy could be formed. This program must organically combine the following assumptions: the methodology of neo-Marxism, including the orientation towards the traditional for these current intellectual objects of analysis, and accurate and thorough studies, as well as a firmness and conceptual coherence, i.e., a level of analysis beyond the immediate empirical material. The author then considers one of the main challenges that social philosophy faces or must face in the nearest future. Social philosophy has to fulfill an important task: to say something sensible about the times we are living in, to determine changes in culture and economy, as well as to give an answer to the question of what comes instead of postmodernity, if such a thing ever existed. On the basis of the above-mentioned points, the following working definition of social philosophy is given: multiple (although not always) philosophical conceptualizations of social problems, phenomena, and complex notions, as well as theoretical attempts at interpreting our or/and another epoch, which, in the interpretation, first of all assumes a normative dimension, and secondly, is based on rich empirical material. This approach can also be explained through the notion of "the parallax of the fox", which assumes that social philosophy deals with many things, but at the same time, tries to give a new look at existing problems and to determine its heuristic potential.

Keywords: social philosophy, neo-Marxism, postmodern, post-postmodern, cultural sociology, political philosophy, social theory, historical sociology

\section{References}

Alexander J. (2013) Smysly sotsial'noi zhizni: kul'tursotsiologiia [The Meanings of Social Life: A Cultural Sociology], Moscow: Praksis.

Alexander J. (2012) Trauma: A Social Theory, Cambridge: Polity.

Alexander J. (2013) The Dark Side of Modernity, Cambridge: Polity.

Anderson P. (2011) Istoki postmoderna [The Origins of Postmodernity], Moscow: Territoriya budushchego.

Anderson P. (2018) Peripetii gegemonii [The H-Word: The Peripeteia of Hegemony], Moscow: Gaidar Institute Press.

Anderson P. (2016) Razmyshleniia o zapadnom marksizme [Considerations on Western Marxism], Moscow: Common Place.

Anderson P. (2017) The H-Word: The Peripeteia of Hegemony, London: Verso.

Arendt H. (2011) O revolyucii [On Revolution], Moscow: Evropa.

Aron R. (1992) Etapy razvitiya sociologicheskoj mysli [Main Currents in Sociological Thought], Moscow: Progress.

Astahov S., Gavrilenko S., Pisarev A. (2017) Aktorno-setevaya teoriya: nezavershennaya sborka

[Actor-Network Theory: Incomplete Assembly]. Logos, no 1, pp. 1-40.

Barker C. (2012) Cultural Studies: Theory and Practice, London: SAGE. 
Bauman Z. (1989) Legislators and Interpreters: On Modernity, Post-Modernity and Intellectuals, Cambridge: Polity.

Bauman Z. (1993) Filosofiia i postmodernistskaia sotsiologiia [Philosophy and Postmodern Sociology]. Russian Studies in Philosophy, no 3, pp. 46-61.

Bauman Z. (1993) Postmodern Ethics, Oxford: Wiley-Blackwell.

Bauman Z. (1997) Postmodernity and Its Discontents, Cambridge: Polity.

Bauman Z. (2008) Tekuchaya sovremennost' [Liquid Modernity], Saint Petersburg: Piter.

Bauman Z. Tester K. (2007) On the Postmodern Debate. Postmodernism: What Moment? (ed.

P. Goulimari), Manchester: Manchester University Press, pp. 22-31.

Chernilo D. (2013) The Natural Law Foundations of Modern Social Theory. A Quest for Universalism, Cambridge: Cambridge University Press.

Collins R. (2009) Chetyre sociologicheskih tradicii [Four Sociological Traditions], Moscow: Territoriya budushchego.

Coser L.A. (2006) Mastera sociologicheskoj mysli: idei v istoricheskom i social'nom kontekste [Masters of Sociological Thought: Ideas in Historical and Social Context], Moscow: Norma.

Dahrendorf R. (2002) Tropy iz utopii: raboty po teorri i istorii sotsiologii [Out of Utopia: Toward a Reorientation of Sociological Analysis], Moscow: Praksis.

DeLanda M. (2017) Novaya filosofiya obshchestva: teoriya assamblyazhej i social'naya slozhnost' [A New Philosophy of Society: Assemblage Theory and Social Complexity], Perm: Hyle Press.

DeLanda M., Harman G. (2017) The Rise of Realism, Cambridge: Polity.

Filippov A. (2015) K opredeleniyu social'nogo [To the Definition of Social]. Sociologia: nablyudenie, opyty, perspektivy. T. 2 [Sociologia: Observation, Experiments, Prospects, Vol. 2], Saint Petersburg: Vladimir Dal, pp. 98-118.

Giddens A. (2011) Posledstviya sovremennosti [Consequences of Modernity], Moscow: Praksis.

Giddens A. (2015) Nespokojnyj i mogushchestvennyj kontinent: chto zhdet Evropu v budushchem? [Turbulent and Mighty Continent: What Future for Europe?], Moscow: Delo.

Giddens A., Satton Ph. (2018) Osnovnye ponyatiya v sociologii [Essential Concepts in Sociology], Moscow: HSE.

Greenfield A. (2018) Radikal'nye tekhnologii: ustrojstvo povsednevnoj zhizni [Radical Technologies: The Design of Everyday Life], Moscow: Delo.

Harman G. (2018) Immaterializm: ob"ekty i social'naya teoriya [Immaterialism: Objects and Social Theory], Moscow: Gaidar Institute Press.

Harman G. (2017) Seti i assamblyazhi: vozrozhdenie veshchei u Latura i Delanda [Networks and Assemblages: The Rebirth of Things in Latour and DeLanda]. Logos, no 3, pp. 1-34.

Harvey D. (2018) Social'naya spravedlivost' i gorod [Social Justice and the City], Moscow: New Literary Observer.

Hassan I. (2003) Beyond Postmodernism: Toward an Aesthetic of Trust. Beyond Postmodernism: Reassessments in Literature, Theory, and Culture (ed. K. Stierstorfer), Berlin: Walter de Gruyter, pp. 199-212.

Hirschman A. (2012) Strasti i interesy: politicheskie argumenty v pol'zu kapitalizma do ego triumfa [The Passions and the Interests: Political Arguments for Capitalism before Its Triumph], Moscow: Gaidar Institute Press.

Hutcheon L. (2002) The Politics of Postmodernism, London: Routledge.

Jameson F. (2007) Postscript. Postmodernism: What Moment? (ed. P. Goulimari), Manchester: Manchester University Press, pp. 213-216.

Jonas H., Knöble W. (2013) Social'naya teoriya: dvadtat vvodnyh lekcij [Social Theory: Twenty Introductory Lectures], Saint Petersburg: Aleteya.

Lachmann R. (2016) Chto takoe istoricheskaia sotsiologiia? [What is Historical Sociology?], Moscow: Delo.

Latour B. (2015) Paster: vojna i mir mikrobov [The Pasteurization of France]. Saint Petersburg: EUSPb.

Latour B. (2014) Peresborka social'nogo: vvedenie v aktorno-setevuyu teoriyu [Reassembling the Social: An Introduction to Actor-Network-Theory], Moscow: HSE.

Latour B., Harman G., Erdélyi P. (2011) The Prince and the Wolf: Latour and Harman at the LSE, Winchester: Zero Books. 
Lipovetsky G. (2015) Time Against Time, or The Hypermodern Society. Supplanting the Postmodern: An Anthology of Writings on the Arts and Culture of the Early 21st Century (eds. D. Rudrum, N. Stavris), London: Bloomsbury Academic, pp. 191-208.

Lukes S. (2010) Vlast': radikal'nyj vzglyad [Power: A Radical View], Moscow: HSE.

Malia M. (2015) Lokomotivy istorii: revolyucii i stanovlenie sovremennogo mira [History's Locomotives: Revolution and the Making of the Modern World], Moscow: ROSSPEN.

Mol A. (2017) Mnozhestvennoe telo: ontologiya v medicinskoj praktike [The Body Multiple: Ontology in Medical Practice], Perm: Gile Press.

Moraru C. (2011) Cosmodernism: American Narrative, Late Globalization, and the New Cultural Imaginary, Ann Arbor: University of Michigan Press.

Nealon J. T. (2012) Post-postmodernism; or, The Logic of Just-in-Time Capitalism, Stanford: Stanford University Press.

Pavlov A. (2018) Obrasy sovremennosti v XXI veke (Didgimodernism: Rezensiya na knigu Alana Kirbi) [Images of Modernity in the Twenty-First Century: (Digimodernism: A Review of Alan Kirby's Book)]. Philosophy: Journal of the Higher School of Economics, vol. 2, no 2, pp. 197-212.

Parker N. (2008) Parallaksy: revoliutsiia i «revoliutsii» v global'nom predstavlenii [Parallaxes: Revolution and "Revolutions" in a Globalized Imaginary]. Kontsept "Revoliutsiia" v sovremennom politicheskom diskurse [The Concept of "Revolution" in Contemporary Political Discourse] (eds. L. Bliakher, B. Mezhuev, A. Pavlov), Saint Petersburg: Aleteya, pp. 163-184.

Ritzer G. (2002) Sovremennye sociologicheskie teorii [Modern Sociological Theory], Saint Petersburg: Piter.

Rudrum D., Stavris N. (eds.) (2015) Supplanting the Postmodern: An Anthology of Writings on the Arts and Culture of the Early 21st Century, London: Bloomsbury Academic.

Selbin E. (2008) Deyatel'nost'i kul'tura v revolyuciyah [Agency and Culture in Revolution]. Koncept "Revolyuciya" $v$ sovremennom politicheskom diskurse [The Concept of "Revolution" in Contemporary Political Discourse] (eds. L. Blyakher, B. Mezhuev, A. Pavlov), Saint Petersburg: Aleteya, pp. 184-195.

Szasz T. (2008) Fabrika bezumiia: sravnitel'noe issledovanie inkvizitsii i dvizheniia za dushevnoe zdorov'e [Manufacture of Madness: A Comparative Study of the Inquisition and the Mental Health Movement], Ekaterinburg: Ultra.Kultura.

Scruton R. (2015) Fools, Frauds and Firebrands: Thinkers of the New Left, London: Bloomsbury.

Seidman S. (1994) The End of Sociological Theory. The Postmodern Turn: New Perspectives on Social Theory (ed. S. Seidman), Cambridge: Cambridge University Press, pp. 119-139.

Seidman S., Fischer N., Meeks Ch. (2011) Introducing the New Sexuality Studies, London: Routledge.

Seidman S. (2012) Contested Knowledge: Social Theory Today, Oxford: Wiley-Blackwell.

Simon R. L. (ed.) (2002) The Blackwell Guide to Social and Political Philosophy, Oxford: Blackwell Publishers.

Sterba J. P. (ed.) (2001) Social and Political Philosophy: Contemporary Perspectives, London: Routledge.

Therborn G. (2008) From Marxism to Post-marxism, London: Verso.

Therborn G. (2015) Mir: rukovodstvo dlya nachinayushchih [The World: A Beginner's Guide], Moscow: HSE.

Tocqueville A. (1992) Demokratiya v Amerike [Democracy in America], Moscow: Progress.

Touraine A. (2007) A New Paradigm for Understanding Today's World, Cambridge: Polity.

Vakhshtayn V. (2017) Revolyuciya i reakciya: ob istokah ob"ektno-orientirovannoj sociologii

[Revolution and Reaction: The Origins of Object-Oriented Sociology]. Logos, no 1, pp. 41-84.

Van den Akker R., Gibbons A., Vermeulen T. (eds.) (2017) Metamodernism: Historicity, Affect, and Depth after Postmodernism, Lanham: Rowman \& Littlefield. 


\title{
Креативные индустрии - модели развития
}

\author{
Руслан Хестанов \\ Доктор философии (PhD), профессор Школы культурологии гуманитарного факультета \\ Национального исследовательского университета «Высшая школа экономики» \\ Адрес: ул. Мясницкая, д. 20, г. Москва, Российская Федерация 101000 \\ E-mail: khestanov@hse.ru
}

\begin{abstract}
Одновременно с возникновением концепта «культура» предпринимались многочисленные попытки его имплементации в государственную политику, что требовало четкой и недвусмысленной дефиниции. В новом историческом контексте, в начале этого века была предпринята новая, ставшая известной как «дебаты о культурных и креативных индустриях». Статья посвящена прояснению основных позиций в этих недавних дебатах и подвергает критическому анализу попытку новой операционализации культуры с помощью и посредством экономического дискурса. Данная попытка осуществлялась под новым академическим слоганом «креативных индустрий», с которыми политики, международные и национальные функционеры, а также представители академических кругов связывали надежду на изобретение новой модели экономического роста. Один из главных тезисов статьи сводится к тому, что подобного рода операционализация неосуществима, поскольку «креативность», как и «культура», не поддается ни математизации, ни коммодификации, ни однозначному истолкованию. Политика «креативных индустрий» рассматривается через усилие к тотальной коммерциализации культурного производства и его глобальной стандартизации. В статье анализируются разные модели ее имплементации, а также ее итоги. Одним из важнейших итогов является постановка под вопрос «архаичности» тех форм знания о культуре, которые формировались в условиях, когда центральную роль играли национальные государства: государственная статистика оказывается неуместной и неадекватной в условиях, когда корпоративный сектор полностью определяет культурное производство. В связи с этим с особой остротой встает вопрос: нуждается ли государство в целостном представлении о культуре и в осуществлении функций контроля в данном секторе производства. В перспективе данного вопроса ставится проблема о целесообразности политики креативных индустрий в Российской Федерации.
\end{abstract}

Ключевые слова: креативность, товар, культурная политика, культурные индустрии, креативные индустрии, коммерциализация

C начала 2000-х годов с креативными индустриями, которые иногда называют также индустриями когнитивными, связываются самые радужные надежды. О них толкуют как о новой модели роста, о «творческом рычаге» производства и даже как о начале цивилизационного сдвига (Клоудова, 2010, 110). В России сторонники креативной экономики видят в ней, кроме всего прочего, панацею избавления от ресурсной зависимости. Устойчивый консенсус сложился вокруг доверия к прозрению Ричарда Флорида: «Творчество становится движущей силой эконо-

(C) Хестанов Р. 3., 2018

(с) Центр фундаментальной социологии, 2018

DOI: $10.17323 / 1728-192 \mathrm{X}-2018-3-173-196$ 
мического роста и инноваций» (Florida, Tinagli, 2004: 5). Но чтобы конвертировать этот тезис в понятную и годную к осуществлению политику, требуется решить одну непростую и назойливую проблему. Творчество (или креативность) не имеет четкости, необходимой для прикладного понятия. Скорее оно представляет собой смутное, многозначное, иногда таинственное представление, непереводимое на язык государственной политики и рыночной экономики. «Творчество» может быть расколдовано лишь тогда, когда оно станет различимым для экономического мышления. Вне зависимости от наших предрасположенностей современные эпистемологические обстоятельства принуждают нас признать следующее: сущее может получить дефиницию только в том случае, если его можно помыслить в форме товара. То, что не обладает товарной формой, не может стать предметом строгой науки. Тем более политики. Поэтому в представленном нами кратком анализе креативных индустрий принципиально важной является непростая история усилий ученых, исследователей и государственных деятелей по операционализации, математизации, коммерциализации и коммодификации творчества.

\section{Главная дилемма}

Сегодня попытки многих правительств мира сформулировать стратегии политики креативности осуществляются на фоне дискуссий об отличии культурных индустрий от креативных индустрий. Ставкой является не только определение двух концептов, но также пересмотр представлений о границах культурной сферы и, как следствие, разное определение стратегических государственных приоритетов в культурной политике. На кону, действительно, дилемма, имеющая стратегически важный характер: сохранить ли за государством миссию поводыря в сфере культуры или ограничить его регулирующими функциями рыночного сторожа; отказать ли национальному государству в прерогативах влияния на культурные и этические ценности общества, но кому в таком случае эти прерогативы достанутся.

В дискуссию вовлечены разные группы интересов: академические сообщества, некоммерческие организации и фонды, корпоративные игроки с узкими национальными и довольно широкими транснациональными интересами, разные фракции деятелей культуры и правительственных бюрократий государств со специфическими политическими режимами. Неудивительно поэтому, что дебаты проходят на различных публичных сценах, а разные группы участников используют зачастую разные словари.

Перед данным исследованием стоят три главные задачи. Во-первых, выявить принципиальное отличие двух современных разновидностей культурной политики - культурных индустрий и креативных индустрий. Поскольку оба выражения до сих пор используются некоторыми участниками дискуссий как синонимы, необходимо внести кое-какие теоретические прояснения, разобраться в том, какие теоретические соображения стоят за обеими политиками. Во-вторых, предложить 
анализ образцовой модели политики креативных индустрий, разработанной в Великобритании, а затем сравнить ее с разными национальными и региональными версиями. Наконец, в-третьих, будет дана оценка политической целесообразности гипотетической перестройки правительственной политики Российской Федерации в пользу имплементации политики креативных индустрий.

\section{Политика культурных индустрий}

Исторически концепция культурных индустрий предшествовала концепции креативных индустрий. После Второй мировой войны правительства субсидировали те виды искусства, которые назывались классическими. Стратегической задачей культурной политики этой эпохи была «демократизация», которая понималась как вовлечение в культурную жизнь, организованную под государственным патронатом, отчужденных от культуры слоев населения и новых аудиторий.

Концепция культурных индустрий была разработана в дисциплинарной перспективе политической экономии культуры. Николас Гарнэм был одним из тех, кто обратил внимание на отличие культурных индустрий от остальных отраслей промышленности. Для этого сектора, по его мнению, характерны особенные проблемы накопления капитала, а именно необычно высокие инвестиционные риски. В культурных индустриях крайне трудно предвидеть, какие продукты или творческие работники (художники, музыканты, писатели и проч.) будут иметь успех у потребителей. Успех не может быть гарантирован даже относительно высокими инвестициями в рекламу и маркетинг. На этом основании Гарнэм заключал, что культурные индустрии представляют собой наиболее рискованный сектор экономики (Hesmondhalgh, 2008: 553-555).

Тезис Гарнэма был подхвачен и развит в основном французскими социологами культуры, которые сформулировали присущий культурным индустриям парадокс: с одной стороны, производство культурных благ (фильмов, романов, картин и т.п.) отличается относительно высокими издержками, с другой стороны, репродукция и тиражирование в промышленных масштабах этих благ обходятся относительно дешево (Miège, 1989: 34). Подобное соотношение издержек производства к издержкам репликации, несмотря на риски, делает культурные индустрии крайне прибыльными. Кроме того, важной чертой товаров, произведенных культурными индустриями, является возможность их повторного потребления: товар не разрушается после того, как был потреблен, но может снова и снова потребляться другими индивидами. Отсюда возникает одна из ключевых для культурной отрасли проблема - контроль за циркуляцией товаров. Главным инструментом производителей в решении этой проблемы становится использование и непрерывное уточнение авторского права.

На правительственном уровне политику культурных индустрий наиболее последовательным образом осуществляло Министерство культуры Франции, возглавляемое Джеком Лангом, при социалистическом премьере Франсуа Миттеране. 
Затем на местном уровне в начале 1980-х годов аналогичная политика проводилась Советом Большого Лондона. Глобальная имплементация политики культурных индустрий началась с инициативы ЮНЕСКО, озабоченного деформациями и неравенством в доступе стран к культурным ресурсам и инвестициям, возникшим в результате международной экспансии корпораций индустрии развлечений (UNESCO, 1982).

Дэвид Хезмондалш выделил следующие основные направления данной политики:

1) Признание, что в культурном производстве центральную роль играют коммерческие компании, которые в наибольшей степени влияют на вкусы и предпочтения населения.

2) Главными адресатами государственных субсидий должны стать не «творцы», а сети распространения культурной продукции, что обосновывалось приоритетом «демократизации» доступа к культурной продукции для населения (Garnham, 1990).

3) Субсидирование культурных индустрий должно было способствовать созданию рабочих мест и качественно новой занятости в тех регионах национальной экономики, откуда в результате глобализации промышленного производства уходила традиционная индустриальная занятость (Хезмондалш, 2014: 194).

Политика культурных индустрий предполагала активную роль правительств, с помощью государственных субсидий корректирующих социальные и региональные деформации, к которым приводила новая глобальная коммерческая активность частного бизнеса не столько в сфере культуры, сколько в экономике в целом, как национальной, так и глобальной. Иначе говоря, культурная политика служила инструментом для решения социальных задач. В старых индустриальных центрах, откуда промышленное производство ушло в зарубежные офшоры, эта политика применялась особенно интенсивно. То была регенерационная, или компенсаторная по своей природе политика, которую проводили левоцентристские правительства европейских стран. Главными ее направлениями были следующие: 1) развитие туристических кластеров и соответствующая маркетинговая и имиджевая политика; 2) «плейсмейкинг», или облагораживание территорий с целью привлечения бизнеса и квалифицированных профессионалов.

Опыты имплементации политики культурных индустрий анализировались, обобщались и мгновенным образом тиражировались национальными правительствами, Европейским союзом и международными организациями. В 1980-1990-е годы политика культурных индустрий была принята на вооружение многими правительствами мира и обрела характер глобального тренда. Основными уровнями ее осуществления стали муниципальный, городской и территориальный. В целом это свидетельствовало о том, что на авансцену глобальной экономической конкуренции за туристические потоки, квалифицированные кадры и инвестиции помимо национальных государств вовлекались отдельные города и территории. Особенно ярко новая роль городов проявилась в ежегодных конкурсах «Europe- 
an Capital of Culture», в которые были вовлечены европейские города с 1985 года, а также в интенсификации конкуренции между городами за проведение встреч Большой семерки, всемирных выставок, фестивалей, разных саммитов и форумов вроде АТЭС и особенно Олимпийских игр. Когда-то Лос-Анджелес был единственным кандидатом на проведение Олимпиады 1984 года - подобную ситуацию сегодня трудно представить.

Политика культурных индустрий, таким образом, лишь косвенно была направлена на развитие искусств. Однако стремление сформировать новую постиндустриальную структуру занятости привело к бурному развитию туристической индустрии и позволило включить в список субсидируемых государством секторов кроме «изящных искусств» такие отрасли, как традиционные ремесла и фольклорное искусство.

Политика культурных индустрий была достаточно успешной, поскольку удалось создать коалицию заинтересованных в ней социальных и профессиональных групп. Во-первых, ее поддержали предприниматели, поскольку она открыла им возможность участия в крупных городских проектах и способствовала коммерциализации музеев, театров, выставок и других отраслей культуры, традиционно субсидируемых государством. Во-вторых, ее поддержали муниципалитеты, поскольку на фоне централизации налоговых поступлений и сокращения финансирования социальных программ, распределяемых на местном уровне, они были лишены значительной части ресурсов, а культурный сектор позволял привлечь новые, до сих пор не используемые ресурсы. В-третьих, дискурс культурных индустрий позволял тем, кто управлял культурным и символическим производством, формулировать новые аргументы в обосновании субсидирования их активности. B-четвертых, политика культурных индустрий была поддержана левыми активистами и движениями, поскольку провозглашала курс на преодоление социального исключения.

\section{Политика креативных индустрий: образцовая британская модель}

Альтернатива, которая была представлена политикой креативных индустрий, формировалась благодаря нескольким изначально не связанным друг с другом тенденциям и движениям. Термин «креативные индустрии» был пущен в ход британскими, американскими и австралийскими менеджерами и активистами культуры еще в 1980-е годы. В этот период термин еще не обрел самостоятельного содержания и практически не отличался от циркулировавшего тогда термина «культурные индустрии». Интенсивная коммерциализация культуры, произошедшая благодаря политике культурных индустриц̆, привлекла в сектор частный капитал и предпринимателей, что способствовало не только созданию конкурентных условий в индустриях, но и поиску новых источников доходов и капитализации. С другой стороны, в экспертном сообществе, близком консалтинговому бизнесу и к академическим кругам, к середине 1990-х годов были обоснованы и сформулированы 
принципы новой политики креативности. Именно креативность была обозначена в качестве главного источника инноваций и экономического роста.

Словарь политики креативных индустрий вырос из таких концептуальных инноваций, как «креативная экономика» (Howakins, 2001), «креативные города» (Landry, Bianchini, 1995), «креативный класс» (Florida, 2002) и «креативные кластеры» (во многом под влиянием концепции «бизнес-кластеров» американского экономиста Майкла Портера (Porter, 2003)). Особую роль в пропаганде нового дискурса креативности сыграла консалтинговая группа «Comedia», основанная в Beликобритании в 1978 году Чарльзом Ландри. Практически одновременно дискурс о креативных индустриях был подхвачен учеными - экономистами и представителями разросшегося цеха cultural studies.

В конце 1990-х была предпринята попытка имплементации пока еще довольно размытого концепта креативных индустрий в конкретную правительственную политику. Первое определение было дано Департаментом культуры, медиа и спорта (DCMS) Великобритании в 1997 году. Утверждалось, что креативные индустрии имеют свой «источник в индивидуальной креативности, умении и таланте и обладают потенциалом создания рабочих мест и благосостояния посредством производства и эксплуатации интеллектуальной собственности» (DCMS, 2001: 5). В этом важнейшем для истории креативных индустрий документе британского департамента было выделено в качестве таковых 13 отраслей. В это определение креативных индустрий были включены следующие: архитектура, ремесла, исполнительские виды искусства, дизайн, интерактивное программное обеспечение, мода, рынок искусств и антиквариата, музыка, производство фильмов и видео, издательское дело, телевидение и радио, программные и компьютерные услуги, реклама (DCMS, 2001, 5).

Инициатива британского минкульта, ответственного за культурную стратегию, некоторым образом выходила за пределы отведенных традицией компетенций и претендовала на решение нетипичных для культурного ведомства вопросов, вроде создания рабочих мест или стимулирование моторов экономического роста. Демарш министерства был воспринят как новый взгляд на культурные индустрии, которые, как оказалось, могут быть не только дотационными, но в перспективе превратиться в главный драйвер роста ВВП.

Инновация британского департамента казалась соблазнительной для правительственных функционеров, ведь она обещала доселе немыслимое - превращение дотационных отраслей в прибыльные. Практически сразу новая политика получила международный резонанс: правительства многих стран тут же приступили к поиску возможностей приспособления британской стратегии к реальностям собственных национальных экономик и культур. Первостепенными для них вопросами были следующие: 1) насколько сбалансированным или исчерпывающим является британский перечень креативных индустрий, можно ли отнестись к этому списку как к универсально приложимому или же он требует определенной коррекции и адаптации к национальным экономическим и культурным реалиям; 
2) какие новые организационные и институциональные формы примут дотационные учреждения культуры, преобразованные в предприятия, генерирующие прибыль; 3) как изменится управление и финансовые стимулы внутри отрасли; 4) каким образом усовершенствовать государственную статистику, чтобы сохранить прозрачность сектора культуры для государственных регуляторов. Иначе говоря, чиновников, политиков и привлеченных ими экспертов интересовала исключительно практическая или методчческая сторона британской инициативы. Вокруг этих вопросов в разных странах мира и в международных организациях развернулась изнурительная, длящаяся до сих пор, но угасающая в последнее время дискуссия.

С другой стороны, возникло вполне понятное смешение двух словосочетаний: культурные индустрии и креативные индустрии, которые до сих пор часто употребляются как синонимы. Основанием для смешения послужил тот факт, что концептуальная инновация была предложена британским департаментом, ответственным за культурные индустрии и культурную политику. Однако два концепта имели отличный друг от друга генезис и формировались на основе разных теоретических предпосылок. Именно креативность должна была стать тем критерием, который позволил бы фундаментальным образом отличить один концепт от другого, а также обосновать предложенный британским департаментом список креативных индустрий. Тем более что к тому времени сформировался как теоретический, так и практический интерес по отношению к креативности. Разрабатывались концепции креативных городов и креативных кластеров (Хезмондалш, 2014: 197). Однако искомой строгости и принципа идентификации креативных uндустрий достичь так и не удалось.

Менее чем за пятилетку модель политики креативных индустрий вышла за пределы англоязычного мира, обрела интернациональную известность и даже получила признание со стороны такой авторитетной организации, как UNESCO (UNESCO, 2009: 22-25). После того как UNESCO дало определение «креативным индустриям», концепт был взят на вооружение целым рядом государств - от Германии и Франции до Сингапура и Китая, - разработавших собственные версии политик развития креативных индустрий. Политика быстро набирала популярность благодаря конъюнктурному совпадению интересов и сотрудничеству политиков и активистов, правительственных и международных бюрократий, некоторых фракций ученых и деятелей культуры.

Пик медийных и научных дискуссий вокруг креативных индустрий, получивших широкий международный резонанс, приходится на 2008-2009 годы. Исследователи предложили множество различных подходов и пояснений, детальный разбор которых является трудноисполнимой и даже "устрашающей задачей» (Rindzevičiūtè, Svensson, Tomson, 2015: 595). На одном полюсе спектра утверждали, что все индустрии, в принципе, являются креативными или предполагают существенный элемент креативности. На другом находились те, кого можно отнести к скептикам, считающим, что понятие креативности многозначно и неопределен- 
но, а потому замена политики «культурных индустрий» на политику «креативных индустрий», инициированная британским минкультом, фактически означает смену приоритетов или даже переход от одного способа производства и распространения культурных благ к другому (Hesmondhalgh, 2008: 552).

Другое проблемное поле, повлиявшее на политику креативных индустрий, связано с выражением «креативная экономика», которое довольно часто употребляется как синоним «креативных индустрий». Впервые термин был использован Питером Кои в 2000 году в одноименной статье в «Business Week» ${ }^{1}$. В ней были определены центральные идеи дискурса о креативных индустриях: приоритет производства идей над производством вещей в современной экономике; креативность и идеи - главные источники инноваций; теснейшая связь креативности и инноваций; креативность - как залог успеха в конкурентной борьбе. Революционные изменения в экономике были выражены публицистически хлестко и ярко как «поворот в производстве от гамбургеров к программному обеспечению».

Выражение быстро вошло в оборот не только в журналистике, в политике, но и в серьезных академических исследованиях. В последовавших дискуссиях ставился вопрос стратегической важности: о формах рационального контроля над непредсказуемостью рыночных циклов разрушения и созидания, о возможности управления алгоритмом креативности таким образом, чтобы минимизировать издержки неизбежной, как показал в свое время Йозеф Шумпетер, фазы разрушения.

Тот факт, что дискурс о креативных индустриях возник на пересечении интересов драйверов современного экономического роста и коммерциализации сектора культурных индустрий, предопределил неустранимую амбивалентность понятия и противоречивость политики креативных индустрий. Поэтому главная линия дискуссий, продолжающихся вплоть до сегодняшнего дня, определяется стремлением отличить креативные и культурные индустрии как разные индустриальные сегментации или подходы. С. Галоуэй и С. Данлоп выделили пять базовых концепций, на основании которых это отличие прослеживается (Galloway, Dunlop, 2007).

Первыци подход основан на понятии креативности. Иначе говоря, сама креативность является принципом выделения данного сектора. Такое тавтологическое определение предполагает, что к креативным индустриям относится любая производственная активность, которую можно охарактеризовать как творческую. Выведение новых племенных пород рогатого скота или новых сортов пшеницы, как и любая другая инновация в сельском хозяйстве, является манифестацией креативности. А потому тот сегмент сельского хозяйства, в котором креативность осуществляется, может быть отнесен к креативным индустриям.

Второй подход принципом различения делает интеллектуальную собственность. В этой перспективе специфика креативных индустрий состоит в производстве и использовании интеллектуальной собственности. Но и внутри данного

\footnotetext{
1. https://www.bloomberg.com/news/articles/20oo-08-27/the-creative-economy.
} 
определения столь же трудно, как и в предыдущем, выделить креативные индустрии в отдельный сектор, поскольку всякая отрасль в условиях универсальной распространенности интеллектуального права подразумевает генерирование интеллектуальной собственности. Поэтому сторонники этого подхода, как, впрочем, и предыдущего, в качестве главного инструмента различения привлекают статистику: отрасль, в которой наибольшую роль играет интеллектуальная деятельность (или добавленная стоимость), можно отнести к креативным индустриям. Такой подход «креативности всего» оказал наибольшее влияние на определение креативности в правительственной политике Великобритании. Так, в правительственном документе «Creative Industries Mapping» (1998) креативные индустрии определялись как «индустрии, в основании которых лежит индивидуальная креативность, умения и таланты, обладающие потенциалом создания богатства и рабочих мест с помощью генерирования и эксплуатации интеллектуальной собственности» (DCMS, 2001: 5).

Третий подход стремится обнаружить в креативных индустриях специфический способ производства символических смыслов. Символические смыслы являются свойством особых товаров, экономическая ценность которых основывается на их культурной ценности, а не на потребительских качествах. Критики отмечают, что главным изъяном такого определения является тот факт, что практически любой товар обладает символическим и культурным смыслами, которые играют свою роль в определении их экономической стоимости, а потому их также можно обнаружить внутри любой отрасли экономики.

Четвертый подход стремится определить креативные индустрии с точки зрения той особенной потребительской стоимости, которую они производят. Но и в данном случае потребительская стоимость мало чем отличается от стоимости символической или от «культурного содержания». А потому с ее помощью трудно определить специфику культурных индустрий, поскольку на все товары можно посмотреть в потребительской перспективе.

Наконец, в рамках пятого подхода креативные индустрии определяются через специфику продукта. Произведенные продукты являются комплексными, поскольку в каждом из них присутствуют два вида ценности одновременно - символическая и функциональная. Однако и это различение лишено необходимой строгости: решение такой задачи представляется немыслимым тем, кто понимает природу товара и значимость его культурного содержания. Трудно выделить «функциональную» ценность, поскольку всякая потребность, а именно она определяется функцией, сама по себе культивирована или создана культурой. Вместо этого символическое можно понимать как нечто, что предопределяет функциональное. Культура обусловливает наши ожидания от «функционального» или «полезного».

Все представленные подходы вряд ли устраняют теоретическую двусмысленность концепта креативных индустрий. В самом общем виде аргументация критиков состоит в том, что неудачные попытки спецификации креативных индустрий связаны с невозможностью изолировать креативность от других практик, 
а потому все индустрии являются креативными. Все эти попытки можно привести к общему знаменателю и примирить в одном допущении - определение культурных и креативных индустрий можно распространить на все отрасли, что подрывает любую попытку определить их специфику. Компания «Coca-Cola» производит не только напитки, но и смыслы. Аналогичным образом, потребители покупают ее продукты не только из-за потребности пить, они приобретают символические свойства и значения, которые им предлагаются. Любой товар в любую эпоху имел символическое и культурное содержание, в той или иной мере представлял собой продукт культуры и креативности.

Одна из важнейших дискуссий вокруг креативных индустрий связана с обсуждением эффектов этой политики. Австралийский исследователь Терри Флю из Queensland University of Technology в Брисбене, в котором расположена одна из влиятельнейших школ, анализирующих и разрабатывающих политику креативных индустрий, считает, что с ней связана важнейшая революция современности - трансформация представлений о национальной идентичности и гражданстве. По его мнению, политика креативных индустрий более не подразумевает культивирование гражданских чувств как прогрессивной культурной цели (Flew, 2005: 244). Концепции гражданства, утверждает Флю, неразрывно связаны с государственными националистическими проектами, навязываемыми населению сверху. Подобные проекты всегда пренебрегали коммерческим сектором и делали ставку на государственные субсидии культурным и артистическим элитам. Глобализация, развитие новых медиатехнологий (спутниковое телевидение и интернет) и все большая интеграция культуры в экономическую жизнь бросают новый вызов институтам, формирующим политику. Флю полагает, что вместо национального протекционизма и централизованной поддержки регионов следует поддерживать способность наций создавать контент таким образом, чтобы избегать навязываемого сверху национализма и предписанных концепций культурных ценностей (Ibid.: 251). Оппозицию между рынком и культурным протекционизмом Флю считает устаревшей и не релевантной для политики креативных индустрий. Новая культурная политика осуществляется не государством или квазигосударственными агентствами, но сетевым образом организованной общественностью.

Прототипом такой наднациональной общественности, субъектом новой политики креативных индустрий является, по мнению Флю, «Движение за свободное программное обеспечение» (Open Source Software Movement), действующее на основе центробежных сил интернета и новых концепций общественного интереса. Роль государства минимизируется. Отныне государство выступает как вспомогательная для рынка сила и в качестве гаранта честной конкуренции, инноваций и плюрализма. Ну и миссия политики креативных индустрий сводится теперь к созданию условий процветания мультикультурной и глобализированной общественности, а не протекционизму национальных культурных индустрий.

Флю твердо верит в демократизирующее воздействие интернета. Он не обсуждает иерархическую организацию экосистемы интернета, как это делает Хосе ван 
Дейк (Dijck, 2013), неравенство в доступе к цифровым технологиям или к интернету как индивидов, так и национальных государств и регионов. Флю полагает, что ценности интернета гомогенны, но в интернете разворачивается острая борьба, в которой конкуренты продвигают разные и противоречивые ценности.

\section{Креативный труд Алана Фримана}

Есть смысл говорить обо всех попытках концептуализации креативных индустрий как об особом способе рационализации и стандартизации культурного или креативного содержания, как о новых экспериментах, призванных придать товарную форму культурному производству и выделить особую компетенцию рабочей силы - креативность. Некоторые из обозначенных подходов предлагают такие допущения, которые с помощью методик статистики и математизированного аппарата экономики можно сделать вполне операциональными и реализуемыми в рамках правительственных политик.

Особого внимания заслуживает теоретическая модель креативных индустрий, разрабатываемая британским экономистом Аланом Фриманом. В одном лице он представляет теоретика и практика, пытавшегося приспособить свою доктрину к конкретной правительственной политике. С 2000 по 2011 год он был членом команды левоцентристского мэра Лондона Кена Ливингстона («Красного Кена») и возглавлял отдел статистики при Совете Большого Лондона. Он принимал непосредственное участие в дебатах вокруг определения креативных индустрий, а также в имплементации политики креативных индустрий, которая стала для многих правительств мира моделью для подражания.

Алан Фриман относится к той группе исследователей, которые считают, что креативные индустрии образуют новую отрасль. Но для него как культурные, так и креативные индустрии не являются новыми явлениями в человеческой истории. Они появились до зарождения мануфактурного и сельскохозяйственного производства или сферы услуг. С эпохи античности люди платили деньги за культуру, а креативность как аспект человеческой деятельности - столь же древний, как человечество. Автомобиль является товаром, созданным благодаря креативности, поскольку представляет собой некоторый символ и имеет культурное содержание. Креативность нельзя выделить, изолировать как нечто самостоятельное, поскольку она присуща всем товарам. Креативность или культура становятся основанием выделения автономной отрасли или индустрии не потому, что они только что появились, но постольку-поскольку креативный труд сегодня превратился в важнейший производственный бактор (Freeman, 2012: 5).

Возвышение и выделение культурных индустрий тем не менее осуществилось лишь в последнее время. Оно было связано с изменением потребительских ориентаций. Потребитель сегодня склонен совершать покупки, ориентируясь не на необходимость или потребность, а на собственный вкус. Вместе с тем креативность и культура подчеркивают уникальность современной ситуации тем, что образуют 
экономически гегемонистский фактор. Примерно подобную гегемонию в производстве осуществляли начиная с 1830 года сначала паровые машины, а затем с 1890-го - электрические машины, а в фордистский период двигатели внутреннего сгорания (Ibid.: 6-7). Так вот, сегодня самые большие в современных креативных индустриях производственные затраты связаны с креативным трудом. И поскольку креативный труд присутствует во всех отраслях современной экономики, постольку те отрасли, в которых он преобладает, можно назвать креативными. Креативные индустрии - «особые пользователи креативного труда», что и характеризует их специфику.

Сделав креативный труд исходной точкой своих рассуждений, Фриман пытается его операционализировать, обнаружить не интуитивные, а жесткие, понятные для статистики параметры креативного труда. Он утверждает, что нужный статистический инструментарий для этого уже существует - он известен как подход «интенсивности».

Фриман начинает с демонстрации подхода «интенсивность». В сельском хозяйстве, например, менее половины рабочей силы непосредственно заняты производством сельхозпродукции. В образовании - только $45 \%$ рабочей силы представлено учителями и профессурой, непосредственно участвующими в процессе образования. В любой отрасли есть определенная доля занятых, которые участвуют в производстве специфического для нее продукта или услуги, остальная доля рабочей силы занята организационной, обслуживающей отрасль работой - бухгалтеры, мастера чистоты, управляющие и проч.

Аналогичным образом внутри креативных индустрий можно определить долю креативных работников, производящих специфический для индустрии продукт, и долю тех, кто обслуживает разнообразные потребности внутри индустрии. Затем отношение количества креативной занятости к занятости вспомогательной для этой индустрии может дать искомый коэффициент интенсивности креативного труда (Freeman, 2015: 354-355).

Если принять список креативных индустрий, которым руководствуется Департамент культуры, медиа и спорта Великобритании, то, по расчетам Фримана, получается следующая таблица интенсивности креативности.

\begin{tabular}{lrrrr} 
Креативный сектор & $\begin{array}{c}\text { Креативная } \\
\text { занятость }\end{array}$ & $\begin{array}{c}\text { Другого рода } \\
\text { занятость }\end{array}$ & $\begin{array}{c}\text { Занятость } \\
\text { в целом }\end{array}$ & Интенсивность \\
\hline Реклама & 45900 & 69400 & 115300 & $40 \%$ \\
Архитектура & 67800 & 36200 & 103500 & $65 \%$ \\
Искусство и антиквариат & 500 & 8300 & 8800 & $6 \%$ \\
Дизайн & 56400 & 42100 & 98500 & $57 \%$ \\
Дизайн моды & 3700 & 2900 & 6600 & $56 \%$ \\
Кино, видео и фотография & 28700 & 29500 & 58200 & $49 \%$ \\
$\begin{array}{l}\text { Музыка, визуальные и пер- } \\
\text { формативные искусства }\end{array}$ & 138400 & 52800 & 191300 & $72 \%$
\end{tabular}




$\begin{array}{lrrrr}\begin{array}{l}\text { Издательство } \\ \text { Программное и электрон- }\end{array} & 71300 & 111,500 & 182700 & 39 \% \\ \begin{array}{l}\text { ное издательство } \\ \text { Цифровые и развлекатель- }\end{array} & 900 & 22300 & 23200 & 4 \% \\ \text { ные медиа } & & & & 15 \% \\ \text { Телевидение и радио } & 2000 & 11200 & 13200 & 64 \% \\ \text { Все креативные индустрии } & 41700 & 34200 & 96000 & 53 \%\end{array}$

Однако данный список, считает Фриман, следует уточнить, и главное, ввести определение креативности, творческого труда. Отвергая существующие попытки определения через индивидуальный талант, образование и так далее, Фриман предлагает определить креативный труд через «не-заменимость» - креативный труд не может быть замещен машиной (Ibid.: 361). Речь идет о труде, в принципе не поддающемся механизации. Не-механизируемый - в данном случае значит неповторимый, уникальный. Любой творческий продукт - фильм, книга, видеоигра - имеет компоненты, созданные и машинами, и творчеством. Уникальность продукта - тот аспект товара, который создан творчеством.

Человечество стремится замещать труд машинами, но только незаменяемый труд может остаться. Это выглядит как тавтология. Но Фриман настаивает на ней. Пределом такого прогресса будет не общество, в котором нет труда вообще, но общество, в котором будет только незаменяемый труд.

Фриман не предлагает альтернативного списка креативных индустрий, поскольку принятые классификации отраслей он считает неадекватным реликтом индустриальной эпохи. Он формулирует лишь подход, который мог бы дать критерии новой классификации индустрий и статистический инструментарий для просчета креативности. Креативности, которая сохранится в условиях самой интенсивной автоматизации или роботизации труда во всех отраслях производства.

Таким образом, креативные индустрии группируются в отдельную отрасль не потому, что имеют статус культурных, но потому, что в своем основании опираются на креативный труд. Несмотря на риторику лево-ориентированного экономиста, Фриман помогает реализации того проекта, который продвигает частный капитал: рационализировать, стандартизировать, разработать адекватный измерительный инструментарий, с помощью которого можно было бы оценивать производительность креативного труда. Неслучайно Фриман даже и не приближается к вопросу о том, каким образом можно было бы просчитать производительность отдельного креативного работника. Его схема схватывает коэффициент интенсивности креативности лишь на уровне той или иной отрасли в целом, поскольку это позволяют сделать существующие в современной статистике допущения.

Подобного рода операциям абстрагирования креативный труд всегда сопротивляется, что и представляет вечную проблему для бизнеса и чиновников. Это сопротивление манифестируется в непрерывной борьбе креативного менеджмен- 
та с относительной автономией креативных работников (Hesmondhalgh, Baker, 2002: 35). Неизмеряемость креативного труда с помощью системы товарного обмена, сравнивающего все и вся, тем не менее не останавливает стремления к специализации, рационализации и стандартизации, то есть к институциализации креативного труда в креативных индустриях.

\section{Модели политики креативных индустрий}

Имплементация политики креативных индустрий в разных странах приводит к такому же ограниченному плюрализму, который можно обнаружить при обсуждении разных теоретических подходов. Эта ограниченность определена британской образцовой моделью политики креативных индустрий.

\section{Американская модель}

Есть две специфические и взаимосвязанные черты, характерные для креативных индустрий США. Во-первых, на федеральном уровне здесь никогда не стремились сформулировать национальную политику для креативных, а также и культурных индустрий. Некоторые исследователи видят в этом даже странность: «великий культурный парадокс» состоит в том, что страна с самым большим в мире экспортом культурной продукции и услуг оказывается совершенно не озабоченной политикой культурных индустрий и вообще какой бы то ни было национальной культурной политикой (Miller, Yudice, 2002: 35).

Вместе с тем проблематика креативных индустрий интенсивно разрабатывается как представителями академического сообщества, так и практиками, а сама политика креативных индустрий чрезвычайно популярна на уровне отдельных штатов и муниципалитетов. Именно на субнациональном уровне рождаются разнообразные инициативы, ставится множество экспериментов, опыт которых изучается и обобщается исследователями и практиками, участвующими в движении «креативных городов».

Кроме того, американскую модель отличает наличие двух сосуществующих культурных секторов, функционирующих на основе разных принципов. С одной стороны, после учреждения в 1965 году федерального агентства National Endowment for the Arts возник некоммерческий, плохо финансируемый, зависимый от политической конъюнктуры и частной филантропии сектор искусств. С другой стороны, в послевоенный период интенсивно рос сектор коммерчески ориентированных, действующих на транснациональном уровне, корпораций, которые часто относят к «копирайт-индустриям», поскольку именно авторское право придает товарную форму их культурной продукции.

Отсюда - историческая расщепленность культурной политики в США и разные способы ее осмысления: 1) дискурс о креативных индустриях, определяющий политику на субнациональном уровне, делает акцент на культурной миссии, на 
равном доступе к культуре и преодолении разных проявлений социального исключения, что сближает его с дискурсом, характерным для большинства европейских стран и самого европейского сообщества; 2) дискурс, характерный для развлекательных индустрий, подчиненных исключительно коммерческому драйву, маркетинговым стратегиям и потребительским предпочтениям. Глобальную значимость американской индустрии развлечений не отменяет тот факт, что «другой большой и важный сегмент [американской креативной экономики] состоит из субсидируемых и неприбыльных искусств и культурных областей» (Wyszomirski, 2008: 200).

Несмотря на такой секторальный и дискурсивный разрыв, именно в США создаются многие инновационные разработки и практики на пересечении креативности, культуры, науки и предпринимательства. Здесь выросла мощная традиция и большое разнообразие институтов гражданского общества в сфере искусства и культуры. В 1990-200о-е годы в американских городах наблюдался бум в строительстве и расширении материальной базы культуры, тогда как на федеральном уровне многие культурные программы либо стагнировали, либо урезались. Сдвиг в сторону субнациональной культурной политики обусловил возникновение двух главных подходов в городских культурных политиках. Первый - предпринимательская культурная политика, сконцентрированная на развитии туризма и новых формах городского брендирования, финансирующая важнейшие культурные проекты и поощряющая частные инвестиции в культурную инфраструктуру. Вторая - стратегии креативного класса, продвигающего городские культурные и иные формы благоустройства среды и качества жизни через развитие городских районов, округов, кварталов или кластеров с оригинальными художественными активностями и развлечениями. Здесь формировалась рабочая сила нового типа - представители так называемого «креативного класса». Публикация книги Ричарда Флориды «The Rise of the Creative Class» совпала с этим сдвигом к местной культурной политике и стратегией формирования креативных городов. Флорида видел в креативности главный источник «конкурентных преимуществ» капитализма XXI века, а также наиболее ценный товар экономики.

\section{Скандинавский путь}

Специфика скандинавской модели (Дании, Исландии, Норвегии, Швеции и Финляндии) определялась тремя важными особенностями. Во-первых, здесь культурная политика осуществлялась в большой мере под влиянием местных моделей социализма и капитализма всеобего благосостояния. Важными инструментами этих моделей были партнерство предпринимателей и рабочих при посреднической роли государства, а также перераспределение налогов и централизованное распределение фондов и ресурсов. Культурная политика носила ярко выраженный централизованный характер. 
Во-вторых, скандинавские страны культурно, географически и лингвистически были отдалены от глобальных культурных центров. Инициированная правительствами политика «креативных индустрий» была поддержана, но без большого энтузиазма, поскольку она провоцировала напряжение между коммерческими предприятиями и субсидируемым государством искусством. В Скандинавии центральную роль играли государственные агентства, сильные корпоративные связи между государственной бюрократией и работниками культуры. Идеологическая склонность к эгалитаризму и национальной идентичности здесь также всегда были сильны.

В-третьих, в начале 1990-х сформировался противоположный центробежный тренд в связи с наметившимся интенсивным развитием сектора так называемой «экономики знаний». На этой волне возникли такие гиганты, как «Nokia» и «Ericsson». Тренд был поддержан представителями экономической науки. Поэтому в последние годы политика креативных индустрий находит определенный отзыв и пробивает себе дорогу.

В стратегии развития креативных индустрий скандинавских стран можно выделить четыре главных пункта:

1) Предпринимательство и креативность: смещение акцента в образовании с навыков рабочей силы на создание креативной атмосферы в процессе обучения и на практическое применение креативности в коммерческой сфере.

2) Поощрение роста креативного бизнеса: смещение акцентов с финансирования культуры на грантовую поддержку, инвестирование в креативный бизнес и внедрение инновационных политик в креативные индустрии.

3) Создание креативных кластеров, что зачастую связано с сохраняющимися централизованными государственными функциями и усилиями.

4) Креативный «плейсмейкинг» (облагораживание территории), что требует развития местных региональных инициатив, а не централизованного государственного вмешательства (Flew, 2005: 39).

Ввиду все еще низкой популярности политики креативных индустрий в скандинавских странах в основном обсуждают приемлемость британской модели в собственных национальных контекстах. Поэтому трудно говорить о каком-то оригинальном вкладе в развитие данной политики в этих странах.

\section{Восточно-азиатские модели}

Трудно выделить особую восточно-азиатскую модель политики креативных индустрий. Однако страны региона имеют схожий социально-исторический контекст, а потому можно говорить о некоторых общих закономерностях и тенденциях. При всех отличиях азиатские правительства формулируют политику креативных индустрий исходя из трех важнейших факторов: 1) чрезвычайно интенсивная динамика социальных и культурно-политических изменений требует радикально новой 
культурной политики; 2) креативные индустрии являются важнейшим ресурсом повышения экспортного потенциала; 3) геополитическое возвышение Китая.

Восточная Азия - регион наиболее динамичной урбанизации и миграции сельского населения в города. При этом здесь снижается значимость сельского хозяйства как экспортной отрасли. Экспортными отраслями становятся сервисные услуги, развиваемые в городских центрах. В мегаполисах при значительной поддержке государства развивается частный бизнес в сфере интернет-коммуникаций, которые оказываются одними из самых динамичных сегментов городских экономик. Изменяются и социальные характеристики населения - растет уровень образования, а потребительские стандарты усложняются и становятся разнообразней.

Сильный импульс к развитию креативных индустрий дали два кризиса - азиатский 1997-1998 года и лопнувший в 2001 году пузырь сектора новых технологий. Из кризисов было извлечено несколько важных уроков. Во-первых, ориентированное на экспорт развитие имеет пределы и зависит от капризной рыночной конъюнктуры. Во-вторых, критике подверглась стратегия государственного капитализма, недооценившего значимость развития человеческого капитала, собственных внутренних рынков и творческих свобод индивида.

Важным фактором обращения к политике креативных индустрий восточноазиатских стран стал рост экономического потенциала Китая. С одной стороны, Китай - это непрерывно увеличивающийся рынок, что позволяет наращивать экспортные возможности соседей. С другой стороны, Китай - агрессивный конкурент.

Характерно, что в первую очередь политику креативных индустрий стали осваивать крупнейшие азиатские мегаполисы - Гонконг (Zhuoquan, 20o4) и Сингапур (Kong, 2012). Иными словами, в Азии она пробивала свой путь как городская политика.

Сингапур сформулировал свою политику креативных индустрий в начале 200о-х годов, приняв «Стратегию города Возрождения для искусств и культуры», за которой последовали другие правительственные документы. В ней декларировался курс на превращение Сингапура в «новый азиатский культурный хаб» и на удвоение вклада креативных индустрий в ВВП к 2012 году. И хотя стратегия Сингапура была построена на использовании в качестве образцов европейских и американских программ развития креативных индустрий, она представляла собой прежде всего проект национального строительства и обновления. Обсуждение курса на развитие креативных индустрий было связано с более широким политическим вопросом: существует ли возможность децентрализации политической власти и ослабления государственного контроля над содержанием медиаконтента во имя развития индивидуальной креативности, которая позволила бы сделать Сингапур креативным кластером.

Гонконг, известный своей выдающейся для Азиатского региона киноиндустрией, уже после воссоединения с Китаем разработал собственную стратегию разви- 
тия креативных индустрий. Правда, в качестве образца были приняты установки британской политики креативных индустрий. При этом особый акцент был сделан на развитии креативных наук и на выработке параметров измерения креативности на отдельных территориях (Zhuoquan, 2004: 15-16, 20).

Тайвань сделал ударение на развитие цифровых и интернет-технологий. Ocoбую роль сыграла правительственная программа «Two Trillion and Twin Star», принятая в 2002 году. Дискурс креативности здесь стимулировался жесткостью конкурентной борьбы Тайваня и Китая на одних и тех же рынках - в основном на рынке видеоигр.

Южная Корея чрезвычайно успешно развивала в последнее десятилетие сектор креативных индустрий, хотя правительство не употребляло этого выражения и не формулировало никакой специфической политики. Явление, которое называют «Корейской волной», возникло по случайному стечению обстоятельств: в результате политики либерализации медиа 1990-х, переориентации корейского кино на вкусы более широкой массовой аудитории, которая последовала за снятием государственного контроля над распространением кинопродукции, и мощной политики превращения Кореи в информационное общество и экономику знаний (рост связанности и сопряженности через интернет).

Отметим, что правительства и исследовательские сообщества практически всех развитых восточно-азиатских стран в той или иной мере знакомы с британским жаргоном политики креативных индустрий, однако в качестве абсолютного образца его приняли только в Сингапуре и Гонконге. Представители других стран не проявляли большой вовлеченности в эту дискуссию.

В этом смысле показателен пример Китая. Здесь выражения «креативные индустрии» и «культурные индустрии» чаще всего, то есть за исключением исследователей, пишущих для англоязычных академических издательств и журналов, употребляются как синонимы. Но это не означает, что китайские эксперты плохо осведомлены о международной полемике по этой теме. Причины, скорее, отсылают нас к особой политической культуре Поднебесной. Хайцинг Ю предостерегает от типичных предубеждений относительно «гибридной» китайской политической культуры, которая является одновременно не-либеральной, антилиберальной и неолиберальной. Поэтому привычные «понятия трудно схватываются, и всегда существует слабая связь между риторикой/дефиницией и реальностью» (Yu, 2011: $34,38)$.

На XVI съезде КПК «культурные индустрии» были представлены как ключевая задача развития следующего пятилетнего плана. C 2005 года в документах партии употребляется выражение «культурные и креативные индустрии». А в академических дискуссиях исследователи предпочитают употреблять выражение «креативные индустрии». Такое внешне неразборчивое употребление и смешение терминологии типично не только для Китая, но и вообще для азиатских национальных контекстов. 
Термин «культурные и креативные индустрии» имеет несколько смысловых уровней. На идеологическом уровне с его помощью обозначают политику «мягкой власти», которую Китай распространяет в не-китайской ойкумене (Keane, 2013: 4). Второе измерение также идеологически маркировано, но отсылает к внутренней политике трансформации Китая из индустриальной державы в постиндустриальную: реформированию подлежат такие обширные сферы, как трудовые практики, повседневная культура и формы рыночной организации. Оно метафорически выражается лозунгом «От сделано в Китае к создано в Китае» («from made in China to created in China») (Ibid.: 6).

Не в первый раз заимствованные на Западе концепты, одобренные и принятые КПК, погружаясь в китайский культурный контекст, начинают затем вести автономное существование мемов и заимствований, внедряющих за собой в чуждую среду целый корпус идей. В рамках китайских культурных дебатов, слабо регулируемых партийной дисциплиной, креативность и культурные индустрии практически сразу разрушили синонимию официального партийного дискурса и маркировали два противоположных контекста и политических течения.

Культурные индустрии отсылают к традиционной китайской культуре и великой цивилизации, к эпохе, когда Китай поставлял внешнему миру идеи, когда европейцы восхищались чудесами китайской архитектуры, городским планированием и организацией общества. Это та культура, которая находится на попечении государства и являет собой мощь китайской «мягкой власти». У культурных индустрий своя великая миссия - построение гармоничного мира посредством распространения китайской древней культуры. Это курс на создание за рубежом культурных баз и кластеров, продажа большого числа DVD о китайской цивилизации, открытие книжных лавок Синьхуа и учреждение большого числа институтов Конфуция по всему миру. Как правило, на языке культурных индустрий говорят наиболее консервативные политики и общественные деятели.

Дискурс о креативных индустриях представляет другую - рыночную - стратегию интернационализации и модернизации Китая. Креативные индустрии обозначают прежде всего интересы частного бизнеса. Они лишены всякого политического пафоса, ориентированы на инвестиции, на завоевание внутренних и внешних рынков. Креативные индустрии настроены на подражание организационным формам крупных западных, прежде всего американских, корпораций, интенсивно используют экспертизу и компетенции западных профессионалов. Поэтому, несмотря на все упомянутые «сложности интерпретаций, не-европейские правительства смотрят в сторону североевропейских политик в поисках вдохновения в своем стремлении развивать культурные и креативные индустрии, а термины „культурные“ и „креативные индустрии“ представляют собой столь же различные генеалогии», как и на Западе (Hesmondhalgh, 20о8: 553-555). 


\section{Заключение}

Не существует разнообразия моделей креативных индустрий, есть политика с определённым набором инструментов, выработанная и последовательно осуществляемая в Великобритании, играющая роль образца. В разных национальных и региональных контекстах она заимствуется и применяется с оглядкой на сложившиеся институциональные и культурные традиции, а также на политические возможности. Этим разнообразием условий и обуславливаются различные результаты имплементации политики креативных индустрий, многообразие национальных «списков» отдельных отраслей, которые относятся к данному сектору. Иначе говоря, «правильного» набора отраслей, которые следует отнести к креативным индустриям, не существует.

Политика креативных индустрий состоит в интенсивной и в идеале тотальной коммерциализации и приватизации культурного производства, в изменении условий труда не только в традиционном секторе культуры, но и в отраслях так называемой новой экономики, массовизации определенной разновидности рабочей силы, превращении ее в креативный класс.

В отличие от политики культурных индустрий, определявшейся национальными рамками, политика креативных индустрий формируется интернационализацией культурных рынков и глобальным характером конкуренции. Концентрация (кластеризация) креативных индустрий в мегаполисах превращает их в конкурирующие центры производства. Вместе с тем имплементация политики креативных индустрий в городах разных стран и регионов способствует созданию отдельного и специфического глобального рынка.

В условиях трансформации культурного сектора, заданной политикой креативных индустриц̆, встает вопрос об «архаичности» тех форм знания, которые были уместны в условиях сохранения центральной роли национальных государств в культурной политике. Государственная статистика оказывается неуместной и неадекватной в условиях, когда корпоративный сектор полностью определяет культурное производство. Данная проблема пока не осознана в полной мере, но развитие приватизированных и фрагментированных форм знания, которые воплощены в корпоративных формах так называемых Big Data, в будущем с особой остротой поставит вопрос о том, нуждается ли государство в целостном представлении о культуре и в осуществлении функций контроля в данном секторе производства.

Вопрос о целесообразности имплементации политики креативных индустрий в Российской Федерации имеет несколько аспектов. Во-первых, возникает проблема, насколько она совместима с курсом на суверенизацию страны, в особенности если этот курс будет долгосрочным. Политика креативных индустрий - это не только коммерциализация культурного сектора, но и включенность в глобальную конкуренцию. Поэтому дилемму можно сформулировать жестко: как принятие или же отказ от участия в глобальном рынке, структурированном коммерческим 
образом. Тем не менее возможны и умеренные или промежуточные варианты решения. Например, американский опыт сосуществования двух параллельных культурных секторов - одного, направленного на глобальную конкуренцию, и второго - оперирующего на субнациональном уровне. Во-вторых, следует отдавать отчет в том, что политика креативных индустрий - это участие на конкурентных рынках, что приводит к эффектам усиления неравенства между территориями и городами. Имеет ли смысл подобного рода политика в столь регионально и культурно пестрой стране, как Россия? Мегаполисы гарантированным образом окажутся в выигрыше по сравнению с иными территориями. Но и здесь возможны промежуточные варианты и сложносоставная культурная политика. В-третьих, следует своевременно озаботиться формами нового знания, которое не было бы фрагментировано и рассредоточено среди разных корпоративных игроков. Дабы иметь общую картину и представление о культурных процессах, следует продумать, какие агенты смогут аккумулировать новые форматы знания.

\section{Литература}

Клоудова Й. (2010). Влияние развития креативной экономики на экономически отсталые регионы // Вопросы экономической политики. № 5. С. 110-125.

Хезмондалш Д. (2014). Культурные индустрии / Пер. с англ. И. Кушнаревой. М.: ВШЭ.

DCMS. (2001). Creative Industries Mapping Document 2001. URL: https://static.a-n. co.uk/wp-content/uploads/2016/12/DCMS-Creative-Industries-Mapping-Document-2001.pdf (дата доступа: 7.08.2018).

Dijck J. (2013). The Culture of Connectivity: A Critical History of Social Media. Oxford: Oxford University Press.

Flew T. (2005). Sovereignty and Software: Rethinking Cultural Policy in a Global Creative Economy // International Journal of Cultural Policy. Vol. 11. № 3. P. 243-260.

Florida R. (2002). The Rise of the Creative Class, and How It's Transforming Work, Leisure and Everyday Life. N.Y.: Basic Books.

Florida R., Tinagli I. (2004). Europe in the Creative Age. URL: http://creativeclass.com/ rfcgdb/articles/Europe_in_the_Creative_Age_2004.pdf (дата доступа: 7.08.2018).

Freeman A. (2015). Twilight of the Machinocrats: Creative Industries, Design, and the Future of Human Labour // Pijl K. van der. (ed.). Handbook of the International Political Economy of Production. Cheltenham: Edward Elgar. P. 352-374.

Freeman A. (2012). Is Creation an Industry? A Constructive Critique of the Economics of the Cultural and Creative Industries. L.: Metropolitan University.

Galloway S., Dunlop S. (2007). A Critique of Definitions of the Cultural and Creative Indus- tries in Public Policy // International Journal of Cultural Policy. Vol. 13. № 1. P. $17-31$.

Garnham N. (1990). Capitalism and Communication. L.: SAGE. 
Hesmondhalgh D. (2008). Cultural and Creative Industries // Bennett T., Frow J. (eds.). Handbook of Cultural Analysis. L.: SAGE. P. 553-555.

Hesmondhalgh D., Baker S. (2011). Creative Labour: Media Work in Three Cultural Industries. L.: Routledge.

Howkins J. (2001). The Creative Economy: How People Make Money from Ideas. L.: Penguin.

Keane M. (2013). Creative Industries in China: Art, Design and Media. Cambridge: Polity. Kong L. (2012). Ambitions of a Global City: Arts, Culture and Creative Economy in «PostCrisis» Singapore // International Journal of Cultural Policy. Vol. 18. № 3. P. 279-294.

Landry Ch., Bianchini F. (1995). The Creative City. L.: Demos.

Miège B. (1989). The Capitalization of Cultural Production. N.Y.: International General.

Miller T., Yudice G. (2002). Cultural Policy. L.: SAGE.

Porter M. (2003). Introduction // Sölvell Ö., Lindqvist G., Ketels Ch. The Cluster Initiative Greenbook. URL: https://www.hhs.se/contentassets/f51b706e1d644egfa6c4d232abdoge63/greenbooksepo3.pdf (дата доступа: 7.08.2018).

Rindzevičiūtė E., Svensson J., Tomson K. (2015). The International Transfer of Creative Industries as a Policy Idea // International Journal of Cultural Policy. Vol. 22. № 4 . P. 594-610.

UNESCO. (1982). The Cultural Industries. URL: http://unesdoc.unesco.org/images/ooo4/ ooo499/o49972eo.pdf (дата доступа: 7.08.2018).

UNESCO. (2009). Framework for Cultural Statistics - UNESCO Culture. 2009. URL: http://unesdoc.unesco.org/images/oo19/oo1910/191061e.pdf (дата доступа: 7.08.2018).

Wyszomirski M. (2008). The Local Creative Economy in the United States of America // Anheier H. K., Raj Isar Y. (eds.). The Cultural Economy. L.: SAGE. P. 199-212.

Yu H. (2011). Dwelling Narrowness: Chinese Media and Their Disingenuous Logic // Continuum. Vol. 25. № 1. P. 33-46.

Zhuoquan Xu. (2004). A Study on Hong Kong Creativity Index: Interim Report. Hong Kong: University of Hong Kong.

\section{Creative Industries — Models of Development}

\section{Rouslan Khestanov}

PhD, Professor, School of Cultural Studies, Department of Humanities, National Research University Higher School of Economics

Address: Myasnitskaya str., 20, Moscow, Russian Federation 101000

E-mail:khestanov@hse.ru

With the rise of the concept of "culture", numerous attempts were made to integrate it into state policy, but failed. "Culture" then required a clear and unambiguous definition. A new effort, known 
as the "debate about cultural and creative industries", was undertaken in a new historical context at the beginning of this century. This article tries to clarify the main arguments and positions in these recent debates, and to analyze the attempt of a new operationalization of culture by means of economic discourse in the critical perspective. This attempt was carried out under the new academic slogan of "creative industries", with which politicians, international and national functionaries, as well as representatives of the academic community pinned their hopes on the invention of a new model of economic growth. One of the principal theses of the article is that this kind of operationalization is not realistic because "creativity", like "culture", is not amenable to any mathematization, commodification, or unambiguous interpretation. The policy of "creative industries" is considered through a tendency to a total commercialization of cultural production and its global standardization. The article analyzes different national models of its implementation, as well as the results. One of the most important outcomes of this policy is a growing distrust of the "archaic" forms of cultural knowledge that have been formed in and by national states: the statistical approach as well as its instruments are inappropriate and inadequate as state-of-the-art when the corporate sector almost completely defines rules and standards of a cultural production. This raises the question of whether the state needs a holistic view of culture and the exercising of control functions in this sector of production. In this perspective, the article raises the problem of whether the policy of creative industries is adequate and appropriate for the Russian Federation.

Keywords: creativity, commodity, cultural policy, cultural industries, creative industries, commercialization

\section{References}

DCMS (2001) Creative Industries Mapping Document 2001. Available at: https://static.a-n.co.uk/wpcontent/uploads/2016/12/DCMS-Creative-Industries-Mapping-Document-2001.pdf (accessed 7 August 2018).

Dijck J. (2013) The Culture of Connectivity: A Critical History of Social Media, New York: Oxford University Press.

Flew T. (2005) Sovereignty and Software: Rethinking Cultural Policy in a Global Creative Economy. International Journal of Cultural Policy, vol. 11, no 3, pp. 243-260.

Florida R. (2002) The Rise of the Creative Class, And How It's Transforming Work, Leisure and Everyday Life, New York: Basic Books.

Florida R., Tinagli I. (2004) Europe in the Creative Age. Available at: http://creativeclass.com/rfcgdb/ articles/Europe_in_the_Creative_Age_2004.pdf (accessed 7 August 2018).

Freeman A. (2015) Twilight of the Machinocrats: Creative Industries, Design, and the Future of Human Labour. Handbook of the International Political Economy of Production (ed. K. van der Pijl), Cheltenham: Edward Elgar, pp. 352-375.

Freeman A. (2012) Is Creation an Industry? A Constructive Critique of the Economics of the Cultural and Creative Industries, London: Metropolitan University.

Galloway S., Dunlop S. (2007) A Critique of Definitions of the Cultural and Creative Industries in Public Policy. International Journal of Cultural Policy, vol. 13, no 1, pp. 17-31.

Garnham N. (1990) Capitalism and Communication, London: SAGE.

Hesmondhalgh D. (2008) Cultural and Creative Industries. Handbook of Cultural Analysis (eds.

T. Bennett, J. Frow), London: SAGE, pp. 553-555.

Hesmondhalgh D. (2014) Kulturnye industrii [The Cultural Industries], Moscow: HSE.

Hesmondhalgh D., Baker S. (2011) Creative Labour: Media Work in Three Cultural Industries, London: Routledge.

Howkins J. (2001) The Creative Economy: How People Make Money from Ideas, London: Penguin.

Keane M. (2013) Creative Industries in China: Art, Design and Media, Cambridge: Polity.

Kloudova Y. (2010) Vliyanie razvitija kreativnoj ekonomiki na ekonomicheski otstalye regiony [The Effect of the Creative Economy Development on the Economically Backward Regions]. Voprosy ekonomicheskoy politiki, no 5, pp. 110-125.

Kong L. (2012) Ambitions of a Global City: Arts, Culture and Creative Economy in "Post-Crisis" Singapore. International Journal of Cultural Policy, vol. 18, no 3, pp. 279-294. 
Landry Ch., Bianchini F. (1995) The Creative City, London: Demos.

Miège B. (1989) The Capitalization of Cultural Production, New York: International General.

Miller T., Yudice G. (2002) Cultural Policy, London: SAGE.

Porter M. (2003) Introduction. Sölvell Ö., Lindqvist G., Ketels Ch., The Cluster Initiative Greenbook. Available at: https://www.hhs.se/contentassets/f51b706e1d644egfa6c4d232abdoge63/ greenbooksepo3.pdf (accessed 7 August 2018).

Rindzevičiūtè E., Svensson J., Tomson K. (2015) The International Transfer of Creative Industries as a Policy Idea. International Journal of Cultural Policy, vol. 22, no 4, pp. 594-610

UNESCO (1982) The Cultural Industries. Available at: http://unesdoc.unesco.org/ images/0004/000499/049972eo.pdf (accessed 7 August 2018).

UNESCO (2009) Framework for Cultural Statistics — UNESCO Culture. Available at: http://unesdoc. unesco.org/images/0019/001910/191061e.pdf (accessed 7 August 2018).

Wyszomirski M. (2008) The Local Creative Economy in the United States of America. The Cultural Economy (eds. H. K. Anheier, Y. Raj Isar), London: SAGE, pp. 199-212.

Yu H. (2011) Dwelling Narrowness: Chinese Media and Their Disingenuous Logic. Continuum, vol. 25, no 1, pp. 33-46

Zhuoquan Xu (2004) A Study on Hong Kong Creativity Index: Interim Report, Hong Kong: University of Hong Kong. 


\title{
Идеология в обществе позднего модерна: исчезновение или трансформация?*
}

\author{
Дмитрий Руденкин \\ Кандидат социологических наук, доцент кафедры интегрированных \\ маркетинговых коммуникаций и брендинга Уральского федерального университета \\ Адрес: ул. Мира, д. 19, г. Екатеринбург, Российская Федерация 620002 \\ E-mail: d.v.rudenkin@urfu.ru
}

\author{
Алексей Логинов \\ Кандидат философских наук, доцент кафедры социальной философии \\ Уральского федерального университета \\ Адрес: ул. Мира, д. 19, г. Екатеринбург, Российская Федерация 620002 \\ E-mail: alexeyloginov@urfu.ru
}

\begin{abstract}
Статья посвящена рассмотрению специфической роли, которую в политической реальности общества позднего модерна играет феномен идеологии. Во введении авторы статьи отмечают как устойчивый интерес к вопросам конкуренции идей и идеологий в современном мире, так и нарастающие сомнения в применимости сложившихся теорий идеологии для описания и осмысления подобной конкуренции. Далее, понимая идеологию как ориентированные на действия системы убеждений, авторы рассматривают сложившиеся в социально-гуманитарной науке наработки в области описания статуса таких систем в обществе позднего модерна. Авторы отмечают, что версии о полном исчезновении идеологии из политического процесса общества позднего модерна не находят полноценных эмпирических доказательств, несмотря на то что некоторые аргументы сторонников таких версий вполне убедительны. В ходе анализа теоретических моделей позднего модерна авторами показано, что общество этого периода создает особые условия для проявления идеологии, выражающиеся в диверсификации информационного пространства, снижении роли политических партий, имиджевой дискредитации многих фундаментальных идеологических проектов и редукции классовой борьбы. Базовые гипотезы авторов соотнесены с результатами собственного социологического исследования идеологической конкуренции в российском обществе накануне выборов в Государственную Думу 2016 года, что позволило в итоге описать идеологию в современной России как гибридную по ценностному ядру, локальную по своей риторике, дисперсивную по субъектам артикуляции систему. Таким образом, авторы обосновывают тезис о принципиальной возможности описания политических процессов общества позднего модерна с использованием термина «идеология», который в новых условиях не утрачивает своих эвристических возможностей, но приобретает новые свойства и требует «перенастройки» методологического аппарата самих социальных наук.
\end{abstract}

Ключевые слова: идеология, постсоветская Россия, модерн, общество позднего модерна, социализм, консерватизм, либерализм, ценности

\footnotetext{
(С Руденкин Д В., 2018

(C) Логинов А. В., 2018

(с) Центр фундаментальной социологии, 2018

DOI: $10.17323 / 1728-192 \mathrm{X}-2018-3-197-220$

* Работа выполнена при поддержке гранта РНФ, проект № 17-18-01165.
} 
Логика развития современной социально-гуманитарной науки наталкивает на мысль, что в настоящий момент все большую актуальность вновь приобретают вопросы о конкуренции идеологий, ценностей и видений развития общества, циркулирующих в различных социальных и политических контекстах. Титульной проблематикой всемирных социологических конгрессов в 2014 году в Йокогаме и в 2018 году в Торонто становятся вопросы социального неравенства и справедливости, осмысление которых традиционно служило отправной точкой для большинства идеологических направлений, оформившихся в истории общественно-политической мысли. Президентами международной и американской социологических ассоциаций в 2010-2014 годах были избраны известные представители современного неомарксизма: М. Буравой и Э. Райт. Трижды за минувшие 10 лет премия Юхана Шютте за вклад в развитие политической науки присуждалась ученым, внесшим значительный вклад в изучение эволюции доминирующих ценностей и идеологической конкуренции в разных регионах мира: в 2011 году ее был удостоен Р. Инглхарт, в 2015 году - Ф. Фукуяма, а в 2016 году - Ю. Эльстер. За последние 10 лет в профильных академических журналах издательства «SAGE» было опубликовано несколько тысяч научных работ, посвященных различным проявлениям классических и неклассических идеологий в современном мире. Иными словами, сразу многие, казалось бы, частные и напрямую не связанные между собой тенденции в совокупности свидетельствуют об интенсивном внимании современной социально-гуманитарной науки именно к вопросам конкуренции видений развития общества и идеологического соперничества, которые еще в 1990-е годы воспринимались многими учеными как не столь значимые.

У этого ренессанса интереса общественных наук к проблемам конкуренции видений развития общества прослеживаются объективные причины. Частые экономические кризисы, охватывающие страны Европы и США, на фоне относительно успешного развития многих азиатских и ближневосточных государств вызывают дискуссии о разумности тех либерально-рыночных идей, которые были положены в основу европейского и американского образа жизни. Активная деятельность террористических и криминальных сообществ (в сочетании с порой этически спорными решениями противостоящих им спецслужб) актуализирует споры о границах дозволенного в государственной политике по поддержанию общественной безопасности. Возрастающие потоки мигрантов из мусульманских государств в страны Европы, многие жители которых исторически придерживались в основном светских или умеренно христианских норм, стимулируют в этих государствах активные и порой весьма жесткие дискуссии не только о религии, но и о приемлемых нормах морали. Эти, как и многие другие, тенденции свидетельствуют о том, что во многих (если не во всех) странах современного нам мира действительно обострился вопрос о наиболее приемлемых векторах дальнейшего развития социума. Учитывая остроту и актуальность таких вопросов, закономерно не только стремление ученых к осмыслению релевантных тем, но и их обращение к некогда утратившим интерес разработкам в области анализа идеологий: 
конкуренция фундаментальных проектов развития общества в истории социально-гуманитарной науки чаще всего описывалась именно как идеологическое соперничество.

Тем не менее на данный момент сохраняется важный и, к сожалению, неразрешенный методологический вопрос о корректности описания соперничества между разными видениями развития общества именно в терминах конкуренции различных идеологий. Классические теории идеологий, как и их типологии, формулировались относительно давно, и их первичной основой была социальная реальность, ощутимо отличающаяся от состояния мира начала XXI века. Даже теоретические дискуссии о возможности деидеологизации коллективных представлений, которые наметились в социально-гуманитарной науке в 1960-е и 1970-е годы, показали: термин «идеология» (по крайней мере, в своем классическом смысле «искаженной» в угоду классовым интересам картине мира) не всегда может быть адекватно применим для анализа тех явлений, которые заявили о себе уже после его введения в категориальный аппарат науки. Поэтому не удивительно, что в академическом сообществе сейчас звучат предложения не только о ревизии классических подходов к идеологии, но даже и о полном отказе от использования самого этого термина при изучении политических процессов. У многих ученых попросту отсутствует уверенность, что происходящие в современном мире мировоззренческие диспуты корректно называть именно противостоянием идеологий. Можно согласиться с Г. И. Мусихиным: «Идеология является одним из самых распространенных терминов в мире политического и одновременно одним из самых оспариваемых понятий в пространстве политической теории... наблюдается парадоксальное явление: в то время как теоретики не скрывают своих затруднений в концептуализации идеологии, политики продолжают уверенно пользоваться этим термином в повседневной жизни» (Мусихин, 2013: 9).

В данной статье мы намерены сделать шаг в разрешении сложившегося противоречия между актуальностью научного анализа идейной, ценностной проблематики в современном мире и отсутствием у социально-гуманитарной науки ясных представлений о допустимости рассмотрения соответствующих вопросов сквозь призму концепта идеологии. Заведомо не претендуя на окончательное разрешение этой запутанной теоретико-методологической проблемы, мы тем не менее намерены оценить перспективы использования концепта «идеология» для анализа актуальных политических процессов общества позднего модерна. Для этого мы намерены выделить основные сложности, затрудняющие рассуждения об идеологиях в политическом процессе общества позднего модерна, оценить их справедливость и обоснованность и предложить свое видение перспектив описания актуальных политических процессов с помощью теорий идеологии. Кроме того, в рамках данной статьи мы планируем представить результаты собственного эмпирического исследования, на базе которого выдвинутые гипотезы будут подвергнуты эмпирической локализации и проверке. 


\section{Подходы к пониманию роли идеологии в обществе позднего модерна}

Прежде чем перейти непосредственно к анализу эвристического потенциала концепта «идеология» в описании политических процессов общества позднего модерна ${ }^{1}$, разумно уточнить основное содержание этого термина. Необходимость такого уточнения, сама по себе очевидная в контексте поднятой в работе проблематики, приобретает дополнительную актуальность в связи с обилием и разнообразием подходов, сложившихся в социально-гуманитарной науке в отношении термина «идеология». С одной стороны, как справедливо подмечает Я. А. Пляйс, сколь бы разнообразны ни были сложившиеся в социально-гуманитарной науке дефиниции идеологии, все они в любом случае сходятся в том, что речь идет о некой системе фундаментальных взглядов на развитие общества (Пляйс, 2010: 70). С другой стороны, мы считаем обоснованной и часто цитируемую позицию К. Лефорта: допустимо выделять как минимум три сложившихся направления концептуализации идеологии, каждое из которых раскрывает сущность подобной системы взглядов по-своему. Сторонники первого направления понимают под термином «идеология» некий всеобъемлющий проект глобальных общественных трансформаций. Для приверженцев второго направления идеология представляет собой особую систему ценностных суждений, оправдывающих господствующее положение в обществе того или иного класса. Наконец, авторы, работающие в русле третьего направления, относят к проявлениям идеологии едва ли не любые вербализованные феномены человеческой мысли (Lefort, 1991: 45-46).

Концептуально каждое из этих направлений имеет как сильные, так и слабые стороны. Придерживаясь первого подхода, мы получаем четкий и конкретный объект для анализа (проекты глобальных общественных трансформаций легко идентифицируются по трудам тех авторов, которые их разработали), но при этом из поля внимания, по меткому замечанию Э. Гидденса, выпадает целый пласт продуктов человеческой мысли, которые содержательно созвучны этим проектам и вдохновлены ими (Giddens, 1991b: 23). Во втором случае мы сталкиваемся с еще одной вариацией узкого подхода: в фокусе внимания тоже оказывается конкретный и эмпирически уловимый объект (проекты легитимации господства), но за рамками внимания остается целый ряд феноменов, которые также могут быть релевантными для исходного термина. Достоинства и уязвимости третьего подхода, в свою очередь, типичны для любых широких трактовок: мы уходим от рисков исключения из понятия идеологии каких-то релевантных феноменов, но одновременно, по справедливому замечанию того же Лефорта (Lefort, 1991: 46), возникает

1. В своих рассуждениях мы намеренно пользуемся именно термином «общество позднего модерна». Дискуссии о соотношении понятий модерна, позднего модерна, «другого модерна» (в терминологии У. Бека) и постмодерна крайне запутанны и сложны, а потому их адекватное рассмотрение явно заслуживает большего внимания, чем позволяет размер данной статьи. Поэтому в данном контексте ограничимся лишь использованием рабочего термина «общество позднего модерна», под которым мы вслед за Э. Гидденсом (Giddens, 1991а) будем понимать особую форму бытия общества модерна, возникающую под влиянием глобализации и ускорения социальных процессов. 
проблема принципиальной неопределенности границ термина, с позиций которого идеологией потенциально можно назвать вообще что угодно.

В задачи нашей статьи не входит ни детальная реконструкция исходной аргументации каждого из этих подходов к концептуализации идеологии, ни поиск окончательной истины в наметившемся теоретико-методологическом диспуте между их сторонниками. Наш интерес в данном случае обладает сугубо прагматическим характером и направлен лишь на поиск того базового понимания идеологии, которое поможет наиболее корректно и точно рассуждать о сути этого явления в дальнейшем тексте работы. Как раз в контексте такого исследовательского интереса упоминание приведенных выше расхождений в позициях разных ученых и имеет принципиальное значение. Даже подобного беглого знакомства с основными научными трактовками достаточно, чтобы убедиться в существовании как опасности понимать идеологию слишком в узком смысле и сводить ее только к программным манифестам конкретных мыслителей, так и риска использовать неоправданно расширительные трактовки, которые позволяют подвести под понятие идеологии практически любой феномен коллективного или индивидуального мышления людей. Учитывая существование таких опасностей, мы полагаем, что точная трактовка термина «идеология» должна одновременно исходить как из того, что это явление принципиально не сводимо только к конкретным (так называемым «авторским») проектам переустройства общества, так и из того, что оно принципиально не способно включать в себя вообще все феномены человеческого мышления.

Именно поэтому мы в своих рассуждениях будем отталкиваться от понимания, которое занимает своеобразную промежуточную позицию между перечисленными выше подходами, и обозначим в качестве рабочего толкования идеологии версию М. Селиджера. По его мнению, понятие «идеология» применимо ко всем системам убеждений, независимо от того, будут ли эти системы руководить действиями, направленными на изменение, сохранение или разрушение политической реальности. «В качестве того, что управляет и влияет на политическое действие, идеология должна определяться лишь в отношении к системам политических убеждений безотносительно к тому, будут ли они революционными, реформистскими или консервативными при взгляде со стороны» (Seliger, 1976: 91-92). Таким образом, идеологии - это ориентированные на действие совокупности убеждений, организованные в качестве систем. Привлекательность подхода Селиджера для нас заключается как в аналитическом удобстве, базирующемся на комбинации эвристичности и лаконичности, так и в его довольно широкой распространенности (которая важна в контексте сопоставления наших выводов с рассуждениями других ученых).

Важно, на наш взгляд, и то обстоятельство, что Селиджер предлагает не только простой, но и гибкий подход к пониманию идеологии. Во-первых, несмотря на то что в его формулировках отсутствует прямое отождествление идеологий с некими «авторскими» проектами переустройства общества, сохраняется возмож- 
ность применять его подход к анализу таких проектов, поскольку все они могут быть истолкованы как «ориентированные на действие совокупности убеждений, организованные в качестве систем». Во-вторых, хотя Селиджер и отказывается от принципиально узкого понимания идеологии, он все же и не относит к идеологиям вообще любые продукты человеческого мышления, поскольку задает четкие критерии их определения: системная организованность и ориентация на действия. Таким образом, подобная трактовка идеологии оказывается принципиально применимой к большинству феноменов, которые в социально-гуманитарной науке описываются как идеологии.

Итак, исходный вопрос о том, допустимо ли рассуждать о конкуренции различных идеологий в обществе позднего модерна, сводится к вопросу о том, сохраняются ли на современной стадии развития общества модерна ориентированные на действия совокупности убеждений, организованные в качестве систем. Если перейти на еще более конкретный уровень, то перед нами встаёт необходимость уточнения двух принципиальных позиций: во-первых, сохраняются ли вообще такие системы в обществе позднего модерна, а во-вторых - если они все же не исчезают, то сопоставимо ли их текущее состояние с прежним?

Один из возможных ответов довольно радикален и сводится к идее о заведомой бессмысленности описания политических процессов общества позднего модерна с помощью понятия «идеология». Нельзя сказать, что эта позиция получила широкое распространение в социально-гуманитарном научном сообществе, но сторонники у неё, безусловно, есть: в частности, соответствующие размышления мы находим в трудах Ф. Конверса (Converse, 2006) и Н. Аберкромби, С. Хилла и Б. Тернера (Abercrombie, Hill, Turner, 1980). Подобная позиция не беспочвенна и базируется на нескольких ясных аргументах. Во-первых, история человечества в XX веке сразу на нескольких ярких примерах показала: последствия от претензий на абсолютность со стороны какой-то одной идеологии вполне могут быть этически спорными или даже деструктивными для социума ${ }^{2}$. Во-вторых, в настоящий момент повышается количество и пестрота информационных потоков, запутывающих и усложняющих сам процесс политической коммуникации, в котором происходит формирование идеологий. В-третьих, сказывается снижение остроты классовой конкуренции: идеология традиционно рассматривалась философами и политологами как инструмент, с помощью которого одни классы претендуют на господство над другими. В-четвертых, уменьшение в политическом процессе роли традиционного субъекта трансляции идеологий - политических партий: едва ли не повсеместной тенденцией современного мира стали как снижающееся доверие

2. Разумеется, негативные эффекты в жизни общества вызывали не любые идеологии, а лишь доведение до крайности нескольких идеологических проектов - в первую очередь, естественно, нацизма, фашизма, коммунизма. Тем не менее сам факт того, что такие последствия потенциально возможны, как мы полагаем, мог привести к скептическому и осторожному отношению западных ученых к любым идеологиям. Антииндивидуализм и насилие, которые, по меткому замечанию X. Йoaca (Joas, 2008: 172), были вполне нормальными реалиями тех обществ, где воплощались подобные идеологии, являются достаточно сильными угрозами для современного индивида. 
людей к партиям, так и повышение доли граждан, полагающих, что партии - это лишь второстепенный (или и вовсе маргинальный) участник политического процесса.

Возможен и более осторожный ответ на вопрос о статусе идеологий в обществе позднего модерна, который сводится к тому, что этот феномен не исчезает в принципе, а всего лишь видоизменяется. Яркий пример концепций такого типа - подход Д. Шварцмантеля, который констатирует кризисное состояние идеологий в современном ему обществе (и даже использует термин «постидеологическое общество»), но полагает, что идеология как феномен из жизни социума не пропадает. В своих рассуждениях Шварцмантель предлагает разделять все идеологии на два типа: классические и новые. Классические, по его логике, масштабны по своим задачам, связаны с государством, предполагают действие в рамках крупных институтов, выражены в программах политических партий, базируются на экономически вычисляемом сегменте социальной структуры (классах). Тогда как идеологии нового типа «молекулярны», партикулярны, внесистемны, организованы по принципу сетей и локальны как по типу поддержки (идентичности), так и по провозглашаемым требованиям (Шварцмантель, 2о09). Позиция Шварцмантеля заключается в том, что мы являемся свидетелями не исчезновения идеологии как феномена, а всего лишь постепенного снижения влияния классических идеологий, сопровождающегося усилением идеологий нового типа. Таким образом, концепт идеологии вполне адекватен для описания политического процесса общества позднего модерна.

Учитывая имеющийся спор между сторонниками идеи об отмирании идеологии и теми, кто настаивает на их трансформации, обозначим свою позицию. С одной стороны, мы признаем логичность тех доводов, которые приводят сторонники версии об исчезновении идеологии как атрибута человеческого общества в стадии позднего модерна. С другой - в их аргументации не прослеживается убедительных доказательств того, что общество позднего модерна действительно столкнулось именно с отмиранием идеологии (по крайней мере, в том понимании Селиджера, которое мы взяли за основу рассуждений). Более точное истолкование приводимой ими аргументации, на наш взгляд, сводится скорее не к отмиранию идеологий, а к констатации исчезновения их насущной необходимости в том виде, в каком такая необходимость понималась на протяжении XIX-XX веков. Тем не менее само по себе это не является неопровержимым свидетельством исчезновения идеологий как феномена. Дискредитация фундаментальных идеологий в сознании многих людей действительно произошла, но это может означать лишь формирование осторожного отношения социума к идеологическим проектам. Острота классовой борьбы в обществе способна снижаться, но это может приводить не только к концу идеологических проектов, но и всего лишь к коррекции их содержания. Диверсификация информационных потоков стала вполне очевидным явлением, но и она сама по себе не означает краха идеологий, а может свидетельствовать лишь об изменении каналов их дистрибуции. Наконец, роль по- 
литических партий в мире способна падать, но это, опять же, может приводить не только к отмиранию идеологий, лишающихся своего традиционного выразителя, но и к появлению нового субъекта их трансляции. Однозначных оснований для утверждения, что идеологии именно исчезли, а не превратились в «свое иное», не прослеживается.

Именно поэтому мы полагаем, что позиция того же Шварцмантеля имеет несколько больший объяснительный потенциал для понимания вопроса об идеологиях в обществе позднего модерна, чем гипотеза об их отмирании. Строго говоря, сторонники такого подхода отталкиваются от тех же самых исходных позиций, просто сделанные ими выводы более осторожны. Соответственно, как мы полагаем, идеологии как организованные в системы совокупности ориентированных на действия убеждений в современном состоянии общества модерна все же не исчезают. По крайней мере, у нас нет убедительных доказательств этого исчезновения. Таким образом, мы утверждаем, что рассуждать о существовании идеологий в обществе позднего модерна принципиально возможно, а тезис об отмирании этого феномена преждевременен.

Вместе с тем сохраняется важный вопрос о характере тех трансформаций, которые, как мы полагаем, потенциально могут происходить с феноменом идеологий в обществе позднего модерна. Выше мы уже констатировали, что основные аргументы, из-за которых изначально возникли дискуссии ученых в отношении проблемы идеологии, сводились к четырем тенденциям: формированию негативного имиджа у многих фундаментальных идеологических проектов, виртуализации и децентрализации политических процессов, снижению напряженности классовой конкуренции на фоне иных социальных антагонизмов, а также к снижению роли политических партий в политическом процессе. На наш взгляд, логично предположить, что все вместе и каждая отдельно эти тенденции способны существенно видоизменять как содержание идеологий, так и характер той роли, которую они играют в обществе позднего модерна. Мы считаем, что совокупность перечисленных «факторов влияния» вполне могла привести к появлению у идеологий неких своеобразных черт, которые были несвойственны им прежде.

Первой из таких черт, как мы полагаем, могло стать дробление и диверсификация того коммуникативного пространства, в котором в обществе позднего модерна происходит оформление идеологических проектов. Непосредственными причинами этого являются и ослабление в политическом процессе роли партий, и общее усложнение коммуникативного пространства политики. Активное распространение интернета и социальных сетей привело к тому, что у каждого пользователя появилась гипотетическая возможность в любой момент времени актуализировать в виртуальном пространстве важные для него политические вопросы, найти сторонников едва ли не из любой точки планеты и даже организовать вместе с ними какие-то скоординированные действия. Разумеется, едва ли стоит вести речь о тотальном превращении интернета в площадку зарождения и развития идеологических проектов, над которыми работают все без исключения пользова- 
тели. Очевидно, что далеко не у каждого из них есть соответствующие желания и необходимые коммуникативные компетенции. Тем не менее обширный набор опций в социальных сетях дал возможность для выражения позиции тем людям, которые хотели бы донести свои взгляды до окружающих, но ранее были лишены доступа в публичное пространство. Учитывая снизившуюся роль партий в политическом процессе, подобные активисты могут оказаться именно теми субъектами, которые в нынешних условиях транслируют новые идеологические проекты.

Второй характерной чертой, которая могла появиться у идеологий под влиянием перечисленных выше факторов, на наш взгляд, является их концептуальная размытость или даже гибридность. Собственно говоря, Шварцмантель предрекал идеологиям в обществе позднего модерна именно взаимный синтез, аргументируя это слабостью и «легковесностью» новых идеологий, из-за которых, по его мнению, большинство из них в принципе не способны отдельно друг от друга претендовать на сколько-нибудь значимую и постоянную роль в политическом процессе (Шварцмантель, 2009: 283). Дополним аргументы Шварцмантеля тем фактом, что общество позднего модерна порождает целый спектр запросов к содержанию идеологий, который достаточно сложно свести к какому-то узкому перечню позиций. Особенности политического и экономического развития многих стран мира на протяжении XX века привели к плюрализму стилей жизни в этих государствах: появилось большое количество самых разных социальных групп, которые придерживаются своих систем ценностей и предъявляют свои, во многом уникальные, запросы к публично формируемой повестке развития. Удовлетворить запросы одновременно всех или хотя бы большинства таких социальных групп настолько сложно, что глобальные всеобъемлющие проекты развития общества могут в таких условиях оказаться не только невостребованными, но и принципиально невозможными.

Еще одной характерной чертой идеологий, которая появляется в обществе позднего модерна, может оказаться узкая, адресная локализация их риторики. Классическая эпоха анализа идеологий XIX-XX веков была связана с описанием их в качестве масштабных всеобъемлющих манифестов переустройства общества или легитимации господства одного класса над другим. На современном этапе такие всеобъемлющие манифесты относительно редки. Отчасти это связано с дискредитацией имиджа подобных идеологий, возникшей после попыток воплощения в жизнь националистических и коммунистических проектов, отчасти же здесь сказывается «регионализация» интересов, вокруг которых формируются общественные группы. Учитывая обилие разных социальных групп и разнообразие выражаемых ими интересов, становится довольно сложно формулировать какието целостные идеологические манифесты «для всех и на всей территории». Соответственно, общество позднего модерна с большей вероятностью способствует формированию идеологий, риторика которых сосредоточена вокруг решения преимущественно отдельных, локализованных в пространстве и времени вопросов, а не на претензиях на всеобъемлющее переустройство социума. 
Кратко обобщая основные результаты теоретико-методологического анализа, отметим основные итоговые положения. Во-первых, несмотря на запутанность и многогранность теоретических дискуссий в отношении феномена идеологий, их вполне допустимо определить в качестве ориентированных на действия систем убеждений. Во-вторых, реалии общества позднего модерна не привели к исчезновению таких систем, а скорее вызвали ряд трансформаций их содержания и роли в политическом процессе. В-третьих, этими трансформациями могли оказаться диверсификация пространства формирования идеологий, их концептуальная гибридность и локальность вопросов, которые становятся основой их ключевой риторики. Впрочем, сами по себе эти предположения - пока лишь логические допущения, вытекающие из определённой концептуальной схемы, а потому требующие полноценной эмпирической проверки. Ниже мы остановимся на результатах эмпирического исследования, которое было проведено нами с целью выполнения такой проверки.

\section{Методология исследования}

Исследование, которое легло в основу проверки высказанных выше гипотез, было проведено нами на базе Уральского федерального университета во второй половине 2017 года. Мы сфокусировались на вопросах о том, как происходит конкуренция между различными идеологическими проектами в контексте эмпирически конкретного политического процесса общества позднего модерна. Эмпирическим кейсом стали выборы в Государственную Думу РФ 18 сентября 2016 года и события, сопутствовавшие их проведению. Указанное поле было выбрано для анализа в силу предполагаемой высокой иллюстративности. Как отмечал в свое время российский социолог Л. Г. Бызов, стабильно высокая явка на выборы президента и депутатов Государственной Думы, как и общее эмоциональное отношение к ним граждан, свидетельствуют о том, что среднестатистический россиянин воспринимает их как заведомо судьбоносные для своего государства (Бызов, 2007: 16). Это создает благоприятную почву для повышения интереса к векторам развития страны и связанным с ними мировоззренческим дилеммам. В таком контексте характер проявлений идеологии можно проследить нагляднее: в социальной реальности актуализируются те процессы, которые в иное время могут обладать латентным статусом.

Инструментарий эмпирического исследования опирался на контент-анализ двух классов документов, по-разному отражавших состояние дискуссий о путях развития общества накануне выборов 2016 года.

- Предвыборные программы политических партий, подготовленные ими накануне выборов в Государственную Думу 18 сентября 2016 года. Стремясь к пониманию лишь наиболее устойчивых тенденций, мы концентрировали внимание на программах партий, которые участвовали в выборах не впервые и претендовали на места в Государственной Думе в 2011 году: «Справедли- 
вая Россия», КПРФ, ЛДПР, «Яблоко», «Единая Россия», «Патриоты России» и «Партия Роста» (стала преемником парии «Правое дело», которая участвовала в выборах в 2011 г.).

- Тексты, появившиеся в политических сообществах российских социальных сетей накануне выборов (с 4 по 18 сентября 2016 года). С помощью собственного инструментария социальных сетей Facebook, ВКонтакте, Живой журнал в каждой из них были отобраны по 1000 сообществ с наибольшим на момент полевых работ количеством подписчиков. Затем по названиям сообществ были отобраны наиболее тематически релевантные группы, в которых прямо или косвенно затрагиваются политические вопросы жизни российского общества. Из полученного списка были исключены такие сообщества, в которых не содержалось текстовых сообщений в изучаемый период, и те, в которых были отключены комментарии пользователей. В итоге в фокусе внимания оказалось 8 сообществ сети Facebook, 11 - сети ВКонтакте и 10 - сети Живой журнал. Полные тексты сообщений и комментариев, опубликованных в них в период, предшествовавший выборам, были подвергнуты анализу наравне с программами партий.

Процедура работы с обоими классами эмпирических объектов опиралась на технику контент-анализа и предполагала поиск в изучаемых текстах определенных слов-индикаторов, по наличию или отсутствию которых можно было судить о степени выраженности в них риторики, характерной для той или иной идеологии. Концептуальной базой этой работы послужила трехчленная классификация идеологий, которую предлагал в своих трудах И. Валлерстайн. Согласно его концепции, в истории человечества наиболее явно заявили о себе три всеобъемлющих идеологических течения: консерватизм, либерализм и социализм (Валлерстайн, 2003: 75). Отталкиваясь от этой трехчленной классификации и от идей, которые приписывал упомянутым идеологиям Валлерстайн, мы составили перечень характерных ценностей, которые могут отражать представления каждой из них о наиболее желательном развитии общества. Мы исходили из того, что для консерватизма могут быть характерны ценности «патриотизм», «нравственность», «стабильность», «семья», «порядок»; для либерализма - «свобода убеждений», «свобода действий», «демократия», «личность», «собственность», «рынок», «закон», «права человека», «мир», «изменения»; для социализма - «сильное государство», «социальные гарантии», «равенство», «солидарность», «труд», «здоровье», «борьба». При помощи толковых словарей и словарей синонимов русского языка мы подобрали по 10 конкретных слов-индикаторов, с помощью которых каждая из этих ценностей могла бы выражаться непосредственно в конкретной политической риторике. В результате мы подготовили кодификатор контент-анализа из 23 ценностей и 230 слов-индикаторов.

Таким образом, главной единицей подсчета в ходе контент-анализа оказались 230 слов-индикаторов, каждое из которых олицетворяло одну из ценностей, присущих консерватизму, либерализму или социализму. Подсчитав частоту упоми- 
нания слов-индикаторов, мы получили возможность судить об интенсивности акцента того или иного текста на ценностях, которые эти слова-индикаторы выражали. Понимание интенсивности акцента на тех или иных ценностях, в свою очередь, помогало делать выводы об общей выраженности в тексте идеологически окрашенной риторики, присущей консерватизму, либерализму или социализму. Далее мы намеревались осуществить сопоставление ценностно-идеологических феноменов, проявившихся в программах российских политических партий и текстовых сообщениях сообществ социальных сетей и выявить на основе этого роль и место различных идеологий в контексте выборов 2016 года.

\section{Результаты исследования: идеологическая полемика в постсоветской России}

Уже первичное знакомство с полученными данными показывает, что предполагавшаяся диверсификация пространства формирования идеологий, по всей видимости, действительно существует. По крайней мере, в том исследовательском кейсе, на основе которого мы делали свои выводы, она прослеживается довольно отчетливо. В первую очередь она проявляется в разном режиме конструирования и вербализации тех систем убеждений, которые являются основой идеологий. Совокупно слова-индикаторы наиболее частых по упоминанию ценностей встречаются в проанализированных текстах из социальных сетей по нескольку тысяч раз: «демократия» - 8935 раз, а «закон» - 7775 раз. В то же время в программах партий картина иная: слова-индикаторы самой популярной ценности («социальные гарантии») там упоминаются только 1280 раз. Это же видно и по сводным показателям: суммарно все слова-индикаторы всех изучаемых ценностей были упомянуты в текстах из социальных сетей 58359 раз, тогда как в программах партий они встречались только 12009 раз. Разумеется, на возникновение этого разрыва влияют и техническая возможность простого дублирования одного и того же текста в разных сообществах социальных сетей, и тип преподнесения информации: если программа политической партии пишется и распространяется единожды, то коммуникация в социальных сетях продолжается непрерывно. Тем не менее в данном случае принципиально само существование этого разрыва, вне зависимости от его причин. Само по себе оно демонстрирует расхождение как минимум в интенсивности обращения к идеологически окрашенной риторике при подготовке предвыборной программы партии и при коммуникации в социальных сетях.

Однако дифференциация между программами партий и текстами из социальных сетей обнаружилась не только в интенсивности интереса к идеологиям, но и в самой риторике, через которую выражается такой интерес (см. табл. 1). 
Таблица 1. Интенсивность упоминания слов-индикаторов различных ценностей в программах партий и текстах социальных сетей

\begin{tabular}{l|c|c}
\hline \multirow{2}{*}{ Ценности } & Доля от общего числа обнаруженных слов-индикаторов (\%) \\
\cline { 2 - 3 } & В программах партий & В текстах из социальных сетей \\
\hline Борьба & 2,7 & 5,1 \\
Демократия & 5,8 & 15,1 \\
Закон & 10,2 & 13,2 \\
Здоровье & 3,1 & 1,0 \\
Изменения & 7,0 & 4,1 \\
Личность & 8,9 & 8,1 \\
Мир & 1,3 & 0,7 \\
Нравственность & 5,9 & 3,6 \\
Патриотизм & 4,2 & 6,3 \\
Порядок & 3,4 & 2,4 \\
Права человека & 2,8 & 2,7 \\
Равенство & 5,1 & 4,7 \\
Рынок & 2,3 & 0,5 \\
Свобода действий & 1,2 & 4,7 \\
Свобода убеждений & 0,4 & 1,0 \\
Семья & 2,4 & 1,7 \\
Сильное государство & 8,8 & 6,2 \\
Собственность & 2,0 & 1,5 \\
Солидарность & 3,2 & 5,7 \\
Социальные гарантии & 10,7 & 7,1 \\
Стабильность & 3,0 & 2,1 \\
Труд & 100,0 & 100,0 \\
Итого & & \\
\hline
\end{tabular}

Как показал анализ, составители программ политических партий наиболее интенсивно употребляли в своих текстах слова-индикаторы, характерные ценностям «социальные гарантии», «закон», «личность», «сильное государство», «изменения», но при этом крайне мало обращались к словам-индикаторам ценностей «рынок», «мир», «свобода убеждений», «порядок», «собственность», «здоровье», «свобода действий». В то же время пользователи социальных сетей в своих рассуждениях чаще всего оперировали словами-индикаторами, которые присущи ценностям «демократия», «закон», «личность», «социальные гарантии», «патриотизм», но почти обходили стороной риторику, характерную ценностям «рынок», «мир», «здоровье», «свобода убеждений», «собственность» и «семья». Несмотря 
на определённые сходства в перечнях наиболее и наименее актуальных ценностей программ партий и текстов из социальных сетей, видно, что ключевая риторика в них всё же различна. Например, ценности «социальные гарантии» и «сильное государство», которые играют одну из ключевых ролей в рассуждениях составителей программ политических партий, не особенно интенсивно актуализируются в коммуникации пользователей социальных сетей. Тогда как ценность «демократия», наоборот, оказывается крайне значимой для пользователей социальных сетей, но в программах партий она отходит на второй план.

Расхождение в риторике имеет своим следствием и некоторые различия в идеологических картинах, которые ею задаются (см. рис. 1, 2).

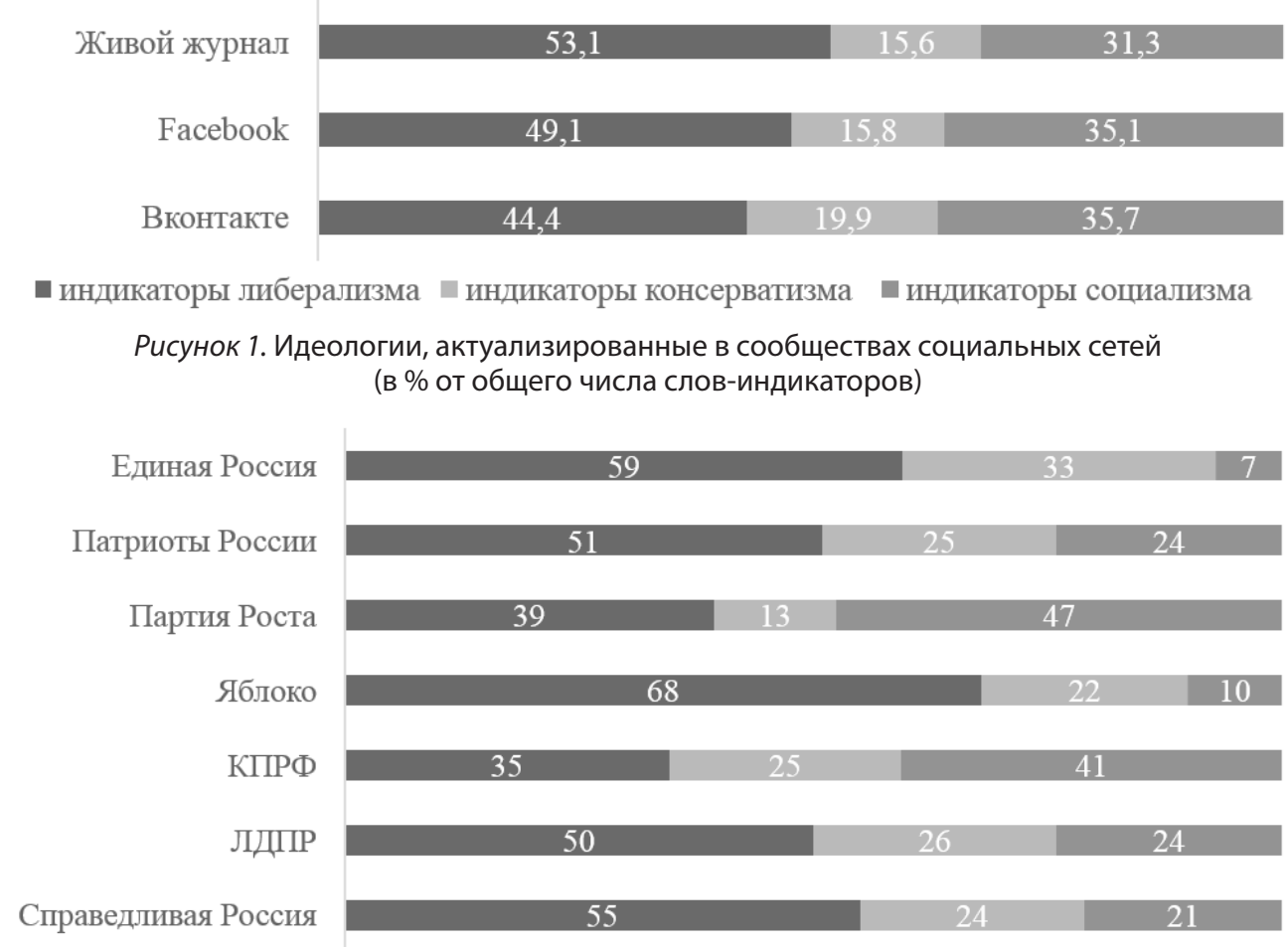

Рисунок 2. Идеологии, актуализированные в программах партий (в \% от общего числа слов-индикаторов)

Видно, что в целом в сообществах социальных сетей слова-маркеры, характерные для либеральной идеологии, получили несколько большее распространение, чем в программах политических партий, причем эта тенденция практически одинаково прослеживается во всех социальных сетях: и в Facebook, и в ВКонтакте, и в Живом журнале (см. рис. 1). Столь устойчивый уклон в сторону либеральной идеологии в программах партий проследить не удается (см. рис. 2). В программах некоторых («Яблоко», «Единая Россия», «Справедливая Россия») слова-маркеры 
ценностей либеральной идеологии также упоминаются чаще прочих. Но есть и такие партии, которые обращаются к либеральной риторике гораздо реже, - например, КПРФ, в предвыборной программе которой слова-индикаторы ценностей либерализма встречаются реже, чем апелляции к социализму. Иными словами, в идеологическом смысле тексты, которые были извлечены из сообществ социальных сетей, и предвыборные программы партий представляют собой относительно разные продукты. Ценностно-идеологическое пространство, обозначенное текстами, извлеченными из разных социальных сетей, в основном гомогенно: во всех случаях слова-маркеры ценностей либерализма используются чаще прочих. Тогда как ценностно-идеологическое пространство, обозначенное программами партий, дифференцировано: есть партии, которые тяготеют к либеральным ценностям, но одновременно есть и партии, которые больше предрасположены к другим идеологиям. Подчеркнем: в любом случае и программы партий, и тексты из социальных сетей не придерживаются какой-то одной идеологии и скорее апеллируют к идеологическим гибридам. Но сущность и природа этих гибридов различны.

Предполагавшаяся идеологическая гибридность также оказалась характерной чертой тех текстов, которые подверглись анализу в ходе исследования. Все изученные тексты построены на сочетании различных элементов консерватизма, либерализма и социализма. В каждом конкретном случае такое сочетание могло оказываться особым. Зачастую выяснялось, что риторика какой-то одной идеологии востребована в конкретном тексте сильнее остальных, но в то же время ситуаций, когда одна идеология полностью вытесняет другие, обнаружить не удалось. Пожалуй, наиболее ярко такая гибридность проявилась в двух конкретных тенденциях. Прежде всего заметна девальвация символического капитала титульного наименования политических партий: так, в программе формально социалистической по своему названию партии КПРФ собственно социалистическая риторика преобладает, но отнюдь не доминирует над либеральной и консервативной и сочетается с ними примерно в равных пропорциях. А в программе партии «Справедливая Россия», также своим названием увязывающей себя с классической для социализма темой социальной справедливости, наибольшую актуализацию получает либеральная риторика. Гибридность заметна еще и в том, что проанализированные тексты из социальных сетей тяготеют в сторону либеральной риторики, но не сводятся к ней целиком. Выраженность либеральной риторики в текстах социальных сетей сопоставима с суммарным числом упоминаний слов-индикаторов, характерных ценностям консерватизма и социализма.

Впрочем, подобная гибридность в рамках политического процесса постсоветской России скорее закономерна, нежели случайна. Дело, на наш взгляд, заключается в нескольких моментах. С одной стороны, существует path dependence интеллектуалов - исторически воспроизводимая схема реакции на кризисные события и идеологический вакуум в стране, предполагающая призывы к построению неких общих, единых идеологических проектов. Кризисные события первой четверти XX века привели к возникновению, в частности, евразийства или попы- 
ток соединить национализм и большевизм. Интеллектуалы постперестроечной России призывали к выработке «интегративной идеологии» (Косолапов, 1994) или редуцированию имеющихся различий региональных идеологических проектов к уровню «тотальной» идеологии (Барботько, Войтов, Мирский, 20оо). Специфика этой схемы реакции предполагает, что системная неопределенность, возникающая в обществе, создает заведомо благодатную почву для призывов объединить под одним «флагом» достаточно разнородные ценности и идеологемы. Возможно - и это могло бы быть предметом дополнительных исследований - «соединение» разного и есть основной наш «идеологический паттерн». Но, в отличие от попыток соединять масштабные идеологии для проектирования будущего сегодняшние идеологические гибриды полностью подчинены оперативной задаче (в терминологии Селиджера) - получить голоса, а потому набор ценностей выстраивается в современных идеологических проектах «по настроению избирателя» и скорее «отражает» настоящее. Используя классическое разделение уровней коллективных представлений, мы могли бы указать и вторую причину «гибридности» идеологий: готовность к ней на уровне сложившихся массовых настроений. На протяжении практически всей постсоветской истории опросы, проводимые социологами, показывают, что большинству российских граждан характерна идеологическая амбивалентность: исследования Г. Г. Дилигенского (Дилигенский, 20оо: 12) в 1990-е годы, а также замеры, сделанные ВЦИОМ уже в 20оо-е годы (Бызов, 2013: 38), демонстрируют, что примерно 75-80\% постсоветских россиян вообще не имеют сколько-нибудь четких идеологических предпочтений. Добавим, что в 2015 году исследование Института социологии РАН подтвердило устойчивость заведомо аполитических настроений: оно показало, что более или менее регулярный интерес к политике характерен лишь для 30\% населения страны (Петухов, 2015: 151). Иначе говоря, вне зависимости от причин появления упомянутой идеологической амбивалентности, сама по себе она прослеживается отчетливо и подтверждается надежными данными. Соответственно, предсказуемо, что в политическом процессе современной России не происходит последовательной апелляции к риторике какой-то одной идеологии: большинству россиян попросту чужды такие рассуждения.

Отчетливо видна и третья предполагавшаяся нами тенденция, а именно локальность вопросов, вокруг которых выстраивается идеологически окрашенная риторика. Для адекватной оценки этого параметра необходимо сопоставить сравнительную выраженность отдельных ценностей каждой из представленных идеологий в программах партий и текстах, которые создавали пользователи социальных сетей (см. табл. 2). Такой анализ показывает своеобразное дробление ценностного ядра каждой из рассматриваемых идеологий на востребованные и невостребованные позиции. Например, среди ценностей либеральной идеологии оказываются крайне невостребованными «рынок», «собственность», «свобода убеждений», но при этом одними из наиболее упоминаемых становятся «демократия», «закон», «личность». Среди консервативных ценностей наименее вос- 
требованы «стабильность» и «семья», но в то же время заметен больший интерес к другим ценностям - «нравственности» и «патриотизму». Из социалистических ценностей наименее востребованными оказываются «труд» и «здоровье», тогда как слова-индикаторы ценности «социальные гарантии», наоборот, становятся одними из самых упоминаемых. Иными словами, заметно отсутствие последовательности в актуализации либеральных, социалистических и консервативных риторик в контексте современной России: какие-то из характерных им ценностей актуализируются, другие - оказываются фактически в забвении.

Таблица 2. Интенсивность актуализации ценностей, присущих различным идеологиям, в программах партий и текстах социальных сетей

\begin{tabular}{|c|c|c|}
\hline \multirow{2}{*}{ Ценности } & \multicolumn{2}{|c|}{ Доля от общего числа обнаруженных слов-индикаторов (\%) } \\
\hline & В программах партий & В текстах из социальных сетей \\
\hline \multicolumn{3}{|c|}{ Ценности консерватизма } \\
\hline Нравственность & 5,9 & 3,6 \\
\hline Патриотизм & 4,2 & 6,3 \\
\hline Порядок & 3,4 & 2,4 \\
\hline Семья & 2,4 & 1,7 \\
\hline Стабильность & 3,0 & 2,1 \\
\hline \multicolumn{3}{|c|}{ Ценности либерализма } \\
\hline Демократия & 5,8 & 15,1 \\
\hline Закон & 10,2 & 13,2 \\
\hline Изменения & 7,0 & 4,1 \\
\hline Личность & 8,9 & 8,1 \\
\hline Мир & 1,3 & 0,7 \\
\hline Права человека & 2,8 & 2,7 \\
\hline Рынок & 2,3 & 0,5 \\
\hline Свобода действий & 1,2 & 4,7 \\
\hline Свобода убеждений & 0,4 & 1,0 \\
\hline Собственность & 2,0 & 1,5 \\
\hline \multicolumn{3}{|c|}{ Ценности социализма } \\
\hline Борьба & 2,7 & 5,1 \\
\hline Здоровье & 3,1 & 1,0 \\
\hline Равенство & 5,1 & 4,7 \\
\hline Сильное государство & 8,8 & 6,2 \\
\hline Солидарность & 3,2 & 5,7 \\
\hline Социальные гарантии & 10,7 & 7,1 \\
\hline Труд & 5,4 & 2,6 \\
\hline Итого & 100,0 & 100,0 \\
\hline
\end{tabular}


Столь избирательная актуализация либеральных ценностей и в социальных сетях, и в программах партий по-своему закономерна. С одной стороны, номинально постсоветская Россия была и продолжает быть демократическим государством, которое во всех документах и официальных заявлениях своих руководителей позиционируется в качестве страны, построенной на либеральных политических и экономических подходах и открытой для тесной кооперации с теми иностранными партнерами, которые придерживаются схожих взглядов. С другой стороны, резкие и слишком быстрые либеральные реформы, с помощью которых страна в 1990-е годы переходила к внедрению рыночной экономики и демократического политического устройства, привели к дискредитации в глазах многих россиян целого ряда идей, составляющих фундаментальную основу либеральной идеологии. Исследования Института социологии РАН показывают, например, что идея свободного неограниченного рынка большинству россиян чужда до сих пор (Бызов, 2017: 239). Закономерно, что в этой ситуации происходит своеобразная ревизия либеральной идеологии: учитывая сам характер политического режима, партии и лидеры общественного мнения не могут отказаться от либеральных идей совсем, но при этом они уходят от обсуждения тех вопросов, которые болезненны для населения.

Аналогично можно объяснить и дисбаланс в актуализации ценностей, характерных консервативной идеологии. Уязвленное чувство национальной гордости, возникшее в российском массовом сознании после распада СССР, явно обострило в стране запрос на радикальную патриотическую риторику. Более того, можно согласиться с С. В. Чугровым: со временем в российском обществе сложился относительный консенсус, построенный на патриотизме и антизападных настроениях (Чугров, 2016: 188). Не менее болезненным для российского социума является и вопрос о нравственности: возможно, в силу совпавших по времени процессов деградации многих характерных для советской системы нравственных нормативов и возвращения в жизнь общества религиозных и псевдорелигиозных учений, которые официальной советской моралью осуждались. Актуальные исследования подтверждают, что вопрос морали остается для россиян болезненным (Кузнецов, 2017). Одновременно с этим внимание к проблематике порядка, присущее российскому общественному мнению на рубеже 1990-20о0-х годов, уже к 2010 году стало ощутимо слабее (Дубин, 2007). Сложившийся баланс настроений создал почву для ревизии консервативной идеологии: вопросы, вызывающие интерес у россиян, акцентировались отчетливо, тогда как тематики, не имеющие принципиального значения, отошли на второй план. Именно поэтому актуализация ценности патриотизма сопровождается относительно редкими апелляциями к тематике порядка.

Наконец, похожим образом объясняется и непоследовательное обращение как партий, так и пользователей социальных сетей к риторике, характерной для социалистической идеологии. В 1990-е годы на волне демократических реформ российское общество решительно отвергло едва ли не все атрибуты советской действительности, отказавшись и от характерной идеологии, и от устоявшихся жизненных 
практик. Тем не менее во многом в силу неоднозначных рыночных реформ 1990-х годов, многие жители постсоветской России начали проявлять ностальгические чувства по отношению к той самой советской действительности, которую прежде так принципиально осуждали. Актуальные исследования показывают выраженную ностальгию российского общества по советским временам. Более половины россиян видят в советском периоде положительные моменты и сожалеют о распаде СССР (Бызов, 2017: 258). Эта ностальгия создала благодатную почву для ревизии социалистической идеологии, некоторые ценности которой получают поддержку, тогда как другие продолжают отвергаться.

Обобщая эти разрозненные эмпирические данные, мы можем отметить, что по итогам исследования состояние идеологического диспута в постсоветском российском социуме предстает довольно своеобразным. Можно констатировать, что это именно дискуссия между идеологиями: и потому, что в риторике различных участников политического процесса отчетливо видны ориентированные на действия системы убеждений, и потому, что это довольно разные системы убеждений, которые расходятся в понимании многих вопросов. Тем не менее состояние этой дискуссии обладает рядом примечательных черт. Во-первых, в силу стремительной интернетизации российского общества произошла диверсификация того коммуникативного пространства, в котором проявляется конкуренция видений развития общества: выразителем мнения по таким вопросам стали не только политические партии, но и пользователи сети Интернет, которые ставят соответствующие вопросы с иной интенсивностью и тональностью. Во-вторых, риторика, акцентирующая соответствующие вопросы, балансирует между социалистическими, либеральными и консервативными ценностями. В-третьих, ценности, служившие базой социализма, либерализма и консерватизма, подвергаются ревизии и узкой локализации: какие-то частные ценностные индикаторы оказываются высоко востребованы в нынешнем российском социуме, а какие-то приобретают фактически маргинальный статус. Таким образом, те предположения о характере проявления идеологий в обществе позднего модерна, которые мы высказали выше, в целом подтверждаются.

\section{Выводы}

Исходным импульсом написания настоящей статьи послужило стремление продвинуться в разрешении принципиального противоречия между отчетливым интересом социально-гуманитарной науки к обострившейся в современном мире конкуренции различных видений общественного развития и отсутствием у ученых уверенности в том, что эту ситуацию можно изучать с помощью концепта «идеология». Знакомясь с различными точками зрения по релевантным вопросам, мы пришли к выводу, что общество позднего модерна создало достаточно своеобразные условия для формирования и функционирования ориентированных на действия систем убеждений, которые мы (вслед за Шварцмантелем) 
и рассматриваем как идеологии. Во-первых, общество позднего модерна приводит к умножению количества информационных потоков и диверсификации того коммуникативного пространства, в котором и возможно формирование идеологий. Во-вторых, в политическом процессе общества позднего модерна оказалась снижена роль традиционного создателя и ретранслятора идеологий - политических партий. В-третьих, специфика экономического и политического процесса общества позднего модерна привела к редукции классовой конкуренции, традиционно рассматривавшейся учеными в качестве базовой для развития идеологий. B-четвертых, сама идея всеобъемлющих, масштабных проектов переустройства общества сильно дискредитировала себя в XX веке и потому жизнеспособность подобных масштабных систем убеждений в обществе позднего модерна оказалась под сомнением.

Признавая определенную убедительность и справедливость перечисленных аргументов, мы тем не менее в своих рассуждениях пришли к выводу, что ни один из них не доказывает однозначно факт исчезновения идеологий из жизни общества позднего модерна, а лишь свидетельствует о том, что режим функционирования идеологических систем меняется. Своеобразная мимикрия идеологии в обществе позднего модерна может проявиться в трех взаимосвязанных тенденциях. Вопервых, в диверсификации пространства формирования идеологий. Во-вторых, в их концептуальной гибридности. В-третьих, в локальности вопросов, которые ложатся в основу их базовой риторики. Соотнеся эти предположения с эмпирически локальным контекстом российского общества накануне и во время выборов в Государственную Думу 18 сентября 2016 года, мы убедились в том, что такие трансформации феномена идеологии действительно имеют место. По крайней мере, в современном российском обществе. Мы убедились, что в силу интернетизации общества в России произошла отчетливая диверсификация того коммуникативного пространства, в котором происходит конкуренция видений развития общества: все более активную роль в этом пространстве начинают играть рядовые граждане, выражающие свое мнение в Интернете. Кроме того, риторика соответствующих дискуссий в России накануне выборов 2016 года оказалась принципиально гибридной и строилась на хрупком балансе идей социализма, консерватизма, либерализма. Наконец, ценности, служившие базой социализма, либерализма и консерватизма в российском социуме подверглись ревизии: значимые в текущем времени вопросы получили большое внимание, тогда как другие, не имеющие сиюминутной значимости, оказались отброшены.

Главный вывод, который был получен нами по итогам проделанной работы, заключается в том, что говорить об отмирании феномена идеологий в обществе позднего модерна нецелесообразно. Проведенный нами анализ показывает, что убедительных аргументов в пользу тезиса о конце идеологий нет. Если исходить из того, что идеология - это ориентированная на действия система убеждений, то констатировать исчезновение таких систем из политического процесса общества позднего модерна преждевременно: преобладающая риторика актуальных 
политических дискуссий говорит о том, что такие системы продолжают функционировать. На наш взгляд, очевидна трансформация того статуса и смыслового наполнения, которые в силу объективных факторов присущи подобным системам в обществе позднего модерна. Соответственно, конкуренция «оптик» дальнейшего развития общества, которая наметилась в современных общественно-политических реалиях и уже привлекла внимание исследователей, вполне может быть описана в качестве идеологической конкуренции. Тем не менее категориальный и методологический аппарат, применяемый социально-гуманитарной наукой в области анализа идеологий, нуждается в ревизии и дополнительных «настройках», которые повысят его эвристические возможности и точность в описании идеологической полемики в специфических условиях общества позднего модерна.

\section{Литература}

Барботько Л. М., Войтов В. А., Мирский Э. М. (200о). Тотальная идеология против тоталитарного государства // Вопросы философии. № 11. С. 12-27.

Быззо Л. Г. (2007). Избирательный цикл 2007-2008 гг.: мотивация участия в выбоpax // Мониторинг общественного мнения. № 1. С. 16-26.

Бъззов Л. Г. (2013). Идейные и ценностные аспекты политической борьбы в избирательном цикле 2011-2012 гг. // Федоров В. В. (ред.). От плебисцита - к выборам: как и почему россияне голосовали на выборах 2011-2012 гг. М.: Праксис. С. $18-99$.

Бъззов Л. Г. (2017). Динамика политических ценностей россиян // Горшков М. К., Петухов В. В. (ред.). Российское общество и вызовы времени. Книга пятая. М.: Весь мир. С. 235-252.

Валлерстайн И. (2003). После либерализма / Пер. с англ. М. М. Гурвица, П. М. Кудюкина, П. В. Феденко под ред. Б. Ю. Кагарлицкого. М.: УРСС.

Дилигенский Г. Г. (200о). «Запад» в российском общественном сознании // Общественные науки и современность. № 5. С. 5-19.

Дубин Б. В. (2007). Первый: Борис Ельцин в общественном мнении России // Вестник общественного мнения. № 4. С. 28-38.

Косолапов И. А. (1994) Интегративная идеология для России: интеллектуальный и политический вызов // Вопросы философии. № 1. С. 3-25.

Кузнецов И. М. (2017). Ценностные ориентиры и социально-политические установки россиян // Социологические исследования. № 1. С. 47-55.

Мусихин Г. И. (2013). Очерки теории идеологий. М.: ВШЭ.

Петухов В. В. (2005). Общественная мораль и государство // Мониторинг общественного мнения. № 7. С. 7-16.

Петухов В. В. (2015). Политическое и социальное участие: новые практики // Горшков М. К., Петухов В. В. (ред.) Российское общество и вызовы времени. Книга вторая. М.: Весь мир. С. 150-164. 
Пляйс Я. А. (2010). Есть ли будущее у политических идеологий? // Обозреватель. № 9. С. 66-82.

Чугров С. В. (2016). Российская политика сквозь призму социологических замеров // Полис. Политические исследования. № 5. С. 183-191.

Шваримантель Д. (2009). Идеология и политика / Пер. с англ. Е. В. Пызиной под ред. Т. И. Арсеньевой. Харьков: Гуманитарный Центр.

Abercrombie N., Hill S., Turner B. S. (1980). The Dominant Ideology Thesis. L.: Allen \& Unwin.

Converse P. (2006). The Nature of Belief Systems in Mass Publics (1964) // Critical Review. Vol. 18. № 1/3. P. 1-74.

Giddens A. (1991a). Modernity and Self-identity: Self and Society in the Late Modern Age. Cambridge: Polity.

Giddens A. (1991b). Four Theses on Ideology // Kroker A., Kroker M. (eds.). Ideology and Power in the Age of Lenin in Ruins. N.Y.: St. Martin's Press. P. 21-24.

Joas H. (2008). Punishment and Respect // Journal of Classical Sociology. Vol. 8. № 2. P. $159-177$.

Lefort C. (1991). On the Genesis of Ideology in Modem Societies // Kroker A., Kroker M. (eds.). Ideology and Power in the Age of Lenin in Ruins. N.Y.: St. Martin's Press. P. $46-86$.

Seliger M. (1976). Ideology and Politics. L.: Allen \& Unwin.

\section{Ideology in Late Modern Society: Disappearance or Transformation?}

\section{Dmitry V. Rudenkin}

Candidate of Sociological Sciences, Associate Professor, Department of Integrated Marketing Communications and Branding, Ural Federal University

Address: Mira str., 19, Ekaterinburg, Russian Federation 620002

E-mail: d.v.rudenkin@urfu.ru

\section{Aleksei V. Loginov \\ Candidate of Philosophical Sciences, Associate Professor, Department of Social Philosophy, Ural Federal University \\ Address: Mira str., 19, Ekaterinburg, Russian Federation 620002 \\ E-mail: alexeyloginov@urfu.ru}

The article is devoted to the analysis of the specific role of ideology in the political reality of late modern society. The authors describe a notable contradiction between a steady interest of social science to the competition of ideas of the development of society and the growing doubts of the applicability of classical theories of ideology for describing and comprehending such a competition. The theoretical analysis of contemporary social theory shows that ideology can be described as an action-oriented system of beliefs, and that there are different views on the status 
of such systems in the political reality of late modern society. During the theoretical analysis, the authors conclude that the idea of the disappearance of ideology from the political process of late modern society has an important conceptual argumentation, but it does not find any cogent empirical evidence. It is more likely that ideology does not disappear from the political reality of late modern society, but it changes to meet new social requirements. Late modern society creates special conditions for the manifestation of ideology by diversifying the information field, reducing the role of political parties, discrediting many fundamental ideological projects, and reducing the class struggle. Altogether, these conditions make ideology change, but they do not make it disappear from the political reality. This hypothesis is correlated with the data of the sociological research conducted by the authors on the case of ideological competition in Russian society before the parliamentary elections in 2016. The analysis of the data of this research shows that ideology still exists in contemporary Russian society, and allows its description as a hybrid in the value kernel and local in its rhetoric system of beliefs. Thus, the authors conclude that it is possible to describe the political processes of late modern society with using the term "ideology". The term "ideology" which does not lose its heuristic possibilities, but requires a "reconfiguration" of the methodology of social science.

Keywords: ideology, post-Soviet Russia, modernity, late modernity, socialism, conservatism, liberalism, values

\section{References}

Abercrombie N., Hill S., Turner B. S. (1980) The Dominant Ideology Thesis, London: Allen \& Unwin. Barbotko L., Voitov V., Mirsky E. (2000) Total'naya ideologiya protiv totalitarnogo gosudarstva [A Total Ideology against a Totalitarian State]. Russian Studies in Philosophy, no 11, pp. 12-27.

Byzov L. (2007) Izbiratel'nyj cikl 2007-2008 gg.: motivacija uchastija v vyborah [Election Cycle 20072008: Motivation for Participation in Elections]. The Monitoring of Public Opinion, no 1, pp. 16-26.

Byzov L. (2013) Idejnye i cennostnye aspekty politicheskoj bor'by v izbiratel'nom cikle 2011-2012 gg. [Ideological and Value Aspects of Political Struggle in the Electoral Cycle 2011-2012.]. Ot plebiscita - $k$ vyboram: kak i pochemu rossijane golosovali na vyborah 2011-2012 gg. [From the Plebiscite to the Elections: How and Why did the Russians Vote in the 2011-2012 Elections] (ed. V. Fyodorov), Moscow: Praksis, pp. 18-99.

Byzov L. (2017) Dinamika politicheskih cennostej rossijan [Dynamics of Political Values of Russians]. Rossijskoe obshhestvo i vyzovy vremeni. Kniga pjataja [Russian Society and the Challenges of Time, Book Five] (eds. M. Gorshkov, V. Petukhov), Moscow: Ves mir, pp. 235-252.

Chugrov S. (2016) Rossijskaja politika skvoz' prizmu sociologicheskih zamerov [Russian Politics through the Prism of Sociological Analysis]. Polis: Political Studies, no 5, pp. 183-191.

Converse P. (2006) The Nature of Belief Systems in Mass Publics (1964). Critical Review, vol. 18, no 1-3, pp. 1-74.

Diligensky G. (2000) "Zapad" v rossijskom obshhestvennom soznanii [The "West" in Russian Public Mind]. Social Sciences and Contemporary World, no 5, pp. 5-19.

Dubin B. (2007) Pervyj: Boris El'cin v obshhestvennom mnenii Rossii [The First One: Boris Yeltsin in the Public Opinion of Russia]. Russian Public Opinion Herald, no 4, pp. 28-38.

Giddens A. (1991) Modernity and Self-identity: Self and Society in the Late Modern Age, Cambridge: Polity.

Giddens A. (1991) Four Theses on Ideology. Ideology and Power in the Age of Lenin in Ruins (eds. A. Kroker, M. Kroker), New York: St. Martin's Press, pp. 21-24.

Joas H. (2008) Punishment and Respect. Journal of Classical Sociology, vol. 8, no 2, pp. 159-177.

Kosolapov I. (1994) Integrativnaya ideologiya dlya Rossii: intellektual'nyy i politicheskiy vyzov [Integrative Ideology for Russia: Intellectual and Political Challenge]. Russian Studies in Philosophy, no 1, pp. 3-25.

Kuznetsov I. (2017) Cennostnye orientiry i social'no-politicheskie ustanovki rossijan [Values and socio-political attitudes of Russians]. Sociological Studies, no 1, pp. 47-55.

Lefort C. (1991) On the Genesis of Ideology in Modem Societies. Ideology and Power in the Age of Lenin in Ruins (eds. A. Kroker, M. Kroker), New York: St. Martin's Press, pp. 46-86. 
Musikhin G. (2013) Ocherki teorii ideologij [Essays on the Theory of Ideologies], Moscow: HSE.

Petukhov V. (2005) Obshhestvennaja moral'i gosudarstvo [Public Morals and the State]. Monitoring of Public Opinion, no 7, pp. 7-16.

Petukhov V. (2015) Politicheskoe i social'noe uchastie: novye praktiki [Political and Social Participation: New Practices]. Rossijskoe obshhestvo i vyzovy vremeni. Kniga vtoraja [Russian Society and the Challenges of Time, Book Two] (eds. M. Gorshkov, V. Petukhov), Moscow: Ves mir, pp. 150-164.

Plyays Y. (2010) Est'li budushhee u politicheskih ideologij? [Is There a Future for Political Ideologies?]. Observer, no 9, pp. 66-82.

Schwarzmantel J. (2009) Ideologija i politika [Ideology and Politics], Kharkov: Humanities Center. Seliger M. (1976) Ideology and Politics, London: Allen \& Unwin.

Wallerstein I. (2003) Posle liberalizma [After Liberalism], Moscow: URSS. 


\title{
Репрезентативная культура современного российского студенчества
}

\author{
Виктор Филоненко \\ Доктор социологических наук, профессор Института философии и социально-политических наук, \\ директор Центра социально-политических исследований Южного федерального университета \\ Адрес: пер. Днепровский, д. 116, г. Ростов-на-Дону, Российская Федерация 344065 \\ E-mail: vfilonenko@sfedu.ru
}

\section{Людмила Штомпель}

Доктор философских наук, профессор кафедры теории культуры, этики и эстетики Института философии и социально-политических наук Южного федерального университета Адрес: пер. Днепровский, д. 116, г. Ростов-на-Дону, Российская Федерация 344065

E-mail: lashtompel@sfedu.ru

\section{Олег Штомпель}

Доктор философских наук, профессор кафедры теории культуры, этики и эстетики Института философии и социально-политических наук Южного федерального университета Адрес: пер. Днепровский, д. 116, г. Ростов-на-Дону, Российская Федерация 344065 E-mail: omshtompel@sfedu.ru

В статье ставится задача, во-первых, определить адекватную современным реалиям методологию социологического анализа культуры и, во-вторых, зафиксировать на данной методологической основе специфику культуры современного российского студенчества в транзитивном, переходном социуме. Утверждается, что становление инновационного общества в глобальном масштабе приводит к перманентному разрушению старых и одновременно возникновению новых социокультурных форм, в результате чего культура становитя прежде всего не «охранительницей устоев», а активной «бродильной» силой социума. В данных нелинейных процессах особую значимость приобретает субъективная культура. Проводится анализ моностилизма и полистилизма студенческой репрезентативной культуры, основанный на идеях Ф. Тенбрука. Зафиксировано, что данные процессы репрезентации носят противоречивый и гибридный характер. Ценности постматериалистического плана (самостоятельность, индивидуальность, свобода), высоко ценимые студенческой молодёжью, репрезентируются прежде всего в сфере досуга и свободного времяпрепровождения. Представленная типология жизненных стилей студентов в области учебной деятельности («профессионалы», «ритуалисты», «общественники» и «конформисты») фиксирует преимущественно приспособленческую стратегию поведения, основанную на принятии патерналистского отношения со стороны администрации и профессорскопреподавательского состава вузов. Статья основана на материалах авторского межрегионального социологического исследования, проводившегося в 2006-2011-2016 годах в Южном федеральном округе.

Ключевые слова: студенчество, репрезентативная культура, моностилизм и полистилизм, типология стилей жизни

\footnotetext{
(c) Филоненко В. И., 2018

(C) Штомпель Л. А., 2018

(C) Штомпель О. М., 2018

(c) Центр фундаментальной социологии, 2018
}

DOI: $10.17323 / 1728-192 \mathrm{X}-2018-3-221-239$ 
Для любого социума, находящегося в состоянии транзита, проблема молодёжи, её социокультурного статуса приобретает особое значение. Ибо характер и направленность социализации и развитие молодого поколения во многом обрисовывают пути становления нового общества. В первую очередь это касается учащихся вузов, из рядов которых рекрутируется управленческая, интеллектуальная, политическая элита страны. Однако в транзитивном социуме перед российскими студентами возникает целый ряд проблем, фиксируемых социологами (Горшков, 2016; Тишков, Бараш, Степанов, 2017; Смолин, 2015). В современной социологической и психологической литературе с различных методологических позиций исследуются процессы перехода молодых людей к взрослому состоянию. Социализация молодого поколения в современной России осуществляется в рамках целого ряда моделей взаимодействия власти, государства и молодежи - патриархальной, социалистической, смешанной, либерально-консервативной, плюралистической. При этом более чем в половине субъектов РФ преобладает патриархальная модель молодёжной политики, что ведёт к возникновению соответствующей системы ценностей в сознании молодых людей (Капустина, 2014). Данная ситуация отражает переходный характер развития нашего общества, когда элементы патернализма и контроля сочетаются с достаточно широкими возможностями личностного выбора. Студенчество рассматривается нами как социально-демографическая группа, чья возрастная транзиция содержит процессы социокультурного воспроизводства, инновизации и трансляции (Чупров, 1994).

В связи с увеличением продолжительности социальной транзиции, изменениями механизма передачи социального опыта, переходным состоянием общества и самого молодого человека риск становится характеристикой не только социума, но и самого индивида. Разнонаправленность развития молодёжи связана с действием рискогенных факторов, социокультурными особенностями молодёжи, трансформацией общества, происходящей на наших глазах (Зубок, Чупров, 2017).

Тем самым нелинейный характер инновационного общественного развития неизбежно приводит к мысли о необходимости использования методологических установок неклассического типа, где социальные структуры и культурная динамика субъектов индивидуального действия рассматриваются с позиций принципа дополнительности, или, точнее, комплементарности. Поэтому основная задача данной статьи - зафиксировать основные репрезентативные моменты современной студенческой культуры на основе определения специфики аналитического подхода к изучению взаимодействия социального и культурного ${ }^{1}$.

\footnotetext{
1. Эмпирической основой настоящей статьи послужили результаты мониторингового межрегионального социологического исследования «Противоречия и парадоксы социализации студенческой молодежи в условиях транзитивности современного российского общества», проведенного Центром социально-политических исследований Института философии и социально-политических наук Южного федерального университета (научный руководитель - д.соц.н. В. И. Филоненко) в 2006-20112016 годах. Всего в 2016 году было опрошено 4387 студентов очной формы обучения и 1122 экспертапреподавателя из 23 вузов/филиалов пяти регионов ЮФО и 4 федеральных университетов. Метод исследования - анкетирование.
} 
Социум втягивается в особую фазу развития, одной из характеристик которой становится всеобщая инновизация, отсюда и возникновение в теоретическом дискурсе нового термина - «инновационное общество». Современная индустриальная система, основывающаяся на инновациях, является новым выражением локальной и глобальной динамики. Само экономическое развитие порождает движение общества от традиционных ценностей к ценностям индивидуализации и самовыражения, что дает мощный толчок к инновизации сознания и культуры (Инглхарт, Вельцель, 2011).

В культуре инновационного социума перестают действовать социокультурные системы, жестко детерминирующие жизнедеятельность индивида. Общество «виртуализируется», институциональные связи «размываются» (Иванов, 2о02). Человек в этих условиях перестает быть лишь элементом социальной структуры и получает большую степень свободы в выборе индивидуальной траектории развития. В связи с этим усиливается роль культуры, которая из «охранительницы устоев» превращается в активный фактор социокультурного формообразования и обновления. Соответственно, возрастает и значимость духовного мира личности в социальной, политической и экономической динамике. Недаром в современных экономических исследованиях происходит отказ от концепции «экономического человека» и переход к моделям человека «исторического», «психологического», «культурного» и т. п. (Лурье, 2009; Марущак, 2017; Капелюшников, 2013; Смит, 2005).

Цивилизационный сдвиг в глобальном развитии свидетельствует в первую очередь о том, что современная культура переориентировалась на перманентное обновление, на ценности инновационного развития. При этом «инновационный транс», в который погружается мир, демонстрирует наступление «эры кризисов», связанных с ускорением социокультурного развития, все усложняющейся дифференциацией, непрерывной инновизацией различных сфер жизни общества в результате утрачивается тождество человека с самим собой и единство социума.

Таким образом, современное общество, где базовым социокультурным механизмом производства и трансляции культуры оказывается не традиция, а инновация во всех сферах жизнедеятельности человека, находится в состоянии бесконечной «гонки за новизной», в результате чего ситуация становится вполне адекватной диалектической формуле: «старое отживает, но еще не отжило, а новое возникает, но еще не возникло». Иначе говоря, социум конца XX - начала XXI века является перманентно кризисным, переходным, транзитивным и все более рискогенным. Непрерывный процесс разрушения господствовавших в обществе старых, давно апробированных социальных практик, технологий, культурных норм, правил и способов поведения сопровождается возникновением новых, что неизбежно приводит к изменению онтологического статуса культуры как активного «бродильного элемента» социума. 


\section{Методология исследования}

Вышеобозначенные обстоятельства объясняют, почему в фокусе методологических поисков в гуманитарных науках находятся не «акультурные», а «культурные» теории (Taylor, 1992). Ещё М. Вебер писал, что «трансцендентальной предпосылкой» всех наук о культуре выступает представление о том, что мы сами «являемся людьми» культуры, то есть можем придавать смысл окружающему миру и занимать определённую позицию по отношению к нему (Вебер, 1990: 379). Отсюда столь важное значение имеет субъективная культура индивида, для которого восприятие самого себя и своего образа жизни оказывается своеобразным «волшебным кристаллом», сквозь который проецируются на общество и реальные социальные действия и личностный образ мысли (Berry et al., 2002).

Ведь реальные действия людей зависят от истолкования действительности, формы которых им предоставляет культура. Какими бы ни были их материальные и нематериальные интересы, с одной стороны, и социальные институты и контроль - с другой, действия людей будут обусловлены интерпретацией ими действительности (Тенбрук, 2013).

Ф. Тенбрук в своей концепции репрезентативной культуры показал, что культура есть социальный факт, поскольку её ценности, идеи, интерпретации лежат в основе социальных действий и активно или пассивно признаются членами данного сообщества. Недействующей, т.е. нерепрезентируемой в социуме культуры не существует. Именно репрезентация (в различных стилях жизни, способах конструирования социальной действительности, характере действия социальных институтов и т.д.) играет роль основного механизма структурированности и развития, статики и динамики любой культуры.

Как отмечает А. В. Комаровский, одним из ключевых свойств репрезентативной культуры выступает «инновативность (культура включает как статичные, устойчивые, так и динамические образования, открытые для изменений)» (Комаровский, 2014: 76).

Репрезентативность многомерна, другими словами, любое событие, факт социальной жизни, действие репрезентируются двойственным образом: в качестве реального элемента социальной действительности и одновременно посредством субъективной интерпретации, смысловой оценки его со стороны индивида. Собственно, превращение человека в субъект возможно благодаря превращению мира в картину: для представляющего субъекта «само мышление стало представлением, устанавливающим отношение к представляемому» (Микешина, 2007: 111). Представляемая картина мира, всей социальной действительности и каждого её элемента, становится «интерпретируемой репрезентацией» мира. При этом принятие (или неприятие) тех или иных «сюжетов», тех или иных нововведений, культурных практик, ориентаций, стилей и образцов поведения и т. п. само по себе выступает репрезентантом культуры тех, кто их в той или иной форме одобряет или отвергает. Фиксация данного обстоятельства обязывает исследователей пере- 
направить исследовательскую оптику с описательного уровня различных проявлений студенческой культуры на то, что любая социальная практика, новшество или рутинное действие должны быть описаны и проинтерпретированы не только с точки зрения их влияния на индивида, но выступать показателем развития самого человека, его субъектности: то, что мы реально принимаем (или отвергаем), говорит о нас больше, чем наши оценочные суждения.

В современной социологической литературе понятие репрезентативной культуры связано с моностилизмом и полистилизмом различных культурных систем (Ионин, 20оо). Именно в определении жизненного стиля как «устойчивой тождественности форм» внутренних интенций индивида и внешних их проявлений фиксируется активное или пассивное принятие способов понимания, интерпретации, оценок явлений и процессов в рамках определённой социальной группы или общества в целом. Эти относительно устойчивые формы жизнедеятельности отражают личностные особенности людей (понимание ими других акторов, своего места в социальной структуре и т. д.) и одновременно выступают средством манифестации себя в глазах «других». Так что известную максиму «стиль - это человек» следует дополнить словами «а также кем он выглядит в глазах окружающих».

В западной социологической мысли категория «стиль жизни» иногда отождествляется с термином «образ жизни» (Рощина, 2007: 135), однако чаще противопоставляется ему как «индивидуальное», в отличие от «жёстко» детерминированного (Miles, 20oo). В постклассический период развития социологии, в том числе в рамках микросоциологии, данное понятие определялось как некоторая целостность устойчиво воспроизводимых образцов поведения (Тоффлер, 2002; Масленцева, 2010). Такое понимание позволяет отойти от ограничений структурно-функционального анализа в исследовании транзитивного, инновационного социума. Данное обстоятельство осмысляется в теориях индивидуализированного общества, где концептуализация стилей жизни даёт возможность не ограничиваться макросоциальными факторами, а исходить из представления об индивиде, его склонностях, потребительском поведении, жизненном выборе (DiMaggio, 1994: 458).

Э. Гидденс, основываясь на положениях своей теории структурации, акцентирует внимание в понимании жизненного стиля на нравственной доминанте (Giddens, 1991).

В целом в западной социологии начиная с конца XX века доминирует представление о человеческом «Я», в котором заложено стремление к самоактуализации, что оказывает влияние на теорию стиля жизни (Smith, 1994). Особое внимание обращалось на стилевые особенности повседневного поведения людей (Chaney, 1996).

Большой и разнообразный материал по повседневным транзакциям современной российской молодёжи и различным стилям поведения в области труда и в сфере отдыха содержится в работах В. И. Ильина и его школы (Ильин, 20о7).

В ходе многолетних дискуссий, проходивших в рамках социологии молодёжи, был сделан вывод о том, что современные молодые люди строят свои жизненные 
стратегии и стили поведения независимо от жёстких социальных структур. Так, институт высшего образования теряет в глазах студентов исключительную направленность на профессионализацию, а природа «взрослости» становится всё более проблематичной (Омельченко, 2005). «Стиль жизни студентов» является понятием, фиксирующим прежде всего активный характер взаимодействия человека с окружающим миром и с самим собой: «Стиль является важнейшей формой самоструктурирования культуры, конституируя и онтологизируя такие смыслы, как индивидуальность, национальная культура, групповая субкультура, культурноисторическая эпоха. Каждая культура представлена стилевой системой с определенным соотношением индивидуальных, групповых, общекультурных стилей как различных социокультурных идентичностей, проявляющих человеческие ритмы и границы социокультурного процесса» (Устюгова, 2006: 244). Именно стиль жизни демонстрирует «бесшовность» соединения социального и культурного, внешних материальных обстоятельств и внутренних духовных интенций индивида. Мы согласны, что «теоретическая и практическая ценность категории „стиль жизни“ обусловлена тем, что она дает целостную картину жизни индивидов в определенных конкретно-исторических условиях, раскрывает макросоциальные закономерности на уровне их проявления в жизнедеятельности людей, тем самым делает возможным переходы от проблематики общества к проблематике личности и наоборот» (Киселев, 2013: 66). Таким образом, стиль жизни является социокультурной формой повседневного поведения индивида, возникающей в ходе его самореализации и свободного выбора.

В демократическом обществе, в отличие от тоталитарного, стилевая дифференциация усложняется, поскольку выбор жизненного стиля или стиля жизни как устойчивой формы индивидуального поведения осуществляется в ходе свободного, а не навязанного различными методами (в том числе и принудительносиловыми) личного решения. В обществах же транзитивного типа, вследствие разрушения единой программы социализации молодёжи, запускается механизм хаотизации стилей жизни, в результате чего формируются гибридные или противоречивые в своей основе способы репрезентации культуры в жизнедеятельности прежде всего молодого поколения. В первом приближении можно согласиться со следующим положением:

Анализ стилей жизни, функционирующих в современном российском обществе, показал, что среди представителей поколения «отцов» преобладает выбор традиционного стиля жизни, который обусловлен приоритетом семейных ценностей, профессиональной деятельности со стабильным заработком, ориентации на простую жизнь, идущую равномерно и упорядоченно, с акцентом на выполнение долга. В шкале ценностей современной российской молодежи одну из приоритетных позиций занимают установки на самореализацию и индивидуализм, а также гедонистические образы действий, которые определяют направленность на индивидуалистический стиль жизни. По отношению к общественно активному стилю жизни в обоих поколениях не наблюдается четко выраженных предпочтений. (Зимина, 2006: 15) 
Хотя студенчество и рассматривается современными исследователями как динамически развивающаяся группа, однако следует иметь в виду, что эта группа является транзитной: человек попадает в неё и через определенное время покидает. Конечно, в мире «всё проходит», однако применительно к студенчеству этот период - обучение в вузе - длится, как правило, от 4 до 6 лет. С получением диплома студент попадает в другую социальную группу - прежде всего работающих людей. Таким образом, студенчество - это пространство и время транзита, в которое попадают, пребывают, а затем неизбежно покидают (исключение - «вечный студент», знакомый ещё по произведениям А. П. Чехова, - лишь подтверждает общее правило). При этом само российское общество транзита находится в переходном состоянии смены культурных парадигм развития. Положение студенчества как особой социально-демографической группы в данных условиях можно кратко представить, используя девиз капитана Немо: «Подвижный в подвижном». В результате репрезентативная культура современного российского студенчества во многом носит переходный, гибридный характер, поскольку включает в себя одновременно элементы моностилизма и полистилизма, традиционализма, индивидуализма и гедонизма. Данная ситуация коррелируется с образом «парадоксального человека», обрисованного Ж. Т. Тощенко (Тощенко, 20о8), который фиксирует наличие в российском обществе в массовых масштабах индивидов, обладающих антиномичным, расколотым сознанием, продуцирующим противоречивые друг другу программы действия.

\section{Стилевая дифференциация в учебной и досуговой сферах}

Прогрессирующая стилевая дифференциация студенческой культуры проявляется прежде всего в сфере учёбы. Стилевое разнообразие в первом приближении может быть сведено к четырём основным типам: «профессионалы», «ритуалисты», «общественники», «конформисты». В качестве основного классификационного признака, оказывающего определяющее влияние на образ жизни, манеру поведения, способ интерпретации формальных и неформальных практик вузовской жизни и т.д., мы выделим самостоятельность/несамостоятельность в выборе профессии и вуза. «Профессионалы» осуществляют целенаправленный и рациональный выбор профессии/вуза, реализуя свои интенции в саморазвитии прежде всего в учебной и научной деятельности. «Ритуалисты» самостоятельно выбирают место своей будущей учёбы, но на их решение оказывают влияние факторы случайного характера. Они стараются вписаться в институциональные нормы поведения, но овладение высокими профессиональными компетенциями не является основной целью их пребывания в вузе. «Общественники» хотя и самостоятельно, но не целенаправленным образом реализуют своё право на получение высшего образования. Из этой среды «рекрутируются» активисты, для которых основная сфера их студенческой жизнедеятельности - это общественная, культмассовая и т. п. работа в самых разных формах. Для «конформистов» характерен несамосто- 
ятельный выбор вуза, где они стараются приспособиться к существующим нормам, не проявляя никакой активности или личной заинтересованности в учебной, общественной или научной деятельности.

Отметим, что вузовское образование рассматривается большинством абитуриентов и студентов в качестве необходимого «соучастника» своего вступления во взрослую жизнь, причём в мотивационной сфере будущих учащихся вузов превалирует ориентация на постматериалистические ценности субсидиарного характера. Так, для респондентов из Ростовской области устойчиво лидирующим мотивом выбора профессии, специальности, вуза выступает «удовлетворение собственных интересов, развитие способностей» - 51,0\% (2006 г.), 57\% (2011 г.), 58,9\% (2016 г.), в то время как за этот же период времени на 11,1\% снизилось количество студентов, ориентирующихся на «высокооплачиваемую» профессию. Тенденция превалирования идеи самосовершенствования в мотивационной структуре студентов при выборе специальности подтверждается и в других регионах: 57,5\% УрФУ (Екатеринбург), 61,2\% КубГУ (Краснодар), 61,3\% К(П)ФУ (Казань), 59,9\% КалмГУ (Элиста), 58,1\% АГУ (Майкоп).

Интересно отметить, что для студентов аграрных вузов мотив удовлетворения собственных интересов и личностный рост (в отличие от учащихся других вузов) не является главенствующим. Так, для обучающихся в крупнейшем в ЮФО Кубанском ГАУ (Краснодар) он оказывается на четвёртом месте (выбор 23,9\% опрошенных), главной же причиной поступления выступает высокий спрос на профессию на рынке труда - 71,4\%. Такого рода установка отражает специфику аграрного Кубанского края, перспективность поиска работы в сельском хозяйстве в условиях санкций и контрсанкций, престижность сельскохозяйственной профессии на Юге России (мотив «престижности» при поступлении назвали 57,2\% респондентов этого вуза). Таким образом, ограниченность потребностей рынка труда ведёт к тому, что значительная часть учащейся молодежи видит «оправдание» своей учёбы в вузе в идее самосовершенствования и накопления культурного капитала, хотя в действительности большая часть студентов в конце концов склоняется к гедонистическому стилю жизни.

Интересно, что среди тех, кто выбирал профессию, специальность прежде всего «для удовлетворения собственных интересов, развития способностей», происходит в дальнейшем в определённой степени переоценка взглядов: количество студентов, согласных с утверждением о том, что вуз должен давать прежде всего профессиональные знания, а мировоззрение, образ жизни, стиль поведения дело сугубо индивидуальное, из года в год увеличивается (36,6\% в 2006 г., 35,5\% в 2011 г. и 41,8\% в 2016 г.).

Данное обстоятельство коррелируется с будущей стратегией поведения: после окончания вуза наиболее предпочтительным для студентов является работа по специальности, причём этот жизненный выбор оказывается приоритетным для всё большего количества респондентов: в 2006 г. их было 25,2\%, в 2011 г. - 36\%, в 2016 г. - 39\%. Желание работать по специальности подтверждается и тем, что 
в поисках хорошей зарплаты готовы «изменить» своей профессии всё меньшее количество респондентов: 33,2\% в 2006 г., 25\% в 2011 г., 22,2\% в 2016 г. Однако эти позитивные тенденции, связанные с пониманием студентами значимости получения профессиональных знаний, умений и компетенций в стенах вуза, явно противоречат реализуемому ими образу жизни. При выборе модели студенческой жизни, несмотря на то что ориентация на упорную учёбу и самоограничение ради успешного профессионального будущего возрастает (9,9\% в 2006 г., 16,6\% в 2011 г. и 20,1\% в 2016 г.), подавляющее большинство респондентов предпочитает потребительскую, а не самоограничительную модель поведения (81,2\% в 2006 г., $75 \%$ в 2011 г. и $67,2 \%$ в 2016 г.), считая, что студенческая жизнь - это прежде всего особая пора молодости, преимущества которой надо полноценно использовать без всяких самоограничений. В результате некоторую возможную невостребованность на рынке труда молодые люди предполагают компенсировать за счёт роста своего социокультурного капитала и самосовершенствования в стенах вуза, а в действительности выстраивают гедонистическую модель поведения, реализуя свои индивидуальные внутренние интенции вне стен высшего учебного заведения.

Общественный запрос современного инновационного общества на самостоятельную творческую личность интерпретируется будущими студентами в качестве основного мотива поступления в вуз (самосовершенствование, «достраивание» личности). Однако для большинства обучающихся молодых людей утверждение ценностей постматериалистического типа происходит и репрезентируется прежде всего в досуговой, а не в учебной сфере. Данное обстоятельство иллюстрируется количественным составом студенческих когорт, «исповедующих» четыре основных стиля жизнедеятельности в учебной сфере.

Наиболее адекватной формой тождества внутренних и внешних проявлений индивидуальных интенций является стиль жизни студента, которого условно можно назвать «профессиональным». Такой студент осуществляет целенаправленный самостоятельный выбор вуза и специальности, рассматривая последнюю как потребность в самореализации и самоутверждения именно в данной сфере профессиональной деятельности. Студенты данного типа академически активны, учатся только на «отлично» или на «хорошо» и «отлично», успешно занимаются научно-исследовательской работой, занятия пропускают лишь в исключительных случаях. При изучении любой учебной дисциплины они руководствуются принципом максимального освоения профессиональных знаний, навыков и умений, направленных на достижение конечной цели - стать профессионально компетентным работником. Они обладают достаточно высокой компьютерной грамотностью. К общественно-политической сфере жизни «профессионалы» равнодушны. «Профессионалы» составляют менее четверти контингента обучающихся, но с каждым годом их число несколько увеличивается.

Данный тип студентов происходит из семей с высоким уровнем образования, со средними или хорошими материальными возможностями, котируемым в нашем обществе социальным статусом родителей (одного из них). Примечательно, 
что девушки проявляют большую самостоятельность в выборе вуза и будущей специальности, более требовательны и профессионально ориентированы на полезность изучаемых социально-гуманитарных дисциплин.

Более половины учащихся вузов можно отнести к «ритуалистам» и «общественникам». Первых отличает самостоятельность выбора вуза и специальности, но в основе своей - это не результат собственных мировоззренческих позиций и установок, а стечение определенных обстоятельств (престижность или близость вуза к месту проживания, высокооплачиваемая профессия, советы друзей или учителей и др.). «Ритуалисты» равнодушны к основной цели вуза - подготовке профессионально компетентных работников, но своим общением и действиями в учебном заведении продолжают соблюдать институциональные нормы. Представители этого типа рассматривают высшее учебное заведение как источник получения разносторонних и добротных знаний о жизни и окружающем мире, но избранная специальность их мало интересует - они берут от вуза все то, что считают нужным, необходимым и полезным для дальнейшей карьеры. В основном равнодушны к НИР, сторонятся общественной и политической деятельности. Студенты данного типа стараются учиться без троек, с дополнительной специальной литературой работают неохотно, по необходимости, активно пользуются интернетом.

Стиль жизни «общественников» - это стиль жизни студентов-активистов, которые выбирают вуз и специальность самостоятельно, но случайно («модный» вуз или профессия, нежелание отстать от друзей и т. д.). Отношение к учебе носит равнодушно-обязательный характер, основным критерием академической активности выступает вечно живущий студенческий принцип «не знать, а сдать». В большинстве своем учатся на «удовлетворительно», хотя нередко получают и «неуды», их цель - получение диплома при минимальных интеллектуальных затратах. Основная сфера их деятельности в вузе - общественные организации, художественная самодеятельность, спорт и т.д. Балльно-рейтинговая система провоцирует этих студентов на «добывание» баллов прежде всего с помощью проявления активности в высоко-балльных мероприятиях, и они очень зорко и ревниво следят за проставлением этих самых баллов. Студенты данного типа обладают высокой степенью общительности, своей внеучебной деятельностью добиваются признания в студенческой среде.

Наконец, четвертый стиль трудового, учебного поведения студентов - конформистский. Для студентов этого типа выбор вуза и специальности не является самостоятельным, это, скорее, выбор их родителей, ближайших родственников. Обучение в вузе для них представляет собой продолжение школьного образования, приспособление к нормативным требованиям вузовской жизни. Студентам данного типа все равно, где, как и на кого учиться, главное - держаться на плаву, не довести дело до исключения. Академическая активность носит равнодушнонеобязательный характер, в основном отличается систематическими пропусками занятий, из сессии в сессию повторяющимися задолженностями. Они пассивны 
и безучастны в общественной и научно-исследовательской работе. Пользуются интернетом в учебных целях — подготовить доклад, контрольную работу или курсовой проект.

Студенты, предпочитающие стили жизни «ритуалистов», «общественников», «конформистов», в большинстве своем отличаются разочарованностью и неудовлетворенностью выбором вуза/специальности, отсутствием конкретных и реальных понятий о социальном статусе, связанном с выбором данной профессии, о достижимости трудоустройства по этой специальности после окончания вуза. Именно эти моменты оказывают непреложное влияние на эффективность социализационно-воспитательного воздействия современного вуза на личность студента.

Исходя из понятия репрезентативной культуры, можно заключить, что моностилизм студенческой культуры остался в основном в прошлом, ибо он был характерен для советского периода, когда социалистическая идеология, моральные оценки, культурная картина мира, базирующаяся на матрице коммунитаризма, неприятии индивидуализма и т. п., в основном активно или пассивно разделялась учащейся молодёжью, причём данные принципы обладали внутренним единством и поддерживались всей мощью государственной и партийно-комсомольской машины. Конечно, и в молодёжной среде возникали различные субкультурные группы со своими специфическими стилями поведения (стиляги, «хиппующие», «пофигисты», «ботаники» и т.д.), однако основные агенты социализации (СМИ, система высшего образования, политические институты, семья) проводили единую воспитательную и репрессивно-ограничительную политику, уменьшающую реальные возможности стилевого разнообразия студенческой культуры. При этом именно политический критерий являлся основным как в оценке художественных стилей в искусстве, образов повседневной жизни, так и в определении необходимого качества и направленности образования. Отметим, что одним из главных элементов парадигмы культурной политики в области образования как в Российской империи, так и в СССР было формирование индивида, полностью вписывающегося в моностилистическую культуру, отличающуюся упорядоченностью, иерархичностью, идеологичностью, нетерпимостью к «чуждым» элементам культуры.

Как это ни парадоксально звучит, но элементы моностилизма советской эпохи в значительной степени всё-таки продолжают жить в системе образования, в первую очередь благодаря усилению её бумажно-электронной регламентации и бюрократизации. Студенчество в вузовской корпоративной культуре по-прежнему является в основном пассивным элементом, неким сосудом, который следует наполнить соответствующими компетенциями. В результате, при всей своей тяге к постматериалистическим ценностям, стратегия поведения студентов в учебной группе мало изменилась: стремлению к свободе и индивидуальному планированию собственной жизни явно противоречит перенесение ответственности за организацию учебной и внеучебной жизни на кураторов и «штатных активистов» 
из студенческой среды. Отсюда можно зафиксировать следующий парадокс в культурной картине мира молодого поколения «сочетается несочетаемое»: субсидиарные, достижительные, индивидуалистические и традиционные, «дорыночные» стили поведения; стремление к самостоятельности и свободе неожиданно сочетается с принятием патерналистского отношения со стороны администрации и ППС вузов.

Внятной репрезентации современной студенческой культуры в процессах кристаллизации стилевой дифференциации во многом мешает неопределённость, «смутность», размытость индивидуального сознания молодых людей. Отсутствие чётких критериев понимания действительности порождает определённое параллаксное видение (Жижек, 2008), смещение в восприятии нормы/патологии, должного/недолжного, разрешённого/ запрещённого, достойного/недостойного, человеческого/нечеловеческого, вернее, даёт возможность помещать их в одну плоскость дозволенной комплементарной реальности. Обозначенные полюса не опосредствуются ничем, они репрезентируются как равновозможные стили поведения. В этих условиях выстраивание осмысленного образа жизни и выбор стратегии поведения может носить случайный, ситуационный характер. Поэтому в ответах респондентов из Ростовской области наблюдается увеличение количества «затруднившихся ответить», причём на вопросы, имеющие важное смысложизненное значение; ответы на них репрезентируют отсутствие сознательно избираемого стиля и стратегии поведения молодых людей, призванных в будущем составить интеллектуальную, духовную и управленческую элиту российского общества. К примеру, в 2016 г. 18,8\% студентов не знают, должен ли «вуз давать знания только по профессии, а мировоззрение, образ жизни - личное дело каждого»; 15,1\% респондентов не могут «обнаружить» положительные черты своего поколения, а 9,2\% - отрицательные (в 2011 г. таковых было 6\%); не могут определиться, давать или не давать взятки, 19,4\%, брать или не брать - 20\%; уклоняться или не уклоняться от службы в армии - 25,9\%; не могут выбрать приоритетную модель образа студенческой жизни - 12,7\% (в 2006 г. таковых было 7,8\%); затрудняются сказать, стали бы снова поступать в тот же вуз, где учатся в настоящее время, 11,9\% респондентов (в 2006 г. их было 8,1\%). Подобная «смутность сознания» характерна для «общества риска». Социум не даёт возможности многим молодым людям чётко определить параметры и направленность их будущей жизни и одновременно предоставляет сугубо внешние, формальные возможности для проявления их индивидуально-творческой «самости». Недаром в 2016 г. только 15,8\% студентов твёрдо знали, где будут работать, зато 22,4\% будущих выпускников видели себя в роли безработных. Количество же желающих после окончания вуза завести собственное дело, стать самому себе хозяином из года в год уменьшается. Ситуация усложняется тем, что «взрослость» в современном мире уже не может рассматриваться в качестве конечного пункта социализации, завершения «молодости». Целый ряд учёных считают, что в XXI веке природа взрослости проблематична (Омельченко, 2005). 
Как уже было показано, большинство студентов предпочитает в значительной степени гедонистический стиль поведения в противовес самоограничительному, направленному на профессиональное самосовершенствование. В результате внутренняя интенция «достраивания», улучшения своей личности реализуется у бывших абитуриентов посредством выбора в пространстве стилевого разнообразия гедонистического образа жизни, осуществляемого в основном в сфере досуга. Именно здесь субсидиарные ценности начинают явно довлеть над коммунитарными.

Первое, на что стоит обратить внимание, - это на устойчивую тенденцию индивидуализации проведения досуга, в ущерб его общим и коллективным формам. Резко (по сравнению с социологическим опросом в Ростовской области десятилетней давности) - почти в четыре раза уменьшилось количество студентов, посещающих дискотеки, ночные клубы, другие коллективные развлекательные мероприятия (42,4\% в 2006 г., 29\% в 2011 г., 11,1\% в 2016 г.). Зато доля индивидуализированных форм общения (встречи с друзьями) увеличилась более чем в три раза за тот же период времени (19,1\% в 2006 г., 75\% в 2011 г. и 59,7\% в 2016 г.). Тенденция индивидуализации досуга подтверждается и повышением количества имеющихся хобби (почти в два раза). Здесь проглядывает наметившаяся эскейпистская тенденция, связанная с желанием «отгородиться» от общества и его проблем, тем более что только 3,3\% студентов в настоящее время участвуют в политической жизни города. Посещение кафе, баров, ресторанов в связи с общим уменьшением доходов и возрастающей дороговизной жизни в 2016 г. сокращается (это позволили себе в 2016 г. 28,4\% респондентов, тогда как в 2011 г. таковых было 40\%). Приумножилось число студентов, занимающихся экстремальными и приключенческими видами спорта.

Таким образом, мы видим, что в досуговой сфере студенты предпочитают свободные, индивидуализированные формы общения и развлечений, что подтверждает наличие тенденции изменения стиля жизни учащихся вузов в направлении постматериалистических ценностей. Возникает парадоксальная ситуация, когда в условиях кризиса вместо направленности на объединение, увеличение сплочённости наблюдается рост индивидуалистических настроений. Но то, что является позитивным в благополучном стабильном обществе, может обернуться негативными последствиями в кризисное, нестабильное время. В культурном плане - это утрата общих нарративов, утрата социальной сплочённости.

Однако в настоящее время наблюдается и противоположный процесс, связанный с формированием так называемых солидарностей в культурных практиках российских молодых людей, принадлежащих к разным субкультурным и социальным группам В ценностном поле культуры, возникают солидаристские коммуникации вокруг принятия/неприятия различных полярных альтернатив: национализм, ксенофобия/толерантность, авторитаризм/демократия, потребительство/ аскетизм и т.д. (Омельченко, 2013). 


\section{Выводы}

Итак, каковы итоговые размышления социолога культуры?

- В социуме, где основным механизмом развития культуры становится инновация, а не традиция, меняется онтологический статус культуры, выступающей в условиях перманентного кризиса (старое исчезает, но ещё не исчезло, новое возникает, но ещё не возникло) как активная преобразующая сила.

- Концепция репрезентативной культуры, возникшая в рамках неовеберианской традиции, рассматривающая взаимодействие культуры и социума, исходя из неклассического принципа комплементарности, фиксирует «бесшовное» соединение культурного и социального и даёт возможность адекватно исследовать нелинейные социализационные процессы, происходящие в студенческой среде. В обществе транзита возникают антиномичные, гибридные формы студенческой культуры, где интерпретация, ценностные оценки, осмысление происходящих событий противоречивым образом репрезентируется в жизненных стилях и стратегиях поведения учащихся вузов.

- Студенчество демонстрирует отход от моностилизма репрезентативной культуры старшего поколения, увеличивается стилевая дифференциация. Однако декларируемая инновационным обществом повестка дня, утверждающая ориентацию на постматериалистические ценности свободы, индивидуального развития, творчества, изначально принимается молодыми людьми (что, например, отражается в мотивации выбора абитуриентами вуза и будущей специальности), но затем репрезентируется в гедонистическом стиле жизнедеятельности.

- Следует выделить, исходя из принципа степени самостоятельности выбора вуза/специальности, четыре жизненных стиля в учебно-трудовой деятельности студентов, характерных для «общественников», «профессионалов», «ритуалистов», «конформистов». Несмотря на то что наиболее ценными качествами своего поколения студенты считают приверженность постматериалистическим ценностям, реальное поведение большинства носит пассивный характер, проявляющийся в принятии студентами патерналистского отношения к себе со стороны администрации и профессорско-преподавательского состава вузов. Репрезентация постматериалистической культуры (свобода, индивидуализация) реализуется при этом в досуговой сфере.

\section{Литература}

Вебер М. (1990). «Объективность» социально-научного и социально-политического познания / Пер. с нем. М. И. Левиной // Вебер М. Избранные произведения. М.: Прогресс. С. $345-415$.

Горшков М. К. (2016). Российский социум в условиях кризисного развития: контекстный подход (статья 1) // Социологические исследования. № 12. С. 26-34. 
Жижек С. (2008). Устройство разрыва: параллаксное видение / Пер. с англ. А. Смирнова, Г. Рогоняна, С. Кастальского, А. Олейникова. М.: Европа.

Зимина O. В. (2006). Телереклама как фактор формирования стиля жизни в современном российском обществе. Дисс. канд. соц. наук. Ставрополь: Ставропольский государственный университет.

Зубок Ю. А., Чупров В. И. (2017). Современная социология молодёжи: изменяющаяся реальность и новые теоретические подходы // Россия трансформирующаяся: Ежегодник. 2015. М.: Новый хронограф. С. 12-48.

Иванов Д. В. (2002). Виртуализация общества. СПб.: Петербургское востоковедение.

Ильин В. И. (ред.). (2007). Быт и бытие молодежи российского мегаполиса: социальная структурация повседневности общества потребления. СПб.: Интерсоцис.

Инглхарт Р., Вельцель К. (2011). Модернизация, культурные изменения и демократия: последовательность человеческого развития. М.: Новое изд-во.

Ионин Л. Г. (200о). Социология культуры: путь в новое тысячелетие. М.: Логос.

Капелюшников Р. И. (2013). Поведенческая экономика и новый патернализм. Препринт WР $3 / 2013 / 03$. М.: ВШЭ.

Капустина Е. Г. (2014). Коммуникативные практики взаимодействия власти и молодежи (социологический анализ) // Историческая и социально-образовательная мысль. № 3. С. 182-19о.

Киселев Е. А. (2013). Основные подходы к исследованию стиля жизни в социологии // Вестник Пензенского государственного университета. № 1. С. 63-67.

Комаровский А. В. (2014). Неовеберианская культурсоциология Фридриха Тенбрука // Социология. № 1. С. 69-77.

Лурье Д. А. (2009). Проблемы виртуализации современного общества и их социологическое осмысление // Философия и общество. Вып. 4. С. 64-168.

Марущак И. В. (2017). Эволюция модели экономического человека в теории человеческого капитала: от homo economicus до homo transactus // Креативная экономика. Т. 11. № 8. С. 839-846.

Масленцева Н. Ю. (2010). Социологические основания концепции стиля жизни // Вестник Челябинского государственного университета. № 31. С. 147-150.

Микешина Л. А. (2007). Эпистемология ценностей. М.: РОССПЭН.

Омельченко Е. Л. (2005). Идентичности и культурные практики российской молодежи на грани XX-XXI вв. Автореф. дисс. докт. социол. наук (22.00.06). М.: Институт социологии РАН.

Омельченко Е. Л. (2013). Солидарности и культурные практики российской молодёжи начала XXI века: теоретический контекст // Социологические исследования. № 10. С. 52-61.

Рощцна Я. М. (2007). Социология потребления. М.: ВШЭ.

Смит В. Л. (2005). Конструктивистская и экологическая рациональность в экономической науке // Мировая экономическая мысль: сквозь призму веков. 
Т. 5. Кн. 2: Всемирное признание: лекции нобелевских лауреатов. М.: Мысль. C. $685-767$.

Смолин О. Н. (2015). Высшее образование: борьба за качество или покушение на человеческий потенциал? // Социологические исследования. № 6. С. 91-101.

Тенбрук Ф. (2013). Репрезентативная культура // Социологическое обозрение. Т. 12. № 3. C. 93-118.

Тишков В. А., Бараши Р. Э., Степанов В. В. (2017). Идентичность и жизненные стратегии студенчества // Социологические исследования. № 8. С. 81-87.

Тофффлер Э. (2002). Шок будущего / Пер. с англ. Е. Рудневой, Л. Бурмистровой, К. Бурмистрова, И. Москвиной-Тархановой, А. Микиша, А. Мирер, В. Кулагиной-Ярцевой, Н. Хмелик, Е. Комаровой под ред. П. Гуревича. М.: АСТ.

Тощенко Ж. Т. (2008). Парадоксальный человек. М.: ЮНИТИ-ДАНА.

Устюгова Е. Н. (2006). Стиль и культура: опыт построения общей теории стиля. СПб.: СПбГУ.

Чупров В. И. (1994) Социальное развитие молодёжи: теоретические и прикладные проблемы М.: Социум.

Berry J. W., Poortinga Y. H., Segall M. H., Dasen P. R. (2002). Cross-Cultural Psychology: Research and Applications. Cambridge: Cambridge University Press.

Chaney D. (1996). Lifestyles. L.: Routledge.

DiMaggio P. (1994). Social Stratification, Life-Style, and Social Cognition // Grusky D. (ed.). Social Stratification: Class, Race, and Gender in Sociological Perspective. Boulder: Westview Press. P. 458-465.

Giddens A. (1991). Modernity and Self-Identity: Self and Society in the Late Modern Age. Stanford: Stanford University Press.

Miles S. (2000). Youth Lifestyles in a Changing World. Buckingham: Open University Press.

Smith M. B. (1994). Selfhood at Risk: Postmodern Perils and the Perils of Postmodernism // American Psychologist. Vol. 49. № 5. P. 405-411.

Taylor Ch. (1992). Modernity and the Rise of the Public Sphere. URL: http://www.mercaba.org/SANLUIS/Filosofia/autores/Contempor\%C3\%A1nea/Taylor,\%20Charles/ Modernity\%2oand\%2othe\%2oRise\%20of\%2othe\%20Public\%2oSphere.pdf (дата доступа: 09.02.2018).

\section{The Representative Culture of Modern Russian Students}

\section{Victor Filonenko}

Doctor of Social Sciences, Professor, Institute of Philosophy and Socio-Political Sciences, Director of the Center for Socio-Political Research, Southern Federal University

Address: Dneprovsky per., 116, Rostov-on-Don, Russian Federation 344065

E-mail: vilonenko@sfedu.ru 


\section{Liudmila Shtompel}

Doctor of Philosophical Sciences, Professor at the Department of Cultural Theory, Ethics and Aesthetics, Institute of Philosophy and Socio-Political Sciences, Southern Federal University

Address: Dneprovsky per., 116, Rostov-on-Don, Russian Federation 344065

E-mail: lastompel@ sfedu.ru

\section{Oleg Shtompel}

Doctor of Philosophical Sciences, Professor at the Department of Cultural Theory, Ethics and Aesthetics, Institute of Philosophy and Socio-Political Sciences, Southern Federal University

Address: Dneprovsky per., 116, Rostov-on-Don, Russian Federation 344065

E-mail: omshtompel@ sfedu.ru

The article touches upon the issues of several problems. Firstly, we attempt to determine the methodology of a sociological analysis of culture which is adequate for modern realities. Secondly, we will apply this methodological basis to the cultural specifics of modern Russian students in a transitive, transitional society. It is stressed that the formation of a global innovative society results in a permanent crisis with the destruction of the old sociocultural forms and the emergence of new ones, with the result that culture becomes not a "guardian of the foundations", but an active "fermenting" power of society. In these nonlinear processes, a special importance is acquired by subjective culture. Based on F. Tenbrook's ideas, an analysis of monostylism and polystylism of a student's representative culture is carried out. It is noted that these processes of representation are contradictory and hybrid. Highly-valued by student youth, the values of independence, individuality, and freedom of the post-materialistic plan are represented primarily in the sphere of leisure and free-time activities. The presented typology of students' lifestyles in the field of educational activity ("professionals", "ritualists", "public men", and "conformists") fixes a predominantly adaptive strategy of behavior based on the adoption of a paternalistic attitude on the part of the administration and the teaching staff of universities. The article is based on the materials of the authors' interregional sociological research, conducted in the Southern Federal District in 2006, 2011, and 2016.

Keywords: student, representational culture, monostylism and polystylism, typology of lifestyles

\section{References}

Berry J. W., Poortinga Y. H., Segall M. H., Dasen P. R. (2002) Cross-cultural Psychology: Research and Applications, New York: Cambridge University Press.

Chaney D. (1996) Lifestyles, London: Routledge.

Chuprov V. (1994) Socialnoe razvitie molodyozhi: teoreticheskie i prikladnye problemy [Social

Development of Youth: Theoretical and Applied Problems], Moscow: Socium.

DiMaggio P. (1994) Social Stratification, Life-Style, and Social Cognition. Social Stratification: Class,

Race, and Gender in Sociological Perspective (ed. D. Grusky), Boulder: Westview Press, pp. 458-465

Giddens A. (1991) Modernity and Self-Identity: Self and Society in the Late Modern Age, Stanford: Stanford University Press.

Gorshkov M. (2016) Rossijskij socium v usloviyah krizisnogo razvitiya: kontekstnyj podhod (stat'ya 1) [Russian Society under the Conditions of Crisis Development: A Contextual Approach (article 1)]. Sociological Studies, no 12, pp. 26-34.

Illin V. (ed.) (2007) Byt i bytie molodezhi rossijskogo megapolisa: socialnaya strukturaciya povsednevnosti obshchestva potrebleniya [Life and Being of Russian Metropolis'Youth: Social Structure of the Everyday Life in Consumption Society], Saint Petersburg: Intersocis.

Inglehart R., Welzel C. (2011) Modernizacija kulturnye izmenenija i demokratija posledovatelnost chelovecheskogo razvitija [Modernization, Cultural Change and Democracy: The Human Development Sequence], Moscow: Novoe izdatelstvo. 
Ionin L. (2000) Sociologiya kultury: put v novoe tysyacheletie [Sociology of Culture: A Way into the New Millennium], Moscow: Logos.

Ivanov D. (2002) Virtualizaciya obshchestva [Virtualization of Society], Saint Petersburg:

Peterburgskoe vostokovedenie.

Kapelyushnikov R. (2013) Povedencheskaya ehkonomika i novyj paternalizm [Behavioral Economics and New Paternalism] (Preprint WP3/2013/o3), Moscow: HSE.

Kapustina E. (2014) Kommunikativnye praktiki vzaimodejstviya vlasti i molodezhi (sociologicheskij analiz) [Communicative Practices of Interaction between Government and Youth (Sociological Analysis)]. Historical and Social-Educational Thought, no 3, pp. 182-190.

Kiselev E. (2013) Osnovnye podhody k issledovaniyu stilya zhizni v sociologii [Basic Approaches to the Study of Life Style in Sociology]. Bulletin of Penza State University, no 1, pp. 63-67.

Komarovsky A. (2014) Neoveberianskaya kultursociologiya Friedricha Tenbrucka [Neoweberian Cultural Sociology by Friedrich Tenbruck]. Sociology, no 1, pp. 69-77.

Lurie D. (2009) Problemy virtualizacii sovremennogo obshchestva i ih sociologicheskoe osmyslenie [Problems of Virtualization of Modern Society and Their Sociological Understanding]. Philosophy and Society, no 4, pp. 64-168.

Marushchak I. (2017) Evolyuciya modeli ehkonomicheskogo cheloveka v teorii chelovecheskogo kapitala: ot homoeconomicus do homotransactus [Evolution of the Model of Economic Man in the Theory of Human Capital: From Homoeconomicus to Homotransactus]. Journal of Creative Economy, vol. 11, no 8, pp. 839-846.

Maslentseva N. (2010) Sociologicheskie osnovaniya koncepcii stilya zhizni [Sociological Foundations of the Concept of Life Style]. Bulletin of the Chelyabinsk State University, no 31, pp. 147-150.

Mikeshina L. (2007) Ehpistemologiya cennostej [Epistemology of Values], Moscow: ROSSPEN.

Miles S. (2000) Youth Lifestyles in a Changing World, Buckingham: Open University Press.

Omelchenko E. (2005) Identichnosti i kulturnye praktik irossijskoj molodezhi na grani XX-XXI vv. [Identity and Cultural Practices of Russian Youth on the Brink of the 20th-21st Centuries] (PhD Thesis), Moscow.

Omelchenko E. (2013) Solidarnosti i kulturnye praktiki rossijskoj molodyozhi nachala XXI veka: teoreticheskij kontekst [Solidarity and Cultural Practices of the Russian Youth of the Early 21st Century: The Theoretical Context]. Sociological Studies, no 10, pp. 52-61.

Roshchina Y. (2007) Sociologiya potrebleniya [Sociology of Consumption], Moscow: HSE.

Smit V. L. (2005) Konstruktivistskaya i ehkologicheskaya racional'nost'v ehkonomicheskoj nauke [Constructivist and Ecological Rationality in Economic Science]. Mirovaya ehkonomicheskaya mysl': skvoz' prizmu vekov. T. 5. Kn. 2: Vsemirnoe priznanie: lekcii nobelevskih laureatov [World Economic Thought: Through the Prism of the Ages, Vol. 5, Book 2: World Recognition: Lectures of Nobel Laureates], Moscow: Mysl, pp. 685-767.

Smith M. B. (1994) Selfhood at Risk: Postmodern Perils and the Perils of Postmodernism. American Psychologist, vol. 49, no 5, pp. 405-411.

Smolin O. (2015) Vysshee obrazovanie: borba za kachestvo ili pokushenie na chelovecheski jpotencial? [Higher Education: The Fight for Quality or an Attempt upon the Human Potential?]. Sociological Studies, no 6, pp. 91-101.

Taylor Ch. (1992) Modernity and the Rise of the Public Sphere. Available at: http://www.mercaba. org/SANLUIS/Filosofia/autores/Contempor\%C3\%A1nea/Taylor,\%20Charles/Modernity\%20 and\%20the\%20Rise\%200f\%20the\%20Public\%20Sphere.pdf (accessed 8 February 2018).

Tenbruck F. (2013) Reprezentativnaya kul'tura [Representational Culture]. Russian Sociological Review, vol. 12, no 3, pp. 93-118.

Tishkov V., Barash R., Stepanov V. (2017) Identichnost i zhiznennye strategii studenchestva [Identity and Life Strategies of the Students]. Sociological Studies, no 8, pp. 81-87.

Toffler E. (2002) Shok bushchego [Shock of the Future], Moscow: AST.

Toshchenko Z. (2008) Paradoksalnyj chelovek [Paradoxical Person], Moscow: YUNITI-DANA.

Ustyugova E. (2006) Stil i kultura: opyt postroeniya obshchej teorii stilya [Style and Culture: An Essay on the General Theory of Style], Saint Petersburg: SPSU. 
Weber M. (1990) “Obiektivnost' social'no-nauchnogo i social'no-politicheskogo poznaniya ["Objectivity" of Social-Scientific and Social-Political Cognition]. Izbrannye proizvedeniya [Selected Works], Moscow: Progress, pp. 345-415.

Žižek S. (2008) Ustrojstvo razryva: parallaksnoe videnie [Break Device: Parallax Vision], Moscow: Evropa.

Zimina O. (2006) Telereklama kak factor formirovaniya stilya zhizni v sovremennom rossijskom obshchestve [TV Advertising as a Factor in the Formation of a Lifestyle in Modern Russian Society] (PhD Thesis), Stavropol: Stavropol State University.

Zubok Y., Chuprov V. (2017) Sovremennaya sociologiya molodyozhi: izmenyayushchayasya realnost i novye teoreticheskie podhody [Contemporary Sociology of Youth: Changing Reality and New Theoretical Approaches]. Rossiya transformiruyushchayasya: Ezhegodnik. 2015 [Russia is Transforming: Yearbook, 2015], Moscow: Novy khronograph, pp. 12-48. 


\title{
«Единственные картины в воспоминании славной войны» Героика, ориентализм и проблемы живописной репрезентации Русско-турецкой войны 1877-1878 г2. *
}

\author{
Андрей Тесля \\ Кандидат философских наук, старший научный сотрудник Academia Kantiana \\ Института гуманитарных наук Балтийского федерального университета им. И. Канта \\ Адрес: ул. А. Невского, д. 14, г. Калининград, Российская Федерация 236016 \\ E-mail: mestr81@gmail.com
}

\begin{abstract}
Русско-турецкая война 1877-1878 гг. породила как со стороны правительства, так и со стороны общества запрос на соответствующую живописную репрезентацию, оцениваемую в категориях "высокого искусства», и выявила неспособность преобладающей эстетики его удовлетворить. Живописные работы, посвященные сюжетам предшествующего Балканского кризиса 1875-1876 гг., легко апеллировали к имеющемуся арсеналу изобразительных средств, в первую очередь обращаясь к ориенталистским мотивам и задействуя интернациональный ориентальный художественный язык. В этом случае таким живописцам, как К. Маковский или В. Поленов, даже не приходилось для достижения эффекта прибегать к некоторым инверсиям, наличествующим в «Туркестанском цикле» В. Верещагина - наличный, разработанный художественный язык позволял без потерь передать желаемое содержание. Напротив, попытки представить живописные репрезентации Русско-турецкой войны обнаружили, что прежняя баталистика уже не воспринимается как собственно «искусство» и не расценивается как надлежащая фиксация «достопамятных событий», а преобладающая новая эстетика оказывается не способной передать желаемые властью пафос и героику. Вместе с тем обнаружилось, что сильный эстетический эффект в военных сюжетах достигается посредством «сериальности», трактовка аналогичных сюжетов как изолированных, самостоятельных не производила значимого эффекта, т. е. живопись как таковая оказывалась несамодостаточна, нуждаясь в помощи текста, последовательности изображений и т. д. Проблема оказалась снята в рамках новых эстетик XX века, однако в последние десятилетия XIX века в связи означенными затруднениями для живописи приобрели новую ценность исторические сюжеты, предоставляя новые возможности для репрезентации героической тематики и одновременно давая большую эстетическую свободу.
\end{abstract}

Ключевые слова: Русско-турецкая война 1877-1878 гг., В. В. Верещагин, общественное мнение, ориентализм, передвижники, репрезентация войны

() Тесля А. А., 2018

() Центр фундаментальной социологии, 2018 DOI: 10.17323/1728-192X-2018-3-240-255

* Исследование выполнено в рамках гранта РНФ (№ 18-18-о0442) «Механизмы смыслообразования и текстуализации в социальных нарративных и перформативных дискурсах и практиках» в Балтийском федеральном университете им. И. Канта. 
Русско-турецкая война 1877-1878 гг. - первая большая война Российской империи, ведшаяся в ситуации уже наличествовавшего «общественного мнения» ${ }^{1}$. Хорошо известно, насколько эта война повлияла, например, на развитие периодической печати - так, ей было обязано своим невиданным взлетом и превращением в общенациональную газету суворинское «Новое время», обеспечившее регулярную и своевременную печать корреспонденций с театра военных действий (Динерштейн, 1998: 55-62, 64, 66-67, 76). В это же время закладываются и основы будущей издательской империи Сытина, начинавшего с «коробейников» и «книгонош», разносной продажи печатных изданий (см.: Рууд, 1996). Более того, в самом решении о вступлении Российской империи в войну с Турцией значительную роль сыграли общественные настроения и необходимость со стороны двора считаться с ними, равно как общественная реакция на заключенный по результатам войны Берлинский договор оказала долговременное влияние на политику империи (см.: Тесля, 2015: 529-551).

Одним из значимых элементов, как влиявших на общественное мнение, так и позволявших судить о состоянии последнего, является изобразительное искусство, в первую очередь - живопись. В отличие от XVIII и первой половины XIX века, когда русский живописный рынок почти целиком определялся двором (что определяло практически монопольное положение Академии художеств, являвшейся одновременно и центром обучения и производства и оценки произведений изящных искусств для основного заказчика), во второй половине XIX века начинает складываться художественный рынок с быстрорастущим числом потребителей и заказчиков. Художественный мир постепенно коммерциализируется ${ }^{2}$ и оказывается тем самым связанным не с узким кругом заказчиков, в первую очередь с императором, а с достаточно широкой публикой, интересам и вкусам которой необходимо соответствовать ${ }^{3}$. Так, в 1871 году возникло Товарищество передвижных художественных выставок, а в 1874-м - Общество выставок художественных произведений, учрежденное Академией в противовес Товариществу. Были попытки, в некоторых случаях довольно успешные, организации индивидуальных выставок.

Война 1877-1878 гг, как и предшествующие войны, стала частью и художественного мира. В официальной корреспонденции из действующей армии от 5 мая 1877 года В. В. Крестовский (печатавшийся в «Правительственном вестнике») изве-

\footnotetext{
1. О проблематике «общественного мнения» в эти годы см.: Сафонова, 2014; Тесля, 2017.

2. Многие из его представителей будут болезненно переживать этот процесс. См., напр., характерное письмо П. П. Чистякова П. М. Третьякову по поводу цены, назначенной Г. И. Семирадским за полотно «Светочи христианства»: «За то, что человек ловок, смел и талантлив, 40 ооо нельзя платить. Нужно ценить честность в деле, уменье и выдержку, а таланты бог дает!» (Галкина, Григорьева, Приймак, 1968: 299, письмо от 28.IV.1877; ср. письмо П. М. Третьякова И. Н. Крамскому от 25.VI.1876: Крамской, 1953: 145-146). О сюжете «художник и деньги» в последние десятилетия XIX - нач. XX в. см.: Северюхин, 2008: 447-458.

3. См. о становлении и развитии художественного рынка Петербурга: Северюхин, 20о8; рассмотрение с этой точки зрения истории ТПХВ: Шабанов, 2015.
} 
щал: «Из числа русских художников при действующей армии находятся пока двое: Е. К. Макаров, состоящий непосредственно при Особе Его Высочества, и В. В. Верещагин, составивший себе почетную известность два года назад большою выставкою [sic! - A. T.] своих картин из средне-азиатской русской и туземной жизни» (Крестовский, 1879: 171-172).

В примечании к книжному (существенно расширенному и дополненному) изданию своих корреспонденций, вышедшему в Петербурге в 1879 году, Крестовский писал:

Впоследствии, а именно в июле месяце 1877 года, приехали еще двое художников, г-да П. Соколов и Буткевич, из коих последний набросал несколько эскизов, ландшафтов, сцен и портретов под Плевной и на Шипке, а из баталистов наших находился в отряде Великого Князя Владимира Александровича г. Коваленский ${ }^{4}$. Но вообще говоря, художников у нас было очень немного, и об этом нельзя не пожалеть, потому что война 1877-1878 годов могла бы представить для их деятельности массу прекраснейшего материала, как в пейзаже, так и в бытовом и военном жанре. В. В. Верещагин, вылечившись от своей раны, полученной при атаке турецкого броненосца на Дунае, возвратился к действующей армии и участвовал в ее предприятиях до самого конца кампании, отличаясь в передовом кавалерийском отряде генерала Струкова не только как художник, но и как волонтер, нередко исполнявший обязанности офицера генерального штаба. Брат его С. В. Верещагин, тоже художник, убит под Плевною зо августа, где он добровольно принял на себя обязанности ординарца при генерале Скобелеве 2-м. (Крестовский, 1879: 172, прим.)

Любопытно, что в этот перечень попали далеко не все русские художники, принимавшие участие в войне, - так, помимо названных на театре военных действий были Н. Н. Каразин, А. П. Боголюбов, В. Д. Поленов и др. Однако совершенно предсказуемо, что центральную роль при перечислении живописцев Крестовский отвел Верещагину. К этому времени последний успел приобрести и всероссийскую, и европейскую известность, в том числе благодаря стратегии презентации своих работ, принципиально отличной от принятой в России, во многом новой и для европейского художественного пространства (см.: Карпова, ред., 2018: 4051). И именно вокруг «Балканского цикла» последнего развернется в начале $1880-\mathrm{x}$ основная полемика, выявляющая проблемы живописной репрезентации войны.

Официальная и официозная реакция на произведения «серьезной живописи», посвященной событиям Русско-турецкой войны 1877-1878 гг., демонстрирует широкий консенсус по поводу устарелости, неактуальности расхожих батальных полотен. В 1880-е и в последующие годы число таких картин еще велико. В частности, целый ряд работ размещен в Военной галерее Зимнего дворца, были и многочисленные заказы для отдельных полков, а также полотна, предназначенные в дар и призванные запечатлеть «привычным» образом значимые события военной

\footnotetext{
4. Принятое современное написание: П. О. Ковалевский.
} 
истории. Однако они не расценивались как надлежащие визуальные образы последней войны. Подобного рода произведения отойдут в область «рутины» и не станут ни экспонатами больших коллективных выставок, ни индивидуальных т. е. окажутся в области «художественного ремесла».

Расхождение во взглядах произошло по поводу того, можно ли «Балканский цикл» Верещагина рассматривать в качестве искомой/приемлемой визуальной репрезентации. Стасов ${ }^{5}$, передавая публике свои впечатления от осмотра парижской мастерской художника, работавшего над циклом, в заключение статьи утверждал: «...пусть только Верещагин доведет начатое дело до конца, и нам нечего будет тужить и беспокоиться: та небывалая, несравненная картинная галерея, какой требовала война, будет создана русским искусством, и великие дни великой русской истории 77 года навеки будут занесены на несокрушимые скрижали» (Стасов, 1937a: 320).

Напротив, цесаревич Александр Александрович писал художнику А. П. Боголюбову 21 декабря 1879 г. в Париж: «Сегодня я получил... каталог картинам Верещагина. <..> Читая каталог картинам Верещагина, а в особенности тексты к ним, я не могу скрыть, что было противно читать всегдашние его тенденциозности, противные национальному самолюбию... Жаль, что это будут единственные картины в воспоминание славной войны 1877-78 г2., и это все, что мы оставим нашему потомству [выделено нами. - A. T.]» (Новицкий, 19о0: 12-13). В этом письме примечательно сразу несколько обстоятельств: во-первых, несмотря на то что в это время многим художникам были официально заказаны картины на соответствующие сюжеты (которые и будут написаны на протяжении 1880-х годов), произведения Верещагина рассматриваются как «единственные». Иначе говоря, только они отнесены к значимым произведениям искусства. Во-вторых, адресат письма - А. П. Боголюбов. Это не только художник, весьма близкий к императорской фамилии, выполнявший своего рода роль русского «агента» в художественном мире Франции, но одновременно и один из живописцев, принявших участие в войне 1877-1878 гг. и создавший серию рисунков, которые в конце 1870-х были фототипическим способом изданы в Петербурге (см.: Боголюбов, 1879). Если работы Боголюбова, как можно предположить, не считались картинами «в воспоминание славной войны», в том числе и по сюжетной ограниченности (они были посвящены исключительно морякам; понятно, что роль флота в минувшей войне была весьма невелика), то гораздо более значимо, что цесаревич не рассматривал ни на тот момент, ни в перспективе в качестве значимого и творчество В. Д. Поленова, который состоял при Рущукском отряде, которым командовал Александр Александрович.

Трудности, с которыми встретились живописцы при работе над сюжетами Русско-турецкой войны при попытке выйти за пределы официозной баталистики, хорошо видны на передвижных художественных выставках 1878-го и последующих

5. Об отношениях Стасова и Верещагина и об оценках критиком работ художника в исторической динамике см.: Каренин, 1927: 528-539. 
годов. Прежде всего следует отметить малочисленность полотен на сюжеты, так или иначе связанные с войной. И. Н. Крамской писал И. Е. Репину 26.III.1878 о VI выставке, открывшейся в начале марта того года: «...три вещи, в равной степени интересные и достойные. Клодта „Прощание перед отъездом“6. Офицер уезжает, должно быть, в Болгарию, и сидит на диване с матерью. Очень мило. Маковского „С ангелом!“ ... Васнецова „Чтение телеграммы“7 очень типично и жизненно. Мне эта картинка очень нравится, но зато все остальное, боже мой!!! Нет, нехорошо, этак он никогда ничего не продаст, будет вечно бегать и нюхать: нет ли где деревяшки? ${ }^{8}$ (Крамской, 2014: 275-276). Из 103 произведений, выставленных в 1878 году (см. каталог выставки: Андреева и др., 1987: 150-157), к сюжетам только что минувшей войны относились только две картины, причем обе трактовали отражение войны на мирной жизни - взламывающей последнюю или приносящую тревогу.

Заметим, что на VI и VII выставках свои работы представлял В. Д. Поленов, ставший членом ТПХВ 27.V.1878 года. Вернувшийся с войны и ранее побывавший добровольцем в Сербии в 1876 году, близкий к славянофилам, он не выставляет работы, связанные с военными сюжетами. Напротив, в 1878 году он представит только что написанный «Московский дворик» $(1878$, ГТГ), ставший одной из наиболее известных работ художника, а в следующем году — три картины: «Бабушка и внучка» («Бабушкин сад», 1878, ГТГ), «Лето» (обозначено в каталоге ТПХВ как собственность Д. П. Боткина, в настоящее время местонахождение неизвестно) и «Удильщики» ${ }^{9}$.

Сюжеты, связанные с войной, появятся лишь два года спустя, на VIII передвижной выставке: «На войну» К. А. Савицкого (1880, ГТГ) ${ }^{10}$, знаменитые «Проводы новобранца» И. Е. Репина $(1879$, РМ) и две работы В. Д. Поленова - «Долина смерти» и «Турецкий аванпост». И здесь можно увидеть характерное удвоение: с одной стороны, повтор в большем масштабе, с большей проработкой сюжетов, родственных выставленным уже в 1878 году, а с другой - Поленов демонстрирует трактовку войны, схожую верещагинской. Правда, в отличие от последнего, избирая менее напряженные сюжеты. О логике же предстоящей в Петербурге верещагинской выставки (после демонстрации в Париже), М. М. Антокольский писал С. И. Мамонтову 10/22.I.1880:

6. Современное название: «Перед отъездом на войну» (1878, Ивановский художественный музей).

7. Современное название: «Военная телеграмма» $(1878$, ГТГ).

8. Крамской в данном случае имеет в виду поиск заказов гравюр на дереве - т. е. для дешевых, «народных» изданий.

9. Обозначено в каталоге ТПХВ как «собственность г-на Матвеева», к этому сюжету Поленов обращался неоднократно, какая именно из известных на данный момент картин является выставленной на VII выставке - неизвестно.

10. Известная одноименная картина К. А. Савицкого, хранящаяся в РМ, исполнена в 1888 г. Картина 188 о г. была разрезана самим художником на несколько частей, большая часть из которых сохранилась и хранится в ГТГ (см.: Андреева и др., 1987: 200, илл. № 135; Гольдштейн, 1957). 
Не знаю, что дадут выставки академическая и передвижная, но нет сомнения, что выставка Верещагина произведет сильное впечатление картинами из последней войны. Тут он теперь как раз хватает за сердце, да и за больные его струны.

Тут множество семейств траура еще не сняли, у многих свежо в памяти то, что они перечувствовали; многие еще не успели дочитать того, что писалось о войне; а тут живо, наглядно, во всей наготе являются перед вами все ужасы войны, с отвратительнейшей стороны. Положим, что художники найдут множество недостатков, критики скажут, что он односторонен, но это потом, потом! Лишь когда рана окончательно заживет, Верещагин займет должное место в истории искусства России; но теперь всем достаточно впечатления, одного намека, и сердце защемит до боли, а тогда можно ли думать и рассуждать? (Антокольский, 1905: 403-404)

Наибольший интерес с точки зрения различий в репрезентации войны представляют картины - отклики на события Балканского кризиса 1875-1876 гг. (восстание в Боснии и Герцеговине, апрельское восстание в Болгарии, Сербо-Черногорско-Турецкая война 1876 года) и на войну 1877-1878 гг. К числу наиболее известных произведений, вызванных Балканским кризисом, принадлежат «Балканская мученица» М. О. Микешина (1876, литография журнала «Пчела» - см.: собрание ГИМ; Журавская и др., 2017: 34) и «Болгарская мученица» ${ }^{11}$ К. Е. Маковского (1877, Национальный художественный музей Республики Беларусь). Характеризуя эти работы, А. А. Бобриков пишет:

Главным патриотом [на волне панславистского энтузиазма 1876 г.] стал коммерческий гений Михаил Микешин... Его соперник по бизнесу Константин Маковский прославился картиной «Болгарская мученица»... изображающая несчастную христианскую женщину, убитую турецкими башибузуками прямо в церкви; не вполне одетую, в соблазнительной позе (и еще одну, которую явно ждет та же участь). Романтизм с оттенком политики - голые женщины «с тенденцией» - это новая формула коммерческого успеха эпохи предвоенного романтизма» - со своим прототипом на весь XIX и значительную часть ХХ века — «Хиосской резней» Делакруа. (Бобриков, 2012: 398-399)

В «Балканской мученице» можно видеть, как Микешин использует значительную часть привычного арсенала религиозной живописи, обильно прибегая к аллегориям, - мученица оказывается распята в позе, напоминающей андреевский крест (при этом апостол Андрей является святым покровителем Константинополя), на груди у нее большой православный крест, в тело ее художник воткнул четыре стрелы, вдохновляясь иконографией св. Себастьяна и т.д.

Маковский, в свою очередь, создает применительно к политическому контексту универсальный живописный текст.

11. Другое название картины, под которым она упоминалась в 1877 г., «Турки в Болгарии» (Северюхин, 2008: 430). 
- Bo-первых, отсылающий к «романтической битве» 1820-х - от Жерико до Делакруа, тем самым задействуя отсылки к либеральной традиции.

- Во-вторых, противопоставление «христианства/ислама», что прочитывается и как «запад/восток», и как «цивилизация/варварство». Здесь для зрителя остается широкий диапазон интерпретаций, которые ему предпочтительнее избрать в своих симпатиях к Балканам - от сочувствия к «единоверцам» до сочувствия поруганным и беззащитным.

- В-третьих, для зрителя остается возможность внеполитического прочтения, как «хорошего куска живописи», упражнения на тему в это время ставшего «классиком» Делакруа (и через него - Рубенса).

Примечательно, что в рамках культа «достоверности» Маковский предпримет даже недолгую поездку на театр военных действий, для самой картины совершенно избыточную, поскольку

для одной [из «мучениц». - A. T.] (прижимающей к груди младенца), вспоминал его сын, известный художественный критик Сергей Константинович, - позировала моя мать; лицо другой, распростертой на полу уже мертвой женщины, написано с тетки, Александры Павловны Летковой. Обе очень похожи - отец оставался портретистом и в жанровых композициях. <...> Тогда же написан и другой, не менее патетический военный сюжет: большая акварель - болгарка над трупом убитого ребенка, на фоне охваченной пожаром окрестности. Болгарку отец писал тоже с жены, так недавно еще оплакавшей свою дочь. Акварель была приобретена значительно позже вел. кн. Владимиром Александровичем. (Маковский, 1955: 45-46)

«Болгарская мученица» имела большой успех. Она была выставлена сначала на академической выставке, а затем - в декабре 1877 года, в пользу Красного Креста, на специальной, в помещении Министерства внутренних дел (Северюхин, 20о8: 430-431; Маковский, 1955: 46), вместе с другой картиной Маковского, «Перенесение ковра» $(1876$, РМ). Выставка двух работ Маковского демонстрирует, что их общий «ориентальный» характер оказывается преобладающим над различием сюжетов.

Поленов, который в дальнейшем столкнется с существенными трудностями при изображении событий войны 1877-1878 гг., перед отправкой добровольцем в Черногорию создаст одну из наиболее успешных на тот момент своих работ «Герцеговинка в засаде» (май 1876 года, написана в Париже), где изображена вооруженная девушка на фоне горного пейзажа ${ }^{12}$. Репин, друживший с Поленовым со времен ученичества в Академии и некоторое время снимавший с ним вместе жилье в Париже, писал 20.I.1877 - увещевая его писать с натуры из «русской действительности»: «Можно [ли] после этого вернуться в rue Blanche, 72, и там из вечно того же шарфа сочинять „Герцеговинку“ и пр. и пр.» (Сахарова, 1950: 143).

12. В письме к В. В. Стасову от 18.І.1877 Поленов оценивает ее в $6 о 0$ рублей — на тот момент она была одной из самых дорогих его картин (Сахарова, 1950: 140). 
Любопытно, что в записках о Русско-турецкой войне Верещагин оказывается гораздо более «ориентален», чем в живописи. Он в стиле «турецких повестей» рассказывает и о повадках каваса Христо (Верещагин, 1898: 293, 307-308), и о попытках грека Фасса в занятом русскими войсками Адрианополе присвоить себе сделавшуюся вакантной должность губернатора (Там же: 276-281, 285-286, 287-288), и об албанцах-башибузуках, творивших вполне хрестоматийные зверства и которых, ради живописного опыта, Верещагин желал повесить, но чего по распоряжению военных властей не удалось (Там же: 288-292). Сцена встречи русского передового отряда жителями Адрианополя, покинутого турецкой армией, как она описывается Верещагиным, годится на парадное полотно:

Только лишь въехали мы и осмотрелись, как навстречу из примыкавшего болгарского квартала вышла огромная процессия из представителей разных церквей и религий. Впереди был греческий митрополит (Дионисий), затем армянский архиепископ, болгарский священник, еврейские раввины, турецкие муллы и с ними громадная толпа народа - вся площадь покрылась людьми; я думаю, было тысяч 30-40. <...> Мы приложились к крестам и поцеловали пухлую, мягкую руку митрополита, видимо, оставшегося довольным таким знаком почтения. (Там же: 279-280)

Создается впечатление, что Верещагин убирает «картинные» сюжеты, помещая их в текст, в то время как для живописи отводит «повседневные», «негероические» сюжеты ${ }^{13}$.

Таким образом, погружение в изучение ближайших по времени живописных отображений Русско-турецкой войны 1877-1878 гг., имеющих самостоятельную художественную ценность, демонстрирует кризис живописной репрезентации войны. Художественное новаторство Верещагина вызывает неприятие со стороны как властей, так и значительной части публики ${ }^{14}$, тогда как иные варианты отражения

13. Так, из рассказа о двух башибузуках и их зверствах в живописном плане оказываются две картины, причем лишенные внешней динамики, - «Башибузук (Албанец)» (с 1932 г. в ГМИИ РТ, ранее - в собрании П. М. Третьякова) и «Два ястреба. Башибузуки» (ГТГ, поступление начала 1920-х гг., ранее - в собрании Н. А. и А. Н. Терещенко, Киев). На первой изображен картинный, одетый в алую рубашку и носящий одноцветный ей тюрбан, подпоясанный широким кушаком, за который вправлены ятаган, ружье и пистолет, башибузук, чьи руки связаны за спиной, а за ним - сливаясь с темным фоном помещения - двое русских солдат-стражников, у одного из них - винтовка с примкнутым штыком, образующая диагональ к телу албанца. На второй - тот же персонаж (если не считать изменения цвета усов, которые из черных стали седыми), связанный спиной к спине с собратом, сидящий на земле посреди русских военных палаток - и на фоне, в верхнем левом углу — часовой, стоящий к ним спиной, с той же винтовкой - позу часового можно истолковать как охрану пойманных башибузуков от расправы местных жителей. В книге очерков Верещагина репродукция с нее помещена под названием «Связанные албанцы» (Верещагин, 1898: 289).

Все напряжение изображаемого считывается не только и не обязательно вместе с текстом - но по крайней мере в динамике ряда живописных изображений, лишенная же «сериальности» последняя картина читается как родственная «Турецкому аванпосту» и аналогичным Поленова.

14. Примечательно, что В. В. Стасов, описывая свое первое знакомство с частью «Балканского цикла» Верещагина, делает акцент сугубо на художественной стороне, оставляя всякую трактовку с точки зрения сюжетной: «Чудесны туркестанские и индийские картины Верещагина, великолепные золотые 
войны прочитываются как недостаточные - фиксирующие нечто связанное с войной, но не войну «как таковую», так и остающуюся незапечатленной. Показательно, что Крестовский в цитированном в начале статьи примечании к своим военным корреспонденциям от 1879 года говорит о материале для живописцев «как в пейзажном, так и в бытовом и военном жанре» (Крестовский, 1879: 172, прим.) Книга Крестовского выходит еще до выставки Верещагина и до демонстрации широкой публике большей части живописных работ, связанных с войной 1877-1878 гг., - тем характернее порядок перечисления жанров, где на первом месте оказывается пейзаж. Большая часть художественной продукции Поленова, не упомянутого Крестовским среди живописцев, находившихся в армии, составят именно пейзажи и бытовые сценки. Аналогичным образом можно истолковать и значительную часть работ Верещагина, отнеся их к «военным пейзажам» и «военным бытовым» картинам, - его способ преодоления исчезающей репрезентации войны заключается в создании серий и помещении картин одновременно в насыщенное текстовое пространство авторских комментариев, очерков и т. п.

Если ориентальные изображения что «мучениц», что «мучителей» имели не только готовый, но и вполне живой канон - ориентированный на Делакруа и последующую традицию, позволяющую совместить целый ряд тем, не вводя их в конфликт, то массовая война, ведущаяся армией призывников и вольноопределяющихся, исключала для образованного зрителя бесстрастно-любопытствующее рассмотрение. Язык художественного и публицистического описания войны был определен Толстым - «Севастопольскими рассказами» (1855), «Казаками» (1863) и «Войной и миром» (1867-1869). На него ориентирован и самый популярный русский военный корреспондент этой войны В. И. Немирович-Данченко. Примечательно, что современный литературовед, анализируя сборник военных корреспонденций Немировича-Данченко, изданных затем в качестве книги под заголовком «Год войны» и принесших ему уже и международную известность, говорит и о фабуле, и о метасюжете книги, рассматривая ее как целостное художественное произведение (Грачёва, 2013: 13). В романах, созданных в последующие годы, где Немирович-Данченко будет старательно разрабатывать тему Русско-турецкой войны ${ }^{15}$, характерно сочетание документальных военных очерков, наложенных на какой-

краски и яркий блеск южной природы, но еще поразительнее мне показались теперь пустынные поля и горы, где толстые слои снега истоптаны тысячами русских и турецких шагов. Несколько десятков картинок - все только серых и белых, все только снег да туман, да облака, да жидкие ряды деревьев и однако же [sic! - A. T.], какая у Верещагина вышла цепь колоритных, разнообразных сцен. И что за tour de force, целая картинная галерея из одного снега и белой краски. Никто еще не осмеливался быть так дерзок и правдив. Национальнее и проще этого, право, кажется, ничего не найдешь ни у какой нации» (Стасов, 1937а: 318). Трактовка «простоты», «правды» изображенного как «национального» любопытным образом выливается, быть может, не вполне осознанным образом, в интерпретацию природы Румелии как «нашей»: «Ни у кого из наших пейзажистов никогда еще не была выражена с большею правдою наша родная славянская серенькая, хмуренькая, маловзрачная природа и день» (Стасов, 1937а: 319).

15. Им будут написаны: «Гроза» (1879), «Плевна и Шипка» (1881), «Вперед!» (1883), «Боевая страда (от Плевны до Шипки)» (1890), «В огне» (1892). 
либо весьма нехитрый сюжет. Так, в «Плевне и Шипке», одном из его «больших романов», сюжетной канвой служит история любви бывшей актрисы, ушедшей от своей пустой жизни в сестры милосердия, и вольноопределяющегося. Но эта фабула столь необязательна, что в первой части романа автор может себе позволить на сотню страниц вовсе забыть о своих героях, притом что большая часть остальных «персонажей» романа - реальные участники войны - описываются посредством схематизированной «психологической прозы». Война изображается глазами ее рядовых участников, правда, только с русской стороны. Но противник, в свою очередь, разделяется на три группы: во-первых, «турки» вообще, враг, творящий зверства, угнетающий славян и прочее, но именно в силу абстрактности ему отведено минимум места. Во-вторых, турецкая армия - обретающая свою конкретность, умелость действий, героизм и т. п. и потому значимая как достойный враг. И в-третьих, конкретные турки, турецкие солдаты, которые как «люди» оказываются симметричны русским солдатам. Негодование автора и вслед за ним читателя направлено на собственных «начальников» и фигуры, с ними связанные, - на немецкого доктора, приписанного к штабу, получающего награды и лишь вредящего делу своей трусостью и некомпетентностью (см., напр.: Немирович-Данченко, 1902: 9), на командиров, отдающих неверные приказы, и т. п. Поскольку противник действует в своей логике, то его стремлению всячески помешать русским войскам нелепо возмущаться. Примечательно, что и изображения собственных и турецких военачальников в русской печати не различаются - они подаются однородным образом. Например, выпущенное литографией Яковлева (Москва) изображение Осман-паши (цензурное разрешение датировано 2 декабря 1877 г.) подписано так: «Храбрый защитник Плевны Осман-паша, взятый в плен русскими войсками 1877 года ноября 28 дня» (см. репродукцию: Журавская и др., 2017: 228).

Официальные изображения и «лубок» (подразумевая под последним применительно ко второй половине XIX - нач. XX века «картинки для народа», зачастую имеющие весьма немного признаков собственно «лубка»: Иткина, 2013: 3-4) совпадают в своей сосредоточенности на «большом», «героическом» уровне событий. Так, выполненный в Хромолитографии В. В. Пономарева листок «Взятие „Плевны“ и сдача Осман-паши» напоминает композиционно и многими элементами художественного языка многочисленные парадные «капитуляции», распространенные в европейской живописи с конца XVI века и шедевры вроде «Сдачи Бреды» Веласкеса (La rendición de Breda o Las lanzas, 1634, Museo del Prado).

Проблема, явственно обнаруженная живописными репрезентациями войны 1877-1878 гг., заключалась в невозможности в рамках новой преобладающей эстетики сообщить героический и мобилизующий пафос, выполнять роль глорификации «исторических деяний». Стасов в статье «Двадцать пять лет русского искусства», подводящей итоги художественному развитию эпохи и обозначившей перспективы, писал: «Грубо ошибся бы тот, кто подумал бы, что Верещагин есть только живописец „военный“. Никогда! Солдаты Верещагина - это все тот же народ, только случайно носящий мундир и ружье» (Стасов, 1937б: 105). Современни- 
ки часто сравнивали его живопись (подразумевая в первую очередь Туркестанский и Балканский циклы) с Толстым, имея в виду, видимо, «Севастопольские рассказы», а критик «La Parisien» в 1888 году добавил к этому ряду и Достоевского (Стасов, 1952: 121). Отчасти это отражало фиксацию «литературности» данного рода живописи, способность - соответствующую желанию самого автора - быть прочитанной как некое повествование (Верещагин-мл., 1982: 146; Карпова, 2018: 56-57). Но сопоставление с другими попытками представить живописную репрезентацию войны 1877-1878 гг. демонстрирует, что возникающее затруднение коренилось отнюдь не в частных, эстетических и мировоззренческих особенностях Верещагина. Если его «Балканский цикл» и вызывал отторжение со стороны цесаревича Александра Александровича, то последний отнюдь не смог противопоставить ему нечто иное, предпочитаемое. Напротив, наследнику престола оставалось лишь сожалеть, никак не обозначая, каким ему самому хотелось бы видеть надлежащую живописную память о войне.

Как отмечалось ранее, у художников не возникало трудностей с представлением «ориентальных» работ - проблемы начинались там, где требовалось изобразить персонажей, которых зрителю надлежало отождествить с собой, представить последних в активной позиции, в рамках наличной эстетики передать «правду», причем историческую, то есть исключая возможность прибегать к арсеналу аллегорических средств.

Разрешение этой проблемы произойдет уже в новом столетии, в рамках иных эстетик - через выход к символическому и далее через создание художественного пространства, размыкающего противопоставление достоверного/ложного. Так, например, уже в Первую мировую войну К. Петров-Водкин откроет возможность нового пафоса и героики в рамках высокого художественного языка, а следом возникнет новая разнообразная эстетика, работающая с героическим и мобилизующим, позволяющая вновь «единственного» и «конкретного» представить выразителем не только «удела человеческого», но и «общего действия». Для ближайшей перспективы, 1880-1890-х гг., возможность заключалась в ином - перемещении сюжета в прошлое, позволяющем одновременно и проецировать современное в минувшее, и предполагать «иных людей, иные нравы», высшие, чем современные зрители. И начинается расцвет исторической живописи, в том числе открывающей новые художественные возможности и приход новых эстетик XX века.

\section{Список сокращений}

ГИМ - Государственный исторический музей

ГМИИ РТ - Государственный музей изобразительных искусств Республики Татарстан

ГТГ - Государственная Третьяковская галерея

РМ - Государственный Русский музей

ТПХВ - Товарищество передвижных художественных выставок 


\section{Литература}

Андреева В. В., Астафьева М. В., Гольдштейн С. Н., Приймак Н. Л. (сост.). (1987). Товарищество передвижных художественных выставок: письма, документы. 1869-1899 гг. М.: Искусство.

[Антокольский M. М.] (1905). Марк Матвеевич Антокольский: его жизнь, творения, письма и статьи / Под ред. В. В. Стасова. СПб.: М. О. Вольф.

Бобриков А. А. (2012). Другая история русского искусства. М.: Новое литературное обозрение.

Боголюбов А. П. (1879). Эпизоды войны 1877-1878 гг. Подвиги наших моряков. 10 фототипий с рисунков профессора А. П. Боголюбова. СПб.: А. Беггров.

Боткина А. П. (1993). Павел Михайлович Третьяков в жизни и искусстве / Под общ. ред. Н. Л. Приймак. М.: Искусство.

Верещагин В. В. (1898). На войне в Азии и Европе. М.: И. Н. Кушнерев и Ко.

Верещцагин B. В. (2014). Очерки, наброски, воспоминания / Сост. Т. Н. Чернышева. СПб.: Лениздат.

Верещзагин В. В., мл. (1982). Воспоминания сына художника. Л.: Художник РСФСР.

Галкина Н. Г., Григорьева М. Н., Приймак Н. Л. (сост.). (1968). Письма художников Павлу Михайловичу Третьякову. 1870-1879. М.: Искусство.

Гольдштейн С. Н. (1957). Из истории создания картины К. А. Савицкого «На войну» // Искусство. № 4. С. 62-65.

Грачёва А. М. (2013). Правдивые приключения и необыкновенные книги «русского дома» (Василий Иванович Немирович-Данченко) // Немирович-Данченко В. И. Цари биржи: каиново племя в наши дни; Сластеновские миллионы / Сост. А. М. Грачёвой. СПб.: Политграф. С. 5-22.

Динерштейн Е. А. (1998). А. С. Суворин: человек, сделавший карьеру. М.: РОССПЭН.

Журавская И. Л., Колганова Е. В., Марштупа Г. С. (сост.). (2017). «За други своя»: к 140-летию войны за освобождение Болгарии. 1877-1878: Каталог выставки. М.: Государственный исторический музей.

Иткина Е. И. (2013). Династия Романовых в массовой печатной графике XVIIIXIX веков. Из собрания Исторического музея. М.: Исторический музей.

Каренин Влад. [Комарова В. Д.] (1927). Владимир Стасов: очерк его жизни и деятельности. Ч. 2. Л.: Мысль.

Карпова Т. Л. (ред.). (2018). Василий Верещагин: Альбом. М.: Государственная Третьяковская галерея.

Крамской И. Н. (2014). Письма к художникам (Ф. А. Васильеву и И. Е. Репину) / Сост. А. Г. Обрадович. СПб.: Лениздат.

Крамской И. Н. (1953). Переписка И. Н. Крамского: И. Н. Крамской и П. М. Третьяков. 1869-1887. М.: Искусство.

Крестовский В. В. (1879). Двадцать месяцев в действующей армии (1877-1879). Письма в редакцию газеты «Правительственный вестник» от ее официаль- 
ного корреспондента, лейб-гвардии уланского Его Величества полка штабсротмистра Всеволода Крестовского. Т. 1. СПб.: Типография Министерства внутренних дел.

Маковский С. К. (1955). Портреты современников. Нью-Йорк: Изд-во им. Чехова. Немирович-Данченко В. И. (1902). Плевна и Шипка. Из событий последней войны. Ч. 2. СПб.: П. П. Сойкин.

Новицкий А. П. (сост.). (190о). Письма императора Александра III к А. П. Боголюбову. СПб.: М. Стасюлевич.

Рууд Ч. (1996). Русский предприниматель московский издатель Иван Сытин / Пер. с англ. А. Б. Лещинского. М.: Терра.

Сафронова Ю. (2014). Русское общество в зеркале революционного террора. 18791881 годы. М.: Новое литературное обозрение.

Сахарова Е. В. (1950). Василий Дмитриевич Поленов: письма, дневники, воспоминания / Под общ. ред. А. Леонова. М., Л.: Искусство.

Северюхин Д. Я. (2008). Старый художественный Петербург: рынок и самоорганизация художников от начала XVIII века до 1932 года. СПб.: Міръ.

Стасов В. В. (1937а). Избранные сочинения. Т. 1: Обзоры. Вставки. Полемика. М., Л.: Искусство.

Стасов В. В. (1937б). Избранные сочинения. Т. 2: Статьи об искусстве. М., Л.: Искусство.

Стасов В. В. (1952). Статьи и заметки, публиковавшиеся в газетах и не вошедшие в книжные издания. Т. 1 / Сост. О. И. Гапоновой, В. М. Лобанова, А. Н. Щекотовой. М.: Изд-во Академии художеств СССР.

Тесля А. А. (2015). «Последний из „отцов“»: биография Ивана Аксакова. СПб.: Владимир Даль.

Тесля А. А. (2017). Кто говорит и кого (не) надлежит слышать: «общественное мнение» в Российской империи 2-й половины XIX века // Пугачева М. Г., Жарков В. П. (ред.). Пути России. Т. 22: Война и мир. М.: Нестор-История. С. 93-109.

Шабанов А. Е. (2015). Передвижники: между коммерческим товариществом и художественным движением / Под науч. ред. И. А. Доронченкова. СПб.: ЕУСПб. 


\title{
"The Only Pictures in Memory of the Great War": The Heroic Spirit, Orientalism, and the Problems of Representational Depictions of the Russo-Turkish War of 1877-1878
}

\author{
Andrei Teslya \\ Candidate of Philosophical Sciences, Senior Research Fellow, Academia Kantiana, Institute of Humanities, \\ Immanuel Kant Baltic Federal University \\ Address: A. Nevskogo str., 14, Kaliningrad, Russian federation 236016 \\ E-mail: mestr81@gmail.com
}

The Russo-Turkish War of 1877-1878 spawned a request from both the government and the public for an appropriate pictorial representation to be evaluated in the categories of 'high art', a request which revealed the inability of the predominant aesthetics to be satisfied. The paintings on the subjects of the preceding Balkan Crisis of 1875-1876 easily appealed to the existing reserve of descriptive means in primarily appealing to Orientalist motives by using the international Oriental-artistic language. In this case, painters such as K. Makovsky or V. Polenov did not need to resort to some inversions in the "Turkestan Series" by V. Vereshchagin: the developed artistic language allowed the conveying of the desired content without loss. On the contrary, attempts to present pictorial representations of the Russo-Turkish War found that the old military art was no longer perceived as genuine "art". Thus, in not being regarded as a proper fixation of "memorable events", the prevailing new aesthetics was unable to convey the pathos and heroics desired by the authorities. At the same time, it was found that a strong aesthetic effect in military plots was achieved through "seriality", the interpretation of similar plots as isolated and independent. However, this did not produce a significant effect, that is to say, painting as such was not selfsufficient since it required the assistance of the text, the sequence of images, etc. The problem was reduced significantly with the new aesthetics of the 2oth century, and in the last decades of the 19th century, in connection with mentioned above difficulties of painting, historical plots acquired new value, providing new opportunities for the representation of heroic themes while simultaneously giving greater aesthetic freedom.

Keywords: Russo-Turkish War of 1877-1878, V. V. Vereshchagin, public opinion, Orientalism, Peredvizhniki (The Wanderers), representation of war

\section{References}

Andreeva V., Astafieva M., Goldstein S., Priymak N. (eds.) (1987) Tovarishchestvo peredvizhnyh hudozhestvennyh vystavok: pis'ma, dokumenty. 1869-1899 gg. [Partnership of Mobile Art Exhibitions: Letters, Documents. 1869-1899], Moscow: Iskusstvo.

[Antokolsky M.] (1905) Mark Matveevich Antokol'skij: ego zhizn', tvoreniya, pis'ma i stat'i [Mark Matveyevich Antokolsky: His Life, Works, Letters and Articles] (ed. V. Stasov), Saint Petersburg: M. Wolf.

Bobrikov A. (2012) Drugaya istoriya russkogo iskusstva [Another History of Russian Art], Moscow: New Literary Observer.

Bogolyubov A. (1879). Epizody vojny 1877-1878 gg. Podvigi nashih moryakov. 10 fototipij s risunkov professora A. P. Bogolyubova [Episodes of War 1877-1878. Deeds of Our Sailors. 10 Phototypes from Drawings of Professor A. Bogolyubov], Saint Petersburg: A. Beggrov.

Botkina A. (1993) Pavel Mihajlovich Tret'yakov v zhizni i iskusstve [Pavel Mikhailovich Tretyakov in Life and Art], Moscow: Iskusstvo.

Dinershtein E. (1998) A. S. Suvorin: chelovek, sdelavshij kar'eru [A. Suvorin: Person Who Made a Career], Moscow: ROSSPEN.

Galkina N., Grigorieva M., Priymak N. (ed.) (1968) Pis'ma hudozhnikov Pavlu Mihajlovichu Tret'yakovu. 1870-1879 [Letters of the Artists to Pavel Tretyakov, 1870-1879], Moscow: Iskusstvo. 
Goldstein S. (1957) Iz istorii sozdaniya kartiny K. A. Savickogo "Na vojnu" [From the History of the Creation of Painting "At War" by K. Savitsky]. Iskusstvo, no 4, pp. 62-65.

Gracheva A. (2013) Pravdivye priklyucheniya i neobyknovennye knigi "russkogo doma" (Vasilij Ivanovich Nemirovich-Danchenko) [True Adventures and Unusual Books of "Russian House" (Vasily Nemirovich-Danchenko)]. Nemirovich-Danchenko V., Cari birzhi: kaninovo plemya v nashi dni; Slastenovskie milliony [Kings of Exchange: Kaninovo Tribe in These Days; Slastenovsky's Millions] (ed. A. Gracheva), Saint Petersburg: Politgraf, pp. 5-22.

Itkina E. (2013) Dinastiya Romanovyh v massovoj pechatnoj grafike XVIII - XIX vekov: iz sobraniya Istoricheskogo muzej [Dynasty of Romanovs in Mass Printing of the 18th-19th Centuries: From the Collection of Historical Museum], Moscow: Historical Museum.

Karenin Vlad [Komarova V.] (1927) Vladimir Stasov: ocherk ego zhizni i deyatel'nosti. Ch. 2 [Vladimir Stasov: An Outline of His Life and Work, Part 2], Leningrad: Mysl.

Karpova T. (ed.) (2018) Vasilij Vereshchagin: Albom [Vasily Vereshchagin: Album], Moscow: State Tretyakov Gallery.

Kramskoy I. (1953) Perepiska I. N. Kramskogo: I. N. Kramskoy i P. M. Tretyakov. 1869-1887

[Correspondence of I. Kramskoy: I. Kramskoy and P. Tretyakov, 1869-1887], Moscow: Iskusstvo.

Kramskoy I. (2014) Pis'ma k hudozhnikam (F. A. Vasil'evu i I. E. Repinu) [Letters to Artists (to F. Vasiliev and I. Repin)] (ed. A. Obradovitch), Saint Petersburg: Lenizdat.

Krestovsky V. (1879) Dvadcat' mesyacev v dejstvuyushchej armii (1877-1879): pis'ma v redakciyu gazety "Pravitel'stvennyj vestnik" ot ee oficial'nogo korrespondenta. T. 1 [Twenty Months in the Army (1877-1879): Letters to Editorial Office of Newspaper "Pravitelstvenny Vestnik" from Its Official Correspondent, Vol. 1], Saint Petersburg: Ministry of Internal Affairs.

Makovsky S. (1955) Portrety sovremennikov [Portraits of Contemporaries], New York: Chekhov Publishing House.

Nemirovich-Danchenko V. (1902) Plevna i Shipka: Iz sobytij poslednej vojny. Ch. 2 [Plevna and Shipka: From the Events of Last War, Part 2], Saint Petersburg: P. Soykin.

Novitsky A. (ed.) (1900) Pis'ma imperatora Aleksandra III k A. P. Bogolyubovu [Letters of Emperor Alexander III to A. Bogolyubov], Saint Petersburg: M. Stasyulevitch.

Ruud Ch. (1996) Russkij predprinimatel' moskovskij izdatel' Ivan Sytin [Russian Entrepreneur Moscow Publisher Ivan Sytin], Moscow: Terra.

Safronova Y. (2014) Russkoe obshchestvo v zerkale revolyucionnogo terrora. 1879-1881 gody [Russian Society in Mirror of Revolutionary Terror, 1879-1881], Moscow: New Literary Observer.

Sakharova E. (1950) Vasilij Dmitrievich Polenov: pis'ma, dnevniki, vospominaniya [Vasily Dmitrievich Polenov: Letters, Diaries, Memoirs], Moscow: Iskusstvo.

Severyukhin D. (2008) Staryj hudozhestvennyj Peterburg: rynok i samoorganizaciya hudozhnikov ot nachala XVIII veka do 1932 goda [Old Art Petersburg: Market and Self-organization of Artists from Beginning of 18th Century to 1932], Saint Petersburg: Mir.

Shabanov A. (2015) Peredvizhniki: mezhdu kommercheskim tovarishchestvom i hudozhestvennym dvizheniem [Peredvizhniki: Between Commercial Partnership and Artistic Movement], Saint Petersburg: EUSPb.

Stasov V. (1937) Izbrannye sochineniya. T. 1 [Selected Works, Vol. 1], Moscow: Iskusstvo.

Stasov V. (1937) Izbrannye sochineniya. T. 2 [Selected Works, Vol. 2], Moscow: Iskusstvo.

Stasov V. (1952) Stat'i i zametki, publikovavshiesya v gazetah i ne voshedshie v knizhnye izdaniya. T. 1 [Articles and Notes Published in Newspapers and Not Included in Book Editions, Vol. 1], Moscow: Academy of Arts of USSR.

Teslya A. (2015) "Poslednij iz 'otcov"': biografiya Ivana Aksakova [“Last of 'Fathers"': Biography of Ivan Aksakov], Saint Petersburg: Vladimir Dal.

Teslya A. (2017) Kto govorit i kogo (ne) nadlezhit slyshat': "obshchestvennoe mnenie" v Rossijskoj imperii 2-j poloviny XIX veka [Who Talk and Who is (Not) to Be Listened: "Public Opinion" in Russian Empire of Second Half of the 19th Century]. Puti Rossii. T. 22: Vojna i mir [Ways of Russia, Vol. 22: War and Peace] (eds. M. Pugacheva, V. Zharkov), Moscow: Nestor-History, pp. 93-109.

Vereshchagin V. (1898) Na vojne v Azii i Evrope [On War in Asia and Europe], Moscow:

I. Kusneryov \& Co. 
Vereshchagin V. (2014) Ocherki, nabroski, vospominaniya [Essays, Sketches, Memoirs] Saint Petersburg: Lenizdat.

Vereshchagin V. Jr. (1982) Vospominaniya syna hudozhnika [Memories of Artist's Son] Leningrad: Artist of RSFSR.

Zhuravskaya I., Kolganova E., Marchstup G. (eds.) (2017) "Za drugi svoya": r 140-letiyu vojny za osvobozhdenie Bolgarii. 1877-1878. Katalog vystavki ["For My Friends": To 140th Anniversary of War for Liberation of Bulgaria, 1877-1878. Catalog of Exhibition], Moscow: State Historical Museum. 


\title{
Грезы Русской революции в утопиях Александра Чаянова и Андрея Платонова
}

\author{
Александр Никулин \\ Кандидат экономических наук, директор Центра аграрных исследований \\ Российской академии народного хозяйства и государственной службы \\ при Президенте Российской Федерации \\ Адрес: пр-т Вернадского, д.82, Москва, Российская Федерация 119571 \\ E-mail: harmina@yandex.ru
}

\begin{abstract}
Тема Русской революции является центральной как для повести А. В. Чаянова «Путешествие моего брата Алексея в страну крестьянской утопии», так и для романа А. П. Платонова «Чевенгур». Предпринимается сравнение хроники и образов Революции в биографиях Чаянова, Платонова, главных героев, жанров, сюжетов, структур утопической повести и утопического романа, ставятся вопросы постижения истории Русской революции и возможных альтернатив ее развития. Особое внимание уделяется не только социально-экономическому устройству утопической Москвы и утопического Чевенгура, но также этическо-эстетическим основаниям обеих утопий. Показано, что две утопии воссоздают, описывают, критикуют Революцию, часто с абсолютно противоположных точек зрения и позиций. В целом Чаянов в своей утопии придерживается релятивистских и плюралистических взглядов на Революцию и историю. Платонов, наоборот, во главу угла своей утопии закладывает принципы абсолютизации конца человеческой истории при эсхатологическом наступлении коммунизма. Русская революция в утопии Чаянова предстает сбывшейся альтернативой гуманистическо-прогрессистских идеалов столичных элит умеренных народническо-социалистических направлений Февральской революции. Революция в утопии Платонова выражает себя в альтернативе эсхатологическо-экологического преобразования мира, осуществляемого провинциальными бунтарями, воодушевленными Октябрьской революцией. Так чаяновская либерально-кооперативная и платоновская анархо-коммунистическая утопии, содержа в себе одновременно и апологию, и критику Русской революции в прозрениях ее прошедших и грядущих побед и поражений, открывают новые горизонты постижения российских революционных альтернатив.
\end{abstract}

Ключевые слова: Русская революция, утопия, Гражданская война, город, деревня, крестьянство, кооперация, коммунизм, эсхатология, анархия, государство

(с) Никулин А. М., 2018

(с) Центр фундаментальной социологии, 2018

DOI: $10.17323 / 1728-192 \mathrm{X}-2018-3-256-290$ 
Если вы действительно современник великой революции, вы должны разъяснить нам смысл этого слова.

А. Чаянов. «Путешествие моего брата Алексея в страну крестьянской утопии»

Революция была задумана в мечтах и осуществляема... для исполнения самых никогда не сбывшихся вещей.

А. Платонов. «Записные книжки»

\section{Революции и утопия в судьбах Чаянова и Платонова}

Значение Русской революции в жизни и творчестве Александра Чаянова и Андрея Платонова огромно, о чем свидетельствуют уже осуществленные оригинальные исследования.

Так, историк-аграрник В. П. Данилов в своей статье «Русская революция в судьбе А. В. Чаянова» подчеркивал: «Чаянов принадлежит к поколению, совершившему Великую российскую революцию 1917 года, он был ее активным участником и разделил ее трагическую судьбу. Без понимания этого решающего факта - вершины на его жизненном пути - нельзя понять ни самого Чаянова, ни его творчества...» (Данилов, 2011: 152).

Политический философ А. В. Магун в статье «Отрицательная революция Андрея Платонова» отмечает: «Андрей Платонов представляется... одним из центральных интеллектуалов периода Русской революции, который был не просто прозаиком, но ярким диалектическим мыслителем, всегда уделявшим особое внимание революционной событийности как горизонту своей жизни и творчества» (Магун, 2010: 66).

Вчитываясь далее в эти тексты, мы обнаруживаем, что и Данилов, и Магун, каждый по-своему, определяют уникальное мировоззренческое и деятельностное место Чаянова и Платонова в композиции идей, имен, событий Революции. По мнению Данилова, основной спектр идейно-личностных отношений к Революции в российской общественной мысли находился между двумя крайними сторонами: сочинениями авторов сборника «Вехи» и работами Ленина. Чаянов, не принимая ни одной из этих систем взглядов, стремился выработать собственное понимание Революции, стремясь к синтезу порой очень различных идейных направлений.

Уникальную точку зрения Платонова на Революцию в диапазоне идей от мрачных консерваторов до ироничных либералов анализировал и Магун, выделяя феномен народного демократизма и романтизма в Революции, безусловно родственный Андрею Платонову (Там же: 67-68). Конечно, демократический романтизм Революции как творческой и созидательной силы, стремящейся объединить вокруг себя все остальные общественные настроения, был присущ и Чаянову. 
Впрочем, понимания демократии и романтики могут быть чрезвычайно различными, что, безусловно, становится ясно при сопоставлении соответствующих революционных сочинений Чаянова (элитарно романтичных) и Платонова (народно романтичных).

Что касается непосредственно утопических сочинений этих двух авторов, то им посвящен целый ряд работ, проясняющих многие уникальные и продуктивные особенности социально-философской футурологии Александра Чаянова ${ }^{1}$ и $\mathrm{Aн}_{\text {- }}$ дрея Платонова ${ }^{2}$.

Обе утопии страстно стремятся соединить в себе умозрительные замыслы и прагматические лозунги Революции с ее самыми невероятными мечтами и эмоциями. Алгебра и геометрия революции здесь смело поверяются революционными эмоциями и грезами. И тут имеет смысл привести мнение социолога Теодора Шанина, высказанного им в исследовании, посвященном Русской революции:

Для тех, кто утончен до степени оторванности от многих реалий жизни, всепоглощающие эмоции кажутся вульгарными или неискренними. Но без учета этого «фактора» любое объяснение Революции остается неадекватным... Мечты имеют вес. Коллективные мечты имеют политический вес. Вот почему нет прямой или простой зависимости между политической экономией и политическим действием. Между ними стоят значения, понятия и мечты, обладающие внутренней последовательностью и собственной динамикой. (Шанин, 1997: 50, 200)

Заметим, что мыслители-утописты, как правило, никогда не пишут лишь одну утопию. Они часто являются именно «серийными» утопистами, за свою жизнь создающими даже несколько утопий, впрочем, обычно самым известным у них остается какой-то один-единственный утопический проект. Так и Чаянов и Платонов написали несколько утопий тоже, но все же самые знаменитые из них именно «Путешествие моего брата Алексея в страну крестьянской утопии» и «Чевенгур»³.

Обратимся к мировоззренческо-биографическим характеристикам авторов этих двух утопий, предположив, что по своим личностным задаткам утописты тяготеют к двум своеобразным и достаточно противоположным социально-политическим и социально-психологическим типам.

Один тип - это «утопист-канцлер». Как правило, к нему принадлежат высокообразованные интеллектуалы, занимающие достаточно ответственные посты в государстве, но при этом еще одаренные философской рефлексией и литератур-

1. Из работ, посвященных утопическому творчеству Александра Чаянова, следует отметить, например: Михаленко, 2016; Никулин, 2017; Симонов, Фигуровская, 1988; Шушпанов, 2000.

2. Становится уже необъятным количество исследований, посвященных утопиям Андрея Платонова, отметим здесь лишь несколько, на наш взгляд, безусловно важных книг, связанных прежде всего с романом «Чевенгур»: Алейников, 2013; Гюнтер, 2012; Корниенко, 2005.

3. Специальное сопоставление утопизма Чаянова и Платонова нам удалось найти лишь в одной статье, но посвященной сравнению чаяновской крестьянской утопии не с «Чевенгуром», а с платоновской повестью «Впрок»: Заваркина, 2013. 
ным талантом. Родоначальник утопического жанра Томас Мор был именно таким канцлером, изначально изобретшим эту самую страну «Утопию», а вскоре вслед за ним другой канцлер, Френсис Бэкон, создает утопию - «Новый Органон».

На противоположной стороне от «канцлера-утописта» располагается «бродягаутопист». Это прежде всего поэт-путешественник, человек, одарённый огромным поэтическим, философским, литературным воображением, а также значительным жизненным опытом, много чего испытавший и переживший, позанимавшийся даже и так ненавистной ему чиновно-бюрократической работой. Такими бродягами-утопистами, например, были Франц Кафка и Джордж Оруэлл. При этом нас не должно смущать, что в отличие от Оруэлла, побывавшего и в Бирме, и в Испании, Кафка нечасто выбирался из Праги и ее окрестностей, - главное здесь поэтическо-философский дар путешествий по альтернативам человеческих существований.

«Канцлер-утопист», как правило, создает свою утопию «сверху» - с точки зрения элит воображаемой им утопической страны. «Бродяга-утопист» создает свою утопию «снизу» - с точки зрения обыкновенных обитателей, часто маленьких людей большой утопической страны.

Чаянов и Платонов очень хорошо репрезентируют эти два идеально-типических утопически-личностных полюса, между которыми находятся огромные промежуточные типажи других оригинальных литераторов-фантазеров.

Чаянов, безусловно, обладал всеми задатками канцлера и, между прочим, успел побывать заместителем министра земледелия Временного правительства за две недели до Октябрьского переворота.

Стремительно взошедшая звезда российской аграрной и кооперативной науки, профессор в 27 лет, Чаянов изначально не принял Октябрьскую революцию, но вскоре все же обратился к сотрудничеству с большевиками, всякий раз стремясь найти компромиссные решения во взаимоотношениях коммунистов с крестьянством и интеллигенцией.

В 1920-е годы Чаянов кроме заведования кафедрой в Тимирязевской сельскохозяйственной академии создает и возглавляет крупнейший сельскохозяйственный научно-исследовательский институт международного уровня - НИИСХЭ ${ }^{4}$. Учёный с мировым именем, безусловно, достойный быть министром земледелия, одним из руководителей нового революционного государства, он как «старый буржуазный специалист» все же находился под пристальным и критическим партийно-советским контролем. С началом форсированной коллективизации Чаянов и его коллеги были подвергнуты гонениям и репрессиям, обвинены в саботаже, вредительстве, контрреволюционном заговоре. Следователи припомнили обвиняемому Чаянову и его авторство в так называемой контрреволюционной утопии (Чаянов, Петриков, 1998). В 1937 году Чаянов был расстрелян.

4. Научно-исследовательский институт сельскохозяйственной экономии. 
Платонову, конечно, не довелось побывать таким выдающимся академическим и хозяйственным деятелем, каким был Чаянов, тем не менее и у поэта-журналиста, техника-изобретателя Платонова в 1922-1926 годах складывалась весьма успешная и бурная инженерно-хозяйственная карьера. На некоторое время в середине 1920х годов он фактически стал главным мелиоратором и энергетиком Воронежской губернии (Антонова, 2016). Под его руководством были построены три электростанции, десятки плотин, организовано более сотни кооперативных мелиоративных товариществ. Впрочем, к 1927 году Платонов забрасывает это административно-хозяйственное ремесло, чтобы полностью посвятить себя литературе.

С началом коллективизации и у Платонова возникли и до конца жизни продолжались серьезные проблемы с его так называемой политической неблагонадежностью (Корниенко, 1993). Многие его произведения подвергаются злобной критике, самые крупные и выдающиеся книги, прежде всего «Чевенгур», партийная цензура не пропускает в печать. Идеологические гонения на Платонова продолжались фактически до самой его смерти.

Подчеркнем теперь разницу и сходства в возрасте авторов этих утопий. Чаянов родился в 1888 году, а Платонов в 1899-м. Для эпохи войн и революций такая разница в возрасте весьма существенна. Фактически Чаянов и Платонов репрезентируют становления разных поколений начала XX века. Чаянову в годы Первой русской революции 1905-1907 исполнилось 18 лет. Платонов восемнадцатилетним встретил 1917 год.

Надо также отметить и разницу в их социальном происхождении и положении. Чаянов выходец из богатой и интеллигентной московской купеческой семьи. Он с детства получил основательное образование. По окончании Московского сельскохозяйственного института в течение двух лет Чаянов стажировался в крупнейших европейских научных центрах, совмещая свои заграничные научные занятия с изучением всемирных культурных достопримечательностей Франции, Италии, Германии, Бельгии. И после Революции как крупный ученый профессор Чаянов неоднократно откомандировывался советской властью в длительные заграничные путешествия, включая Англию и США.

Платонов вырос в многодетной рабочей семье Воронежа. Подростком был вынужден перепробовать различные места работы. После Революции он окончил Воронежский электротехнический техникум. Одно время даже учился в Воронежском университете, но высшего образования так и не получил. За границей Платонову побывать не удалось.

Чаянов всегда был и оставался умеренным беспартийным социалистом-либералом, лишь в 1917 году - член партии народных социалистов. Платонов в годы Революции и Гражданской войны ярко проявил себя как радикально левый коммунистический философ-публицист. В начале 1920-х годов он даже вступал в партию большевиков, впрочем, побыв некоторое время кандидатом в члены партии, Платонов так никогда в нее принят не был. 
Ушли из жизни они почти ровесниками. Чаянов был расстрелян в 49 лет, Платонов умер от туберкулеза в 51 год.

Все же оба гения успели достаточно быстро и плодотворно, почти одновременно проявить себя. Чаянов в возрасте зо лет - уже автор ряда глубоких и оригинальных аграрно-экономических трудов, лидер нового научного направления. Платонов также к зо годам - автор замечательных литературных сочинений, у которого уже написан в стол великий авангардистский роман XX века.

Оба автора именно в возрасте 30 лет также создают и свои революционные утопии, по жанрам, сюжетам, изобразительным средствам чрезвычайно различные и многоплановые, но тем не менее объединенные единым стремлением постичь значение и перспективы Русской революции.

\section{Жанры утопий и образы Революции}

Изначально жанры обеих утопий объединяют акценты на путешествиях, обнаруживающиеся уже в заголовке чаяновской утопии и подзаголовке платоновской: «Путешествие моего брата Алексея...», «Чевенгур. Путешествие с открытым сердцем» (выделено мною).

Путешествие главного чаяновского героя партийца-интеллектуала Алексея Кремнева краткое, оно начинается провалом его сознания в собственном кабинете, произошедшем за перелистыванием книжки Герцена октябрьским вечером в Москве 1921 года. Герой приходит в себя в квартире одной гостеприимной интеллигентной московской семьи в сентябре 1984 года, с испуга выдав себя за какогото американца, которого все и ожидали в этой семье. Кремнев с семьей проводит еще несколько дней в беседах и путешествиях по Москве и Подмосковью, вникая в ход истории и современности России и мира к концу XX века. В финале повести обман Кремнева раскрывается, но ему никто не верит, что он на самом деле явился в конец XX века из его начала. В результате заявленная автором первая часть повествования обрывается одиночеством Кремнева посередине Москвы 1984 года, а вторая часть этой утопии так никогда Чаяновым и не была написана.

Путешествие главного платоновского героя Александра Дванова гораздо длительнее, композиционно оно соответствует трем основным частям самого романа. 1) Детство героя в сельской черноземной России, когда Дванов, потеряв крестьянина-отца, утонувшего в озере, становится сиротой и странником-побирушкой. 2) Отрочество-юность: обретя приемного отца - рабочего, Дванов живет и учится в губернском городе кануна Революции. Затем вступившего в партию большевиков Дванова во время Гражданской войны направляют с заданием в сельские районы его родной центрально-черноземной губернии исследовать, может быть «социализм уже где-нибудь нечаянно получился, потому что людям некуда деться, как только сложиться вместе от страха бедствий и для усилия нужды» (Платонов, 2011: 82). 3) В своих активистских странствиях, мужая от юности к молодости, Дванов во время наступления нэпа в 1921 году натыкается на уездный город Чевенгур, 
обитатели которого утверждают, что живут в коммунизме. Дванов остается в этом городе до самой его гибели, а затем уходит из жизни на дно того самого озера, в котором утонул его отец.

По своему объему и структуре чаяновская утопия - маленькая повесть - около 40 страниц с лихо закрученным и тщательно выверенным детективно-гламурным столичным сюжетом, наполненным увлекательными социально-политическими рефлексиями о возможных альтернативах развития будущей истории ХХ века. Чаяновская повесть написана стремительно, в цейтноте бесконечной научно-административной занятости ее автора в 1919 году.

По объему платоновская утопия - достаточно большой 4оо-страничный роман - поток фантасмагорических событий, причудливо движущихся среди периферийных мест и противоречивых исторических фактов кануна Революции, Гражданской войны и нэпа. Платоновский роман создавался непросто, включая в себя работу над разнородными кусками текста между 1926 и 1928 годами, прерываемый различными бытовыми и профессиональными мытарствами автора.

Жанр утопии Чаянова - это ироническо-патетический политический памфлет, посвященный отстаиванию и развитию идеалов Февральской революции под знаменем кооперативного аграризма (Бруиш, 2012). В какой-то степени чаяновская утопия посвящена переосмыслению того, как можно было бы снова дать делу правильный ход с точки зрения той аграрной идеологии, которую выражал сам Чаянов, до конца воплощая идеалы Февральской революции, ведомой союзом буржуазных, народнических и социал-демократических партий. В целом утопия Чаянова - «розовая» прогрессистская утопия умеренного аграрника-социалиста. Это попытка выдумать союз между либерализмом и социализмом.

Жанр утопии Платонова - это сатирическо-элегический эпос, вобравший в себя мотивы самых удивительных, фантастических народных мечтаний и чаяний времен Русской революции. Утопия Платонова - утопия Октябрьской революции, ее самых радикальных идеалов. Это «красно-зеленая» эсхатологическая утопия - юродствующего анархиста-коммуниста. Это попытка выдумать союз между анархизмом и коммунизмом.

Для обеих утопий чрезвычайно важен такой типичный прием запуска утопических путешествий, как сон. Главный герой Чаянова, потеряв сознание, просыпается загадочным образом в Москве 1984 года. Но далее все повествование в этой утопии пронизано удивительной ясностью и четкостью (впрочем, такая гиперясность тоже бывает в сновидениях). Вся эта утопическая московско-подмосковная крестьянская страна по своей интенсивной пространственно-временной рациональной обустроенности подобна регулярному европейскому парку времен Версаля короля Людовика-Солнце и так представляется двум утопическим путешественникам из окна автомобиля:

Город казался сплошным парком... Направо и налево тянулись такие же прекрасные аллеи, белели двухэтажные домики, иногда целые архитектурные 
группы, и только вместо цветов между стенами тутовых деревьев и яблонь ложились полосы огорода, тучные пастбища и сжатые полосы хлебов... при той плотности населения, которой достигло крестьянство Московской губернии, деревня приняла необычный для сельских поселений вид. Вся страна образует теперь кругом Москвы на сотни вёрст сплошное сельскохозяйственное поселение, прерываемое квадратами общественных лесов, полосами кооперативных выгонов и огромными климатическими парками. В районах хуторского расселения, где семейный надел составляет 3-4 десятины, крестьянские дома на протяжении многих десятков вёрст стоят почти рядом друг с другом, и только распространённые теперь плотные кулисы тутовых и фруктовых деревьев закрывают одно строение от другого... (Чаянов, 1989: 174-175)

В утопии Чаянова рационализм, точнее, не один рационализм, но различные виды рационализмов, стараясь мирно соперничать, хотя порой и открыто враждуя меж собой, последовательно трансформируют, доводят до своего рационального замысла всю окружающую природную и социальную жизнь.

Главный же герой Платонова, как и остальные персонажи этого романа, пребывает в каком-то перманентно томительно-причудливом сновидении, даже в клубке личных и коллективных сновидений, что позволяет некоторым исследователям «Чевенгура» утверждать, что вся его третья - собственно утопическая часть есть сонный бред главного героя, переболевшего тифом и не до конца в со-

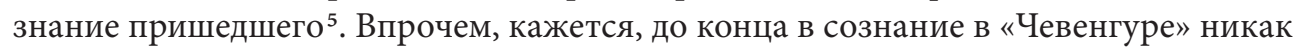
прийти не могут всего его участники: «Чевенгур просыпался поздно; его жители отдыхали от веков угнетения и не могли отдохнуть. Революция завоевала Чевенгурскому уезду сны и главной профессией сделала душу» (Платонов, 2011: 215).

Сам город Чевенгур и его утопические окрестности отнюдь не регулярный европейский парк, но что-то ему глубоко хаотически экологически противоположное: «Деревья росли почти по всем улицам Чевенгура и отдавали свои ветки на посохи странникам, бредущим сквозь Чевенгур без ночевки. По чевенгурским дворам процветало множество трав, а трава давала приют, пищу и смысл жизни целым пучинам насекомых в низинах атмосферы, так что Чевенгур был населен людьми лишь частично - гораздо гуще в нем жили маленькие взволнованные существа, но с этим старые чевенгурцы не считались в своем уме... Днем чевенгурцы бродили по степям, рвали растения, выкапывали корнеплоды и досыта питались сырыми продуктами природы, а по вечерам они ложились в траву на улице и молча засыпали» (Там же: 200).

Для характеристики пространственно-временных структур революционной утопии Чаянова чрезвычайно важна оппозиция «рациональное» vs. «не-, и-рациональное». Когда «рациональное», пусть и не окончательно, но все же последовательно и успешно трансформирует, перерабатывает иррациональное в самое себя.

5. Подробный анализ сновидений в «Чевенгуре» см.: Хрящева, 2005; Червякова, 2005. 
Для характеристик платоновской революционной утопии важна оппозиция «сознательное» $u$ «не-, бес-сознательное». «Сознательное» периодические пытается бороться с «несознательным», впрочем, все как-то безуспешно, и в конце концов они вместе - «сознательное» и «несознательное» - пребывают во взаимной дружбе-конфликте на границах чевенгурского «бессознательного».

Утопия Чаянова поразительно конкретна. Она пестрит разнообразными датами с точностью не то что до года, а даже до дня. Чаянов упоминает множество имен своих современников, а также некоторых их воображаемых потомков, живописуя красочные подробности их судеб (долгих, плодотворных, счастливых). Например, он предсказывает уже весьма известному в начале XX века архитектору И. В. Жолтовскому место главного архитектора крестьянской утопической России. Дорогой друг и коллега Чаянова воронежский профессор А. Н. Минин упомянут академическим патриархом, занимающим кафедру в Константинопольском университете, и так далее.

Удивительно футуристическое чутье Чаянова в предугадывании ключевых годов в происшествиях российской и мировой политической истории ХХ века (как правило, с положительным для крестьянства и демократии России знаком, в реальности все было наоборот). Возможно, из многочисленных гуманитарных увлечений Чаянова так проявились и его персональные занятия астрологией. Итак, в утопии особо упоминаются: 1929 год как время окончательного перехода власти к крестьянским партиям в России (в реальной советской истории это был год фатального слома крестьянской свободы и самостоятельности), 1934 год - время политической консолидации и укрепления крестьянского правительства (в реальности это год консолидации сталинского режима), 1937 год - неудавшаяся попытка ужасного диктатора Варварина свергнуть крестьянский режим (в реальности удавшееся Сталину избиение советских элит в год Великого террора) и так далее.

Многие исследователи платоновской утопии обращают внимание именно на неточность и размытость чевенгурских пространств и времен (Алейников, 2013). События в Чевенгуре, кажется, пульсируют и переплетаются в прихотливой и противоречивой последовательности между 1919 и 1921 годами. Чевенгур словно живет с пастернаковским ощущением «Какое, милые, у нас / Тысячелетье на дворе?» (Пастернак, 1993: 348), буквально выпадая из всемирной и советской истории, достаточно длительное время существуя вполне уединенно.

Платоновский «Чевенгур» в отличие от чаяновской «Москвы» не пестрит лихорадочным перечислением многих десятков настоящих и вымышленных имен российских и зарубежных гениев и талантов, зато в нем чрезвычайно много простых, невзрачных, порой безымянных персонажей: рабочих, домохозяек, крестьян, бандитов, стариков, старух, детей, нищих и, конечно, революционеров - и почти каждый из них, даже эпизодический персонаж, описан Платоновым с невероятным художественно-психологическим мастерством.

Наоборот, хотя утопия у Чаянова называется крестьянской, в ней нет ни одного индивидуально личного описания крестьянина 1984 года. В его повести толпы 
крестьян создают лишь некий абстрактный фон, массовку для соло конкретных фигур интеллектуальных элит, рассуждающих о прогрессивном значении кооперированного крестьянства в экономике многоукладной России.

Чтобы продемонстрировать, насколько различны идейные и изобразительные средства двух утопий, обратимся к описаниям утопических памятников Революции в повести Чаянова и романе Платонова.

В чаяновской повести ее главный герой Алексей Кремнев, загадочным образом попавший из 1921 года в центр утопической Москвы 1984 года, оказавшись рядом с местным жителем, его спутником:

Посмотрел налево, и сердце его учащённо забилось. «Метрополя» ${ }^{6}$ не было. На его месте был разбит сквер и возвышалась гигантская колонна, составленная из пушечных жерл, увитых металлической лентой, спиралью, поднимавшейся кверху и украшенной барельефом. Увенчивая колоссальную колонну, стояли три бронзовых гиганта, обращённые друг к другу спиной и дружески взявшиеся за руки. Кремнев едва не вскрикнул, узнав знакомые черты лица.

Несомненно, на тысяче пушечных жерл, дружески поддерживая друг друга, стояли Ленин, Керенский и Милюков.

Кремнев успел на барельефе различить несколько фигур Рыкова, Коновалова и Прокоповича, образующих живописную группу у наковальни, Середу и Маслова, занятых посевом, и не смог удержаться от недоуменного восклицания, в ответ на которое его спутник процедил сквозь зубы:

- Памятник деятелям великой революции.

- Да послушайте... ведь эти же люди вовсе не образовывали в своей жизни таких мирных групп!

- Ну, для нас в исторической перспективе они сотоварищи по одной революционной работе, и поверьте, что теперешний москвич не очень-то помнит, какая между ними была разница! (Чаянов, 1989: 170-171)

Описываемый Чаяновым утопически-революционный монумент по своему дизайну классически старомоден: громадная колонна, декорированная разнообразными барочными элементами, а по своему политическому смыслу либерально компромиссен: премьер-министры и министры сельского хозяйства Временного и большевистского правительств слились в динамичном экстазе дружной революционной работы.

У Платонова главный герой его утопии Александр Дванов, попав в 1920 году в одну из сельских коммун глубинного Черноземья, выступает на собрании коммуны с проектом памятника Революции:

6. Гостиница «Метрополь» - один из символов роскошного урбанизма начала ХХ века и революционных событий времен Гражданской войны в России. 25 октября (7 ноября) - 2 (15) ноября 1917 года гостиница была форпостом сопротивления юнкеров вооружённым силам большевиков. В 1918 году, после переезда в Москву советского правительства, «Метрополь» стал одной из ключевых резиденций большевистской власти, здесь проводились заседания ВЦИК, на которых выступали Ленин и Троцкий. 
Подал изображение председателю и объяснил:

- Лежачая восьмерка означает вечность времени, а стоячая двухконечная стрела - бесконечность пространства.

Председатель показал фигуру всему собранию:

- Тут и вечность, и бесконечность, значит - все, умней не придумаешь: предлагаю принять... Памятник решили соорудить среди усадьбы на старом мельничном камне, ожидавшем революцию долгие годы. Самый же памятник поручили изготовить из железных прутьев железному мастеру. (Платонов, 2011: 137)

В отличие от чаяновской в платоновской утопии речь идет о памятнике революции не в столичной Москве, а в глухой сельской провинции. Дизайн памятника чевенгурского в противоположность московскому не старомодно помпезен, но авангардистки лаконичен. Памятник посвящен не взаимопрославлению союза конкретных персон и институтов, но взаимопроникновению абстракций вечности и бесконечности. Этот памятник обсуждается не рафинированными столичными интеллектуалами, а обычными сельскими провинциалами.

И, конечно, в обеих утопиях подчеркивается стремление всякой революции до основания переустроить мир. Революционно-крестьянская чаяновская Москва нанесла сокрушительный удар по российскому урбанизму, разрушив и уничтожив кварталы многоэтажек во всех городах по всей стране. Чевенгур на своих регулярных субботниках для революционной профилактики все переносит и перетаскивает дома и деревья внутри самого себя для упрочения коммунистической жизни.

Также в обеих утопиях подчеркивается, что уничтожить безвозвратно некоторые общественные институты не удается даже самым радикальным революциям. Главный тому пример - семья. В утопии Чаянова, несмотря на утопический грозный декрет от 27 октября 1921 года об уничтожении в недельный срок всякого семейного очага, в Москве 1984 года возможно снова повсюду обнаружить достаточно замечательных семей в самом традиционном смысле этого слова. В «Чевенгуре» коммунисты, упразднившие семью, частную собственность и государство, в конце концов признают, что семью все-такие надо вернуть в коммунизм, - и снова пытаются начать жить семейной жизнью.

\section{Главные герои и революционные сюжеты}

Главные герои чаяновской повести (Алексей Кремнев) и чевенгурского романа (Александр Дванов) - революционеры, концентрирующие в самих себе основные идейные противоречия и идеологические искания двух утопий. По своему возрасту и социальному статусу они в определенной степени соответствуют возрасту и социальному статусу самих авторов утопических сочинений к началу 1920-х годов. Хотя ни у Чаянова, ни у Платонова не называется точный возраст их главных героев, тем не менее из разнообразных косвенных биографических характеристик 
мы можем достаточно уверенно предположить, что Кремневу около 35, а Дванову - около 25 лет.

Алексей Кремнев - настоящий русский интеллигент-революционер, прекрасно и разносторонне образованный, знающий несколько иностранных языков. С одной стороны, он наделен даром проницательной рефлексии, отягченной некоторыми болезненными душевными сомнениями, с другой - ему присущ бюрократический активизм коммунистического толка, о чем свидетельствует такая его жутковато забавная характеристика из музейного паноптикума восковых фигур, выставленных на подмосковной ярмарке утопической России 1984 года: «Алексей Васильевич Кремнев, член коллегии Мирсовнархоза, душитель крестьянского движения России. По определению врачей, по всей вероятности, страдал манией преследования, дегенерация ясно выражена в асимметрии лица и строении черепа» (Чаянов, 1989: 192).

Впрочем, из всего изложения повести мы догадываемся, что этот образ слишком упрощает личность Кремнева в угоду тенденциозному видению политической истории идеологов крестьянской страны. Тем временем утопическая женщина этой страны, влюбившаяся в Кремнева, а потому, конечно, тоже необъективная в своем видении, но, возможно, что-то верное и чувствующая в предмете своей страсти, утверждает, что: «Он человек необыкновенный, хищный и прекрасный, как волк...» (Там же: 203).

В противоположность интеллектуалу Алексею Кремневу, богато одаренному окружающей его культурной средой, простец Саша Дванов, сирота, выросший среди вопиющей крестьянской нужды, недоучившийся студент политехникума времен Гражданской войны, любознательный читатель, жадно занимающийся самообразованием, отнюдь не производит впечатления сильного и умного «хищника-зверя», наоборот, ему, пожалуй, присущи некоторые черты беззлобного странника-юродивого. Неравнодушная к Дванову женщина о нем отзывается так:

«Этот человек думает две мысли сразу и в обоих не находит утешения, поэтому такое лицо не имеет остановки в покое и не запоминается.

- Он не интересный... Зато с ним так легко водиться! Он чувствует свою веру, и другие от него успокаиваются. Если бы таких было много на свете, женщины редко выходили бы замуж...» (Платонов, 2011: 364-365).

Здесь также надо отметить, что сами женские образы, отношения к ним мужчин чрезвычайно отличны в обеих утопиях. В утопии Чаянова юные, прекрасно телесно сложенные, как на полотнах Тициана, к тому же всесторонне образованные девушки, что немаловажно, способные приготовить изысканно вкусный обед, «положительно сводили Алексея Кремнева с ума».

В утопии Платонова большинство описываемых женщин, изможденных и преждевременно старящихся в тяжелом физическом труде, частых родах, повседневных заботах о домохозяйстве посреди крестьянской центрально-черноземной нищеты, отягченной разрухой, Гражданской войной, похожи на старух-нищенок с полотен Рембрандта. При этом отношение к ним большинства чевенгурских 
мужчин почтительно застенчиво целомудренное. Есть лишь одна плотоядная красавица в Чевенгуре, напоминающая своими прелестями девушек чаяновской Москвы, но она и описывается Платоновым как абсолютная стерва.

Вообще надо отметить, что в чаяновской утопии гендерные отношения имеют какой-то куртуазно консервативный оттенок. Платоновский Чевенгур стремится к космической перезагрузке гендерных отношений. Отрицая традиционные нравы русской провинции с грубоватым доминированием мужчин и подчиненно мещанским занудством женин, коммунисты Чевенгура сперва стремятся существовать совсем без женщин, а потом приглашают их в город, для воплощения прежде всего братско-сестринских и материнско-отеческих отношений.

Тем временем Алексей Кремнев и окружающие его интеллектуалы и интеллектуалки Москвы-1984 постоянно заводят разговоры о значении культуры для устойчивого прогресса России и человечества, например, в таком пассаже: «Поверьте, что духовная культура народа, раз достигнув определённого, очень высокого духовного уровня, далее удерживается автоматически и приобретает внутреннюю устойчивость» (Чаянов, 1989: 188).

В отличие от этого восторженного гомона «чаяновских культурологов» Александр Дванов среди своих путешествий, взыскуя коммунизм,

...в душе любил неведение больше культуры: невежество - чистое поле, где еще может вырасти растение всякого знания, но культура - уже заросшее поле, где соли почвы взяты растениями и где ничего больше не вырастет. Поэтому Дванов был доволен, что в России революция выполола начисто те редкие места зарослей, где была культура, а народ как был, так и остался чистым полем - не нивой, а порожним плодородным местом. И Дванов не спешил ничего сеять: он полагал, что хорошая почва не выдержит долго и разродится произвольно чем-нибудь небывшим и драгоценным, если только ветер войны не принесет из Западной Европы семена капиталистического бурьяна. (Платонов, 2011: 138)

В чем, впрочем, схожи меж собой герои этих революционных утопий, так это в опрометчивых поступках, которые они совершают, конечно, из искренних и самых чистосердечных побуждений, словно являясь наглядными примерами к афоризму Энгельса, на который любил ссылаться и Ленин: «Во всякой революции неизбежно делается множество глупостей» (Маркс, Энгельс, 1961: 516). Именно с точки зрения «глупостей революции» имеет смысл кратко проанализировать сюжетную канву революционных событий и поступков в обеих утопиях.

Чаянов в своей утопии относится с изначальной иронией, фактически как к глупости, к идее мирового коммунистического единообразия, намекая в своем утопическом повествовании, что даже если коммунисты победят повсюду, как о том они мечтают, по крайней мере четыре причины взорвут их всемирный коммунизм изнутри. 
Во-первых, это банальный национализм. В чаяновской утопической истории $\mathrm{XX}$ века именно очередные националистические всплески Германии разрушают царство предустановленной гармонии всемирной революции.

Второе - это коррупция. Признавая не только в своей утопии, но и в других сочинениях, что большевики действительно люди идейные, Чаянов тем не менее задавался вопросом, что может в исторической перспективе спасти коммунистический режим, предпочитающий экономическим стимулам внеэкономические, от постепенной экспансии коррупции, и не находил ответа.

Третье - это властные амбиции любых политических лидеров, среди которых коммунисты не составляют исключения. В свое время Жан Жорес упрекал самого Карла Маркса в незнакомстве с рутинами партийного руководства социалистическими партиями, а значит, и в недооценке значения персональных склочных амбиций социалистических лидеров. Или как однажды пошутил современник Чаянова, либеральный историк и писатель Марк Алданов: «Быть может, капиталистическому строю везде пришлось бы плохо, если бы революционеры ненавидели „буржуазию“ так, как они ненавидят друг друга» (Алданов, 1994: 271).

Наконец, четвертое, и возможно самое главное, - перманентная неэффективность планово-бюрократической коммунистической экономики, лишающей ее граждан стимулов к производительному труду, обеспечивающих им извечные проблемы с тотальным дефицитом.

Итак, по ироническому мнению Чаянова, не прямо, но косвенно, неоднократно упоминаемые все эти четыре условия - местный национализм, рутинная коррупция, ревнивый вождизм, экономическая неэффективность, в конце концов обессилят панглобалистское коммунистическое стремление к мировой экспансии ${ }^{7}$. На смену ему в результате нового бурного и стремительного периода международных войн и конфликтов Чаянов предрекает приход мира, как бы мы сейчас сказали, многополярного, состоящего к концу XX века, по Чаянову, из пяти достаточно автаркических социально-экономических систем: англо-французской, германской, американской, русской и японо-китайской. Каждая из систем, занимая значительные территории, обустроена на основах собственных национально-культурных и политико-экономических предпочтений, как то: японо-китайского феодализма, американского капитализма, германского социалистического планового хозяйства, англо-французского капитализма.

А что в России? Для России характерна многоукладная экономика, где кооперативный уклад является ведущим, модерирующим взаимодействие и продуктивное

7. Между прочим, надо признать, что после 1984 года начавшаяся советская перестройка социализма потерпела крушение в значительной степени по сформулированным Чаяновым четырем причинам: рост национализма, экспансия коррупции, конфликт между прогорбачевскими и проельцинскими элитами на фоне трудового абсентеизма, товарного дефицита из-за общей неэффективности социалистической экономики. Причину пятую - фатальное падение цен на нефть в стране, ориентированной на экспорт углеводородов, - Чаянов, правда, не предвидел. Апелляция к идеалам чаяновской кооперации в период перестройки как интегратору единства политических и экономических интересов советского общества оказалась необходимой, но, увы, недостаточной. 
сотрудничество между собой государства, капитализма, крестьянских семейных экономик.

Каким образом российской кооперации удается так слаженно и четко выполнять свои регулятивно-консолидирующие функции? Это происходит прежде всего благодаря разрешению фундаментальной задачи гармонизации процессов разделения труда между городом и деревней. Напомним, что во многом из-за фатальных дезинтеграции и распада народнохозяйственных связей между городом и деревней произошел крах старого режима и становление режима нового революционного, также судорожно метавшегося в разрешении проклятых проблем смычки города и села.

Чаянов же в рамках своей утопии, с позиций разделяемого им аграризма, описывает радикальное разукрупнение и даже разрушение городов и прежде всего столицы - Москвы, через развитие идей сельско-городского континуума, связанного с гармоничным сельско-городским расселением жителей России. В итоге среди сплошь комфортабельных селений крестьян города представляют собой только культурно-информационные узлы социальных связей для высокомобильного населения, использующего разнообразные виды транспорта, движущегося среди инфраструктуры мощных и комфортабельных коммуникаций.

Москва в чаяновской утопии - это уже не традиционная столица-город-империалист, для которой покорно-кормящим пьедесталом служит вся остальная страна, но лишь культурно-управленческий центр, первый среди равных ей других больших и малых сельско-городских культурно-коммуникационных центров.

Какая же власть оказалась способной, разрушив города России и поддержав российское село, создать эту сплошную утопию взаимопродуктивного сельскогородского симбиоза? По Чаянову, здесь решающая положительная роль принадлежит могучим олигархам интеллекта, увлеченным и высококвалифицированным людям искусства управления социальными процессами, высокообразованным личностям, сторонникам плюралистического мировоззрения развития человеческого общества. Которые, и это подчеркивает экономист Чаянов, понимают, что главное в реформах - это не столько экономика, сколько культура, и прежде всего высокая, настоящая культура, а не ее масс- и поп-культурные суррогаты. В результате именно таких реформ в России ее население живет, естественно руководствуясь импульсами великой литературы, живописи, музыки.

Если Достоевский провидел в европейской политической культуре выдающуюся роль Великого инквизитора, а заключенные ГУЛАГа точно определили значение в советском обществе Сталина как Великого хлебореза, Оруэлл трансформировал этот образ в своем «1984 году» в Большого брата - Великого технократа, то Чаянов в своей утопической стране создает своеобразный образ Великого искусствоведа - агронома человеческих душ, пестующего и проращивающего человеческие личности в компосте высокохудожественной культуры.

Впрочем, в утопии один из таких Великих искусствоведов уверяет главного героя утопии Алексея Кремнева, что цель истинно высокохудожественной поли- 
тики управления людьми заключается в достижении такого высококультурно-политического состояния общества, при котором в конце концов отпадает нужда в главенстве над страной сплоченной группы высокоодаренных интеллектуаловолигархов. Теперь культурно-демократический строй этой крестьянской страны может поддерживаться и развиваться вполне автоматически, имея своей целью рост равномерно справедливого производства и распределения благ во имя приобщения и участия всего населения во все более совершенном культурном процветании. Ну и конечно, не только культура, но и наука в этой крестьянской утопии добилась определенных успехов, например, в совершенном регулировании погоды. Здесь созданы специальные аппараты метеорофоры, благодаря которым можно с точностью до минуты вызвать или прекратить в любой точке этой необъятной страны дождь любой степени интенсивности или в милитаристских целях, в случае отражения чьей-то агрессии, переключить всю мощь метеорофоров на генерирование ураганов и смерчей, наносящих урон противнику, сопоставимый с последствиями ударных волн от атомных взрывов.

А платоновская утопия совершенно иная. Если у Чаянова ведущие силы утопии это аграрно-кооперативные мудрецы, то у Платонова - анархо-коммунистические простецы. Если в чаяновской утопии все события происходят в центре - в Москве, то у Платонова все свершается в глубинке, на периферии. Герои платоновской утопии и не собираются захватывать столицу, но здесь и сейчас в несусветной глуши переустраивают уездный город Чевенгур с его ярко выраженными сельскими чертами типичного малого города России, в чевенгурскую коммуну, лелея надежду, что по ее образцу можно будет переустроить весь мир.

О чевенгурских революционерах написано уже много самых противоречивых аналитических текстов в России и за рубежом. Например, британская исследовательница Анджела Ливингстон с истинно английской вежливостью констатировала: «Одиннадцать не очень умных большевиков, отвечающих за небольшой провинциальный город в степи, расчищают место для построения - в их понимании - коммунизма и верят в то, что они добились этого. Наступление коммунизма ведет - в их представлении - к „окончанию“времени» (Ливингстон, 2005: 21). Отечественный писатель Алексей Варламов определяет чевенгурских коммунистов вполне по-русски: «...бандитская преступная шайка, изуверская секта „смертепоклонников“ в нарушение всех человеческих законов узурпировала власть в отдаленном беззащитном поселении, занимаясь грабежом и проедая остатки дореволюционного буржуазного добра, утверждая, что вот это и есть коммунизм» (Варламов, 2011: 154).

Итак, эти «идиоты», впрочем, не только в отрицательном, но и в положительном мышкинско-достоевском значении этого слова, хотя и в более жестоко-кровавом значении, стремятся в Чевенгуре где-то лета-осени 1921 года осуществить полный и законченный коммунизм. Чевенгурским большевикам не нравится нэп, пугающий их возвращением и усилением признаков капитализма. Нет, они стремятся как можно скорее и полнее воплотить окончательные идеалы именно ком- 
мунистической революции. Например, они до основания изничтожают не то что капитализм, но любые и малейшие признаки частной собственности, осуществляя настоящий геноцид - максимальное физическое искоренение - так называемого класса чевенгурской буржуазии, а вслед ей и всяческой «остаточной сволочи», истребляя, проживая, проедая, оставшееся после зажиточных классов имущество. Делают это они сосредоточенно и почти беззлобно, будто перефразируя слова мафиози из «Крестного отца»: «Ничего личного, только коммунизм».

В результате, истребив и выгнав все зажиточное население, в Чевенгуре остается лишь дюжина коммунистов. А далее в Чевенгуре фактически запрещается труд, потому что с точки зрения революционеров-чевенгурцев, когда человек трудится, начинают появляться вещи, а за ними наступает эксплуатация с ее ложным богатством.

Чевенгурцы же добиваются главного богатства по Карлу Марксу - свободного времени, чтобы щедро его потратить для проявления своих искренних чувств дружбы и товарищества по отношению друг к другу. Критики Чевенгура признают, что чевенгурские большевики ничего толком не умеют делать, но, впрочем, они действительно умеют любить друг друга. И не только друг друга, чевенгурцам свойственно чувство любви не только к ближним, но и к дальним - всем страждущим и обремененным на земном шаре. Они готовят свой Чевенгур к приходу всемирного пролетариата, всех цветных и разукрашенных народов. К ним в город приходят в конце концов жить даже не пролетарии, но люди еще более бедные и обездоленные, так называемые «прочие» - абсолютно нищие сироты. И чевенгурские коммунисты с торжеством и благоговением размещают «прочих» в своем городе.

Здесь надо признать, что в отличие от чаяновской кооперативной революции, по-рыночному расчетливо рациональной в отношениях между людьми и народами, платоновская коммунистическая революция щедра до безумия. Чевенгур находится посередине революционно нищей страны, которая: «В то время... тратилась на освещение пути всем народам, а для себя в хатах света не держала» (Платонов, 2011: 153). Чевенгурцы мечтают пригласить в свой коммунистический рай все «цветные и разукрашенные народы» земли, включая «арапов и уродов».

Чевенгурцы полагают, что при капитализме были нарушены фундаментальные законы взаимодействия человека с природой. Природа за это мстила человеку экстракцией из самой себя элементов социальной эксплуатации. Но теперь, раз настает коммунизм, то и природа благоволит человеку, приходя с ним в естественное равновесие.

Чевенгурцам нет нужды в чаяновских метеорофорах. Природа с пониманием относится к их коммунистическому городу, вовремя посылая ему и столько, сколько нужно дождя и солнца.

И здесь вновь надо отметить очередные поразительные отличия в обеих утопиях - в отношении к экологии. Странно, что аграрник Чаянов с его описаниями сверхинтенсивного сельского хозяйства в утопической России и других утопиче- 
ских странах ни разу не упомянул хоть о каких-нибудь экологических приметах, проблемах, тревогах 1984 года. Создается впечатление, что он в создании своего утопического мира просто не нуждался в этой экологической гипотезе.

Не то электрик Платонов. Экологические заботы, тревоги, надежды, чаяния пронизывают «Чевенгур» от первой до последней страницы: угроза засухи, заболачиваемые реки, вырубленный лес, выпаханный чернозем, сосуществование культурных и диких растений, симбиоз людей и животных: лошадей, собак, кошек, воробьев, тараканов и прочих насекомых - весь этот энвайронментализм является естественной органической средой для «Чевенгура» и его героев.

Но тем временем чевенгурцы оказываются страшно огорчены и озадачены смертью ребенка, случившейся в Чевенгуре, страданиями от этого его матери, болезнью одного старого чевенгурца: значит, смерть, страдание, болезнь не преодолены в Чевенгуре, какой же это коммунизм?!

И тогда, только во имя помощи и поддержки своего ближнего в болезни, в страдании, продолжении жизни, ближе к концу утопического повествования частично реабилитируется труд. Теперь трудиться можно, но исключительно во благо другого человека. Так труд в Чевенгуре начинается вновь с заботы о заболевшем пожилом чевенгурце. Этот труд для другого в Чевенгуре осуществляется в форме дара - персонифицированных отношений дружеского дарообмена продуктами своего труда между чевенгурцами, напоминающего в какой-то степени социальные практики, описываемые в исследованиях Марселя Мосса (Mocc, 2011) и Карла Поланьи (Поланьи, 2014).

Отметив самые общие сюжетные особенности обеих утопий, нам теперь необходимо подробней сосредоточиться на их социально-философских и политэкономических основаниях. Таким основанием для чаяновской утопии является кооперация, а для платоновской — коммунизм.

\section{Либеральная кооперация, анархический коммунизм и вопросы власти}

Понятия кооперации и в особенности коммунизма весьма многозначны. В истории человечества они порой находили воплощение в самых разнообразных и достаточно противоречивых формах.

Все же с чаяновской кооперацией разобраться, кажется, легче, чем с платоновским коммунизмом. В своей крестьянской утопии Чаянов, от имени одного из ее руководителей, так кратко и ёмко объясняет, как кооперация на основе крестьянской культуры и экономики добилась определяющего положения в России ХХ века:

Уже в начале XX века крестьянство коллективизировало и возвело в степень крупного кооперативного предприятия все те отрасли своего производства, где крупная форма хозяйства имела преимущество над мелким, в своём настоящем виде представляя организм наиболее устойчивый и технически совершенный. 
Такова опора нашего народного хозяйства. Гораздо труднее было поставить обрабатывающую промышленность. Было бы, конечно, глупо рассчитывать в этой области на возрождение семейного производства.

Ремесло и кустарничество при теперешней заводской технике исключено в подавляющем большинстве отраслей производства. Однако и здесь нас вывела крестьянская самодеятельность; крестьянская кооперация, обладающая гарантированным и чрезвычайным объемом сбыта, задушила в зародыше для большинства продуктов всякую возможность конкуренции. Правда, мы в этом несколько помогли ей и сломили хребет капиталистическим фабрикам внушительным податным обложением, не распространявшимся на производства кооперативные.

Однако частная инициатива капиталистического типа у нас всё же существует: в тех областях, в которых бессильны коллективно управляемые предприятия, и в тех случаях, где организаторский гений высотою техники побеждает наше драконовское обложение. Мы даже не стремимся её прикончить, ибо считаем необходимым сохранить для товарищей кооператоров некоторую угрозу постоянной конкуренции и тем спасти их от технического застоя. Мы ведь знаем, что и у теперешних капиталистов щучьи наклонности, но ведь давно известно, что на то и щука в море, чтобы карась не дремал.

Однако этот остаточный капитализм у нас весьма ручной, как, впрочем, и кооперативная промышленность, более склонная брыкаться, ибо наши законы о труде лучше спасают рабочего от эксплуатации, чем даже законы рабочей диктатуры, при которых колоссальная доля прибавочной стоимости усваивалась стадами служащих в главках и центрах.

Ну а кроме того, сбросив с себя все хозяйственные предприятия, мы оставили за государством лесную, нефтяную и каменноугольную монополии и, владея топливом, правим тем самым всей обрабатывающей промышленностью.

Если к этому прибавить, что наш товарооборот в подавляющей части находится в руках кооперации, а система государственных финансов покоится на обложении рентой предприятий, применяющих наёмный труд, и на косвенных налогах, то вам в общих чертах ясна будет схема нашего народного хозяйства. (Чаянов, 1989: 186-187)

Вообще эти абзацы, написанные за пару лет до введения нэпа, в изящно идиллической форме, кажется, предсказывают самые идеалистические мечтания по мотивам ленинского строя цивилизованных кооператоров как необходимой переходной ступени к грядущей победе коммунизма.

Но именно здесь заключаются и главные различия между чаяновской утопией и ленинским кооперативным планом. Чаяновская утопия, кажется, признает свой вышеописанный кооперативный режим за верх совершенства. И в этой утопии не предусмотрен, по крайней мере, не упоминается в перспективе какой-то еще более высокий, развитой и прогрессивный строй. Утопия достигла своего апогея как в собственном кооперативном развитии, так и в главенствующем кооперативном регулировании взаимоотношений между крестьянскими домохозяйствами, государством и капитализмом. 
Но для тотально большевистско-коммунистического утопического взгляда на мир через призму грядущего господства моноукладного, громадно фабричного хозяйства, управляемого из единого центра, чаяновский многоукладный и, главное, достаточно либеральный режим экономики и политики, конечно, неприемлем.

А Чаянов именно на первых страницах своей утопии упоминал, что системная слабость либерализма заключалась в неспособности создать собственную утопию. Фактически чаяновская утопия и стремилась восполнить этот пробел, синтезируя основы либерализма с идеями кооперативного социализма.

Чаяновская утопия есть вымышленная история драматического восхождения к власти через череду хронических конфликтов и кризисов либеральной кооперации в экономически и культурно разнообразной России. Это история трудного, но успешного обучения российского общества основам сохранения и развития политического плюрализма и экономической многоукладности. Кажется, что смысл существования этой утопической крестьянской страны только и заключается во все более разнообразном политико-культурном существовании федеративного конгломерата самых разнообразных политических и экономических форм, или как декларирует один из олигархов ее политического кооперативного духа: «Мы... в проведении всей этой механики в жизнь охотно допускаем и местные варианты; так, в Якутской области у нас парламентаризм, а в Угличе любители монархии завели „удельного князя“, правда, ограниченного властью местного совдепа, а на Монголо-Алтайской территории единолично правит „генерал-губернатор“ центральной власти» (Там же: 197).

Самое главное, что эта утопическая страна живет с ощущением ценности прогрессивного значения бесконечного возрастания политического, экономического и культурного разнообразия социальной жизни как главного фактора эволюции и смысла человеческого существования.

Чевенгурские общественные настроения принципиально отличны от мироощущения чаяновской утопии. В тот исторический момент, когда партия объявила о переходе к нэпу и многоукладной экономике с упором на развитие кооперации, в Чевенгуре и его окрестностях находится достаточно революционных персонажей, недовольных сменой предшествующего курса на форсированное строительство коммунизма любой ценой. Эти революционеры продолжают жить апокалиптическим чувством достижения коммунизма немедленно здесь и сейчас. Например, председатель чевенгурского ревкома товарищ Чепурный «замучился буржуазия живет, коммунизма нет, а в будущее ведет, как говорилось в губернских циркулярах, ряд последовательно-наступательных переходных ступеней, в которых Чепурный чувством подозревал обман масс» (Платонов, 2011: 225).

Потому же и идеи постепенно эволюционистской кооперации чаяновского типа приходятся не ко двору в Чевенгуре. Андрей Платонов красочно рисует трагикомически неудачную попытку либерально-компромиссной кооперации вступить в продуктивный диалог с коммунистически неприступным Чевенгуром в развитие ленинского кооперативного плана через диалог кооператора Алексея 
Алексеевича Полюбезьева с председателем чевенгурского ревкома Чепурным. Между прочим, случайно ли эти имя и отчество чевенгурского кооператора совпадают с именами двух главных кооперативных героев чаяновской утопии Алексея Кремнева и Алексея Минина?! Вполне возможно, что Платонов читал утопию Чаянова, и если читал, то добродушно и печально высмеял ее в следующей чевенгурской истории:

Алексей Алексеевич... не понимал науки советской жизни, его влекла лишь одна отрасль - кооперация, о которой он прочитал в газете «Беднота»... Изучив статью о кооперации, Алексей Алексеевич прижался душой к Советской власти и принял ее теплое народное добро. Перед ним открылась столбовая дорога святости, ведущая в божье государство житейского довольства и содружества. До этого Алексей Алексеевич лишь боялся социализма, а теперь, когда социализм назвался кооперацией, Алексей Алексеевич сердечно полюбил его. В Чевенгур Алексей Алексеевич пришел искать кооперацию спасение людей от бедности и от взаимной душевной лютости... В первую очередь Алексей Алексеевич хотел достать кооперативный устав, а затем... братски побеседовать с председателем, товарищем Чепурным, об организации кооперативной сети...

- Полюбезьев! - узнал Алексея Алексеевича Чепурный... - Говори, пожалуйста, что тебе причитается.

- Мне о кооперации хочется вкратце сказать... Читали, товарищ Чепурный, про нравственный путь к социализму в газете обездоленных под тем же названием, а именно «Беднота»?

Чепурный ничего не читал.

- Какая кооперация? Какой тебе путь, когда мы дошли?.. Теперь, братец ты мой, путей нету - люди доехали.

- Куда? - покорно спросил Алексей Алексеевич, утрачивая кооперативную надежду в сердце.

- Как куда? В коммунизм жизни. Читал Карла Маркса?

- Нет, товарищ Чепурный.

- А вот надо читать, дорогой товарищ: история уж кончилась, а ты и не заметил.

Алексей Алексеевич смолк без вопроса и пошел вдаль... (Там же: 203-204)

Из дальнейшего чевенгурского повествования выясняется, что Чепурный и сам не читал Карла Маркса, чьим именем лишь постарался смутить вежливого и робкого кооператора. Впоследствии, когда Чепурный со своими товарищами все же принимается за чтение Маркса, то становится ясно, что марксизм для них является учением сакрально темно-непонятным, хотя, безусловно, достойным благоговейного отношения, как это видно из описания: «Чепурный взял в руки сочинение Карла Маркса и с уважением перетрогал густонапечатанные страницы: писал-писал человек, сожалел Чепурный, а мы все сделали, а потом прочитали - лучше бы и не писал!» (Там же: 243).

Итак, в Чевенгуре настает коммунизм после уничтожения в нем буржуазии и примыкающей к ней остаточной сволочи?! Или еще нет?! А если все-таки нет, то 
каковы к коммунизму ведут пути? Такими вопросами постоянно, так или иначе, терзаются все чевенгурцы, как обыватели, так и коммунисты. В описаниях Платонова это выглядит следующим образом:

\begin{abstract}
Чевенгур рано затворялся, чтобы спать и не чуять опасности. И никто, даже Чепурный со своим слушающим чувством, не знал, что на некоторых двоpax идет тихая беседа жителей. Лежали у заборов в уюте лопухов бывшие приказчики и сокращенные служащие и шептались про лето господне, про тысячелетнее царство Христово, про будущий покой освеженной страданиями земли - такие беседы были необходимы, чтобы кротко пройти по адову дну коммунизма; забытые запасы накопленной вековой душевности помогали старым чевенгурцам нести остатки своей жизни с полным достоинством терпения и надежды. Но зато горе было Чепурному и его редким товарищам - ни в книгах, ни в сказках, нигде коммунизм не был записан понятной песней, которую можно было вспомнить для утешения в опасный час; Карл Маркс глядел со стен, как чуждый Саваоф, и его страшные книги не могли довести человека до успокаивающего воображения коммунизма; московские и губернские плакаты изображали гидру контрреволюции и поезда с ситцем и сукном, едущие в кооперативные деревни, но нигде не было той трогательной картины будущего, ради которого следует отрубить голову гидре и везти груженые поезда. Чепурный должен был опираться только на свое воодушевленное сердце и его трудной силой добывать будущее, вышибая души из затихших тел буржуев и обнимая пешехода-кузнеца на дороге. (Платонов, 2011: 247)
\end{abstract}

Есть ли в пространстве социальной жизни этих двух революционных утопий потенциальные конфликты, способные возмутить и подорвать неуклонное следование избранным идеалам кооперативной Москвы и коммунистического Чевенгура?

Да, есть, и эти конфликты связаны с вопросами власти, вполне соответствуя знаменитому ленинскому утверждению: «Коренной вопрос всякой революции есть вопрос о власти в государстве. Без уяснения этого вопроса не может быть и речи ни о каком сознательном участии в революции, не говоря уже о руководстве ею» (Ленин, 1969а: 146).

Вопросы власти в их потенциально конфликтном значении для общества в обеих утопиях формулируются одинаково, но заключительные ответы на них даются различные.

И Чаянов, и Платонов подчеркивают значение демократической власти для Революции, ее прорастания снизу из первичной необходимости спонтанной и добровольной самоорганизации людей и сообществ на местах. Такое видение революционной самоорганизации населения повсюду, кажется очень близким по духу к идеям анархизма Кропоткина (Кропоткин, 2014), к которому и Чаянов и Платонов относились с симпатией.

Чаяновская Москва 1984 года представляет собой вертикаль власти самых разномасштабных кооперативно-муниципальных конгломератов, укорененных 
в процедурах контроля со стороны именно низовых, первичных муниципальных и кооперативных организаций. Иногда здесь на местном уровне могут зарождаться относительно опасные конфликты, которые тут же подвергаются демократическому обсуждению всей страны. Таков случай некоего авторитарного муниципального лидера из-под Кинешмы и Костромы Архипа Таратина. Являясь лидером большинства в местном Кинешемском совете, а также фанатом античной культуры и гимнастики, он принялся повсюду насаждать идеалы древнегреческой физкультуры и ретиво бороться против другого местного культурного сообщества старообрядцев-федосеевцев, предпочитавших античным философам сочинения Григория Богослова и Патерик Печерский. Этот скандал дошел до колонного зала крестьянско-утопического ВЦИКа, откуда Архипу Таратину было сделано гневное внушение о том, что он своими действиями нарушает Великий декрет 1928 года о неотъемлемых правах гражданина. Главный крестьянский кооперативный политолог Алексей Минин в связи с этим отмечал, что если раньше против таких авторитарных фанатиков, как Архип Таратин, применялись крутые государственные меры, подвергавших преследованиям то иезуитов, то франкмасонов, а то и социалистов, то теперь общество найдет в себе силы осадить Архипа и его сторонников без государственного вмешательства.

Впрочем, властные конфликты могут исходить не только от территориальнополитических образований, но также и от социально-экономических укладов. Поэтому Чаянов и упоминает о необходимости контроля в интересах всего общества над государством, капитализмом и даже кооперацией, чтобы они «не брыкались» в своих моноукладных эгоистических интересах.

Наконец, в мировом масштабе во взаимоотношениях между пятью социальноэкономическими системами, одной из которых является Россия, также возможны конфликты, поэтому крестьянская утопия имеет вполне боеспособные вооруженные силы.

В итоге в приватной беседе с Кремневым Минин от имени утопической власти подчеркивает: «Мы никогда не были тупо принципиальны, и когда нашему делу угрожало насилие со стороны, а целесообразность заставляла вспомнить, что в наших руках была государственная власть, то наши пулемёты работали не хуже большевистских» (Чаянов, 1989: 184).

Итак, в утопической крестьянской стране существует сложнейший конгломерат самых различных видов и уровней власти, объединенных идей общественного контроля и согласия. Власть не отменятся в крестьянской утопии, но бесконечно диверсифицируется в системе сдержек и противовесов различных институтов во имя соблюдения прав отдельного индивида. Если же возникнет действительно серьезная угроза этой системе, что ж, тогда в защиту ее будет приведен последний довод крестьянских олигархов - «пулеметы не хуже большевистских».

А «Чевенгур» вслед за частной собственностью стремится отменить и государственную власть, и любую другую. Сделать это и трудно, и легко посреди крестьянско-черноземной страны, страдающей от ужасов Гражданской войны со всем 
ее безначалием и бандитизмом. В середине повествования романа его главные герои Саша Дванов и Степан Копенкин только тем и занимаются, что путешествуют по разным селам и деревням, на местах обнаруживая самые диковинные формы местной властной самоорганизации - «коммуны», "ревзаповедник», село, прислушивающееся к односельчанину, объявившему себя богом, просто бандитские малины и так далее. В этом хаосе безвластия крестьяне, равно страшившиеся бандитского грабежа и советской продразверстки, тоскуют по крепкой власти и одновременно опасаются ее.

В самом же «Чевенгуре», где коммунизм был создан местным ревкомом во главе с товарищем Чепурным, теперь считают власть никчемным явлением, остатки которого надо поскорее окончательно упразднить. Теперь, после победы коммунизма, иметь власть, находиться у власти, при власти просто стыдно. Советская власть в «Чевенгуре» должна раствориться в царстве «множества природных невзрачных людей», стать как «природная сила» (Платонов, 2011: 168).

Сам глава чевенгурского ревкома стремится поскорее сложить с себя ставшие постыдными при коммунизме властные полномочия, обуреваемый следующими нравственными угрызениями: «Чепурный вспомнил, что он не Советская власть... он побоялся, как бы не подумали про него: вон самый умный и хороший пошел, богатым начальником бедноты коммунизма хочет стать! И Чепурный присел за одним поперечным плетнем, чтобы про него сразу забыли и не успели ничего подумать» (Там же: 346).

Мы рассматривали возможные конфликты и угрозы в вопросах власти в крестьянской утопии, а существуют ли они в утопии чевенгурской? Да, тоже существуют. Это угрозы как внешние, так и внутренние. Внешняя угроза - контроль из центра, хотя бы из губернии. Как объясняет все тот же Чепурный: «Только знаешь, если мы в губернию... отвечать не будем, что у нас все хорошо, а то оттуда у нас весь коммунизм ликвидируют» (Там же: 220).

Угроза внутренняя - возможная претензия на власть - одного из главных идеологов и хозяйственных деятелей чевенгурского коммунизма Прокофия (Прошки) Дванова, обуреваемого собственными шкурными интересами.

Если в утопии Чаянова Архип Таратин олицетворял собой архаичного властолюбца авторитарной идеи, то в утопии Платонова Прошка Дванов является также архаичным властолюбцем, но идеи собственнической. Он все время держит в уме, что старые времена могут и обратно вернуться, а потому постоянно ведет счет коммунистическому имуществу, подобно партийно-хозяйственной номенклатуре времен перестройки, предвкушающей для себя благо шоковой приватизации.

В отличие от чаяновской кооперативной утопии, где власть контролируется искусной командой на удивление сплоченных демократически ориентированных олигархов (их почему-то не разделяют личностные политические амбиции, о конфликтном значении которых для лидеров буржуазных и социалистических партий любил упоминать Чаянов), чевенгурские коммунисты, не признавая никакой власти и неуклонно от нее отказываясь, тем не менее ведут принципиальные споры 
о признаках и путях коммунизма, что позволило проницательному исследователю платоновской утопии выделить внутри чевенгурского ревкома периодически противостоящие друг другу романтическую линию Розы Люксембург - Копенкина-Дванова (Саши), и догматическую линию Ленина - Чепурного-Дванова (Проши) (Ходел, 200о). В конце концов Чевенгурский ревком, уничтожив буржуазию, с одной стороны, раскрывает двери для прихода в город всех страждущих и обремененных пролетариев, с другой - заявляет о сложении с себя всех властных полномочий. Чевенгурцы боятся и стесняются любой власти, а более всего власти собственной.

А еще в чаяновском и платоновском сочинениях описываются враждебные властные силы, которые к концу обоих повествований испытывают обе утопии на прочность, обрывая этими испытаниями путешествия главных героев.

\section{Путешествия, оборванные очередной войной}

Итак, около 1921 года герой чаяновской утопии проваливается во времени в столично-кооперативную Москву 1984 года, а герой Платонова в том же 1921 году проваливается в пространстве в уездно-коммунистический Чевенгур. Как богатая культурой и достатком кооперативная Москва, так и нищий духом и телом коммунистический Чевенгур в основном полагают, что они достигли того идеала, ради которого и свершалась Русская революция. Лишь главные герои обеих утопий, путешествуя по всем их закоулкам, с тревогой пытаются прощупать в своих размышлениях и действиях возможные слабости и несовершенства утопических стран.

Безусловным испытанием для любой страны, а уж тем более страны, победившей революции, является война. Ибо как говорил В. И. Ленин: «Всякая революция лишь тогда чего-нибудь стоит, если она умеет защищаться...» (Ленин, 19696: 123). Более того, он же утверждал и задавался вопросом: «Революция может состоять и, вероятно, будет состоять из долголетних битв... - И какое же оружие применять в этих битвах?» (Ленин, 1969в: 57).

В обеих утопиях, конечно, упоминается неоднократно опыт бесчисленных больших и малых военно-политических столкновений в истории. И обе утопии завершаются описанием очередных грозных военных испытаний, выпавших на долю двух утопических стран, стремительно обрываясь описанием чувств главных героев - свидетелей разразившейся военной грозы.

В утопии Чаянова главная угроза для кооперативной Московии - ее агрессивная соседка - советско-бюрократическая Германия. Эта страна свято пронесла через десятилетия экономический строй планово-бюрократической централизованной экономики, так схожей с экономикой России времен военного коммунизма. В результате у немцев, измученных проблемами извечного советского продовольственного дефицита, возникает соблазн поправить свои дела вероломным вторжением в изобильно богатую кооперативную Россию. В чаяновской утопии Россия 
оказывается готовой к войне на все сто процентов. Она мгновенно отмобилизовывается в чувствах всенародного патриотического ликования, нанося противнику немедленный сокрушительный удар своим чудо-оружием, после которого германец запрашивает скорого мира, соглашаясь на уплату щедрой культурно-скотоводческой контрибуции. Война так описывается глазами главного героя утопии:

Алексей узнал, что 7 сентября три армии германского Всеобуча, сопровождаемые тучами аэропланов, вторглись в пределы Российской крестьянской республики и за сутки, не встречая никаких признаков не только сопротивления, но даже живого населения, углубились на 50, а местами и на 100 вёрст.

В 3 часа 15 минут ночи на 8 сентября по заранее разработанному плану метеорофоры пограничной полосы дали максимальное напряжение силовых линий на циклоне малого радиуса, и в течение получаса миллионные армии и десятки тысяч аэропланов были буквально сметены чудовищными смерчами. Установили ветровую завесу на границе, и высланные аэросани Тары оказывали посильную помощь поверженным полчищам. Через два часа берлинское правительство сообщило, что оно прекращает войну и выплачивает вызванные ею издержки в любой форме.

Таковой формой русский Совнарком избрал несколько десятков полотен Боттичелли, Доменико Венециано, Гольбейна, Пергамский алтарь и 1000 китайских раскрашенных гравюр эпохи Танг, а также 1000 племенных быковпроизводителей. (Чаянов, 1989: 207)

Описание утопической войны с Германией может вызвать неловкость читателя из-за всей ее водевильно-легкомысленной эйфории метеорофорного блицкрига, ведь Чаянов как-никак был современником и свидетелем неимоверных тягот и страданий Первой мировой (германской) войны для всего мира и России. Тем не менее в чаяновских утопических строчках опять проступают некоторые пророческие чувства и факты грядущего реального российско-германского конфликта будущей мировой войны. Чаянов точно передает предвоенные утопические чувства будущей легкой победы малой кровью, запечатленные в прекраснодушных песне и фильме с одноименными названиями «Если завтра война» (1938). Чаянов также по-хозяйски предсказывает, что с немцев в возмещение нанесенного чудовищного ущерба возьмут и полотна старых европейских мастеров, и если не Пергамский алтарь, то клад Приама (золото Трои), и еще всяческие культурные и хозяйственные ценности.

Лично Чаянов, будучи патриотом России, никогда не проявлял шовинистических настроений ни по отношению к Германии, ни по отношению к какой-либо другой стране. Тем не менее, должно быть, унизительное поражение России в Первой мировой войне оставило досадный след в душе Чаянова. Поэтому неслучайно победоносная утопическая война с Германией разыгрывается в 7о-летний юбилей начала Первой мировой войны - в сентябре 1984 года. И неслучайно Чаянов упоминает своего друга воронежского профессора Минина в будущем профессором Константинопольского университета, значит, намекает Чаянов, Турцию еще раньше Германии победили?! «Константинополь наш!» 
Тем временем к возможному военному конфликту в конце своего романа готовятся и платоновские чевенгурцы. Живя в первобытном единении с природой, особо не доверяя науке, технике и культуре, они имеют в своем арсенале лишь доставшиеся им от Гражданской войны винтовки, пистолеты, сабли, пулемет и несколько заржавевших, негодных гранат. Саша Дванов, впрочем, пытается для грядущей обороны Чевенгура придумать некое чудо-оружие, достойное всей его предшествующей сонно-бредовой фантасмагории: «Нужно колесо, - вслух определил Дванов. - Кованый деревянный диск, с него можно швырять в противника кирпичи, камни, мусор - снарядов у нас нет. А вертеть будем конным приводом и помогать руками - даже пыль можно отправлять и песок...» (Платонов, 2011: 393).

Впрочем, это единственное чудо-оружие чевенгурцы не успели подготовить и ввести в дело, потому что неведомый враг напал на них со стороны степи столь решительно и по-военному организованно, что чевенгурцы все как один, включая стариков и женщин, лишь успели высыпать навстречу противнику на окраину своего города и героически, почти все до одного, погибли в неравной борьбе.

В отличие от чаяновской утопии, где как всегда все четко и ясно: враг - германец, в платоновской утопии непонятно: чья же все-таки конница изрубила Чевенгур? В романе чевенгурцы кричат, что это кадеты. Но многие историки и литературоведы вполне резонно замечают, что к 1921 году в России кадеты исчезли, разбитые в предшествующие годы Гражданской войны. Тогда остаются бандиты? Но конница, напавшая на Чевенгур, представляет собой регулярное военное формирование, никак не похожее на разномастных бандитских кавалеристов. Тут вполне правдоподобной может быть и третья версия: это была регулярная Красная армия, посланная именно из центра для наведения порядка, чтобы покончить с пережитками анархо-бандитского коммунизма в уездном городе Чевенгур. Читателю этого романа остается как всегда гадать и выбирать достоверный вариант, руководствуясь прежде всего личными чувствами и разумениями.

Платоновское описание этой последней чевенгурской битвы - торжественное и трагическое, достойное в своей трогательности античных и скандинавских сказаний о гибели настоящих героев от могучих врагов, у которых

были команда и строй, поэтому они держались ровно и бесстрашно против первых выстрелов Чевенгура. Дванов понял их преимущество и, установив ноги в ложбинке, сшиб четвертой пулей командира отряда из своего нагана. Но противник опять не расстроился, он на ходу убрал командира куда-то внутрь построения и перевел коней на полную рысь. В этом спокойном наступлении была машинальная сила победы, но и в чевенгурцах была стихия защищающейся жизни. Кроме того, на стороне Чевенгура существовал коммунизм... (Там же: 403)

Коммунизм не спас чевенгурцев в этот последний и решительный бой. Город Чевенгур на последней странице повести предстает полностью опустошенным. 


\section{Опустошающие путешествия в поисках братства}

Опустошением душ главных героев заканчиваются их утопические путешествия. «Американец» Алексей Кремнев изначально радушно принятый в интеллигентной профессорской семье утопической Москвы, все больше вызывает недоумение странностями и промахами своего поведения. Из-за доноса главы семейства, заподозрившего его в шпионаже, Кремнева арестовывают и подвергают допросу как германского шпиона. На допросе Кремнев чистосердечно рассказал, что он является всего лишь современником великой Русской революции, сам непонимающий, каким образом он перенесся в будущее-настоящее на несколько десятилетий вперед. Специально обсуждавшая его случай экспертная комиссия, включавшая в себя также историков, внимательно и корректно выслушав все его ответы о якобы родственном ему времени, приходит к отрицательному заключению: «Его собеседники-профессора долго и с сожалением качали головами и заявили ему на прощание, что он, несомненно, начитан в революционной литературе, в нём видно знакомство с архивами, но что он совершенно не представляет собою духа эпохи и чудовищно по непониманию толкует исторические события, а потому ни в коем случае не может быть признан современником их» (Чаянов, 1989: 206).

Впрочем, Кремнев быстро признается безвредным, хотя и странным гражданином, принимается решение о его немедленном освобождении из-под ареста. Чаянов подчеркивает, что за все время заключения с Кремневым обращались вежливо и предупредительно, по окончании ареста даже предоставив ему возможность позавтракать на веранде гостиницы за казенный счет. От всего с ним случившегося главный герой к концу повествования оказывается совершенно опустошенным. Повесть о нем завершается так: «Кофе был допит, ростбиф окончен, и Кремнев поднялся со стула. Сгорбленный и подавленный происшедшим, он медленно спускался с лестницы веранды, идя один, без связей и без средств к существованию, в жизнь почти неведомой ему утопической страны. Конец первой части» (Там же: 208).

Еще более трагичной оказывается ситуация Александра Дванова, чудом уцелевшего в чевенгурской бойне. Из битвы конь выносит Дванова к озеру, где когдато утопился его отец. Измучившийся бесконечными поисками социализма и коммунизма, потрясенный гибелью Чевенгура, не обнаруживая в окружающих его деревенских ландшафтах и людях никаких перемен со времен детства, Дванов решает следовать участи своего отца, погружаясь в глубину озерных вод.

После исчезновения Дванова следующими строчками заканчивается и сам роман:

В Чевенгуре... было пусто и скучно, только в одном месте, близ кирпичного дома, сидел Прошка и плакал среди всего доставшегося ему имущества.

- Ты чего ж, Прош, плачешь, а никому не жалишься? - спросил Захар Павлович [приемный отец Дванова. - A. H.]. - Хочешь, я тебе опять рублевку дам [когда-то в детстве за рубль Прошка отыскал своего сводного бра- 
та, сироту-побирушку Сашу для Захара Павловича. - A. H.] - приведи мне Сашу.

- Даром приведу, - пообещал Прокофий и пошел искать Дванова. (Платонов, 2011: 409)

Читателям обоих произведений остается лишь слабая надежда, что, возможно, в намеке на вторую часть утопии Чаянова и в обещании прохиндея Прошки в утопии Платонова все-таки последуют какие-то продолжения утопических путешествий в поисках дальнейшего осуществления революции.

В заключение отмечу, что все глубокомысленные и остроумные описания социально-экономического устройства крестьянской Москвы и бродяжьего Чевенгура направлены к постижению главной цели всякой великой социальной революции - достижению свободы, равенства, братства. Впрочем, тема братьев и сестер - любви между ними - столь экзистенциально важна в двух утопиях, что потребует для своего раскрытия особого исследовательского текста. Здесь лишь отметим, что главного героя крестьянской утопии коммуниста Кремнева, конечно, неслучайно называет своим братом ее автор-«крестьянист». В «Чевенгуре» братья Двановы, Александр и Порфирий, также являясь по духу антагонистами, все же искренне ищут родства меж собой. Алексей Кремнев в Москве 1984 разрывается в своих симпатиях меж двумя сестрами, в то время как Александр Дванов и другие чевенгурцы также стремятся обнаружить в женщинах прежде всего своих сестер. Впрочем, и здесь мы можем отметить различный эмоциональный градус братско-сестринских исканий в двух утопиях. У Чаянова это описывается с отстраненной симпатией, у Платонова - с напряженным сочувствием.

\section{Заключение: утопии в поисках исторических революционных альтернатив}

Несмотря на безусловную симпатию к своим революционным утопиям, Чаянов и в особенности Платонов также проницательно, а порой даже жестоко критикуют экзистенциальные основания собственных революционно-утопических построений. Особенно уникален здесь «Чевенгур», представляющий собой синтез яростной апологетики коммунизма с его самой убийственной антикоммунистической критикой. В этой связи хочется сослаться на проницательные замечания Ханса Гюнтера: «Утопическая структура в платоновских произведениях находится в становлении - и одновременно в распаде... Нет эпизода, в котором не было бы обсуждения действия с разных позиций. С этой точки зрения мы можем назвать роман метаутопией - утопия и антиутопия в нем вступают в не находящий завершения диалог» (Гюнтер, 2012: 12).

В отличие от платоновского романа кажется, что чаяновская повесть является все же и прежде всего позитивной утопией, обосновывающей действительно некий лучший и гуманный из возможно существующих мир. Тем не менее и в «кре- 
стьянской Москве 1984» проступают зловещие антиутопические черты, пожалуй, вопреки воле своего автора, в развитие некоторых интеллектуально этических и эстетических предпосылок его собственного мировоззрения. Исследователь антиутопического потенциала чаяновской повести Н. В. Михаленко обоснованно отмечает его главную суть: «Утопические правители, «авгуры духа», изменившие ход истории и поднявшие государство из руин, мыслят свою деятельность как теургическую, не случайно государственным гимном здесь является «Прометей» А. Н. Скрябина. В стране крестьянской утопии осуществляется искусственный отбор - «терапия неудавшихся жизней», все стремления направлены на то, чтобы ни один талант не был бы утерян. Таким образом, человек ставит себя в центр мира, нивелируется идея соработничества с Богом» (Михаленко, 2016: 428).

Действительно, если обратиться к теме взаимоотношений революционных и религиозных альтернатив в обеих утопиях, то надо признать, что «Чевенгур» это произведение, пронизанное поисками новой веры, находящееся в непрестанно напряженном диалоге с христианством.

Например, так пронзительно юродиво описывает Платонов размышления славного чевенгурского революционера Копенкина перед кладбищенской церковью, переделанной в «Совет социального человечества Чевенгурского освобожденного района»:

Сам же Совет помещался в церкви. Копенкин проехал по кладбищенской дорожке к паперти храма. «Приидите ко мне все труждающиеся и обремененные и аз упокою вы» - написано было дугой над входом в церковь. И слова те тронули Копенкина, хотя он помнил, чей это лозунг.

«Где же мой покой? - подумал он и увидел в своем сердце усталость. Да нет, никогда ты людей не успокоишь: ты же не класс, а личность. Нынче 6 ты эсером был, а я б тебя расходовал». (Платонов, 2011: 308)

Впрочем, и в повести Чаянова упоминаются некие «апостолы новой веры», церковь, религиозные волнения, настроения, виртуозная игра на церковных колоколах. Тем не менее во всех этих описаниях не обнаруживается никаких собственно религиозных чувств ни героев, ни самого автора утопии. Чаяновская утопия относится к упоминаемым в ней иконам суздальского письма, старинным церквям, церковному хоровому пению и колокольному звону с культурологическим почтением, но без всякого религиозного пиетета. Остается впечатление, что «крестьянская Москва 1984" по своему господствующему духовному облику есть страна прежде всего культурно-толерантного атеизма и агностицизма, чему свидетельствуют упоминаемые в утопической повести столичные руины храма Христа Спасителя, тщательно сохраняемые и увитые плющом.

Что удивительным образом объединяет эти две столь различные утопии, так это общая временная точка утопических бифуркаций - год, в который два главных героя повести отправляются в свои утопии - 1921-й, и сезон, когда утопии заканчиваются, - начало осени, сентябрь, бабье лето. 
Чаянов, создавая свою утопию в 1919 году, словно предчувствовал острейший политический и экономический кризис 1921 года, когда упоминал, что его герой именно в 1921-м устремится в новую утопическую Москву осени 1984 года. Платонов из 1928 года возвращается на семь лет назад, в лето и осень Чевенгура 1921 года.

По мнению большинства современников и историков, 1921 год был действительно судьбоносным для Русской революции. В этом году большевистская власть находилась на краю катастрофы, потрясенная Кронштадтским мятежом, крестьянскими восстаниями, всеобщей разрухой Гражданской войны и военного коммунизма.

Советский режим тогда чудом выстоял благодаря искусному ленинскому маневру с нэпом. Но этот год, несмотря еще и на чудовищную засуху, поразившую Центр, Юг и Поволжье России, был чрезвычайно урожайным на прогнозы, проекты, предложения дальнейших альтернативных путей развития Русской революции (May, 2017). Чаяновское утопическое либерально-кооперативное предчувствие в 1919 году и платоновское утопическое анархо-коммунистическое переосмысление в 1928 году альтернатив бифуркации 1921 года остаются проницательно-загадочными памятниками революционной мысли, ищущими ответы на извечные вопросы целей и ценностей Революции.

\section{Литература}

Алданов М. А. (1994). Портреты. Кн. 1. М.: Новости.

Алейников О. Ю. (2013). Андрей Платонов и его роман «Чевенгур». Воронеж: Наука-Юнипресс.

Антонова Е. В. (2016). Воронежский период жизни и творчества А. П. Платонова: биография, текстология, поэтика. М.: ИМЛИ.

Бруиш К. (2012). Крестьянская идеология для крестьянской России: аграризм в России начала XX века // Крестьяноведение. Вып. 7. С. 142-158.

Варламов А. (2011). Андрей Платонов. М.: Молодая гвардия.

Гюнтер X. (2012). По обе стороны от утопии: контексты творчества А. Платонова. М.: Новое литературное обозрение.

Данилов В. П. (2011). Русская революция в судьбе А. В. Чаянова // Данилов В. П. История крестьянства России в ХХ веке: избранные труды. Ч. 2. М.: РОССПЭН. С. $149-177$.

Заваркина М. В. (2013). «Кулацкая утопия» А. Чаянова и «кулацкая хроника» А. Платонова // Скворияов B. Н. (ред.). Пушкинские чтения 2013: Материалы XVIII международной научной конференции. С. 41-48.

Корниенко Н. В. (1993). «Меня убьет только прямое попадание по башке»: материалы к творческой биографии Платонова 1927-1932 // Новый мир. № 4. С. 89-121.

Корниенко Н. В. (ред.). (2005). «Страна философов» Андрея Платонова: проблемы творчества. Вып. 6. М.: ИМЛИ. 
Кропоткин П. А. (2014). Поля, фабрики, мастерские: промышленность, соединенная с земледелием, и умственный труд с ручным. М.: ЛЕНАНД.

Ленин В. И. (1969а [1917]). О двоевластии // Ленин В. И. Полное собрание сочинений. Т. 31. М.: Политиздат. С. 145-148.

Ленин В. И. (1969б [1918]). Объединенное заседание ВЦИК 22 октября 1918 г. // Ленин В. И. Полное собрание сочинений. Т. 37. М.: Политиздат. С. 113-125.

Ленин В. И. (1969в [1924]). Истинные интернационалисты: Каутский, Аксельрод, Мартов // Ленин В. И. Полное собрание сочинений. Т. 27. М.: Политиздат. C. $52-58$.

Ливингстон А. (2005). Время в Чевенгуре // Корниенко Н. В. (ред.). «Страна философов» Андрея Платонова: проблемы творчества. Вып. 6. М.: ИМЛИ. С. 20-33.

Магун А. В. (2010). Отрицательная революция Андрея Платонова // Новое литературное обозрение. № 6. С. 65-95.

Маркс К., Энгельс Ф. (1961). Программа бланкистских эмигрантов коммуны // Маркс К., Энгельс Ф. Полное собрание сочинений. Т. 18. М.: Госполитиздат. C. 510-517.

Мау В. А. (2017). Революция: механизмы, предпосылки и последствия радикальных общественных трансформаций. М.: Изд-во Ин-та Гайдара.

Михаленко Н. В. (2016). Символика Вавилонской башни в «Путешествии моего брата Алексея в страну крестьянской утопии» А. В. Чаянова // Проблемы исторической поэтики. Т. 14. С. 428-440.

Мосс M. (2011). Общества. Обмен. Личность: труды по социальной антропологии / Пер. с франц. А. Б. Гофман. М.: КДУ.

Никулин А. М. (2017). Чаяновский утопизм: балансируя среди кризисов интенсификации оптимумов // Крестьяноведение. 2017. Т. 2. № 1. С. 6-3о.

Пастернак Б. Л. (1993). Про эти стихи // Бавин С. П., Семибратова И. В. Судьбы поэтов Серебряного века. М.: Книжная палата. С. 347.

Платонов А. П. (2011). Чевенгур. Котлован. М.: Время.

Поланьи К. (2014). Великая трансформация: политические и экономические истоки нашего времени / Пер. с англ. А. А. Васильева, С. Е. Федорова, А. П. Шурбелева под общ. ред. С. Е. Федорова. СПб.: Алетейя.

Симонов В. В., Фигуровская Н. К. (1988). Вопросы Чаянова // Социокультурные утопии ХХ века. Вып. 6. М.: ИНИОН. С. 97-133.

Ходел Р. (200о). Чевенгур и Роза Люксембург // Корниенко Н. В. (ред.). «Страна философов» Андрея Платонова: проблемы творчества. Вып. 4. Юбилейный. М.: ИМЛИ РАН, Наследие. С. 535-540.

Хрящева Н. (2005). «Тонок сон»: к поэтике снов в «Чевенгуре» // Корниенко Н. В. (ред.). «Страна философов» Андрея Платонова: проблемы творчества. Вып. 6. М.: ИМЛИ. С. 442-449.

Чаянов А. В. (1989). Путешествие моего брата Алексея в страну крестьянской утопии // Чаянов А. В. Венецианское зеркало. М.: Современник. С. 161-208. 
Чаянов В. А., Петриков А. В. (1998). А. В. Чаянов в следствии ОГПУ по делу Трудовой крестьянской партии (1930-1932 гг.) // Сельский мир. Вып. 2. С. 4-146.

Червякова Л. (2005). Поэтика сна в романе «Чевенгур» // Корниенко Н. В. (ред.). «Страна философов» Андрея Платонова: проблемы творчества. Вып. 6. М.: ИМЛИ. С. 450-454.

Шанин Т. (1997). Революция как момент истины: Россия 1905-1907 гг. — 1917-1922 гг. М.: Весь Мир.

Шушпанов А. Н. (200о). А. В. Чаянов и утопия 1920-х годов: проблема жанра // Потаенная литература: исследования и материалы. Вып. 2: Приложение. Иваново: Ивановский государственный университет. С. 74-8о.

\title{
Dreams of the Russian Revolution in the Utopias of Alexander Chayanov and Andrei Platonov
}

\author{
Alexander Nikulin \\ Candidate of Economical Sciences, Head of the Center for Agrarian Studies, Russian Presidential Academy of \\ National Economy and Public Administration \\ Address: Vernadskogo prospekt, 82, Moscow, Russian Federation 119571 \\ E-mail: harmina@yandex.ru
}

The Russian Revolution is the central theme of both A. Chayanov's novel The Journey of My Brother Alexei to the Land of Peasant Utopia and A. Platonov's novel Chevengur. The author of this article compares the chronicles and images of the Revolution in the biographies of Chayanov and Platonov as well as the main characters, genres, plots, and structures of the two utopian novels, and questions the very understanding of the history of the Russian Revolution and the possible alternatives of its development. The article focuses not only on the social-economic structure of utopian Moscow and Chevengur but also on the ethical-aesthetic foundations of both utopias. The author argues that the two utopias reconstruct, describe, and criticize the Revolution from different perspectives and positions. In general, Chayanov adheres to a relativistic and pluralistic perception of the Revolution and history, while Platonov, on the contrary, absolutizes the end of humankind history with the eschatological advent of Communism. In Chayanov's utopia, the Russian Revolution is presented as a viable alternative to the humanistic-progressive ideals of the metropolitan elites with the moderate populist-socialist ideas of the February Revolution. In Platonov's utopia, the Revolution is presented as an alternative to the eschatological-ecological transformation of the world by provincial rebels inspired by the October Revolution. Thus, Chayanov's liberal-cooperative utopia and Platonov's anarchist-communist utopia contain both an apologia and a criticism of the Russian Revolution in the insights of its past and future victories and defeats, and opens new horizons for alternative interpretations of the Russian Revolution.

Keywords: Russian Revolution, utopia, civil war, city, village, peasantry, cooperation, communism, eschatology, anarchy, state

\section{References}

Aldanov M. (1994) Portrety [Portraits], Moscow: Novosti.

Aleinikov O. (2013) Andrey Platonov i ego roman "Chevengur" [Andrey Platonov and His Novel Chevengur], Voronezh: Nauka-Unipres. 
Antonova E. (2016) Voronezhskij period zhizni i tvorchestva A.P. Platonova: biografiya, tekstologiya, poehtika [Voronezh Period of A, Platonov's Life and Work: Biography, Textology, Poetics], Moscow: IMLI.

Bruish K. (2012) Krest'yanskaya ideologiya dlya krest'yanskoj Rossii: agrarizm v Rossii nachala XX veka [Peasant Ideology for Peasant Russia: Agrarianism in Russia at the Beginning of the 2oth Century]. Krestyanovedenie, no 7, p. 142-158.

Chayanov A. (1989) Puteshestvie moego brata Alekseya v stranu krest'yanskoj utopii [The Journey of My Brother Alexei to the Land of Peasant Utopia]. Venecianskoe zerkalo [Venetian Mirror], Moscow: Sovremennik, pp. 161-208.

Chayanov V., Petrikov A. (1998) A. V. Chayanov v sledstvii OGPU po delu Trudovoj krest'yanskoj partii (1930-1932 gg.) [A. Chayanov under the Investigation of the OGPU in the Case of the Workers' Peasant Party (1930-1932)]. Selsky mir, vol. 2, pp. 4-146.

Chervyakova L. (2005) Poehtika sna v romane "Chevengur" [The Poetics of Sleep in the Novel Chevengur]. "Strana filosofov" Andreya Platonova. Vyp. 6 [Andrey Platonov's "Country of Philosophers", Vol. 6] (ed. N. Kornienko), Moscow: IMLI, pp. 450-454.

Danilov V. (2011) Russkaya revolyuciya v sud'be A. V. Chayanova [The Russian Revolution in the Fate of A. Chayanov]. Istoriya krest'yanstva Rossii v XX veke: izbrannye trudy. Ch. 2 [The History of Russian Peasantry: Selected Works, Part 2], Moscow: ROSSPEHN, pp. 149-177.

Günther H. (2012) Po obe storony ot utopii: konteksty tvorchestva A. Platonova [On Both Sides of Utopia: Contexts of A. Platonov's Work], Moscow: New Literary Observer.

Hodel R. (2000) Chevengur i Roza Lyuksemburg [Chevengur and Rosa Luxemburg]. "Strana filosofov" Andreya Platonova. Vyp. 4 [Andrey Platonov's "Country of Philosophers", Vol. 4] (ed. N. Kornienko), Moscow: IMLI, pp. 535-540.

Khryashcheva N. (2005) "Tonok son": k poetike snov v"Chevengure" ["A Thin Dream": Toward the Poetics of Dreams in Chevengur]. "Strana filosofov" Andreya Platonova. Vyp. 6 [Andrey Platonov's "Country of Philosophers", Vol. 6] (ed. N. Kornienko), Moscow: IMLI, pp. 442-449.

Kornienko N. (1993) "Menya ub'et tol'ko pryamoe popadanie po bashke": materialy k tvorcheskoj biografii Platonova 1927-1932 ["Only a direct hit on the head will kill me": Materials for the Writer's Biography of Platonov, 1927-1932]. Novy mir, no 4, pp. 89-121.

Kornienko N. (ed.) (2005) "Strana filosofov" Andreya Platonova. Vyp. 6 [Andrey Platonov's "Country of Philosophers", Vol. 6], Moscow: IMLI.

Kropotkin P. (2014) Polya, fabriki, masterskie: promyshlennost', soedinennaya s zemledeliem, i umstvennyj trud s ruchnym [Fields, Factories, Workshops: The Industry, Combined with Agriculture, and Mental Work with Manual], Moscow: LENAND.

Lenin V. (1969 [1917]) O dvoevlastii [On the Dual Power]. Polnoe sobranie sochineniy. T. 31 [Complete Works, Vol. 31], Moscow: Politizdat, pp. 145-148.

Lenin V. (1969 [1918]) Obyedinennoe zasedanie VCIK 22 oktyabrya 1918 g. [Joint Meeting of the All-Russian Central Executive Committee on October 22, 1918]. Polnoe sobranie sochineniy. T. 37 [Complete Works, Vol. 37], Moscow: Politizdat, pp. 113-125.

Lenin V. (1969 [1924]) Istinnye internacionalisty: Kautskij. Aksel'rod. Martov [True internationalists: Kautsky, Axelrod, Martov]. Polnoe sobranie sochineniy. T. 27 [Complete Works, Vol. 27], Moscow: Politizdat, pp. 52-58.

Livingston A. (2005) Vremya v Chevengure [Time in Chevengur]. "Strana filosofov" Andreya Platonova. Vyp. 6 [Andrey Platonov's "Country of Philosophers", Vol. 6] (ed. N. Kornienko), Moscow: IMLI, pp. 20-33.

Magun A. (2010) Otricatel'naya revolyuciya Andreya Platonova [Andrey Platonov's Negative Revolution]. New Literary Observer, no 6, pp. 65-95.

Marx K., Engels F. (1961) Programma blankistskih emigrantov kommuny [The Program of the Blanquist Commune Emigrants]. Polnoe sobranie sochineniy. T. 18 [Complete Works, Vol. 18], Moscow: Gospolitizdat, pp. 510-517.

Mau V. (2017) Revolyuciya: mekhanizmy, predposylki i posledstviya radikal'nyh obshchestvennyh transformacij [Revolution: The Mechanisms, Preconditions and Effects of the Radical Social Transformations], Moscow: Gaidar Institute Press. 
Mauss M. (2011) Obshchestva. Obmen. Lichnost': trudy po social'no antropologii [Society. Exchange. Personality: Works in Social Anthropology], Moscow: KDU.

Mikhalenko N. (2016) Simvolika Vavilonskoj bashni v "Puteshestvii moego brata Alekseya v stranu krest'yanskoj utopii" A. V. Chayanova [The Symbolism of the Tower of Babel in the A. Chayanov's Journey of My Brother Alexei to the Country of Peasant Utopia]. Problemy istoricheskoy poetiki, vol. 14, pp. $428-440$.

Nikulin A. (2017) Chayanovskij utopizm: balansiruya sredi krizisov intensifikacii optimumov [Chayanovian Utopian Visions: Looking for the Balance under the Crises of Optima Intensification]. Krestyanovedenie, vol. 2, no 1, pp. 6-30.

Pasternak B. (1993) Pro eti stihi [About these Poems]. Sud'by poehtov serebryanogo veka (eds. S. Bavin, I. Semibratova), Moscow: Knizhnaya palata, pp. 347.

Platonov A. (2011) Chevengur. Kotlovan [Chevengur; Pit], Moscow: Vremya.

Polanyi K. (2014) Velikaya transformaciya: politicheskie i ehkonomicheskie istoki nashego vremeni [The Great Transformation: The Political and Economic Origins of Our Time], Saint Petersburg: Aleteya.

Simonov V., Figurovskaya N. (1988) Voprosy Chayanova [Questions of Chayanov]. Sociokul'turnye utopii XX veka. Vyp. 6 [Sociocultural Utopias of the $20^{\text {th }}$ Century, Vol. 6], Moscow: INION, pp. 97133.

Shanin T. (1997) Revolyuciya kak moment istiny: Rossiya 1905-1907 gg. - 1917-1922 gg. [Revolution as a Moment of Truth: Russia 1905-1907 - 1917-1922], Moscow: Ves Mir.

Shushpanov A. (2000) A. V. Chayanov i utopiya 1920-h godov: problema zhanra [A. Chayanov and the Utopia of the 1920s: The Problem of the Genre]. Potaennaya literature: issledovaniya i materialy. Vyp. 2. Prilozhenie [The Concealed Literature: Studies and Materials, Vol. 2, Supplement], Ivanovo: IGU, pp. 74-80.

Varlamov A. (2011) Andrey Platonov [Andrey Platonov], Moscow: Molodaya gvardia.

Zavarkina M. (2013) "Kulackaya utopiya” A. Chayanova i "kulackaya hronika" A. Platonova ["Kulak Utopia" by A. Chayanov and "Kulak Chronicle" by A. Platonov]. Pushkinskie chteniya 2013: Materialy XVIII mezhdunarodnoj nauchnoj konferencii [Pushkin Readings 2013: Proceedings of 18th International Conference], Moscow: IMLI, pp. 41-48. 


\title{
Гипотеза модернизации и неолиберализм*
}

\author{
Светлана Щербак \\ Кандидат философских наук, научный сотрудник \\ Института философии им. Г. С. Сковороды НАН Украины \\ Адрес: ул. Трехсвятительская, д. 4, Киев, Украина 01001 \\ E-mail: svedep4@gmail.com
}

\begin{abstract}
В настоящей работе рассматриваются дискуссии вокруг гипотезы модернизации, согласно которой экономическое развитие является причиной установления демократии. Гипотеза модернизации была сформулирована в экономических и социально-политических реалиях середины XX века. С тех пор многое изменилось - и сами общества, и представления о них. Однако эти изменения не учитываются в современных исследованиях взаимосвязи экономического развития и демократии; данная работа ставит своей целью восполнить этот пробел. В статье прослеживается, как с неолиберальным поворотом изменились представления об экономическом развитии и демократии, а также те социальные трансформации, к которым привела реализация неолиберальной экономической политики. В частности, речь идет о росте неравенства и подъеме популизма, которые трактуются как угроза либеральной демократии. В то же время гипотеза модернизации опирается на предположение, что экономическое развитие приводит к выравниванию доходов и формированию широкого слоя среднего класса. Как показывает анализ, в целом эмпирические исследования подтверждают наличие связи между экономическим развитием и демократизацией. Но экономический рост не обязательно влечет за собой более равномерное распределение доходов. Рост популизма косвенно подтверждает справедливость гипотезы модернизации и позволяет сделать вывод, что в демократизации важную роль играет не только установление либеральных институтов, но и изменение социальной структуры вследствие выравнивания доходов.
\end{abstract}

Ключевые слова: гипотеза модернизации, экономическое развитие, демократия, неолиберализм, неравенство

\section{1. Предпосылки и суть гипотезы модернизации}

Вопрос о взаимосвязи экономического развития и демократии является одним из ключевых и наиболее исследуемых - с середины XX века по сей день. И вопрос этот отнюдь не праздный, особенно для постсоветских стран - он напрямую затрагивает вопросы реформирования экономических и политических институтов. Кроме того, он важен для понимания тех тенденций в политической сфере, кото-

(С Щербак С. И., 2018

(c) Центр фундаментальной социологии, 2018

DOI: $10.17323 / 1728-192 \mathrm{X}-2018-3-291-328$

* Статья написана по результатам стажировки в Council for Research in Values and Philosophy, Washington, DC, USA в 2015 г. 
рые сейчас наблюдаются как в развивающихся странах, так и в устойчивых демократиях - речь идет о подъеме популизма.

Изначально обращение к вопросу о взаимосвязи экономического развития и демократии было обусловлено задачами демократического строительства и экономического возрождения послевоенной Европы и развивающихся стран. После Второй мировой войны предшествующий миропорядок претерпел существенные изменения, связанные с дезинтеграцией европейских колониальных империй и возникновением обществ третьего мира как самостоятельных политических и экономических акторов. В условиях биполярного мира для США как страны, в которой получили практическое воплощение идеи либеральной демократии, остро стояла задача противостояния коммунизму как альтернативной стратегии реорганизации обществ (Войтоловский, 2007). Эта задача имела две взаимосвязанные составляющие: во-первых, распространение и утверждение принципов капиталистической экономики, а во-вторых, распространение демократии и демократических ценностей по всему миру.

В этом контексте и возник вопрос о взаимосвязи экономического развития и демократизации, о том, что ставить во главу угла - экономическое развитие или политические реформы? История знает различные варианты практического ответа на эти вопросы. Так, М. Горбачев начал с политических реформ, сопровождаемых вялыми попытками возродить экономику в условиях стагнации, в то время как китайцы предпочли реформировать экономику в рамках авторитарного режима. Это привело к развалу СССР и стремительному экономическому росту Китая в конце XX - начале XXI века. Схожая ситуация экономического роста в условиях авторитаризма наблюдалась в Южной Корее, Испании, Тайване, Сингапуре, Чили. Большинство этих стран в итоге перешло к демократии, но не все, и вопрос о том, с чем это связано и можно ли ожидать демократического перехода в дальнейшем, остается открытым.

На сегодня есть огромное количество литературы, посвященной обсуждаемому вопросу, которую Х. Чейбаб и Дж. Вриланд предлагают сгруппировать следующим образом: связь между экономическим развитием и демократизацией: а) реальная, каузальная и позитивная; б) реальная, каузальная и негативная; в) реальная, но не каузальная; г) ложная (Cheibub, Vreeland, 2012).

Первый вариант и выражает суть гипотезы модернизации, сформулированной, как считается, С. Липсетом (Lipset, 1959). Долгое время она была господствующей, несмотря на то что практически с самого начала ей противостоял альтернативный подход (б), продвигаемый такими авторами, как Б. Myp (Moore, 1966), С. Хантингтон (Huntington, 1968) и Г. О’Доннел (O’Donnell, 1973). Варианты (в) и (г) были сформулированы относительно недавно - (в) был предложен А. Пшеворски и Ф. Лимонжи (Przeworski, Limongi, 1997), а потом развит А. Пшеворски, М. Альваресом, Х. Чейбабом и Ф. Лимонжи (Przeworski, Alvarez, Cheibub, Limongi, 200о), a (г) был сформулирован в работах Д. Аджемоглу, С. Джонсона, Дж. Робинсона и П. Яреда (Acemoglu, Johnson, Robinson, 2001; Acemoglu, Johnson, Robinson, Yared, 
2005, 2008, 2009), затем теоретически расширен и дополнен Аджемоглу и Робинсоном (Acemoglu, Robinson, 2012).

Гипотеза модернизации базировалась на ранней теории модернизации, которая, как ожидалось в начале 1950-х, должна была предложить универсальный рецепт преобразования социальных институтов для постколониальных стран, с целью ускорения их социально-экономического и политического развития. Констелляция институтов, присущая странам Запада, в частности англоязычным протестантским странам, получила статус нормативного образца, и сформировалось убеждение, что достичь успеха в деле социального и экономического развития можно за счет экспорта в другие страны структурных условий этих обществ (Sachsenmaier, 2002).

Теория модернизации во главу угла ставила замену традиционных институтов модерными. Ключевая роль в этом процессе отводилась индустриализации, а фабрика рассматривалась как «школа модерна». Наиболее распространенный подход в изучении модернизации рассматривал «экономический рост как определяющий источник изменений, который привязывает все остальные модификации к себе» (Кутуев, 2005: 83). Таким образом, предполагалось, что ускоренная индустриализация приведет к ценностным, социальным и политическим трансформациям обществ по западному образцу.

На основе этого подхода и была сформулирована гипотеза модернизации (mоdernization hypothesis) ${ }^{1}$. Основная ее идея в том, что экономическое развитие приводит к развитию человеческого капитала и возникновению новой социальной структуры, слишком сложной для авторитарного управления, и таким образом в определенный момент диктатура сменяется демократией. Речь идет именно о каузальной связи между экономическим ростом и демократизацией общества о том, что экономическое развитие является главным эндогенным бактором, определяющим демократический переход, который в то время понимался как переход к электоральной системе формирования власти.

Считается, что гипотезу модернизации сформулировал Липсет, обративший внимание на связь между уровнем дохода на душу населения и демократией: «Чем богаче нация, тем выше вероятность того, что она поддержит демократию» (Lipset, 1959: 75). Речь шла о том, что экономическое развитие сопряжено с качественными изменениями в разных общественных сферах, которые способствуют развитию демократической культуры. Липсет взял несколько индикаторов социально-экономического развития - индустриализацию, урбанизацию, уровень образования, доходов и охраны здоровья (так называемый «комплекс развития») - и проследил их корреляцию с политическим режимом. И сделал вывод, что «общество, разделенное на широкие обедневшие массы и небольшую привилегированную элиту, придет или к олигархии (диктаторскому правлению узкого высшего слоя),

1. В отличие от теории модернизации, которая занимается вопросами развития обществ и перехода к модерну, гипотеза модернизации концентрируется исключительно на вопросе каузальной связи между экономическим развитием и демократией. 
или к тирании (диктатуре, основанной на популизме)» (Lipset, 1959: 75). Особое значение он придавал уровню образования как решающему фактору, влияющему на поддержку индивидом демократической культуры. Однако индустриализация, урбанизация, высокий уровень дохода и образование являются необходимьмми, но не достаточными условиями для установления реальной демократии. Липсет подчеркивает специфичность условий возникновения европейской демократии в частности, роль рабочего движения и трейд-юнионов в приближении к экономическому равенству в welfare state, а также в борьбе широких масс населения за политические права. Ссылаясь на М. Вебера, он утверждает, что наличие корреляционной связи между перечисленными факторами и демократизацией «не оправдывает оптимистическую надежду либералов на то, что возрастание доходов, численности среднего класса, образованности и другие сопряженные факторы будут с необходимостью означать распространение демократии или устойчивость демократии» (Lipset, 1959: 103). Таким образом, позиция Липсета неоднозначна - она дает основания ссылаться на него как на своего предшественника и сторонникам гипотезы модернизации, и авторам из числа неоинституционалистов (Норт, Уоллис, Вайнгаст, 2011).

Стоит заметить, что Липсет, говоря о трансформации общества в ходе экономического развития, имел в виду прежде всего изменение классовой структуры формирование широкого слоя благополучного среднего класса, снижение уровня бедности и возрастающую толерантность высших классов к требованиям перераспределения (Cheibub, Vreeland, 2012). Как замечают Дж. Вухерпфенниг и Ф. Дойч, у Липсета «равенство имеет центральное значение как в социально-политическом, так и в экономическом плане. <..> Именно перераспределение и гражданские права и обязанности предотвращают революционную борьбу рабочих, и возникающее в результате экономическое равенство обеспечивает эффективную демократию» (Wucherpfennig, Deutsch, 2009: 1-2). Немаловажно, что статья Липсета была написана в период, именуемый ныне «славным тридцатилетием», которое характеризовалось беспрецедентным снижением неравенства в странах развитого капитализма. Эта тенденция нашла свое отражение в теории «кривой Кузнеца» (Kuznets, 1955), согласно которой на начальных этапах индустриализации неравенство увеличивается, однако внутренняя логика дальнейшего развития приводит естественным путем к более равномерному распределению дохода и постепенному снижению неравенства. Соответственно, под экономическим развитием в гипотезе модернизации подразумевался не просто рост ВВП на душу населения, но реальный рост доходов семей, доступность образования, здравоохранения и прочих общественных благ - словом, кардинальное изменение жизненных условий в развитых странах в середине XX века. 


\section{2. Демократия - случайный элемент динамики режима}

В течение долгого времени гипотеза модернизации считалась общепризнанной, и то, что экономическое развитие непременно приведет к установлению демократического режима, не ставилось под сомнение. Работы, в которых проводилась мысль, что модернизация не обязательно приводит к демократии, а при определенных условиях приводит к диктатуре, оставались маргинальными - эмпирическая корреляция между уровнем экономического развития и демократизацией была слишком очевидна. Между тем авторы этих работ обратили внимание на то, что: 1) экономическое развитие не обязательно влечет за собой все те трансформации, которые, согласно теории модернизации, должны происходить одновременно; 2) помимо экономического развития есть другие факторы, влияющие на возникновение демократии. Для Мура ключевым добавочным фактором является классовая структура; для Хантингтона это институционализация; для О’Доннела - международные отношения страны с глобальным капитализмом (Cheibub, Vreeland, 2012).

Серьезным вызовом гипотезе модернизации стали работы Пшеворски, а также исследование Пшеворски, Чейбаба, Альвареса и Лимонжи (Przeworski et al., 200о) «Демократия и развитие». Проанализировав статистические данные за период с 1950 по 1990 год, авторы пришли к выводу, что демократия является случайным результатом динамики режима и не обусловлена социально-экономическим развитием - она может быть установлена при любых условиях. То есть нет оснований полагать, что экономическое развитие порождает демократии (Ibid: 167). На установление демократии влияют как объективные процессы, происходящие в том или ином обществе (изменения социальной структуры, возникновение гражданского общества, культурные изменения, экономическая динамика), так и взаимная игра интересов различных разнонаправленных социальных сил. Иными словами, демократия является контингентным результатом конфлик$m a$, возникающего между акторами (например, между группами элит или между элитой и низшими сословиями), как способ стабилизации ситуации, выгодный всем участникам (Przeworski, 2004a: 304). Установление демократии не является неизбежным, необходимым и необратимым, и предсказать возникновение демократии трудно.

Однако предсказать ее выживание довольно легко. В неразвитых странах демократия хрупка и может быстро прийти к коллапсу - сохранение демократии требует эффективного экономического развития и поддержания высокого уровня доходов. Хотя образование, распределение доходов, политические институты и отношения между политическими силами также оказывают влияние на устойчивость демократии, уровень дохода имеет определяющее значение (Przeworski, 2004: 311). Ни один демократический режим, включая период перед Второй мировой, не сменился в странах с доходом на душу населения выше \$6,055: «Богатые демократии пережили войны, мятежи, скандалы, экономические и правительственные 
кризисы, бедствия и наводнения» (Przeworski, 2004а: 309). В случае падения доходов ниже некоего порогового уровня, который для каждой страны свой, может возникнуть угроза авторитаризма. Но экономические кризисы не угрожают демократии в более благополучных странах ${ }^{2}$.

Таким образом, Пшеворски и соавторы отвергают эндогенную теорию демократического перехода. В другой своей работе Пшеворски указывает, что демократические институты не обязательно эндогенны - есть множество примеров внедрения чисто экзогенных институтов. Например, переход к электоральной демократии на Тайване зависел не от внутренних причин, но был стимулирован потребностью в поддержке со стороны демократических стран в его геополитическом конфликте с Китаем (Przeworski, 2004b). При этом в модели Пшеворски и соавторов демократии менее стабильны, если изначально наличествует или растет неравенство (Wucherpfennig, Deutsch, 2009).

Эти результаты были подвергнуты критике, которая касалась как слишком узкого понимания демократии, так и методологии исследования и трактовки его результатов. В частности, Д. Эпштейн с коллегами предложили ввести между демократией и диктатурой категорию промежуточных режимов - «partial democracies», которая также позволяет установить четкую связь между экономическим развитием и демократизацией (Epstein et al., 20o6).

В свою очередь, К. Бойкс и С. Стоукс (Boix, Stokes, 2003) расширили выборку, дополнительно проанализировав данные за период с 1850 по 1950 год, и объединили их с данными Пшеворски и его коллег. Их анализ показал, что: а) развитие в бедных странах и странах со средним доходом повышает не только вероятность выживания уже установленной демократии, но и вероятность демократического перехода ${ }^{3}$; б) причиной перехода к демократии является не доход сам по себе, но другие изменения, сопутствующие развитию, из которых важнейшим является равномерность распределения доходов; в) причины перехода к демократии и стабильности режима различны - вероятность перехода к демократии зависит от экономической структуры общества. По мнению авторов, диверсификация экономики и снижение спецификации экономических активов существенно повышает шансы на демократический переход. Значимость спецификации активов объясняется тем, что в сырьевой экономике, как в случае нефтяных стран Ближнего Востока, доход зависит главным образом от продажи природных ресурсов, и элита, будучи не в силах увезти с собой источник дохода, заинтересована в сохранении авторитарного режима, чтобы противостоять требованиям перераспределения.

2. Как показали недавние исследования, между подушевым ВВП и интенсивностью переворотов и попыток переворотов наблюдается явно выраженная отрицательная корреляция, хотя в целом между уровнем экономического развития и социально-политической нестабильностью наблюдается криволинейная перевернутая U-образная зависимость (Коротаев, Васькин, Билюга, 2017).

3. Любопытно, что переход к демократии осуществлялся до 1949 года при гораздо более низком уровне дохода на душу населения, чем в последующие годы. Авторы оставляют открытым вопрос о том, с чем связано повышение порога доходов, необходимых для перехода к демократии, после 1950 года. 
Таким образом, Бойкс и Стоукс показали, что распределение дохода и структура экономики имеют ключевое значение при оценке устойчивости демократии и вероятности демократического перехода. Можно предположить, что такая значимость распределения дохода и структуры экономики связаны с тем, что более равномерное распределение и наличие большого количества ниш в экономике препятствуют концентрации экономической власти и ее конвертации в политическую, как это происходит при олигархии. Собственно, считается общепризнанным, что именно наличие широкого слоя среднего класса делает демократию устойчивой.

Подробный разбор и ответную критику работ Бойкса и Стоукс, а также Эпштейна и соавторов можно найти у Чейбаба и Вриланда (Cheibub, Vreeland, 2012), которые, со своей стороны, показывают проблематичность данных, используемых в этих работах.

\section{3. Неоинституциональная альтернатива гипотезе модернизации}

В настоящее время основной альтернативой гипотезе модернизации считается гипотеза переломных моментов (critical junctures hypothesis) - вариант (г) в нашем списке. Она опирается на неоинституциональный подход, согласно которому взаимосвязь между экономическим развитием и демократией ложная и объясняется типом институтов, присущим развитым странам. В таком случае именно типы институтов, понимаемые как способ организации общества в целом, являются основным фактором, обуславливающим как экономическое развитие, так и демократию. Аджемоглу, Джонсон, Робинсон и Яред в своих работах (Acemoglu, Johnson, Robinson, 2001; Acemoglu et al., 2005, 2008, 2009) показали, что учет факторов, которые симультанно воздействуют как на доход, так и на демократию фиксированных страновых эффектов, - устраняет значимую корреляцию между доходом и демократией. На деле указанная корреляция скрывает важные системные различия между странами, которые влияют как на рост дохода, так и на развитие демократии, и эти различия заключаются в качестве экономических и политических институтов, которые тесно взаимосвязаны и образуют единый комплекс. На примере развития Южной и Северной Америки авторы показывают, что недемократические политические режимы и экономическая стагнация неотделимы друг от друга - система принудительного труда (гасиенды) и контроля над индейскими общинами в Андах не способствовали индустриализации и быстрому экономическому росту и в то же время были несовместимы с демократическим представительством. А социальная структура североамериканского общества, состоявшего из мелких собственников, способствовала как экономическому росту, так и развитию демократических институтов (Acemoglu et al., 20o8).

Общий вывод Аджемоглу и соавторов заключается в том, что экономическое развитие и демократизация зависят от экономических и политических инстиmутов, которые носят искусственный характер и которые могут быть изменены 
в переломные моменты - в частности в ходе революций. В дальнейшем Аджемоглу и Робинсон различают экстрактивные и инклюзивные социальные институты, которые определяют направление развития экономической и политической сфер (Acemoglu, Robinson, 2012). По сути, под инклюзивными институтами подразумеваются либеральные политические и экономические институты, а под экстрактивными - все остальные.

\section{1. Неолиберальный поворот и переоткрытие институтов}

Неоинституциональная альтернатива гипотезе модернизации возникла отнюдь не случайно. Открытие ключевой роли институтов в экономическом развитии произошло в середине 1990-х - это был крупнейший сдвиг в экономической теории того времени (Williamson, 2003). К тому времени в странах Запада уже более 10 лет как утвердилась неолиберальная ортодоксия, пришедшая на смену кейнсианству. Неолиберализм ${ }^{4}$ стал ответом на кризис «кейнсианского государства всеобщего благосостояния», вызванный окончанием послевоенного бума восстановления, а также ростом расходов на войну против Вьетнама (Clarke, 2005). Кризис проявился в замедлении темпов глобального капиталистического накопления, наряду со стагфляцией и проблемой финансирования дефицита государственного бюджета, что вынудило правительства ввести жесткую денежно-кредитную политику и сократить планы государственных расходов. И хотя кейнсианство и неолиберализм ориентировались на общий либеральный идеал общественного устройства, в результате неолиберального поворота произошел существенный сдвиг в трактовке общества и экономики, целей развития и способов их достижения.

Если во времена Рузвельта лозунгом либерализма были благосостояние и равенство как условие свободы (Friedman, 1992), то неолибералы своей критикой концепта социальной справедливости перевернули это отношение. В итоге установка послевоенных десятилетий на достижение равенства и справедливости сменилась неолиберальной установкой на максимальную экономическую свободу, которая считалась необходимым и достаточным условием достижения благосостояния и равенства - политического и правового, но не экономического. Соответственно, государство в неолиберализме становится минимальным neoliberal state, роль которого сводится к защите прав частной собственности, установлению верховенства права (rule of law) и созданию институтов свободного рынка и свободной торговли.

В это время развивающимся странам - в эту волну попали и постсоветские страны - предлагался уже совершенно иной набор рекомендаций и рецептов

4. У нас нет возможности в данной работе разобрать дискуссии вокруг неолиберализма. Некоторые считают неолиберализм свободным набором идей относительно того, как должны быть организованы отношения между государством и внешним окружением (Thorsen, Lie, 2006). Другие считают его всеохватывающей утопической идеологией на манер социализма (Mann, 2013). Для нашей работы этот вопрос не принципиален. 
перестройки экономики и институтов управления, чем в период господства кейнсианства. Ни о каком developmental state на манер Японии или Южной Кореи в то время речь уже не шла (Pirie, 2013). Задача стимулирования экономического роста обрела иной смысл - если в кейнсианстве непосредственной целью экономической политики были полная занятость населения и построение welfare state, для чего допускалось и приветствовалось вмешательство государства в экономику, то неолиберализм сместил акценты, вернувшись к представлению о «невидимой руке» рынка. Кейнсианство признавало несовершенство рыночных механизмов и считало, что задача государства - смягчить последствия их работы. Неолиберализм же, напротив, обратился к "рыночному фундаментализму», трактуя рынок как лекарство от всех болезней, а государственное вмешательство - как главную угрозу свободе: «Неолибералы рассматривают правительство как особо некомпетентный институт, которого чем меньше, тем лучше. Рынок же рассматривается как саморегулирующийся - более гибкий и быстро реагирующий, чем любое государственное регулирование» (Crouch, 2017: 11).

Соответственно, задачей экономической политики стала либерализация финансовых рынков, приватизация, снижение налогов для бизнеса, максимальное снятие барьеров со свободного рынка, включая допуск иностранных компаний к банковскому сектору и прочим активам, сокращение социальных расходов, фискальная дисциплина и т.д., - то есть создание свободного рынка и минимизация государственного регулирования. Собственно целью экономической политики стало накопление капитала и создание богатства как основной меры для улучшения благополучия населения в целом. Предполагалось, что рынок сам выполнит все те задачи перераспределения и повышения благосостояния широких масс населения, которое ставило перед собой кейнсианское государство, и что обогащение отдельных лиц и корпораций работает на всеобщее благо, потому что «приливная волна поднимает все лодки». Таким образом, перераспределение путем прогрессивного налогообложения или же государственного соцобеспечения становится излишним, вводятся меры жесткой экономии.

Итогом неолиберальных реформ стало подчинение реального сектора экономики финансовому (Mann, 2013). Развитие производства не означало более с необходимостью рост доходов на душу населения, зато концентрация финансовых услуг определенно означала. Поэтому поддержка финансовых институтов и неприкосновенность финансовой системы стала приоритетом сообщества неолиберальных государств, в частности членов G7 (Harvey, 2005).

Индустриализаиия перестала рассматриваться как базовый путь экономического развития. На смену пришла идея глобального разделения труда, подкрепленная убеждением о равнозначности разных видов экономической активности (Райнерт, 2014). Стратегия индустриализации и импортозамещения, присущая developmental state, сменилась стратегией всеобщей либерализации, предполагавшей открытие торговых границ, имплементацию институтов свободного рынка, приватизацию, обеспечение доступа к активам для иностранного капитала, создание 
«благоприятного инвестиционного климата» и т.д. Эти меры рассматривались как необходимые и достаточные для стимулирования экономического роста. Совокупность указанных мер, которая в 1989 году была обобщена Дж. Уильямсоном под заголовком «Вашингтонский консенсус», активно продвигалась международными финансовыми организациями, такими как МВФ и Всемирный банк, в развивающихся странах.

Важный аспект неолиберального поворота заключается в том, что неолиберальная экономическая программа стала ключевым элементом глобализации формирования либерального мирового порядка. Либеральный мировой порядок предполагал создание общего экономического пространства, которое связало бы страны инфраструктурой и потоками товаров, услуг, капитала, знаний и (в меньшей степени) людей (Стиглиц, 2016). Так что концепт «минимального государства» теснейшим образом связан с глобализацией - для осуществления последней необходима минимизация государственного контроля над экономикой и финансами и передача части функций национальных правительств международным организациям, таким как международные финансовые институты и неправительственные организации. Ожидалось, что либерализация экономики и включение стран в либеральный мировой порядок «подтолкнет государства в прогрессивном направлении, определяемом в терминах либеральной демократии» (Ikenberry, 2018: 11).

Проблема, однако, в том, что проведение в жизнь неолиберальных реформ в развивающихся странах, в частности на постсоветском пространстве, привело совсем к иному результату, чем предполагалось. Глубокий финансовый кризис потряс Мексику (1994), Восточную Азию (1997), Бразилию (1998), Россию (1998), Турцию (200о) и Аргентину (2002), которые до этого более-менее последовательно проводили в жизнь рекомендации МВФ (World Bank, 2005). Снимая барьеры для импорта и финансового капитала, указанные реформы на деле не способствовали развитию реального сектора экономики, особенно в случае технологической отсталости экономики и необеспеченности прав собственности, как в бывшем СССР. Не случайно итогом неолиберальных реформ во многих постсоветских странах стало не формирование свободного рынка по образцу развитых стран, а резкое обнищание населения и формирование узкой прослойки сверхбогатой элиты.

Кроме того, как оказалось, либерализация экономики вовсе не обязательно влечет за собой демократизацию. Наиболее яркий пример - Китай: когда в стране начались реформы по либерализации экономики, все ожидали, что за ними в скором времени последует демократизация под влиянием либеральных требований нарождающегося среднего класса (Mesquita, Downs, 2005). Однако этого не произошло. Более того, недавние политические реформы Си Цзиньпина позволяют говорить об усилении авторитарных тенденций в Китае. Другим примером сочетания неолиберального (в определенных аспектах) экономического курса и политического авторитаризма является Россия (Miller, 2018). 
В поисках причин подобных провалов экспертная мысль обратилась к несовершенству экономических и политических институтов развивающихся стран. Дело в том, что неолиберальные теоретики считали само собой разумеющимся существование институтов, необходимых для нормального функционирования свободного рынка, или же предполагали, что как только правительственное регулирование будет устранено, они появятся сами собой (Lee, 2001). Cо временем проводники политики Вашингтонского консенсуса пришли к выводу, что стандартные реформы не дают предполагаемого эффекта, если фоновые институциональные условия плохие (Rodrik, 20o6). Без всеобъемлющих и всеохватывающих реформ, затрагивающих общество в целом, либеральные экономические институты не работают должным образом, поэтому имплементация стандартных экономических институтов западного типа без учета контекста не может обеспечить долгосрочный экономический рост. Недаром уже в Барселонском консенсусе 2004 года теме институтов посвящен первый раздел документа, а качество институтов стоит на первом месте среди факторов успешности стратегий развития (Ананьин, Хаиткулов, Шестаков, 2010). Недостаточно глубокое и всеобъемлющее проведение институциональных реформ стало главным объяснением МВФ провалов Вашингтонского консенсуса ${ }^{5}$ в странах Латинской Америки: «Реформы были неравномерными и остались незавершенными» (Singh et al., 2005: xiv). Таким образом, оригинальный вариант Вашингтонского консенсуса, не предполагавший глубоких институциональных преобразований, был дополнен длинным списком так называемых реформ «второго поколения» («second-generation» reforms), институциональных по своей сути (Rodrik, 2006), направленных на более глубокие неолиберальные преобразования.

Таким образом, появление неоинституциональной альтернативы в значительной мере стало результатом провалов политики Вашингтонского консенсуса в развивающихся странах. Открытие институтов на практике получило подкрепление в академической литературе по экономическому росту, в которой институтам приписывается решающая роль как в экономическом развитии, так и в становлении демократии (Easterly, Levine, 2003; Норт, Уоллис, Вайнгаст, 2011; Acemoglu, Robinson, 2012 etc.). Вопрос о том, как «пересадить» констелляцию либеральных политических и экономических институтов на чужеродную культурную почву, встал с новой силой. На смену «рыночному фундаментализму» 1990-х пришел «институциональный фундаментализм», и «мантра установления правильных цен» сменилась «мантрой установления правильных институтов» (Rodrik, 2006: 10).

Подобный «институциональный фундаментализм» порождает пессимизм относительно возможности устойчивого экономического роста и демократизации без кардинального и всеохватывающего преобразования общества. Однако учи-

5. Это объяснение подвергается критике со стороны других экономистов, указывающих на быстрый экономический рост Индии и Китая, отвергнувших рецепты МВФ и выбравших собственный путь реформирования. Подробнее см.: Д. Родрик (Rodrik, 2006) и доклад Всемирного банка (World Bank, 2005). 
тывая глубокую укорененность институтов в обществе, подобные преобразования возможны главным образом в периоды социальных потрясений и революций, преимущественно путем смены элит. Согласно концепции переломных моментов (critical junctures), именно тогда открывается принципиальная возможность изменить существующие институты, заменив «плохие» (экстрактивные) институты «хорошими» (инклюзивными). В остальное время работает приниип зависимости om nymu (path dependence) - преемственность институтов обеспечивает институциональную стабильность и в то же время определяет направление дальнейшего развития. Только фундаментальная замена институтов позволяет выбраться из ловушки круговой взаимосвязи плохих институтов и обеспечить успешный экономический рост. С этой точки зрения украинский Евромайдан 2014 года стал именно таким переломным моментом, стартовой точкой для полной институциональной перестройки украинского общества.

Эта точка зрения оспаривается другими авторами - как теми, кто считает, что институты не самодостаточны и не могут играть роль primary cause (Przeworski, 2004b; Райнерт, 2014), так и теми, кто отвергает идею прерывности институциональной истории, исходя из представления о ключевой роли неформальных институтов, идеологии и культуры как детерминант экономического процесса (Норт, 1997; Норт, Уоллис, Вайнгаст, 2011). Мы не можем в рамках данной работы подробно разобрать дискуссии на эту тему, отметим только, что специалистами Всемирного банка также предлагается не всеобъемлющее глубинное преобразование всех институтов, по образцу расширенного Вашингтонского консенсуса, но устранение ограничений, сдерживающих рост, которые индивидуальны для каждой страны, с ее уникальным набором институтов (World Bank, 2005).

Следует отметить, что во всех этих дискуссиях речь не шла об отказе от глобализации и неолиберализма как ее политико-экономического краеугольного камня. Либертарианский идеал М. Фридмана и Ф. Хайека оставался своего рода теоретической моделью, обсуждались только пути ее реализации. Вызов неолиберализму бросил кризис 2008 года и поднявшаяся после него волна популизма (Yakupec, 2018).

\section{2. От справедливости к свободе - иобратно?}

Итак, неолиберальный поворот в значительной мере изменил смысл самого вопроса об экономическом развитии и демократии. Во-первых, изменилось представление о целях и способах общественного развития - социальная справедливость перестала быть основным общественным благом, уступив место индивидуальной свободе, главным выражением которой стала экономическая свобода. Во-вторых, экономический рост стал обеспечиваться не развитием промышленности, но открытостью экономики, иностранными инвестициями, притоком финансового капитала и проч. В-третьих, в понимании демократии акцент сдвинулся с политического участия на построение правового государства и обеспечение гражданских 
прав и свобод. Как ни странно, впоследствии возникли определенные проблемы с демократией - не только в развивающихся странах, но и в развитых.

Подъем популизма, как правого, так и левого, в устойчивых демократиях тема номер один в текущих дискуссиях по демократии и политической экономии. Большинство исследователей видят в популизме угрозу либеральной демократии (Mudde, Kaltwasser, 2017). Среди причин подъема популизма указывают прежде всего глобализацию, породившую волну иммиграции в развитые страны в результате открытия границ, деиндустриализацию из-за переноса производства в страны с дешевой рабочей силой, неолиберальные меры жесткой экономии (austerity measures), сопутствующий рост безработицы, снижение уровня заработной платы и рост неравенства (Stankov, 2017).

\subsection{1. РОСТ НЕРАВЕНСТВА — УГРОЗА ДЕМОКРАТИИ}

Предположение о более равномерном распределении дохода в ходе экономического развития, равно как и идея о том, что рынок одинаково работает на благо каждого («экономика просачивания»), имели ключевое значение для обоснования неолиберальных реформ. В этой связи уже упоминалась теория «кривой Кузнеца». Она основывалась на статистических данных о национальном доходе и налоговых поступлениях за период 1913-1948 годы в США. Однако, по мнению Т. Пикетти, сжатие доходов в эти годы во многом стало результатом стечения обстоятельств - Великой депрессии 1930-х, Нового курса Рузвельта, Первой и Второй мировой войны, повлиявших на мировую экономику и геополитику. Кузнец прекрасно отдавал себе отчет в умозрительности своих оптимистических предсказаний, поэтому его концепция носила стратегический характер - ее задачей, по его собственному признанию, было всего-навсего удержание слаборазвитых стран «в орбите свободного мира» (Пикетти, 2015: 32-33) ${ }^{6}$.

Как показывают недавние исследования, справедливость этих предположений спорна - с 1980-х годов неравенство выросло как внутри стран, так и между странами. Однако до кризиса 2008 года эта тема была табуирована неолиберальным мейнстримом и презрительно третировалась как проявление ресентимента, или, по выражению Р. Капелюшникова, «узкой этики зависти» (Капелюшников, 2017). После кризиса вопросы дистрибутивной справедливости, неравенства и его негативных последствий для общества вновь обрели легитимность - о них заговорили не только узкие специалисты, но и политики уровня Б. Обамы (Atkinson, 2015; Boushley, DeLong, Steinbaum, 2017). В теме неравенства речь идет прежде всего о неравенстве доходов, поскольку именно уровень дохода является «индикатором

6. Бранко Миланович оспаривает эту точку зрения, предлагая расширение гипотезы Кузнеца, которое он называет волнами, или циклами Кузнеца, согласно которым периоды роста и снижения неравенства чередуются в результате взаимодействия экономических и политических факторов (Milanović, 2016). 
потенциального контроля над ресурсами» (Atkinson, 2015: 37), - доход имеem omношение не только к потреблению, но и к распределению власти и влияния.

Немалый вклад в дискуссии на тему неравенства внесла книга Пикетти «Капитал в XXI веке» (Пикетти, 2015), посвященная росту имущественного неравенства, начиная с 1980-х годов. Автор объясняет рост неравенства тем, что уровень доходности капитала превышает показатели роста производства и доходов, как это было до Первой мировой войны. Бурный экономический рост, снижение неравенства и формирование среднего класса после Второй мировой войны было обусловлено уникальным стечением обстоятельств и политическими мерами по перераспределению, сейчас же экономика возвращается к нормальным для нее низким темпам роста. Сохранение этой тенденции в дальнейшем приведет к еще большей концентрации капитала и формированию нового класса рантье. Это будет означать все большую роль происхождения, наследства и связей в продвижении по социальной лестнице, и все меньшую - личных талантов и усилий, что будет способствовать формированию обществ, далеких от меритократических ценностей, лежащих в основе демократических обществ. Соответственно, нужны политические меры по сокращению неравенства.

Книга вызвала бурные дискуссии среди экономистов и представителей других социальных наук ${ }^{7}$ (Boushley, DeLong, Steinbaum, 2017). Рост неравенства, как в глобальном масштабе, так и внутри стран, активно обсуждается в литературе. Так, в «Докладе о глобальных рисках» Мирового экономического форума-2013 «глобальное неравенство доходов» определено как глобальный риск, который, скорее всего, даст о себе знать в течение ближайших десяти лет (Nino-Zarazua, Roope, Tarp, 2016). За период с 1975 по 2010 год, относительное глобальное неравенство неуклонно и существенно сокращалось, главным образом за счет быстрого роста экономик Индии и Китая ${ }^{8}$. Однако фокус на относительном неравенстве скрывает совсем иную картину, которая вырисовывается с использованием «абсолютных» и «центристских» мер неравенства и которая показывает выраженный рост абсолютного неравенства в течение анализируемого периода ${ }^{9}$ (Nino-Zarazua, Roope,

7. Книга подверглась резкой критике - как по части методологии и предложенной объяснительной модели, так и в отношении использованных данных. Широкое освещение в прессе получила дискуссия автора «Капитала XXI века» с изданием «Financial Times», опубликовавшем статью своего экономического редактора К. Джайлса, где тот заявил, что в данных Пикетти есть «необъяснимые ошибки», несовпадения с источниками, что он некорректно использует данные, манипулируя ими (Giles, 2014). Пикетти дал развернутый ответ на критику (Irwin, 2014). Суть аргументов Пикетти состоит в том, что значение аргументов FT преувеличено и что они не опровергают главный тезис его книги о росте имущественного неравенства и концентрации богатства в руках элит с начала 1980-х годов.

8. Примечательно, что реформы в обеих странах были неоднократно раскритикованы за то, что они не следовали предписаниям МВФ и двигались собственным путем (Rodrik, 2oo6; World Bank, 2005).

9. Рост абсолютного неравенства при уменьшении относительного будет иметь место, если, скажем, А и В, зарабатывавшие в 1975 году по \$1 и \$10 в день, к 2010 году будут зарабатывать по \$12 и \$10о соответственно. Относительное неравенство остается неизменным, когда доходы увеличиваются равно пропорционально - скажем, увеличиваются вдвое. В данном случае ключевой критический 
Tarp, 2016). Аналогичный рост абсолютного неравенства, вопреки предсказаниям, отмечается в Европе, причем неравенство между странами выше, чем неравенство внутри них (Dauderstädt, Keltek, 2017). Внутри стран неравенство растет неравномерно, в зависимости от политики налогообложения и перераспределения доходов (Alvaredo et al., 2017).

Дж. Стиглиц после публикации книги «Цена неравенства», посвященной американской экономике, заметил, что основные тезисы его работы не вызвали возражений: «Даже ориентированный на „свободный рынок“журнал „Economist“ мечает, что в Америке доля национального дохода, принадлежащего о,о1\% (а это примерно 16 тысяч семей), увеличилась с 1\% в 1980 году до почти 5\% сейчас - это более лакомый кусок, чем получила верхушка (о,о1\%) во времена „Позолоченного века“» (Стиглиц, 2016: 13). Проблема, однако, не в том, что богатые богатеют, но в том, что бедные при этом беднеют, поскольку потоки богатства на рынке направлены снизу вверх. Исследования показывают, что с середины 1980-х годов в США доля нижних 9о\% семей в общем пироге национального богатства значительно уменьшилась, и в среднем их реальное благосостояние в 2012 году было не выше, чем в 1986 году, в то время как доля верхнего о,1\% резко возросла (Saez, Zucman, 2016). П. Темин (Temin, 2017) в этой связи указывает на постепенное исчезновение среднего класса в США и формирование дуальной экономики (согласно модели Льюиса), присущей развивающимся странам, с узкой прослойкой обеспеченной элиты и широкими обедневшими массами населения. По его мнению, президентская гонка 2016 года в США обнаружила гнев и отчаяние низкооплачиваемого сектора населения в условиях нарастающего дисбаланса, что и обусловило победу Д. Трампа.

В проблеме неравенства важнейшей составляющей является рост неравенства возможностей и благосостояния вследствие радикального уменьшения социального обеспечения, компенсирующего неравенство доходов, в неолиберальном государстве. Дебаты о сути и показателях благосостояния (welfare) ведутся с 19301940-х годов, и многие видные экономисты выступали против того, чтобы считать рост ВВП показателем роста социального благосостояния (van den Bergh, 20o9). По мнению Стиглица, «успех функционирования экономической системы можно оценить лишь в ходе исследования стандартов уровня жизни (в широком смысле) обычных граждан в течение определенного временного промежутка» (Стиглиц, 2016: 83). Исследование неравенства благосостояния затруднено несовершенством и неполнотой доступных статистических данных (Alvaredo et al., 2017). Тем не менее, как показали Ч. Джоунс и П. Кленов (Jones, Klenow, 2016), если помимо ВВП

аргумент заключается в том, что если это изменение в распределении означает, что богатейший сможет купить две яхты вместо одной, в то время как беднейший сможет купить двух цыплят вместо одного, неравенство явно вырастет. Абсолютное же неравенство не изменяется, если доходы равномерно увеличиваются на определенную фиксированную величину. Ключевой критический аргумент здесь тот, что если доходы каждого увеличатся на, скажем, 1 млн, то говорить о неравенстве будет бессмысленно. Для преодоления недостатков обоих подходов были разработаны «центристские» показатели неравенства, учитывающие обе крайности. Подробнее см.: Nino-Zarazua, Roope, Tarp, 2016. 
учитывать свободное время, уровень потребления, продолжительность жизни и уровень неравенства, показатели благосостояния существенно меняются. Так, с учетом большей продолжительности жизни, большего количества свободного времени и более низкого уровня неравенства уровень жизни в Западной Европе оказывается значительно выше (85\% от американского), чем можно было бы ожидать, ориентируясь на ВВП на душу населения (67\% от американского). В то же время для большинства развивающихся стран уровень благосостояния оказывается значительно ниже, чем уровень ВВП на душу населения. Соответственно, уровень неравенства в благосостоянии между странами оказывается даже выше, чем уровень неравенства доходов.

Высокий уровень имущественного неравенства ведет к нарушению базового принципа демократии - процедурного равенства (Levin-Waldman, 2016). Hехватка ресурсов не позволяет людям реализовывать собственную свободу и автономию в разных сферах жизни, включая выбор жизненного стиля, реализацию своих целей, участие в публичной жизни (Sen, 1999). Неравенство способствует размыванию общественной сферы и подрыву гражданской солидарности (Sandel, 2009; Colgan, Keohane, 2017), усиливает власть и влияние элит и приводит к эрозии демократии даже в устойчивых демократиях, не говоря уже о более бедных странах (Levin-Waldman, 2016).

В этой связи многие авторы указывают на необходимость определенного уровня перераспределения - как минимум обеспечения доступа к здравоохранению и образованию для малообеспеченных слоев - как одну из главных задач государственной политики: «Денежные результаты - это только одна грань благосостояния. <...> В какой бы мере неравенство доходов, относительное или абсолютное, ни было неизбежным, полисимейкеры должны сделать все возможное, чтобы минимизировать его [неравенства. - C. Щ.] воспроизведение в других областях, обеспечивая равенство возможностей» (Nino-Zarazua, Roope, Tarp, 2016).

\subsection{2. ЛИБЕРАЛИЗМ И ДЕМОКРАТИЯ}

Помимо роста неравенства стоит еще учитывать тот факт, что либеральная демократия - совсем недавнее и очень хрупкое образование и что между либерализмом и демократией существует определенное напряжение.

Демократия и либерализм имеют разные истоки, разный социальный базис и политические импликации, и до середины XIX века они находились в противоречии друг с другом (Fukuyama, 2014). Социальной базой либерализма была состоятельная элита, чья цель заключалась в ограничении властного произвола короны. Ранние либералы хотели верховенства права, но не стремились к тому, чтобы разделить власть с массами. На самом деле классические теоретики либерализма были против всеобщего права голоса - они боялись «тирании большинства». Так, Милль заявлял, что принципы, которые он сформулировал в «On Liberty», не pacпространяются на малообразованные и неимущие массы (Mukand, Rodrik, 2015). 
Современная же демократия стала результатом социальной мобилизации, вызванной индустриальной революцией. Суть демократического движения в XIX веке заключалась в борьбе за расширение политических прав, в требовании политической инклюзии. Социальной базой демократического движения был рабочий класс - в установлении всеобщего избирательного права огромную роль сыграла деятельность консолидированных левых движений конца XIX - начала XX века. Когда западные либералы приняли демократию, это было вынужденное и неохотное согласие. Политически это означало, что либеральные идеи распространяются не только на «достойных» состоятельных людей, но и на всех остальных, независимо от их уровня образования, доходов, социального статуса и прочего (Fawcett, 2014). Либеральная демократия стала компромиссом между либеральными элитами и массами: «Рабочий класс и народные движения были вынуждены взамен признать либеральные ограничения на власть народной воли... а также принять либеральные конституционные процедуры, верховенство права и уважение собственности» (Fawcett, 2014: 144).

Стабильного практического результата либеральная демократия добилась только после 1945 года. Середина XX века - период «встроенного либерализма» (embedded liberalism) (Harvey, 2005), когда либеральные свободы были ограничены целями достижения равенства и социальной справедливости. Однако приход неолиберализма отменил эти ограничения, в результате чего индивидуальная свобода получила значение высшей ценности. Общество перестало восприниматься как совокупность социальных групп или классов, а распалось на отдельных индивидов, преследующих свои интересы. Как провозгласила М. Тэтчер, «нет такой вещи, как общество. Есть отдельные мужчины и женщины, и есть семьи» (Clarke, 2014: 52). Вместе с тем политика перестала быть способом реализации мобилизованными массами своих интересов, а партии - их репрезентантами.

Либеральные элиты Запада по-прежнему сохраняют недоверие по отношению к демократическому большинству, во-первых, опасаясь требований перераспределения, а во-вторых, считая большинство некомпетентным для определения целей и способов развития, участия в принятии решений (Patterson, 2014). Неолиберализм элитарен и технократичен: «Хотя современные демократии и поддерживают фасадную видимость формального соблюдения демократических принципов, они всё больше переходят под контроль привилегированных элит» (Муфф, 2013).

Притягательность неолиберализма, на наш взгляд, заключается в сочетании пафоса морального универсализма и притязаний рационального господства. Первый связан с модерным идеалом свободы как базовым, неотчуждаемым и самоочевидным правом человека. Наилучшим образом выраженный в кантианстве, в неолиберализме этот идеал воплощается в идее максимальной экономической свободы и минимального государства. Что касается рационального господства, речь идет о целенаправленном рациональном преобразовании общественного устройства в соответствии с универсальными социальными - в данном случае экономическими - законами, которые являются предметом познания (Wagner, 
1994). Не случайно в критической литературе пропоненты неолиберализма часто изображаются как скептически настроенные по отношению к демократии, считающие, что «если демократический процесс замедляет неолиберальные реформы или угрожает индивидуальной или предпринимательской свободе, тогда демократию следует отставить и заменить управлением экспертов или законодательными инструментами, созданными для этой цели» (Thorsen, Lie, 2006: 15).

Эта двойственность нашла свое отражение как в практиках насильственного проведения неолиберальных реформ в развивающихся странах - к примеру, в Чили, Аргентине, Сингапуре, Ираке и ряде других стран, так и в теоретическом обосновании предпочтительности диктатур, продвигающих либеральные ценности, перед нелиберальными демократиями (Zakaria, 1997). Левые движения также признали безальтернативность неолиберальной доктрины, сместив акценты с достижения социальной справедливости на защиту индивидуальных прав и свобод, в том числе для разного рода меньшинств (Fraser, 2017). В контроверзе демократического принципа народного суверенитета и либерального принципа индивидуальной свободы победил последний. В итоге доминирующая тенденция сегодня - сводить демократию почти исключительно к правовому государству и защите прав человека, оставляя в стороне вопросы равенства и народного самоуправления как устаревшие (Mouffe, 2000).

В этой связи представляет интерес модель ценностных трансформаций Р. Инглхарта и К. Вельцеля, на примере которой можно увидеть содержательные изменения в гипотезе модернизации. С одной стороны, эта модель согласуется с главной идеей гипотезы модернизации, развивая ее и предлагая каузальное объяснение демократического перехода - «упущенную связь между экономическими изменениями и демократизацией» (Inglehart, Welzel, 2010: 552). С другой стороны, она ставит формирование демократической культуры в зависимость не от индустриализации, а от постиндустриальной экономики, демократию же понимает не как электоральную, но как «эффективную», с акцентом на правах человека и правовом государстве.

\subsection{3. ЦЕННОСТНЫЕ ТРАНСФОРМАЦИИ И ПОЛИТИЧЕСКОЕ УЧАСТИЕ}

Концепция ценностных трансформаций примечательна тем, что трактует демократию не столько как институциональный, сколько как гражданский феномен (Welzel, Inglehart, Klingemann, 2003). Авторы проводят разграничение между формальной и эффективной демократией, исходя из того, насколько формально институализированные гражданские права эффективны на практике, на низовом уровне (Inglehart, Welzel, 2005). Иными словами, под «эффективной демократией» подразумевается не столько форма правления, сколько «демократическая гражданская культура», реализующая на практике то, что Инглхарт и Вельцель считают центральным элементом либеральной демократии - защиту гражданских прав и верховенство права (rule of law). В такой трактовке акцент делается на обе- 
спечение свободы выбора - демократия «институциализирует гражданские и политические свободы, предоставляя людям правовые гарантии делать свободный выбор в их приватной и публичной деятельности» (Inglehart, Welzel, 2005: 248). Соответствующую эффективной демократии гражданскую культуру Инглхарт и Вельцель связывают с распространением ценностей самовыражения, или постматериалистических ценностей, противопоставляя их ценностям выживания, или материалистическим ценностям. Эта концепция опирается на результаты лонгитюдных исследований, измеряющих динамику ценностных установок в разных странах мира с 1970-х по настоящее время ${ }^{10}$ (Inglehart, 2008).

Ценностные трансформации - переход от материализма к постматериализму (Inglehart, 20о8), или же от ценностей выживания к ценностям самовыражения (Инглхарт, Вельцель, 2011) - трактуются авторами как результат социально-экономического развития. Они выделяют два вектора результирующих ценностных изменений - от традиционных до рационально-секулярных ценностей, и от ценностей выживания к ценностям самовыражения. Промышленная революция была связана с переходом от традиционных ценностей к секулярно-рациональным; на постиндустриальном же этапе модернизации определяющую роль начинает играть иной сдвиг в культурной сфере - ценности выживания замещаются ценностями самовыражения, что приводит к возрастающей эмансипации людей от власти как таковой. По мнению авторов, формирование этих ценностей обусловлено ослаблением материальных, когнитивных и социальных ограничений свободы выбора, возникновением у людей субъективного ощущения жизненной защищенности.

Некоторые эмпирические данные ставят под вопрос концепцию Инглхарта и Вельцеля о сдвиге ценностных приоритетов в условиях постиндустриальной экономики - на примере исследования Сингапура (Ghang, 2010; Brooks, Manza, 1994). Кроме того, к авторам есть определенные претензии методологического плана (Wucherpfennig, Deutch, 2009; Руднев, 2011; Teorell, Hadenius, 2006), в частности связанные с выбором индикаторов «ценностей самовыражения». Но нас интересует другое - как эта концепция отражает и переосмысляет изменение экономической и демократической составляющей в гипотезе модернизации. На наш взгляд, то, что Инглхарт и Вельцель маркируют как «ценности самовыражения», относится к либеральным установкам, характерным для развитых либеральных обществ. Верховенство права, индивидуальная свобода и защита прав человека - это базовые элементы либерального дискурса, а не демократического. Ценности демократической традиции иные - это ценности равенства и народного суверенитета (Mouffe, 20о0). Концепция ценностных трансформаций, в отличие от классической теории модернизации, делает в связке либерализма и демократии акцент на свободе, а не на равенстве. Недаром, по мнению авторов, наиболее сильное влияние на эффективность демократии оказывают ценности самовыражения, в осно- 
ве которых лежит «однозначный акцент на свободе выбора» (Инглхарт, Вельцель, 2011: 371). Однако они не имеют никакого отношения к борьбе за предоставление избирательных прав и социальную справедливость, которая и привела к становлению либеральной демократии. Скорее, они отражают смещение акцентов в понимании современной либеральной демократии с политического участия к свободе выбора и самовыражения.

В рамках концепции ценностных трансформаций нельзя объяснить постдемократические тенденции, характеризующиеся формальным расширением демократии в условиях социальной апатии и концентрации власти в руках старых элит и корпораций (Крауч, 2010). Причем речь идет именно о развитых странах, с эффективной демократией и доминированием ценностей самовыражения, в терминах Инглхарта и Вельцеля. Миланович в этой связи пишет о плутократии в США и популизме или нативизме в Европе (Milanović, 2016).

В контексте обсуждаемой тематики очень любопытны исследования, представленные Паттерсоном. И глубинные интервью, и опросы показали, что для американцев «политическая жизнь в целом и демократия в частности не являются больше содержательной частью семантического поля свободы» (Patterson, 2014: 24). Речь идет о расщеплении свободы и демократии. Паттерсон объясняет это как особенностями американской истории, так и общими чертами современной культуры. Помимо длительности рабства и страха элит перед неуправляемой демократией, он упоминает еще и идею о потенциальном конфликте между свободой и демократией, связанной с взглядом на государство как на злую силу (sinister power), угрожающую свободе. Государство является в лучшем случае «ночным сторожем», полицейским, обеспечивающим национальную безопасность и личную свободу, а в худшем - потенциальным монстром под управлением коррумпированных политиков.

Как мы видели, именно этот взгляд на государство - базовая составляющая неолиберализма, по мнению которого рынок защищает свободу, тогда как государство угрожает ей. Такой взгляд на государство не мог не подорвать демократию, поскольку демократия по самой своей сути - это акт участия в политической жизни и вовлеченность в государство (Patterson, 2014). «Ослабление политической власти также не позволяет людям использовать государственную власть для радикальных изменений. Таким образом, возникает тенденция к ослаблению политической демократии» (Mann, 2013: 132).

Политическое демократическое представительство неизбежно предполагает представление о групповых интересах, групповой солидарности и общем благе. Если же главным регулятором социальных отношений становится рынок, представление об общем благе растворяется (Sandel, 2009). Государство в таком понимании превращается не в посредника между конкурирующими интересами разных групп, а в менеджера по предоставлению услуг населению.

Неолиберализм разделяет свободу и власть экономическую и политическую, перемещая власть из сферы политики в сферу экономики, от государства к рынку 
и, в конце концов, от законодательной и исполнительной ветвей власти к судебной (Thorsen, Lie, 2006). Однако если свобода отождествляется со свободой экономической, свободой самореализации, выбора стиля жизни, это ведет к дистанцированию от политического участия и государственной власти, которая становится всего лишь делом эффективного управления.

Еще один важный аспект современной культуры, усиливающий отрыв приватной свободы от публичной жизни - акцент на демонстративное потребление как центральный элемент свободы. В соответствии с установками на индивидуализм и потребление преследующие собственные интересы граждане все больше рассматривают политику (policies) правительства по аналогии с другими рыночными транзакциями, оценивая ее по тому, насколько хорошо они лично были обслужены. Таким образом, гражданин превращается в приватного потребителя, отвергающего политику, преследующую общее благо, как «предоставление чего-либо другим задаром» (Patterson, 2014: 34). М. Крензон и Б. Гинзберг для обозначения этого паттерна отношения к публичной политике вводят термин «персональная демократия»: «Народная демократия превращается в персональную, поскольку новые техники управления разобщают народ в собрание приватных граждан» (Crenson, Ginsberg, 2002: X). Таким образом, приватизированная свобода начинает доминировать над демократией, которая утрачивает свою значимость и переходит в ведение эффективного менеджмента.

Можно предположить, что подобное расщепление свободы и демократии имеет место не только в США. В любом случае рост неравенства в сочетании с проблемами, вызванными глобализацией и неолиберализацией, включая ослабление политической сферы, перенос власти в сферу экономическую, индивидуализацию и превращение избирателей в потребителей, технократизацию управления, не могли не оказать влияние на кризис демократии и подъем популизма. В частности, если под популизмом понимать «идеологию, которая рассматривает общество как в конечном счете разделенное на два гомогенных и антагонистических лагеря, «чистый народ» против «коррумпированной элиты», и которая доказывает, что политика должна быть выражением volonté générale (общей воли) народа» (Mudde, Kaltwasser, 2017: 6). Легко объединяясь с другими идеологиями, правыми и левыми, «в мире, где господствуют демократия и либерализм, популизм, по сути, стал нелиберальным демократическим ответом недемократическому либерализму» (Mudde, Kaltwasser, 2017: 116).

В таком случае подъем популизма является результатом неолиберальной экономической политики - в частности, следствием противоречия между либеральными основами свободного рынка и принципами демократии (Крауч, 2012).

\section{4. Гипотеза модернизации vs. гипотеза переломных моментов}

Описанные трансформации политической и экономической сфер способствовали появлению институциональной альтернативы, перенесшей акцент на построение 
либеральных институтов, и в то же время получили определенное осмысление в рамках гипотезы модернизации. Работы Аджемоглу и соавторов вызвали бурные дискуссии и целую волну публикаций, посвященных обсуждению их выводов. Наиболее систематический обзор и критику методологических решений Аджемоглу и др., в частности способа кодирования данных, можно найти у Д. Элбоу (Albouy, 2006), Дж. Фримена и Д. Квинна (Freeman, Quinn, 2012), а также у Х. Фариа, Х. Монтесинос-Юфы и Д. Моралеса (Faria, Montesinos-Yufa, Morales, 2014).

В настоящее время волна публикаций на эту тему стихла - главным образом в связи с актуализацией проблемы неравенства и популизма в развитых странах. Именно поэтому интересно посмотреть на результаты исследований сквозь призму новых реалий. В наши задачи не входит оценка этих исследований с эконометрической точки зрения ${ }^{11}$, поэтому мы только вкратце остановимся на их результатах и выводах. Общая тенденция сводится к попыткам подтвердить или опровергнуть построения Аджемоглу и соавторов благодаря новым эмпирическим данным, или же объединить гипотезу модернизации и неоинституционализм, признав опосредующую роль либеральных институтов.

Так, Дж. Бенхабиб, А. Корвалан и М. Шпигель (Benhabib, Corvalan, Spiegel, 2013) проанализировали нелинейную связь между доходом и демократией и пришли к выводу, что позитивное влияние дохода на демократию, очевидно, имеет место даже после взятия под контроль ненаблюдаемой страновой гетерогенности. Для установления этой связи были использованы более расширенные данные о доходах, а также иные методики оценивания уровня демократии ${ }^{12}$. Кроме того, в этих работах использовались Тобит-модели, основывающиеся на идее, что шкала демократии является цензурированной (т. е. что есть некий максимальный уровень демократии, который нельзя превысить).

В свою очередь, Э. Морал-Бенито, Б. де Эспана, С. Бартолуччи и С. Альберто, используя тот же набор инструментов и те же данные, что и Аджемоглу с соавторами, и включив в регрессию фиксированные страновые эффекты, показали, что доход все же влияет на демократию, но это влияние является нелинейным при достижении определенного порога экономического развития это влияние исчезает (Moral-Benito, Espana, Bartolucci, Alberto, 2012). По мнению авторов, такая зависимость обусловлена тем, что в бедных странах институты менее устойчивы и вынуждены реагировать на изменения в доходах, в то время как политические институты богатых стран меньше зависят от флуктуаций в экономической эффективности. Поэтому недемократические страны, достигающие хороших экономических результатов, могут позволить себе не менять свои политические институты. Этим, по мнению Морал-Бенито и др., объясняется феномен Китая, Сингапура или ОАЭ.

11. Отдельная благодарность д.э.н. С. Левицкому и социологу Е. Большову за консультации по вопросам эконометрики и статистики.

12. Если Аджемоглу и др. пользовались показателями демократии, основанными на данных Freedom House и Polity IV, то Бенхабиб и др. учитывали также индекс демократизации Ванханена. 
Еще один вариант трактовки взаимосвязи между демократией и экономическим развитием предлагает Д. Трейсман (Treisman, 2015): экономическое развитие все же приводит к демократии, но не постепенным, непрерывным путем - переход может быть скачкообразным. Стремительное экономическое развитие при авторитарном лидере может привести к демократическому переходу после его смерти, как это случилось в Испании после смерти Франко или в Южной Корее после Пак Чон Хи.

Э. Гундлах и М. Палдам (Gundlach, Paldam, 2009), используя индекс Polity IV в качестве показателя демократии, на выборке с 1820 по 2003 год также нашли доказательства для подкрепления гипотезы демократического перехода. С их точки зрения, гипотеза модернизации подразумевает долгосрочные тренды, а не краткосрочные.

Интересные результаты получились у М. Сервелатти, Ф. Юнга, У. Сунде и Т. Вишера (Cervellati et al., 2012), которые, опираясь на выводы Аджемоглу с соавторами, а также на предложенное ими различие между экстрактивными и инклюзивными институтами, выдвинули гипотезу, что влияние дохода на демократию должно различаться в странах с относительно более экстрактивными институтами и относительно более инклюзивными. На той же выборке, что и Аджемоглу и соавторы, Сервелатти и другие получили иной результат, проанализировав отдельно бывшие колонии и страны, которые никогда не были колониями, а среди колоний - отдельно страны с более инклюзивными институтами, и отдельно - с более экстрактивными ${ }^{13}$. Результат поразителен: «Доход имеет значимое позитивное влияние на демократию в странах, которые никогда не были колонизированы. В противоположность этому результаты показывают значимое негативное влияние дохода на демократию в бывших колониях» (Ibid.: 10). Также наблюдаются различия между колониальными странами - негативное влияние дохода на демократию является значимым для стран, которые управлялись колониальными властями дольше и позже получили независимость, и незначимым для стран, получивших независимость до 1900 года. Эти различия авторы, опираясь на Аджемоглу и соавторов, объясняют тем, что ранняя колонизация носила менее экстрактивный характер - колонии выступали скорее новыми рынками сбыта для европейских товаров, и эти страны получили независимость раньше. В то же время в странах, колонизированных в период империалистической волны колонизации, были установлены более экстрактивные институты.

По мнению авторов, полученные результаты согласуются с предположением Аджемоглу и др. о том, что влияние дохода на демократию гетерогенно и зависит от качества институтов. Иными словами, влияние дохода на демократию опосредовано институтами.

13. При исследовании колоний показателями качества институтов являлись: 1) существование ограничений исполнительной власти в 1900 году; 2) получение независимости до 1900 года или после (предполагается, что более длительный срок независимости позволил развиться более инклюзивным институтам). 
Исследование Х. Фариа, Х. Монтесинос-Юфы и Д. Моралеса (Faria, MontesinosYufa, Morales, 2014) также посвящено пересмотру и проверке гипотезы модернизации с учетом данных, полученных Аджемоглу и др. Они применили обобщенный метод моментов в варианте, предложенном Бланделлом-Бондом (system GMM), к выборке с 1970 по 2010 год и включили в исследование в качестве независимой переменной экономическую свободу наряду с доходом, человеческим капиталом и демократией. В качестве показателя экономической свободы был взят индекс EFW, публикуемый Институтом Фрейзера. Как отмечают Фария и др., «центральным показателем экономической свободы является качество правовой инфраструктуры, в частности, степень верховенства права и независимости судебной системы» (Faria et al., 2014: 19). Верховенство права и независимость судебной системы - это ключевые либеральные институты, которые играют центральную роль в neoliberal state.

Результаты подтверждают гипотезу модернизации - доход и образование предсказывают демократию даже в краткосрочном (5 лет) плане, в зависимости от экономической свободы. Также уровень дохода и человеческого капитала в 1975 году предсказывает демократические изменения в течение последующих 35 лет, в то время как уровень экономической свободы их не предсказывает. Иными словами, с ростом доходов и уровня образования населения растет и вероятность демократизации страны.

На основании полученных результатов авторы делают вывод, что экономическое развитие влияет на демократию, но это влияние опосредовано институтами. Речь идет о предположении, что один канал причинно-следственных связей идет от институтов и человеческого капитала к развитию, и что «другой канал ведет от развития к демократии» (Faria et al., 2014: 29). По сути дела, эти результаты близки выводам Р. Барро о значимом положительном влиянии «верховенства права, свободных рынков, небольших государственных расходов и высокого человеческого капитала», то есть минимального государства и человеческого капитала, на демократию (Barro, 1996: 23).

Схожие результаты получили Б. Хейд, Д. Лангер, М. Ларч (Heid, Langer, March, 2011), которые нашли подтверждение гипотезы модернизации, используя обобщенный метод моментов Бланделла - Бонда (system GMM). Однако они не включали в регрессию показатели экономической свободы и не учитывали влияние образования на модернизацию.

В этом и предыдущем исследованиях авторы берут в качестве показателя демократии индекс политических прав от Freedom House за 2010 год. Однако данные Freedom House измеряют не столько электоральный процесс, сколько состояние политических прав и гражданских свобод - в отличие, скажем, от индекса Ванханена, который концентрируется исключительно на электоральном процессе. Поскольку уровень демократии не поддается прямому количественному измерению, выбор показателей демократии зависит от того, ограничивается ли анализ электоральной демократией или же обращается к более широким концепциям. 
На данный момент нет всеми признанного определения демократии и перечня ее форм и признаков - это остается предметом острых дебатов (Campbell, 20o8). Coответственно, нет консенсуса относительно того, как измерять демократии - разные рейтинги принимают разные единицы анализа, от независимых государств до территорий, используют разные шкалы и индикаторы. И если еще Пшеворски с соавторами концентрировались главным образом на электоральном процессе, то работы Аджемоглу и соавторов, равно как и Инглхарта и Вельцеля, передвинули акцент на обеспечение прав человека и качество либеральных институтов.

Другая проблема заключается в выборе показателей благосостояния, о чем шла речь выше. Рост ВВП на душу населения, зачастую используемый как показатель экономического роста, не дает достаточной информации о том, что действительно происходит в экономике и обществе, - о распределении богатства и участия среднего класса, о возможности удовлетворения базовых нужд, о влиянии на окружающую среду и прочих экстерналиях (van den Bergh, 2009).

Очевидно, что на результаты эмпирических исследований влияет выбор стран и временных рамок исследования, выбор показателей социально-экономического развития, трактовка демократии, выбор показателей демократизации и т.д. (Wucherpfennig, Deutch, 2009). Тем не менее налицо стремление учитывать в эмпирических исследованиях по гипотезе модернизации роль либеральных институтов - как экономических, так и политических.

\section{5. Липсет был прав?}

Итак, с одной стороны, эмпирические исследования скорее подтверждают позитивную связь между экономическим развитием и демократизацией. С другой стороны, остается открытым вопрос о том, является ли эта связь каузальной.

Сложности в построении объяснительной модели, помимо прочего, связаны с тем, что общества изменчивы, историчны, и в разные периоды в демократизации ключевую роль могут играть разные факторы. Скажем, до Второй мировой войны ключевую роль могли играть скорее эндогенные факторы, но со временем международное влияние, как экономическое, так и политическое, становилось все более выраженным (Geddes, 2014). Не случайно, как показали Бойкс и Стоукс (Boix, Stokes, 2003), экономическое развитие оказывало существенное влияние на демократизацию до Второй мировой войны, после влияние ослабло.

Вместе с тем в большинстве случаев анализ предполагает финансово закрытую экономику, не принимая во внимание экономическое и политическое влияние глобализации (Freeman, Quinn, 2012). Глобализация существенно изменила ситуацию, задав развивающимся странам мощные внешнеполитические стимулы к демократизации. Демократия, вкупе с неолиберальной экономикой и теорией демократического мира, которой в середине 1990-х был придан статус социального закона (Levy, 1994), стали базовыми составляющими построения либерального мирового порядка - продвижение демократии и распространение принципов неолибера- 
лизма стали важнейшей целью внешней политики США, особенно после распада СССР. Поэтому фактор экзогенного происхождения демократических институтов, на который указывал Пшеворски, тоже нельзя сбрасывать со счетов.

В то же время, капиталистическая экономика под влиянием неолиберализма существенно трансформировалась в сторону финансиализации, снятия торговых барьеров, гибкости рынков труда и т.д. В итоге возникла определенная угроза для демократии со стороны глобальной экономики, или, как это обозначил Родрик, «фундаментальная политическая трилемма мировой экономики: мы не можем одновременно утверждать демократию, национальное определение и экономическую глобализацию» (Rodrik, 2011: XVIII). В результате переноса власти в сферу экономики и появления новых центров власти, никем не контролируемых и ничем не ограниченных - международных финансовых организаций и ТНК, - национальные правительства утратили контроль над решением многих важнейших для общества проблем. Это порождает у людей ощущение, что их жизнь контролируют иностранные силы - отдаленные и недемократичные (Colgan, Keohane, 2017). При этом демократические институты выхолащиваются, становятся формальными, утрачивая свое прежнее значение и способность контролировать капитал, говоря словами К. Крауча, «демократия описала параболу» (Крауч, 2010: 20).

Второй аспект современной ситуации - то, что неолиберальная глобализация не только стимулирует экономический рост и увеличивает жизненные стандарты, но и усиливает неравенство, недаром Э. Аткинсон назвал неолиберальный поворот 1980-х «поворотом к неравенству» (Atkinson, 2015). В этой связи стоит обратить внимание на то, что гипотеза модернизации, начиная с Липсета, опиралась на следующее предположение: экономическое развитие влечет за собой развитие демократической культуры в силу большей доступности образования и других базовых благ, и главным образом в силу более равномерного распределения доходов. Предполагалось, что экономическое развитие ведет к сокращению разрыва между богатыми и бедными и построению более справедливого общества: «Разрыв между доходами белых воротничков, синих воротничков... и обычных рабочих... намного больше в более бедных, чем в развитых странах» (Lipset, 1960: 49). Бойкс и Стоукс также приписывали экономическому равенству центральную роль в возникновении и устойчивости демократии: «По мере развития стран доходы распределяются более равномерно» (Boix, Stokes, 2003: 539-540). В гипотезе модернизации речь идет не об экономическом развитии как таковом, но именно о повышении уровня жизненных стандартов для населения (Barro, 1996), о том, что «более высокий доход может редуцировать конфликты и обеспечить поддержку редистрибутивной политики» (Benhabib, Corvalan, Spiegel, 2013: 489).

Гипотеза модернизации приводит к двум главным выводам: 1) установление демократии не является ключом к экономическому росту, поскольку влияние демократии на экономический рост слабое, а «политические свободы имеют тенденцию разрушаться с течением времени, если они не находятся в соответствии с уровнем жизни в стране» (Barro, 1996: 24); 2) лучший способ распространения 
демократии - это пропаганда и продвижение западных экономических институтов, а демократические институты разовьются сами в результате экономического роста.

Однако, как показали эмпирические исследования, адаптация неолиберальной западной политики (policies) развивающимися странами в большинстве случаев не приводит к выравниванию доходов ни внутри стран, ни между бедными и богатыми странами (Stankov, 2017). Дерегулирующая политика в духе неолиберализма способствует росту доходов на душу населения, но в то же время повышает неравенство. Более того, она не производит больше благосостояния, если понимать его расширенно (Stankov, 2017). Таким образом, предположение о том, что экономическое развитие само по себе ведет к более равномерному распределению дохода, лучшему доступу к образованию и росту человеческого капитала, оказывается как минимум спорным. Как отмечает Э. Аткинсон, экономические результаты во многом зависят от политики - нет одной-единственной экономики (Atkinson, 2015). Неолиберализм ведет к экономическому росту и накоплению капитала, но накопление капитала отнюдь не означает рост благосостояния для всех - рынок не работает так, как это предусматривает теория (Крауч, 2012; Стиглиц, 2016; Rodrik, 2011). В итоге рост неравенства и уменьшение среднего класса как основы либеральной демократии, наравне с колонизацией государства корпоративными интересами, может угрожать либеральной демократии даже в развитых странах, не говоря уже о развивающихся.

Таким образом, получается парадоксальная ситуация: с одной стороны, международное сообщество всячески приветствует и поддерживает демократизацию; с другой стороны, экономические трансформации в результате неолиберальной глобализации приводят к деформации, выхолащиванию демократических институтов, утрате избирателями возможности влиять на политику через политическое представительство. Этот парадокс находит свое выражение в том, что, согласно исследованию Дж. Фримена и Д. Куина (Freeman, Quinn, 2012), открытость и интеграция автократических экономик в глобальный финансовый рынок одновременно повышает неравенство в стране и увеличивает вероятность демократизации. Авторы исследования объясняют это тем, что элиты диверсифицируют свои активы, инвестируя за рубежом, и становятся менее зависимыми от налоговой - и не только - политики внутри страны.

На наш взгляд, это свидетельствует о том, что Липсет был прав, и между изменением социальной структуры, распределением доходов, развитием человеческого капитала, с одной стороны, и демократией - с другой, есть устойчивая связь. Но не в том смысле, что экономическое развитие является prima causa deмократии, а в том, что экономические изменения приводят к определенным соииальным трансформациям, которые влияют на работу и форму политических институтов. Базовой предпосылкой гипотезы модернизации является эгалитарное перераспределение экономических активов и развитие человеческого капитала, влияющее на перераспределение политической власти. Таким образом, в демокра- 
тизации главную роль играет не только установление либеральных институтов, но и классовая динамика, возможность широких слоев населения продвигать свои интересы. Неолиберализм же, предоставляя широким массам доступ к политическому участию, одновременно ослабляет их влияние на принятие решений, усиливая влияние глобализированных элит (Colgan, Keohane, 2017).

По мнению многих авторов (Rodrik, 2011; Стиглиц, 2016; Stankov, 2017; Ikenberry, 2017; Yakupec, 2018; Deneen, 2018 etc.), в настоящее время наблюдается кризис неолиберализма и либеральной демократии - в результате того, что мы можем обозначить как «нарушение социального контракта» между либеральными элитами и широкими массами. В качестве «лечения» предлагается сдвиг от прорыночной к продистрибутивной политике, восстановление определенного уровня полномочий национального государства, установление менее либерального, но более толерантного международного порядка. Дальнейшее же развитие гипотезы модернизации требует рефлексии на изменившиеся обстоятельства и уточнения базовых понятий.

\section{Литература}

Ананьин О., Хаиткулов Р., Шестаков Д. (2010). Вашингтонский консенсус: пейзаж после битв // Мировая экономика и международные отношения. № 12. С. 15-27.

Войтоловский Ф. Г. (2007). Единство и разобщенность Запада: идеологическое отражение в сознании элит США и Западной Европы трансформаций политического миропорядка 1940-200о-е гг. М.: Крафт+.

Инглхарт Р., Вельцель К. (2011). Модернизация, культурные изменения и демократия: последовательность человеческого развития / Пер. с англ. М. Коробочкина. М.: Новое издательство.

Капелюшников Р. (2017). Неравенство: как не примитивизировать проблему // Вопросы экономики. № 4. С. 117-139.

Коротаев А., Васькин И., Билюга С. (2017). Гипотеза Олсона - Хантингтона о криволинейной зависимости между уровнем экономического развития и социально-политической дестабилизацией: опыт количественного анализа // Социологическое обозрение. Т. 16. № 1. С. 9-49.

Крауч К. (2010). Постдемократия / Пер. с англ. Н. В. Эдельмана. М.: ВШЭ.

Крауч К. (2012). Странная не-смерть неолиберализма / Пер. с англ. Д. Кралечкина. М.: Дело.

Кутуєв П. В. (2005). Концепції розвитку та модернізації в соціологічному дискурсі: еволюція дослідницьких програм. К.: Сталь.

Myøб Ш. (2013). Постдемократия и постполитика // Гефтер. URL: http://gefter.ru/ archive/10510 (дата доступа: 07.04.2016).

Норт Д. (1997). Институты, институциональные изменения и функционирование экономики / Пер. с англ. А. Н. Нестеренко. М.: Начала. 
Норт Д., Уоллис Д., Вайнгаст Б. (2011). Насилие и социальные порядки. Концептуальные рамки для интерпретации письменной истории человечества / Пер. с англ. Д. Узланера, М. Маркова, Д. Раскова, А. Расковой. М.: Изд-во Ин-та Гайдара.

Пикетти Т. (2015). Капитал в XXI веке / Пер. с франц. А. Дунаева. M.: Ad Marginem press.

Райнерт Э. С. (2014). Как богатые страны стали богатыми и почему бедные страны остаются бедными / Пер. с англ. Н. Автономовой. М.: ВШЭ.

Руднев М. Г. (2011). Причины и следствия изменения массовых ценностей (рецензия на книгу: Инглхарт Р., Вельцель К. Модернизация, культурные изменения и демократия. М.: Новое издательство) // Экономическая социология. Т. 12. № 2. С. $138-143$.

Стиглии, Д. (2016). Цена неравенства: чем расслоение общества грозит нашему будущему / Пер. с англ. Е. Рождественской. М.: Эксмо.

Токарев А. А. (2014). Рейтинги демократии: от ангажированности к науке // Перспективы. URL: http://www.perspectivy.info/misl/idea/rejtingi_demokratii_ot_ angazhirovannosti_k_nauke_2014-03-06.htm (дата доступа: 11.06.2017).

Acemoglu D., Robinson J. A. (2012). Why Nations Fail: The Origins of Power, Prosperity and Poverty. N.Y.: Crown Publishers.

Acemoglu D., Johnson S., Robinson J. A. (2001). The Colonial Origins of Comparative Development: An Empirical Investigation // American Economic Review. Vol. 91. № 4 . P. 1369-1401.

Acemoglu D., Johnson S., Robinson J. A., Yared P. (2005). From Education to Democracy? // American Economic Review. Vol. 95. № 2. P. 44-49.

Acemoglu D., Johnson S., Robinson J. A., Yared P. (2008). Income and Democracy // American Economic Review. Vol. 98. № 3. P. 808-842.

Acemoglu D., Johnson S., Robinson J. A., Yared P. (2009). Reevaluating the modernization hypothesis // Journal of Monetary Economics. Vol. 56. P. 1043-1058.

Albouy D. (2008). The Colonial Origins of Comparative Development: An Investigation of the Settler Mortality Data (NBER Working Paper No. 14130). URL: http://www. nber.org/papers/w14130 (дата доступа 20.11.2015)

Alvaredo, F., Chancel L., Piketty T., Saez E., Zucman G. (2017). Global Inequality Dynamics: New Findings from WID.world // American Economic Review. Vol. 107. № 5. P. 404-409.

Atkinson A. B. (2015). Inequality: What Can Be Done? Cambridge: Harvard University Press.

Barro R. J. (1996). Democracy and Growth // Journal of Economic Growth. Vol. 1. P. 1-27. Benhabib J., Corvalan A., Spiegel M. (2013). Income and Democracy: Evidence from Nonlinear Estimations // Economics Letters. Vol. 118. № 3. P. 489-492.

Boix C., Stokes S. C. (2003). Endogenous Democratization // World Politics. Vol. 55. № 4. P. 517-549. 
Boushley H., DeLong B. J., Steinbaum M. (eds.). (2017). After Piketty: The Agenda for Economics and Inequality. Cambridge: Harvard University Press.

Brooks C., Manza J. (1994). Do Changing Values Explain the New Politics? A Critical Assessment of the Postmaterialist Thesis Author(s) // Sociological Quarterly. Vol. 35. № 4. P. 541-570.

Campbell D. F. J. (2008). The Basic Concept for the Democracy Ranking of the Quality of Democracy. URL: http://www.democracyranking.org/downloads/basic_concept_democracy_ranking_2008_A4.pdf (дата доступа 10.06.2017).

Cervellati M., Jung F., Sunde U., Vischer T. (2014). Income and Democracy: Comment // American Economic Review. Vol. 104. № 2. P. 707-719.

Chang J. H. (2010). The Values of Singapore's Youth and Their Parents: A Case Challenging the Adequacy of Inglehart's Interpretation of Top Value Priorities Derived from World Values Surveys // Journal of Sociology. Vol. 46. № 2. P. 149-168.

Cheibab J. A., Vreeland J. R. (2011). Economic Development and Democratization // Brown N. J. (ed.). The Dynamics of Democratization: Dictatorship, Development and Diffusion. Baltimore: Johns Hopkins University Press. P. 145-182.

Clarke S. (2005). The Neoliberal Theory of Society // Saad-Filho A., Johnston D. (eds.). Neoliberalism: A Critical Reader. L.: Pluto Press. P. 50-59.

Colgan I. J., Keohane R. O. (2017). The Liberal Order is Rigged: Fix It Now or Watch It Wither // Foreign Affairs. Vol. 96. № 3. P. 36-44.

Crenson M. A., Ginsberg B. (2002). Downsizing Democracy: How America Sidelined Its Citizens and Privatized Its Public. Baltimore: Johns Hopkins University Press.

Crouch C. (2017) Can Neoliberalism be Saved from Itself? L.: Social Europe.

Easterly W., Levine R. (2003). Tropics, Germs, and Crops: The Role of Endowments in Economic Development // Journal of Monetary Economics. Vol. 50. № 1. P. 3-39.

Epstein D. L., Bates R., Goldstone J., Kristensen I., O’Halloran S. (2006). Democratic Transition // American Journal of Political Science. Vol. 50. № 3. P. 551-569.

Dauderstädt M., Keltek C. (2017). Inequality in Europe Relatively Stable, Absolutely Alarming. URL: http://library.fes.de/pdf-files/id/ipa/13354.pdf (дата доступа 15.07.2017).

Deneen P. J. (2018). Why Liberalism Failed. New Heaven: Yale University Press.

Faria H. J., Montesinos-Yufa H. M., Morales D. R. (2014). Should the Modernization Hypothesis Survive Acemoglu, Johnson, Robinson, and Yared? Some More Evidence // Econ Journal Watch. Vol. 11. № 1. P. 17-36.

Fawcett E. (2014). Liberalism: The Life of an Idea. Princeton: Princeton University Press. Fraser N. (2017). The End of Progressive Neoliberalism // Dissent. January 2. URL: https://www.dissentmagazine.org/online_articles/progressive-neoliberalism-reactionary-populism-nancy-fraser (дата доступа 4.02.2017)

Freeman J. R., Quinn D. P. (2012). The Economic Origins of Democracy Reconsidered // American Political Science Review. Vol. 106. № 1. P. 58-80.

Friedman M. (1992). Capitalism and Freedom. Chicago: Chicago University Press. 
Fukuyama F. (2014). Political Order and Political Decay: From the Industrial Revolution to the Globalization of Democracy. N.Y.: Farrar, Straus \& Giroux.

Geddes B. (2009). What Causes Democratization? // Boix C., Stokes S. C. (eds.). The Oxford Handbook of Comparative Politics. Oxford: Oxford University Press. P. 317-339.

Giles Ch. (2014). Thomas Piketty's Exhaustive Inequality Data Turn Out to Be Flawed // Financial Times. May 23. URL: https://www.ft.com/content/c9ce1a54-e281-11e3-89fdoo144feabdco (дата доступа 3.05.2017).

Gundlach E., Paldam M. (2009). A Farewell to Critical Junctures: Sorting Out LongRun Causality of Income and Democracy // European Journal of Political Economy. Vol. 25. № 3. P. 340-354.

Harvey D. (2005). A Brief History of Neoliberalism. Oxford: Oxford University Press.

Heid B., Langer J., Larch M. (2012). Income and Democracy: Evidence from System GMM Estimates // Economics Letters. Vol. 116. № 2. P. 166-169.

Huntington S. P. (1968). Political Order in Changing Societies. New Haven: Yale University Press.

Ikenberry G. J. (2018). The End of Liberal International Order // International Affairs. Vol. 94. № 1. P. 7-23.

Inglehart R. (2008). Changing Values among Western Publics from 1970 to 2006 // West European Politics. Vol. 31. № 1/2. P. 130-146.

Inglehart R., Welzel C. (2005). Modernization, Cultural Change and Democracy: The Human Development Sequence. Cambridge: Cambridge University Press.

Inglehart R., Welzel C. (2010). Changing Mass Priorities: The Link between Modernization and Democracy // Perspectives on Politics. Vol. 8. № 2. P. 551-567.

Irwin N. (2014). Thomas Piketty Responds to Criticism of His Data // The New York Times. May 29. URL: https://www.nytimes.com/2014/05/30/upshot/thomas-pikettyresponds-to-criticism-of-his-data.html? mcubz=о (дата доступа 5.05.2017).

Jacobsen J. (2015). Revisiting the Modernization Hypothesis: Longevity and Democracy // World Development. Vol. 67. P. 174-185.

Jones Ch. I., Klenow P. J. (2016). Beyond GDP? Welfare across Countries and Time // American Economic Review. Vol. 106. № 9. P. 2426-2457.

Lee Ch. H. (2001). From Financial to Democratic Crisis in Asia // Project Syndicate. URL: http://www.project-syndicate.org/commentary/from-financial-to-democratic-crisisin-asia (дата доступа 5.09.2015).

Levin-Waldman O. M. (2016). How Inequality Undermines Democracy // E-International Relations. 10 December. URL: http://www.e-ir.info/2016/12/10/how-inequality-undermines-democracy/ (дата доступа 10.04.2016).

Levy J. S. (1994). The Democratic Peace Hypothesis: From Description to Explanation // Mershon International Studies Review. № 38. P. 352-354.

Lipset S. M. (1959). Some Social Requisites of Democracy: Economic Development and Political Legitimacy // American Political Science Review. Vol. 53. № 1. P. 69-105.

Kuznets S. (1955). Economic Growth and Income Inequality // American Economic Review. Vol. 45. № 1. P. 1-28. 
Mann M. (2013). The Sources of Social Power. Vol. 4: Globalizations, 1945-2011. Cambridge: Cambridge University Press.

Mesquita B. B. de, Downs G. W. (2005). Development and Democracy // Foreign Affairs. Vol. 84. № 5. P. 77-86.

Milanović B. (2016). Global Inequality: A New Approach for the Age of Globalization. Cambridge: Belknap Press.

Miller C. (2018). The Surprising Success of Putinomics // Foreign Affairs. 7 February. URL: https://www.foreignaffairs.com/articles/russian-federation/2018-02-07/surprising-success-putinomics (дата доступа 23.02.2018).

Moral-Benito E., Espana B. de, Bartolucci C., Alberto C. C. (2012). Income and Democracy: Revisiting the Evidence // Economics Letters. Vol. 117. № 3. P. 844-847.

Moore B. (1966). Social Origins of Dictatorship and Democracy: Lord and Peasant in the Making of the Modern World. Boston: Beacon Press.

Mouffe Ch. (2000). The Democratic Paradox. L.: Verso.

Mudde C., Kaltwasser C. R. (2017). Populism: A Very Short Introduction. Oxford: Oxford University Press.

Mukand S., Rodrik D. (2015). The Political Economy of Liberal Democracy. NBER Working Paper № 21540. URL: http://www.nber.org/papers/w21540 (дата доступа 18.11.2015).

Nino-Zarazua M., Roope L., Tarp F. (2016). Global Inequality: Relatively Lower, Absolutely Higher // Review of Income and Wealth. URL: http://onlinelibrary.wiley.com/ doi/10.1111/roiw.12240/full (дата доступа 20.07.2017).

O’Donnell G. (1973). Modernization and Bureaucratic-Authoritarianism: Studies in South American Politics. Berkeley: University of California Press.

Patterson O. (2014). The Privatization of Freedom in America: Its Meaning and Consequences (Working Paper). URL: https://scholar.harvard.edu/patterson/publications/privatization-freedom-america-its-meaning-and-consequences (дата доступа: 03.03.2018).

Pirie I. (2013). Globalization and the Decline of the Developmental State // Fine B., Saraswati J., Tavasci D. (eds.). Beyond the Developmental State: Industrial Policy into the Twenty-First Century. L.: Pluto Press. P. 146-168.

Przeworski A. (2004a). Democracy and Economic Development // Mansfield E. D., Sisson R. (eds.). The Evolution of Political Knowledge: Democracy, Autonomy, and Conflict in Comparative and International Politics. Columbus: Ohio State University Press. P. 300-324.

Przeworski A. (2004b). The Last Instance: Are Institutions the Primary Cause of Economic Development? // European Journal of Sociology. Vol. 45. № 2. P. 165-188.

Przeworski A., Cheibub J. A., Alvarez M.E., Limongi F. (200o). Democracy and Development: Political Institutions and Material Well-being in the World, 1950-1990. Cambridge: Cambridge University Press.

Przeworski A., Limongi F. (1997). Modernization: Theories and Facts // World Politics. Vol. 49. № 2. P. 155-183. 
Rodrik D. (2011). The Globalization Paradox: Democracy and the Future of World Economy. N.Y.: W. W. Norton \& Co.

Rodrik D. (2006). Good Bye Washington Consensus, Hello Washington Confusion?. URL: https://drodrik.scholar.harvard.edu/files/dani-rodrik/files/goodbye-washington.pdf (дата доступа 15.10.2016).

Sachsenmaier D. (2002). Multiple Modernities: The Concept and Its Potential // Sachsenmaier D., Eisenstadt S., Riedel J. (eds.). Reflections on Multiple Modernities: European, Chinese and Other Interpretations. Leiden: Brill. P. 42-67.

Saez E,. Zucman G. (2016). Wealth Inequality in the United States since 1913: Evidence from Capitalized Income Tax Data // Quarterly Journal of Economics. Vol. 131. № 2. P. $519-578$.

Sandel M. (2009). Justice: What's the Right Thing to Do. N.Y.: Farrar, Straus \& Giroux.

Sen A. (1999). Development as Freedom. Oxford: Oxford University Press.

Singh A., Belaisch A., Collyns C., Masi P., Krieger R., Meredith G., Rennhack R. (2005). Stabilization and Reform in Latin America: A Macroeconomic Perspective on the Experience Since the Early 1990s. IMF Occasional Paper № 238. URL: https://www.imf. org/external/pubs/ft/op/238/pdf/foreword.pdf (дата доступа 1.08.2017).

Stankov P. (2017). Economic Freedom and Welfare Before and After the Crisis. L.: Palgrave Macmillan.

Temin P. (2017). The Vanishing Middle Class: Prejudice and Power in a Dual Economy. Cambridge: MIT Press.

Teorell J., Hadenius A. (2006). Democracy without Democratic Values: A Rejoinder to Welzel and Inglehart // Studies in Comparative International Development. Vol. 41. № 3. P. 95-111.

Thorsen D. E., Lie A. (2006). What is Neoliberalism? URL: http://folk.uio.no/daget/neoliberalism.pdf (дата доступа 5.03.2018).

Treisman D. (2015). Income, Democracy and Leader Turnover // American Journal of Political Science. Vol. 59. №. 4. P. 927-942.

Van den Bergh J. C. J. M. (2009). The GDP Paradox // Journal of Economic Psychology. № 30. P. 117-135.

Wagner P. (1994). Sociology of Modernity: Liberty and Discipline. L.: Routledge.

Wang Y. (2017). The China Model and the New World Order // Trends: Research and Advisory. URL: http://trendsinstitution.org/the-china-model-and-the-new-worldorder/ (дата доступа 11.01.2018).

Welzel C., Inglehart R., Klingemann H.-D. (2003). The Theory of Human Development: A Cross-Cultural Analysis // European Journal of Political Research. Vol. 42. № 2. P. 341-380.

World Bank. (2005). Economic Growth in the 1990s: Learning from a Decade of Reform. Washington: World Bank.

Williamson J. (2003). Our Agenda and the Washington Consensus // Kuczynski P. P., Williamson J. (eds.). After the Washington Consensus: Restarting Growth and Reform in Latin America. Washington: Institute for International Economics. P. 323-331. 
Wucherpfennig J. Deutsch F. (2009). Modernization and Democracy: Theories and Evidence Revisited // Living Review in Democracy. Vol. 1. P. 1-9.

Yakupec V. (2018). Development Aid: Populism and the End of Neoliberal Agenda. Berlin: Springer.

Zakaria F. (1997). The Rise of Illiberal Democracy // Foreign Affairs. Vol. 76. № 6. P. 22-43.

\title{
Modernization Hypothesis and Neoliberalism
}

\author{
Svitlana Shcherbak \\ $\mathrm{PhD}$, research officer, Skovoroda's Institute of Philosophy of Ukrainian National Academy of Sciences \\ Address: Tryokhsvyatitelskaya str., 4, Kiev, Ukraine 01001 \\ E-mail: svedep4@gmail.com
}

In this article, we discuss the modernization hypothesis in consideration of the causes of democratization related to economic development. The modernization hypothesis was formulated in the mid-twentieth century in the midst of specific economic and socio-political conditions. Since then, both societies and representations of their developments have changed. Current research disregards these transformations; therefore, with this work, we aim to fill the gap. We make clear how the neo-liberal turn influenced representations of economic development and democracy. Realization of the neo-liberal economic policy resulted in important social changes, particularly the rise of inequality and the wave of populism that endangers liberal democracy. At the same time, the modernization hypothesis is based on presumptions that economic development leads to income equalization and the creation of the broad middle class. Our analysis reveals that empirical surveys tend to confirm the relationship between economic development and democracy. However, economic growth does not necessarily entail more equal income distribution. The rise of populism indirectly confirms the rightness of the modernization hypothesis and suggests an important role for class dynamics. Democratization necessitates not only the establishment of liberal institutions but also the transformation of the social structure via convergence of incomes.

Keywords: modernization hypothesis, economic development, democracy, neoliberalism, inequality

\section{References}

Acemoglu D., Robinson J. A. (2012) Why Nations Fail: The Origins of Power, Prosperity and Poverty, New York: Crown Publishers.

Acemoglu D., Johnson S., Robinson J. A. (2001) The Colonial Origins of Comparative Development: An Empirical Investigation. American Economic Review, vol. 91, no 4, pp. 1369-1401.

Acemoglu D., Johnson S., Robinson J. A., Yared P. (2005) From Education to Democracy? American Economic Review, vol. 95, no 2, pp. 44-49.

Acemoglu D., Johnson S., Robinson J. A., Yared P. (2008) Income and Democracy. American Economic Review, vol. 98, no 3, pp. 808-842.

Acemoglu D., Johnson S., Robinson J. A., Yared P. (2009) Reevaluating the Modernization Hypothesis. Journal of Monetary Economics, vol. 56, pp. 1043-1058.

Albouy D. (2008) The Colonial Origins of Comparative Development: An Investigation of the Settler Mortality Data (NBER Working Paper No 14130). Available at: http://www.nber.org/papers/w14130 (accessed 28 November 2015). 
Alvaredo, F., Chancel L., Piketty T., Saez E., Zucman G. (2017) Global Inequality Dynamics: New Findings from WID.world. American Economic Review, vol. 107, no 5, pp. 404-409.

Ananyin O., Khaitkulov R., Shestakov D. (2010) Vashingtonskij konsensus: pejzazh posle bitv [Washington Consensus: Landscape after Battles]. World Economy and International Relations, no 12 , pp. 15-27.

Atkinson A. B. (2015) Inequality: What Can Be Done? Cambridge: Harvard University Press.

Barro R. J. (1996) Democracy and Growth. Journal of Economic Growth, vol. 1, pp. 1-27.

Benhabib J., Corvalan A., Spiegel M. (2013) Income and Democracy: Evidence from Nonlinear Estimations, Economics Letters, vol. 118, no 3, pp. 489-492.

Boix C., Stokes S. C. (2003). Endogenous Democratization. World Politics, vol. 55, no 4, pp. 517-549.

Boushley H., DeLong B. J., Steinbaum M. (eds.) (2017) After Piketty: The Agenda for Economics and Inequality, Cambridge: Harvard University Press.

Brooks C., Manza J. (1994) Do Changing Values Explain the New Politics? A Critical Assessment of the Postmaterialist Thesis Author(s). Sociological Quarterly, vol. 35, no 4, pp. 541-570.

Campbell D. F. J. (2008) The Basic Concept for the Democracy Ranking of the Quality of Democracy. Available at: http://www.democracyranking.org/downloads/basic_concept_democracy_ ranking_2008_A4.pdf (accessed 10 June 2017).

Cervellati M., Jung F., Sunde U., Vischer T. (2014) Income, Democracy, and Critical Junctures (IZA Discussion Paper No 7069). American Economic Review, vol. 104, no 2, pp. 707-719.

Chang J. H. (2010) The Values of Singapore's Youth and Their Parents: A Case Challenging the Adequacy of Inglehart's Interpretation of Top Value Priorities Derived from World Values Surveys. Journal of Sociology, vol. 46, no 2, pp. 149-168.

Cheibab J. A., Vreeland J. R. (2011). Economic Development and Democratization. The Dynamics of Democratization: Dictatorship, Development and Diffusion (ed. N. J. Brown), Baltimore: Johns Hopkins University Press, pp. 145-182.

Clarke S. (2005) The Neoliberal Theory of Society. Neoliberalism: A Critical Reader (eds. A. Saad-Filho, D. Johnston), London: Pluto Press, pp. 50-59.

Colgan I. J., Keohane R. O. (2017) The Liberal Order is Rigged: Fix It Now or Watch It Wither. Foreign Affairs, vol. 96, no 3, pp. 36-44.

Crenson M. A., Ginsberg B. (2002) Downsizing Democracy: How America Sidelined Its Citizens and Privatized Its Public. Baltimore: Johns Hopkins University Press.

Crouch C. (2010) Postdemokratia [Post-democracy], Moscow: HSE.

Crouch C. (2012) Strannaya ne-smert neoliberalizma [The Strange Non-death of Neo-liberalism], Moscow: Delo.

Crouch C. (2017) Can Neoliberalism be Saved from Itself?, London: Social Europe.

Easterly W., Levine R. (2003) Tropics, Germs, and Crops: The Role of Endowments in Economic Development. Journal of Monetary Economics, vol. 50, no 1, pp. 3-39.

Epstein D. L., Bates R., Goldstone J., Kristensen I., O'Halloran S. (2006) Democratic Transition. American Journal of Political Science, vol. 50, no 3, pp. 551-569.

Dauderstädt M., Keltek C. (2017) Inequality in Europe Relatively Stable, Absolutely Alarming. Politik für Europa, no 2017 plus. Available at: http://library.fes.de/pdf-files/id/ipa/13354.pdf (accessed 15 July 2017).

Deneen P. J. (2018) Why Liberalism Failed, New Heaven: Yale University Press.

Faria H. J., Montesinos-Yufa H. M., Morales D. R. (2014) Should the Modernization Hypothesis Survive Acemoglu, Johnson, Robinson, and Yared? Some More Evidence. Econ Journal Watch, vol. 11, no 1, pp. 17-36.

Fawcett E. (2014) Liberalism: The Life of an Idea, Princeton: Princeton University Press.

Friedman M. (1992) Capitalism and Freedom, Chicago: Chicago University Press.

Freeman J. R., Quinn D. P. (2012) The Economic Origins of Democracy Reconsidered. American Political Science Review, vol. 106, no 1, pp. 58-80.

Fraser N. (2017) The End of Progressive Neoliberalism. Dissent. Available at: https://www. dissentmagazine.org/online_articles/progressive-neoliberalism-reactionary-populism-nancyfraser (accessed 4 February 2017). 
Fukuyama F. (2014) Political Order and Political Decay: From the Industrial Revolution to the Globalization of Democracy, New York: Farrar, Straus \& Giroux.

Geddes B. (2009) What Causes Semocratization? The Oxford Handbook of Comparative Politics (eds. C. Boix, S. C. Stokes), Oxford: Oxford University Press, pp. 317-339.

Giles Ch. (2014) Thomas Piketty's Exhaustive Inequality Data Turn Out to Be Flawed. Financial Times, May 23. Available at: https://www.ft.com/content/c9ce1a54-e281-11e3-89fd-00144feabdco (accessed 3 May 2017).

Gundlach E., Paldam M. (2009) A Farewell to Critical Junctures: Sorting Out Long-Run Causality of Income and Democracy. European Journal of Political Economy, vol. 25, no 3, pp. 340-354.

Harvey D. (2005) A Brief History of Neoliberalism, Oxford: Oxford University Press.

Heid B., Langer J., Larch M. (2012) Income and Democracy: Evidence from System GMM Estimates. Economics Letters, vol. 116, no 2, pp. 166-169.

Huntington S. P. (1968) Political Order in Changing Societies, New Haven: Yale University Press.

Ikenberry G. J. (2018) The End of Liberal International Order. International Affairs, vol. 94, no 1, pp. 7-23.

Inglehart R. (2008) Changing Values among Western Publics from 1970 to 2006. West European Politics, vol. 31, no 1-2, pp. 130-146.

Inglehart R., Welzel C. (2010) Changing Mass Priorities: The Link between Modernization and Democracy. Perspectives on Politics, vol. 8, no 2, pp. 551-567.

Inglehart R., Welzel C. (2005) Modernization, Cultural Change and Democracy: The Human Development Sequence, Cambridge: Cambridge University Press.

Inglehart R., Welzel C. (2011) Modernizacija, kulturnye izmenenija i demokratija: posledovatelnost chelovecheskogo razvitija [Modernization, Cultural Change and Democracy: The Human Development Sequence], Moscow: Novoe izdatelstvo.

Irwin N. (2014) Thomas Piketty Responds to Criticism of His Data. The New York Times, May 29. Available at: https://www.nytimes.com/2014/05/30/upshot/thomas-piketty-responds-tocriticism-of-his-data.html? mcubz=0 (accessed 5 May 2017).

Jacobsen J. (2015) Revisiting the Modernization Hypothesis: Longevity and Democracy. World Development, vol. 67, pp. 174-185.

Jones Ch. I., Klenow P. J. (2016) Beyond GDP? Welfare across Countries and Time. American Economic Review, vol. 106, no 9, pp. 2426-2457.

Kapelushnikov R. (2017) Neravenstvo: kak ne primitivizirovat' problem [Inequality: How Not to Simplify the Problem]. Voprosy ekonomiki, no 4, pp. 117-139.

Korotayev A., Vaskin I., Bilyuga S. (2017). Gipoteza Olsona-Hantingtona o krivolinejnoj zavisimosti mezhdu urovnem jekonomicheskogo razvitija i social'no-politicheskoj destabilizaciej: opyt kolichestvennogo analiza [Olson-Huntington Hypothesis on a Bell-Shaped Relationship Between the Level of Economic Development and Sociopolitical Destabilization: A Quantitative Analysis]. Russian Sociological Review, vol. 16, no 1, pp. 9-49.

Kutuev P. (2005) Koncepcii' rozvytku ta modernizacii' v sociologichnomu dyskursi: evoljucija doslidnyc'kyh program [Development and Modernization Concepts in Sociological Discourse: Evolution of Research Programs], Kiev: Stal.

Kuznets S. (1955) Economic Growth and Income Inequality. American Economic Review, vol. 45, no 1, pp. 1-28.

Lee Ch. H. (2001) From Financial to Democratic Crisis in Asia. Project Syndicate. Available at: http://www.project-syndicate.org/commentary/from-financial-to-democratic-crisis-inasia\#ycsT5m22QmOP3FwC.99 (accessed 5 September 2015).

Levin-Waldman (2016) How Inequality Undermines Democracy. E-International Relations, 10 December. Available at: http://www.e-ir.info/2016/12/10/how-inequality-underminesdemocracy/ (accessed 10.04.2016).

Levy J. S. (1994) The Democratic Peace Hypothesis: From Description to Explanation. Mershon International Studies Review, no 38, pp. 352-354.

Lipset S. M. (1959) Some Social Requisites of Democracy: Economic Development and Political Legitimacy. American Political Science Review, vol. 53, no 1, pp. 69-105. 
Mann M. (2013). The Sources of Social Power, Vol. 4: Globalizations, 1945-2011, Cambridge: Cambridge University Press.

Mesquita de B. B., Downs G. W. (2005) Development and Democracy. Foreign Affairs, vol. 84, no. 5, pp. 77-86.

Milanović B. (2016) Global Inequality: A New Approach for the Age of Globalization, Cambridge: Belknap Press.

Miller C. (2018) The Surprising Success of Putinomics. Foreign Affairs, 7 February. Available at: https://www.foreignaffairs.com/articles/russian-federation/2018-02-07/surprising-successputinomics (accessed 23 February 2018).

Moral-Benito E., de Espana B., Bartolucci C., Alberto C. C. (2012) Income and Democracy: Revisiting the Evidence. Economics Letters, vol. 117, no 3, pp. 844-847.

Moore B. (1966) Social Origins of Dictatorship and Democracy: Lord and Peasant in the Making of the Modern World, Boston: Beacon Press.

Mouffe Ch. (2000) The Democratic Paradox, London: Verso.

Mouffe Ch. (2013) Postdemokratija i postpolitika [Post-democracy and Post-politics]. Gefter. Available at: http://gefter.ru/archive/10510 (accessed 7 April 2016).

Mudde C., Kaltwasser C. R. (2017) Populism: A Very Short Introduction, Oxford: Oxford University Press.

Mukand S., Rodrik D. (2015) The Political Economy of Liberal Democracy (NBER Working Paper No 21540). Available at: http://www.nber.org/papers/w21540 (accessed 18 November 2015).

Nino-Zarazua M., Roope L., Tarp F. (2016) Global Inequality: Relatively Lower, Absolutely Higher. Review of Income and Wealth. Available at: http://onlinelibrary.wiley.com/doi/10.1111/roiw.12240/ full (accessed 20 July 2017).

North D. (1997) Instituty, institucionalnye izmenenija i funkcionirovanie jekonomik [Institutions, Institutional Change and Economic Performance], Moscow: Nachala.

North D., Wallis J., Weingast B. (2011) Nasilie i socialnye porjadki [Violence and Social Orders], Moscow: Gaidar Institute Press.

O' Donnell G. (1973) Modernization and Bureaucratic Authoritarianism: Studies in South American Politics, Berkeley: University of California Press.

Patterson O. (2014) The Privatization of Freedom in America: Its Meaning and Consequences (Working Paper). Available at: https://scholar.harvard.edu/patterson/publications/privatizationfreedom-america-its-meaning-and-consequences (accessed 3 March 2018).

Piketti T. (2015) Kapital v XXI veke [Capital in the Twenty-First Century], Moscow: Ad Marginem.

Pirie I. (2013) Globalization and the Decline of the Developmental State. Beyond the Developmental State: Industrial Policy into the Twenty-First Century (eds. B. Fine, J. Saraswati, D. Tavasci), London: Pluto Press, pp. 146-168.

Przeworski A. (2004) Democracy and Economic Development. The Evolution of Political Knowledge: Democracy, Autonomy, and Conflict in Comparative and International Politics (eds. E. D. Mansfield, R. Sisson), Columbus: Ohio State University Press, pp. 300-324.

Przeworski A. (2004) The Last Instance: Are Institutions the Primary Cause of Economic Development? European Journal of Sociology, vol. 45, no 2, pp. 165-188.

Przeworski A., Cheibub J. A., Alvarez M.E., Limongi F. (2000) Democracy and Development: Political Institutions and Material Well-being in the World, 1950-1990, Cambridge: Cambridge University Press.

Przeworski A., Limongi F. (1997) Modernization: Theories and Facts. World Politics, vol. 49, no 2, pp. 155-183.

Reinert E. S. (2014) Kak bogatye strany stali bogatymi i pochemu bednye strany ostajutsja bednymi [How Rich Countries Got Rich... and Why Poor Countries Stay Poor], Moscow: HSE.

Rodrik D. (2011) The Globalization Paradox: Democracy and the Future of World Economy, New York: W. W. Norton \& Company.

Rodrik D. (2006) Good Bye Washington Consensus, Hello Washington Confusion?. Available at: https://drodrik.scholar.harvard.edu/files/dani-rodrik/files/goodbye-washington.pdf (accessed 15 October 2016).

Rudnev M. (2011) Prichiny i sledstvija izmenenija massovyh cennostej (recenzija na knigu: Inglhart R., Vel'cel' K. 2011. Modernizacija, kul'turnye izmenenija i demokratija. M.: Novoe izdatel'stvo) 
[Reasons and Consequences of Mass Value Transformation (Book Review: Inglehart R., Welzel Ch. 2010. Modernizacija, kulturnye izmenenija i demokratija: posledovatelnost chelovecheskogo razvitija. Moscow: Novoe izdatelstvo)]. Economic Sociology, vol. 12, no 2, pp. 138-143.

Sachsenmaier D. (2002) Multiple Modernities: The Concept and Its Potential. Reflections on Multiple Modernities: European, Chinese and Other Interpretations (eds. D. Sachsenmaier, S. Eisenstadt, J. Riedel), Leiden: Brill, pp. 42-67.

Saez E., Zucman G. (2016) Wealth Inequality in the United States since 1913: Evidence from Capitalized Income Tax Data. Quarterly Journal of Economics, vol. 131, no 2, pp. 519-578. Sandel M. (2009) Justice: What's the Right Thing to Do, New York: Farrar, Straus \& Giroux. Sen A. (1999) Development as Freedom, Oxford: Oxford University Press.

Singh A., Belaisch A., Collyns C., Masi P., Krieger R., Meredith G., Rennhack R. (2005) Stabilization and Reform in Latin America: A Macroeconomic Perspective on the Experience Since the Early 1990 (IMF Occasional Paper 238). Availible at: https://www.imf.org/external/pubs/ft/op/238/pdf/ foreword.pdf (accessed 1 August 2017).

Stankov P. (2017) Economic Freedom and Welfare Before and After the Crisis, London: Palgrave Macmillan.

Stigliz D. (2016) Cena neravenstva: chem rassloenie obshhestva grozit nashemu budushhemu [The Price of Inequality: How Today's Divided Society Endangers Our Future], Moscow: Eksmo.

Temin P. (2017) The Vanishing Middle Class: Prejudice and Power in a Dual Economy, Cambridge: MIT Press.

Teorell J. Hadenius A. (2006) Democracy without Democratic Values: A Rejoinder to Welzel and Inglehart. Studies in Comparative International Development, vol. 41, no 3, pp. 95-111.

Thorsen D. E., Lie A. (2006) What is Neoliberalism?. Available at: http://folk.uio.no/daget/ neoliberalism.pdf (accessed 5 March 2018).

Treisman D. (2015) Income, Democracy and Leader Turnover. American Journal of Political Science, vol. 59, no 4, pp. 927-942.

Tokarev A. (2014) Rejtingi demokratii: ot angazhirovannosti k nauke [Democracy Indexes: From Commitment to Science]. Perspektivy. Available at: http://www.perspectivy.info/misl/idea/ rejtingi_demokratii_ot_angazhirovannosti_k_nauke_2014-03-06.htm (accessed 11 June 2017).

Van den Bergh J. C. J. M. (2009) The GDP Paradox. Journal of Economic Psychology, no 30, pp. 117-135.

Voitolovsky F. (2007) Edinstvo i razobshhennost' Zapada: ideologichnoe otrazhenie v soznanii jelit SShA i Zapadnoj Evropy transformacij politicheskogo miroporjadka, 1940-200o-e gg. [The Unity and Disunity of the West: Ideological Reflection in the US and European Elites' Mind of Transformation of the Political World Order, 1940-2000], Moscow: Kraft+.

Wagner P. (1994) Sociology of Modernity: Liberty and Discipline, London: Routledge.

Wang Y. (2017) The China Model and the New World Order. Trends: Research and Advisory. Available at: http://trendsinstitution.org/the-china-model-and-the-new-world-order/ (accessed 11 January 2018).

Welzel C., Inglehart R., Klingemann H-D. (2003) The Theory of Human Development: A CrossCultural Analysis. European Journal of Political Research, vol. 42, no 2, pp. 341-380.

World Bank (2005) Economic Growth in the 1990s: Learning from a Decade of Reform, Washington: World Bank.

Williamson J. (2003) Our Agenda and the Washington Consensus. After the Washington Consensus: Restarting Growth and Reform in Latin America (eds. P. P. Kuczynski, J. Williamson), Washington: Institute for International Economics, pp. 323-331.

Wucherpfennig J., Deutsch F. (2009) Modernization and Democracy: Theories and Evidence Revisited. Living Review in Democracy, vol. 1, pp. 1-9.

Yakupec V. (2018) Development Aid: Populism and the End of Neoliberal Agenda, Berlin: Springer.

Zakaria F. (1997) The Rise of Illiberal Democracy. Foreign Affairs, vol. 76, no 6, pp. 22-43. 


\title{
Глобальная (им)мобильность в зеркале постмодернистских трансформаций: политический аспект
}

\author{
Вера Тормочева \\ Соискатель кафедры международных отношений и политологии \\ Нижегородского государственного лингвистического университета им. Н. А. Добролюбова \\ Адрес: ул. Минина, д. 31А, г. Нижний Новгород, Российская Федерация 603155 \\ E-mail: tormosh@mail.ru
}

\begin{abstract}
Одним из проявлений глобализации считается усиление пространственной подвижности населения в целом и вовлечение всё большего количества граждан в процессы международной миграции в частности. Однако процессы, способствующие движению и глобальным связям, одновременно порождают физическую и социально-политическую иммобильность, отчуждение и разобщённость. Феномен (им)мобильности рассмотрен в статье с политологической точки зрения. Используя институциональный подход, автор характеризует (им)мобильность как процесс, с одной стороны, обусловленный деятельностью международных и национальных политических институтов с другой, стимулирующий возникновение формальных и неформальных политических практик. Государственное регулирование трансграничной миграции выражается в требовании убедительных оснований для легального въезда на территорию того или иного государства, в развитии дистанционных форм управления мобильностью, использовании финансовых механизмов и введении ограничительных миграционных мер. Ограничительные практики модерна встречаются с цифровыми практиками постмодерна. При этом политические барьеры препятствуют движению как потенциально опасных групп и индивидов, так и не представляющих угрозу обществу граждан, нарушая права и свободы, так называемые «права на мобильность». Инициативы политических партий и общественных объединений закрывают мобильным гражданам доступ не только к политическому лидерству, но и к участию в формировании политической повестки.
\end{abstract}

Ключевые слова: миграция, мобильность, иммобильность, постмодерн, институциональный подход, политические институты

\section{Научные дискуссии о мобильности}

Понятие «мобильность» (mobility) нельзя отнести к новым феноменам социально-гуманитарного знания. В английский язык оно вошло ещё в XVII веке для обозначения человеческих тел, конечностей и органов. Впоследствии оно получило распространение в естественных науках для описания возможности двигаться и использовалось взаимозаменяемо с понятием «движение» (movement). K XVIII веку употребление понятия «mobility» отмечено и в общественных науках по отношению к движущейся и легковозбудимой толпе (Cresswell, 2006: 20-21).

(C) Тормошева В. С., 2018

(с) Центр фундаментальной социологии, 2018

DOI: $10.17323 / 1728-192 \mathrm{X}-2018-3-329-345$ 
Широкое распространение оба понятия получили в эпоху модерна, отмеченную поступательным сжатием пространства и времени благодаря развитию коммуникационных и транспортных средств. Чрезвычайно актуальны они и сегодня, в эпоху постмодерна, характеризующуюся глобальными трансформациями и противоречиями, когда мир представляет собой «не только пространство сетей, потоков и мобильности, но и мир границ, нарушающих мобильность, свободы, права и идентичность» (Rumford, 2006: 163-164).

Научные дискуссии на страницах ведущих российских изданий сфокусированы на нескольких направлениях исследований. Региональную специфику пространственной мобильности представляют: этнографический взгляд на среднеазиатскую миграцию в транснациональном пространстве (Абашин, 2012); анализ общероссийских тенденций возвратной мобильности - внутренних трудовых и сезонных дачных миграций россиян (Бреславский, 2017); особенности управления миграционными потоками в странах Европейского союза (Барберо, 2014); меры по защите территорий на пути трансграничных потоков из Азии и Африки (Голунов, 20о9). Теоретико-методологчческие подходы к изучению данного феномена включают работы о гендерных эффектах международной мобильности населения (Толстокорова, 2014); этнической проблематике современных миграционных процессов на международном и межнациональном уровнях (Захарян, 2012); сетевом подходе к исследованию международных миграционных потоков (Алескеров и др., 2016); мотивационных факторах влияния на интенсивность мобильности в глобальном масштабе (Попов, 2011); количественных и качественных аспектах международной миграции трудовых ресурсов (Шишков, 2011).

В современной общественной мысли понятия, ассоциирующиеся с мобильностью, преимущественно имеют позитивную коннотацию. Быть текучим, динамичным, движущимся либо мобильным - значит, быть прогрессивным, впечатляющим и современным. В этой логике мобильности приписывают победу над сковывающей способностью пространства, а глобально мобильным личностям - добровольным участникам межкультурного взаимодействия - лёгкость адаптации к новым условиям: пространственным, темпоральным, информационным, культурным, идеологическим (Сизиков, 2005: 100-101, 114-115). Напротив, укоренённость, устойчивость, статичность либо ограниченность в чём-либо расцениваются как нечто реакционное, скучное и устаревшее (Cresswell, 2006: 25). Негативные оценки иммобильности включают такие характеристики, как «культурный примитивизм, препятствие на пути к прогрессу, лишение, отстранение, неполноценность, недостаток» (Khan, 2016: 94). Нулевую степень мобильности, реальной и виртуальной, другими словами, локальную скованность связывают с социальной периферией транснационального культурного пространства, к которой люди вынужденно привязаны, страдают от избытка времени, осознают свою связь с пространством как непреодолимое препятствие и жёстко идентифицируют себя с локальными культурами, что порождает напряжённость и чревато крупномасштабными конфликтами (Сизиков, 2005: 91-92, 101, 113). 
Основная масса исследований глобализации посвящена открытости и проницаемости границ, тогда как исследователи уделяют недостаточно внимания ограничениям, которые несёт с собой «глобальный режим мобильности» (Shamir, 2005: 214). Многочисленные ограничения пространственной мобильности делают преждевременным утверждение о глобализации миграции. Статистика последних трёх десятилетий показывает, что человеческая мобильность ещё не вышла на уровень мобильности капитала, товаров и услуг. Создаются благоприятные условия для движения товаров и капитала через государственные границы, и в то же время ужесточается контроль над движением человеческих потоков (Ribas-Mateos, 2005: 175-176). Следовательно, изучение иммобильности в условиях глобализации весьма актуально.

\section{Постмодернистское определение (им)мобильности}

То, что интеракции в человеческом обществе тесно связаны не только с мобильностью, но и с иммобильностью, т. е. отсутствием мобильности, ограниченной мобильностью или неподвижностью, позволяет исследователям-постмодернистам включать обе характеристики в определение мобильности. Согласно постмодернистскому видению мобильности, это «реальное или потенциальное движение вплетённых в сети потоков людей, товаров, идей, образов и информации, характеризующееся напряжённостью между подвижностью и неподвижностью, территоризацией и детерриторизацией и субъектами мобильности и иммобильности» (Jensen, 2011: 256-257). В свою очередь, понятие «иммобильность» (immobility) относят к совокупности упорядоченных, сдерживающих либо переходных состояний движения, включающих политические, экономические, социальные, культурные и географические компоненты. Каждая форма движения имеет иммобильные последствия в разных местах и разнообразных проявлениях (Khan, 2016: 93). Иммобильность связывают с теми, кто исключён из глобального потребления и глобального движения, или чьё перемещение вызвано войной, бедностью либо экологической катастрофой (Ray, 2002).

Чрезмерное исследовательское увлечение мобильностью в ущерб иммобильности, предупреждают учёные, может заслонить «статичное» влияние, к примеру, национальных политических институтов на социальную и физическую мобильность граждан через лишение их свободы, регулирование трансграничной миграции и т. п. (Rau, 2010: 237). В то же время человеческая мобильность практически всегда является предметом вмешательства государства и других заинтересованных сторон, таких как корпорации. Как пишет Б. С. Тёрнер, глобализации свойственны экономические процессы мобильности товаров и услуг и политические процессы иммобильности граждан как способа государственного регулирования (Turner, 2007: 287). Политические институты нормативно определяют и ограничивают пространственную мобильность так, что иммобильность становится нормой (Salazar, Smart, 2011: v). 
Изучение источников по проблематике мобильности позволило нам выявить две исследовательские позиции, которые, однако, не получили комплексного политологического рассмотрения: 1) контроль первичен, мобильность вторична; 2) мобильность первична, контроль вторичен.

Согласно первой позиции, отличительной характеристикой современного мира является то, что человеческая мобильность вписана в рамки глобальной политической системы, в которой государства, устанавливающие и контролирующие параметры (транс)национального передвижения, предпочитают относительно иммобильное население (Salazar, Smart, 2011: iii). Так, к началу 2010-х годов сформировался комплекс международно-правовых норм, которые стали влиять на отдельные направления миграционной политики, образовав нормативную базу для регулирования международной мобильности. Сюда вошли: Конвенция о статусе беженцев (1951 г.), Международная конвенция о правах всех трудящихся-мигрантов и членов их семей (1990 г.), Генеральное соглашение о торговле услугами ГАТС (1994 г.), Конвенция ООН против транснациональной организованной преступности (200о г.) и др. (Троицкая, 2012: 144-145).

Согласно второй позиции, предлагается сместить акцент с главенства государства в вопросах контроля над территорией на примат мобильности и подойти к пониманию суверенитета через призму мобильности, а не наоборот. «Автономия миграции» (термин предложен Y. Moulier-Boutang в 1998 г.) предполагает, что миграция - это не движение, предопределённое нормами институциональной власти либо социально-экономической ситуацией, а общественно-политическое движение (Trimikliniotis, Parsanoglou, Tsianos, 2015: 35). Неслучайно мобильное сообщество характеризуют как «мир знаний, информации, способов выживания, взаимопомощи, общественных отношений, обмена услугами, солидарности, коммуникабельности, который поддерживается и расширяется людьми» (Nyers, 2015: 32). То, что мигрантам приходится изобретать новые способы осуществления мобильности, не значит, что мобильность существует независимо от контроля (Nyers, 2015: 25, 28). Мобильность стимулирует появление государственного контроля вплоть до введения таких жёстких форм, как незаконное задержание либо депортация.

На наш взгляд, использование институционального подхода позволит объединить обе позиции и охарактеризовать (им)мобильность как процесс, с одной стороны, обусловленный деятельностью международных и национальных политических институтов, с другой стороны, стимулирующий возникновение формальных и неформальных политических практик. Мы рассмотрим следующие аспекты проблемы (им)мобильности: 1) наднациональный и национальный уровни регулирования мобильности; 2) традиции и инновации в управлении международной мобильностью; 3 ) вопросы (им)мобильности в политической повестке дня. 


\section{Наднациональный уровень управления мобильностью}

Утверждается, что общественно-политические вопросы, касающиеся мобильности, представлены в управленческом процессе на локальном, национальном и наднациональном уровнях (Rau, 2010: 237). При этом отдельные государства, межгосударственные объединения, региональные блоки и международные организации руководствуются «парадигмой подозрительности», препятствуя доступу индивидов и групп к «правам мобильности» посредством территориального регулирования (Shamir, 2005: 214).

К примеру, усилия по ограничению притока иммигрантов и беженцев рассматриваются как важнейшая составная часть внешнеполитического измерения пространства свободы, безопасности и правосудия - самостоятельного вектора внешней политики Европейского союза (Рябов, 2012: 6о). При этом ЕС справедливо подвергается критике за политику двойных стандартов: с одной стороны, поддерживая движение за свободу и демократию, а с другой - демонстрируя нежелательность масштабных миграционных процессов, охвативших Средиземноморский регион (Примакова, 2012: 16). С помощью набора директив, дискурсов, практик и политических программ для управления миграционными потоками создаются режимы свободного перемещения граждан ЕС и «европеизированных» иностранцев, в то же время через технологии гражданства и пограничный контроль ограничивается мобильность субъектов, предположительно представляющих потенциальную угрозу или неспособность к интеграции (Барберо, 2014: 153).

Главным внешнеполитическим средством ограничения притока иммигрантов стала так называемая гармонизация списков стран, граждане которых должны иметь визу для легального въезда на территорию государств - членов ЕС. Примечательно, что гармонизация осуществлялась путём увеличения, а не уменьшения числа стран в списке: с 70 стран в 1985 году до 126 стран в 1995 году. Список стран, граждане которых должны обладать визой для легального въезда на территорию шенгенской зоны, по своей сути - список необъявленных врагов, от которых ЕС стремится защититься. Задача по выявлению представляющих угрозу лиц и, соответственно, по недопущению получения ими легальных оснований для въезда на территорию шенгенской зоны (т.е. визы) лежит на дипломатических и консульских представительствах стран ЕС (Рябов, 2012: 62). В процессе разработки находятся механизмы по предотвращению свободного перемещения мигрантов внутри ЕС (Войников, 2015: 80). Европейские институты фактически возрождают колониальные методы управления мобильностью, устанавливая административные пространства для «окультуривания» и вестернизации мигрантов, используя колониальную иерархическую схему «гражданин - подданный» (Барберо, 2014: 161-162).

Кроме того, в процесс миграционного контроля Евросоюзом вовлечены третьи страны. На них возложена ответственность по рассмотрению ходатайств о предоставлении политического убежища. В соответствии с существующей нормой 
ищущий политическое убежище может столкнуться с отказом на том основании, что он уже имел возможность обратиться за защитой к властям государства, через которое он транзитом следовал на территорию ЕС, однако не сделал этого (Рябов, 2012: 64).

Игнорировать явление иммобильности не позволяет и сложившаяся в международной системе практика политической изоляции. Одним из примеров служат «непризнанные государства». Этот термин используется для названия регионов, которые провозгласили себя суверенными государствами и обладают отдельными признаками государственности, но в то же время не имеют дипломатического признания со стороны государств - членов ООН, а их территория, как правило, расценивается как находящаяся под суверенитетом одного или нескольких государств - членов ООН. М. Риегл приводит список из 42 непризнанных государств, возникших в период 1946-2009 годов, среди которых государства, не имеющие международного признания, имеющие частичное или ограниченное международное признание, имеющие международное признание на уровне отдельных государств - членов ОOH (Riegl, 2014: 23-25). Для обозначения территории непризнанного государства используют метафору «ничья земля» (no man's land). Быть гражданином «ничьей земли» - значит иметь политический статус отверженного, что не позволяет участвовать в общепринятых международных трансакциях академических, научно-профессиональных, трудовых, спортивных, туристических, социально-политических (Navaro-Yashin, 2003: 107-108). За чуть более чем 60 лет существования непризнанных государств проблема иммобильности так или иначе коснулась значительного числа граждан, превышающего 100 млн человек.

Мы разделяем мнение тех учёных, которые считают, что установка законодательных барьеров на уровне международной системы и пренебрежение нормами прав человека в управлении миграцией заставляют усомниться в становлении гармоничного международного миграционного режима. Существующая система управления не позволяет международному сообществу эффективно реагировать на возникающие гуманитарные кризисы, способствует чрезмерному напряжению государственных ресурсов, направленных на сдерживание, фильтрацию и контроль при неочевидном положительном эффекте от этих мер, не принимает в расчёт последствия миграционной политики для третьих стран (Троицкая, 2012: 148-149).

\section{Национальный уровень регулирования мобильности}

Что касается отдельных государств, то здесь мы наблюдаем ту же тенденцию. Руководствуясь защитой прав человека и гражданских свобод, они инициируют властный контроль, вводят ограничительные миграционные меры, что, в свою очередь, усиливает давление на свободу мобильности (Trimikliniotis, Parsanoglou, Tsianos, 2015: 28). 
Один из первых примеров в развитии всемирной системы содействия-ограничения международной мобильности датируется 1882 годом, когда Конгресс США принял «Акт о запрещении въезда китайцам» (Chinese Exclusion Act). Акт регулировал вопросы въезда китайцев в США и их перемещения внутри страны и опирался на идею коренного отличия между китайцем и американцем, гражданином и иностранцем, предпринимателем и рабочим. Наиболее наглядным проявлением действия этого акта стал центр временного размещения на острове Энджел в заливе Сан-Франциско, где одновременно содержалось несколько десятков тысяч китайцев в ожидании решения о въезде или выдворении (Cresswell, 2006: 186). Первоначально рассчитанный на 10 лет, данный акт просуществовал с некоторыми изменениями до 1965 года.

Сегодня в США в центре внимания находится вопрос о правомочности американского правительства удерживать иностранных граждан в лагере, находящемся в заливе Гуантанамо на Кубе. Согласно постановлению Апелляционного суда США, федеральные суды не имеют юрисдикции рассматривать ходатайства иностранных граждан, находящихся вне пределов США. Решение преднамеренно помещать мигрантов в подобные условия рассматривается правозащитниками как нарушение международного права и ограничение задержанных в праве на передвижение (Rumford, 2006: 165).

Несмотря на деятельность глобального общественного движения «Незаконных нет» (No one is illegal) и ему подобных, статистика демонстрирует значительное снижение мобильности в США. Если в 1990-е годы количество нелегальных иммигрантов в США показывало положительную динамику, то с 2000 по 2009 год оно упало на 72\% - с 1,4 млн до 400 тыс. человек (Warren, Warren, 2013: 323).

Ограничение доступа мигрантов на территорию своей страны с нарушением международного права характерно и для других стран. Так, «Тихоокеанское решение» кабинета министров Дж. Ховарда (2001-20о8 годы, 2013 год - настоящее время) связано с размещением центров приёма мигрантов на островных территориях Австралии, выведенных из-под австралийского законодательства о миграции. Согласно этому решению, лица, прибывшие в Австралию морем, отправляются в офшорные центры, а не принимаются в качестве беженцев, что, в свою очередь, противоречит статьям таких международных документов, как Всеобщая декларация прав человека и Женевская конвенция «О статусе беженцев» (Wong, 2015: 41).

В общей сложности развитые страны установили ряд селективных административных механизмов, институциональных и личностных, встречающихся в разных точках на пути мобильного сообщества и призванных идентифицировать, локализовать и отбирать только нужные кадры. Классические границы модерна сменились «пограничными зонами» постмодерна, где, с одной стороны, оспаривается мобильность людей, а с другой - сама мобильность оспаривает границы, возможности контроля и даже государственный суверенитет (Барберо, 2014: 156). 


\section{Традиции и инновации в управлении международной мобильностью}

Одним из подобных механизмов выступает так называемое «дистанционное управление» международной мобильностью. Этот механизм был впервые применён в США после Первой мировой войны с внедрением важности паспортов и виз. Его суть заключалась в том, что мигранты подвергались контролю ещё до того, как покинуть территорию страны проживания (Cresswell, 2oo6: 184). Механизм представлял собой тщательно разработанную и дорогостоящую систему регистрации, включающую рассмотрение документов персоналом и выдачу виз дистанционно, другими словами, государственную монополизацию легитимных способов передвижения.

Европейская практика показывает, что дистанционное управление используется непосредственно посольствами и консульствами в момент рассмотрения заявок на получение визы. Это происходит с активным использованием данных о «культивируемых» в третьей стране способах мошенничества, неблагонадёжных заявителях и туристических агентствах и составлением портрета потенциального нежелательного иммигранта, описанного в терминах пола, возраста, этнического происхождения, религиозных убеждений, места рождения или жительства, уровня доходов и т.д. (Рябов, 2012: 63). Наиболее вероятными кандидатами на пост «варваров» для современной Европы выступают мусульмане (Барберо, 2014: 164). В описании Л. Дж. Рэя иммобильный субъект - небелый по цвету кожи, бедный, безработный, находящийся на нелегальном положении (Ray, 2002). В более широком смысле это социальный, политический и юридический феномен «антигражданина» (Барберо, 2014: 155).

Повторим, что такое формирование иммиграционных режимов предполагает отрицание ценностей демократии, верховенства права и свободы со стороны самих бюрократических институтов, их «защищающих», поскольку оно влечёт нарушение не только миграционного законодательства, но и фундаментальных прав человека (Барберо, 2014: 164). К сожалению, незаконное задержание либо депортация без права апелляции являются сегодня достаточно распространёнными практиками государственного регулирования пересечения границ. Даже иностранным гражданам, находящимся в относительно привилегированном положении, может быть отказано в праве перемещения по подозрению в расовой, этнической или иной принадлежности к так называемым Другим. В целом миллионы потенциально мобильных граждан уязвимы в отношении применения к ним различных видов дискриминации, силы либо ненадлежащего обращения в случае пересечения ими границ (Gündoğdu, 2015: 2).

Дистанционное управление международной мобильностью связано не только со сбором данных с помощью компьютеризированной сети контроля, но и с привлечением к ответственности за нарушения. Создаётся новый режим управления миграцией - «цифровая депортация», или «кибердепортация», как основанный на информационно-коммуникационных технологиях ответ на быструю, гибкую, 
многонаправленную мобильность. Цифровая депортация возникает, когда появляется риск нелегальной мобильности людей или финансов, либо нарушение сроков. Таким образом, Европейская база данных обеспечивает государствам участникам ЕС инфраструктуру для дистанционного выявления и изоляции потенциальных мигрантов-нарушителей. Изоляция выражается в двух формах: отказ в регистрации и выдаче документов и отказ посредством ограничений в документах и регистрации. Цифровая депортация, в свою очередь, поддерживает взаимосвязь между формами отказа, которая усиливается благодаря практическому использованию ИКТ (Trimikliniotis, Parsanoglou, Tsianos, 2015: 44).

Государства зачастую используют финансовые механизмы ограничения миграции, несмотря на сложные для национальных социально-экономических систем времена. Так, в 2011 году инициативы итальянского правительства по прекращению притока мигрантов из Туниса вылились в подписание совместного соглашения об оказании финансовой помощи Тунису в размере 250-30о млн евро, большая часть которой безвозмездна. Средства пошли на противодействие нелегальной иммиграции, создание радарной системы по охране границ, покрытие долгов, поддержку малого и среднего бизнеса. В результате действия данного соглашения приток тунисских иммигрантов в Италию во втором квартале 2011 года сократился на 75\% (Примакова, 2012: 26).

Кроме того, государства продолжают использовать и традиционные механизмы защиты, а именно возведение пограничных стен (против военной агрессии, нелегальной миграции, трансграничной преступности - боевиков, наркоторговцев и контрабандистов) (Голунов, 2009: 92). В качестве ответа на рост числа нелегальных иммигрантов государства - члены ЕС приступили к укреплению своих южных рубежей: Венгрия, Болгария, Греция, Испания начали возведение стен на своих внешних границах (Войников, 2015: 80). В 1999 году между Марокко и Испанией был установлен трёхметровый стальной забор, оснащённый башнями наблюдения, видеокамерами, микрофонами, сенсорами движения и прожекторами. Общая стоимость ограждения составила 3,4 млн евро. В 2005 году ещё 20 млн евро было вложено в техническое усовершенствование и укрепление ограждения (Барберо, 2014: 155).

Места, технологии и «ворота», которые повышают мобильность одних, усиливая при этом неподвижность других, стремительно множатся (Урри, 2012: 80). Растущая мобильность в обществе и между государствами требует новых границ для регулирования новых форм активности, с которыми традиционные границы не справляются. В этой связи отметим ещё две тенденции: участие граждан в охране существующих границ и установление гражданами новых границ на пути мобильного населения.

Проиллюстрируем первую тенденцию. Многие бедные мексиканцы пытаются нелегально преодолеть так называемый «Тортилловый занавес» (Tortilla Curtain) - границу протяжённостью $300 о$ км на пути в США. Более миллиона человек ежегодно подвергаются аресту, а около 500 погибают. Результатом стало 
появление феномена «групп бдительности», или отрядов самообороны, которые добровольно патрулируют пустынные приграничные территории в поисках мексиканцев, пытающихся преодолеть границу в отдалённых местах. Политики характеризуют их деятельность как «усилия общественности по защите своей страны» (Rumford, 2006: 165).

Вторая тенденция связана с избирательностью и адресностью границ, которые в эпоху постмодерна могут создаваться, перемещаться и разрушаться различными акторами. Здесь уместно вспомнить падение Берлинской стены, организованное гражданами, которые не дождались правительственных и дипломатических решений. Сегодня в различных населённых пунктах Европы «властью народа» строятся жилые комплексы закрытого типа и охраняемые посёлки, устанавливающие границы на пути переселенцев. В Великобритании активно лоббируется вопрос создания внутренней пограничной службы. Граждане, как и государства, вправе устанавливать и переустанавливать границы (Ibid.: 164).

В целом развитые и развивающиеся государства в последние десятилетия проводят миграционную политику предпочтения национальным интересам в ущерб международным обязательствам (Троицкая, 2012: 145). Б.С. Тёрнер вводит понятие «режим иммобильности» - меры контроля по защите местного населения от рисков, которые несут мигранты, беженцы и другие нежелательные мобильные группы населения (Turner, 2007: 289). Эти меры включают как организацию известных со времён премодерна закрытых обществ, гетто, карантинных зон, тюрем, лагерей, так и использование современных достижений для противодействия высокотехнологичным вызовам постмодерна - биотерроризму и распространению биологического оружия (Ibid.: 301). Политические барьеры не только работают с разной степенью результативности по отношению к представляющим опасность группам и индивидам, но и оказывают пагубное влияние, ограничивая права и свободы граждан, не представляющих угрозу обществу, так называемые «права на мобильность» (право получения паспорта, право въезда в страну, право просить убежища, право на проживание в стране, право на заключение брака с гражданином другой страны, права трудящихся-мигрантов, права беженцев, право покупки зарубежной собственности, право инвестировать в другие страны) (Ibid.: 301).

\section{(Им)мобильность в политической повестке дня}

(Им)мобильность сегодня широко представлена в политической повестке. Повышенное внимание к проблеме иммиграции в европейских странах объясняет, почему она стоит отдельным номером в программах основных политических партий не только правого, но и левого фланга (Барберо, 2014: 161). Несмотря на то что иммиграция стала заметным фактором социально-экономического развития европейских стран, она вызывает у европейцев чувство незащищённости перед разрушением национальных культурных и религиозных ценностей, ростом преступности, ужесточающейся конкуренцией на рынке труда и соперничеством за 
социальные блага. В результате в предвыборный период политики нередко разыгрывают антииммигрантскую карту, что, несомненно, ведёт к политизации миграционного вопроса (Примакова, 2012: 42).

Российская практика свидетельствует, что в заявлениях официальных лиц феномен миграции выражается преимущественно в отрицательных и карательных терминах контроля, ограничений и квот, что оправдывает «сражение» власти с незаконными мигрантами. Мигрант в подаче медиа представляет собой две крайности: либо жертву, либо нелегала-преступника, что выставляет его в неблагоприятном свете. По большому счёту антииммигрантская риторика агрессивна и неэффективна как средство достижения целей адаптации и интеграции мигрантов, поскольку вызывает в обществе страх перед угрозой безработицы, исламизации и азиатизации российских городов и протесты общественности против мигрантов (Даве, 2013: 106, 108, 109, 113).

Исследователи отмечают, что мигранты не вовлечены в обсуждение политических вопросов относительно миграции. Поскольку политическая деятельность мигрантов нерепрезентативна с точки зрения доминирующей политики, это позволяет относиться к ней как к не-политике, антирепрезентативной политике, общественному не-движению. Однако незаметная ежедневная деятельность, так называемый неполитический опыт, встречаясь с консервативностью политического порядка, выливается в радикальные трансформации и порождает коллективные протестные действия (Trimikliniotis, Parsanoglou, Tsianos, 2015: 39). При этом то, что с точки зрения государства является нелегальным деянием, с позиции мигрантов - акт справедливости, необходимый в повседневной жизни. Мобильность влияет на своих оппонентов, изменение их стратегий, заставляет серьёзно относиться к самой идее мобильности - «свободу передвижения мне, моим детям, моим родным, моим друзьям, моим попутчикам - людям, которые этого заслуживают (Ibid.: 40).

Движение всё больше обозначает некое право, на что указывает и Декларация $\mathrm{OOH}$ о правах человека, и конституция Европейского союза. Те, кто по какимлибо причинам лишен права на подобное движение, страдают от самых разных форм отчуждения (Урри, 2012: 89). В этой связи отметим отсутствие равного доступа к политическому лидерству представителей различных этнических, религиозных, идеологических, классовых и гендерных групп, включая представителей мобильного сообщества (Schaake, 2008: 52). В отсутствие данных о ситуации в России остановимся на примерах из американской и европейской практики политического отчуждения мобильных граждан.

В последние годы в США в связи с ужесточением иммиграционного законодательства осуществимость американской мечты, т. е. идеалов свободы и открытых возможностей для всех, претерпела значительную коррекцию. Сегодня американские мусульмане - прежде всего мусульмане и лишь затем американцы. Политическая репрезентация мусульман в американской политике незначительна: из 435 членов палаты представителей Конгресса США лишь два мусульманина. Предста- 
вители других этнических меньшинств отсутствуют, исходя из процентного соотношения к общей численности населения.

Даже избрание чернокожего президента не поменяло расстановку сил в американском политическом истеблишменте, поскольку сегрегация по этническому принципу остаётся весьма значительной. Обама был единственным афроамериканцем в Сенате, после его ухода Сенат опять стал «белым». Аналогичным образом количество других этнических меньшинств в политике не отражает их средний показатель по стране (Ibid.: 46, 48-49).

В европейском обществе достаточно легко идентифицировать политически доминантную группу. Это белые мужчины - высокообразованные представители высшего либо среднего класса, многие годы посвятившие работе в национальном партийном аппарате и парламентской системе (Ibid.: 47-48). Появление здесь «европейского Обамы» пока маловероятно. В зависимости от страны потребуются десятилетия, прежде чем представитель того или иного меньшинства, включая принадлежность к мобильному сообществу, сможет занять высокий государственный пост. Социологические опросы показывают, что даже в одной из самых прогрессивных европейских стран, Нидерландах, кандидат от какого-либо этнического меньшинства не смог бы набрать более 50\% голосов. За премьер-министра мусульманина готовы проголосовать не более $27 \%$ избирателей (Ibid.: 46).

Примеры представительства меньшинств в политической жизни европейских стран крайне малочисленны. Так, Франция отличается полным отсутствием этнических меньшинств в Национальной ассамблее. Палата общин Великобритании насчитывает 15 представителей этнических меньшинств из 646 членов. В палате лордов на 741 члена всего 24 подобных представителя. Из 613 членов немецкого Бундестага всего 5 этнических турок, хотя в стране проживают около трёх миллионов граждан турецкого происхождения. В высших эшелонах турецкой власти нет ни одного атеиста, представителя религиозных или субэтнических меньшинств либо носителя нетрадиционной сексуальности. Этнические меньшинства крайне малочисленны не только в европейских законодательных органах, но и в медиакорпорациях, советах директоров компаний, судебной и исполнительной власти (Ibid.: 49-50). Всё это наряду с антииммигрантской риторикой большинства политических партий свидетельствует о проблематичности доступа мобильных граждан к политическому лидерству.

\section{Выводы}

Таким образом, (им)мобильность представляет собой двунаправленный процесс, обусловленный деятельностью международных и национальных политических институтов и стимулирующий возникновение формальных и неформальных политических практик. Государственное регулирование трансграничной миграции выражается в требовании убедительных оснований для легального въезда на территорию того или иного государства, развитии дистанционных форм управле- 
ния мобильностью, использовании финансовых механизмов и введении ограничительных миграционных мер (составление списков неблагонадёжных граждан, удержание иностранных граждан в зонах вне пределов места назначения, делегирование рассмотрения ходатайств о политическом убежище третьим странам, политическая изоляция граждан непризнанных государств). Практики модерна (строительство и техническое усовершенствование традиционных пограничных стен) встречаются с практиками постмодерна (цифровая депортация). При этом политические барьеры препятствуют движению как потенциально опасных групп и индивидов, так и не представляющих угрозу обществу граждан, ограничивая права и свободы, так называемые «права на мобильность». Политические партии с их антииммигрантскими программами и группы общественности, инициирующие охрану приграничных территорий и возведение внутренних границ, создают новые физические и идеологические ограничения на пути мобильного населения. Мобильным гражданам закрыт доступ не только к политическому лидерству, но и к участию в формировании политической повестки.

\section{Литература}

Абашин С. Н. (2012). Среднеазиатская миграция: практики, локальные сообщества, транснационализм // Этнографическое обозрение. № 4. С. 3-13.

Алескеров Ф. Т., Мещерякова Н. Г., Резяпова А. Н., Швыдун С. В. (2016). Анализ влияния стран в сети международной миграции // Политическая наука. № 4 . С. $137-158$.

Барберо И. (2014). Ориентализация мигрантов в Европейском союзе // Журнал исследований социальной политики. Т. 12. № 2. С. 153-168.

Бреславский А. С. (2017). Поправка на мобильность: как трудовая и дачная миграция влияет на расселение россиян? // Социологическое обозрение. Т. 16. № 1. C. $278-295$.

Войников В. В. (2015). Правовые аспекты политики Европейского союза по борьбе с незаконной иммиграцией // Балтийский регион. Т. 26. № 4. С. 73-89.

Голунов С. В. (2009). Вперёд в прошлое? Пограничные стены в Азии и Африке // Мировая экономика и международные отношения. № 11. С. 85-93.

Даве Б. (2013). Дискуссия о статусе мигрантов и законности в России в глобальном дискурсе управления миграцией // Известия ИГУ. Серия «Политология. Религиоведение». № 2. Ч. 2. С. 103-114.

Захарян И. Э. (2012). Особенности и последствия международной миграции: исследовательские концепции и перспективы изучения // Журнал исследований социальной политики. Т. 10. № 1. С. 127-132.

Попов В. А. (2011). Мобильность и деньги: попытка конвергенции двух социологических теорий // Социологическое обозрение. Т. 10. № 1/2. С. 34-53. 
Примакова Н. С. (2012). Европейские противоречия в области миграционной политики на фоне событий «арабской весны» // Актуальные проблемы Европы. № 4. С. $14-59$.

Рябов Ю. А. (2012). Экстернализация миграционного контроля в Европейском союзе: первые шаги по формированию внешнеполитического измерения пространства свободы, безопасности и правосудия // Балтийский регион. Т. 11. № 1. C. 60-69.

Сизиков А. А. (2005). Динамика формирования транснационального культурного пространства в контексте глобализации. Дисс. ... канд. культ. наук (24.00.01). СПб.: Санкт-Петербургский государственный университет культуры и искусств.

Толстокорова А. В. (2014). Социогуманитарные производные глобализации: гендерный эффект международной миграции и мобильности населения // Социологическое обозрение. Т. 13. № 3. С. 64-88.

Троиикая О. В. (2012). Международный миграционный режим? // Международные процессы. Т. 10. № 2. С. 143-153.

Урри Дж. (2012). Мобильности / Пер. с англ. А. В. Лазарева. М.: Праксис.

Шишков Ю. В. (2011). Вызовы и перспективы глобальных миграций // Международные процессы. Т. 9. № 3. С. 4-17.

Cresswell T. (2006). On the Move: Mobility in the Modern Western World. N.Y.: Routledge.

Gündoğdu A. (2015). Rightlessness in an Age of Rights: Hannah Arendt and the Contemporary Struggles of Migrants. Oxford: Oxford University Press.

Jensen A. (2011). Mobility, Space and Power: On the Multiplicities of Seeing Mobility // Mobilities. Vol. 6. № 2. P. 255-271.

Khan N. (2016). Immobility // Salazar N.B., Jayaram K. (eds.). Keywords of Mobility: Critical Engagements. N.Y.: Berghahn Books. P. 93-112.

Navaro-Yashin Y. (2003). «Life is Dead Here»: Sensing the Political in No Man's Land // Anthropological Theory. Vol. 3. № 1. P. 107-125.

Nyers P. (2015). Migrant Citizenships and Autonomous Mobilities // Migration, Mobility, and Displacement. Vol. 1. № 1. P. 23-39.

Rau H. (2010). (Im)mobility and Environment-Society Relations: Arguments for and against the Mobilisation of Environmental Sociology // Gross M., Heinrichs H. (eds.). Environmental Sociology: European Perspectives and Interdisciplinary Challenges. Dordrecht: Springer. P. 237-254.

Ray L. J. (2002). Crossing Borders? Sociology, Globalization and Immobility // Sociological Research Online. Vol. 7. № 3. P. 1-18.

Ribas-Mateos N. (2005). The Mediterranean in the Age of Globalisation: Migration, Welfare and Borders. New Brunswick: Transaction.

Riegl M. (2014). Prospects and Limits of Economic Development of Unrecognized States: Between Organized Hypocracy and Private Interests // European Scientific Journal. Vol. 10. № 4. P. 17-35. 
Rumford C. (2006). Theorizing Borders // European Journal of Social Theory. Vol. 9. № 2. P. $155-169$.

Salazar N. B., Smart A. (2011). Anthropological Takes on (Im)Mobility // Identities: Global Studies in Culture and Power. Vol. 18. № 6. P. i-ix.

Schaake M. (2008). Lands of Opportunity? Comparing Political Mobility for Minorities in the United States, Europe and Turkey // Turkish Policy Quarterly. Vol. 7. № 4. P. 45-52.

Shamir R. (2005). Without Borders? Notes on Globalization as a Mobility Regime // Sociological Theory. Vol. 23. № 2. P. 197-217.

Trimikliniotis N., Parsanoglou D., Tsianos V. S. (2015). Mobile Commons, Migrant Digitalities and the Right to the City. Basingstoke: Palgrave Macmillan.

Turner B. S. (2007). The Enclave Society: Towards a Sociology of Immobility // European Journal of Social Theory. Vol. 10. № 2. P. 287-303.

Warren R., Warren J. R. (2013). Unauthorized Immigration to the United States: Annual Estimates and Components of Change, by State, 1990 to 2010 // International Migration Review. Vol. 47. № 2. P. 296-329.

Wong T. K. (2015). Rights, Deportation, and Detention in the Age of Immigration Control. Stanford: Stanford University Press.

\title{
Global (Im)mobility in the Mirror of Postmodern Transformations: The Political Aspect
}

\author{
Vera S. Tormosheva \\ Postgraduate Student, International Relations and Political Science Department, \\ Nizhny Novgorod Linguistics University \\ Address: Minin str., 31A, Nizhny Novgorod, Russian Federation 603155 \\ E-mail: tormosh@mail.ru
}

The increasing spatial fluidity of the population in general and the inclusion of a wider range of people in international migration in particular is recognized as one of the most visible manifestations of globalization. However, processes contributing to the movement and global relations at the same time generate physical and socio-political immobility, alienation, and dissociation. The phenomenon of (im)mobility is considered from a political point of view. Making use of the institutional approach, the author defines (im)mobility as a process caused by international and national political institutions' activities, on one hand, and stimulating the emergence of formal and informal political practices, on the other hand. Government regulation of cross-border migration is reflected in the demands of the valid grounds for the legal entering the territory of a state, the development of distance forms of mobility management, the establishment of financial mechanisms, and the imposition of restrictive migration measures. The isolating practices of modernity meet up with postmodern digital practices. Herewith, political barriers prevent the movement of potentially dangerous individuals and groups, and those not representing a danger to the community, violating human rights and fundamental freedoms, which are so-called mobility rights. Initiatives performed by political parties and public 
associations prevent mobile citizens from accessing not only political leadership, but also their participation in political agenda setting.

Keywords: migration, mobility, immobility, postmodernity, institutional approach, political institutions

\section{References}

Abashin S. (2012) Sredneaziatskaja migracija: praktiki, lokal'nye soobshhestva, transnacionalizm [Central Asian Migration: Practices, Local Communities, Transnationalism]. Etnograficheskoe obozrenie, no 4, pp. 3-13.

Aleskerov F., Meshcheryakova N., Rezyapova A., Shvydun S. (2016) Analiz vlijanija stran v seti mezhdunarodnoj migracii [An Analysis of Countries' Influence Through International Migration Network]. Political Science, no 4, pp. 137-158.

Barbero I. (2014) Orientalizacija migrantov v Evropejskom Sojuze [Orientalising Migrants in the European Union]. Journal of Social Policy Studies, vol. 12, no 2, pp. 153-168.

Breslavsky A. (2017) Popravka na mobil'nost': kak trudovaja i dachnaja migracija vlijaet na rasselenie rossijan? [Correction for Mobility: How Do Labour and Dacha's Migrations Influence the Settlement of Russians?]. Russian Sociological Review, vol. 16, no 1, pp. 278-295.

Cresswell T. (2006) On the Move: Mobility in the Modern Western World, New York: Routledge.

Dave B. (2013) Diskussija o statuse migrantov i zakonnosti v Rossii v global'nom diskurse upravlenija migraciej [Debating Migrant Status and Legality in Russia within a Global Discourse on Migration Management]. IGU Bulletin. Politology \& Religious Studies Series, vol. 2, no 11, part 2, pp. 103-114.

Golunov S. (2009) Vperjod v proshloe? Pogranichnye steny v Azii i Afrike [Forward to the Past? Border Walls in Asia and Africa]. Mirovaya ekonomika i mezhdunarodnye otnosheniya, no 11, pp. 85-93.

Gündoğdu A. (2015) Rightlessness in an Age of Rights: Hannah Arendt and the Contemporary Struggles of Migrants, Oxford: Oxford University Press.

Jensen A. (2011) Mobility, Space and Power: On the Multiplicities of Seeing Mobility. Mobilities, vol. 6, no 2, pp. 255-271.

Khan N. (2016) Immobility. Keywords of Mobility: Critical Engagements (eds. N. B. Salazar, K. Jayaram), New York: Berghahn Books, pp. 93-112.

Navaro-Yashin Y. (2003) "Life is Dead Here": Sensing the Political in No Man's Land. Anthropological Theory, vol. 3, no 1, pp. 107-125.

Nyers P. (2015) Migrant Citizenships and Autonomous Mobilities. Migration, Mobility, and Displacement, vol. 1, no 1, pp. 23-39.

Popov V. (2011) Mobil'nost' i den'gi: popytka konvergencii dvuh sociologicheskih teorij [Mobility and Money: An Attempt for the Convergence of the Two Sociological Theories]. Russian Sociological Review, vol. 10, no 1-2, pp. 34-53.

Primakova N. (2012) Evropejskie protivorechija v oblasti migracionnoj politiki na fone sobytij "arabskoj vesny" [European Contradictions in Migration Policies in the Light of the Arab Spring Events]. Urgent Problems of Europe, no 4, pp. 14-59.

Rau H. (2010) (Im)mobility and Environment-Society Relations: Arguments for and against the Mobilisation of Environmental Sociology. Environmental Sociology: European Perspectives and Interdisciplinary Challenges (eds. M. Gross, H. Heinrichs), Dordrecht: Springer, pp. 237-254.

Ray L. J. (2002) Crossing Borders? Sociology, Globalization and Immobility. Sociological Research Online, vol. 7, no 3, pp. 1-18.

Ribas-Mateos N. (2005) The Mediterranean in the Age of Globalisation: Migration, Welfare and Borders, New Brunswick: Transaction.

Riegl M. (2014) Prospects and Limits of Economic Development of Unrecognized States: Between Organized Hypocracy and Private Interests. European Scientific Journal, vol. 10, no 4, pp. 17-35.

Ryabov Y. (2012) Jeksternalizacija migracionnogo kontrolja v Evropejskom Sojuze: pervye shagi po formirovaniju vneshnepoliticheskogo izmerenija prostranstva svobody, bezopasnosti i pravosudija [The Externalisation of Migration Control in the European Union: First Steps Towards 
the External Dimension of the Space of Freedom, Security and Justice]. Baltic Region, vol. 11, no 1, pp. 60-69.

Rumford C. (2006) Theorizing Borders. European Journal of Social Theory, vol. 9, no 2, pp. 155-169.

Salazar N. B., Smart A. (2011) Anthropological Takes on (Im)Mobility. Identities: Global Studies in Culture and Power, vol. 18, no 6, pp. i-ix.

Schaake M. (2008) Lands of Opportunity? Comparing Political Mobility for Minorities in the United States, Europe and Turkey. Turkish Policy Quarterly, vol. 7, no 4, pp. 45-52.

Shamir R. (2005) Without Borders? Notes on Globalization as a Mobility Regime. Sociological Theory, vol. 23, no 2, pp. 197-217.

Shishkov Y. (2011). Vyzovy i perspektivy global'nyh migracij [Challenges and Perspectives of Global Migrations]. International Trends, vol. 9, no 3, pp. 4-17.

Sizikov A. (2005) Dinamika formirovanija transnacional'nogo kul'turnogo prostranstva v kontekste globalizacii [The Dynamics of Transnational Cultural Space Development in the Context of Globalization] (PhD Thesis), SPb: Saint-Petersburg State University of Culture and Art.

Tolstokorova A. (2014) Sociogumanitarnye proizvodnye globalizacii: gendernyj jeffekt mezhdunarodnoj migracii i mobil'nosti naselenija [Socio-Human Derivatives of Globalization: Gender Effect of International Migration and Population Mobility]. Russian Sociological Review, vol. 13, no 3, pp. 64-88.

Trimikliniotis N., Parsanoglou D., Tsianos V. S. (2015) Mobile Commons, Migrant Digitalities and the Right to the City, Basingstoke: Palgrave Macmillan.

Troitskaya O. (2012) Mezhdunarodnyj migracionnyj rezhim? [International Migration Regime?]. International Trends, vol. 10, no 2, pp. 143-153.

Turner B. S. (2007) The Enclave Society: Towards a Sociology of Immobility. European Journal of Social Theory, vol. 10, no 2, pp. 287-303.

Urry J. (2012) Mobil'nosti [Mobilities], Moscow: Praksis.

Vojnikov V.V. (2015) Pravovye aspekty politiki Evropejskogo Sojuza po bor'be s nezakonnoj immigraciej [Legal Aspects of the EU Policy on Irregular Immigration]. Baltic Region, vol. 26, no 4, pp. 73-89.

Warren R., Warren J. R. (2013) Unauthorized Immigration to the United States: Annual Estimates and Components of Change, by State, 1990 to 2010. International Migration Review, vol. 47, no 2, pp. 296-329.

Wong T. K. (2015) Rights, Deportation, and Detention in the Age of Immigration Control, Stanford: Stanford University Press.

Zaharyan I. (2012) Osobennosti i posledstvija mezhdunarodnoj migracii: issledovatel'skie koncepcii i perspektivy izuchenija [Essential Features and Effects of International Migration: Research Concepts and Prospects of Studying]. Journal of Social Policy Studies, vol. 10, no 1, pp. 127-132. 


\section{Русская культура
в философской перспективе}

ЖУКОВА О. А. (2017). ФИЛОСОФИЯ РУССКОЙ КУЛЬТУРЫ. МЕТАФИЗИЧЕСКАЯ ПЕРСПЕКТИВА ЧЕЛОВЕКА И ИСТОРИИ. М.: СОГЛАСИЕ. 624 С. ISВN 978-5-906709-88-2

\section{Дмитрий Носов}

Кандидат философских наук, профессор Школы философии факультета гуманитарных наук Национального исследовательского университета «Высшая школа экономики». Адрес: ул. Мясницкая, д. 20, г. Москва, Российская Федерация 101000 E-mail: dnossov@hse.ru

В статье рассматривается новая монография российского философа и культуролога, профессора Национального исследовательского университета «Высшая школа экономики» О. А. Жуковой. Предметом обсуждения статьи является предлагаемый Жуковой философский подход к анализу культурной истории России, опирающийся на основные идеи и сюжеты истории и актуального состояния русской общественной и религиозной мысли. Автор книги создает широкую панораму развития российской истории, выявляя особенности формирования ценностной структуры и специфику бытия национальной культуры. Жукова рассматривает русскую культуру как сложный результат взаимодействия религиозных, политических и художественных традиций, их преемственности и их разрывов. В монографии прослеживается путь формирования русского типа философствования с его повышенным вниманием к проблемам истории, культуры, нравственности и творчества. В статье показано, что автор, анализируя социальные и духовные трансформации, происходившие с русским обществом при переходе от традиционной культуры к модерну, продолжает линию познания национальной истории, начатую русскими философами-европеистами в XIX - первой половине XX века. Жукова создает любопытную реконструкцию отечественной культуры, осуществляя историко-философскую рецепцию наследия русских мыслителей. Данная работа представляет собой критический анализ исследования Жуковой. Помимо рассмотрения культурологической концепции О. А. Жуковой автор статьи размышляет и об идеальной модели, и о практике редакционно-издательской деятельности. Анализируемый текст исследуется автором статьи не только как плод работы ученого-исследователя, но и как результат деятельности издательства, специализирующегося на публикации научной литературы. Статья демонстрирует «зоны ответственности» ученого - автора текста и редакционно-издательских работников, готовящих книгу к встрече с читателем.

Ключевые слова: философия культуры, история русской философии, история русской культуры, история России, религиозный опыт

Держу в руках 622-страничный том «Философия русской культуры: метафизическая перспектива человека и истории», автор которого О. А. Жукова, профессор Национального исследовательского университета «Высшая школа экономики».

() Носов Д. М., 2018

() Центр фундаментальной социологии, 2018

DOI: $10.17323 / 1728-192 \mathrm{X}-2018-3-346-355$ 
Уже сам масштаб этого исследования побуждает каждого библиофила не только с уважением отнестись к Magnum Opus автора текста, но и придирчиво взглянуть на книгу как на продукт издательской деятельности и полиграфического производства. Соответственно, и мои рассуждения проделают три «круга» во-первых, поразмышляем над текстом автора, во-вторых, посмотрим на продукцию редакционно-издательской работы и, в-третьих, «попробуем на зубок» полиграфическое изделие.

Итак, первый «круг».

Очевидно, что такой масштабный текст - 39 печатных листов - невозможен без огромной предварительной работы. Опубликованная монография продолжает многолетние изыскания автора в области философии русской культуры и истории отечественной мысли (Жукова, 2014, 2007: 1-10). В новом исследовании Ольга Анатольевна сосредотачивает свое внимание на проблеме «смысловой взаимообусловленности религиозной, художественной и социально-политической традиции в российской истории» (с. 2). Вопрос о специфике российской культурной истории она ставит как философский вопрос о человеке, культуре и творчестве.

Саму возможность подобного подхода автор обосновывает во Введении, провозглашая, что «подход к истории культуры как к культурному преданию, к культурному мифу, создаваемому личностью... позволяет осуществить философскую рефлексию и тематизировать философскую проблематику, извлекаемую из событий жизни и сублимируемых в тексты - произведения культуры» (c. 12).

Цели и задачи, на которые автор «замахнулся» и которые сформулированы во Введении (задачи, решаемые как всей работой в целом, так и Введением в частности), чрезвычайно масштабны и амбициозны:

1) осуществить методологическую перезагрузку в российских исследованиях культуры и истории;

2) подступиться к проблеме освоения и трансляции русской философской мысли, «ввязаться» в борьбу за наследие, по-новому поставить вопрос о русской философии, о том, «что можно понимать под концептами „русская философия“, „философия русской культуры“, „философия русской истории“, так же как и вопрос о самой возможности существования и развития „русского проекта“ филособствования в современной интеллектуальной культуре» (с. 7);

3) проанализировать цивилизационный спор о России, ее культурной идентичности, о значении религиозного фактора в русской духовной и социальнополитической жизни, который, по мысли Жуковой, во многом определил «дискурс о русской культуре» (с. 9) ${ }^{1}$;

1. Как мне кажется, подобная постановка вопроса отсылает читателя к традиции интерпретации русской философии представителями религиозно-философской мысли (Зеньковский, 1991: 11-22; Лосев, 1991: 209-236; Лосский, 1994). Жукова ссылается на актуальность и эвристическую ценность опыта религиозно-философской мысли Серебряного века: «Обозначенные ими религиозно-философские подходы к осмыслению феноменов культуры и истории вполне могут вписаться в современный тренд конструирования новых концептуальных моделей философского знания в области метафизики, онтогносеологической теории, обновления топики и методологии культурфилософских и историософских исследований» (с. 10). 
4) выявить методологические трудности исследования, предмет которого располагается на пересечении философского и богословского полей (с. 10);

5) осуществить переход от мифа о русской культуре к философской интерпретации культурной истории как «истории прецедентов творчества» (с. 13);

6) описать методологические подходы, используемые в исследовании (философско-культурологический, герменевтический, структурно-семиотический) (c. 15-19);

7) обозначить рамки исследования, осуществить программную селекцию сюжетов и идей:

Специально заметим, что в нашей работе главным образом будет рассматриваться линия преемственности русской культуры, связанная с опытом непосредственного восприятия Бога, целостности природы, мира культуры и человека, а также рецепция этой традиции, где данная особенность русской культуры, ее ценностно-смысловая и практикоориентированная религиозность становится самостоятельной и доминантной темой философской рефлексии. Русские мыслители, осуществившие рецепцию данного типа, переводят культурфилософскую проблематику в плоскость метафизики истории и культуры, прочитывая за событиями жизни и истории их трансцендентный смысл, что, по выражению Бердяева, свидетельствует о том, как «метаистория прорывается в историю. (С. 16);

8) дать описание собственной философско-методологической позиции, своего понимания феномена культуры:

Сквозь призму философско-культурологического подхода человек предстает в многообразии форм своей творческой деятельности, социальных интеракций и смысловых взаимосвязей с интеллектуальными и духовными традициями культуры. Подобный поворот пролагает путь к персонализированной истории культуры, которая мыслится как интеллектуальная история - история творческих прецедентов, где результатом творчества выступают идеи, овеществленные в произведениях искусства и текстах культуры. Отбор и философское осмысление фактов жизни и творчества позволяют осуществить новую интерпретацию русской культуры, проведя процедуру реконструкции творческого опыта. В такой истории работают не только законы исторической случайности и закономерности, релевантные для больших социальных общностей и всемирно-исторических событий, но и личностные законы субъектов творчества. Индивидуальное событие творчества в ряду других историй творчества составляет интеллектуальное пространство культуры континуум культурной истории. (С. 19-20);

9) продемонстрировать, что историософская и культурфилософская логика автора близка русским мыслителям-европеистам. В рамках традиционного для русской культуры спора о России и Европе Жукова интерпретирует европейскую культуру как «свое-другое национальной культуры» (с. 20). 
На первый взгляд кажется, что замысел неподъемен для одного исследователя. Но Жукова справляется с этой грандиозной задачей. Ответ на вопрос, как ей это удается, лежит, скорее всего, в широте ее профессионализма: она, с одной стороны, профессиональный культуролог, с другой - высококвалифицированный исследователь-философ. Благодаря такому - стереоскопическому - взгляду на изучаемый предмет (по определению автора, ее работа - это «метафизическое введение в философию русской культуры» [с. 21]) поставленная цель оказалась достижимой.

Посмотрим на то, как автор двигался к своей цели.

В первом разделе «Человек русской культуры: опыт философско-культурологической реконструкции» дана авторская модель интерпретации культурной истории России и типология русской культуры, основанием которой выступают модели творческого опыта. Особое внимание исследовательница уделяет христианской компоненте отечественной культуры и искусства.

В первой части данного раздела проведен обстоятельный разбор литературной традиции, даны характеристики эстетики иконописи и культового искусства, описаны нравственные константы русской культуры, которые выявлены через анализ произведений древнерусской письменности и русской литературной классики.

Культурологическая составляющая профессионализма Жуковой ярко проявляет себя в предпринятой ею реконструкции эстетических идеалов русских композиторов, анализе их художественного опыта, вычленении религиозной составляющей их творчества. Интересны размышления автора о моральной ответственности Художника, о личности Творца.

Неожиданным вкраплением в исследование о метафизической перспективе человека и истории оказывается пятая глава первого раздела, посвященная пейзажному образу в русском искусстве. Автор предпринимает попытку увязать эстетику пейзажного образа с философским взглядом на мир, пишет о красоте и совершенстве, об идеалах гармонии природного, культурного и божественного. Но от этих, достаточно идиллических сюжетов Жукова переходит к куда более трагическим феноменам - к трансформации идеалов русской классики в периоды, которые автором монографии определены как «постклассика» и «неклассический опыт» культуры. Проблема преемственности и отталкивания от традиции - вот то, что интересует исследовательницу в первую очередь.

Позитивизм и утопия русского авангарда, мистическая интуиция и философия творчества символизма, следование религиозно-философским идеалам и ценностям русской культуры, историческая динамика русской культуры на примере образа ночи в литературе и кинематографе - интереснейшие сюжеты, ставшие объектом изучения в заключительных главах первого раздела.

Во втором разделе монографии «Русская культура: философская оптика исторических трансформаций» предметом анализа становится рецепция культурной истории России в творчестве русских мыслителей, совершивших попытку ин- 
теллектуального синтеза дискурсивных и недискурсивных практик европейской и русской культуры.

Второй раздел - это реконструкция философии русского европеизма с ведущими для нее темами философии российской истории, метафизики власти, метафизики культуры, философии творчества. Автор предпринимает попытку подняться к теоретическим обобщениям на основе изучения творческого опыта выдающихся деятелей русской культуры, их интеллектуальной эволюции, философской интерпретации тем, определяющих направленность и характер размышлений самых глубоких авторов, выявляя глубинную мотивацию творческих личностей, описывая интеллектуальный и нравственный горизонт их жизни.

С моей точки зрения (я понимаю, что это обусловлено моей собственной профессией), наиболее интересна та часть монографии, которая посвящена анализу философских взглядов выдающихся отечественных мыслителей.

Жукова переходит от размышлений об идеях Карамзина и Станкевича к воззрениям Федотова, Бердяева, Трубецких, Вейдле и Степуна. «Фокус» ее исследовательского «объектива» постепенно смещается от философии истории к религиозной метафизике культуры. Не берусь здесь - в небольшой статье - подробно описать все те сюжеты, что становятся предметом исследования в монументальной книге, но уже одного их перечисления достаточно, чтобы оценить широту и глубину авторского подхода: дискурс о национальной культуре, нравственный идеал в истории, творчество в истории, христианство как основа социальной и культурной жизни России, моральное измерение политического, онтология русской свободы, универсализм русской культуры, философия Логоса (онтологизм русской мысли), экзистенциальный и духовный модус творчества, метафизика революции, историческая и метафизическая идея России.

Проведенное автором обстоятельное исследование позволяет ей сформулировать ряд обобщающих заключений. Полученные Жуковой выводы на первый взгляд содержат в себе определенные противоречия.

1. С одной стороны, отмечаются черты, роднящие русскую интеллектуальную традицию с европейской. Действительно, озабоченность мыслителей - особенно мыслителей XX века - вопросами бытия человека, судьбами европейской культуры и христианской цивилизации очевидный факт (с. 6о2-6о3). Эта озабоченность «не замечает», «не ощущает» «границы, пролегающей по реке Западный Буг».

С другой стороны, не менее скрупулезно в монографии вычленяются и черты, специфичные именно для русской интеллектуальной традиции.

Все без исключения герои, о которых идет речь в настоящей книге, понимали свою задачу именно как культурную работу в выстраивании преемственности традиции через философское постижение культуры и истории, центром которых был человек, обремененный последними вопросами бытия и «проклятыми» вопросами русской жизни. В этом заключался главный культурфилософский и историософский пафос русской мысли и литературы, которая во многом самоопределялась в круге проблем онтологии культуры 
и искусства, метафизики истории, нравственной философии и учения о человеке. В данном контексте справедливо утверждать, что идея русской философии направлена как на создание оригинальной христианской метафизики, так и на сохранение единства смьслового поля отечественной культуры, ее «семиосферь»", удерживающей исторический массив российской цивилизации в большом времени мировой культуры. (С. 607)

2. Автор много внимания уделяет христианской составляющей в истории отечественной художественной (первый раздел) и интеллектуальной (второй раздел монографии) истории. И наглядно демонстрирует, насколько эта составляющая значима. И одновременно с таким же тщанием анализирует «деконструкцию христианской цивилизации», энтропию ее идеалов, что ставит под сомнение саму возможность вопроса «как можно быть в онтологическом смысле, когда провозглашена свобода от вечности?» (с. 604).

Однако следует констатировать, что отмеченные противоречия - это не логические ошибки автора, а фиксация той «разорванной» реальности, того кризиса культуры, через которые прошли и Европа, и Россия в XX веке. И именно осознание масштабности и глубины этого кризиса «вынуждает» автора задаться кантовским вопросом: «На что можно надеяться?»

Как в этом контексте возможна русская культура с ее метафизическим горизонтом и идеалами, с ее устремленностью к духовному совершенствованию и с творческим путем жизни и, следовательно, как возможна «русская мысль, содержащая религиозную интуицию», рефлексирующая над этим опытом и сама являющаяся путем восхождения к высшему смыслу?

Положительный ответ, по мнению Жуковой, возможен только в том случае, если борьба за человека и историю - та борьба, которая была стержнем русской культуры и философии, - будет нами продолжена (с. 6о8).

Подводя итог первому «кругу» своих размышлений, еще раз выражу свое восхищение той отвагой, с которой автор монографии взялась за столь масштабный проект, и тем результатом, который ей удалось достичь.

Но перейду ко второму «кругу» - взгляну на выпущенную издательством «Согласие» книгу как на продукт редакционно-издательской работы. Открою непосвященным маленькую тайну издательского сленга: автор книгу «пишет», а редактор книгу «делает». Так вот, давайте поговорим про то, как книга «сделана».

Прежде всего следует отметить, что в выходных данных книги нет фамилии корректора. Можно предположить, что корректора и в самом деле не было. Свидетельством тому заметное число опечаток в наборе. Да, я как человек с десятилетним стажем книжного редактора знаю, что книг без опечаток не бывает. К сожалению, в этом большом тексте бросаются в глаза обидные, пропущенные буквы «о» в слове «историософский», разные написания буквы «ё» - то с точками, то без точек - в фамилиях Трёльча (с. 12) и Гете (с. 17), как и неверные переносы слов. К этому списку можно добавить допущенную неточность в оформлении цитат. 
Так, на страницах с 53-й по 57-ю обсуждаются идеи Псевдо-Дионисия Ареопагита и цитируется труд «О божественных именах». На всех этих страницах сноски даны «Там же. С. ...». Но первая сноска на стр. 56 - это сноска к цитате Максима Исповедника (его комментарию к тексту Псевдо-Дионисия Ареопагита в этом издании), но стоит все то же «Там же...».

Опираясь на свой редакторский опыт, конкретные претензии я мог бы адресовать также редактору книги Т. В. Глазковой.

Что обычный потребитель книгоиздательской продукции знает о работе редактора? Боюсь, что многие читатели даже не задумываются о том, что редактор и корректор - это совершенно разные функции. А те хорошо подкованные читатели, которые эту разницу знают, зачастую думают, что роль редактора сводится к борьбе со словосочетаниями «имеет роль», «играет значение», «передовой авангард» и «расширение экспансии». Да, это действительно часть работы редактора. Но далеко не только это.

Напишу сейчас о некоторых весьма непростых задачах, которые приходится решать книжному редактору. Прежде всего: редактор - это первый читатель авторского текста, причем читатель квалифицированный. И в процессе чтения «рукописи» («рукопись» - это тот авторский текст, даже если этот текст набран на компьютере, из которого редактор «делает» книгу) редактор встречает какие-то фрагменты, смысл которых ему кажется не совсем понятным.

Тогда редактор показывает автору смутивший его абзац и говорит: «Этот абзац я не понял. Поясните свою мысль, пожалуйста». Автор начинает объяснять «непонятливому» редактору, что он хотел сказать, а редактор радостно восклицает: «Вот и напишите все то, что мне сейчас сказали!»

И оказывается, что автор давно сроднился с некоторыми своими глубоко продуманными мыслями, эти ходы рассуждения ему хорошо знакомы, поэтому он не задумывается о том, что для читателя все это есть terra incognita, и читатель не видит «свернутые» ходы. В результате в рукопись между первым и вторым предложением абзаца вставляются еще две фразы, а между вторым и третьим предложением оказывается еще целый самостоятельный абзац текста.

Так вот, мне кажется, что изданный текст редактором «сделан» без должного внимания к этой задаче. Есть целый ряд мест, где Глазкова должна была попросить автора развернуть его мысли, «прописать» более подробно свои рассуждения:

«Просветители славянских народов святые равноапостольные братья Кирилл и Мефодий созданием славянской азбуки сделали возможным обучение древних русичей азам христианской мудрости на родном языке» (с. 24).

«Самостоятельность авторской позиции продиктована прочным знанием и глубоким пониманием текста Св. Писания» (с. 26).

«Логика гармонии - это и есть внутренний событийный ряд работ Андрея Рублева. Коллизия рублевской „Троицы“ - коллизия тонического трезвучия приведенная к единству разногласного и утверждения гармонии в качестве „основного тона“» (с. 39). 
«Главным социальным институтом в России оказывалась личность, опирающаяся на знание, разум, интеллектуальную волю, духовно-нравственный опыт, развитое эстетическое чувство» (с. 338) и др.

Еще одной функцией редактора при работе с «рукописью» является следование своего рода бритве Оккама - осуществлять отсечение всего лишнего. Автору естественным образом хочется высказать все свои мысли, донести до читателя все результаты его - автора - интеллектуальных усилий. Но в итоге в «рукописи» зачастую оказываются те или иные главы, которые полностью выбиваются из общей логики именно этой «рукописи». Могу припомнить, что из второй на моем редакторском пути «рукописи» (ею была работа члена-корреспондента АН СССР Михаила Николаевича Руткевича и его соавтора Людмилы Яковлевны Рубиной «Общественные потребности, система образования, молодёжь») был «снят» целый раздел, а опубликованная книга была процентов на 40 «худее» первоначального текста.

Так вот, приведись мне работать с «рукописью» «Философия русской культуры. Метафизическая перспектива человека и истории», я бы стал убеждать автора снять третью главу первой части первого раздела «Нравственный порядок человеческого бытия: христианский этос русской литературы» или как минимум ее радикально сократить. Эта глава посвящена теме грехов ${ }^{2}$ и в основном состоит из святоотеческих цитат (и прочих цитат религиозных мыслителей и деятелей церкви). По моему мнению, это богословский текст, который по содержанию лишь косвенным образом связан с остальным корпусом книги. Вставки про русских писателей, что-либо сказавших про рассматриваемые грехи, выглядят не вполне убедительно для того, чтобы вписать главу в общий текст.

Повторю: я не сомневаюсь в достоинствах этой главы, сама по себе она очень интересна, и заинтересованность автора в том, чтобы донести до читателя и этот пласт своих размышлений, мне совершенно понятна. Но книга без указанной главы оказалась бы более целостным произведением.

И, наконец, третий «круг» моих размышлений.

Книга - результат усилий не только автора и издательства, но еще и продукт полиграфического производства. И я могу высказать свое сугубое восхищение продукцией акционерного общества «Т8 Издательские Технологии». Я прочитал книгу от корки до корки с карандашом в руках, я ее читал и за письменным столом, и в транспорте, и лежа, я ее разворачивал (перегибал блок пополам) более чем на 180 градусов, и этот огромный 39-листный блок и сейчас выглядит практически девственно. Данную книгу можно сдавать в читальный зал студенческой библиотеки, она пройдет через сотни рук и через десятки лет будет готова и дальше исправно служить своим читателям.

В целом же всех нас можно поздравить с тем, что из печати вышел такой глубокий, масштабный труд О. А. Жуковой и в таком прекрасном полиграфическом

2. Что само по себе чрезвычайно интересно, и я этими материалами в дальнейшем буду пользоваться в своих лекционных курсах. 
исполнении. Хочется пожелать и автору, и издательству, и полиграфпредприятию дальнейшего плодотворного сотрудничества и новых свершений на ниве интеллектуального книгоиздания.

\title{
Литература
}

Жукова О. А. (2007). История русской культуры в вузе: историческое знание и духовная традиция // Вопросы истории. № 8. С. 1-10.

Жукова О. А. (2014). Избранные работы по философии культуры. Культурный капитал. Русская культура и социальные практики современной России. М.: Согласие.

Жукова О. А. (2017). Философия русской культуры: метафизическая перспектива человека и истории. М.: Согласие.

Зеньковский В. В. (1991). История русской философии. Т. 1. Ч. 1. Ленинград: Эго. Лосев А. Ф. (1991). Философия. Мифология. Культура. М.: Политиздат.

Лосский Н. О. (1994). История русской философии. М.: Прогресс.

\section{Russian Culture in the Philosophical Perspective}

\author{
Dmitry Nosov \\ PhD in Philosophy, Professor, School of Philosophy, Faculty of Humanities, National Research University \\ Higher School of Economics \\ Address: Myasnitskaya str., 20, Moscow, Russian Federation 101000 \\ E-mail:dnossov@hse.ru
}

This article reviews the new research of the Russian philosopher and culturologist and National Research University Higher School of Economics professor Olga Zhukova. Zhukova proposes new philosophical approach to Russian cultural history analysis, based on the major ideas and stories of Russian social and religious thought. The author creates a broad review of the Russian historical development and reveals key features of the formation of system of values. Zhukova examines the Russian culture as a complex structure of religious, political, and artistic traditions. The monograph illustrates the formation of the Russian philosophy with its accent on historical and cultural problems. In analyzing the social and spiritual transformation that accompanied the transition of Russian society from a traditional to a modern culture, the author continues the study of national culture that was started by Russian philosophers of the 19th and the first half of the 2oth century. Zhukova forms an inconvenient reconstruction of national culture and implements historical and philosophical concepts of the Russian thinkers. This article presents a critical analysis of Zhukova's research. Besides a review of Zhukova's culturological concept, the author explores the ideal model and the practice of the editorial and publishing business. The monograph is analyzed not only as a study of scientist and researcher, but also as a result of publishing office work. The article displays the "areas of responsibility" of the author and editors and publishers.

Keywords: philosophy of culture, the history of Russian philosophy, the history of Russian culture, Russian history, religious experience 


\section{References}

Losev A. (1991) Filosofija. Mifologija. Kul'tura [Philosophy. Mythology. Culture], Moscow: Politizdat. Lossky N. (1994) Istorija russkoj filosofii [History of Russian Philosophy], Moscow: Progress.

Zenkovsky V. (1991) Istorija russkoj filosofii. T. 1. Ch. 1 [History of Russian Philosophy, Vol. 1, Part 1], Leningrad: Ego.

Zhukova O. (2007) Istorija russkoj kul'tury v vuze: istoricheskoe znanie i duhovnaja tradicija [History of Russian Culture at the University: Historical Knowledge and Spiritual Tradition]. Voprosy istorii, no 8, pp. 1-10.

Zhukova O. (2014) Izbrannye raboty po filosofii kul'tury. Kul'turnyj kapital. Russkaja kul'tura i social'nye praktiki sovremennoj Rossii [Selected Works on the Philosophy of Culture: Cultural Capital. Russian Culture and Social Practices of Contemporary Russia], Moscow: Soglasie.

Zhukova O. (2017) Filosofija russkoj kul'tury: metafizicheskaja perspektiva cheloveka i istorii [Philosophy of Russian Culture: Metaphysical Perspective on Man and History], Moscow: Soglasie. 


\title{
Изучение эмоций как область междисциплинарной интеграции: история и социология в поисках объяснения «эмоционального поворота»*
}

\author{
К выходу русского перевода \\ книги Яна Плампера «История эмоций»
}

ПЛАМПЕР ЯН. (2018). ИСТОРИЯ ЭМОЦИЙ / ПЕР. С АНГЛ. К. ЛЕВИНСОНА. М.: НОВОЕ ЛИТЕРАТУРНОЕ ОБОЗРЕНИЕ. 568 С. ISBN 978-5-4448-0755-2

\author{
Ольга Симонова \\ Кандидат социологических наук, доцент кафедры общей социологии \\ Национального исследовательского университета «Высшая школа экономики» \\ Адрес: ул. Мясницкая, д. 20, г. Москва, Российская Федерация 101000 \\ E-mail: osimonova@hse.ru
}

\begin{abstract}
Рецензия на книгу Я. Плампера «История эмоций» вряд ли смогла бы полностью отразить все затронутые автором проблемы в современной науке об эмоциях, поэтому автор данной статьи ограничился значением монографии Плампера для социологического исследования эмоций, выделив некоторые моменты пересечения истории и социологии эмоций, в частности социологическое объяснение современного «эмоционального поворота» в науке. Главное теоретико-методологическое противостояние - между социальным конструктивизмом и универсализмом/натурализмом - затрагивает сегодня все социальные и гуманитарные науки об эмоциях, и от выбора позиции в этом вопросе зависит будущее исследователя в данной области. Именно такой выбор и позволяет сделать эта книга, склоняя исследователей к синтетическому подходу. Она помогает обогатить социологическое изучение эмоций фактическим материалом и новой терминологией. Одной из важнейших задач книги является объяснение изменения эмоциональной культуры современных обществ, с которым, по мнению автора статьи, связан «взрыв» интереса к эмоциям в науке и повседневной жизни: возможно, начинается новый «сентиментальный век» как непреднамеренное последствие рационализации всех сторон жизни общества. Сочетание рационального отношения к эмоциям и одновременно особое внимание к чувствам, взрывы коллективных эмоций, настойчивый поиск аутентичных чувств характеризуют эмоциональную культуру современности.
\end{abstract}

Ключевые слова: история эмоций, социология эмоций, конструктивизм и универсализм, эмоциональная культура, рационализация, эмоциональная рефлексивность

В издательстве «Новое литературное обозрение» вышла в свет фундаментальная монография Яна Плампера (профессора истории Голдсмитского колледжа в Лон-

(с) Симонова О. А., 2018

(C) Центр фундаментальной социологии, 2018

DOI: $10.17323 / 1728-192 \mathrm{X}-2018-3-356-378$

* Статья является частью исследования, проводившегося при поддержке Российского научного фонда в рамках проекта «Многообразие видов социокультурной сплоченности в условиях российских реформ: концептуализация и квалиметрия», грант № 14-18-03784. 
доне) в переводе с английского Кирилла Левинсона ${ }^{1}$, посвященная «эмоциональному повороту» в социально-гуманитарном знании. Книга, впервые изданная в 2012 году в издательстве «Siedler» (Германия) на немецком языке, остается остроактуальной и до сего дня. Как отмечает сам автор, это была «попытка сфотографировать ракету в фазе ускорения после запуска» (с. 15). Количество научных конференций на тему эмоций увеличивается с каждым годом, так же как ассоциаций ученых, изучающих эмоции в разных областях (см. об этом: Bericat, 2016; Gonzalez, 2017; Stets, Turner, 2014). Это же можно сказать и о нашей стране (см., например: Винницкий, 2012; Зорин, 2016; Голубев, 2018; Российская империя чувств, 2010). Оживление интереса к эмоциям можно наблюдать повсеместно: Интернет пестрит рекламными объявлениями о тренингах по развитию эмоционального интеллекта и защите от эмоционального выгорания, публичные персоны выступают с лекциями о том, что делать и как жить с негативными эмоциями, как добиться успеха, используя знания об эмоциях, книжные прилавки заполнены научно-популярной литературой об эмоциях, пользователи социальных сетей постоянно делятся своими чувствами и «вбрасывают» их в виртуальное публичное пространство ${ }^{2}$.

\begin{abstract}
Возможно, когда-нибудь в будущем историки констатируют, что в наше время слова «эмоции» и «эмоциональный» весьма распространены в западноевропейских и североамериканских обществах и почти вытеснили в языке повседневности, рекламы, политики и спорта такие близкие по значению слова, как «психология», «психологический» или «моральный», широко употреблявшиеся в 1980-х. Сегодня, когда кто-то открывает стрельбу в школе, родственникам погибших приходится «эмоционально» - а не «морально» или «психологически», как сказали бы еще двадцать лет назад, - справляться с утратой близких... С чем связан этот сдвиг от «морального» и «психологического» к «эмоциональному»?.. Этот вопрос требует исторического анализа. (С. 157-158)
\end{abstract}

Как разобраться в этом многоголосье информации об эмоциях, избежать устаревших научных выводов, моральных наставлений и сомнительных в профессиональном отношении тренингов по управлению эмоциями? Одной из возможностей является изучение книги Плампера, доступной для понимания широкой публикой и позволяющей сориентироваться в науках об эмоциях. Тем более она интересна социологам, поскольку написана в тот момент, когда в социологии, уже накопившей солидный багаж теорий и исследований, многие важнейшие проблемы, о которых пишет Плампер, так и не артикулированы. На наш взгляд, многие важные выводы монографии смогут объяснить причины «эмоционального пово-

1. В русском издании указано, что перевод осуществлен с английского, однако, как выяснилось, Кирилл Левинсон использовал и немецкое, и английское издание: «Geschichte und Gefühl: Grundlagen der Emotionsgeschichte» и «The History of Emotions: An Introduction».

2. См., например, семинары-тренинги: http://cityclass.ru/hakamada_emotional_capital/ или http://5psy.ru/obrazovanie/vlastelin-svoih-emocii-igra-trening-dlya-podrostkov.html и многие другие пользующиеся спросом платные «услуги». 
рота» в социальных науках и определить дальнейшие перспективы развития истории и социологии эмоций.

Плампер утверждает, что «эмоциональный поворот» в социально-гуманитарном знании связан с событием 11 сентября 2001 года, когда стало понятно, что с подобными переживаниями могут не справиться системы социального контроля. С нашей точки зрения, это событие, возможно, и было катализатором, но «эмоциональный поворот» начался раньше - с приходом новой эмоциональной культуры. Повышенный интерес к эмоциям со стороны науки и других социальных институтов, отдельных людей и различных сообществ является свидетельством изменения культурных норм, о чем в последнее время все настойчивее говорят социологи (см. об этом, напр.: González, 2012). Добавим, что сегодня четкое различие между научным исследованием эмоций и современной эмоциональной кульmурой отсутствует, поэтому в понятийном аппарате об эмоциях смешиваются научные и обыденные представления.

При прочтении книги становится ясно, что междисциплинарность в науках об эмоциях неизбежна и необходима. Читатель с самого начала оказывается в клубке дисциплин, которые изучают эмоции, - философия, история, антропология, социология, психология, биология... Монография включает в себя огромнейшее количество ссылок, описаний, примеров, но читается она легко благодаря внимательному отношению к каждому термину. Структура книги представляет собой движение от возникновения истории эмоций до ее перспектив через анализ изучения эмоций в других областях науки. Первая глава «История истории эмоций» представляет собой обзор формирования современной истории эмоций, авторскую интерпретацию причин «эмоционального поворота» в истории, размышления автора о предпочтительной концептуализации эмоциональности. Вторая глава посвящена социальному конструктивизму и антропологии эмоций, а третья - универсализму/натурализму/эссенциализму в изучении эмоций и, соответственно, «наукам о жизни». Завершается основная часть книги главой «Перспективы истории эмоций». Замечательно, что библиография к книге разделяется по рубрикам: книжные серии, специализированные журналы, блоги и форумы, сайты, собственно список литературы, рассортированный по разным дисциплинам (истории, истории науки, антропологии, психологии, философии, визуальным исследованиям, правоведению, лингвистике, политологии, социологии, нейроисследованиям и др.), междисциплинарный глоссарий. Автор книги также считает, что социальные и гуманитарные науки об эмоциях должны реагировать на последние разработки в нейрофизиологии, совершенствуя объяснительные возможности собственных дисциплин. Эта книга - свидетельство того, что именно эмоции являются точкой междисииплинарной сборки не только для социальных и гуманитарных наук, но и естественонаучного и соииально-гуманитарного знания. Причем дисциплинарные границы отнюдь не размываются, а осознаются все лучше, одновременно появляются новые «платформы» для междисциплинарной кооперации. Монография заслуживает внимания социологов, поскольку ведет 
к историческому и культурному пониманию эмоций, к признанию их изменчивости и укорененности в социальной структуре в противовес универсализму некоторых направлений в психологии и нейроисследованиях. Это и является главным в социологическом подходе к эмоциям (Симонова, 2016), которые представляют собой не столько универсальные реакции, «отпечатки в мозгу» (Фельдман Баррет, 2018: 2021), сколько аффективно-когнитивные комплексы, сформированные культурой, историческим и социальным контекстами. Одно из главных преимуществ данной монографии состоит в том, что автор предстает социологом науки - развенчивает мифы об эмоциях, анализирует различные способы размышлять о них и подвергает обоснованному сомнению некоторые обыденные представления.

\section{Лейтмотивы книги и социология эмоций}

В монографии отчетливо прослеживаются два лейтмотива. Первый связан с осторожным отношением к трактовке эмоций в «науках о жизни», биологически ориентированных естественных науках, включая некоторые направления в психологии, которым посвящена самая объемная глава. Автор убежден в необходимости критической оценки «легкомысленных заимствований из нейронауки, которые столь модны ныне в некоторых гуманитарных и социальных дисциплинах, особенно в литературоведении и искусствоведении, а также в политологии» (с. 15). Второй лейтмотив - это призыв к разработке сбалансированного подхода к эмоциям, который мог бы существовать между Сциллой универсализма, свойственного наукам о жизни, и Харибдой социального конструктивизма, свойственного наукам о культуре. «Фактически структура научного изучения эмоций - и структура книги - задана именно дихотомией „социальный конструктивизм vs универсализм“» (с. 193). Автор книги, анализируя разные дисциплинарные подходы к эмоциям, везде обозначает это противостояние, чтобы «в конце концов навести через него мосты» (с. 17). Для этого Плампер часто доводит до радикальной позиции разницу между универсализмом и конструктивизмом, постоянно задавая вопрос - действительно ли существуют эмоции, или это только понятие западной науки и культуры, - и ищет подходы к пониманию эмоций за пределами дилеммы конструктивизма и универсализма.

Водораздел между социальным конструктивизмом и универсализмом начинается с понимания того, что такое эмоция. Уже во введении и первой главе книги Плампер начинает разоблачение универсальности эмоций, прежде всего тех, что считаются «базовыми», - страх, гнев, радость, отвращение, удивление (этот список может быть увеличен до 10-11 эмоций [см. об этом: Turner, 2007]). Вопреки определенным направлениям в современной психологии и нейронауке, эти эмоции не имеют, согласно автору, четкой локализации в мозге и, соответственно, их нельзя обнаружить в чистом виде в других культурах, да и, как оказалось, не во всех западноевропейских обществах тоже. В связи с этим Плампер осуществляет краткий экскурс в историю философии (от Платона и Аристотеля до современ- 
ной философии эмоций и нейронауки), предлагая проследить, как в западном мире менялись представления о том, что мы сегодня называем эмоциями. Главное в истории понятия «эмоция» заключается в том, что общеупотребительным в философии и в науке оно становится только к концу XIX века. Ученые «ухватились» за него», чтобы отделить научное представление об эмоциональной сфере от морального и религиозного содержания (Dixon, 2003), поэтому так и получилось, что «эмоции» охватывают огромное количество состояний и выступают в качестве метапонятия ${ }^{3}$. «Я решил использовать слово «эмоции» как метапонятие. В качестве синонима я использую слово «чувство». Вместе с тем я не хочу уклоняться от историзации, поэтому стараюсь четко обозначать специфичное использование каждого из этих двух терминов всякий раз, когда они встречаются в языке источника» (с. 22).

Одним из важных вопросов является «у кого бывают эмоции?», ведь в мире современной (западной) культуры эмоции сегодня рассматриваются как возникающие внутри человека и представляющие собой нечто личное, индивидуальное убежище автономии и уникальности. Однако «ответы на этот вопрос связаны с большими различиями, имеющими место в истории человечества - социальными, гендерными, этническими... Поэтому, вместо того чтобы за отправную точку брать вопрос «Кто чувствует?» и искать на него неопровержимый ответ, историку эмоций предпочтительнее сделать предметом своего изучения исторически меняющиеся ответы на этот вопрос» (с. 48-49).

С этим сопряжен и вопрос «Где место эмоций?», который также требует ответа с учетом исторического контекста: так, в традиционных обществах не всегда считалось, что эмоции локализованы в самом человеке, в его теле («в сердце»). Согласно довольно распространенному типу верований, эмоции были присущи духам или богам и по их воле могли внезапно одолевать людей. Плампер показывает, что история имеет дело с огромным разнообразием представлений о чувствах, за которыми могут стоять и врожденные способности (хотя это не главное). Сегодня побеждает представление, что эмоции локализуются в самом человеке, в его теле, прежде всего в его нервной системе, мозге, но все также может измениться: «было бы фатальной ошибкой думать, что тело есть нечто вневременное и одинаковое во всех культурах» (с. 52-53). Иными словами, у эмоиий есть своя история, а у дисциплины «история эмоций» - своя предьстория.

Плампер называет ряд влиятельных фигур, заложивших фундамент современной истории эмоций. Это В. Дильтей, К. Лампрехт, Г. Штейнгаузен, К. Брейзиг, Г. Зиммель, М. Вебер, Й. Хейзинга, Т. Зелдин и др. Он особенно выделяет работы Люсьена Февра и Норберта Элиаса, которые, по его мнению, фактически «узаконили» исследование эмоций в истории. Из работ Февра социологи могут за-

3. Например, страх русского солдата во время Первой мировой войны (Плампер и др., 2010), страх маори перед сражением или древнеримского легионера - это всегда один и тот же страх? Сопровождается ли он одинаковыми физиологическими реакциями? Впрочем, в работе о страхе Плампер так и не дает его определения. 
имствовать идеи и их фактические иллюстрации, к примеру, о том, что эмоции глубоко интерсубъективны, многослойны и амбивалентны, и порой проявляются одновременно. Февр выразил сомнение в том, что социально-исторический процесс движется по пути большего контроля над эмоциями, что является основным в подходе Элиаса, но оба мыслителя расшатывали эссенциалистское представление о чувствах (с. 82). Плампер не разделяет подхода Элиаса, считая, что многие исторические события его опровергают, но для социолога насущной задачей оказывается именно анализ современного общества и последствий возрастания формальной рациональности, в числе которых присутствует особое отношение к эмоциям. Однако для историков - это своеобразный «гранд-нарратив» (Rosenwein, 2002), который не является доказанным, в свою очередь, социологам есть повод задуматься и, возможно, пересмотреть работы Элиаса с точки зрения новых концептуализаций эмоций в истории и социологии.

Начало формирования современной истории эмоций Плампер отсчитывает от книги Уильяма Редди «Навигация чувств» (Reddy, 2001), который свел «воедино социально-конструктивистские подходы из антропологии эмоций и универсалистские из когнитивной психологии, предложил синтетическую теорию истории эмоций» (с. 97), приложив ее к истории Франции XVIII века. Плампер также упоминает как программную статью американских историков Питера и Кэрол Стернсов - «Эмоционология: проясняя историю эмоций и эмоциональные стандарты» (Stearns, Stearns, 1985), хотя она вышла намного раньше. В этой статье провозглашалось создание новой дисциплины «эмоционологии», занимающейся исторически обусловленными правилами и стандартами, с помощью которых регулируются выражения чувств (Stearns, Stearns, 1985: 814). Эмоциональный опыт и правила культуры, согласно которым происходит выражение чувств, здесь концептуально разделяются, как и в социологии. Однако, хотя этими историками были опубликованы несколько монографий по истории эмоций и эмоциональной культуре США, история эмоций, по мнению Плампера, еще не стала считаться отдельной областью исследований. По нашему мнению, американские историки, подчеркивая важнейший момент различия между переживанием и выражением эмоций и отделяя эмоциональные нормы от непосредственного опыта, следуют за идеями социолога Арли Хохшильд, акцентировавшей роль эмоциональной культуры в конце 1970-х годов (см.: Hochschild, 1983), то есть немногим раньше историков эмоций.

\section{Определение эмоций в истории и социологии}

Плампер отказывается от радикального социального конструктивизма, признавая, что историкам нужно "рабочее определение эмоции», но не дает его, поскольку «вся эта книга задумана как навигационный прибор, помогающий в поисках такого определения» (с. 63-64). Каждый исследователь должен определиться в своих взглядах на эмоции и искать, что понимали в другие эпохи под чувствами в зависимости от различных верований и групповой принадлежности. Наряду с этим 
автор подчеркивает, что история эмоций является преимущественно европейской и североамериканской, а «роль авангарда в истории эмоций играет медиевистика» (с. 109). С нашей точки зрения, Плампер выбирает в качестве рабочей концепцию «эмоциональных сообществ» историка-медиевиста Барбары Розенвейн, которая в определенной степени преодолевает представления об эмоциях как универсальных явлениях: это

те же самые сообщества, что и социальные: семьи, кварталы, парламенты, цехи, монастыри, церковные приходы. Но исследователь, изучая их, ищет прежде всего системы чувств: что эти общины (и индивиды в них) определяют и расценивают как ценное или вредное для себя; оценки, которые они дают чувствам других; характер аффективных связей между людьми, которые они признают; а также модусы выражения эмоций, которые они ожидают, поощряют, терпят или осуждают. (Цит. по: с. 111)

Среди эмоциональных сообществ Розенвейн выделяла «социальные», характеризующиеся единством норм, регулирующих эмоциональную жизнь их участников, и «текстуальные», основанные на общности идеологии. Один и тот же человек может входить одновременно в разные социальные и текстуальные сообщества, системы норм в которых могут противоречить друг другу (Rosenwein, 2006: 24-25). Эта концепция особенно полезна для социологии, поскольку дает возможность критически рассмотреть основные черты эмоциональной культуры современных обществ, где рациональный контроль над эмоциями становится ценностью, институционализируется в различных социальных сферах, а управление эмоциями оказывается «вездесущим» и настоятельным, что, возможно, есть уникальная примета времени (Gonzalez, 2017; Hochschild, 1983; Элиас, 2001). Именно управление эмоциями попадает в сферу интереса социологии, а потому Плампер для своего краткого экскурса в социологию эмоций (во второй главе) выбирает работы Арли Хохшильд и Эвы Иллуз (Hochschild, 1983, 2007; Illouz, 2007, 2012), исследующие последствия рационального управления чувствами.

О трудностях формулировки определения эмоций пишут специалисты практически во всех областях науки, и консенсус по этому поводу до сих пор не выработан. Сегодня в зависимости от целей исследования социологи и психологи определяют эмоции через их различные компоненты (иногда функции) (см. об этом: Симонова, 2016), многие ученые не делают окончательного выбора между конструктивизмом и универсализмом, пытаясь предложить синтетические определения. Приведем для примера одно из определений, которое, на наш взгляд, как-то схватывает суть этого сложного феномена: «Эмоция это универсальная, функциональная реакция на внешний стимул-событие, временно интегрирующая физиологические, когнитивные, феноменологические, поведенческие выражения, способствующая приспособительной и формирующей окружение реакции на те- 
кущую ситуацию» (Kalat, Shiota, 2007: 313)4. Это громоздкое определение - примета современного состояния науки об эмоциях, оно несет в себе неизбежные недостатки, связанные с отсутствием в явном виде культурных (языковые обозначения и определения) и социальных компонентов (непонятен субъект и объект эмоции и связь с окружением). Однако это определение позволяет до некоторой степени отличать эмоции от других переживаний, здесь эмоция трактуется сродни «вспышке» (или целостному переживанию разной длительности), в которой сливаются и опыт, и оценка текущей ситуации, и знание, и телесность, и поведение, и общая функциональность. Однако в нем слабо отражается конкретное содержание эмоции. Социология эмоций, как и история эмоций, стремится отразить культурно-историческое содержание, но настаивает на поиске определений и моделей ${ }^{5}$, новых классификаций, поскольку метапонятия многих уже не устраивают (Bericat, 2016). Социологи отходят от простейших классификаций эмоций на негативные и позитивные, базовые/универсальные и культурно специфичные, однако ими все еще до конца не продуманы способы справляться с дилеммой конструктивизма/универсализма (Симонова, 2016). Представляется, что в поисках новых концептуализаций эмоций социологам сегодня важно обратиться к истории и антропологии эмоций.

\section{Конструктивистский путь для истории эмоций: антропология, социология и история}

Для того чтобы написать историю эмоций, Плампер «отправляется» в антропологию - во второй главе «Социальный конструктивизм: Антропология» он рассматривает самые интересные, по его мнению, работы об эмоциях: «...случаи из антропологической литературы подрывают представление об универсальности человеческих чувств. Они показывают, что существует такое межкультурное разнообразие эмоций и способов их проявления, что приходится окончательно отбросить идею, будто все люди чувствуют одинаково и что именно сходство на эмоциональном уровне объединяет всех людей» (с. 126).

Плампер прослеживает антропологическое изучение эмоций, начиная с ранних этнографических работ об эмоциях (1970-е годы, в основном работы Дж. Бриггс и Р. Леви), которые принесли широкое признание западным антропологам. Конструктивистский подход в антропологии окончательно сформировался в только в 1980-е годы, когда они признали эмоциональный опыт культурным, а не докуль-

\footnotetext{
4. Определения (с неизбежными ограничениями) дают и другие специалисты: эмоции - «эпизодические, относительно кратковременные, биологически заложенные образцы восприятия, опыта, физиологии, действия, коммуникации, которые возникают в ответ на специфические физические и социальные вызовы и возможности» (Keltner, Gross, 1999: 468). Здесь также можно найти отсутствие языковых обозначений эмоций, сведение их к кратковременным переживаниям, не виден субъект реакции.

5. Социологи продолжают настаивать, что следует дать определения хотя бы некоторым эмоциям, которые представляются универсальными: «стыд», «любовь», «зависть» и др. (Scheff, 2011).
} 
турным, что было связано с «культурным» и «лингвистическим» поворотом. Среди антропологов Плампер особенно выделяет Мишель Розалдо, Лилу Абу-Луход и Кэтрин Латц, считая работы последней апогеем социального конструктивизма в антропологии эмоций. В книге «Неестественные эмоции» (1988) она писала:

На первый взгляд может показаться, что нет ничего более природного и, следовательно, менее культурного, чем эмоции; ничего более приватного и, следовательно, менее открытого для взора социума; ничего более зачаточного и менее совместимого с логосом общественных наук. Однако подобные представления можно рассматривать как элементы культурного дискурса, чьи традиционные предположения о человеческой природе и чьи дуализмы тела и сознания, публичного и приватного, сущности и внешности, иррациональности и мысли - конституируют то, что мы принимаем за самоочевидную природу эмоций... (Цит. по: с. 175)

Латц рассматривает эмоции как идеологическую практику, призывая изучать вербальные и невербальные знаки эмоций, встроенные в человеческую деятельность. Однако если довести данную позицию до логического конца, то получается, что антропология также не имеет права использовать понятие «эмоция» при описании других культур, поскольку оно «сконструировано» в западной культуре. Исходя из этого и антропологи, и историки, и социологи сталкиваются с необходимостью выработки новых моделей эмоционального опыта, учитывающих огромное культурное разнообразие. У историков эта проблема стоит острее, поскольку они не всегда могут общаться со свидетелями изучаемых исторических событий.

Анализ антропологических исследований дополняется совсем небольшим экскурсом в социологию, в котором Плампер отмечает потенциал именно классической социологии в изучении эмоций и одновременно высказывает удивление по поводу молчания в отношении эмоций, которое наблюдалось в социологической науке с конца 1920-х до 1970-х годов. Из всех работ по социологии эмоций автор выбирает для анализа книгу А. Р. Хохшильд «Управляемое сердце» (1983) и некоторые идеи Э. Иллуз, в которых делается акцент на рациональном контроле над чувствами, поскольку именно в них видится возможность противостоять эссенциализму в понимании эмоций (Hochschild, 1983, 2007; Illouz, 2007, 2012). Заметим, что трактовка Плампером взглядов Хохшильд кажется довольно упрощенной, он упрекает ее, как и Н. Элиаса, в распространении тенденций западного общества на другие культуры (прежде всего коммерциализации чувств через эмоциональный труд), что «лишает работу Хохшильд морально-критической остроты» (с. 202). Книгу Иллуз о «коммерциализации романтической любви» (Illouz, 2014) Плампер признает полезной, но критикует за «хронологический беспорядок» и эклектизм (с. 212). Но главное, что, несмотря на скудный экскурс в социологию, автор справедливо обращает внимание на то, что социологов по большей части недостаточно заботит проблема универсализма/конструктивизма, и они продолжают изучать 
эмоции, не определившись по отношению к ней. В отличие от социологов антропологи с 200о-х годов стали искать выход из известных бинарных оппозиций в изучении эмоций (разум/тело, рациональное/иррациональное и др.), примером чему служат синтетические подходы У. Викан, Л. Митчелл, К. Хайдера. Это повлияло на развитие истории эмоций: опираясь на работы историков Паскаля Айтлера и Моник Шеер, Плампер пишет, что историческое изучение эмоций должно строиться не на способах «говорения об эмоциях» (speaking emotion) и «мышления об эмоциях» (thinking emotion), а скорее на «делании эмоций» (doing emotions) или «испробььвании эмоций» (trying emotions) (с. 225). Иными словами, нужно рассматривать исторически проявленные "случаи эмоций», которые опознаются таковыми и фактически выполняют функиии, схожие с суждениями. Эмоции - это скорее смысловое наполнение переживаний в связи с ситуацией, создающее «распоряжения для действия» (Фельдман Баррет, 2018: 154). Впрочем, в социологии примерно в это же время также стали появляться синтетические подходы к пониманию и концептуализации эмоций (см.: Бардина, 2017).

\section{Исследование эмоций в науках о жизни и в науках о культуре: притяжения и отторжения}

Автор книги выстраивает историю формирования представлений об эмоциях в «науках о жизни» от Чарльза Дарвина до современных нейроисследований с точки зрения борьбы между социальными конструктивистами и универсалистами. Он «разоблачает» теорию «базовых эмоций» Пола Экмана, завоевавшую в свое время огромное количество сторонников и утвердившую эссенциалистский взгляд на эмоции. В этой теории доказывается наличие эмоций, универсальных для всех культур: для них характерна одинаковая физиологическая реакция, экспрессивная мимика, общее эволюционное происхождение, содержание и функции. Главным образом это радость, гнев, отвращение, страх, печаль и удивление, хотя этот список все время корректируется. Первые эксперименты Экмана базировались на выборках студентов, которым показывали фотографии «эмоций в чистом виде», затем им были проведены унифицированные эксперименты в разных культурах по узнаванию эмоций по фотографиям и сделан вывод об универсальности «базовых» эмоций. Ученый создал универсальную кодовую систему определения эмоций по выражениям лица, которая используется не только в науке, но и системах безопасности США. Плампер пытается с позиций социологии науки понять, почему его теория потеснила конструктивизм. Первая критика теории Экмана прозвучала со стороны антропологов М. Мид, Г. Бейтсона, Р. Бердвистела, которые полагали, что в экспериментах демонстрировались симуляции эмоций, кроме того, предлагался только семантически ограниченный ряд эмоций (на английском (!) языке). По их мнению, мимика не обязательно связана с чувствами, а в передаче эмоций царит безграничное культурное разнообразие. Однако в США теория Экмана была широко принята и поддержана. Как пишет Плампер, «это был 
триумф суггестивной силы фотографических и кинематографических изображений над честной наукой; триумф удобства, так как эксперименты могут быть легко воспроизведены с помощью набора фотографий, которые можно приобрести у фирмы Экмана через интернет; триумф стратегического способа действий и маргинализации несогласных» (с. 256). Интересно, что теория Экмана приобрела популярность в массовой культуре и продолжает оставаться очень влиятельной в науке, но теперь ее критика все чаще исходит от психологов, ориентирующихся на критерии экспериментальной психологии. Оппоненты Экмана, к которым относит себя и автор книги, предупреждают об опасных социальных последствиях убежденности в универсальности эмоций: признание эмоций не зависящими от мышления и контроля человека (как полностью иррациональных эволюционных механизмов) ведет к тому, что они могут «именем науки» приписываться (со стороны разных заинтересованных групп) другим людям, их не переживающим, а отсюда недалеко до тотального контроля и разных видов дискриминации. На этом рассуждении Плампер строит «миссию» самой большой главы в книге - «предостеречь историков от необдуманных заимствований из „экспериментальной психологии, особенно в ее новой, нейрологической разновидности“» (с. 265).

Плампер реконструирует историю изучения эмоций в психологии, фокусируясь на экспериментальной части этой науки, отслеживает «рождение психологических концепций эмоций из духа эксперимента» и попыток измерить эмоции, начиная со времен образования лаборатории В. Вундта. Изобретения инструментов измерения психологической жизни способствовали тому, что «значение субъективных и языковых аспектов эмоций принижалось. Фактически чувства были демистифицированы» и практически не отделялись от других переживаний, к примеру, боли (с. 301). Психологические теории середины XX века становились все более сложными, но все еще полагали эмоции частью неизменной человеческой природы, которая слабо зависит от культуры. Самым интересным в этой связи является анализ современных нейрологических исследований эмоций с помощью MPT и других технологий визуализации. Томограф Плампер называет «душеразведочной шахтой», его изобретение стало началом бума нейроисследований эмоций. Плампер рассматривает три важнейшие нейрологические теории в области изучения эмоций - теорию страха Дж. Леду, гипотезы соматических маркеров А. Дамасио и зеркальных нейронов Дж. Риццолатти, В. Галлезе, М. Якобони, а также «миграцию» этих гипотез в гуманитарные и социальные науки («нейроисторию», «нейрополитологию», «нейроэкономику», «нейросоциологию» и т.д.). Эти дисциплины фокусируются на неосознаваемых непосредственных переживаниях и процессах в мозге, которые обусловливают индивидуальное и социальное поведение. Например, политологи полагают, что «аффективно заряженное действие происходит еще до того, как кристаллизуется восприятие» (с. 377). Получается, что хотя эмоции - важнейшая часть нашей жизни, в том числе рациональных процессов мышления, но все же они обусловлены нашей биологией. Некоторые представители социальных и гуманитарных наук стали полагаться на результаты 
нейроисследований, сочтя это «надежным и успокаивающим». «Как возникла эта ориентация на нейронауки?.. Одно из объяснений - триумфальное шествие этих дисциплин в области самих естественных наук. Новое знание и новые методы... впервые позволили визуализировать процессы, идущие в мозге. Важны были также и внутренние тенденции в гуманитарных науках, прежде всего - начавшийся распад постструктурализма...» (с. 364-365). Плампер объясняет этот успех нейрологических теорий тем, что их авторы - одновременно известные популяризаторы науки. Так, нейрополитологи часто цитируют популярные, а не академические тексты (с. 382). Идеи, возникающие в недрах нейронауки, обретают популярность у политических активистов. В книге «Империя» (200о) Майкла Хардта и Антонио Негри показано, как в современном обществе человеку не скрыться от всепроникающей системы биовласти постиндустриального капитализма, где поведение людей контролируется через эмоциональный труд, создавая «позитивное» отношение к труду и к властям. Но поскольку эмоциональность человека - это сфера, которую нельзя полностью взять под контроль, она же может быть и источником сопротивления этой власти или нейроаффективным фундаментом для сопротивления, «возможностью для политической организации и коллективных практик отказа и освобождения» (с. 386-387).

Критика таких подходов звучит и со стороны гуманитарных и социальных наук, и со стороны представителей естествознания, особенно критической нейронауки. Критическая нейронаука и конструктивистская когнитивная психология (Фельдман Баррет, 2018) базируются на интегральной концепиии мозга (сетевой характер мозга не позволяет точно сказать, где «локализованы» эмоции) и на пластичности мозга, который изменяется под воздействием социально-культурного мира (эмоциональные переживания каждый раз могут быть сконструированы, и томограмма мозга может оказаться сопоставимой с артефактами человеческой культуры). Все это означает, что эмоции являются понятиями, которые конструируются нашим мозгом в соответствии с внутренними телесными ощущениями и окружающим социальным миром. Но и здесь, по замечанию Плампера, многие проблемы остаются нерешенными - понятия перемешиваются, эмоции выступают как «когмоции» (cogmotions), их трудно отделить от другой деятельности мозга. Таким образом, в результате критического взгляда на нейроисследования мозг для историка оказывается историческим и культурным объектом, представления о котором меняются (с. 399-401).

В социологических исследованиях эмоций распространены универсалистские концепции эмоций и задействованы гипотезы и технологии нейроисследований (см., например: Franks, 2012; Stets, Turner, 2014). Книга Плампера, в свою очередь, «охлаждает» пыл социологов-универсалистов и заставляет принимать во внимание необходимость осторожно относиться к гипотезам нейроисследователей при концептуализации эмоций, ориентироваться на метаанализ (сравнение множества исследований по одной теме) (с. 451-452) и строить собственные классификации, искать «культурные конфигурации», в которых отражаются разные компо- 
ненты эмоциональных переживаний. Нельзя полагаться только на анализ мимики и физиологических реакций.

\section{Современное состояние истории эмоций и перспективы для социологии}

В заключительной главе книги «Перспективы истории эмоций» Плампер показывает, как современные историки уходят от дихотомии социального конструктивизма и универсализма. Он выделяет только те работы, авторы которых, с его точки зрения, осознанно выбирают синтетический подход и предлагают новые концепции для анализа эмоций. У. Редди пытается преодолеть дихотомию социального конструктивизма и универсализма с помощью концептов «эмотивов», «эмоциональной навигации», «эмоциональных режимов», «эмоциональных убежищ», «эмоциональной либерализации», «эмоционального страдания» и др., которые, с одной стороны, являются генерализующими, а с другой - дают возможность сравнивать различные исторические периоды и культуры (Reddy, 2001). Редди предлагает изучать способы высказывания об эмоциях в каждую эпоху «эмотивы», в которых заключается констатация факта переживания, оценка ситуации и подготовка к действию. «Эмотивы», речевые акты об эмоциях, не только обозначают, но и конструируют реальность, то есть могут менять действия людей. «Эмоциональныц̆ режим» - это ансамбль предписанных «эмотивов» и связанные с ними ритуалы и практики, которые обычно сопровождают/поддерживают каждый политический режим. Хотя Редди придает «эмоциональному режиму» политическое звучание, сегодня это понятие, в частности в социологии, используется для общего обозначения ансамбля эмоциональных норм и стандартов (Gonzalez, 2012). «Эмоциональная навигация» - это маневрирование между различными конфликтующими объектами, на которые направлены эмоции. По Редди, «эмотивы» дисфункциональны, если затрудняют «эмоциональную навигацию» и ведут к нарушению равновесия между противоречивыми целями эмоций. Чем сильнее конфликты между различными ориентациями и чем меньше у человека «эмоциональных убежищ», тем сильнее «эмоциональное страдание». «Эмоциональная свобода» - это минимизация «эмоционального страдания», идеал и сознательное усилие, относительно которой можно сравнивать разные «эмоциональные режимы». Плампер считает полезными концепты Редди, особенно «эмотивы»: «эмоциональные высказывания исторических акторов нельзя отделить от их чувств: всегда существует петля обратной связи между высказанной мыслью и чувствуемой эмоцией», однако «эмотивы» ставят слова в привилегированное положение перед другими формами эмоционального поведения, упускается роль ситуации и воспоминания, столь важного для исторического исследования (с. 419, 426-427). По нашему мнению, для социологов «эмотивы» могут стать многообещающим подспорьем, поскольку иные способы узнать о чувствах часто недоступны.

Помимо терминологии Редди, Плампер уделяет внимание понятию «эмоциональных практик» немецкого историка М. Шеер (Scheer, 2012), которое представ- 
ляет собой попытку преодолеть дуализм разума и тела, структуры и агентности, переживания и выражения эмоций. Тело, а вслед за ним и эмоции, рассматриваются как культурно-исторические феномены, сознание человека требует одновременно «работы» тела, мозга и культурного мира. Шеер выделяет различные типы эмоциональных практик, в которых люди манипулируют телом и мыслью с целью вызвать чувства, либо с их помощью находят способы придать смысл своим чувствам. Например, именующие эмоциональные практики (наряду с мобилизующими, регулирующими, сообщаюими) связаны с порождением значений, когда именование эмоций делает их доступными для опыта и управления. В этих практиках человек скорее «делает» или «пробует» эмоции, которые можно расположить в континууме от непреднамеренных и неосознанных до преднамеренных и осознаваемых. В эмоциональной практике возникает и сам чувствующий субъект, располагающий себя в рамках габитуса. В социологии в последние годы активизировался подход «телесно-ориентированной» социологии эмоций (см. об этом: Бардина, 2017), который позволил связать действие, тело, эмоцию и суждения, обусловленные социальным миром. Используя этот подход, мы можем исследовать совершенно уникальные или, возможно, в чем-то подобные переживаниям в других культурах, эмоциональные «сгустки», обусловленные одновременно телесностью и культурой, эмоционально окрашенные культурные конфигурации, описывающие и даже объясняющие наблюдаемые явления.

«Золотая лихорадка» в истории эмоций, согласно Пламперу, имеет совершенно отчетливые перспективы при изучении политической истории (особенно социальных движений); экономической истории (особенно культуры потребления); истории права; истории современных коммуникаций; коллективной памяти; эмоиий историков в процессе познания; эмоциональных стереотипов; коллективных эмоций; сравнительных исследований по истории эмоций и др. В социологии уже есть впечатляющий корпус исследований эмоций в разных сферах общества, в том числе как раз по указанным областям (Stets, Turner, 2014). Важным следствием выявления этих перспектив для социологов является «принципиальная» междисциплинарность, которая потребует не только корректной адаптации находок из других дисциплин, но и прежде всего новой квалификации самих социологов. Уже сейчас очевидно: чтобы исследовать эмоции в каком-либо контексте, нужна дополнительная специализация, например, в области лингвистики («словари» эмоциональной культуры), истории (отслеживать временные изменения в эмоциональных нормах) или психологии (знания о психологической динамике эмоций) (Симонова, 2016).

\section{Эмоциональная культура современного общества и эмоциональный поворот в науке.}

Контрапунктом книги Плампера является попытка объяснить причины «эмоционального поворота» в западной науке. Согласно автору, он произошел не толь- 
ко в силу общего развития дисциплин и окончания так называемого «лингвистического поворота» в социально-гуманитарном знании, но прежде всего как следствие крупнейшего теракта 11 сентября 2001 года. Это событие вызвало «вал эмоциональной коммуникации» и настоятельную необходимость эмоциональной переработки травматического события:

\begin{abstract}
Что скажет анализ дискурса о таких явлениях, как религиозный экстаз и ненависть, феноменах, которые после 11 сентября казались настолько неопосредованными, доязыковыми, что их то и дело сопровождали эпитетами «архаический» и «стихийный»? Теракты в Нью-Йорке, Вашингтоне и Пенсильвании поставили под сомнение аналитический инструментарий постструктуралистской исторической науки и способствовали дальнейшему подъему наук о жизни. (С. 99-100)
\end{abstract}

Плампер считает, что с этого момента началась новая эпоха интенсификации интереса к эмоциям, массированное изучение эмоций в новых и традиционных областях. Так, это событие ускорило революцию в биологии - мозг становится главным объектом исследований, затем эти идеи мигрируют в социальные и гуманитарные науки. Плампер пытается определить и другие предпосылки «эмоционального поворота»:

\begin{abstract}
Вероятно, отчасти это связано с внутренними процессами в психологии и с тенденциями в других науках. Важную роль сыграли, вероятно, прежде всего то большое значение, которое эмоции имели в философском экзистенциализме, и глобальная мода на экзистенциализм среди студентов. Вполне возможно также, что и общие социальные процессы привели к изменению отношения к эмоциям. Женское движение и тот факт, что женщин становилось все больше в университетах и в профессиональной жизни, несомненно, подняли престиж качеств, традиционно приписываемых женщинам, в том числе эмоциональности. В 1970-1980-х гг. широкое проникновение психотерапии в повседневность, появление многочисленных групп самопомощи, а также движение New Age способствовали тому, что люди стали больше говорить о собственных чувствах, и это тоже внесло вклад в повышение ценности эмоций в общественном сознании. (С. 326 ).
\end{abstract}

Однако замечу, что социологи уже более 40 лет назад наметили концептуальные пути изучения эмоций, а классики социологии давно обратили внимание на то, что в природе капитализма заложено особое отношение к эмоциям: считающиеся неподконтрольными эмоции становятся проблемой, контроль над чувствами - одной из основных ценностей, а сами эмоции «смещаются» в мир интимного и приватного и ценятся как нечто подлинное, уникальное, живое. Современная эмоциональная культура и «особый эмоциональный режим капитализма» (Illouz, 2007) связаны с высокой рационализацией и индивидуализацией. Сегодня распространено общее представление, что именно во внутреннем мире индивида и кроется источник социальных проблем, которые должны в силу этого решаться 
самим индивидом. Это часть общего процесса индивидуализации, в результате которого «социальные проблемы все более воспринимаются в терминах психологических установок: как личная неадекватность, чувство вины, тревоги, конфликты и неврозы» (Beck, Beck-Gernsheim, 2001). Многие социологи писали о процессе «психологизации» современного общества, моральном упадке сообществ, нарциссической культурной тенденции вследствие идеологии индивидуализма, которую несет с собой «поздний капитализм» (Rieff, 1987; Ahmed, 2004; Lasch, 1979; Hookway, 2013 и др.). Эта психологизация обусловливает интерес к отдельной жизни человека, его переживаниям, мыслям, его биографии и, соответственно, эмоциям (Flamarique, 2012). Научная и практическая психология, психотерапия оказываются одним из доступных языков говорения об эмоциях на обыденном уровне. Эта тенденция во многом связана с «терапевтизацией» культуры (Furedi, 2004; Illouz, 2012; Gonzalez, 2017). Все эти процессы снижали значение социальных и культурных условий в общественном сознании в пользу обсуждения личных эмоций, которые одновременно нужно контролировать или выражать сообразно контексту. «Вчерашний экономический и социальный детерминизм был преодолен новым и не менее жестким детерминизмом - эмоциональным детерминизмом» (Scheff, 2011: 353).

Социальные изменения происходят сегодня в ускоренном темпе, одно за другим случаются события глобальных масштабов. Осознание рисков, сопровождающих социальные изменения, выражается в усилении страха и тревоги, озабоченности будущим (Beck, 2000; Furedi, 1997; Sennett, 2006), поэтому контроль над чувствами дает основание думать, что можно справиться и с ситуацией, сами же эмоции обладают способностью преодолевать неопределенность будущего наряду с рациональным мышлением (Barbalet, 1997: 49). Управление эмоциями в современном обществе - знак «жизненной связи между социальными противоречиями и частными попытками управлять своими чувствами» (Hochschild, 1983: 202). Этому соответствует развитие области исследований «эмоционального интеллекта» и терапевтическая и коммерческая практики «работы с трудными эмоциями», играющие роль «защитного мифа индивидуализма» (Scheff, 1990: 12). Разнородность, сложность эмоциональной культуры можно трактовать как разнообразие реакций на типичные угрозы, которые несет в себе современный мир.

Ведущей чертой современной эмоциональной культуры часто называют «культуру страха» (Furedi, 1997), в свою очередь, классики писали о «культуре эмоциональной холодности» (Illouz, 2007), «непризнанного стыда» (Scheff, 2014), «культуpe симпатии» (Clark, 1997), «грусти/депрессии» (см.: Бардина, 2017) и др. С нашей точки зрения, эмоциональная культура не имеет одной ярко выраженной характеристики и скорее всего представляет собой некую конфигурацию культурных представлений и соответствующих эмоциональных норм, практикуемых сообществами («эмоциональные сообщества»). Эмоциональную культуру характеризует особое сочетание эмоциональных практик, стилей, сценариев, возникающих в ответ на разные стимулы, вызовы и угрозы. Поэтому наряду с усилением трево- 
ги и страха, может также сохраняться режим симпатии, а видимая бесчувственность - оборачиваться переживанием непризнанного стыда, имеющего свои особые последствия, стремление к контролю над эмоциями - сочетаться с фиксацией на разного рода переживаниях, поиске аутентичных чувств, культе чувств (Hochschild, 1983; Illouz, 2012; Gonzalez, 2012; Salmela, Mayer, 2009 и др.). Эмоции, как мы убеждаемся в том числе и с помощью книги Плампера, выступают высоко рефлексивными феноменами, и внимание к ним есть проявление общей социальной рефлексивности по поводу сложного и быстро изменяющегося мира (Giddens, 1990; Gonzalez, 2017). Рефлексивность выражается в рефлексивной идентичности, рефлексивной жизненной истории, а наблюдение за чувствами обеспечивает индивиду ощущение подлинности/аутентичности. Эмоции становятся «драйверами» морального выбора в стремлении подтвердить свою идентичность (Bauman, 1993: 67).

Таким образом, эмоциональная культура современных (западных) обществ представляет собой комбинацию рационального отношения к эмоциям и сопровождается коллективными (часто ограниченными институционально) всплесками энтузиазма и чрезмерным акцентированием отдельных чувств (например, подлинной романтической любви [Illouz, 2012], подлинного «Я» [Hochschild, 1983]). Эмоциональная рефлексивность, которая рассматривается как свойственная большинству социальных действий, характеризует индивидуальное сознание, которое схватывает сложный и быстро изменяющийся мир посредством чувств, преодолевая тем самым его сложность и фрагментированность и придавая ему через чувства целостность и подлинность. Это подкрепляется современной культурой потребления (Campbell, 2005) и развитием медиа (Gonzalez, 2012), которые производят соответствующие продукты и нарративы для осмысления себя (идентичности) в столь сложном мире. Эмоции становятся одним из основных инструментов социальной рефлексивности: люди не только интересуются самим эмоциональным опытом, но пытаются усваивать знания об эмоциях, чтобы управлять ими.

В целом «эмоциональный поворот» в науках и культуре обусловлен появлением новой эмоциональной рефлексивности: «эмоциональный поворот» можно назвать «неосентименталистским течением в современной науке», исследователи видят человека как [прежде всего] чувствующее существо, стремятся установить гносеологические, этические и эстетические основания человеческих переживаний, говорят о роли определенных эмоций в формировании личности и целых сообществ (Винницкий, 2012). Мы осмелимся назвать культуру современных обществ новым «чувствительным» веком, хотя она имеет свои особенности. Мы вовсе не исключаем, что у эмоционального поворота есть и другие причины, но упомянутые представляются наиболее общими и существенными.

Теперь научная картина мира не выглядит полной без изучения эмоциональных измерений человеческого опыта: эмоции представляются своего рода «ключом» к подлинному опыту человека. Сегодня социальный опыт индивида претерпевается через акцентирование его личных чувств. Различие между разумом 
и чувствами можно рассматривать как исторический социальный конструкт, на что указывают и современные исследования. Однако заметим, что человек одновременно и управляет эмоциями, и стремится к свободному их выражению, а рациональный индивидуализм сосуществует в современном мире с коллективным энтузиазмом и воодушевлением.

Задачей социологического исследования здесь является поиск того, при каких условиях и в соответствии с какими правилами люди управляют эмоциями. Эмоции помогают выстроить собственную идентичность, осуществляя оценку ситуации и коммуникативную функцию (Stets, Turner, 2014: 33-50). Эмоции являются динамичным переживанием моральных правил, влияют на ориентацию социальных действий и интерпретацию ситуаций, способствуют закреплению культурных символов, совмещая в себе одновременно и физическую, и когнитивную, и феноменологическую (языковую, культурную), а иногда явную поведенческую реакцию. Эмоции «говорят» индивиду о его связи с социальным миром, комментируют его интересы и стремления (Archer, 2003), являются источниками самопознания, «строительными блоками» идентичности. Книга Плампера еще долго не потеряет актуальности, поскольку способствует пониманию происходящего именно в этом ключе, выделяя важную роль проживаемого опыта человека, и одновременно дает возможность задуматься над генерализующими моделями эмоциональности, дальнейшей разработкой терминологии, методами изучения эмоций на основе документальных и визуальных источников. Социология эмоций, безусловно, обладает своими особенностями, но, отказавшись от фактологического богатства истории, рискует ошибаться, настаивая на обобщениях и общих тенденциях. В целом, вероятно, панэмотивизм современного общества даст возможность более глубокого проникновения в культуру, привлекая междисциплинарный потенциал науки.

\section{Литература}

Винницкий И. (2012). Заговор чувств, или Русская история на «эмоциональном повороте» // Новое литературное обозрение. № 117. С. 441-46о.

Бардина С. М. (2017). Психофармакологическое конструирование эмоций: Prozac против дуализма сознания и тела // Социология власти. Т. 29. № 3. С. 41-58.

Зорин А. Л. (2016). Появление героя: из истории русской эмоциональной культуры конца XVIII - начала XIX века. М.: Новое литературное обозрение.

Голубев A. (2018). Стыд за нацию: аффективная идентификация и политическое высказывание в России начала XXI века // Неприкосновенный запас. № 117. C. 309-327.

Плампер Я., Шахадат Ш., Эли М. (ред.) (2010). Российская империя чувств: подходы к культурной истории эмоций. М.: Новое литературное обозрение. 
Симонова О. А. (2016). Базовые принципы социологии эмоций // Вестник СанктПетербургского университета. Серия 12: Психология. Социология. Педагогика. № 4. C. $12-27$.

Фельдман Баррет Л. (2018). Как рождаются эмоции: революция в понимании мозга и управлении эмоциями / Пер. с англ. Е. Поникарова. М.: Манн, Иванов и Фербер.

Элиас Н. (2001). О процессе цивилизации. Т. 2 / Пер. с нем. А. М. Руткевича. М., СПб.: Университетская книга.

Ahmed S. (2004). The Cultural Politics of Emotion. Edinburgh: Edinburgh University Press.

Archer M. S. (2000). Being Human: The Problem of Agency. Cambridge: Cambridge University Press.

Barbalet J. M. (1999). Emotion, Social Theory and Social Structure: A Macrosociological approach. Cambridge: Cambridge University Press.

Bauman Z. (1993). Postmodern Ethics. Cambridge: Polity.

Beck U. (200o). The Risk Society and Beyond: Critical Issues for Social Theory. L.: SAGE.

Beck U., Beck-Gernsheim E. (2001). Individualization. Institutionalized Individualism and Its Social and Political Consequences. L.: SAGE.

Bericat E. (2016). The Sociology of Emotions: Four Decades of Progress // Current Sociology. Vol. 64. № 3. P. 491-513.

Campbell C. (2005). The Romantic Ethic and the Spirit of Modern Consumerism. Oxford: Blackwell.

Clark C. (1997). Misery and Company: Sympathy in Everyday Life. Chicago: University of Chicago Press.

Dixon T. (2003). From Passions to Emotions: The Creation of a Secular Psychological Category. Cambridge: Cambridge University Press.

Flamarique L. (2012). From the Psychologization of Experience to the Priority of Emotions in Social Life // González A. M. (ed.). The Emotions and Cultural Analysis. Burlington: Ashgate. P. 51-68.

Furedi F. (2004). Therapy Culture. Cultivating Vulnerability in an Uncertain Age. L.: Routledge.

Furedi F. (1997). Culture of Fear: Risk-taking and the Morality of Low Expectation. L.: Cassell.

Giddens A. (1990). Foreword // Scheff Th. Microsociology: Discourse, Emotion and Social Structure. Chicago: University of Chicago Press. P. ix-xiv.

González A. M. (2012). Emotional Culture and the Role of Emotions in Cultural Analysis // González A. M. (ed.). The Emotions and Cultural Analysis. Burlington: Ashgate. P. $1-18$.

Gonzalez A. M. (2017). In Search of a Sociological Explanation for the Emotional Turn // Sociologia, Problemas e Prácticas. № 85. P. 27-45.

Hochschild A. R. (1983). The Managed Heart: Commercialization of Human Feeling. Berkeley: Univ. of California Press. 
Hochschild A. R. (2007). The Commercialization of Intimate Life: Notes from Home and Work. Berkeley: University of California Press.

Hookway N. (2013). Emotions, Body and Self: Critiquing Moral Decline Sociology // Sociology. Vol. 47. № 4. P. 841-857.

Illouz E. (2007). Cold Intimacies: The Making of Emotional Capitalism. Cambridge: Polity.

Illouz E. (2012). Why Love Hurts: A Sociological Explanation. Cambridge: Polity.

Kalat J. W., Shiota M. N. (2007). Emotion. Belmont: Wadsworth.

Keltner, D., Gross, J. J. (1999). Functional Accounts of Emotions // Cognition \& Emotion. Vol. 13. № 5. P. 467-480.

Lasch Ch. (1979). The Culture of Narcissism: American Life in an Age of Diminishing Expectations. N.Y.: Norton.

Reddy W. M. (2001). The Navigation of Feeling: A Framework for the History of Emotions. Cambridge: Cambridge University Press.

Reiff Ph. (1987). The Triumph of the Therapeutic: Uses of Faith after Freud. N.Y.: Harper \& Row.

Rosenwein B. H. (2006). Emotional Communities in the Early Middle Ages. Ithaca: Cornell University Press.

Rosenwein B. (2002). Worrying about the Emotions in History // American Historical Review. Vol. 107. № 3. P. 821-845.

Salmela M., Mayer M. (2009). Emotions, Ethics and Authenticity. Amsterdam: John Benjamins.

Scheer M. (2012). Are Emotions a Kind of Practice (and is That What Makes Them Have a History)? A Bourdieuian Approach to Understanding Emotion // History and Theory. Vol. 51. № 2. P. 193-220.

Scheff Th. (1990). Microsociology: Discourse, Emotion and Social Structure. Chicago: University of Chicago Press.

Scheff Th. (2011). Social-Emotional World: Mapping a Continent // Current Sociology. Vol. 59. № 3. P. 347-361.

Scheff Th. (2014). The Ubiquity of Hidden Shame in Modernity // Cultural Sociology. Vol. 8. № 2. P. 129-141.

Sennett R. (2006). The Culture of the New Capitalism. New Haven: Yale University Press.

Stearns P. N., Stearns C. Z. (1985). Emotionology: Clarifying the History of Emotions and Emotional Standards // American Historical Review. Vol. 9o. № 4. P. 813-836.

Stets J. E., Turner J. H. (eds) (2014). Handbook of the Sociology of Emotions. Vol. 2. Berlin: Springer.

Turner J. H. (2007). Human Emotions: A Sociological Theory. L.: Routledge. 


\title{
The Study of Emotions as an Area of Interdisciplinary Cooperation: The History and Sociology of Emotions in the Search for the Explanation of "Emotional Turn" (On the Russian Translation of the Jan Plamper's The History of Emotions)
}

\author{
Olga Simonova \\ Candidate of Sociological Sciences, Associate Professor, Department of Sociology, National Research University \\ Higher School of Economics
}

Address: Myasnitskaya str., 20, Moscow, Russian Federation 101000

E-mail: osimonova@hse.ru

A review of Y. Plamper's book The History of Emotions could hardly reflect its content of the process of the emergence of the history of the discipline of emotions, and the rich variety of problems and themes in the field of emotion research. Therefore, the topic of this article concerns the meaning of this monograph for the sociological study of emotions. We tried to highlight the points of the intersection of the history and the sociology of emotions, including the sociological explanation of the so-called "emotional turn" in social sciences and humanities and in everyday life of contemporary society. The main theoretical and methodological opposition - social constructivism versus universalism/naturalism - pervades all sciences researching emotions today, and a researcher's destiny depends on the choice within the framework of this opposition. Plamper's book allows the making of that choice, while inciting researchers to a synthetic approach. The book helps to refine and enrich the sociological study of emotions on the basis of factual evidence and new terminology. One of the most important tasks of both disciplines is the explanation of the changes of the emotional culture of modern societies, which, according to the author of the article, involves an "explosion" of interest in emotions in theory, research, and everyday life. Perhaps a new "sentimental age" has begun as an unintended consequence of the rationalization of all spheres of society. The combination of a rational attitude to emotions and, at the same time, the special attention to feelings, the explosions of collective emotions, and the persistent searching for authentic feelings are features of the emotional culture of our time.

Keywords: the history of emotions, the sociology of emotions, constructivism and universalism, emotional culture, rationalization, emotional reflexivity

\section{References}

Ahmed S. (2004) The Cultural Politics of Emotion, Edinburgh: Edinburgh University Press.

Archer M. S. (2000) Being Human: The Problem of Agency, Cambridge: Cambridge University Press.

Barbalet J. M. (1999) Emotion, Social Theory and Social Structure: A Macrosociological approach,

Cambridge: Cambridge University Press.

Bardina S. (2017) Psikhofarmakologicheskoe konstruirovanie emotsiy: Prozac protiv dualizma soznaniya i tela [Psychopharmacology Constructing Emotions: Prozac versus Mind-Body Dualism]. Sociology of Power, vol. 29, no 3, pp. 41-58.

Bauman Z. (1993) Postmodern Ethics, Cambridge: Polity.

Beck U. (2000) The Risk Society and Beyond: Critical Issues for Social Theory, London: SAGE.

Beck U., Beck-Gernsheim E. (2001) Individualization: Institutionalized Individualism and Its Social and Political Consequences, London: SAGE.

Bericat E. (2016) The Sociology of Emotions: Four Decades of Progress. Current Sociology, vol. 64, no 3, pp. 491-513.

Campbell C. (2005) The Romantic Ethic and the Spirit of Modern Consumerism, Oxford: Blackwell.

Clark C. (1997) Misery and Company: Sympathy in Everyday Life, Chicago: University of Chicago press.

Dixon T. (2003) From Passions to Emotions: The Creation of a Secular Psychological Category,

Cambridge: Cambridge University Press. 
Elias N. (2001) O processe civilizacii. T. 2 [On the Process of Civilisation, Vol. 2], Moscow: Universitetskaya kniga.

Feldman Barret L. (2018) Kak rozhdayutsya emotsii. Revolyutsiya v ponimanii mozga i upravlenii emotsiyami [How Emotions are Made: The Secret Life of the Brain], Moscow: Mann, Ivanov i Ferber.

Flamarique L. (2012) From the Psychologization of Experience to the Priority of Emotions in Social Life. The Emotions and Cultural Analysis. (ed. A. M. González), Burlington: Ashgate, pp. 51-68.

Furedi F. (2004) Therapy Culture: Cultivating Vulnerability in an Uncertain Age, London: Routledge. Furedi F. (1997) Culture of Fear: Risk-taking and the Morality of Low Expectation, London: Cassell. Giddens A. (1990) Foreword. Scheff Th., Microsociology: Discourse, Emotion and Social Structure, Chicago: University of Chicago Press, pp. ix-xiv.

Golubev A. (2018) Styd za natsiyu: affektivnaya identifikatsiya i politicheskoe vy-skazyvanie v Rossii nachala XXI veka [Nation Shame: Affective Identification and Political Rhetoric in Russia in the Early 21st Century]. Neprikosnovenny zapas, no 117, pp. 309-327.

González A. M. (2012) Emotional Culture and the Role of Emotions in Cultural Analysis. The Emotions and Cultural Analysis (ed. A. M. González), Burlington: Ashgate, pp. 1-18.

Gonzalez A. M. (2017) In Search of a Sociological Explanation for the Emotional Turn. Sociologia, Problemas e Prácticas, no 85, pp. 27-45.

Hochschild A. R. (1983) The Managed Heart: Commercialization of Human Feeling, Berkeley: University of California Press.

Hochschild A. R. (2007) The Commercialization of Intimate Life: Notes from Home and Work, Berkeley: University of California Press.

Hookway N. (2013) Emotions, Body and Self: Critiquing Moral Decline Sociology. Sociology, vol. 47, no 4 , pp. 841-857.

Illouz E. (2007) Cold Intimacies: The Making of Emotional Capitalism, Cambridge: Polity Press.

Illouz E. (2012) Why Love Hurts: A Sociological Explanation, Cambridge: Polity Press.

Kalat J. W., Shiota M. N. (2007) Emotion, Belmont:Wadsworth.

Keltner, D., Gross, J. J. (1999). Functional Accounts of Emotions. Cognition \& Emotion, vol. 13, no 5, pp. 467-480.

Lasch Ch. (1979) The Culture of Narcissism: American Life in an Age of Diminishing Expectations, New York: Norton.

Plamper Y. (2018) Istoriya emotsiy [The History of Emotions], Moscow: New Literary Observer.

Plamper Y., Shakhadat Sh., Eli M. (eds.) (2010) Rossiyskaya imperiya chuvstv: podkhody k kul'turnoy istorii emotsiy [Russian Empire of Feelings: An Approaches to the Cultural History of Emotions], Moscow: New Literary Observer.

Reddy W. M. (2001) The Navigation of Feeling: A Framework for the History of Emotions, Cambridge: Cambridge University Press.

Reiff Ph. (1987) The Triumph of the Therapeutic: Uses of Faith after Freud, New York: Harper \& Row.

Rosenwein B. H. (2006) Emotional Communities in the Early Middle Ages, Ithaca: Cornell University Press.

Rosenwein B. (2002) Worrying about the Emotions in History. American Historical Review, vol. 107, no 3, pp. 821-845.

Salmela M., Mayer M. (2009) Emotions, Ethics and Authenticity, Amsterdam: John Benjamins.

Scheer M. (2012) Are Emotions a Kind of Practice (and is That What Makes Them Have a History)? A Bourdieuian Approach to Understanding Emotion. History and Theory, vol. 51, no 2, pp. 193-220.

Scheff Th. (1990) Microsociology: Discourse, Emotion and Social Structure, Chicago: University of Chicago Press.

Scheff Th. (2011) Social-Emotional World: Mapping a Continent. Current Sociology, vol. 59, no 3, pp. 347-361.

Scheff Th. (2014) The Ubiquity of Hidden Shame in Modernity. Cultural Sociology, vol. 8, no 2, pp. 129-141.

Sennett R. (2006) The Culture of the New Capitalism, New Haven: Yale University Press.

Simonova O. (2016) Bazovye printsipy sotsiologii emotsiy [Basic Principles of the Sociology of Emotions]. Vestnik SPbSU. Sociology, no 4, pp. 12-27. 
Stearns P. N., Stearns C. Z. (1985) Emotionology: Clarifying the History of Emotions and Emotional Standards. American Historical Review, vol. 90, no 4, pp. 813-836.

Stets J. E., Turner J. H. (eds.) (2014) Handbook of the Sociology of Emotions, Vol. 2, Berlin: Springer.

Turner J. H. (2007) Human Emotions: A Sociological Theory, London: Routledge.

Vinnitsky I. (2012) Zagovor chuvstv ili russkaya istoriya na "emotsional'nom povorote" [Conspiracy of Feelings; or, The Russian History on the "Emotional Turn"]. New Literary Observer, no 117, pp. 441-460.

Zorin A. (2016) Poyavlenie geroya: iz istorii russkoy emotsional'noy kul'tury kontsa XVIII — nachala XIX veka [Appearance of the Character: Excerpts from the History of Russian Emotional Culture of the late 18th — early 19th centuries], Moscow: New Literary Observer. 


\title{
Социальная мобильность: успех или неудача?*
}

LAWLER S., PAYNE G. (EDS.). (2018). SOCIAL MOBILITY FOR THE 21ST CENTURY: EVERYONE A WINNER? L.: ROUTLEDGE. 184 P. ISBN 9781315276588

\author{
Александрина Ваньке \\ Кандидат социологических наук, докторант Школы социальных наук \\ Манчестерского университета \\ Научный сотрудник Государственного академического университета гуманитарных наук \\ Aдpec: Oxford Road, Arthur Lewis Building, Manchester, UK M13 9PL \\ E-mail: a.vanke@postgrad.manchester.ac.uk
}

Книга «Социальная мобильность в XXI веке: все в выигрыше?» под редакцией Стеф Лоулер и Джеффа Пэйна, вышедшая в серии «Социология будущего», попалась мне на глаза во время участия в ежегодной конференции Британской социологической ассоциации «Идентичности, сообщества и социальная солидарность», прошедшей в Ньюкасле в 2018 году. Неудивительно, что в Великобритании, где сегодня ведутся жаркие дебаты о том, следует ли правительству работать над стимулированием восходящей мобильности, данная книга представляет критический взгляд на проблему не-мобильности уязвимых социальных групп. Ее авторы ставят под вопрос традиционные модели изучения социальных перемещений в жестко иерархизированных обществах.

Во введении Лоулер и Пэйн предлагают добавить новые измерения в устоявшиеся исследовательские подходы к анализу социальной мобильности. Речь идет о необходимости уделять больше внимания политическому, идеологическому и социальному контекстам при анализе социальных перемещений. Другими словами, важно не только изучать количественные показатели межпоколенной мобильности, зафиксированной в один момент времени, но и учитывать изменения социальной среды, рынка труда, карьерных структур и стратегий приема на работу (р. 1-2). Лоулер и Пэйн не отрицают значимости классических подходов, но показывают, что аппарат Пьера Бурдье с его понятиями «габитуса», «капиталов» и «классов» открывает новые возможности для анализа мобильности (р. 2). Редакторы провозглашают методологический плюрализм, для которого значим как количественный, так и качественный анализ, что позволяет посмотреть на

(c) Ваньке А. В., 2018

() Центр фундаментальной социологии, 2018

DOI: $10.17323 / 1728-192 \mathrm{X}-2018-3-379-388$

* Статья подготовлена в рамках проекта «Межпоколенная социальная мобильность от XX века к XXI: четыре генерации российской истории», поддержанного Российским научным фондом. Грант № 14-28-00217. 
социальную мобильность как на идеологический дискурс (р. 5). В этом смысле большинство глав книги содержат критику неолиберальной идеологии, в основе которой лежит принцип: «Каждый может стать победителем, если будет хорошо стараться» (р. 7). На материалах социологических исследований авторы опровергают данный тезис и показывают обратную сторону социального восхождения, которое окрашено не только позитивными чувствами, но и сопровождается эмоциональными издержками (р. 11).

В первой главе «Социальная мобильность: какие пути сейчас есть?» Пэйн дает краткий обзор исследований мобильности. Он начинает с обсуждения ранних проектов по социальной мобильности в Англии, посвященных вопросу о том, насколько сыновья наследуют рабочие профессии отцов (р. 13). Затем он переходит к рассмотрению концепции Питирима Сорокина о вертикальной, горизонтальной и альтернативной мобильности, получившей распространение на севере Соединенных Штатов Америки (р. 14, 15). Далее Пэйн уделяет внимание проектам Лондонской школы экономики 1940-х годов, рассматривавших проблемы образовательной политики, брачной мобильности, трехпоколенной мобильности, субъективных аспектов мобильности и др. (р. 14). Завершается обзор обсуждением подходов Джона Голдторпа и Пьера Бурдье. Пэйн приходит к выводу, что наибольший интерес на сегодняшний день представляет бурдьевистская перспектива, поскольку она позволяет проследить в динамике, как индивиды проживают, ощущают и проговаривают свои жизненные истории после того, как они совершили социальные перемещения (р. 16).

Основной посыл главы Пэйна заключается в том, что на первый план должен выйти анализ абсолютной мобильности и рынка труда. Автор утверждает, что различия между типами занятости изменяются с течением времени, поэтому социальные дистанции между социальными классами тоже меняются (р. 17). Такой фокус изучения показывает, как трансформируется положение социальных групп в социальном пространстве по мере того, как происходит их релокация на рынке труда (р. 18). Другой аргумент Пэйна состоит в необходимости учета гендера при анализе профессиональной мобильности. Согласно данным Социально-экономической классификации национальной статистики (NS-SeC), шансы женщин на успешное продвижение на рынке труда ограничены по сравнению с возможностями мужчин (р. 21). В завершение автор заключает, что для современного британского общества наиболее реалистичным все же оказывается лозунг «Большинство из нас неудачники», а сама мобильность и политические дебаты о ней только легитимируют социальное неравенство (р. 22-23).

Во второй главе «Разрыв с семьей рабочего класса: истоки социальной мобильности и habitus clivé» Марк Маллман сосредоточивается на анализе расщепленного габитуса на материалах 29 нарративных интервью с австралийцами, выходцами из рабочих семей, осуществившими вертикальную мобильность. Как пишет Маллман, расщепленный габитус представляет собой разлом в восприятии своей самости, внутренний конфликт, возникающий при переходе из одной среды в дру- 
гую (р. 26). Тема расколотого габитуса приобретает все большую популярность среди социологов. Немногим ранее авторы книги «Бурдье: следующее поколение. Развитие интеллектуального наследия Бурдье в современной социологии Великобритании», изданной под эгидой БСА, уже обращались к проблеме habitus clivé. Например, социолог Сэм Фридман описывает эмоциональные эффекты восходящей мобильности при вхождении в группу элит ${ }^{1}$. Социологи Никола Инграм и Джесси Абрахамс разрабатывают типологию разрывов габитуса ${ }^{2}$.

Исходная посылка исследования Маллмана состоит в том, что родительская семья зачастую передает не только экономические преимущества или невыгодное положение, но и габитус, представляющий собой систему переносимых диспозиций, вписанных в тело (р. 25, 31). Вместе с тем автор отмечает, что семьи рабочих гетерогенны (р. 26). Они отличаются друг от друга по возможностям, которые родители могут дать детям для построения «успешных» социальных траекторий. Опрошенные Маллманом делали акцент на том, что их социальное восхождение служит осуществлением нереализованного в свое время семейного потенциала (р. 29). Это означает по меньшей мере то, что, с одной стороны, родители информантов ориентировали их на достижение и социальный успех, а с другой настаивали на том, чтобы информанты не отрывались от семьи (р. 30). В этом противоречии Маллман усматривает внутреннее напряжение, приводящее к расщепленному габитусу информантов, осуществивших вертикальную мобильность в средний класс. Таким образом, автор приходит к выводу, что рабочие семьи до сих пор могут быть источником для социального восхождения, но в то же самое время они неявным образом воспроизводят неравенства и служат условием для возникновения расщепленного габитуса (р. 35-36).

Третья глава «Мобильные не-мобильности: формирование габитуса в „уязвимых“ семьях», написанная в соавторстве с Марией Гарднер, Кирсти Моррин и Джеффом Пэйном, основывается на эмпирическом исследовании изменений габитуса у представителей двух социальных групп. Авторы сравнивают способности к адаптации в новой среде: 1) студентов из «приемной» группы в возрасте от 18 до 27 лет, в детстве разорвавших со своими биологическими родителями и находившихся под опекой не менее 6 месяцев (р. 40), и 2) студентов рабочего происхождения из группы «Улица Стед», где традиционно живут белые британцы, представители рабочего класса, занятые в сервисе или на производстве (р. 41). Исследование показывает, что студенты из «приемной» группы демонстрируют бо́льшую гибкость и способность справляться с ситуациями, типичными для образовательной среды, где доминирует средний класс (р. 43), по сравнению со сту-

1. Friedman S. (2016). The Limits of Capital Gains. Using Bourdieu to Understand Social Mobility into Elite Occupations. // Thatcher J., Ingram N., Burke C., Abrahams J. (eds.) Bourdieu: The Next Generation. The Development of Bourdieu's Intellectual Heritage in Contemporary UK Sociology. L.: Routledge. P. 107-122.

2. Ingram N., Abrahams J. (2016). Stepping Outside of Oneself. How a Cleft Habitus Can Lead to Greater Reflexivity Through Occupying "the Third Space" // Thatcher J., Ingram N., Burke C., Abrahams J. (eds.) Bourdieu: The Next Generation. The Development of Bourdieu's Intellectual Heritage in Contemporary UK Sociology. L.: Routledge. P. 140-156. 
дентами из рабочих семей. Габитус представителей «приемной» группы обладает рефлексивностью и адаптивностью, что, однако, не означает их способности к интеграции (р. 45).

Для габитуса жителей улицы Стед, информантов из рабочего класса, характерен отказ от получения высшего образования из-за страха влезть в долги (р. 47). Следует пояснить, что высшее образование в Англии полностью платное, но у британцев вне зависимости от классовой принадлежности есть возможность получить государственный кредит на обучение в университете, который они выплачивают после устройства на работу. Однако, как пишут авторы, молодые люди из рабочих семей испытывают нужду в деньгах. Отказываясь продолжать обучение из-за страха не выплатить долг, они делают выбор в пользу работы на производстве или в сервисе (р. 48). Авторы объясняют данную ситуацию тем, что родители студентов с Улицы Стед желают своим детям лучшей жизни, но не дают им ориентиров для достижений и не ставят перед ними четких образовательных задач (р. 49). Для женщин из рабочих семей типичен отказ от получения высшего образования в пользу раннего замужества и социально одобряемого материнства (р. 52). К схожим выводам мы приходим с Ириной Тартаковской в нашей статье об условиях выбора карьеры рабочего, написанной на российских данных ${ }^{3}$.

Четвертая глава «Поднимаясь вверх и держась на плаву: понимание социальной мобильности через три поколения в Великобритании» за авторством Викки Боливер и Элис Сулливан строится на количественных данных Британского исследования когорт (BCS70), которое представляет собой лонгитюдный проект, направленный на изучение социальной мобильности индивидов, рожденных в Англии в одну неделю в 1970 году (р. 56). Данные опроса содержат информацию о классовых позициях трех поколений семей. В ходе исследования проводятся регулярные замеры классовых позиций респондентов в следующих возрастах: о, 5, $10,16,26,29-30,34-35,38$ и 42 года; кодируется профессия отца в соответствии со схемой, состоящей из 6 классовых групп (the Registrar General's class schema) (p. 56). Для изучения траекторий мобильности представителей рабочего и среднего классов в двухпоколенной и трехпоколенной перспективах авторы используют простые проценты (р. 57). Они также рассчитывают разницу между позицией третьего поколения, попавшего в средний класс, и позицией отцов из рабочего/среднего классов и дедушек по отцовской линии (р. 57).

Расчет абсолютной мобильности в трехгенерационной перспективе показывает, что около 6о\% участников исследования происходят из первого поколения семей среднего класса, то есть их отцы совершили вертикальную мобильность в средний класс (р. 57, 59). Двухгенерационная перспектива демонстрирует, что только 27,8\% детей совершили вертикальную мобильность в средний класс, при этом большинство из них происходили из устойчивых семей рабочего класса (long-standing working-class families) (p. 59). Вместе с тем двухгенерационная пер-

3. Тартаковская И. Н., Ваньке А. В. (2016). Карьера рабочего как биографический выбор // Социологическое обозрение. Т. 15. № 3. С. 9-48. 
спектива дает следующий результат: 37,4\% детей из рабочего класса немобильны, а дочери с меньшей долей вероятности по сравнению с сыновьями достигают позиций среднего класса по всем категориям происхождения (р. 59). Расчет относительной мобильности шансов с точки зрения трех поколений свидетельствует о том, что дети из семей среднего класса с намного большей вероятностью останутся в среднем классе по сравнению с детьми из семей первого поколения среднего класса (р. 6о). А большинство тех, кто осуществил нисходящую мобильность, происходят из семей, которые совершали социальное восхождение лишь в одном поколении (р. 6о). Боливер и Сулливан заключают, что трехгенерационная перспектива позволяет реконструировать более нюансированно процессы социальных перемещений, нежели двухгенерационная перспектива. В этом смысле проект «Межпоколенная социальная мобильность от XX века к XXI: четыре генерации российской истории», участницей которого я являюсь, объединяя несколько баз данных, показывает полную картину мобильности четырех поколений с учетом трансформации социально исторического контекста ${ }^{4}$.

Глава пятая «Время, аккумуляция и траектория: Бурдье и социальная мобильность», написанная Сэмом Фридманом и Майком Сэвэджем, обращает читателя к теме темпоральности мобильности, которая практически не изучена в современной социологии. В первой части главы авторы делают критический обзор существующих способов изучения мобильности и приходят к выводу о том, что классические таблицы мобильности (например, Голдторпа) фиксируют лишь два момента времени: класс происхождения и класс прибытия (р. 68). Более сложные процедуры лог-линейного моделирования позволяют проследить тенденции на протяжении времени, однако большинство исследователей сходятся во мнении, что отображение времени линейно будет значительным упрощением сложных временны́х траекторий (р. 68). Фридман и Сэвэдж признают вклад Голдторпа в исследования мобильности, но критикуют его подход за то, что он в большей степени сосредоточен на межпоколенной мобильности, нежели внутрипоколенной (р. 70). По этой причине авторы обращаются к аналитическому аппарату Бурдье и переосмысляют его социологию с точки зрения динамического изменения как габитуca, так и социальных структур. Цитируя Бурдье, авторы подчеркивают тезис о том, что социальные классы обладают различной темпоральностью и историчностью (р. 73), а мобильность осуществляется во времени и сквозь время (р. 74).

Фридман и Сэвэдж утверждают, что такие концепты бурдьевистской социологии, как «сила» и «траектория», позволяют более детально и тонко описать процессы социальной мобильности. Однако центральным концептом для них все-таки служит габитус, который характеризуется инертностью и обладает темпоральностью. Иными словами, габитус представляет собой забытую историю. Другой важный концепт, который вводят авторы главы, - понятие «стеклянного потолка», позаимствованное ими из феминистской критики и преобразованное

4. Семенова В. В., Черныш М. Ф., Ваньке А. В. (ред.). (2017). Социальная мобильность в России: поколенческий аспект. М.: Институт социологии РАН. 
до «классового потолка» (р. 75). Понятие «классовый потолок» обозначает объективные пределы и барьеры для вертикальной мобильности. Эффекты классового потолка проявляются, например, в том, что индивиды, совершившие социальное восхождение, получают меньшую зарплату по сравнению с теми, кто занимал высокие позиции изначально (р. 75). И, наконец, еще один концепт, пригодный для анализа значительной вертикальной мобильности, - это понятия «расщепленного габитуса» (habitus clivé) и «гистерезиса» (hysteresis) ${ }^{5}$, к которым обращаются авторы и других глав книги (например, см. главу 2). В завершение Фридман и Сэвэдж резюмируют: бурдьевистский категориальный аппарат дает более полное понимание микропроцессов социальной мобильности и позволяет объяснить эмоциональные эффекты социальных перемещений (р. 79).

В шестой главе «Продолжая двигаться вверх? Социальная мобильность, класс и высшее образование» Харриет Брэдли делится результатами своего лонгитюдного качественного исследования мобильности выпускников двух высших учебных заведений: Университета Западной Англии и Бристольского университета. Автор отмечает, что, с одной стороны, сегодня британские политики только и говорят, что о социальной мобильности (р. 81) и о необходимости ее интенсификации. С другой стороны, учеба в так называемом Оксбридже (производное от соединения названий двух топовых университетов Оксфорда и Кембриджа) и в престижных университетах группы Рассел по-прежнему работает на воспроизводство социального неравенства, открывая своим выпускникам путь к высоким позициям и высокооплачиваемой работе (р. 81). Тезис о классовом воспроизводстве через высшее образование в Великобритании подтверждают и результаты количественно-качественного исследования под руководством Майка Сэвэджа, результаты которого изложены в книге «Социальный класс в XXI веке» ${ }^{6}$.

В своем исследовании Брэдли отталкивается от подходов Голдторпа и Бурдье, учитывает актуальную политическую повестку и формирует свое альтернативное видение социальной мобильности, согласно которому позиции всех уязвимых социальных слоев должны быть улучшены с помощью социальной политики государства (р. 82). Для демонстрации влияния классового происхождения на образовательный опыт студентов и их последующие стратегии поиска работы Брэдли с 2010 года проводит интервью на выборке в 90 студентов, окончивших два английских университета в Бристоле. Следует пояснить, что в практически ориентированный Университет Западной Англии поступают студенты с более низким социальным происхождением (р. 82). Данный университет славится тем, что интегрирует своих выпускников в локальные фирмы. В то время как в Бристольском университете из группы Рассел, ориентированном на исследовательскую деятельность, обучаются студенты из привилегированного среднего класса (р. 82).

5. Про расщепленный габитус и гистерезис см. подробнее: Friedman S. (2016). Habitus Clivé and the Emotional Imprint of Social Mobility // Sociological Review. Vol. 64. № 1. P. 129-147.

6. Savage M., Cunningham N., Devine F., Friedman S., Laurison D., McKenzie L., Miles A., Snee A., Wakeling P. (2015). Social Class in the 21st Century. L.: Pelican. 
В ходе анализа интервью Брэдли приходит к выводу о том, что статус университета, имя научного руководителя, общий балл диплома, с которым студенты выходят из университета, оказывают влияние на дальнейшую карьерную траекторию выпускника (р. 85). Однако ключевым фактором для получения хорошей работы служит социальный капитал родителей или родственников выпускника или ее/его умение ориентироваться в сфере, где предполагается вести поиск хорошей позиции (р. 84). Как отмечает автор, выходцы из рабочих семей с большой вероятностью не будут обладать необходимыми экономическими ресурсами для оплаты обучения в магистратуре и не смогут позволить себе прохождение неоплачиваемой практики, например, в престижных фирмах Лондона, поскольку не располагают ни связями, ни финансовыми возможностями (р. 85). Тем не менее, как заключает автор, индивидуальная вертикальная мобильность выходцев из рабочего класса до сих пор еще возможна, в случае если эти студенты продолжают обучение и отправляются на поиски рабочих мест после получения магистерской степени (р. 91). При этом Брэдли акцентирует внимание на том, что все не могут занять высшие позиции, поскольку их набор ограничен, поэтому, по ее мнению, политики должны фокусироваться не на стимулировании восходящей мобильности, а работать над улучшением уровня жизни уязвимых социальных групп и над уменьшением социального неравенства (р. 92).

Седьмая глава «„Чтобы совершить социальное восхождение, ты должна быть шведкой“: женская вертикальная классовая мобильность в неолиберальном социальном государстве Швеции» написана Леной Золь по мотивам ее диссертации. В исследовании приняли участие 16 информанток в возрасте 25 и 34 лет, родившихся в рабочих семьях мигрантов и проживающих в настоящее время в Швеции. Все опрошенные совершили социальное восхождение за счет получения высшего образования (р. 93). Однако для того, чтобы стать успешными и мобильными в шведской системе, необходимо отказаться от идентичности рабочего класса, который расово маркирован (р. 94). В силу того что с конца 1970-х годов Швеция перешла от модели социального государства к неолиберальной модели, новый шведский рабочий класс теперь зачастую не имеет образования и работы или оформлен по временным контрактам (р. 99), живет в бедности, характеризуется опытом миграции, дискриминируется в силу расовых и этнических признаков на рынке труда (р. 96). По словам информанток Золь, сегодня рабочий класс фактически представляет собой социальные низы (underclass, понятие, которое используется в интервью) (р. 99). По этой причине участницы исследования отмежевываются от культуры и среды рабочих мигрантов, из которой они происходят, и стремятся перенять национальную шведскую идентичность, чтобы иметь возможность для «более хорошей» жизни (р. 102).

В главе восьмой «Опыт восходящей мобильности: случай самозанятых предпринимателей» Андреас Гиазитзоглу описывает мужской опыт мелких предпринимателей после совершения ими восходящей мобильности в средний класс. В фокусе рассмотрения исследователя два кейса - жизненные истории гетеро- 
сексуальных белых мужчин-англичан в возрасте 50-58 лет по имени Том и Денни, создавших мелкий бизнес в сельской местности в Англии. Оба они происходят из семей рабочего класса, женаты и не имеют детей (р. 109). Гиазитзоглу выделяет три ключевые темы, определяющие их жизненные нарративы. Во-первых, Том и Денни испытывают фрустрацию и нетерпение - категории, с помощью которых они описывают свой опыт восходящей мобильности (р. 110). Они хотели бы уже сейчас иметь больше финансовой прибыли, поскольку верят, что расширение потребления позволит им приобрести новый статус (р. 111). Во-вторых, оба информанта не демонстрировали успехов в школе и, как следствие, приобрели габитусную неуверенность. Однако по мере развития бизнеса чувство их уверенности в себе резко возросло и даже превратилось в некотором роде в высокомерие по отношению к тем, кто не может работать на себя (р. 113). И, наконец, третья тема, определяющая рассказ о мобильности, связана с ролью супруг двух бизнесменов в достижении ими профессионального успеха. Том и Денни признают, что именно жены через поддержку и заботу стимулировали их к вертикальной мобильности, а также предостерегали от чрезмерных денежных трат. Гиазитзоглу резюмирует, что случаи Тома и Денни показывают двойственность их восходящей мобильности. Несмотря на то что оба они достигли определенной экономической независимости, тем не менее их положение по-прежнему остается неустойчивым, ставя под сомнение их статус как успешных мужчин-бизнесменов (р. 116).

В главе девятой «Разговор о социальной мобильности: производство классов в неолиберальное время» Стеф Лоулер сосредотачивается на формах репрезентации социальной мобильности в публичной речи, а именно в отчетах экспертноаналитических центров и секретариата кабинета министров в период с 2009 по 2016 год. В этих отчетах социальная мобильность выступает как абсолютно «хорошая вещь», и ассоциируется она с прогрессом (р. 121). Данные отчеты формируют представление о том, что социальное происхождение генерирует неравенство доходов, а социальный «успех» приходит только в случае, если индивид обладает «правильными» устремлениями, установками и характером (р. 121). Лоулер делает вывод, что разговоры о социальной мобильности конструируют определенный тип субъективности - индивидуальности, способной к осуществлению вертикальной мобильности. При этом фактор классовой принадлежности исключается из рассмотрения составителями отчетов. Так, публичный дискурс о мобильности в Великобритании конструирует образ субъектов, которые ценятся в силу того, что полностью отвечают запросам рынка (р. 123). Однако субъективность мобильных индивидов отражает лишь черты среднего класса (р. 132), например, целеустремленность, организованность, достижительность и т.д. В рамках данной неолиберальной идеологии представители рабочего класса заведомо обладают «не тем характером», что фактически натурализует недостаток культурного капитала и отсутствие социальных связей у рабочих (с. 122).

Тему индивидуальной ответственности за социальное восхождение в неолиберальном обществе развивает Тони Чапман в десятой главе «Продвижение со- 
циальной мобильности молодежи: применение социологической перспективы к анализу целей социальной политики». Глава представляет результаты анализа государственных программ по стимулированию мобильности молодежи в Великобритании. Чапман выстраивает свою аргументацию вокруг тезиса о том, что молодые люди, происходящие из более депривированных или маргинальных социальных групп, должны преодолеть бо́льшую дистанцию в социальной иерархии для достижения успеха (р. 140) по сравнению с теми, кто происходит из более привилегированных классов. Автор утверждает, что представители среднего класса обладают специфическими знаниями для навигации в образовательных системах и на рынке труда, что позволяет им получать доступ к более хорошей, стабильной и высокооплачиваемой работе (р. 144). Данный тезис Чапмана перекликается с аргументом Чарли Уокера о том, что российская рабочая молодежь, получая среднее образование, не обладает навыками навигации на рынке образования и труда, что приводит в неолиберализирующемся российском обществе к их нисходящей мобильности ${ }^{7}$. Чапман заключает, что правительственные программы по интенсификации мобильности, составленные представителями среднего и высшего классов, не учитывают тот факт, что барьеры для социального восхождения в случае рабочего класса намного выше и что не все рабочие желают быть мобильными, предпочитая оставаться в привычной для себя среде и культуре, которая представляет для них ценность (р. 144).

Социолог Дайан Рей поднимает вопрос личных издержек социального восхождения в заключительной главе «Жестокость социальной мобильности. Индивидуальный успех за счет коллективной неудачи». С первых страниц автор обрушивается с критикой на капиталистическую систему Великобритании и на укоренившиеся в ней неравенства, оправдываемые неолиберальной идеологией. Социальную несправедливость по отношению к выходцам из уязвимых социальных групп - мигрантов и рабочих - Рей демонстрирует на двух кейсах. Первый случай основан на биографическом интервью автора с 18-летним студентом из бангладешской семьи беженцев, проживающим в Англии (р. 153). Информант, не обладая достаточными социальными связями и финансами, стремится своими действиями изменить порядок вещей, сделать мир более справедливым. По этой причине он учится на юриста и в будущем планирует помогать своей многодетной семье, которая находится на социальном дне. Второй кейс строится вокруг биографического сюжета из жизни самой Рей, которая происходит из рабочего класса, в силу чего в детстве и студенчестве она подвергалась стигматизации со стороны учителей и преподавателей, которые оценивали ее шансы на социальный успех как минимальные (р. 154-155). Отмечу, что на данный момент Дайан Рей является профессором Кембриджского университета и получила признание как специалист по образовательному неравенству.

7. Walker C. (2011). Learning to Labour in Post-Soviet Russia: Vocational Youth in Transition. L.: Routledge. P. 167. 
Однако в главе Рей приходит к неутешительным выводам о последствиях социального неравенства и индивидуализированном проекте социального восхождения. Она отмечает, что социальная мобильность зачастую не приносит удовлетворения и не делает людей счастливыми или более свободными, как принято считать, а производит негативный эффект на эмоциональную жизнь индивида. В этом состоят издержки и жесткость социальной мобильности (р. 147). Политики утверждают, что все хотят быть мобильными, но молодые люди из рабочего класса могут желать чего-то другого, например, лучшей жизни для людей той среды, из которой они происходят (р. 156). В этом смысле социальная мобильность в обществах с сильным неравенством скорее - неудача, нежели успех (р. 157). Мобильные индивиды становятся более равными с привилегированными людьми, но оказываются в неравных отношениях с теми, кого они любят и о ком заботятся (р. 157).

После прочтения книги становится понятно, что социальная мобильность характеризуется амбивалентностью и должна рассматриваться более нюансированно, чем это делалось ранее в классических подходах. Производя позитивный эффект на жизнь отдельных индивидов, социальное восхождение отражается негативно на их эмоциональном состоянии и субъективном благополучии, поскольку они отрываются от среды своего происхождения, покидая близких людей, которые по-прежнему находятся в уязвимом положении. В этой связи мобильные индивиды одновременно оказываются победителями и проигравшими, а единичные случаи вертикальной мобильности могут субъективно восприниматься и как успех, и как неудача. Социологи сходятся во мнении, что сегодня социальная мобильность, о которой так много дискутируют политики и разработчики социальных программ, является частью дискурса, определяемого неолиберальной идеологией. Именно поэтому на страницах книги авторы аргументированно доказывают, что главная проблема, о которой важно и нужно говорить, - это не мобильность, а социальные неравенства.

\title{
Social Mobility: Success or Failure?
}

\author{
Alexandrina Vanke \\ PhD Student, School of Social Sciences, University of Manchester \\ Candidate of Sociological Sciences, Research Fellow, State Academic University for the Humanities \\ Address: Oxford Road, Arthur Lewis Building, Manchester, UK M13 9PL \\ E-mail: a.vanke@postgrad.manchester.ac.uk
}

Book Review: Steph Lawler, Geoff Payne (eds.) Social Mobility for the 21st Century: Everyone a Winner? (London: Routledge, 2018). 
АРОНСОН О. (2017). СИЛЫ ЛОЖНОГО: ОПЫТЫ НЕПОЛИТИЧЕСКОЙ ДЕМОКРАТИИ. М.: ФАЛАНСТЕР. 446 C. ISBN 978-999999-0-42-4

\author{
Александра Володина \\ Аспирант Института философии Российской академии наук \\ Адрес: ул. Гончарная, д. 12, стр. 1, г. Москва, Российская Федерация 109240 \\ E-mail: sasha.volodina@gmail.com
}

На протяжении всей истории философии язык философского рассуждения и письма постоянно трансформировался, реагируя на общественные изменения. Новые проблемные точки требовали нового понятийного аппарата и новых стратегий описания, и философия современности занята решением этих же задач. Однако сегодня нам кажется интересным не просто прослеживать хронологию процесса изобретения и переизобретения языка мышления, но и обращать внимание на изменения механики самого процесса. Новизна того или иного подхода может состоять не только в экспериментах с лексикой и синтаксисом философии, но и в поиске разнообразия условий для потенциальных изменений. Механика открытия нового может основываться как на обновлении уже существующей традиции, так и на попытках её деконструирования, а также на радикальной смене оптики - то есть отказе работать в рамках существующих теоретических структур, где значения и употребление самих терминов «традиция», «система», «понятие», «теория» и др. чётко закреплены. Эксперименты с переосмыслением не методологий, но условий возникновения и функционирования методологий, а также внимание к потенциальным возможностям мышления, лежащим за их пределами, в иной координатной сетке, могут оказаться весьма продуктивными для исследования современной культуры, в которой в свою очередь происходят те же процессы - не только и не столько обновления, сколько трансформации системы координат. Вслед за Ж. Делёзом и Ф. Гваттари мы можем рассматривать философию не только в качестве «искусства формировать, изобретать или же изготавливать концепты». Отказываясь использовать механизмы, производящие универсалии, и предлагая расширенное понимание концепта (который не обязательно является универсалией, находкой или продуктом), Делёз и Гваттари называют философию «дисциплиной, состоящей в творчестве концептов» (курсив авторов) ${ }^{1}$. Меняющийся мир и новые формы жизни и культуры требуют изменений не только языка описания (точнее, языков - во множественном числе), но и представлений о языке и о мышлении, а также представлений о том, кто же сегодня пользуется этим языком, как и где сегодня возникают новые смыслы и как возможно с ними рабо-

\footnotetext{
() Володина А. В., 2018

() Центр фундаментальной социологии, 2018

DOI: $10.17323 / 1728-192 X-2018-3-389-399$

1. Делёз Ж., Гваттари Ф. (1998). Что такое философия? / Пер. с франц. С. Н. Зенкина. СПб.: Алетейя. С. 14.
} 
тать. С этим кругом вопросов и связана книга философа и теоретика кино Олега Аронсона.

Тексты, составившие сборник, не объединены общей темой или методологией, поскольку каждый из них глубоко контекстуален и вырастает из локальной культурной ситуации. Именно конкретная, локальная проблемная точка, а не абстрактная теоретическая проблема, становится отправной для выстраивания как логики рассуждения, так и понятийного аппарата. Подобное смещение акцентов, безусловно, так или иначе, характерно для многих направлений современной философской мысли - от спекулятивной философии и объектно-ориентированной онтологии до феминистской философии. В этом году книге «Силы ложного» была присуждена Литературная премия имени Александра Пятигорского, вручаемая за лучшее философическое сочинение на русском языке. Председатель жюри премии Ксения Голубович также упомянула об этой смене вектора размышления, отметив книгу «за современность философского подхода к описанию актуальной действительности, за разработку русского философского языка в свете вызовов большого мира, на равных условиях со всеми, без скидок на национальные особенности» ${ }^{2}$. Сам автор в предисловии указывает, что объектами его исследований являются те связи и отношения, которые выступают свидетельствами радикальных перемен, происходящих в современной жизни. Чтобы уловить потенциал нового смысла, изменяющего или подрывающего структуру, в которую уже, казалось бы, встроена та или иная культурная ситуация, нужно предпринять попытку рассуждения на языке, имманентном этой ситуации. А поскольку сегодня производство отношений и смыслов «куда в большей степени обусловлено нашей принадлежностью общности, нежели ценностью индивидуального» (с. 12), что стало следствием развития массового общества и новых технологий, то Аронсона главным образом интересует общность, её логика и практики. Чтобы понять нечто об общности, нужно создать новый способ разговора о ней.

Вектор интерпретации понятия общности, пожалуй, центрального в этой книге, во многом близок теории множества (multitude) П. Вирно, М. Хардта и А. Негри, которые в свою очередь опираются на рассуждения Спинозы о массе и толпе (Аронсон подробно рассуждает о разных подходах к политическому потенциалу толпы у Спинозы и Гоббса в тексте «Эпидемиология политического»). Как пишет Вирно, в отличие от гоббсовского «народа», обладающего единой волей и способного на единое действие ${ }^{3}$, miltitudo Спинозы - это «множественность, которая существует как таковая на общественной сцене, в коллективном действии, по отношению к общим делам, не соединяясь в Едином и не растворяясь в центростремительном движении» ${ }^{4}$. Сам же Вирно развивает понятие множества,

2. Речь председателя жюри Литературной премии имени Александра Пятигорского. См.: http:// piatigorskyprize.ru/news/124.

3. Гоббс Т. (1989). О гражданине / Пер. с лат. Н. А. Федорова // Гоббс Т. Сочинения. Т. 1. М.: Мысль. C. 395 .

4. Вирно П. (2013). Грамматика множества: к анализу форм современной жизни / Пер. с ит. А. Петровой под ред. А. Пензина. М.: Ад Маргинем. С. 10. 
демонстрируя, что в современную эпоху множества получают возможность существовать благодаря general intellect - «общему интеллекту», «общим местам» лингвистических, культурных и логических конструкций, обеспечивающих связи и отношения, и именно эти отношения (а не совокупность индивидов) и представляют собой множество. Таким образом понятое множество, или общность, обладает собственной логикой действия, и эту логику Аронсон называет аффективной. Понятие аффекта, следуя делёзовскому подходу, нам следует отделять от понятия эмоции, связанной с психической жизнью индивида. Область связей, порождённых аффектом, это «особая чувственность общности» (с. 57), которая всегда процессуальна - аффективное событие подразумевает выход за пределы индивидуального переживания и движение к не-человеческому, становление множеством - то есть чем-то совершенно иным, нежели единичной личностью.

Как свидетельствует эта книга, исследования общности, специфики коллективной чувственности и коллективного действия могут проводиться на самом разнообразном материале. Именно живая конкретность материала, исходя из которой выстраивается рассуждение, позволяет по-новому ставить проблемы и открывать новые способы уловить характер той общности, которая не только не оформилась в единое, аналитически схватываемое целое, но и принципиально недоступна для схватывания, незавершимая и нередуцируемая до единичности. Говоря о такой общности, Аронсон описывает её как «грядущую» - как то чувственное событие, которое уже затрагивает нас, но пока ещё не поймано в сетку культурных структур, систем и институций, поэтики и политики. Подобное сообщество грядущего, «множественность отношений существования определяет мир до его схваченности тем или иным способом ввести заново единство бытия» (с. 43). Чем же являются эти метки грядущего, свидетельства перемен, происходящих прямо сейчас? Это указатели на места неразличимости, события, переживаемые ещё не оформленной общностью, ускользающие от существующих структур и бинарных альтернатив и открывающие новые практики и формы чувствования. Поскольку речь идёт о чувственных формах, в книге много внимания уделяется искусству. Однако аффективная логика коллективного чувствования призывает к тому, чтобы отказаться от традиционного эстетического инструментария и попытаться прочесть культурные тексты под новым углом. Аронсон пишет о литературе - «Крейцеровой сонате» Л. Толстого (статья «Искусство и половой хиазм») и «Дракуле» Б. Стокера («Трансцендентальный вампиризм»); о кино - «Шоа» К. Ланцмана («К антропологии свидетельства») и «Советнике» Р. Скотта («Снафф: популярная механика»); o readymade М. Дюшана («Машина и женщина (неискусство Марселя Дюшана)») и акционизме П. Павленского («Право на искусство»). В тексте о поэзии Мандельштама («Товарищество земли (логика стихий Осипа Мандельштама)») находим объяснение того, почему материал искусства оказывается так важен для разговора об общности. Отходя от привычного литературоведческого анализа поэзии, прочитывающего образы как «поэтические, риторические тропы или смысловые конструкции» (с. 57), и принимая, что стихотворение необязатель- 
но должно рассматриваться как завершённая форма и может включать в себя различные, в том числе и несовместимые вариации, можно расширить понимание образа, включив в рассмотрение отношение образов, речевых фигур и сил между собой и эффекты, порождаемые этими отношениями. В привычном восприятии стихотворения «чувственность общности, данная в отношении образов между собой, стирается», в то время как у Мандельштама аффективный план стихотворения является и темой, и задачей, и способом её решения. В «Стихах о неизвестном солдате» способ выражения общности раскрывается через фигуру «неизвестного солдата», «в которой соединено единичное индивидуальное существование (сингулярность) и анонимность множества в его исчезновении, в коллективной гибели» (с. 55). Потенциал расширительного понимания образа не ограничивается только эстетической сферой - а точнее, показывает (что становится очевидным во многих текстах этого сборника), что изолировать реальность эстетического от повседневной действительности вообще едва ли продуктивно. Образы, скрепляющие «собой практику сосуществования людей друг с другом», Аронсон и называет «силами ложного», которые «выявляют отношения, для которых логика противопоставления истины и лжи уже не работает» (с. 9).

Проблематизация бинарных оппозиций - один из основных векторов этой книги. Противопоставления истины и лжи, мужского и женского, силы и слабости - привычные культурные структуры, однако эффекты коллективной чувственности не встраиваются в эти оппозиции. Они не только избегают их, но и проблематизируют, ставят под вопрос. Именно эти ситуации подрыва бинарных структур интересны исследователю, поскольку действительно способны открыть доступ к иным альтернативам и новым смыслам. Таким подрывным механизмом может, к примеру, стать описанная Львом Толстым логика «заражения» искусством, неполитическая общность киевского Майдана и неполитическая солидарность, «грубый коммунизм» или «грядущий» феминизм. Во всех этих кейсах схватываемые философом «силы ложного» действуют парадоксальным образом - они обладают как потенциальной подрывной силой, так и слабостью, которая в свою очередь тоже обнаруживает подрывной потенциал. Эти образы-силы не наделены властью и, более того, открывают пути для ускользания от властных структур; они занимают слабую позицию, вне мейнстрима и где-то на границах ценностных иерархий, основываясь не на присвоении, но на даре. Эти силы жизни «всегда слабее сил политики» (с. 122), и порождаемые ими различные стратегии избегания власти, с одной стороны, отчасти лежат в области несбыточного, принципиально незавершимого, а с другой - именно они и маркируют способы выхода из ловушек бинарных оппозиций.

Подзаголовок книги «Опыты неполитической демократии» подчёркивает ещё одну важную проблемную линию, тесно связанную со спецификой бытия общности. Многие тексты в «Силах ложного» так или иначе затрагивают тему политики и власти. В современном западном мире капитализма, где демократия является признанной ценностью, политика как устоявшаяся система властных отношений, 
с одной стороны, обросла неразрешимыми противоречиями и апориями и имеет ряд ограничений, которые в рамках собственных системных механизмов кажутся непреодолимыми, а с другой стороны, обладает мощной апроприирующей силой, распространяясь на все доступные общественные, культурные и знаковые территории, институциализируя их и включая в структуру властных отношений. Возможно ли в сегодняшнем мире существование нескомпрометированных зон неполитического, ускользающих от апроприации и представляющих альтернативный, продуктивный взгляд на апории политического? Эта книга посвящена зонам, где неполитическое измерение общности обнаруживает себя и где действуют «слабые силы», создающие эти общности свободы. Важно отметить, что такие общности легче именно обнаружить, а не помыслить - об этом, в частности, читаем в тексте «Анархическая этничность», где автор рассуждает о возможности неполитической этничности. Общность-множество непредставима, поскольку логика её возникновения противоречит самому механизму представления: если политическая этничность, стремящаяся к тому, чтобы объединиться в государство, формируется благодаря инструментарию идентификации по принципу «свой - чужой» и, следовательно, сама формирует чёткое представление о себе как о единстве, то анархическая этничность действует через ускользание и исход, через отступание от стратегии идентификации индивида как части единства. Понятие «исход» в данном случае не метафорично, а конкретно - рассуждения автора разворачиваются на материале еврейской мифологии, где реализуются обе линии формирования этничности; первая из них, политическая линия, действует благодаря фигуре героя и пророка Моисея, а вторая логичным образом не эксплицируется из какоголибо конкретного индивидуального воплощения, поскольку логика её развития в нём не нуждается. Общность в исходе не стремится к объединению в действии, но возникает благодаря и во время этого действия - иначе говоря, составляющие её отношения внутри множества складываются вынужденно, «в слабости», в побеге. Это общность с теми, с кем мы не способны её представить; с теми, с кем ты обречён на совместное выживание. Оптику, позволяющую усмотреть эту общность, мы можем обнаружить в мифологии, тем самым попытавшись, во-первых, приблизиться к пониманию строения общества до государственности, а вовторых, увидеть действие мифологической этики в современном мире - этики, избегающей политического. Отказ от идентичности, от «противопоставлений «друг - враг», «свой - чужой» как оснований некоторой поведенческой этики» (c. 130) - это слабая позиция в рамках господствующей общественной системы и экономики, однако она оказывается чрезвычайно гибкой и жизнеспособной, функционируя в рамках другой экономики - экономики не обладания, но дара. Опираясь на труды антропологов и философов, писавших о логике дара, Аронсон подходит к разговору об этике гостеприимства. В дерридианской трактовке понятие «событие гостеприимства» обнаруживает возможность обойти не только дихотомию «свой - чужой», окрашенную негативным отношением к «чужому», но и «свой - другой», в логике которой даже позитивная открытость другому вле- 
чёт за собой вписывание его в жёсткую рамку оппозиции, несущую в себе «вирус противостояния» (с чем в современную эпоху западное общество неоднократно сталкивалось, пытаясь разрешить проблемы колониализма, выйти из ловушки неизбежной экзотизации других культур и справиться с побочными эффектами «политики идентичности», которая подразумевает присвоение ценностей какой-либо группой и необходимость выбрать своё однозначное положение на шкале «свой чужой»). Отказ же от идентичности влечёт за собой потенциал безусловной открытости, готовности быть вовлечённым в аффективное переживание общности.

Механизм этой вовлечённости удачно раскрывается через понятие заражения, потенциал которого Аронсон описывает в тексте «Искусство и экономика бедности (заметки о теории заражения Льва Толстого)». И хотя о механике заражения Толстой писал применительно к искусству (работа «Что такое искусство?»), тем не менее сфера его действия не ограничивается областью эстетического. Следует оговорить, что интерпретацию заражения Аронсон не заимствует у Толстого, но развивает, прочитывая его чуть иначе, чем все мы привыкли, перетолковывая и иначе расставляя акценты. Определяя искусство как коллективное дело, Толстой пытается выявить принципы настоящего искусства и ложного. В качестве определяющего принципа для этого разделения он рассматривает красоту, но обнаруживает несостоятельность этой категории («с ее миметизмом, формой и техникой представления и ее подспудным эротизмом» (с. 288)), что вполне созвучно консенсусу в большинстве направлений мысли современной эстетики. Подлинное искусство, управляемое действием заражения, пишет Толстой, есть «средство общения людей, соединяюеее их в одних и тех же чувствах». Предостерегая против психологической интерпретации этого явления, Аронсон подчёркивает слова Толстого о том, что при заражении «человек с целью передать другим людям испытанное им чувство снова вызывает его в себе и известными внешними знаками выражает его»- то есть механизм заражения переводится из внутреннего, субъективно-психологического пласта вовне, в область коллективных форм жизни. На нас воздействует не авторская интенция или личные переживания автора или исполнителя, но «некая бессубъектная форма произведения» (с. 291), складывающаяся в процессе действия аффективных отношений - не объект или образ, но аффект или сила. Таким образом, механика заражения не встраивается в «наши привычные дихотомии идеальное/материальное, рациональное/чувственное, внутреннее/ внешнее» (с. 294) и осуществляется именно в общности людей, захваченных теми или иными отношениями чувствования.

«Заражённое» сообщество действует в том режиме общности, который «можно назвать коммунизмом без идеологии, или коммунистической чувственностью» (с. 298). Неидеологический и неполитический, «грядущий» коммунизм в «Силах ложного» подробно рассматривается в текстах «Грубый коммунизм, или Этика праздности» и «Искусство и половой хиазм». Понимая под коммунизмом тот тип отношений, в котором «преодолен отчужденный трудом индивид во имя неотчуждаемой общности» (с. 23), Аронсон отталкивается от линии рассуждения 
К. Маркса, называвшего «грубым коммунизмом» реальные коммунистические практики, уже существующие в общности и обладающие критическим потенциалом по отношению к господствующим властным структурам. Это практики такого труда, который не воспринимается как ценность (и, собственно, как труд) самим участвующим в нём сообществом. Специфика таких практик раскрывается как в искусстве и инновациях, так и в весьма провокативных зонах общности: воровстве (не просто нарушающем закон, но меняющем само отношение к собственности) и проституции, трактуемых как поле сопротивления господствующему типу общественных отношений и та область, в которой реализовывается «освобождённый труд» женщины. Хотя следует отметить, что с учётом социокультурных данных о том, как плачевно обстояли и до сих пор обстоят дела в индустрии проституции, авторская аргументация порой представляется дискуссионной (к примеру, тезис о том, что проститутка «не принадлежит мужчине, она не участвует в процессе производства, она не трудится в привычном понимании этого слова. Покупается ее время, но это время ее жизни, а не «рабочее время» пролетария, из которого извлекается прибавочная стоимость» [с. 34]).

Однако проблематика женского в книге встречается в разных контекстах и оказывается указателем на различные области неразличимости, «слепые пятна» власти и политики, границы аффективных общностей. Именно силы и практики женского позволяют высветить возможности ускользания от контроля власти, поскольку они связаны с иными типами труда и зарождаются в «зонах неразумного - в чувственности и в сексуальности». Область женского - «место, где никакое господство невозможно», и по-настоящему подрывной потенциал женского проблематизирует власть мужского, не стремясь при этом занять место мужчин в структурах господства. Таким образом, продолжая линию мысли Толстого в «Крейцеровой сонате», Аронсон рассуждает об отношениях полов не как о конфликте, а как о хиазме, замечая, что в сегодняшнем мире «сам акт именования чего-то как мужского и женского становится опасным и практически невозможным», и предлагая тем не менее попытаться вернуть возможность размышления в этих терминах, поскольку «мужское» и «женское» даны нам «как факт нашей жизни» (с. 324-325). (Последний тезис с точки зрения феминистских и гендерных теорий тоже может показаться дискуссионным, в том числе потому, что в следовании этой логике возникает риск вновь вернуться к исследованию не отношений, а объективированных конструктов.) Однако памятуя об основном проблемном векторе книги - обнаружении тех практик общности, которые дают возможности продуктивной критики бинарных структур и противостояний, - обратим внимание на критический потенциал общности «женского». Эту этику женского, как представляется, следует рассматривать в тесной связке с проблематикой солидарности (о которой Аронсон пишет в других текстах - «Майдан: переопределение демократии» и «Государство непокорности (возвращаясь к Генри Торо)»), смещая акцент с гендерной идентичности и таким образом избегая отмеченных выше спорных решений. «Солидарность» здесь также раскрывается как понятие непо- 
литическое, ускользающее от политической институциализации, - она «ощутима, пока люди объединены не властью и не борьбой за нее, а смутным намерением, общим импульсом, общностью действия» (с. 249), где действие оказывается вне механизмов существующих общественных субститутов солидарности (партий или группировок по интересам), вне правовых механизмов и сферы действия законов. Такое неполитическое действие таким образом необязательно является незаконным - в качестве объектов рассмотрения выбраны движение "Оссиру» (его московская версия у памятника Абаю на Чистых прудах в 2012 г.) и сочинение Генри Торо «О долге гражданского неповиновения», где он пишет об отказе от уплаты налогов и отношениях с представителями закона, и ставит под сомнение саму формулу представительства, которая противостоит прямой солидарности. Именно через конкретное действие неповиновения и «открывается возможность альтернативного взгляда на политику, когда «ущерб», «слабость» и даже «обреченность» каждого отдельного индивида оказываются строительным материалом для той «пассивной революции», достижений которой всегда не замечают и недооценивают, поскольку подчинение одному закону спешно сменяет подчинение закону новому» (с. 250). Справедливо критикуя революционный протест, совершающийся в логике государственности и тем сам влекущий вслед за подрывным процессом возвращение к воспроизводству той же политической логики, что господствовала до переворота, Аронсон вслед за Торо пишет о коллективном действии, основанном не на протесте, а на долге - долге неповиновения и солидарности.

Представляется, что этика «женского» в упомянутой выше трактовке чрезвычайно близка этике солидарности, а также этике заботы. В истории понятие солидарности возникает в различных теоретических контекстах, и даже в отдельно взятой области философии значение этого понятия сохраняет свою неуловимость и вариабельность. Это объясняется тем, что сегодня мы говорим в первую очередь о практиках солидарности, то есть о солидарности как факте жизни, воплощающейся лишь в динамике отношений между людьми. Когда солидарность определяется через коллективную практику ${ }^{5}$, а не в качестве принципа (как, скажем, в логике мысли Э. Дюркгейма, изложенной в работе «О разделении общественного труда»), ценности или чувства ${ }^{6}$, она не рассматривается как неотъемлемое или приобретаемое свойство человеческой общности или индивида и связывается не с объектами, а с их отношениями (следуя этой же логике, философ Матти Хяурю противопоставляет практики солидарности абстрактным ценностям независимости и справедливости ${ }^{7}$. Также намечая линию философской критики представлений о справедливости, Аронсон пишет о «позитивной несправедливости»- отношении, которое позволяет существовать общности с другим. В этом

5. Prainsack B., Buyx A. (2012). Solidarity in Contemporary Bioethics: Towards a New Approach // Bioethics. Vol. 26. № 7. P. 346.

6. См., например: Stjernø S. (2004). Solidarity in Europe: The History of an Idea. Cambridge: Cambridge University Press.

7. Häyry M. (2005). Precaution and Solidarity // Cambridge Quarterly of Healthcare Ethics. Vol. 14. № 2. P. 199. 
рассмотрении реальности другого не как объекта или образа, а как отношения получает развитие идея Э. Левинаса о бесконечности другого, для встречи с которым приходится преодолевать границы самотождественного «я». Эта слабая позиция «я» освобождает место аффективной силе, возникающей в воздействии позитивной, продуктивной несправедливости, где при встрече обоюдный дар слабости и солидарности создаёт новое сообщество. Итак, вынося явление солидарности за идеологические рамки, мы получаем возможность обнаружить в нём неполитическое измерение.

Солидарность выступает одним из важнейших понятий в этике заботы. Это направление этической мысли, получившее начало в работе «In a Different Voice» (1982) специалистки по психологии и феминистской теории Кэрол Гиллиган, стоит на критической позиции по отношению к классической этике и этике дискурса. В частности, подвергается сомнению способность абстрактных метаэтических теорий стать основой для обеспечения интересов «конкретного другого» и заботы о нём. С позиций феминистской критики и кантовская мораль, и этика утилитаризма в силу своей абстрактности не отвечают специфике конкретных человеческих потребностей и, как и контрактуализм, они не дают достаточного инструментария для исследования отношений внутри групп людей, заботящихся друг о друге ${ }^{8}$. Первые теоретики феминизма XVIII-XIX вв. уже проблематизировали распространённое допущение о том, что полноценно развитой личностью можно полагать ту личность, которая в наибольшей степени автономна и независима от других. Отказавшись от этого допущения, они предложили обратить внимание на важность отношений и связей между людьми и принять в качестве теоретической установки положение о том, что чем более конкретным, частным и эмоциональным является знание, тем более точно оно позволяет рассуждать о реальных переживаниях людей в окружающем их мире 9 . В последние десятилетия ряд теоретиков феминизма исследуют конкретные практики общностей, трактуя заботу как эффект актуальных совместных практик, а не как частную эмоцию или универсальную ценность ${ }^{10}$. Этика заботы, осмысляющая женский моральный опыт (в противовес «маскулинной» морали, которая в рамках классической этики подразумевалась как универсальная), призвана стать «теоретическим основанием для критики любых социальных практик, поддерживающих подчинённое положение женщин, и для сопротивления осуществлению этих практик» ${ }^{11}$. Как пишет Кэрол Гиллиган, вместо языка справедливости, устанавливающего права и законы, женская этика способна выработать язык заботы, делающий акцент на отношениях и ответственности.

8. Held V. (2006). The Ethics of Care: Personal, Political, and Global. Oxford University Press. P. 24.

9. Подробнее см.: Tong R. (1993). Feminine and Feminist Ethics. Belmont: Wadsworth.

10. Подробнее см.: Ruddick S. (1989). Maternal Thinking: Toward a Politics of Peace. Boston: Beacon; Tronto J. C. (1993). Moral Boundaries: A Political Argument for an Ethic of Care. L.: Routledge.

11. Артемьева О. В. (200о). Этика заботы: феминистская альтернатива классической философии // Этическая мысль. Вып. 1. М.: ИФ РАН. С. 196. 
Также в рассуждениях об этике заботы придаётся особое значение понятию различия, при этом предлагается вынести различия из рамок релятивистского дискурса и не считать их проблемами, требующими разрешения, а воспринимать в качестве видимых «указателей» отношений, меток, указывающих на изменения состояния человека и общности ${ }^{12}$. Женская этическая стратегия включает в своё поле то, от чего абстрагируется «маскулинная» этика - в том числе благодаря осмыслению проблематики различия и её глубокой контекстуализации она получает возможность не отказываться от релятивизма как непродуктивной и неприемлемой позиции в современном обществе, но переориентировать эту проблематику в область отношений и взаимозависимостей. Таким образом, этика заботы открывает способы работать как с недопустимым, так и внеморальным, а моральные высказывания оказываются вариативными, поскольку рождаются в конкретной материи жизни, конкретном событии, в контексте которого они предстают несомненными $^{13}$. Суждения о справедливости в рамках такой этики основываются не на системе норм и ориентации на принцип равенства, а на допущении множественности ситуативных моральных истин ${ }^{14}$. Так, сама этика заботы представляет собой не протест против «мужской» этики, но попытку выхода за пределы её господства; практики заботы и солидарности - не «антимужские», но отличные от них. Таким образом, если расширить рамки разговора об этике за пределы гендерной идентичности (к чему, в частности, справедливо призывают критики феминизма), то этика солидарности и заботы сама по себе может восприниматься как способ ускользания от дихотомических противостояний, а также позволит найти способы рассуждать о множественности общности и в то же время не терять из виду конкретность жизненных отношений.

Возвращаясь к проблеме поиска выхода из ловушки релятивизма, следует отметить, что в определённом отношении эта книга - весьма успешный ход в игре против критиков современного положения дел в гуманитарных науках, культуре и обществе, которые выступают с широкими обобщениями с традиционалистских позиций. Усиление релятивистских настроений часто указывается в качестве одного из пороков современности, однако, как можно заключить, рассуждая о проблематике постправды, происходящие процессы следуют более сложным механизмам, чем гомогенизирующая релятивизация взглядов. Не только содержание информационных высказываний, общественных мнений и истин, но и сами формы представлений общества об истине и мнении, и их воздействия - всё это возникает в качестве эффектов медиа. С ростом разнообразия и дифференциации медиа множатся и эти формы. Перед нами встаёт задача осмысления и обсуждения явлений и идей, лежащих в поле относительного, ложного, внеморального, вне закона; каким может быть исследовательский инструментарий для работы с этими

12. Gilligan C. (1993). In a Different Voice: Psychological Theory and Women's Development. Cambridge: Harvard University Press. P. xviii.

13. Ruddick S. Op. cit. P. 128.

14. Gilligan C. Op. cit. P. 166. 
явлениями, структурами и смыслами, кроме двух очевидных путей - тривиальная релятивизация или апроприация властной риторикой? Эта книга предлагает нам эксперименты по поиску иных альтернатив, поиску ещё не скомпрометированных политикой и идеологией зон, поиску сообществ, которые не ограничены подобно filter bubbles социальных сетей, а открыты, революционны и непредставимы. В последнем тексте книги Аронсон пишет об этике ложного, развивая идею Ф. Ницше о продуктивной фальсификации - то есть о важности и необходимости для жизненной практики человека тех суждений, которые являются ложными и безосновными (каковыми Ницше полагает априорные синтетические суждения), однако универсально сообщаемыми и общими. Медиа и массовые коммуникации, потенцирующие эту сообщаемость, создают бесконечные серии суждений, в данной механике воспроизводства не являющиеся уже ни вполне истинными, ни строго ложными. В стремлении контролировать производство истины политика постоянно имеет дело «с логикой неуникального, с режимами бессмысленных повторов, с аффективными знаками (шоками)» (с. 441), пытаясь их апроприировать, однако в зоне ещё недоговоренной речи, в зоне до суждений можно обнаружить моменты действия аффективной радости обмана, «невидимые анонимные коммуникативные связи, которые ею (политикой) оказываются уже неконтролируемы» (с. 443). Здесь становится совершенно очевидным, сколь сложно теоретику ухватить в качестве предмета исследования то едва намеченное действие сил, создающих ещё не оформившиеся общности, и вычленить тот подрывной потенциал неподчинения, который ещё не пойман институциональной ловушкой политического. Книга «Силы ложного» свидетельствует о том, что подобные исследования не только сложные, провокативные и актуальные, но и чрезвычайно захватывающие для читателя.

\title{
Book Review: Oleg Aronson, Sily lozhnogo: opyty nepoliticheskoy demokratii [Powers of Falseness: Essays on Non-political Democracy] (Moscow: Falanster, 2017) (in Russian)
}

\author{
Alexandra Volodina \\ Postgraduate Student, Institute of Philosophy of the Russian Academy of Sciences \\ Address: Goncharnaya str., 12/1, Moscow, Russian Federation 109240 \\ E-mail: sasha.volodina@gmail.com
}


БЕРАР Е. (2016). ИМПЕРИЯ И ГОРОД: НИКОЛАЙ ॥, «МИР ИСКУССТВА» И ГОРОДСКАЯ ДУМА В САНКТПЕТЕРБУРГЕ. 1894-1914. М.: НОВОЕ ЛИТЕРАТУРНОЕ ОБОЗРЕНИЕ. 344 С. ISBN 978-5-4448-0513-8*

\section{Борис Степанов}

Кандидат культурологии, ведущий научный сотрудник Института гуманитарных историко-теоретических исследований им. А. В. Полетаева, доцент Школы культурологии Национального исследовательского университета «Высшая школа экономики» Адрес: ул. Мясницкая, дом 2о, г. Москва, Российская Федерация E-mail: bstepanov@hse.ru

Своим присутствием в горизонте современной урбанистической рефлексии Петербург в значительной степени обязан русской литературе. Будучи порождением культуры Серебряного века, «петербургский миф» инспирировал не только развитие краеведения в Петербурге и других российских городах, но и оказал значительное влияние на современное гуманитарное знание. Речь идет не только о концепции «петербургского текста», выдвинутой представителями тартуско-московской семиотики и в значительной степени унаследовавшей историософские подтексты петербургской мифологии. Благодаря работам Этторе Ло Гатто и в еще большей степени Дональда Фангера образ города на Неве стал достоянием литературоведческой урбанистики ${ }^{1}$. Ярким примером востребованности этого материала в социальной науке можно считать книгу Маршалла Бермана, где Петербург, увиденный сквозь призму классических литературных текстов (от «Медного всадника» до «Петербурга» Андрея Белого) выступает одной из лабораторий изучения природы модерного общества ${ }^{2}$. Современные исследования феномена Петербурга в той или иной степени продолжают вдохновляться описаниями «петербургского мифа» и «петербургского текста» от Николая Анциферова до Владимира Топорова. Разумеется, большинство современных ученых, особенно представляющих американскую славистику, относятся к этим теоретическим конструкциям весьма критически ${ }^{3}$. Преодолевая ее ограниченность, они не только пересматривают ее историософскую догматику, но и расширяют корпус изучаемых текстов за счет

(С) Степанов Б. Е., 2018

(0) Центр фундаментальной социологии, 2018

DOI: $10.17323 / 1728-192 \mathrm{X}-2018-3-400-405$

* Статья подготовлена в ходе проведения исследования в рамках Программы фундаментальных исследований Национального исследовательского университета «Высшая школа экономики» и с использованием средств субсидии в рамках государственной поддержки ведущих университетов Российской Федерации «5-100».

1. Fanger D. (1965). Dostoevsky and Romantic Realism: A Study of Dostoevsky in Relation to Balzac, Dickens, and Gogol. Cambridge: Harvard University Press.; Lo Gatto E. (1960). Il mito di Pietroburgo: storia, leggenda, poesia. Milano: Feltrinelli.

2. Berman M. (1982). All That is Solid Melts into Air: The Experience of Modernity. N.Y.: Simon \& Schuster. СПбГу.

3. См., напр.: Маркович В. М., Шмид В. (ред.). (2005). Существует ли Петербургский текст? СПб.: 
тривиальной литературы, очерков и фельетонов, газетных статей и путеводителей ${ }^{4}$. При этом полноценного выхода в социально-историческую плоскость все же не происходит. Количество и известность подобных исследований неизмеримо меньше, чем работ, посвященных «петербургскому тексту», не говоря уже о еще более традиционных «биографиях» города на Неве. Пожалуй, наиболее заметен здесь вклад историков архитектуры, не только реконструирующих развитие петербургской архитектуры, но и вписывающих ее в контекст модернистского градостроительства ${ }^{5}$. Однако по понятным причинам комплексный анализ взаимосвязи социальных, культурных и политических факторов истории Петербурга как своеобразной лаборатории модерности пока еще встречается крайне редко ${ }^{6}$.

Книгу Евы Берар «Империя и город: Николай II, „Мир искусства“ и городская дума в Санкт-Петербурге. 1894-1914», выпущенную в 2016 году издательством «Новое литературное обозрение», можно считать важным вкладом в разработку социальной и культурной истории города в предреволюционные десятилетия. В классической работе «Душа Петербурга» Николай Анциферов назвал Петербург «городом трагического империализма». Став колыбелью Революции, город на Неве утратил с ее победой статус столицы, а затем и свое имя. Подхватывая эту формулу, французская исследовательница сразу же дистанцируется от историософской традиции и ее семиотических эманаций. Во введении к книге она пишет о том, что предметом ее интереса будет «не столько сущность „петербургского мифа“, сколько его преображение и та роль, которую он сыграл при неизбежном для современного города столкновении с функциональными требованиями и научными знаниями» (с. 8). Однако, в отличие от большинства работ, посвященных изучению российской урбанизации конца XIX - начала XX века, с одной стороны, и историко-архитектурных исследований российского градостроительства с другой, автор фокусирует свое внимание на истории урбанистических проектов. В этом отношении замысел книги Евы Берар близок к концепции классической ра-

4. Наиболее интересные подходы к развитию и переосмыслению традиции исследований «петербургского текста» см. в: Каганов Г. 3. (1995). Санкт-Петербург: образы пространства. СПб.: Индрик; Buckler J. (2005). Mapping St Petersburg: Imperial Text and Cityshape. Princeton: Princeton University Press; Николози Р. (2009). Петербургский панегирик XVIII века: миф - идеология - риторика / Пер. с нем. М. Н. Жаровой под ред. К. А. Богданова. М.: Языки славянской культуры; Matich O. (ed.). (2010). Petersburg/Petersburg: Novel and City, 1900-1921. Madison: University of Wisconsin Press.

5. См., напр.: Лисовский В. Г. и др. (2010). Градостроительство России середины ХІХ — начала ХХ века. Книга третья. М.: Прогресс-Традиция. Из новейших работ на эту тему можно упомянуть статью В. Басса: Басс В. (2018). Изобретение «Старого Петербурга» 100 лет назад: к истории самого успешного отечественного предприятия по отделению архитектуры от политики // Новое литературное обозрение. № 1. С. $145-174$.

6. В наибольшей степени этот подход реализован в следующих работах: Clark K. (1995). Petersburg, Crucible of Cultural Revolution. Cambridge: Harvard University Press; Schlögel K. (2002). Petersburg: Das Laboratorium der Moderne, 1909-1921. München: Hanser; Schlögel K., Schenk F. B., Ackeret M. (Hg.). (2007). Sankt Petersburg: Schauplätze einer Stadtgeschichte. Frankfurt am Main: Campus; Steinberg M. D. (2011). Petersburg: Fin de Siecle. New Haven: Yale University Press. 
боты Карла Эмиля Шорске «Вена на рубеже веков: политика и культура» ${ }^{7}$ Однако, в отличие от книги Шорске, в которой развитие австрийской столицы показано как один из классических образцов модернизации городского пространства, в рецензируемой книге описывается ситуация исторической неудачи попыток модернизировать столицу российской империи, удовлетворить насущную потребность превращения ее в «метрополис» ${ }^{8}$.

Заглавие книги четко обозначает не только хронологические рамки исследования, но также и круг лиц, о которых повествует книга. Первым из этих лиц становится последний российский самодержец. Развивая уже отмеченную исследователями (например, Ричардом Уортманом и Катериной Кларк) идею о нелюбви Николая II к Петербургу, Ева Берар показывает, что это неприятие не было лишь выражением его страхов, эстетических и идеологических пристрастий, но свидетельствовало о фундаментальном непонимании и неприятии городской культуры. Растущее влияние буржуазии и городского населения настоятельно требовало от самодержавия готовности к реализации масштабных городских проектов, к превращению столицы в пространство для «городских церемоний» и «сценариев власти» (Уортман). Между тем событийная канва правления свидетельствовала о неумении сделать последние формой коммуникации с городом, что ярко проявилось уже в момент коронации императора, завершившейся Ходынской трагедией, в революционных событиях 1905 года, юбилейных торжествах 1913-го и т.д. Сопротивление, которое встречали проекты реформирования города - начиная от демократизации городского управления и заканчивая модернизацией системы канализации, свидетельствовало о сохраняющемся отчуждении возглавляемой Николаем государственной системы от городского населения в целом и в первую очередь от населения российской столицы. В конечном итоге это означало нечувствительность к проблематике большого города, непонимание того, что представляет из себя горожанин в разных его ипостасях - как буржуа, как квартиронаниматель, как профессионал и субъект разворачивающейся в публичном пространстве города коммуникации.

Борьбой за модернизацию российской столицы определяется активность других протагонистов книги. Ева Берар подробно прослеживает творческую биографию Александра Бенуа - идеолога «Мира искусства» и одного из вдохновителей петербургского градозащитного движения, а также его соратников - Сергея Дягилева, Дмитрия Философова и др. Ключевая роль «мирискусников» в формировании идеологии русского модернизма и в создании культа Петербурга широко известна и неоднократно освещалась в научной литературе (здесь можно упомянуть тексты целой когорты исследователей - начиная от Татьяны Каждан, Елены Борисовой, Александра Осповата и Романа Тименчика и заканчивая Эмили

7. Шорске К. Э. (2001). Вена на рубеже веков: политика и культура / Пер. с англ. под ред. М. В. Рейзина. СПб.: Изд-во имени Н. И. Новикова.

8. Эта перспектива отличает ее и от хронологически близких к сюжету ее книги исследований Карла Шлегеля и Катерины Кларк. 
Джонсон и Вадимом Бассом). Прослеживая истоки и контексты возникновения эстетической программы журнала и других аналогичных проектов, таких как сборник «Художественные сокровища России» и журнал «Былые годы», Ева Берар акцентирует их урбанистический пафос, связанный с идеей формирования образа города, достойного европейской столицы. Обращаясь к социальному и политическому контексту работы этих изданий, французская исследовательница показывает, что вопреки восприятию их как прибежища эстетов, декадентов и пассеистов их программа была попыткой откликнуться на потребности современного общества. Сравнивая эту программу с аналогичными инициативами, возникшими в других европейских столицах, автор книги подчеркивает присущую ей модернистскую противоречивость: будучи антибуржуазной по своему пафосу, идея петербургского наследия была адресована именно буржуазии; отстаивая идею городского наследия как наследия национального, эта программа дистанцируется от провинциализма народников и бюрократии и создается в европейском горизонте и с оглядкой на европейский урбанизм. Как показывает Ева Берар, смысл этой программы выходил далеко за пределы не только чисто эстетических дискуссий, но и собственно петербургского контекста. Она предполагала реформирование художественного образования и музейного дела, созидание новой государственной эстетики. «Под прикрытием „культа Старого Петербурга“ он [Бенуа. - Б. С.] разрабатывает программу художественной политики новой России, т. е. России буржуазной, конституционной и европейской» (с. 219).

Наконец, третьей стороной описываемого в книге «петербургского диалога» выступают участники дискуссий о модернизации Петербурга - министры и меценаты, чиновники и депутаты, инженеры и архитекторы. Эти дискуссии не только обращают нас к практическим вопросам управления городом - начиная от принятия городского положения ${ }^{9}$ и заканчивая постройкой городской канализации, в отсутствие которой Петербург занимал одно из первых мест среди европейских столиц по уровню смертности среди населения. В них просматриваются пути обсуждения тех вопросов, которые изначально были прерогативой социологии города и городских исследований - природа городского сообщества и кооперации городских жителей, значение миграции, создание и использование публичных пространств и т.д. Возвращая из исторического небытия фигуры петербургских реформаторов, таких как последний петербургский городской голова граф Иван Толстой, архитектор Леонтий Бенуа (старший брат Александра Бенуа), инженеры Николай Астров и Федор Енакиев и др., книга Евы Берар вносит важный вклад в осмысление традиции российской урбанистики. Начатая этими людьми работа по осмыслению городской жизни была прервана войной, а затем - Революцией и не успела вылиться в какие-то полноценные формы ни в теоретическом, ни

9. Этот сюжет рассматривался также в работах Анны Сухоруковой. См., напр.: Сухорукова A. C. (200о). Петербургская городская Дума и проблемы градостроительства в конце XIX - начале XX в. Дисс. канд. ист. наук. СПб.: Санкт-Петербургский филиал Института российской истории Российской Академии наук. 
в практическом плане, в отличие от градозащитного движения, которое получило мощное продолжение после Революции ${ }^{10}$. Имена отечественных пионеров городских исследований весьма слабо знакомы российской публике, не говоря уже об отсутствии их в международном урбанистическом пантеоне, на что сетовал в свое время Вячеслав Глазычев ${ }^{11}$. Их появление в контексте истории петербургской модернизации позволяет вывести их за рамки профессиональной градостроительной криптотрадиции ${ }^{12}$, увидеть их деятельность в контексте эволюции российской городской культуры.

Наряду с социологической чувствительностью, присущей подходу автора книги (притом что собственно социологическая традиция представлена в тексте достаточно скупо $\left.{ }^{13}\right)$, «Империя и город» обладает и несомненными литературными достоинствами. Несмотря на масштабы подготовительной работы и объем перелопаченных автором источников, текст не выглядит тяжеловесно, хотя отсутствие большого количества ссылок вполне может вызвать претензии поборников позитивистской научности. Легкость стиля, замечательно воспроизведенная в переводе Марии Неклюдовой, насыщенность исторической фактурой и яркость отдельных сюжетов (таких, например, как характеристика восприятия Парижа Николаем II в ходе его французского путешествия 1896 года или рецепция идей Отто Вагнера российскими архитекторами) дополняется захватывающим ритмом повествования, который создает у читателя ощущение темпа истории ${ }^{14}$. Эти достоинства неизбежно оборачиваются издержками: стремясь не утяжелять текст, автор вынуждена в некоторых случаях оставлять за рамками изложения некоторые детали «исследовательской кухни». К примеру, некоторая недостаточность аргументации ощущается в разделе, посвященном формированию идеи петербургского наследия. Описывая роль журнала «Старые годы» и одного из его главных идеологов, Николая Врангеля в формировании «культа Петербурга», Ева Берар говорит о значении ностальгии по усадебному быту как одном из важнейших источников формирования идеи городского наследия, однако подробно связь между

10. Феномен петербургского краеведения сегодня довольно неплохо изучен. См.: Гладарев Б. (2011). Историко-культурное наследие Петербурга: рождение общественности из духа города // Хархордин О. (ред.). От общественного к публичному. СПб: ЕУСПб. С. 69-304; Johnson E. D. (2006). How St Petersburg Learned to Study Itself: The Russian Idea of Kraevedenie. Pennsylvania: Pennsylvania State University Press; Kelly C. (2014). St. Petersburg: Shadows of the Past. New Haven: Yale University Press; Kelly C. (2014). Remembering St. Petersburg. Oxford: Triton Press; Maddox S. M. (2014). Saving Stalin's Imperial City: Historic Preservation in Leningrad, 1930-1950. Bloomington: Indiana University Press.

11. См.: Глазычев В. Л. (2008). Урбанистика. М.: Европа. Показательно, что свой труд автор посвятил трем родоначальникам этой традиции - Владимиру Семенову, Григорию Дубелиру и Льву Велихову.

12. См., напр.: Волкова Н. (2016). Генеалогия российской урбанистики. Как наследие городских инженеров 1930-х вошло в современную брань // Коммерсант. 28 декабря. URL: https://www.kommersant. $\mathrm{ru} / \mathrm{doc} / 3184725$.

13. Автор ограничивается ссылками на классические работы Макса Вебера, Георга Зиммеля, Роберта Парка и Луиса Вирта.

14. В главе, посвященной событиям первой русской революции, автор даже использует технику монтажа цитат, погружая читателя в поток разворачивающейся исторической драмы. 
ними не раскрывается (с. 203). Между тем, с учетом значимости вопроса о связи интереса к наследию с утверждением буржуазных ценностей, этот сюжет требовал бы более подробных пояснений.

Впрочем, такого рода критика, как и претензии фактического порядка ${ }^{15}$, вряд ли могут повлиять на оценку того вклада, который книга Евы Берар вносит в развитие исторической урбанистики. Разворот проблематики «петербургского текста» в плоскость социологии и социальной и политической истории радикально выводит ее за пределы краеведческой рефлексии, к которой тяготеют многие образцы этой исследовательской традиции. Анализ того, как городские проекты формируются в разных социальных полях и под влиянием различных политических конъюнктур, как они затрагивают не только интересы элит, но и способствуют кристаллизации городской публики, можно рассматривать как удачный опыт изучения современного урбанизма ${ }^{16}$. Будучи адресована как специалистам, так и широкой читательской аудитории, книга Евы Берар дает интересный материал для обсуждения тех процессов модернизации российских городов и попыток реализации диалога между властями, дизайнерами и экспертами, которые разворачиваются на наших глазах.

Book Review: Eva Berar, Imperija i gorod: Nikolay II, "Mir iskusstva" i gorodskaja duma v Sankt-Peterburge. 1894-1914 [Empire and City: Nikolay II, "Mir iskusstva" and City Duma in Saint Petersburg, 1894-1914] (Moscow: New Literary Observer, 2016) (in Russian)

\section{Boris Stepanov}

Candidate of Culturology, Leading Research Fellow, Poletayev Institute for Theoretical and Historical Studies in the Humanities, National Research University Higher School of Economics

Associate Professor, School of Cultural Studies, National Research University Higher School of Economics Address: Myasnitskaya str., 20, Moscow, Russian Federation 101000

E-mail: bstepanov@hse.ru

15. Зайцев М. В. (2017). Рец.: Берар Е. Империя и город: Николай II, «Мир искусства» и городская дума в Санкт-Петербурге. 1894-1914. М.: Новое литературное обозрение, 2016 // Историческая экспертиза. № 1. С. 181-185.

16. Обсуждение развития городских исследований в славистике см., напр., в: Антропологический форум. 2010. № 12. С. 7-210. 